

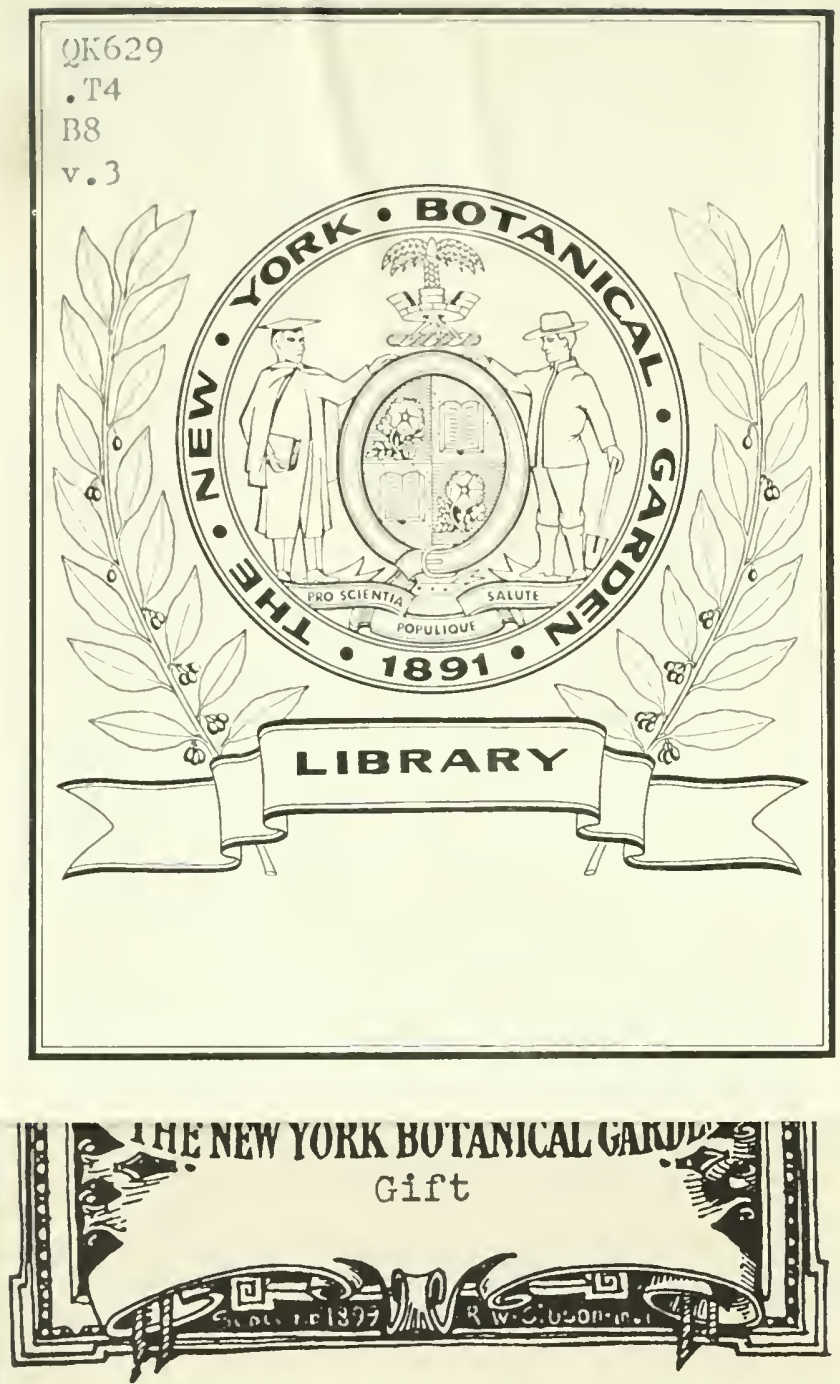




The Thelephoraceae of North America. XIII

Cladoderris, Hypolyssus, Cymatella, Skepperia, Cytidia, Solenia, Matruchotia, Microstroma, Protocoronospora, and Asterostroma

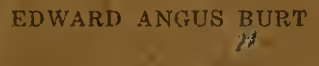

Reprinted from ANNALS of THE MIssouri BotaAitcal

GARDEN 11: 1-36. Feloruary, 1924 
THE THELEPHORACEAE OF NORTH AMERICA. XIII ${ }^{1}$

Cladoderris, Hypolyssus, Cymatella, Skepperia, Cytidia, Solenia, Matruchotia, Microstroma, ProtocoroNOSPORA, AND Asterostroma

EDWARD ANGUS BURT

Mycologist and Librarian to the Missouri Botanical Garden

Professor in the Henry Shaw School of Botany of

Washington University

\section{CLADODERRIS}

Cladoderris Persoon in Gaudichaud, Voy. Urania Bot. 176. $p l$. 1, f. 4. 1826; Berkeley, Hooker's London Jour. Bot. 1:152. 1842; Léveille, Ann. Sci. Nat. Bot. III. 2: 213. 1844; Fries, Fungi Natal. 20, in K. Sv. Vet. Akad. Handl. 1848; Sacc. Syll. Fung. 6: 547. 1888; Engl. \& Prantl, Nat. Pflanzenfam. (1:1**):126. 1898; Lloyd, Myc. Writ. 4: Syn. Cladoderris 2. 1913.-Cymatoderma Junghuhn, Fl. Crypt. Javae. 1838. Translation of description of the new genera and species by Montagne, Ann. Sci. Nat. Bot. II. 16:320. 1841, Cymatoderma being designated as a synonym of Cladoderris.-Actinostroma Klotzsch, Nova Acta Acad. Leop.Carol. 19:236. 1843.-Beccariella Cesati, Atti Accad. Sci. Napoli 83: 9.1879.

Fructification coriaceous, pileate, stipitate or sessile; hymenium inferior, with radiating or branched folds, ribs, or veins, verrucose also in some species; basidia simple; spores white, even.

The type species is Cladoderris dendritica.

Issued July 25, 1924.

Ann. Mo. Bot. Gard., Vol. 11, 1924 
The species of Cladoderris have the same internal structure as those of Stereum, and the genus is distinguished from the latter merely by the conspicuously ribbed configuration of the hymenial surface. The genus is tropical in its geographical distribution, although one species has been described from England and another from Florida; the fructifications grow on rotten wood. The earlier gatherings, consisting of only one or two fructifications at a time taken by explorers, sometimes had the stem central in the specimens saved, at other times lateral, and at others, sessile. Each such gathering was made the basis for a new species and the species were arranged in the genus in central-stemmed, lateralstemmed, or sessile sections. Field observations and more ample collections by mycologists have reduced many such species to synonyms and show that the above sections are of little value; for in Cladoderris, as in the other Thelephoraceae growing on logs, the inclination of the substratum at the point of attachment and the position of the substratum as to whether over or under the fructification are important in determining the habit and form of the fructification, as already pointed out for Stereum and Hymenochaete (Mo. Bot. Gard. Ann. 5: 302. 1918).

\section{Key to THE Species}

Hymenium not at all or but slightly verrucose............. C. dendritica Hymenium abundantly verrucose...................... C. floridana

1. Cladoderris dendritica Persoon in Gaudichaud, Voy. Urania Bot. 176. pl. 1, f. 4. 1826 (under Cladoderris of Thelephora); Léveillé, Ann. Sci. Nat. Bot. III. 2: 213. 1844; Fries, Fungi Natal. 22, in K. Sv. Vet. Akad. Handl. 1848; Berk. \& Curtis, Linn. Soc. Bot. Jour. 10: 328. 1868; Sacc. Syll. Fung. 6: 549. 1888; Lloyd, Myc. Writ. 4: Syn. Cladoderris 3. text f. 520-523. 1913. Plate 1, fig. 1.

Actinostroma crassum Klotzsch, Nova Acta Acad. Leop.-Carol. 19:237. 1843.-Cladoderris crassa (Klotzsch) Fries, Fungi Natal. 22, in K. Sv. Vet. Akad. Handl. 1848; Sacc. Syll. Fung. 6: 549. 1888.-C. Candolleana Léveillé, Ann. Sci. Nat. Bot. III. 5: 153. 1846; Sacc. Syll. Fung. 6: 549. 1888; Lloyd, Myc. Writ. 4: Syn. Cladoderris 10. 1913. 
Pileus coriaceous, usually flabelliform, drying pinkish buff, sometimes stained with adhering algae, stipitate or sessile, the upper surface spongy by the heavy coat of tomentum, the margin entire or nearly so; hymenium glabrous, marked with radiating, narrow, branched ribs, usually free from or with few warts; pileus in structure consisting of an intermediate layer, up to $150 \mu$ thick, composed of densely longitudinally arranged hyaline hyphae about $3 \mu$ in diameter, of a very much broader layer forming the tomentum of the upper surface of the pileus, and of a hymenial layer containing numerous, flexuous, fusoid gloeocystidia up to $60 \times 8-12 \mu$; basidia simple, with 4 sterigmata; spores hyaline, even, $3-4 \times 3 \mu$; no cystidia found; stem spongytomentose but often absent.

Pileus about $2-8 \mathrm{~cm}$. in diameter.

On rotten wood. Mexico, West Indies, South America, Philippine Islands, Australia, and the East Indies. The usual species.

Cladoderris infundibuliformis of the Philippines and the East Indies differs from $C$. dendritica in having the upper side much less tomentose, hazel or kaiser-brown in color, radially ridged and with the ridges radially squamulose, and the hymenium containing some incrusted cystidia.

Specimens examined:

Mexico: Orizaba, W. A. \& E. L. Murrill, 775 (in N. Y. Bot. Gard. Herb., 775, and Mo. Bot. Gard. Herb., 54611). Cuba: C. Wright, 279 (in Curtis Herb.); Alto Cedro, Earle \& Murrill, 443, comm. by N. Y. Bot. Gard. Herb.; Baracoa, L. M. Underwood \& F. S. Earle, 1217, comm. by N. Y. Bot. Gard. Herb., 1139 (in N. Y. Bot. Gard. Herb.); Fecha, Habana, Cooke \& Horne, comm. by Estacion Central Agronomica, 137; Oriente, J. A. Shafer, 3748 (in Mo. Bot. Gard. Herb., 62171, and N. Y. Bot. Gard. Herb.); Pinar del Rio Province, Earle \& Murrill, 225, comm. by N. Y. Bot. Gard. Herb.

Porto Rico: on dead cane, Rio Piedras, J. R. Johnston \& J. A. Stevenson, 1110 (in Mo. Bot. Gard. Herb., 55091). Jamaica: - 331 (in N. Y. Bot. Gard. Herb., and Mo. Bot. Gard. Herb., 62172); Castleton Gardens, W. Harris, 128, comm. by N. Y. Bot. Gard. Herb. under the herbarium name Stereum Harrisii Mass.; Moore Town, W. A. \& E. L. Murrill, 136, comm. by N. Y. Bot. Gard. Herb. 
Colombia, S. Am.: Cauca River, W. D. Denton, comm. by W. G. Farlow.

Philippine Islands: Todaya, Mindanao, A. D. E. Elmer, 10747 (in Mo. Bot. Gard. Herb., 705748).

2. C. floridana Lloyd, Myc. Writ. 4. Letter 47: 15. 1913; Myc. Writ. 4. Myc. Notes 39: 535. text f. 794. 1915.

Plate 1, fig. 2.

Type: in Lloyd Herb. and in Mo. Bot. Gard. Herb.

Pileus coriaceous, cup-shaped, flabelliform or orbicular, drying tawny olive, spongy tomentose but with the tomentum thinning out towards the margin and the surface there zonate, shortstipitate or sessile, the margin thin, entire; hymenium wood-brown, paler towards the margin, densely, minutely warted, with very numerous, short, radially elongated ridges not continuous in a branched system; pileus in structure consisting of an intermediate layer, about $800 \mu$ broad, composed of interwoven, longitudinally arranged, hyaline hyphae $21 / 2-41 / 2 \mu$ in diameter, of a broad layer of the tomentum of the upper surface of the pileus, and of a hymenial layer containing numerous flexuous gloeocystidia up to $60 \times 4 \frac{1}{2}-6 \mu$; spores hyaline, even, $3 \times 2 \mu$; hymenial warts up to $\delta 0 \mu$ high, 100-200 $\mu$ in diameter at the base, composed of a mass of erect, granule-incrusted hyphae; no cystidia found.

Pileus up to $5 \mathrm{~cm}$. in diameter.

On frondose wood. Florida.

The hymenial warts are conspicuous in sections, even though not appreciably elevated above the hymenial surface, by contents of localized masses of granule-incrusted hyphae. This incrusting matter is of different nature from that usually present in the walls of hyphae, because it dissolves completely when the sections are treated with dilute potassium hydrate solution; lactic acid does not destroy the incrusting matter.

Specimens examined:

Florida: Bayard, type, comm. by C. G. Lloyd (in Mo. Bot. Gard. Herb., 56609).

\section{HYPOLYSSUS}

Hypolyssus Persoon, Myc. Eur. 2: 6. 1825, emend. Berkeley, Hooker's London Jour. Bot. 1: 139. pl. 6, f. 1. 1842; Sacc. Syll. 
Fung. 6: 521. 1888; Engl. \& Prantl, Nat. Pflanzenfam. (1:1**): 127. 1898 .

Fructification urn-shaped or top-shaped, hard, corky; hymenium even, lateral.

In adopting the name Hypolyssus and defining it anew, Berkeley stated, loc. cit., "As Persoon's genus Hypolyssus is altogether effete, and its characters are very like those of the plant before us, I have thought it advisable to restore it."

This genus differs from Craterellus by not having the fructifications at all fleshy and by their becoming hard when dry.

1. Hypolyssus Montagnei Berkeley, Hooker's London Jour. Bot. 1: 139. pl. 6, f. 1. 1842; Sacc. Syll. Fung. 6: 521. 1888; Engl. \& Prantl, Nat. Pflanzenfam. $\left(1: 1^{* *}\right): 127$. text f. 70 E. 1898.

Plate 1, fig. 4.

An Hypolyssus foetidus Massee, Jour. Bot. 30: 197. pl. 325, f. 3-5. 1892; Sacc. Syll. Fung. 11: 115. 1895?

Type: in Kew Herb. probably.

Fructifications gregarious, dirty white, 1-2 $\mathrm{cm}$. high, hard when dry, solid, turbinate or urn-shaped, the apex sterile, convex at first, at length slightly depressed; stem slender, central, curved, shorter than the pileus when mature; hymenium covering the outside of the fructification with the exception of the apex, even or nearly so; spores hyaline, even, $3-4 \mu$ in diameter, none seen attached to basidia.

Fructifications 1-2 cm. high, $2-7 \mathrm{~mm}$. in diameter.

On rotten wood. Mexico, Central America, Guadeloupe, and South America to Bolivia. February in Mexico, July in Bolivia.

The fructifications are hard when dry but soften when moistened so that they may be readily sectioned; Craterellus taxophilus is of somewhat similar form but more fleshy consistency. In all the specimens cited below the hymenium is too deteriorated to show the basidia in my preparations. $H$. foetidus occurs on the island of St. Vincent in the region of $H$. Montagnei and was distinguished from the latter by Massee by fetid odor and rugulose hymenium, but there is no observation on record yet as to absence of odor for H. Montagnei. Mycological explorers rarely note such data. 
Specimens examined:

Mexico: near Sanborn, Oaxaca, C. R. Orcutt, 3936 (in N. Y. Bot. Gard. Herb. and Mo. Bot. Gard. Herb., 37345).

Honduras: P. Wilson, 237, comm. by N. Y. Bot. Gard. Herb. Guiana: Spruce, 70 (in Curtis Herb.).

Bolivia: Mapiri, A. M. Bang, distributed by Columbia College Herb., 1479 (in Burt Herb., and Mo. Bot. Gard. Herb., 5002).

\section{CYMATELLA}

Cymatella Patouillard, Soc. Myc. Fr. Bul. 15: 193. pl. 9, f. 4-6. 1899; Sacc. Syll. Fung. 16: 49. 1902.

Marasmioid fungi, minute, stipitate, reviving with moisture; pileus lacking a pellicle; hymenium inferior, lacking lamellae, even or slightly wavy; spores hyaline.

Cymatella is a genus of a few species of tropical fungi, segregated from Craterellus, with which the specimens agree in the even bymenium and consistency, but related to Marasmius in structure of the pileus and the reviving of the specimens with moisture. The specimens are not notably marasmioid in the recent gathering which I have seen and the genus seems unnecessary.

1. Cymatella minima Patouillard, Soc. Myc. Fr. Bul. 15: 193. pl. 9, f. 6. 1899; Sacc. Syll. Fung. 16: 49. 1902.

Plate 1, fig. 6.

Pileus plano-convex, reniform, glabrous, pale russet (roux), $3-4 \mathrm{~mm}$. broad, thin, very slightly fleshy, without a pellicle, the margin entire, straight, indented at the base; stem filiform, stuffed, $3 \mathrm{~mm}$. long, glabrous, black, marasmioid, a little larger towards the base, attached to the pileus eccentrically near the indentation; trama composed of loosely arranged, septate, pallidreddish hyphae 3-5 $\mu$ in diameter; hymenium inferior, dark red, even or with few radial, shallow undulations; basidia clavate, 20-23 $\times 5-6 \mu$, with 4 sterigmata; no cystidia; spores hyaline, even, ovoid, 3-4 $\mu$ long.

On decaying bark. Guadeloupe.

I have seen no specimens of $C$. minima. The figure, after Patouillard, somewhat resembles Craterellus Humphreyi, a much larger species, white in color and fleshy. 
2. C. pulverulenta (Berk. \& Curtis) Patouillard, Soc. Myc. Fr. Bul. 15 : 194. pl. 9, f. 4. 1899; Sacc. Syll. Fung. 16: 50. 1902. Plate 1, fig. 5.

Craterellus pulverulentus Berkeley \& Curtis, Linn. Soc. Bot. Jour. 10: 328. 1868; Sacc. Syll. Fung. 6: 520. 1888.

Type: in Kew Herb. and Curtis Herb.

Fructification pallid ferruginous; pileus orbicular, pulverulent, the margin inflexed; stem thickened towards the base, black; hymenium sparingly venose, colored like the pileus.

Pileus $2 \mathrm{~mm}$. broad; stem $21 / 2 \mathrm{~mm}$. long.

On bark of sticks. Cuba and Porto Rico. May and July. A collection of a dozen or so fructifications from Porto Rico by Professor Stevens, taken in connection with specimens of the type collection in Curtis Herb., shows that while the original description of $C$. pulverulenta by Berkeley \& Curtis, literally translated above, is correct as far as it goes it does not give details enough for critical comparison with $C$. minima. The specimens of $C$. pulverulenta are plano-convex rather than campanulate as stated by Patouillard, and the margin only slightly inflexed, entire but slightly notched behind near point of attachment of the stem which is sometimes nearly central but usually distinctly eccentric. The spores are hyaline, even, $3 \frac{1}{2} \times 2 \mu$ in the type, $3-6 \times 2-21 / 2 \mu$ in more copious occurrence in the Porto Rican gathering, and the hyphae slightly colored, 3-4 $\mu$ in diameter. The dry specimens in Curtis Herbarium now have the upper surface of the pileus Natal brown of Ridgway and the hymenium and the stem bone-brown.

Specimens examined:

Cuba: C. Wright, 564, type (in Curtis Herb.).

Porto Rico: Monte Alegullo, F. L. Stevens, 1358 (in Mo. Bot. Gard. Herb., 55402, and Stevens Herb.).

3. C. marasmioides (Berk. \& Curtis) Patouillard, Soc. Myc. Fr. Bul. 15: 194. pl. 9, f. 5. 1899; Sacc. Syll. Fung. 16: 50. 1902.

Craterellus marasmioides Berkeley \& Curtis, Linn. Soc. Bot. Jour. 10: 328. 1868; Sacc. Syll. Fung. 6: 520. 1888.

Type: in Curtis Herb. and Kew Herb. probably. 
Pileus eccentric, rugose, glabrous, rufous, the margin inflexed; stem springing from creeping rhizomorphs, thickened below, black; hymenial folds thick, venose; basidia simple; spores hyaline, even, globose, $4 \mu$ in diameter-only one found and this not attached to a basidium; no cystidia.

Pileus $1 \frac{1}{2}-2 \mathrm{~mm}$. in diameter; stem 1-3 mm. long, about 140 $\mu$ in diameter.

On dead ferns. Cuba.

The fructifications are solitary or in small clusters of up to 5 , branching from a common point on the bark and bone-brown throughout; stem central or eccentric in attachment to the pileus. The note on the label as to substratum is "on stumps."

Specimens examined:

Cuba: C. Wright, 32, type (in Curtis Herb.).

\section{SKEPPERIA}

Skepperia Berkeley, Linn. Soc. Bot. Trans. 22: 130. pl. 25, f. A. 1857; Sacc. Syll. Fung. 6: 603. 1888; Engl. \& Prantl, Nat. Pflanzenfam. ( $\left.1: 1^{* *}\right): 127$. text f. \%O. A-D. 1898.

Stem short, lateral, abruptly passing over and confluent for some distance with the upper side of the pileus; pileus clavate, eonvolute on each side so as to form a longitudinal groove, fibrous within.

Skepperia convoluta is the type species.

Skepperia is a genus of tropical fungi of which three species have been described; two of these occur in South America and one in the West Indies.

1. Skepperia spathularia (Berk. \& Curtis) Patouillard, Soc. Myc. Fr. Bul. 15: 194. pl. 9, f. S. 1899; Sacc. Syll. Fung. 16: 189. 1902.

Plate 1, fig. 3.

Craterellus spathularius Berkeley \& Curtis, Linn. Soc. Bot. Jour. 10: 328. 1868; Sacc. Syll. Fung. 6: 603. 1888.

Type: in Curtis Herb. and Kew Herb. probably.

Fructifications minute, stipitate, everywhere pinkish buff in dried condition; pileus oblique, spathulate; stem springing from an orbicular base, becoming glabrous; pileus in structure $40-80 \mu$ thick, composed of a layer of longitudinally arranged hyphae 
and the hymenial layer; hymenium inferior, nearly even; no cystidia; basidia simple; spores hyaline, even, 5-71/2 $\times 3-4 \mu$.

Dried fructifications about $21 / 2 \mathrm{~mm}$. long; pileus $1-11 / 2 \mathrm{~mm}$. long, $1 \mathrm{~mm}$. broad; stem $1 \mathrm{~mm}$. long, $120 \mu$ in diameter.

On dead wood in Cuba and on Nostoc coating rocks in Trinidad. Specimens examined:

Cuba: C. Wright, 3, type (in Curtis Herb.).

Trinidad: Maravel Beach, near Port of Spain, R. Thaxter (in Farlow Herb.).

\section{CYTIDIA}

Cytidia Quelet, Fl. Myc. Fr.-. 1888; Patouillard, Essai Tax. . . . ; Bourdot \& Galzin, Soc. Myc. Fr. Bul. 26: 222. 1910; Rea, Brit. Basid. 697. 1922.-Lomatia Karsten, Finska Vet.-Soc. Bidrag Natur och Folk 48: 403. 1889.-Auriculariopsis R. Maire, Rech. Cyt. Tax. 102. 1902, and Soc. Myc. Fr. Bul. 18: Suppl. 102. 1902; Sacc. Syll. Fung. 21: 423. 1912.

Fructifications coriaceous-gelatinous, cup-shaped, sessile, scattered or crowded, often confluent; hymenium even at first, becoming more or less wrinkled or veined; basidia simple; spores white.

Cytidia is a genus whose few species have usually been included in Corticium but differ from this genus in being resupinate by the middle only, with margins free as in some species of Stereum. The configuration of the hymenial surface is decidedly merulioid in our single indigenous species.

\section{Key to the Species}

White or nearly so, pubescent or tomentose............... flocculenta White villose; hymenium blood-red....................... C. salicina Deep olive-buff to drab; hymenium becoming coarsely merulioid ...S. C. tremellosa

1. Cytidia flocculenta (Fr.) v. Höhn. \& Litsch. K. Akad. Wiss. Wien Sitzungsber. 116: 758. 1907; Wiesner Festschr. Wien 61. 1908; Bourdot \& Galzin, Soc. Myc. Fr. Bul. 26: 222. 1910; Rea, Brit. Basid. 697. 1922.

Plate 1, fig. 7.

Thelephora flocculenta Fries, Elench. Fung. 1: 184. 1828.Corticium flocculentum Fries, Epicr. 559. 1838; Hym. Eur. 647. 1874; Sacc. Syll. Fung. 6: 605. 1888.-Cyphella ampla Léveillé, Ann. Sci. Nat. Bot. III. 9: 126. 1848; Fries, Hym. Eur. 662. 
1874; Sacc. Syll. Fung. 6: 667. 1888; Patouillard, Tab. Anal. Fung. 1: 113. f. 254. 1884.-Auriculariopsis ampla (Lév.) R. Maire, Soc. Myc. Fr. Bul. 18: Suppl. 102.pl. 9, f. 22. 1902; Sacc. Syll. Fung. 21: 423. 1912.-Stereum pubescens Burt, Mo. Bot. Gard. Ann. 7: 178. pl. 5.f. 50. 1920.

Fructifications membranaccous, cup-shaped, sessile, whitetomentose, the margin entire, free all around; hymenium veined, fawn-color or bright brown; spores white, even, $6-10 \times 3-4 \mu$.

Fructifications $3-10 \mathrm{~mm}$. in diameter, reflexed 1-3 $\mathrm{mm}$.

On Salix. Montana and Wyoming. April and May. Rare. In Europe, this fungus is more frequent on Populus. I described the Montana gathering as Stereum pubescens with some misgivings. A more recent collection from Wyoming has finally enabled me to refer this species to Cytidia flocculenta, a reference which I have confirmed by specimens kindly communicated to me by Bourdot. Since $C$. flocculenta occurs in the United States on Salix, gatherings in the past may have been referred to the common Cytidia (Corticium) salicina, from which it differs in smaller, more heavily tomentose pilei and much shorter spores.

Specimens examined:

France: Allier, H. Bourdot, 4726, and two unnumbered specimens; Aveyron, A. Galzin, 19021, comm. by H. Bourdot, 22632.

Montana: Sheridan, Mrs. L. A. Fitch, in Ellis Collection, 7014, type of Stereum pubescens (in N. Y. Bot. Gard. Herb., and Mo. Bot. Gard. Herb., 56784).

Wyoming: Boulder, F. S. Wolpert, comm. by J. R. Weir, 9742 (in Mo. Bot. Gard. Herb., 56222).

\section{C. salicina (Fries) Burt, n. comb.}

Thelephora salicina Fries, Syst. Myc. 1: 442. 1821.-Corticium salicinum Fries, Epicr. 558. 1838; Hym. Eur. 647. 1874; Sacc. Syll. Fung. 6: 605. 1888; Massee, Linn. Soc. Bot. Jour. 27: 118. pl. 6, f. 1. 1890.-Lomatia salicina (Fr.) Karsten, Finska Vet.Soc. Bidrag Natur och Folk 48: 404. 1889; Icones Hym. Fenniae, 6. f. 10. 1885.-An Cytidia rutilans (Pers.) Quelet in Rea, Brit. Basid. 698. 1922?

Plate 1, fig. 8.

Type: authentic specimen from Fries in Kew Herb. 
Fructifications coriaceous, soft, drying horn-like, rigid, pezizoid when young, becoming expanded, more or less confluent, affixed by the center, the margin free all around and upturned, minutely white-villose; hymenium blood-red, even at first, drying somewhat wrinkled; in structure $400-800 \mu$ thick, composed of parallel, longitudinally arranged and ascending hyphae with narrow lumen and walls gelatinously modified; basidia simple, with 2 or 4 sterigmata; spores hyaline, even, cylindric, curved, 12-15 $\times$ $31 / 2^{-5} \mu$ in American specimens, $16-18 \times 6-8 \mu$ in European specimens as recorded by Karsten also.

Fructifications 1-2 mm. in diameter at first, at length up to 6-12 $\mathrm{mm}$. long by confluence.

On dead limbs of Salix. Northern Europe and Canada and northern United States. May to December. Common.

Rea gives Corticium salicinum as a synonym of Cytidia rutilans (Pers.) Quel., with spores globose, $8 \mu$ in diameter. I do not find a species rutilans in the index of Persoon's 'Synopsis Fungorum' for any thelephoraceous genus and have not access to Quelet's 'Fl. Myc. France.' The globose spores point to a different species from Corticium salicinum Fries, with an authentic specimen of which, in Kew Herbarium, I compared one of my gatherings. The description of Thelephora cruenta Persoon, Syn. Fung., is too vague to take priority for the specific name over salicinum of Fries.

Specimens examined:

Exsiccati: Bartholomew, Fungi Col., 4218; Ellis, N. Am. Fungi, 609; Ell. \& Ev., Fungi Col., 1212; Shear, N. Y. Fungi, 54; de Thümen, Myc. Univ., 114.

Sweden: E. Fries (in Kew Herb.).

Finland: Mustiala, P. A. Karsten, in de Thümen, Myc. Univ., 114.

Austria: Gastein Salisb., Niessl (in Mo. Bot. Gard. Herb., 43459); Innsbruck, V. Litschauer.

Canada: J. Macoun.

Ontario: Byron, J. Dearness, in Bartholomew, Fungi Col., 4218; Ottawa, J. M. Macoun, 15, comm. by N. Y. State Mus. Herb. (in Mo. Bot. Gard. Herb., 56082); Toronto, J. H. Faull, Univ. Toronto Herb., 315 (in Mo. Bot. Gard. Herb., 44882). 
Maine: Cumberland, J. Blake, comm. by P. L. Ricker; Piscataquis County, W. A. Murrill, 2089 (in N. Y. Bot. Gard. Herb., and Mo. Bot. Gard. Herb., 61421).

New Hampshire: Shelburne, W. G. Farlow (in Mo. Bot. Gard. Herb., 4777, 4836).

Vermont: Middlebury, E. A. Burt, three collections and in Ell. \& Ev., Fungi Col., 1212; Shelburne, C. G. Pringle, 1044 (in N. Y. State Mus. Herb., and Mo. Bot. Gard. Herb., 55908).

Massachusetts: Cambridge, W. G. Farlow (in Mo. Bot. Gard. Herb., 4386).

Connecticut: Litchfield, Miss V. S. White (in N. Y. Bot. Gard. Herb., and Mo. Bot. Gard. Herb., 61360).

New York: Albany, C. H. Peck, in Ellis, N. Am. Fungi, 609, H. D. House (in N. Y. State Mus. Herb., and Mo. Bot. Gard. Herb., 59692); Alcove, C. L. Shear, in Shear, N. Y. Fungi, 54; East Galway, E. A. Burt; Ithaca, L. B. Walker, 3 (in Mo. Bot. Gard. Herb., 6693); Middle Grove, E. A. Burt; Van Etten, W. C. Barbour, 1299 (in N. Y. Bot. Gard. Herb., and Mo. Bot. Gard. Herb., 61666).

Pennsylvania: Trexlertown, W. Herbst, comm. by C. G. Lloyd, 0053.

Michigan: Ann Arbor, E. B. Mains, comm. by A. H. W. Povah, 888 (in Mo. Bot. Gard. Herb., 58173); East Lansing, G. H. Hicks (in Mo. Bot. Gard. Herb., 4850); Marquette County, W. Trelease (in Mo. Bot. Gard. Herb., 60659).

Wisconsin: Palmyra, comm. by Univ. Wis. Herb., 58.

Colorado: Placer, C. L. Shear, 1022; Canyon City, T. S. Brandegee (in N. Y. Bot. Gard. Herb., and Mo. Bot. Gard. Herb., $61427)$.

Manitoba: Shoal Lake, I. L. Conners, comm. by G. R. Bisby (in Mo. Bot. Gard. Herb., 58973).

Idaho: Priest River, J. R. Weir, 95, 357 (in Mo. Bot. Gard. Herb., 9534 and 17037 respectively).

Washington: Falcon Valley, W. N. Suksdorf, 2.

3. C. tremellosa Lloyd, Myc. Writ. 4. Myc. Notes 38: 516. text f. 512, 513. 1912.

Plate 1, fig. 9.

Type: in Lloyd Herb. probably. 
Fructifications coriaceous, soft, resupinate, at first circular, pezizoid, and with the thickened, paler margin slightly upturned, at length confluent, effused, and with the hymenial surface merulioid by the elevated confluent margins and reticulate veins, drying deep olive-buff to drab; hyphae with walls gelatinously modified, nodose-septate; basidia simple, with 2-4 sterigmata; spores white in spore collection, simple, even, 8-11 $\times 5-6$ $\mu$.

Fructifications at first 1-3 mm. in diameter, finally confluent over areas $3-8 \times 3-5 \mathrm{~cm}$.

On bark of decaying limbs of frondose species in low woods. Louisiana. November to June.

Although the young fructifications of $C$. tremellosa are decidedly pezizoid in aspect, yet, in the specimens seen by me, these small fructifications are in such close proximity to resupinate confluent masses of the same color that the resemblance to a Merulius is the more striking.

Specimens examined:

Louisiana: St. Martinville, A. B. Langlois, 2620, 2670, aw, 594

(in N. Y. Bot. Gard. Herb., and Mo. Bot. Gard. Herb., 61681); C. G. Lloyd, 2402 (in N. Y. Bot. Gard. Herb. and Burt Herb.).

\section{SOLENIA}

Solenia Persoon, Roemer Neues Mag. Bot. 1: 116. 1794; Syn. Fung. 675. 1801; Myc. Eur. 1: 334. 1822; Hoffman, Deutschl. Fl. 2: pl. 8. 1795; Fries, Syst. Myc. 2: 200. 1823; Hym. Eur. 595. 1874; Sacc. Syll. Fung. 6: 424. 1888; Engl. \& Prantl, Nat. Pflanzenfam. (1:1**):129. 1898; Rea, Brit. Basid. 701. 1922.

Fructifications coriaceous or membranaceous, sessile or nearly so, cylindric or turbinate, gregarious, fasciculate, rarely solitary, but not joined together except by confluence, seated on a superficial, felt-like, floccose and sometimes fugacious mycelium; basidia simple; spores white or colored.

The type species is Solenia candida Pers.

Solenia is closely related to Cyphella but differs from the latter by more numerous and less scattered fructifications which are more cylindric in the case of most species, and in having the gregarious fructifications seated on a more or less manifest mycelium. The 
priority of Persoon's publication of Solenia is clearly established by Hoffmann's own work, for on the page of text following plate 8 he gives the full title of Persoon's work and its place of publication.

\section{Key to the Species}

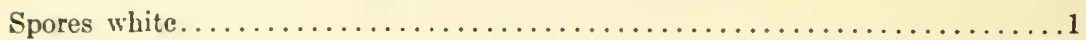

Spores colored.............................. S. endophila

1. Fructifications white or but slightly cream-colored...........

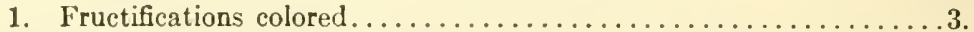

2. Fructifications white, scattered, cylindric, mouth not contracted; spores subglobose.............................. Sandida

2. Fructifications white, fasciculate, mouth contracted; spores subglobose

...................................... fasciculata

2. Fructifications straw-color or shining white; in California...12. S. gracilis

2. Fructifications white, crowded, confluent into a reticulate form; spores $41 / 2-5 \times 4-41 / 2 \mu \ldots \ldots \ldots \ldots \ldots \ldots \ldots \ldots \ldots \ldots . \ldots \ldots . . \ldots \ldots$. S. polyporoidea

2. Fructifications densely crowded, slightly tinted with cream; spores $4-6 \times 2-3 \mu \ldots \ldots \ldots \ldots \ldots \ldots \ldots \ldots \ldots \ldots . . \ldots \ldots . . \ldots \ldots$. conferta

2. Fructifications white, cylindric, villose; in Sweden.............13. S. villosa

3. Fructifications ochraceous; spores $10-11 \times 4 \frac{1}{2} \mu$; on stems of ferns.............................. filicina

3. Fructifications sulphur-colored; spores subglobose...6. S. sulphurea

3. Fructifications some shade of brown; spores $6-11 \times 1 \frac{1}{2}-4 \frac{1}{2} \mu$

3. Fructifications pallid neutral gray, cylindric-clavate or pyriform; spores $9 \times 5 \frac{1}{2} \mu$; in California.............. cinerea

3. Fructifications cinereous, cup-shaped, sessile; spores $41 / 2-61 / 2 \times$ $41 / 2-5 \mu \ldots \ldots \ldots \ldots \ldots \ldots \ldots \ldots \ldots \ldots . . \ldots \ldots$. . poriaeformis

3. Fructifications partially buried in the subiculum; spores $5-6 \times$ $3 \mu$; in Venezuela.................... S. subporiaeformis

1. Solenia candida Persoon, Roemer Neues Mag. Bot. 1: 116. 1794; Syn. Fung. 676. 1801; Myc. Eur. 1:334. 1822; Hoffmann, Deutschl. Fl. 2: pl. 8, f. 1. 1795; Fries, Syst. Myc. 2: 200. 1823; Hym. Eur. 596. 1874; Sacc. Syll. Fung. 6: $424 . \quad$ 1888; Bourdot \& Galzin, Soc. Myc. Fr. Bul. 26: 226. 1910; Rea, Brit. Basid. 702. 1922.

Fructifications scattered or solitary, 2-3 mm. high, cylindric, shining white, glabrous; spores hyaline, even, $4-5 \times 3 \frac{1}{2^{-4}} \mu$.

On rotten wood, New York to Louisiana, and on palm in Bermuda. August to December. Rare.

The specimens which I have referred to S. candida are white when fresh but becoming pale pinkish buff in the herbarium, uniformly cylindric, often only $1 \mathrm{~mm}$. long by $150 \mu$ in diameter, 
and notable by the mouths being nearly or quite the full diameter of the cavity of the fructification, as though the fructification were truncate. In Hoffmann's illustration, cited for $S$. candida by Persoon in his following works, the enlarged figure shows the fructifications as true cylinders with mouths open the full width of the cavity. In this figure the fructifications are enlarged to length of about $4 \mathrm{~mm}$. and diameter of about $1 \mathrm{~mm}$. and about the same distance apart as their length. In the collections which I refer to $S$. candida, the fructifications may be closer together than their length but always with small spaces between the fructifications, which are soft and crush easily under the cover glass in preparations.

Specimens examined:

New Hampshire: Hanover, G. R. Lyman, 32 (in N. Y. Bot. Gard. Herb., and Mo. Bot. Gard. Herb., 61693).

New York: Buffalo, G. W. Clinton (in U. S. Dept. Agr. Herb., under the name Solenia fasciculata, and in Burt Herb.); East Galway, E. A. Burt.

Louisiana: St. Martinville, A. B. Langlois, 1743.

Bermuda: S. Brown, N. L. Britton \& F. J. Seaver, 1499 (in N. Y. Bot. Gard. Herb., and Mo. Bot. Gard. Herb., 61649).

2. S. fasciculata Persoon, Myc. Eur. 1: 335. pl. 12, f. 8 and 9. 1822; Fries, Syst. Myc. 2: 200. 1823; Hym. Eur. 596. 1874; Schweinitz. Am. Phil. Soc. Trans. N. S. 4: 180. 1832; Morgan, Cincinnati Soc. Nat. Hist. Jour. 9: 7. 1886; Sacc. Syll. Fung. 6: 424. 1888; Bourdot \& Galzin, Soc. Myc. Fr. Bul. 26: 225. 1910 ; Rea, Brit. Basid. 702. 1922.-An Solenia gracilis Copeland, Ann. Myc. 2: 508. 1904?

Fructifications gregarious and usually fasciculate, cylindricclavate, somewhat enlarged towards the apex, 2-7 mm. high, white, minutely silky, almost smooth, sometimes rising from a thin, white mycelium; spores of European specimens white, even, 4-51/2 $\times 3-4 \mu, 4-6 \times 3-5 \mu$ in American specimens.

The specimens of $S$. fasciculata from France, sent to me by Bourdot and determined by him, have retained their white color for the seven years since gathered; they are seated on a white subiculum, common to the group of fructifications, and are 
soft and easily crushed under the cover-glass in preparations and the hairs on the outside of the fructifications are colorless and soft in my preparations stained with eosin. The American specimens become pallid in the herbarium in a short time and may have spores slightly larger than European specimens. Two of our gatherings cited below have still the thin mycelium or subiculum, common to small groups of young fructifications; this apparently disappears as the fructifications become older and is not evident in most gatherings. The diameter of the mouth is somewhat smaller than that of the cavity into which it opens in this species, so that the apex is merely obtuse.

Specimens examined:

Exsiccati: Ellis, N. Am. Fungi, 937, under the name Solenia villosa; Ravenel, Fungi Car. 4: 21.

France: Loubotis, A. Galzin, 18240, 18241, comm. by H. Bourdot, 16094 and 15752 respectively.

Canada: Toronto, J. H. Faull, Univ. Toronto Herb., 640 (in Mo. Bot. Gard. Herb., 44909).

Vermont: Middlebury, E. A. Burt, three gatherings.

New York: Altamont, E. A. Burt; East Galway, E. A. Burt. New Jersey: Newfield, Ellis \& Harkness, in Ellis, N. Am. Fungi, 937.

Virginia: Mountain Lake, W. A. Murrill, 403 in part (in Mo. Bot. Gard. Herb., 54531).

South Carolina: H. W. Ravenel, in Ravenel, Fungi Car. 4: 21. Florida: Daytonia, R. Thaxter, comm. by Farlow Herb., 234 (in Mo. Bot. Gard. Herb., 63044).

Louisiana: St. Martinville, A. B. Langlois, 2998.

3. S. polyporoidea Peck, Mss. n. sp.

Solenia villosa Fr. var. polyporoidea Peck, N. Y. State Mus. Rept. 41: 86. 1888 .

Type: in N. Y. State Mus. Herb.

At first granuliform and distinct, finally confluent along the sides in contact and forming a more or less connected, reticulate layer with the bare wood showing in many little areas $1 / 2-1 \mathrm{~mm}$. in diameter; no subiculum present; fructifications pure white, sessile, tubular, $700 \mu$ long, $200-300 \mu$ in diameter, about 5 to a 
mm. where confluent, the free surfaces of the exterior clothed with weak, matted, hyaline, even hairs up to $30 \mu$ long by $1 \mu$ in diameter; spores copious, hyaline, even, subglobose, slightly flattened on one side, $41 / 2-5 \times 4-41 / 2 \mu$.

Covering areas $3-7 \mathrm{~cm}$. long, $1 / 2 \mathrm{~cm}$. broad.

On decorticated, decaying wood of Tsuga. Adirondack Mountains, New York.

The hairs on the exterior are like ordinary hyphae of the walls and radiate outward only up to $30 \mu$ rather than like the much larger, distinctive, external hairs of $C$. fasciculata; the cups are so firmly grown together that they are more or less mutilated and the walls torn in teasing the fructifications apart with needles under the dissecting microscope when immersed in water. This species is noteworthy by the confluence of the cups as well as by the matted, weak hairs.

Specimens examined:

New York: Adirondack Mts., C. H. Peck, type (in N. Y. State Mus. Herb.).

4. S. conferta Burt, n. sp.

Type: in Mo. Bot. Gard. Herb.

Fructifications crowded, sometimes up to 4 to a $\mathrm{mm}$. and then somewhat confluent, cylindric, white with slight creamy tint, clothed with slender, appressed, even hairs $75 \times 21 / 2-3 \mu$, subhyaline, slightly yellowish in preparations stained with eosin; basidia simple, $12-15 \times 4 \mu$, with 4 sterigmata; spores white in a spore collection, even, 4-6 6 2-3 $\mu$.

Fructifications about $1 \mathrm{~mm}$. high, 200-300 $\mu$ in diameter, covering areas $10 \mathrm{~cm}$. or more in diameter.

On rotten wood. Alabama and Missouri. November.

This species may be only a small-spored form of S. fasciculata but it seems to me distinct by its fructifications becoming densely crowded and somewhat confluent, by the smaller spores, and by the hairs being slightly yellowish. It was distributed by Ravenel under the name $S$. villosa, with the European concept of which it does not agree. Where most densely crowded, the fructifications shrink apart in drying, showing bare areas of wood as in $S$. polyporoidea from which $S$. conferta differs in oblong 
spores and larger, true, external hairs and less marked confluence of fructifications.

Specimens examined:

Exsiccati: Ravenel, Fungi Car. 5: 42, under the name Solenia villosa.

Alabama: Peters, in Ravenel, Fungi Car. 5: 42.

Missouri: Meramec Highlands, L. O. Overholts, type (in Mo. Bot. Gard. Herb., 14505).

5. S. filicina Peck, N. Y. State Mus. Rept. 28: 52. 1876; Sacc. Syll. Fung. 6: 426. 1888.

An S. villosa Fr? var., Bourdot \& Galzin, Soc. Myc. Fr. Bul. 26: 225. 1910?

Type: in N. Y. State Mus. Herb.

"Cups springing from an ochraceous, white-margined, tomentose subiculum, elongated, clavate or cylindrical, deflexed, clothed with appressed hairs or tomentum, ochraceous; spores hyaline, broadly fusiform, containing one or two nuclei," even, 10-11 $\times 4 \frac{1}{2} \mu$; basidia simple.

Fructifications about $250-350 \mu$ in diameter.

Base of living fern stems. Lake Pleasant, New York. August.

Peck noted that the basal part of the cups sometimes turns brown and shrinks in drying so that they appear stipitate. In the course of nearly fifty years, the subiculum and cups have become clay color with the margin paler. The hairs clothing the fructifications are only very slightly colored, even, flexuous, $75-85 \times 3-31 / 2 \mu$, tapering to a sharp tip; the spores are not curved but straight, with equal sides, tapering to both base and apex.

Specimens examined:

New York: Lake Pleasant, C. H. Peck, type (in N. Y. State Mus. Herb.).

6. S. sulphurea Saccardo \& Ellis, Michelia 2: 564. 1882; Sacc. Syll. Fung. 6: 426. 1888.

Type: probably in Saccardo Herb., and N. Y. Bot. Gard. Herb.

Fructifications gregarious, sometimes rather crowded and up to 2-3 to a mm., cup-shaped, short-stemmed, sulphur-colored, 
1924]

fading in the herbarium, strigose-pilose, the margin whitish fringed; hairs minutely rough, flexuous, 75-90 $\times 4-41 / 2 \mu$, sharppointed; spores hyaline, even, subglobose, $6-71 / 2 \mu$ in diameter, copious.

Fructifications $250-400 \mu$ in diameter and of about the same height.

On dead places in living trunk of Magnolia glauca. Newfield, New Jersey. January and April. Apparently local.

The specimens which I have seen were collected forty years ago and now show only traces of the original color, which is noted on the packets as "yellowish white when fresh, with white fringed margin, and disk white or nearly so." The larger globose spores should distinguish this species from Cyphella sulphurea and C. laeta.

Specimens examined:

New Jersey: Newfield, J. B. Ellis, four gatherings (in N. Y. Bot.

Gard. Herb., Burt Herb., and Mo. Bot. Gard. Herb., 61697$61700)$.

7. S. anomala (Pers.) Fuckel, Symb. Myc., App. 1: 290. 1872; Fries, Hym. Eur. 596. 1874; Sacc. Syll. Fung. 6: 427. 1888; Bourdot \& Galzin, Soc. Myc. Fr. Bul. 26: 227. 1910; Rea, Brit. Basid. 702. 1922.

Peziza anomala Persoon, Obs. Myc. 1: 29. 1796; Syn. Fung. 656. 1801; Fries, Syst. Myc. 2: 106. 1823.-P. stipata Persoon, Myc. Eur. 1:270. 1822.-Solenia ochracea Hoffmann, Deutschl. Fl. 2: $p l .8, f .2 . \quad 1795$; Persoon, Syn. Fung. 675. 1801; Myc. Eur. 1:334. 1822; Fries, Syst. Myc. 2: 201. 1823; Hym. Eur. 596. 1874; Morgan, Cincinnati Soc. Nat. Hist. Jour. 9: 8. 1886; Sacc. Syll. Fung. 6: 425. 1888; Karsten, Finska Vet.-Soc. Bidrag Natur och Folk 48: 283. 1889; Bourdot \& Galzin, loc. cit.-S. anomaloides Peck, Torr. Bot. Club Bul. 25:326. 1898; Sacc. Syll. Fung. 16: 173. 1902.-S. anomala var. ochracea (Hoffm.) Berk. in Rea, loc. cit.-An S. confusa Bresadola, Ann. Myc. 1: 84. 1903 ?

Fructifications drying Dresden brown, snuff-brown, or Rood's brown, turbinate or pyriform, crowded or scattered, clothed with thick-walled hairs $21 / 2-3 \mu$ in diameter which give their color 
to the fructifications and at the apex of the fructifications are often rough-walled near their tips; hymenium paler, urceolate, the margin incurved; basidia simple, with 4 sterigmata; spores hyaline, even, cylindric, curved, 6-11 $\times 1 \frac{1}{2}-41 / 2 \mu$.

Fructifications in dried condition $1 / 2-1 \mathrm{~mm}$. high, 200-300 $\mu$ in diameter, where crowded $3-4$ to a $\mathrm{mm}$.

Usually crowded into small areas on pustules or crevices in the bark of dead twigs of Alnus, Prunus, Quercus, Betula, Salix, etc., or covering broad areas of decorticated wood, fewer and more scattered when the wood is very rotten. Throughout Europe, Newfoundland to Louisiana, westward to Oregon and British Columbia, and in Porto Rico. August to May. Common.

European specimens of S. anomala in the exsiccati cited below have somewhat larger spores than those of gatherings from eastern United States but do not differ at all from those of the extreme West. Those from British Columbia have spores $7-10 \times$ $4-41 / 2 \mu$ and hairs rough near the tips, agreeing in both respects with the Westendorp distribution from Belgium. In one Colorado and one Montana gathering the spores are $3 \mu$ thick, as in those of the Berkeley and the Libert distributions, and in another Colorado specimen $3-31 / 2 \mu$ thick as in the Cavara distribution. They are $2 \frac{1}{2} \mu$ thick in two Montana gatherings and in the Rabenhorst distribution, although many of the latter are only $2 \mu$ thick as is the usual thickness of spores of New York and New England gatherings. In my opinion these spore differences do not warrant specific distinction, and I doubt furthermore whether $S$. confusa of Europe, separated from $S$. anomala on the sole ground of spores $7-10 \times 2-21 / 2 \mu$, is really distinct from the latter. The distributions by Berkeley, Libert, and Cavara are true intermediates.

Specimens examined:

Exsiccati: Bartholomew, Fungi Col., 2085, under the name S. ochracea; Berkeley, Brit. Fungi, 260; Cavara, Fungi Longobardiae, 108; Cooke, Fungi Brit., 405, under the name $S$. ochracea; Desmazières, Crypt. France, 1059; Ellis, N. Am. Fungi, 611, under the name S. ochracea; Reliquiae Farlowianae, 363; Karsten, Fungi Fenniae Exs., 7; Kunze, Fungi Sel. Exs., 301; Libert, Pl. Crypt. Arduennae, 227; Rabenhorst, Herb. 
Myc., 307 ; Ravenel, Fungi Car. 4: 7 ; Saccardo, Myc. Veneta, 1407, 1408; Sydow, Fungi Exotici, 323; Westendorp, Herb. Crypt. Belge, 398.

Finland: P. Karsten, in Karsten, Fungi Fenniae Exs., 7.

Sweden: Tyroso, L. Romell, No. A in part.

Germany: Dresden, in Rabenhorst, Herb. Myc., 307.

Austria: Sonntagberg, P. Strasser (in Mo. Bot. Gard. Herb., 42683).

Switzerland: G. Winter, in Kunze, Fungi Sel. Exs., 301.

Italy: Padua, in Cavara, Fungi Longobardiae, 108; in Saccardo, Myc. Veneta, 1407, 1408.

France: in Desmazières, Crypt. France, 1059; in Libert, Pl. Crypt. Arduennae, 227.

Belgium: Bruges, in Westendorp, Herb. Crypt. Belge, 398.

England: in Berkeley, Brit. Fungi, 260; Shrewsbury, W. Phillips, in Cooke, Fungi Brit., 405, under the name $S$. ochracea.

Newfoundland: Bay of Islands, A. C. Waghorne (in Mo. Bot. Gard. Herb., 4601).

Canada: Ontario, Kenora, A. H. R. Buller, 559 (in Mo. Bot. Gard. Herb., 58979); London, J. Dearness, in Bartholomew, Fungi Col., 2085, and Sydow, Fungi Exotici, 323.

Maine: Kittery Point, R. Thaxter \& E. A. Burt.

Vermont: Middlebury, E. A. Burt, three collections.

Massachusetts: Arlington, E. A. Burt; Cambridge, M. A. Barber; Milton, H. Webster, 800; Newton, M. A. Barber (in Mo. Bot. Gard. Herb., 3913); Sharon, W. G. Farlow (in Mo. Bot. Gard. Herb., 62749); A. P. D. Piguet, in Reliquiae Farlowianae, 363.

New York: Bronx Park, W. A. Murrill (in N. Y. Bot. Gard. Herb., and Mo. Bot. Gard. Herb., 61688); Syracuse, A. H.W. Povah, 890 (in Mo. Bot. Gard. Herb., 58175); L. M. Underwood (in N. Y. Bot. Gard. Herb., and Mo. Bot. Gard. Herb., 61690); White Plains, L. M. Underwood (in Mo. Bot. Gard. Herb., 61687).

Pennsylvania: Bethlehem, Ellis \& Harkness, in Ellis, N. Am. Fungi, 611.

South Carolina: H. W. Ravenel, in Ravenel, Fungi Car. 4: 20. L ouisiana: St. Martinville, A. B. Langlois. 
Michigan: Beal, 214, type of Solenia anomaloides (in N. Y. State Mus. Herb.).

Iowa: Webster County, O. M. Oleson, 446 (in Mo. Bot. Gard. Herb., 14556); Woodbine, Humphrey \& Edgerton, comm. by C. J. Humphrey, 6510 (in Mo. Bot. Gard. Herb., 42920).

Missouri: Concordia, Demetrio (in Mo. Bot. Gard. Herb., 4592); Creve Coeur, S. M. Zeller, 1567 (in Mo. Bot. Gard. Herb., 55567).

Nebraska: Lincoln, L. B. Walker (in Mo. Bot. Gard. Herb., 55016).

Colorado: Geneva, F. J. Seaver \& E. Bethel (in N. Y. Bot. Gard. Herb., and Mo. Bot. Gard. Herb., 61692); Tolland, F. J. Seaver \& E. Bethel (in N. Y. Bot. Gard. Herb., and Mo. Bot. Gard. Herb., 61691).

Montana: Choteau, J. A. Hughes, comm. by J. R. Weir, 5489 (in Mo. Bot. Gard. Herb., 55947); Helena, F. D. Kelsey (in Mo. Bot. Gard. Herb., 62750); Missoula, J. R. Weir, 424 (in Mo. Bot. Gard. Herb., 22430); Sheridan, Miss Fitch (in N. Y. Bot. Gard. Herb., and Mo. Bot. Gard. Herb., 61689).

Oregon: Corvallis, S. M. Zeller, 2064 (in Mo. Bot. Gard. Herb., 57504).

British Columbia: Sidney, J. Macoun, 67 (in Mo. Bot. Gard. Herb., 5745); Victoria, J. Macoun, 563 (in Mo. Bot. Gard. Herb., 55308).

Porto Rico: Rio Piedras, J. A. Stevenson \& R. C. Rose, 6532 (in Mo. Bot. Gard. Herb., 55657).

Jamaica: Chester Vale, W. A. \& E. L. Murrill, 347, comm. by N. Y. Bot. Gard. Herb.

8. S. cinerea Burt in Millspaugh \& Nuttall, Flora Santa Catalina Island, 315. 1922.

Type: in Field Mus. Nat. Hist. Herb. and Mo. Bot. Gard. Herb.

Fructifications cespitose, 30-100 in dense circular clusters on cracks and pustules of the bark, short-stipitate, cylindric-clavate or pyriform, pallid neutral gray of Ridgway, minutely hairy, the apex obtuse and pore nearly closed; surface hairs colored, flexuous, $100 \times 31 / 2 \mu$, paler towards the tips and there rough- 
1924]

BURT-THE THELEPHORACEAE OF NORTH AMERICA. XIII

walled; basidia simple, $30 \times 6 \mu$, with 4 slender sterigmata; spores hyaline, even, cylindric or slightly curved, $71 / 2-10 \times 4-$ $51 / 2 \mu$, usually $9 \times 5 \frac{1}{2} \mu$.

Fructifications $700 \mu$ high, $200-300 \mu$ in diameter.

On bark of rotting oak. California. May.

The fructifications are colored like those of $S$. poriaeformis but in other respects are more like $S$. anomala when growing on pustules and crevices of the bark.

Specimens examined:

California: Avalon, Santa Catalina Island, L. W. Nuttall, 396, type (in Field Mus. Nat. Hist. Herb., and Mo. Bot. Gard. Herb., 57610).

9. S. poriaeformis (Pers.) Fries, Hym. Eur., 597. 1874; Winter in Rabenhorst, Krypt.-Fl. 1: 391. 1884; Bourdot \& Galzin, Soc. Myc. Fr. Bul. 26: 226. 1910.

Peziza poriaeformis Pers. $\gamma$ of Peziza anomala Pers. Syn. Fung. 656. 1801.-P.? poriaeformis (Pers.) De Candolle, Fl. France 6: 26. 1815; Fries, Syst. Myc. 2: 106. 1823.-P.tephrosia Pers. Myc. Eur. 1: 271. 1822.-Solenia poriaeformis (DC.) Fuckel, Symb. Myc. App. 1:290. 1872.--Sacc. Syll. Fung. 6: 428. 1888; Coker, Elisha Mitchell. Scientif. Soc. Jour. 36: 151. pl. 15, pl. 30. f. 4-6. 1921; Rea, Brit. Basid.703. 1922.-An Peziza pruinata Schweinitz, Naturforsch. Ges. Leipzig Schrift. 1: 120. 1822?-An P. Daedalea Schweinitz, Am. Phil. Soc. Trans. N. S. 4: 174. 1832?

Illustrations: Brefeld, Untersuch. Myk. 7: pl. 11, f. 21. 1888; Coker, loc. cit.

Fructifications about $1 \mathrm{~mm}$. high, cinereous, light neutral gray or hair-brown, cup-shaped, sessile, hairy, more or less crowded, 2-4 to a mm., seated on a grayish mycelium; hymenium pale gray, concave; flesh thin, brownish; basidia simple, with 2-4 sterigmata; spores hyaline, even, subglobose, $41 / 2^{-61 / 2} \times 41 / 2-$ $5 \mu$.

On decaying limbs and logs of frondose species. Europe, New Jersey to Alabama, and in Minnesota. April to January. Infrequent.

This species covers small areas $1-3 \mathrm{~cm}$. long by $1 / 2-1 \mathrm{~cm}$. broad on bark of oak, birch, maple, grape, etc. It has the aspect of a 
cinereous, crustaceous lichen bearing numerous small apothecia. It is distinguished from $S$. subporiaeformis by larger cups and more globose spores. I failed to study the authentic specimens of Peziza Daedalea Schw. and Peziza pruinata Schw. when there was an opportunity.

Specimens examined:

Exsiccati: Ell. \& Ev., N. Am. Fungi, 2317; Jaap, Fungi Sel. Exs., 65; Ravenel, Fungi Car. 1: 38, under the name Peziza pruinata Schw.; Ravenel, Fungi Car. 1: 37, under the name Peziza Daedalea Schw.

Sweden: Femsjö, L. Romell.

Germany: Brandenburg, in Jaap, Fungi Sel. Exs., 65.

France: Aveyron, A. Galzin, 1784, comm. by H. Bourdot, 4747. New Jersey: Newfield, J. B. Ellis, in Ell. \& Ev., N. Am. Fungi, 2317.

Maryland: Takoma Park, C. L. Shear, 1087.

North Carolina: Chapel Hill, W. C. Coker, 4686 (in Mo. Bot. Gard. Herb., 57331).

South Carolina: H. W. Ravenel, in Ravenel, Fungi Car. 1: 37,38 .

Alabama: Auburn, F. S. Earle (in N. Y. Bot. Gard. Herb., and Mo. Bot. Gard. Herb., 57330).

Minnesota: Vermilion Lake, E. W. D. Holway (in U. S. Dept. Agr. Herb., Burt Herb., and Mo. Bot. Gard. Herb., 4800), and J. C. Arthur, L. H. Bailey \& E. W. D. Holway, 2548 (in Mo. Bot. Gard. Herb., 4599).

10. S. subporiaeformis Burt, n. sp.

Type: in Farlow Herb. and Mo. Bot. Gard. Herb.

Fructifications spherical, 120-150 $\mu$ in diameter, 4-5 to a mm., nearly buried in the pale neutral gray subiculum, with the white mouths and adjacent portion of the wall protruding; mouth about 60-80 $\mu$ in diameter; hymenium black as seen from above, the subhymenium opaque, nearly black; basidia simple, pyriform, 9-12 $\times 5-6 \mu$; spores hyaline, even, flattened on one side, 5-6 $\times 3 \mu$.

Fructifications in small patches $4 \times 3 \mathrm{~cm} ., 3 \times 2 \mathrm{~cm}$, , and $3 \times 1 \frac{1}{2} \mathrm{~cm}$. in the three specimens collected. 
On decorticated, very rotten wood. Margarita Island, Venezuela. July.

This species is closely related to $S$. poriaeformis, but may be distinguished from the latter by smaller, partially buried fructifications, smaller basidia, and smaller spores of elongated rather than subglobose form. It may possibly range farther north into the West Indies.

Specimens examined:

Venezuela: Margarita Island, A. F. Blakeslee, type (in Farlow Herb., and Mo. Bot. Gard. Herb., 56064).

11. S. endophila (Ces.) Fries, Hym. Eur. 705. 1874; Sacc. Syll. Fung. 6: 427. 1888.

Cyphella endophila Cesati in Rabenhorst, Fungi Eur., 1513, with description. 1872; Mattirolo, Accad. Scienze Torino Atti 22:-pl. 4. 1887.

Type: type distribution in Rabenhorst, Fungi Eur., 1513.

Fructifications densely crowded together, curving upward from a continuous carpet (often evanescent) of short, suberect, colored hyphae, furfuraceous-villose, at first whitish, becoming ochraceous when old, attenuated towards the base into a short stem; the disk rather pale; hairs colored, even, flexuous, 40-45 $\times 3-4 \frac{1}{2} \mu$; basidia simple, $12-14 \times 4 \frac{1}{2}-5 \mu$; spores colored, even, $6-7 \times 4-5 \mu$, copious.

Fructifications $1 \mathrm{~mm}$. long, 200-300 $\mu$ in diameter, usually somewhat scattered but crowded in some places up to 2-3 to a $\mathrm{mm}$.

On rotten, decorticated wood and bark of Populus and other frondose species. Southern Europe, Maine, Vermont, Florida, Colorado, and South America. August to March. Rare.

A great deal of powdery matter covers the hairy fructification and is the cause of its whitish color. S. endophila is readily distinguished from our other species by its colored spores.

Specimens examined:

Exsiccati: Rabenhorst, Fungi Eur., 1513, type distribution; Theissen, Dec. Fung. Brasilium, 165.

Italy: Cesati, in Rabenhorst, Fungi Eur., 1513.

Maine: Kittery Point, R. Thaxter, comm. by W. G. Farlow, 1 (in Mo. Bot. Gard. Herb., 43804). 
Vermont: Middlebury, E. A. Burt.

Florida: Palm Beach, R. Thaxter, comm. by Farlow Herb., 247 (in Mo. Bot. Gard. Herb., 63046).

Colorado: Denver, F. J. Seaver \& E. Bethel (in N. Y. Bot. Gard.

Herb., Burt Herb., and Mo. Bot. Gard. Herb., 61695).

Venezuela: Margarita Island, A. F. Blakeslee, comm. by Farlow

Herb. (in Mo. Bot. Gard. Herb., 56067).

Brazil: Rick, in Theissen, Dec. Fung. Brasilium, 165.

\section{SPECIES IMPERFECTLY KNOWN}

12. S. gracilis Copeland, Ann. Myc. 2: 508. 1904; Sacc. Syll. Fung. 21: 362. 1912.

"Sparsa; cupulis primo urceolatis, brevissime stipitatis, demum cylindraceis, denique late sessilibus, sursum attenuatis, oribus incrassatis, integris, glabris, stramineis nitentibus, vel candidis et deorsum fuscescentibus, $0.5 \mathrm{~mm}$. altis; sporis globosis, $7.5-8 \mu$ diam.

"Ad lignum putridum Alni. Saratoga." [California.]

13. S. villosa Fries, Syst. Myc. 2: 200. 1823; Hym. Eur. 596. 1874; Schweinitz, Am. Phil. Soc. Trans. N. S. 4: 180. 1832; Sacc. Syll. Fung. 6: 425. 1888.

Fructifications gregarious, cylindric, villose, white. Related to the preceding species (S. candida, S. fasciculata, S. pallens) but a little larger, distinctly villose, by this approaching $S$. ochracea. On fallen rotten wood.

The above is a translation of the original description, to which I have found no distinctive additions from later European research. The description is given here because American mycologists have so frequently referred gatherings to $S$. villosa, a species which seems to be imperfectly known in its own country.

\section{MATRUCHOTIA, MICROSTROMA, PROTOCORONOSPORA}

Matruchotia varians Boulanger, Rev. Gen. Bot. 5: 401. pl. 12-14. 1893; Rev. Myc. 16: 68. pl. 142-144. 1894. Sacc. Syll. Fung. 11: 118. 1895.

Under the above name Boulanger described as a new genus and new species a fungus of soft consistency and aspect of the 
Hyalostilbeae but having spores borne one or two to a sporophoreusually but one. This fungus appeared in cultures of the bark of Piscidia erythrina, used in pharmacy and obtained from South America northward to Florida. On account of sometimes two spores to a spore-bearing cell Boulanger would class Matruchotia as a Basidiomycete-as an intermediate connecting the Basidiomycetes with the Hyphomycetes and showing their phylogenetic origin from the latter.

The account and illustrations present Matruchotia as having an erect trunk composed of cohering hyphae, branched above, and bearing spores along the sides of the trunk and branches and at the tips of the final branchlets.

I am disposed to regard Matruchotia as a genus of the Stilbiaceae and do not attach great importance to the fact that the spores are sometimes in twos.

The range of Matruchotia is northward to Maine at least and on other kinds of wood than Piscidia, for while collecting at Kittery Point with Professor Thaxter we found plentifully there a soft, white, mucedinous fungus which he recognized as Matruchotia.

Microstroma Niessl, Mähr. Crypt. Fl., 163. 1861; Sacc. Syll. Fung. 4: 9. 1886; Engl. \& Prantl, Nat. Pflanzenfam. $\left(1: 1^{* *}\right)$ : 105. 1898.

This genus is represented in North America by $M$. albus, $M$. Juglandis, $M$. leucosporum, $M$. americanorum, and $M$. ingainicola. The more frequent species occur as small white patches on living leaves of Carya, Juglans, Quercus, etc. Some authors have referred Microstroma to the Basidiomycetes on account of several spores being produced at the apex of the spore-bearing cell. R. Maire, Rec. publ. Occ. Jubilé sc. Prof. Le Monnier 131-139. 1913, concludes that Microstroma is not a Basidiomycete but one of the Melanconieae.

Protocoronospora Atkinson \& Edgerton, Jour. Myc. 13: 186. 1907; Sacc. Syll. Fung. 21: 421. 1912; Wolf, Elisha Mitchell Scientif. Soc. Jour. 36: 82. 1920.

The type species, Protocoronospora nigricans Atk. \& Edg., is a virulent parasite on all parts above ground, including the pods, of Vicia sativa and V. villosa. Protocoronospora was proposed as 
a genus of the Thelephoraceae because the spores are borne in a whorl at the apex of the spore-bearing cell. Wolf, loc. cit., has presented the morphology and development of $P$. nigricans and concludes that Protocoronospora is not a Basidiomycete but one of the Melanconieae, a conclusion in which I concur.

\section{ASTEROSTROMA}

Asterostroma Massee, Linn. Soc. Bot. Jour. 25: 154. pl. 46, f. 8, 9. 1889; Sacc. Syll. Fung. 9:236. 1891; Engl. \& Prantl, Nat. Pflanzenfam. (1:1**): 122. 1898; Bourdot \& Galzin, Soc. Myc. Fr. Bul. 36: 44 . 1920.

Fructifications resupinate, effused, dry, composed of loosely interwoven hyphae, some of which terminate in brown, stellate organs composed of slender rays; basidia simple, with 2-4 sterigmata; spores hyaline.

The species of Asterostroma are likely to be referred to Corticium unless sections are examined. In sections the brown, stellate organs are conspicuous when viewed with the microscope and sharply separate Asterostroma from other resupinate thelephoraceous fungi. Similar organs occur, however, in Asterodon of the Hydnaceae and in a species of Lachnocladium.

\section{Key to The Species}

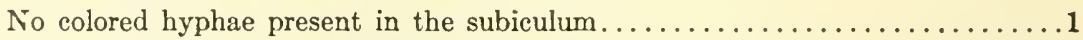
Some colored hyphae in subiculum................. A. ochrostroma

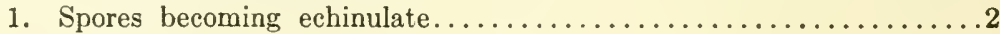

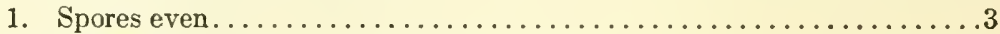

2. Stellate organs with unbranched rays as a rule.............. cervicolor

2. Many stellate organs have some rays branched..........2. A. muscicolum

3. Hymenium drying whitish; no cystidia; rays $3 \frac{1}{2}-41 / 2 \mu$ in diameter........................................... A.

3. Like $A$. bicolor except that rays up to $130 \times 9 \mu$ protrude beyond hymenium, like setae...................... spiniferum

3. Stellate organs have notably long, slender rays up to $100-150 \times$ $3-3 \frac{1}{2} \mu$; fructification not spongy................. gracile

1. Asterostroma cervicolor (Berk. \& Curtis) Massee, Linn. Soc. Bot. Jour. 25: 155. 1889; Sacc. Syll. Fung. 9: 237. 1891; Bourdot \& Galzin, Soc. Myc. Fr. Bul. 36: 44. 1920.

Corticium cervicolor Berk. \& Curtis, Grevillea 1: 179. 1873; Sacc. Syll. Fung. 6: 621. 1888.-Asterostroma corticola Massee, Linn. Soc. Bot. Jour. 25: 155. 1889; Sacc. Syll. Fung. 9: 236. 
1891.-A. albido-carneum Massee, Linn. Soc, Bot. Jour. 25: 155. pl. 46. f. 8, 9. 1889. Not Thelephora albido-carnea Schweinitz, Am. Phil. Soc. Trans. N. S. 4: 169. 1832.-A . pallidum Morgan, Cincinnati Soc. Nat. Hist. Jour. 18: 38. pl. 1, f. 6. 1895; Sacc. Syll. Fung. 14: 223.1899.

Type: in Kew Herb. and Curtis Herb.

Fructification effused, thin, spongy, dry, avellaneous to cinnamon-drab within, the margin fibrillose-floccose, paler; hymenium even, pulverulent, becoming pallid where well-fruited; structure in section 150-300 $\mu$ thick, composed of thin-walled, loosely arranged, hyaline hyphae $2-21 / 2 \mu$ in diameter and of conspicuous, colored, thick-walled, rigid, stellate organs with $3-7$, usually about 5 , unbranched rays $15-60 \mu$ long and $3-31 / 2 \mu$ in diameter, distributed throughout the fructification; cystidia (gloeocystidia?) fusoid, often sharp-pointed, not incrusted, 30-45 $\times 8-12 \mu$, protruding up to $25 \mu$ above the basidia; basidia simple, with 4 sterigmata; spores white in spore collections, spherical, becoming echinulate, with the spore body $4-5 \mu$ in diameter.

On decaying wood, earth, and on outside of a flower pot. Canada to Louisiana, in Washington, California, Mexico, West Indies, and Japan. July to March. Widely distributed but not abundant.

The color of this species varies somewhat with the presence and degree of development of the hymenium; young fructifications still lacking basidia or with only few scattered basidia have a tawny color due to the numerous colored stellate bodies which are present in the surface of the fructification. As the hymenium becomes continuous in patches or over the whole surface it conceals the stellate organs and shows as a whitish or pallid pellicle in the regions where developed, with comparatively few colored rays protruding through it. The type specimen of $A$. pallidum has the hymenium fully developed. Under my method of staining sections with eosin and then preserving in glycerine mounts, the fusoid organs in the hymenium are what I understand as nonincrusted cystidia containing little granular matter, a great deal of cell sap, and with such thin walls that they collapse in the glycerine preparations. Bourdot has a special reagent and method which he employs as a test for gloeocystidia, and he has decided that these organs are gloeocystidia. 
The specimens of A. ochroleuca Bres. from France, communieated by Bourdot, seem to me specifically distinct from our $A$. cervicolor by their lack of the continuous, whitish hymenial pellicle and the abundant rays in the hymenial surface being well branched so that very many of them resemble antlers rather than stellate organs.

Specimens examined:

Exsiccati: Ravenel, Fungi Am., 228, under the name Corticium cervicolor; Ravenel, Fungi Car. 4: 14, type distribution of Asterostroma albido-carneum Massee, under the name Corticium albido-carneum but not the species of Schweinitz.

Canada: St. Lawrence Valley, J. Macoun, 18.

New Hampshire: Chocorua, E. A. Burt, two collections; W. G. Farlow, 2a, 2b, an unnumbered specimen in Burt Herb., and 2, 3, 155 and an unnumbered specimen (in Mo. Bot. Gard. Herb., 55601, 55602, 55246, and 6883 respectively).

Massachusetts: Belmont, W. G. Farlow.

New York: Albany, H. D. House \& J. Rubinger (in N. Y. State Mus. Herb., and Mo. Bot. Gard. Herb., 6327); East Galway, E. A. Burt.

Pennsylvania: Bethlehem, Schweinitz (in Herb. Schweinitz under the names Thelephora reticulata and Thelephora mollis). District of Columbia: Washington, J. R. Weir, 19741 (in Mo. Bot. Gard. Herb., 59167).

South Carolina: H.W. Ravenel, in Ravenel, Fungi Car. 4: 14. Georgia: Darien, H.W. Ravenel, in Ravenel, Fungi Am., 228. Florida: $W . W$. Calkins, 150, comm. by W. G. Farlow (in Mo. Bot. Gard. Herb., 44635); Cutler Hammock, W. A. Murrill, 85 (in N. Y. Bot. Gard. Herb., and Mo. Bot. Gard. Herb., 62104).

Alabama: Peters, type of Corticium cervicolor (in Curtis Herb., 4026, and Kew Herb.); Montgomery County, R. P. Burke, 110 and 311 (in Mo. Bot. Gard. Herb., 19896 and 57185 respectively).

Louisiana: St. Martinville, A. B. Langlois, cx, 1948, 203 (in Burt Herb., Lloyd Herb., 3144, and Mo. Bot. Gard. Herb., 55621 ).

Ohio: Cincinnati, C. G. Lloyd. 
Idaho: Priest River, J. R. Weir, 581 (in Mo. Bot. Gard. Herb., 63172).

Washington: Hoquiom, C. J. Humphrey, 6411.

California: A.J. McClatchie, type of Asterostroma pallidum (in Kew Herb., and Mo. Bot. Gard. Herb., 4792).

Mexico: Xuchiles, near Cordoba, W. A. \& E. L. Murrill, 1206, 1212, comm. by N. Y. Bot. Gard. Herb. (in Mo. Bot. Gard. Herb., 54593 and 54594 respectively); near Guernavaca, W. A. \& E. L. Murrill, 516, comm. by N. Y. Bot. Gard. Herb. (in Mo. Bot. Gard. Herb., 54517); Jalapa, W. A. \& E. L. Murrill, 300, comm. by N. Y. Bot. Gard. Herb. (in Mo. Bot. Gard. Herb., 54444).

Porto Rico: Central Alianga, J. A. Stevenson, 6071 (in Mo. Bot. Gard. Herb., 54684); Rio Piedras, comm. by Mrs. F. W. Patterson.

Japan: Awaji, Mt. Mikuma, A. Yasuda, 38 (in Mo. Bot. Gard. Herb., 56170).

2. A. muscicolum (Berk. \& Curtis) Massee, Linn. Soc. Bot. Jour. 25: 155.1889.

Hymenochaete muscicola Berk. \& Curtis, Linn. Soc. Bot. Jour. 10: 334. 1868; Sacc. Syll. Fung. 6: 602. 1888.

Type: in Kew Herb. and Curtis Herb.

Fructification broadly effused, thin, spongy, dry, wood-brown of Ridgway, the margin narrow, whitish; hymenium concolorous with the subiculum or but slightly paler, even; in structure in section 300-400 $\mu$ thick, composed of thin-walled, loosely arranged hyaline hyphae and of very numerous, colored, stellate organs with $3-9$ rays, the rays about $30-45 \times 3-41 / 2 \mu$, sometimes unbranched but many branched, becoming smaller and more branched towards, and in, the hymenium and bearing secondary whorls of small branches or with 2 stellate organs connected by a short, thick axis; cystidia few, not incrusted, $6 \mu$ in diameter, protruding up to $27 \mu$, tapering to a sharp point; spores hyaline, spherical, echinulate, the body $5-7 \mu$ in diameter, the spines numerous, close together, very distinct.

Fructifications up to $7 \times 4 \mathrm{~cm}$. when well developed.

On dead branches of trees covered with moss, on cocoanut 
petioles, and on rotting wood. West Virginia, Arkansas, Louisiana, and the West Indies. July to December.

A. muscicolum has so many tough, stellate organs that it is not easy to cut sections free hand which are thin enough to show clearly the details of the hymenium; it differs in this respect from $A$. cervicolor and also by the very numerous, branched rays and the thicker-walled spores covered with stouter and more numerous spines.

Specimens examined:

West Virginia: Eglon, C. G. Lloyd, 1457 (in Mo. Bot. Gard. Herb., 55611).

Louisiana: Dr. Hale (under the name Stereum Halei in Kew Herb. and Curtis Herb., 3660); St. Martinville, A. B. Langlois, 2703.

Arkansas: Fordyce, C. J. Humphrey, 2530 (in Mo. Bot. Gard. Herb., 11952).

Cuba: C. Wright, 253, type of Hymenochaete muscicola (in Kew Herb. and Curtis Herb.); Ceballos, C. J. Humphrey, 2579 (in Mo. Bot. Gard. Herb., 14841); Habana Province, Fecha, F. S. Earle, 141.

Grenada: Grand Etang, R. Thaxter, comm. by W. G. Farlow, 15.

3. A. bicolor Ellis \& Everhart, Acad. Nat. Sci. Philadelphia Proc. 1893: 441. 1893; Sacc. Syll. Fung. 11: 128. 1895.

Type: in N. Y. Bot. Gard. Herb., U. S. Dept. Agr. Herb., and Burt Herb.

Effused, thin, avellaneous when fresh, the hymenium becoming whitish in the herbarium, the margin thin, cobwebby; in structure in section 200-300 $\mu$ thick, composed of loosely arranged, hyaline hyphae $2-21 / 2 \mu$ in diameter and of rather scattered-not crowded - colored, stellate organs with unbranched rays 45-120 $\mu$ long, $31 / 2-41 / 2 \mu$ in diameter; no cystidia; basidia with 4 sterigmata; spores white in a spore collection, even, globose, apiculate at the base, $5-7 \mu$ in diameter.

Fructifications 1-6 cm. long, 1-4 cm. broad.

On rotten wood of both frondose and coniferous species but more abundant on the latter. New York to Louisiana and westward to British Columbia. August to November. 
Specimens of $A$. bicolor acquire in the herbarium the whitish hymenium of a well-fruited $A$. cervicolor from which they are only distinguishable by the even spores and the absence of cystidia. On the basis of the similar spores, I formerly referred to $A$. bicolor a small specimen collected in Sweden by Romell. Bourdot has recently sent to me from France several specimens, published by him under the name $A$. laxum Bres., which are identical in structure with the specimen from Romell and constantly distinct from our $A$. bicolor by having occasional cystidia and stellate organs with branched rays-so conspicuously branched in the hymenium as to approach antler form.

Specimens examined:

New York: Floodwood, E. A. Burt.

Delaware: Wilmington, Commons, 2356, type (in N. Y. Bot. Gard. Herb., U. S. Dept. Agr. Herb., and Burt Herb.).

Maryland: Glen Sligo, C. L. Shear, 1141.

Louisiana: St. Martinville, A. B. Langlois, ac.

Kentucky: Crittenden, C. G. Lloyd (in Lloyd Herb., 1401, 1425, and Mo. Bot. Gard. Herb., 55616 and 55617 respectively). Illinois: Christopher, C.J. Humphrey, 1991 (in Mo. Bot. Gard. Herb., 59018).

British Columbia: Kootenai Mts., near Salmo, J. R. Weir, 454, 495, 520, 541 (in Mo. Bot. Gard. Herb., 13274, 21977, 19438, and 3774 respectively).

4. A. spiniferum Burt, n. sp.

Type: in Mo. Bot. Gard. Herb.

Fructifications effused, with the subiculum avellaneous and the hymenium pale pinkish buff; in structure 300-350 $\mu$ thick, with hyphae hyaline, arranged longitudinally along the substratum and passing into a loosely arranged layer and becoming intermixed with the colored, stellate organs; stellate organs not densely crowded together, with unbranched rays 50-90 $\times 6-7 \mu$ usually, but next to the hymenium having rays perpendicular to the latter, larger than the other rays, up to $130 \times 9 \mu$, and protruding beyond the basidia up to $110 \mu$, like setae; cystidia not incrusted, $25 \times 5 \mu$, sparingly present; spores hyaline, even, subglobose, $5-6 \mu$ in diameter. 
Fructifications up to $4 \mathrm{~cm}$. long, $2 \mathrm{~cm}$. broad.

On rotten wood. Porto Rico. July.

This species is related to $A$. bicolor but is distinct from the latter and noteworthy by the very large, unsymmetrical, setalike rays which stand out above the general level of the hymenium. The occasional cystidia are an additional separating character. Specimens examined:

Porto Rico: Rio Piedras, J. A. Stevenson, 5579, type (in Mo. Bot. Gard. Herb., 13415).

\section{A. gracile Burt, n. sp.}

Type: in Mo. Bot. Gard. Herb.

Fructifications effused, very thin, cobwebby, delicate, with the subiculum light drab and the hymenium pale olive-buff, not continuous but with the basidia in clusters; in structure 150 $\mu$ thick, with hyphae loosely arranged, hyaline, $2-21 / 2 \mu$ in diameter, and with colored, stellate organs with central body $6 \mu$ in diameter and very slender, unbranched rays up to 100-150 $\times$ $3-31 / 2 \mu$, often protruding beyond the hymenium up to $45 \mu$; cystidia numerous, not incrusted, fusoid, $30 \times 8 \mu$; basidia $15 \times 6 \mu$; spores hyaline, even, spherical, $6 \mu$ in diameter.

Fructifications $1 / 2^{-1} \mathrm{~cm}$. in diameter.

On very rotten, frondose wood. Alabama. October.

The small gray fructifications of $A$. gracile have the aspect of a delicate, cobwebby Hyphomycete rather than the more compact, spongy structure of other species of this genus. The long, slender rays of the stellate organs and the cystidia are also distinctive. Specimens examined:

Alabama: Montgomery County, R. P. Burke, 409, type (in Mo. Bot. Gard. Herb., 57202).

6. A. ochrostroma Burt, n. sp.

Type: in Mo. Bot. Gard. Herb., and Farlow Herb. probably. Fructification effused, dry, felty, ochraceous tawny, with surface becoming shallowly granular in fruiting; in structure 200-300 $\mu$ thick, composed of both hyaline, thin-walled, flaccid hyphae $2 \mu$ in diameter, and of some ochraceous, stiff, thickwalled hyphae $2 \mu$ in diameter, and of very numerous, densely 
crowded stellate organs of varying size; stellate organs with unbranched rays $20-60 \times 3-6 \mu$ which protrude beyond the hymenium in such great numbers and so crowded as to nearly conceal the basidia; no cystidia found; basidia simple, $10 \times 5 \mu$, with 4 sterigmata, but few basidia found; floating spores in each preparation are hyaline, even, $4-41 / 2 \times 3 \mu$, neither copious nor seen attached to basidia.

Fructifications 1-11/2 mm. long, about $1 / 2 \mathrm{~mm}$. broad.

On bark and decorticated wood of Abies. New Hampshire. September.

A. ochrostroma differs from all other species of Asterostroma known to me by the presence in its subiculum of some slender, rigid, thick-walled hyphae of the same diameter as the usual, thin-walled hyphae but of the same color as the stellate organs. I find these colored hyphae more abundant in the sterile portions of the fructification; they have bleached in sections preserved for several years in glycerine mounts. The stellate organs are more numerous than in any other of our species and prevent cutting satisfactorily thin sections of the hymenium by free hand. Some hyaline, even spores $4-41 / 2 \times 3 \mu$ were found floating in each preparation but not abundantly and are probably the spores of this species.

Specimens examined:

New Hampshire: Crystal Cascade, White Mts., W. G. Farlow, 1, type (in Mo. Bot. Gard. Herb., 55578).

( $T$ o be continued) 


\section{Explanation of Plate}

PLATE 1

Fig. 1. Cladoderris dendritica. a, showing upper side, collected in Cuba by W. A. \& E. L. Murrill, 136; $b$, showing ribbed hymenium, collected in Colombia by W. D. Denton.

Fig. 2. C. floridana. Part of type, showing warts of hymenium, collected in Florida.

Fig. 3. Skepperia spathularia. After Patouillard.

Fig. 4. Hypolyssus Montagnei. a, collected in Bolivia by A. M. Bang; $b$, collected in Honduras by $\mathrm{P}$. Wilson.

Fig. 5. Cymatella pulverulenta. a, piece of wood bearing several fructifications; $b, 2$ fructifications seen from under (hymenial) side, magnified, collected in Porto Rico by F. L. Stevens, 1358.

Fig. 6. C. minima. After Patouillard.

Fig. 7. Cytidia flocculenta. Collected in Montana by Mrs. L. A. Fitch.

Fig. 8. C. salicina. Showing both young, pezizoid and expanded fructifications, collected in Canada by J. Macoun.

Fig. 9. C. tremellosa. Collected in Louisiana by A. B. Langlois, 2620. 


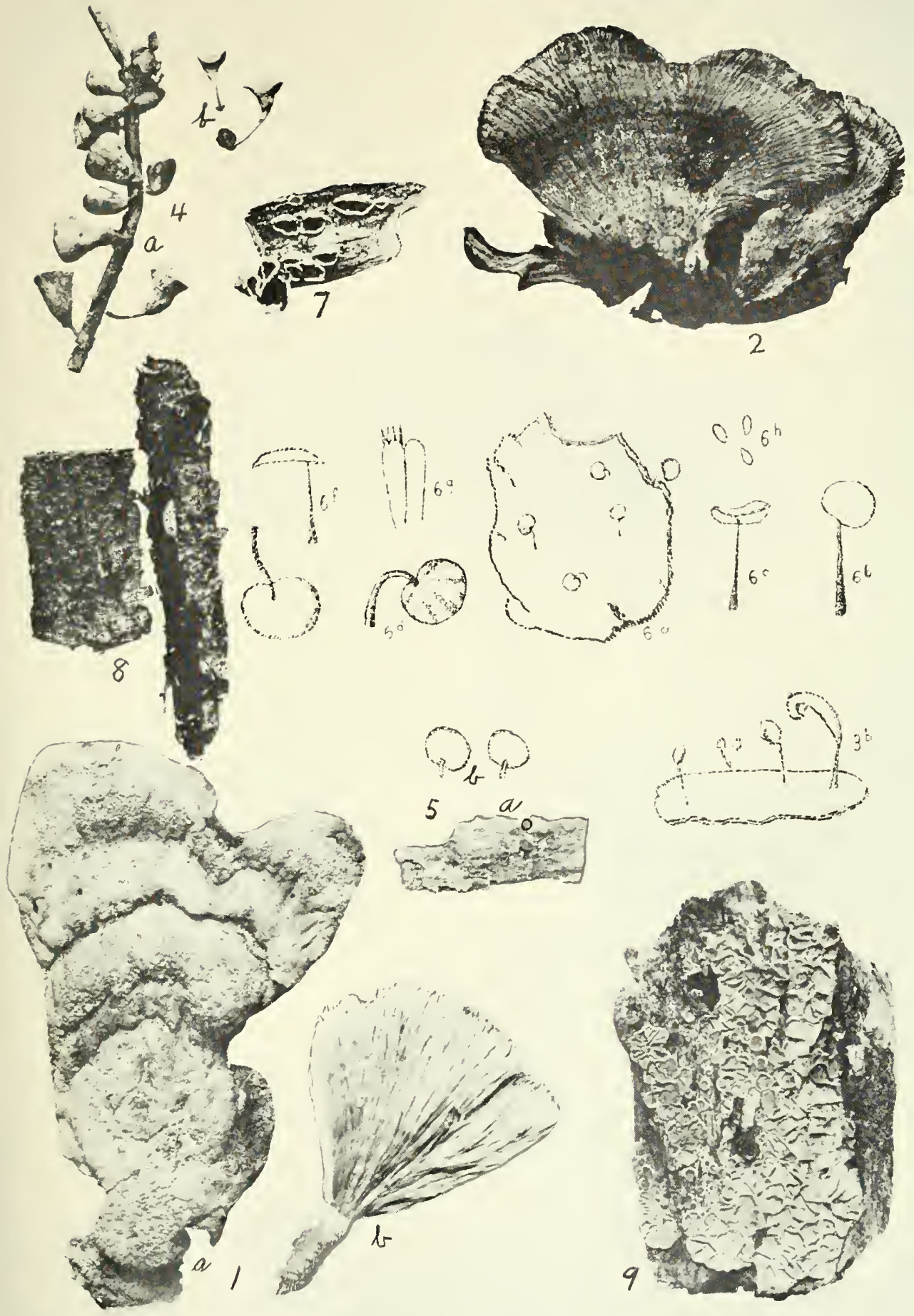

BURT-THELEPHORACLAE OF NORTH AMERICA

1. CLADODERRIS DENDRITICA.-2. C. FLORIDANA.-3). SKEPPERIA SPATHULARIA.

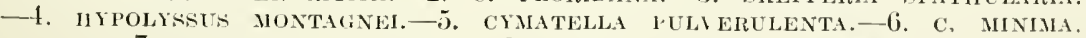

一7. CYTIDIA FLOCCULENTA. - S. C. SALICINA. -9. C. TREAIELLOSA. 



\section{The Thelephoraceae of North America. XIV}

\section{Peniophora}

\section{EDWARD ANGUS BURT}

Reprinted from AnNals of the Missodri Botanical

GARDEN 12: 213-357, September, 1925 


\section{9}

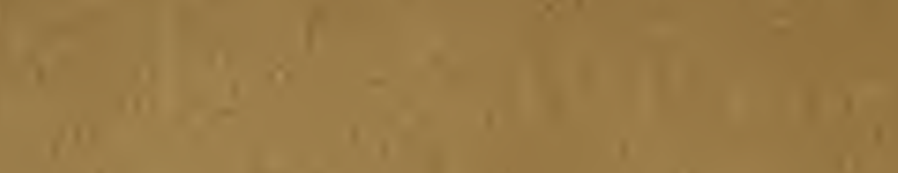

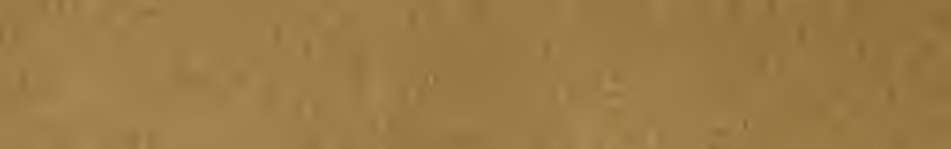

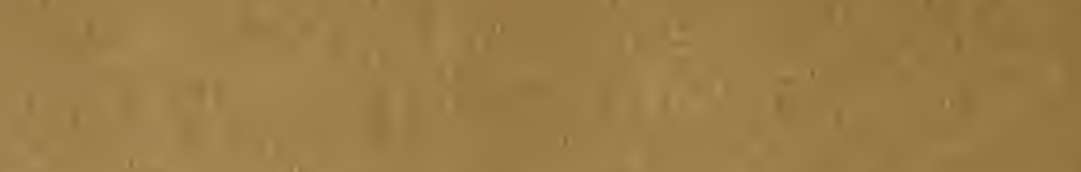

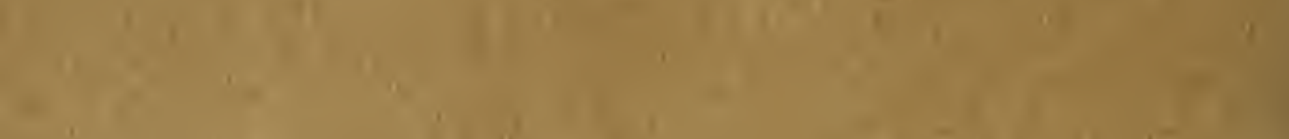

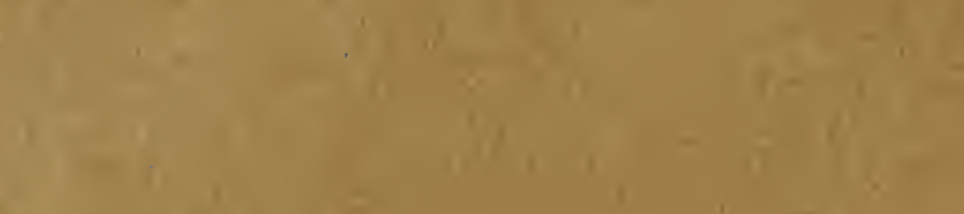<smiles></smiles>

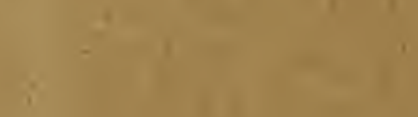

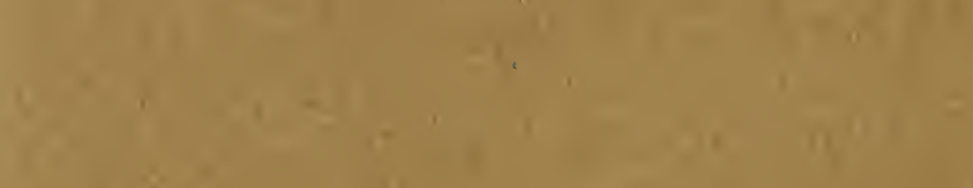

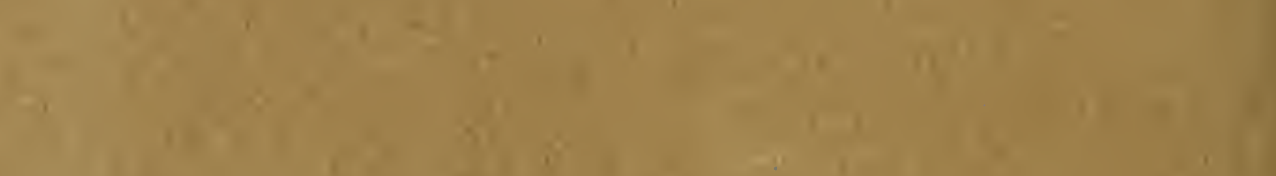

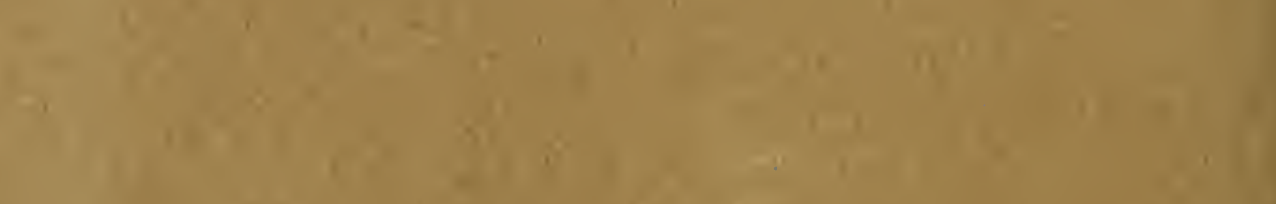

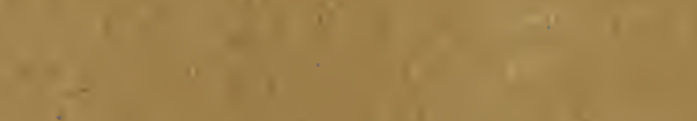

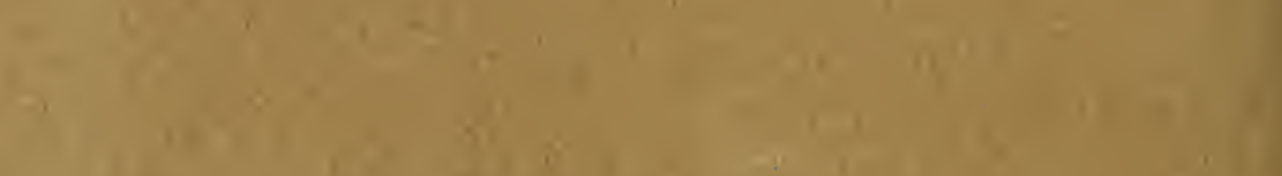

I

$+8$

in

E.

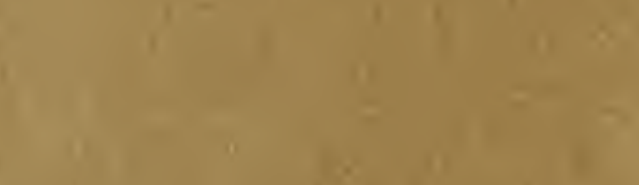

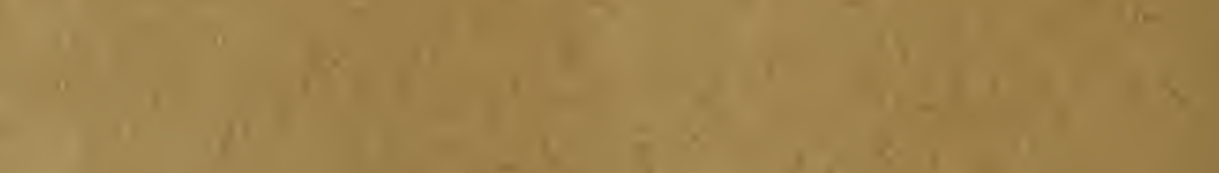

n

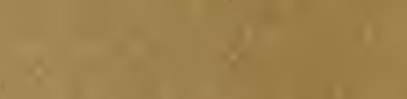

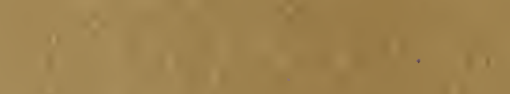

(4)

1
4.2
4.2

$\operatorname{lin}_{1}+2$

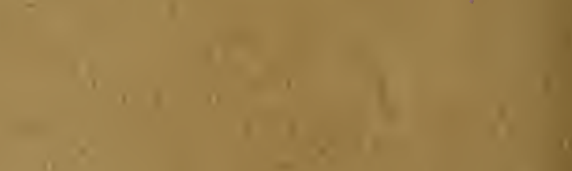

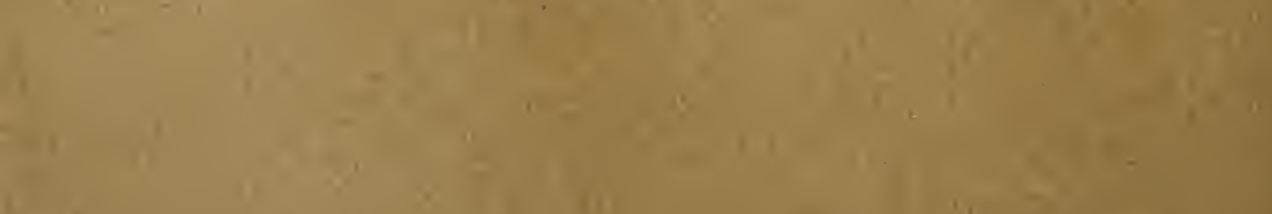

$y$

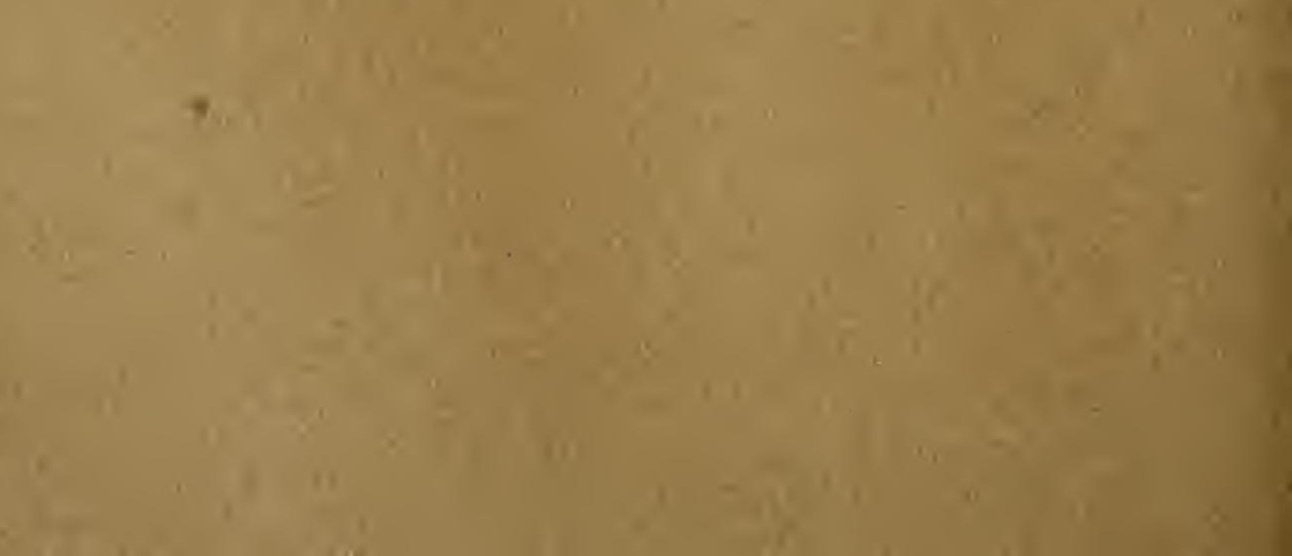




\title{
THE THELEPHORACEAE OF NORTH AMERICA. XIV'
}

\section{EDWARD ANGUS BURT}

\author{
Mycologist and Librarian to the Missouri Botanical Garden \\ Professor in the Henry Shaw School of Botany of \\ Washington University
}

\section{PENIOPHORA}

Peniophora Cooke, Grevillea 8: 20. pl. 122-125. 1879; Sacc. Syll. Fung. 6: 640. 1888; Massee, Linn. Soc. Bot. Jour. 25: 140. pl. 47, f. 14-19. 1889; Karsten, Finska Vet.-Soc. Bidrag Natur och Folk 48: $421 . \quad 1889$; Engl. \& Prantl, Nat. Pflanzenfam. $\left(1: 1^{* *}\right): 119$. 1898; Bourdot \& Galzin, Soc. Myc. Fr. Bul. 28: 372. 1913; Burt, Mo. Bot. Gard. Ann. 1: 191, 193, 198. 1914; Rea, Brit. Basid. 687. 1922.-Kneiffa (in part) Bresadola, Ann. Myc. 1: 99. 1903. - Includes Gloeopeniophora v. Höhnel \& Litschauer, K. Akad. Wiss. Wien Sitzungsber. 116:815. 1907. -Includes in part Gloeocystidium Karsten, Finska Vet.-Soc. Bidrag Natur och Folk 48: 429. 1889.

Fructifications waxy, coriaceous, cartilaginous, membranaceous, submembranaceous, floccose, or filamentous, always resupinate, effused, even; simple basidia with 2-4 white spores; cystidia incrusted or not incrusted, present in the hymenium and often more or less immersed in the substance; substance variously differentiated in some species but not containing colored, stellate organs.-Distinguished from Corticium by the presence of cystidia.

The North American species of Peniophora are here arranged in five groups according to the color of the substance of the fructification, nature of the cystidia, and presence or absence of gloeocystidia. These groups are further subdivided to such degree as

\footnotetext{
1 Issued February 18, 1926.
} 
seems desirable by color of hymenium, adnation to substratum, and incrustation of cystidia or of hyphae, into minor groups of so few species that the characters of the component species of any group within which a species seems to belong, may all be considered in determining the probable species of the specimen in course of identification. An appalling amount of time and labol has been required for the accumulation from sectional preparations of the structural characters of the individual specimens of species of Peniophora listed in this work. The older descriptions of resupinate Hymenomycetes were based on so few definite characters that a specimen in hand might seem to be referable equally well to more than one published species, or that several specimens in hand and certainly different specifically might all seem referable to one species, judging from its published description. However, by the addition of the knowledge of the definite features of structure characteristic of species, determining additional characters have been found for so many species that the specific taxonomy of the large genus Peniophora in North America becomes practicable. In the use of this work sectional preparations of fertile specimens are necessary.

Of the 120 species of Peniophora described herein, 36 occur in Europe as well as in North America and 11 others have been already recognized as North American species. The remaining 73 species are unlike those which the writer has been able to recognize among the known species from other regions of the world and have therefore to be described as new. It is quite probable that nearly all of these 73 species will bear the test of study by foreign mycologists and be demonstrated eventually to be really new, for most of them are of local occurrence, known from a single collection and distributed with surprising uniformity over the great area of North America which has in its different regions such great differences in temperature, moisture, altitude, and composition of its forests that the conditions are ideal for the origin and survival of species of merely local distribution. This is in accord with the fact that 9 of our new species occur in more than one state and that others occur as follows:- 7 from Louisiana; 4 each from New York, British Columbia, Washington, Mexico, and Jamaica; 3 each from Vermont, Idaho, Oregon, 
and Texas; 2 each from Canada, New Hampshire, Alabama, Florida, Colorado, and Porto Rico; and 1 each from Virginia, Georgia, Kentucky, Montana, Alaska, California, New Mexico, Nicaragua, Cuba, and Bermuda.

It might be well for American students who use this work for the determination of their gatherings of Peniophora to concentrate their attention in first attempts on the characters of the species of wide distribution and on such of the new species as are local in their respective regions.

Mycologists, with special knowledge of the Thelephoraceae in every nation, work not only to make better known the fungous floras of their own countries, but also to determine which of their species occur in other countries. As an aid to such study in the future and for checking my work, there is here given the following list of foreign species of Peniophora, not known to me except from the more or less satisfactory published descriptions, viz., Peniophora abietis, $P$. amaniensis, $P$. atro-cinerea, $P$. avellanea, $P$. bambusicola, $P$. carneola, $P$. Cheesmanii, $P$. cineracea, $P$. citrina, P. coccinea, P. Coffeae, P. convolvens, P. Corsica, P. crustosa, P. diffissa, $P$. discoidea, $P$. Dussii, $P$. fimbriata, $P$. gigaspora, $P$. habgallae, $P$. leprosa, $P$. lilacea, $P$. Martelliana, $P$. mimica, $P$. ochroleuca, $P$. orphanella, $P$. pirina, $P$. rimicola, $P$. rufomarginata, $P$. sordidella, $P$. sororia, $P$. sparsa, $P$. subavellanea, $P$. subglebulosa, $P$. sublaevis, $P$. subtilis, $P$. tomentella, $P$. tremelloidea, and $P$. vermicularis. It is probable that most of these species are of local interest but I should like to have been sure that I have not redescribed any of them as new American species. Much time and effort have been required to make this list as small as it is.

\section{Key to Arrangement of the Species}

I. Substance not colored, with the usual cystidia, no gloeocystidia.

1. Hymenium white or whitish.

*At least small pieces separable when moistened.

a. Cystidia incrusted ...................... 1-7

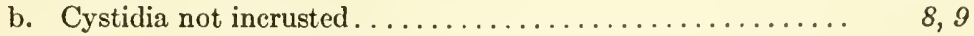

${ }^{* *}$ Closely adnate, not separable.

a. Antler-shaped paraphyses not present.

†Cystidia incrusted.

††Cystidia rough-walled or denticulate........... 14, 15

†† Cystidia not incrusted, even............... 16-24

b. Antler-shaped paraphyses present............. 25-27 
2. Hymenium colored and the subhymenium also in a few species.

*Closely adnate, not scparable.

a. Cystidia not incrusted.

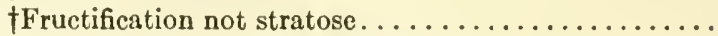

††Fructification becoming stratose........... $\$ 1, \$ 2$

b. Cystidia incrusted..................... $\$ \$-\$ 8$

**At least small pieces separable when moistened.

a. Cystidia incrusted.

tHyphae incrusted. . . . . . . . . . . . . . . . . . . . . .

$39-44$

††H phae not incrusted or not obviously incrusted.....

$45-58$

b. Cystidia not incrusted.

†Hyphae incrusted . ................ $5 \$-56$

$\dagger+\mathrm{Hyphae}$ not incrusted or not obviously incrusted... $\quad 57-61$

II. Substance not colored almost without exception, cystidia very long, cylindric, thick-walled, not normally incrusted, often visible through whole thickness of the fructification, no gloeocystidia-the

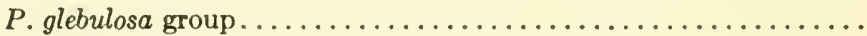

III. Substance not colored, gloeocystidia present as well as cystidia-the gloeocystidial group.

1. At least small pieces separable when moistened.

*Cystidia incrusted.

†Some cystidia $40-100 \times 20-50 \mu \ldots \ldots \ldots \ldots \ldots \ldots$

t+Cystidia of the usual size................... $70-79$

${ }^{* *}$ Cystidia not incrusted....................... 80-89

2. Closely adnate, not separable................ 84-90, 111

IV. Substance yellow or yellowish rather than dark-colored and often bleached by potassium hydrate solution.

1. At least small pieces separable when moistened . . . . . . . . . . . 91-97

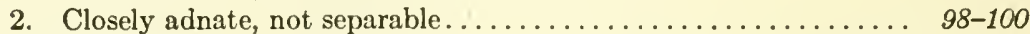

V. Substance more or less dark-colored, the dark color retained in preparations stained with eosin. Gloeocystidia sometimes present.

1. Fructification stratose . . . . . . . . . . . . . . . 101-102

2. Fructification not stratose.

*At least small pieces separable when moistened. Compare also resupinate Stereum ferreum. . . . . . . . . . . . . . . . 103-110

${ }^{*}$ Closely adnate, not separable................... 111-120 (Including as 117-120 the $P$. cinerea group with opaque zone next to substratum and the largest cystidia on this zone.)

1. Peniophora gigantea (Fr.) Massee, Linn. Soc. Bot. Jour. 25: 142. Je. 1889; Karsten, Finska Vet.-Soc. Bidrag Natur och Folk 48: 422. 1889; Bresadola, I. R. Accad. Agiati Atti III. 3: 113 . 1897; Bourdot \& Galzin, Soc. Myc. Fr. Bul. 28: 401. 1913; Rea, Brit. Basid. 693.1922.

Thelephora gigantea Fries, Obs. Myc. 1: 152. 1815; Syst. Myc. 1: 448. 1821.-Corticium giganteum Fries, Epicr. 559. 1838; Hym. Eur. 648. 1874; Peck, N. Y. State Mus. Rept. 28: 52. 1876; Sacc. Syll. Fung. 6: 610. 1888. 
Illustrations: Fries, Icones Hym. 2: pl. 197, f. 3 .

Fructifications broadly effused, hyaline, white, waxy, swelling when moist and separable from substratum, when dry horn-like and parchment-like, the hymenium even, pale pinkish buff, pale olive-buff, or pallid mouse-gray in the herbarium, the margin white, fibrillose, radiating, sometimes becoming free and curling away from the substratum in drying; in section $100-500 \mu$ thick, not colored, with the broad layer towards the substratum composed of crowded and more or less longitudinally arranged hyphae so highly gelatinously modified that only the lumen and cell contents usually show distinctly in preparations, about $3-5 \mu$ in diameter; cystidia incrusted, about $40-50 \times 8-12 \mu$, confined to the hymenium or a zone up to $100 \mu$ broad; spores hyaline, even, about $4 \frac{1}{2^{-}}-5 \times 2 \frac{1}{2}-3 \mu$ as found in preparations.

Fructifications $3-30 \mathrm{~cm}$. in diameter.

On bark and wood of dead conifers such as Pinus, Abies, and Tsuga. In Europe, Canada to Texas, westward to the Pacific states, in Mexico, and in Japan. June to January. Widely distributed and abundant locally.

$P$. gigantea may usually be recognized at sight by its occurrence on coniferous bark in large, whitish or pinkish buff fructifications of cartilaginous structure, separable from the substratum and more or less curling away from it in drying.

Specimens examined:

Exsiccati: Bartholomew, Fungi Col., 2422, 4242, 4622; Ellis, N. Am. Fungi, 410; Krieger, Fungi Sax., 117; Ravenel, Fungi Am., 452; Fungi Car. 2: 38; Romell, Fungi Scand., 34; Sydow, Myc. Germ., 553; de Thümen, Myc. Univ., 909.

Finland: Mustiala, P. A. Karsten, in Myc. Univ., 909. Sweden: L. Romell, 97, 98, 349, and in Romell, Fung. Scand., 34. Germany: Brandenburg, H. Sydow, in Sydow, Myc. Germ., 553; Königstein, W. Krieger, in Krieger, Fungi Sax., 117.

Austria: Karwendel, Tirol, V. Litschauer; Stubai, Tirol, V. Litschauer.

Italy: Trient, G. Bresadola.

France: Fautrey, comm. by Lloyd Herb., 4354; Jura, N. Patouillard (in N. Y. State Mus. Herb., and Mo. Bot. Gard. Herb., 55907). 
Canada: Montreal, on timbers in a mill, R. J. Blair, 337, comm. by L. O. Overholts, 4113 (in Mo. Bot. Gard. Herb., 55632); Belleville, Ontario, J. Macoun, 253; Ottawa, J. Macoun, 48. New Hampshire: Chocorua, W. G. Farlow, 32.

Massachusetts: Fall River, on floor beams in a mill, W. H. Snell (in Mo. Bot. Gard. Herb., 57379).

New York: ex herb. Torrey, 112 (in N. Y. Bot. Gard. Herb., and Mo. Bot. Gard. Herb., 61437); Beaver River, Adirondacks, G. F. Atkinson, 4606; Mechanicville, C. H. Peck (in N. Y. State Mus. Herb., and Mo. Bot. Gard. Herb., 55575).

New Jersey: Newfield, J. B. Ellis, in Ellis, N. Am. Fungi, 410. Pennsylvania: Adelaide, on cross ties, H.v. Schrenk (in Mo. Bot. Gard. Herb., 6685); State College, L. O. Overholts, 4810 (in Mo. Bot. Gard. Herb., 56124).

Maryland: Takoma Park, C. L. Shear, 1266, and in Bartholomew, Fungi Col., 2422.

Virginia: Rio, F. Gravatt (in Mo. Bot. Gard. Herb., 44042).

North Carolina: Biltmore, E. Bartholomew, 5658 (in Mo. Bot.

Gard. Herb., 44216), and in Bartholomew, Fungi Col., 4622; Chapel Hill, J. N. Couch, comm. by Univ. N. C. Herb., 4306 (in Mo. Bot. Gard. Herb., 57422).

South Carolina: H. W. Ravenel, in Ravenel, Fungi Car. 2: 38; Aiken, H.W. Ravenel, in Ravenel, Fungi Am., 452.

Georgia: Brunswick, H. v. Schrenk (in Mo. Bot. Gard. Herb., 43887).

Florida: W. W. Calkins, 63 (in N. Y. Bot. Gard. Herb., and Mo. Bot. Gard. Herb., 61446).

Louisiana: Shreveport, E. Bartholomew, in Bartholomew, Fungi Col., 4242, and (in Mo. Bot. Gard. Herb., 4943).

Texas: Houston, H. W. Ravenel, 221; Quitman, W. H. Long, 12074, and comm. by C. J. Humphrey, 2552 (in Mo. Bot. Gard. Herb., 55046 and 9804 respectively); Somerville, H. v. Schrenk (in Mo. Bot. Gard. Herb., 42884).

Michigan: Bay City, J. R. Weir, 301 (in Mo. Bot. Gard. Herb., 20143).

Wisconsin: Madison, on log of Pinus Taeda in timber yard, M. C. Jensen, comm. by C. J. Humphrey, 719 (in Mo. Bot. Gard. Herb., 42729). 
Minnesota: Cass Lake, J. R. Weir, 394 (in Mo. Bot. Gard. Herb., 13981); St. Louis River, J. C. Arthur, L. H. Bailey \& E. W. D. Holway, 175 St. (in Mo. Bot. Gard. Herb., 4821).

Arkansas: Texarkana, on cross ties, H. v. Schrenk (in Mo. Bot. Gard. Herb., 56378).

Colorado: Tolland, L. O. Overholts, 1834 (in Mo. Bot. Gard. Herb., 54879).

Montana: Libby, E. E. Hubert, comm. by J. R. Weir, 11449 (in Mo. Bot. Gard. Herb., 63276); Rockhill, E. E. Hubert, comm. by J. R. Weir, 11966, 11979, 11984 (in Mo. Bot. Gard. Herb., 63336-8).

Idaho: Coolin, J. R. Weir, 11097, comm. by U. S. Dept. Agr., Path. Myc. Coll., 1335 (in Mo. Bot. Gard. Herb., 62988); Priest River, J.R. Weir, 80 (in Burt Herb.) and 5825, 6331, 11985, 12018, 14938 (in Mo. Bot. Gard. Herb., 58289, 55950, 63350, 63374, and 56800 respectively); Santa, E. E. Hubert, comm. by J. R. Weir, 11603 (in Mo. Bot. Gard. Herb., 63304). British Columbia: Hastings, J. Macoun, 24.

New Mexico: Gila National Forest, G. G. Hedgcock \& W. H. Long, comm. by C. J. Humphrey, 2524 (in Mo. Bot. Gard. Herb., 21669).

Mexico: Orizaba, Nuevo, W. A. \& E. L. Murrill, 767, comm. by N. Y. Bot. Gard. Herb. (in Mo. Bot. Gard. Herb., 54649). Japan: Sendai, A. Yasuda, 76 (in Mo. Bot. Gard. Herb., 56315).

2. P. globifera Ellis \& Everhart, Am. Nat. 1897: 340. 1897; Sacc. Syll. Fung. 14: 224. 1899.

Type: in N. Y. Bot. Gard. Herb. and a fragment in Burt Herb.

Fructifications broadly effused, separable when moistened, when dry horn-like, whitish to pale smoke-gray, the hymenium with somewhat convex granules, bristling with the crowded cystidia; in section $400-500 \mu$ thick, not colored, with a layer about $200-300 \mu$ thick towards the substratum composed wholly of densely interwoven, hyaline hyphae $3-5 \mu$ in diameter, with the walls so gelatinously modified as to be very indistinct; no gloeocystidia; cystidia heavily and coarsely incrusted, 30-70 $\times 12-15 \mu$, very abundant both in the hymenium and im- 
mersed throughout an outer zone up to $150 \mu$ thick; basidiospores hyaline, even, $4-6 \times 2-21 / 2 \mu$.

Fructifications up to $10 \mathrm{~cm}$. in diameter.

On bark of conifers. New York and Ontario, and in Montana, Idaho, British Columbia, Oregon, and New Mexico. August to October. Rare.

$P$. globifera is either known only from the type collection or else it is an extreme form of $P$. gigantea, for each of the more recent gatherings cited below has some character approaching $P$. gigantea. The distinctive features of the type of $P$. globifera are whiter color, much more numerous and larger cystidia which are also more coarsely incrusted, and a hymenial surface with some convex granules like those of Grandinia granulosa. The original description is erroneous in stating that the fructifications are closely adnate and that the spores are globose and $3 \mu$ in diameter.

Specimens examined:

Ontario: Ottawa, McKay's Lake, J. Macoun, 175, type (in N. Y.

Bot. Gard. Herb.) and a specimen from the type collection, comm. by J. Macoun; Harraby, E. T. \& S. A. Harper, 680; St. Lawrence Valley, J. Macoun, 85.

New York: Mt. McIntyre, C. H. Peck (in N. Y. State Mus. Herb., and Mo. Bot. Gard. Herb., 55777).

Montana: Rockhill, E. E. Hubert, comm. by J. R. Weir, 11960 (in Mo. Bot. Gard. Herb., 63317).

Idaho: Coolin, J. R. Weir, 11158M, 11491 (in Mo. Bot. Gard. Herb., 63254, 63279); Priest River, J. R. Weir, 20.

British Columbia: Kootenai Mts. near Salmo, J. R. Weir, 517, 525 (in Mo. Bot. Gard. Herb., 5068, 19430).

Oregon: Portland, C. J. Humphrey, 6126.

New Mexico: Cloudcroft, W. H. Long, 19524 (in Mo. Bot. Gard. Herb., 44765).

3. P. arachnoidea Burt, n. sp.

Type: in N. Y. Bot. Gard. Herb. and Burt Herb.

Fructifications effused, very thin, fragile, small pieces separable, white, becoming cartridge-buff in the herbarium, the hymenium continuous, not shining, fragile, loosely supported on an arachnoid subiculum, the margin delicately fibrillose or arach- 
noid; in section 150-300 $\mu$ thick, not colored, 2-layered, with the layer next to the substratum composed of very loosely arranged, nodose-septate, hyaline hyphae $3-4 \mu$ in diameter and with the hymenial layer about $50 \mu$ thick, compact; no gloeocystidia; cystidia numerous, tapering, rough or granule-incrusted near the tips, 4-6 $\mu$ in diameter, protruding up to $40 \mu$ beyond the basidia; spores hyaline, even, $3-4 \times 2-21 / 2 \mu$, copious.

Fructifications $1-4 \mathrm{~cm}$. in diameter.

On bark of fallen limbs of Populus and Alnus. New Hampshire, New York, Alabama, and Oregon. October and November. Rare.

$P$. arachnoidea has the aspect of Corticium arachnoideum but is a Peniophora. The hyphae and their arrangement are like those of $P$. cremea. The microscopic characters are so similar to those of Coniophora byssoidea that the gatherings from northern localities may possibly be white forms of the latter which I have erroneously included under $P$. arachnoidea.

Specimens examined:

New Hampshire: Hanover, on Populus, G. R. Lyman, 27 (in N. Y. Bot. Gard. Herb., Mo. Bot. Gard. Herb., 61589, and Burt Herb.).

New York: Ithaca, G. F. Atkinson, 2589, formerly referred by me to C. byssoidea; Karner, on Populus, H. D. House (in N. Y. State Mus. Herb., and Mo. Bot. Gard. Herb., 54376).

Alabama: Auburn, on Alnus, F. S. Earle, 97, type, comm. by N. Y. Bot. Gard. Herb.; Montgomery County, R. P. Burke, 367 (in Mo. Bot. Gard. Herb., 57234).

British Columbia: Salmo, J. R. Weir, 472, 480 (in Mo. Bot. Gard. Herb., 63357, 63387).

Oregon: White Pine, on hymenium of Thelephora terrestris, $J . R$. Weir, 620 (in Mo. Bot. Gard. Herb., 13999).

4. P. inconspicua (B. \& C.) Massee, Linn. Soc. Bot. Jour. 25 : 149. pl. 47, f. 14. 1889; Sacc. Syll. Fung. 21:410. 1912.

Corticium inconspicuum Berkeley \& Curtis, Linn. Soc. Bot. Jour. 10: 336. 1868; Sacc. Syll. Fung. 6: 615. 1888.

Type: in Kew Herb. and Curtis Herb.

Fructifications effused, thin, small, orbicular, gregarious, becoming confluent, membranaceous, small pieces separable, white 
when fresh, bceoming light buff in the herbarium, even, setulose with the cystidia, the margin composed of radiating hyphae; in section 250-300 $\mu$ thick, not colored, composed of densely interwoven, rather thick-walled and rigid, ascending hyphae $3-4 \mu$ in diameter, not incrusted; no gloeocystidia; eystidia incrusted, fusoid, $50-60 \times 12-15 \mu$, scattered in the surface of the hymenium; spores in a crushed preparation are hyaline, even, $4 \times 3 \mu$, so few that they may not belong.

Fructifications about $2 \mathrm{~mm}$. in diameter, becoming more or less confluent over areas up to $3 \mathrm{~cm}$. long and $1 \mathrm{~cm}$. wide.

On bark of dead frondose limbs. West Indies. December and March.

$P$. inconspicua has small clustered fructifications becoming confluent and very large cystidia scattered along the surface of the hymenium and none wholly immersed. In one portion of my sections the hyphae next to the substratum are slightly brownish and suggestive of those of a resupinate Stereum but I do not recall an effuso-reflexed Stereum of which $P$. inconspicua may be the resupinate fructification.

Specimens examined:

Cuba: Mountain of Rangel, C. Wright, Fungi Cubenses Wrightiani, 841, type (in Kew Herb., Curtis Herb., Mo. Bot. Gard. Herb., Burt Herb., and an unnumbered portion in N. Y. Bot. Gard. Herb.).

Porto Rico: Rio Piedras, J. R. Johnston, 1664, comm. by J. A. Stevenson (in Mo. Bot. Gard. Herb., 13223).

5. P. galochroa Bresadola, Hedwigia 35: 200 . 1896; Sacc. Syll. Fung. 14: 224.1899.

Type: a part in Burt Herb.

Broadly effused, membranaceous, small pieces separable, from white becoming pinkish buff, finally cracked and silky along the crevices, the margin somewhat fimbriate at first, soon similar; in section 250-400 $\mu$ thick, not colored, with hyphae rather stiff, thick-walled, $2-21 / 2 \mu$ in diameter, not incrusted, not nodoseseptate, longitudinally arranged in a thin layer next to the substratum, densely interwoven in the broad middle region, the hymenial layer about $50 \mu$ thick; no gloeocystidia; cystidia coarsely 
incrusted, fusiform, $25-50 \times 9-10 \mu$, barely protruding, usually immersed in all parts of the hymenial layer; spores published by Bresadola as $51 / 2-61 / 2 \times 4-41 / 2 \mu$ but I find the type sterile.

Fructifications $3-6 \mathrm{~cm}$. long, $1 \frac{1}{2}-2 \frac{1}{2} \mathrm{~cm}$. wide.

On bark of decaying branches and on wood. Brazil and West Indies. August to December. Rare.

In aspect $P$. galochroa is somewhat suggestive of Corticium portentosum but much thinner and very different in structure by the presence of cystidia which are confined to a hymenial layer not more than $50 \mu$ thick in the specimens studied. The specimens from the West Indies, which I have referred to $P$.galochroa, have subglobose spores about $3 \mu$ in diameter and are perhaps a distinct species if $P$. galochroa has as large spores as published by Bresadola, but $I$ find the portion of the type communicated to me wholly sterile.

Specimens examined:

Brazil: Blumenau, A. Möller, type, from Bresadola.

Jamaica: Chester Vale, W. A. \& E. L. Murrill, 331, 751, comm. by N. Y. Bot. Gard. Herb.

Porto Rico: Rio Piedras, J. A. Stevenson, 2985 (in Mo. Bot. Gard.

Herb., 7799).

6. P. odontioides Burt, n. sp.

Type: in Mo. Bot. Gard. Herb.

Fructifications effused, very thin, arachnoid-membranaceous, tender, small pieces separable when moistened, white, even, not shining, the margin thinning out, fibrillose; in section 50-130 $\mu$ thick, not colored, composed of thin-walled, loosely interwoven, suberect hyphae about $4-41 / 2 \mu$ in diameter, incrusted, becoming collapsed; no gloeocystidia; cystidia of Odontia type, transversely septate, cylindric-obtuse, $8 \mu$ in diameter, protruding up to $45 \mu$, not incrusted or with a few incrusting granules; spores hyaline, even, $9-12 \times 4-4 \frac{1}{2} \mu$, copious.

Fructifications in fragments which are 2-3 cm. long, 5-6 mm. wide.

On decaying frondose wood. Canada. July to September.

$P$. odontioides is distinguished among our thin, white species by having large, cross-septate cystidia such as are common in 
many species of Odontia where they are clustered together in the granules, but in the present species such cystidia are distributed along an even hymenium devoid of granules.

Specimens examined:

Canada: J. Macoun, 20; St. Lawrence Valley, J. Macoun, 14. Manitoba: $52^{\circ} 15^{\prime}$ north latitude, Swan River, G. R. Bisby, 1047, type (in Mo. Bot. Gard. Herb., 59034).

\section{P. exigua Burt, n. sp.}

Type: in Mo. Bot. Gard. Herb. and N. Y. Bot. Gard. Herb.

Fructifications effused, small, circular, gregarious, thin, somewhat membranaceous, tender, small pieces separable when moistened, snow-white, even, contracting in drying and cracking into polygonal masses $1-2 \mathrm{~mm}$. in diameter, with the white arachnoid subiculum visible on the sides of the fissures, the margin narrow, white, arachnoid; in section $150-180 \mu$ thick, not colored, with some hyphae densely arranged parallel with the substratum and then ascending and loosely interwoven to the hymenial layer, about $3 \mu$ in diameter, thin-walled, not nodoseseptate, perhaps slightly incrusted in the hymenial layer; no gloeocystidia; cystidia incrusted, cylindric, 30-60 ×6-7 $\mu$, confined to the hymenial layer and usually wholly immersed, a few protruding up to $12 \mu$ beyond the basidia; spores hyaline, even, $4-5 \times 2 \frac{1}{2} \mu$.

Fructifications $1-12 \mathrm{~mm}$. in diameter -8 in an area $4 \times 1$ cm. and probably becoming confluent.

On bark of dead, fallen limbs, about $12 \mathrm{~mm}$. in diameter, of a frondose species. Mexico. December.

$P$. exigua is distinguished among our species by its clustered, small, snow-white fructifications which crack into small polygonal masses.

Specimens examined:

Mexico: near Guernavaca, altitude 4500 m., W. A. \& E. L. Murrill, 37\%, type, and 378 (in Mo. Bot. Gard. Herb., 54474, 54473 , respectively).

8. P. laxa Burt, n. sp.

Type: in Mo. Bot. Gard. Herb. 
Fructifications broadly effused, thin, waxy-membranaceous, loosely attached to the substratum by a cottony subiculum, tender, small pieces separable, becoming pale ivory-yellow in the herbarium, even, not much cracked, the margin thinning out, fibrillose, with some mycelial strands; in section $200-300 \mu$ thick, not colored, with the thin, compact hymenium supported by a very broad layer of loosely interwoven, thin-walled, granuleincrusted hyphae $11 / 2-2 \mu$, rarely $3 \mu$, in diameter, with the hyphae more densely arranged in a middle zone of this layer; no gloeocystidia; cystidia not incrusted or with only a few incrusting granules, $41 / 2-6 \mu$ in diameter, protruding up to about $30-50 \mu$ beyond the basidia, often capitate and $6-9 \mu$ in diameter at the apex; basidia up to $6 \mu$ in diameter, with 4 sterigmata; spores hyaline, even, spherical, $41 / 2^{-6} \mu$ in diameter, copious.

Fructifications $2-6 \mathrm{~cm}$. long, $1-2 \frac{1}{2} \mathrm{~cm}$. wide.

In woods on bark with the wood underneath wholly decayed. British Columbia. December.

$P$. laxa is probably white when growing and assumed the pale ivory-yellow tint in the herbarium; the aspect is like that of $P$. arachnoidea but with globose spores. P. sphaerospora of Europe has similar spores but much coarser, erect hyphae and different cystidia.

Specimens examined:

British Columbia: Sidney, J. Macoun, 8, type (in Mo. Bot. Gard.

Herb., 5767).

9. P. humifaciens Burt, n. sp.

Type: in Burt Herb.

Fructifications effused, circular, thin, membranaceous, loosely attached by white rhizomorphic strands from the substratum, easily separable, white, becoming somewhat pale pinkish buff in the herbarium, the margin thinning out, floccose; in section $150 \mu$ thick, not colored, with hyphae hyaline, up to $5 \mu$ in diameter and coarsest next to the substratum, very loosely arranged, branching and becoming $3 \mu$ in diameter towards the hymenial layer, nodose-septate, with few incrusting granules; no gloeocystidia, hymenial layer $30-40 \mu$ thick, continuous; cystidia not incrusted, $3-31 / 2 \mu$ in diameter at base, protruding $25-40 \mu$, 
tapering, attenuated to a long and very sharp point; basidia with 4 sterigmata; spores hyaline, even, subglobose, about $21 / 2$ $\times 2 \mu$, copious.

Fructifications $2-21 / 2 \mathrm{~cm}$. in diameter.

On very rotten coniferous log-perhaps Thuja. Washington. October. Rare.

$P$. humifaciens was so sparingly and loosely connected with the substratum by the white, mycelial strands that the impact of a hatchet against the $\log$ caused fructifications to fall away. $P$. arachnoidea, a related species, has quite different hyphae and cystidia and mode of attachment.

Specimens examined:

Washington: Chehalis, C. J. Humphrey, 6266, type.

10. P. candida (Pers.) Lyman, Boston Soc. Nat. Hist. Proc. 33: 167. pl. 20, f. 44-55, pl. 26, f. 138. F. 1907.

Aegerita candida Persoon, Roemer Neues Mag. Bot. 1: 120. 1794 (imperfect stage); Syn. Fung. 684. 1801; Fries, Syst. Myc. 3:220. 1829; Sacc. Syll. Fung. 4:661. 1886.-Sclerotium Aegerita Hoffmann, Fl. Germ. 2: pl. 9, f. 1. 1795.-Peniophora Aegerita (Hoffm.) v. Höhnel \& Litschauer, K. Akad. Wiss. Wien Sitzungsber. 116: 814. 1907; 123: 83. 1914; Sacc. Syll. Fung. 21: 410. 1912; Bourdot \& Galzin, Soc. Myc. Fr. Bul. 28: 382. 1913; Rea, Brit. Basid. 687. 1922.-Kneiffa farinosa Bresadola, Ann. Myc. 1: 105. 1903; Sacc. Syll. Fung. 17: 178. 1905.

Illustrations: See Sacc. Syll. Fung. 19: 25, for numerous figures of imperfect stage.

Fructifications effused, thin, adnate, very tender, at first farinose, then forming a continuous hymenium, white to pale creamcolor, very minutely velvety under a lens, the margin thinning out, indeterminate, usually with clusters of the minute, globose, white, imperfect stage adjoining; in section 40-100 $\mu$ thick, not colored, with hyphae suberect, thin-walled, collapsing, of irregular outline, about $4 \mu$ in diameter; no gloeocystidia; cystidia incrusted, scattered, starting from the substratum, 40-100 $\times$ 6-12 $\mu$; spores hyaline, even, subglobose, $6-7 \times 4 \frac{1}{2}-6 \mu$.

Fructifications $2-4 \mathrm{~cm}$. long, 1-2 cm. wide.

On decaying wood and fallen branches of Alnus, Populus, Acer, 
Ulmus, etc., and on the ground. In Europe, and from Massachusetts to Missouri. October and November. Rare.

The association of the effused, white fructifications of $P$. candida, with the clustered, small, globose, white or cream-colored fructifications-about 5 or 6 to a $\mathrm{mm}$.- -of the imperfect stage, Aegerita candida, affords an easy means of recognizing $P$. candida.

Specimens examined:

Poland: Eichler, part of the type of Kneiffia farinosa, comm. by Bresadola.

France: Allier, H. Bourdot, 19908.

New Hampshire: Hanover, G. R. Lyman.

Massachusetts: Arlington, A. P. D. Piguet, comm. by W. G.

Farlow, 33; Waverly, G. R. Lyman, two gatherings.

New York: Ithaca Flats, G. F. Atkinson.

Missouri: Creve Coeur, E. A. Burt (in Mo. Bot. Gard. Herb.,

56059), and F. P. McWhorter (in Mo. Bot. Gard. Herb., 57309).

11. P. cana Burt, n. sp.

Type: in Mo. Bot. Gard. Herb. and N. Y. Bot. Gard. Herb.

Fructifications effused, closely adnate, very thin, hypochnoid, not forming an interwoven membrane, pilose under a lens, the margin pruinose, indeterminate; in section $10-30 \mu$ thick, not colored, consisting of short, erect, simple or once- or twicebranched hyphae $3-31 / 2 \mu$ in diameter, not incrusted, not nodoseseptate, and of large cystidia; no gloeocystidia; cystidia heavily incrusted, conical, 50-60 × 10-18 $\mu$, protruding 30-45 $\mu$, starting from the substratum, very numerous; spores hyaline, even, $3-31 / 2 \times 1 \frac{1}{2} \mu$ as seen on basidia.

Fructifications fragmentary, with the fragments $1 \frac{1}{2}-2 \mathrm{~cm}$. long, 10-15 mm. wide.

On dark, brittle wood humus-probably of a frondose species. Florida. March.

$P$. cana is so thin and hoary that it is likely to be regarded as a Hyphomycete unless examined with the microscope. The large, conical, incrusted cystidia and small spores distinguish it from P. albugo.

Specimens examined:

Florida: Cutler Hummock, W. A. Murrill, 82, type, and 83, 
comm. by N. Y. Bot. Gard. Herb. (in Mo. Bot. Gard. Herb., $62102,62103)$.

12. P. irregularis Burt, n. sp.

Type: in Mo. Bot. Gard. Herb.

Fructifications effused, very thin, adnate, flocculent, tender, white, interrupted, somewhat lacunose, not shining, the margin thinning out, with hyphae interwoven; in section $45-75 \mu$ thick, not colored, composed of interwoven, hyaline, incrusted hyphae $21 / 2 \mu$ in diameter; no gloeocystidia; cystidia incrusted with coarse granules, $15-22 \times 8-12 \mu$, barely protruding, confined to the hymenium; spores hyaline, even, $4 \frac{1}{2} \times 2 \frac{1}{2} \mu$, borne 4 to a basidium.

Fructification $31 / 2 \mathrm{~cm}$. long and broken off at one end, $1 \mathrm{~cm}$. wide.

On bark of a rotten frondose limb about $7 \mathrm{~mm}$. in diameter. Cuba. December.

$P$. irregularis is a thin, white species of flocculent texture rather than waxy, with the dark substratum visible in small spaces not covered by the fructification.

Specimens examined:

Cuba: near Havana, C. J. Humphrey, 2953, type (in Mo. Bot. Gard. Herb., 9010).

\section{P. albofarcta Burt, n. sp.}

Type: in N. Y. Bot. Gard. Herb., Mo. Bot. Gard. Herb., and Burt Herb.

Fructifications effused, adnate, dry, spongy-membranaceous, light buff to pinkish buff in the herbarium, minutely velutinous under a lens, even, but little cracked, the margin thinning out, minutely tomentose; in structure $200-350 \mu$ thick, not colored, composed of a broad layer of loosely interwoven, rather rigid hyphae $3-31 / 2 \mu$ in diameter, not incrusted, not nodose-septate, and of a dense hymenial layer about $100 \mu$ thick; no gloeocystidia; cystidia incrusted, slender-fusiform, $50-90 \times 6-9 \mu$, protruding up to $30 \mu$, numerous in all parts of the hymenial layer; spores hyaline, even, spherical, $3-4 \mu$ in diameter, only few found but seem to belong. 
Fructifications in fragments $5 \mathrm{~mm} .-2 \mathrm{~cm}$. long, 5-10 mm. wide. On very rotten wood of stump of orange tree (Citrus). Louisiana. December.

The fructifications of $P$. albofarcta are scarcely distinguishable in color from the rotten wood upon which grown. The occurrence on Citrus wood, velvety hymenium, globose spores, and thick and loosely interwoven subiculum seem good, distinctive characters.

Specimens examined:

Louisiana: Point à la Hache, A. B. Langlois, 894, type (in N. Y. Bot. Gard. Herb., Mo. Bot. Gard. Herb., 63729, and Burt Herb.).

14. P. longispora (Pat.) v. Höhnel, Ann. Myc. 3: 325.1905 ; Bourdot \& Galzin, Soc. Myc. Fr. Bul. 28: 392 . 1913; Rea, Brit. Basid. 690. 1922.

Hypochnus longisporus Patouillard, Jour. de Bot. 1894: 221. 1894; Sacc. Syll. Fung. 11: 130. 1895.-Kneiffia longispora (Pat.) Bresadola, Ann. Myc. 1: 105. 1903.

Fructifications widely effused, thin, pubescent, hypochnoid, not separable, white, becoming pale smoke-gray to pale olivebuff in the herbarium, the margin thinning out; in structure 30-120 $\mu$ thick, not colored, composed of suberect, loosely arranged, thin-walled, rough-walled, nodose-septate hyphae $21 / 2^{-}$ $3 \mu$ in diameter, and of cystidia; no gloeocystidia; cystidia acicular, rough-walled, $40-80 \times 3-4 \mu$, protruding up to $60 \mu$; spores white in spore collection, even, $6-15 \times 21 / 2^{-3} \mu$.

Fructifications $3-10 \mathrm{~cm}$. long, 1-5 cm. wide.

On bark and decaying wood of frondose species usually-especially Populus-rarely on conifers. In Europe and Africa and from Maine to Louisiana, Montana to Washington, and in the West Indies. July to March. Frequent.

$P$. longispora is well marked by its thin, white fructifications, hyphae, and needle-shaped cystidia rough or somewhat barbed with minute crystals, and the slender spores. There are few resupinate species which may be more confidently recognized.

Specimens examined:

Sweden: Lappland, L. Romell, 316; Stockholm, L. Romell, 411. Poland: Russian Poland, Eichler, comm. by G. Bresadola. 
Austria: Innsbruck, Tirol, V. Litschauer.

France: Allier, H. Bourdot, 4073, 20807; Aveyron, A. Galzin, 11842, 17636, comm. by H. Bourdot, 20861, 20862.

England: Doncaster, E. M. Wakefield (in Mo. Bot. Gard. Herb., 57118).

Maine: Kittery Point, R. Thaxter \& E. A. Burt.

New York: East Berne, C. H. Peck (in N. Y. State Mus. Herb., and Mo. Bot. Gard. Herb., 14859).

Florida: Royal Palm Hummock, W. A. Murrill, 105, comm. by N. Y. Bot. Gard. Herb. (in Mo. Bot. Gard. Herb., 62105).

Louisiana: Baton Rouge, C. J. Humphrey, 2529 (in Mo. Bot. Gard. Herb., 20690); St. Martinville, A. B. Langlois, br, dk.

Montana: Columbia Falls, C. J. Humphrey, 7239 (in Mo. Bot. Gard. Herb., 12526).

Idaho: Coolin, J. R. Weir, 11255, 11541 (in Mo. Bot. Gard. Herb., 63259, 63296).

Washington: Olympia, C. J. Humphrey, 6339.

Cuba: C. G. Lloyd, 436 (in Mo. Bot. Gard. Herb., 55169).

Jamaica: Blue Hole, W. A. Murrill, 231, comm. by N. Y. Bot. Gard. Herb.

Grenada: Grand Etang, R. Thaxter, comm. by W. G. Farlow, 5 .

15. P. asperipilata Burt, n. sp.

Type: in Burt Herb. and U. S. Dept. Agr. Herb.

Fructifications effused, very thin, closely adnate, snow-white, velvety, the margin thinning out; in section $45-60 \mu$ thick, not colored, composed of somewhat erect, loosely interwoven, thinwalled hyphae $3 \mu$ in diameter, not incrusted, occasionally nodoseseptate, which terminate in cystidia and clusters of basidia forming a hymenium barely continuous; no gloeocystidia; cystidia hair-like, slender, tapering to a sharp point, conspicuously denticulate or rough, $30-60 \times 3-5 \mu$, protruding up to $50 \mu$ beyond the basidia, very numerous; basidia 4-spored; spores hyaline, even, subglobose, $31 / 2-4 \mu$ in diameter.

Fructifications $1-2 \frac{1}{2} \mathrm{~cm}$. in diameter in the fragmentary specimens known to me.

On rough bark of a frondose species. Louisiana and Texas. April and May. Rare. 
$P$. asperipilata is a delicate, white, hypochnoid species covering very rough decaying bark. It is noteworthy by the abundant, needle-shaped, thin-walled cystidia with denticulate sides and by the globose spores.

Specimens examined:

Louisiana: St. Martinville, A. B. Langlois, 44, comm. by Lloyd Herb., 2395, and 1225, comm. by W. G. Farlow (in Mo. Bot. Gard. Herb., 44067).

Texas: Houston, H. W. Ravenel, 265, type (in U. S. Dept. Agr. Herb. and Burt Herb.).

16. P. albugo Burt, n. sp.

Type: in Burt Herb.

Fructifications longitudinally effused, filmy-pruinose, adnate, whitish, pale smoke-gray in the herbarium, even, the margin indeterminate, pruinose; in section 25-50 $\mu$ thick, not colored, with the basidia and cystidia starting directly from the substratum or with only very short, erect, intervening hyphae $21 / 2-3 \mu$ in diameter, thin-walled, collapsing; no gloeocystidia; cystidia not incrusted, $40-50 \times 41 / 2^{-} 6 \mu$, protruding up to $40 \mu$; spores white in spore collections, even, $5-8 \times 3-41 / 2 \mu$, borne 4 to a basidium.

Fructifications $5-8 \mathrm{~cm}$. long, $1 \frac{1}{2}-3 \mathrm{~cm}$. wide.

Under side of decaying frondose wood. Louisiana. December and April.

$P$. albugo is a whitish, pruinose, filmy growth resembling in aspect the young sterile mycelia which are sent in for determination in nearly all extensive series of specimens, but in this instance Mr. Langlois took spore falls on glass from the specimens-a highly commendable method of saving time, which is wasted when sectional preparations are made of mere mycelia, and also of keeping rubbish from preservation in the herbarium. $\quad P$. albugo is related to $P$. detritica of France but has less membranaceous fructifications and more elongated spores.

Specimens examined:

Louisiana: St. Martinville, A. B. Langlois, ba, type, and $d l$.

17. P. albula Atkinson \& Burt, n. sp.

Type: in Burt Herb. 
Fructifications long-effused, adnate, thin, tender, small pieces separable, white, becoming light buff when old and in the herbarium, somewhat granular, becoming cracked into polygonal masses 1-2 mm. in diameter, the margin thinning out; in section 70-200 $\mu$ thick, not colored, composed of suberect, thin-walled, branching hyphae about $3 \mu$ in diameter, occasionally nodoseseptate, not incrusted, sometimes slightly brownish near the substratum; no gloeocystidia; cystidia not incrusted, $3 \mu$ in diameter, tapering towards the apex, protruding 10-20 $\mu$, sometimes very few and inconspicuous; spores hyaline, even, $4-6 \times 21 / 2^{-}$ $3 \mu$.

Fructifications 2-20 $\mathrm{cm}$. long, 1-2 cm. wide.

On bark of fallen decaying branches on the ground, of Alnus, Acer, Tilia, Populus, and other frondose species. Canada to Alabama and westward to Washington. July to February. Frequent.

$P$. albula belongs near $P$. Sambuci on account of its white color, somewhat granular hymenium, and minute cystidia which are not incrusted and sometimes so few and inconspicuous that they may possibly be overlooked, and the specimen referred to Corticium. $P$. albula differs from $P$. Sambuci in not having the hyphae incrusted in a subhymenial zone and in having them sometimes slightly brownish towards the substratum.

Specimens examined:

Exsiccati: Ellis, N. Am. Fungi, 409, under the name Corticium calceum.

Canada:J. Macoun, 5, type; Beechwood Cemetery, other locality not given, J. Macoun, 58; Ottawa, J. Macoun, 9.

Maine: Kittery Point, R. Thaxter \& E. A. Burt.

New Hampshire: Chocorua, W. G. Farlow, D (in Mo. Bot. Gard. Herb., 56132).

Massachusetts: Sharon, A. P. D. Piguet, 137, comm. by Farlow Herb. (in Mo. Bot. Gard. Herb., 59628); Wayland, A. B. Seymour, T 8 (in Mo. Bot. Gard. Herb., 19550).

New York: Albany, H. D. House, 3 gatherings (in N. Y. State Mus. Herb., and Mo. Bot. Gard. Herb., 57447, 59683, 59686); Ithaca, several collections by G.F.Atkinson, H. L. Jackson, C. O. Smith, and Van Hook, comm. by G. F. Atkinson, 8028, 
8069, 8072, 8235, 14392, 14393; Karner, H. D. House (in N. Y. State Mus. Herb., and Mo. Bot. Gard. Herb., 54373); New York, Bronx Park, L. M. Underwood (in N. Y. Bot. Gard. Herb., Mo. Bot. Gard. Herb., 61592, and Burt Herb.).

New Jersey: Newfield, J. B. Ellis, $J$ 87, D 81, comm. by Farlow Herb. (in Mo. Bot. Gard. Herb., 8266, 14689, 7458), and in Ellis, N. Am. Fungi, 409.

Pennsylvania: Philadelphia, A. S. Rhoads, comm. by L. O. Overholts, 2679 (in Mo. Bot. Gard. Herb., 5919).

Maryland: Takoma Park, C. L. Shear, 1271, 1272.

District of Columbia: Chive Chose, J. R. Weir, 372 (in Mo. Bot. Gard. Herb., 17649).

Virginia: Chain Bridge, A. S. Rhoades, comm. by L. O. Overholts, 3969 (in Mo. Bot. Gard. Herb., 54986).

Florida: W. W. Calkins, comm. by U. S. Dept. Agr. Herb. Alabama: Montgomery, R. P. Burke, 127, 157 (in Mo. Bot. Gard. Herb., 5499, 44964).

Iowa: Woodbine, C. J. Humphrey \& C. W. Edgerton, comm. by C. J. Humphrey, 6511, 6546 (in Mo. Bot. Gard. Herb., 11063, 11276).

Washington: Bingen, W. N. Suksdorf, 894, 900.

18. P. Sambuci (Pers.) Burt, n. comb.

Corticium Sambuci Persoon, Roemer Neues Mag. Bot. 1: 111. 1794; Fries, Epicr. 565. 1838; Hym. Eur. 660. 1874; Berkeley, Outlines Brit. Fung. 276. 1860; Massee, Linn. Soc. Bot. Jour. 27: 137. 1890; Wakefield, Brit. Myc. Soc. Trans. 4: 115. pl. 3, f. 1,2. 1913; Rea, Brit. Basid. 677. 1922.-Thelephora Sambuci Persoon, Syn. Fung. 581. 1801; Myc. Eur. 1: 152.1822 (in subgenus Corticium).-Hypochnus Sambuci (Pers.) Sacc. Syll. Fung. 6: 656. 1888. - Thelephora sera Persoon, Syn. Fung. 580. 1801; Myc. Eur. 1: 151. 1822 (in subgenus Corticium).-Corticium serum (Pers.) Bresadola, I. R. Accad. Agiati Atti III. 3: 112. 1897; Bourdot \& Galzin, Soc. Myc. Fr. Bul. 27:246. 1911.

Fructifications effused, closely adnate, incrusting, not separable, snow-white or chalk-white, sometimes becoming pale cream-color in the herbarium, granular and pruinose, the margin thinning out; in section 100-250 $\mu$ thick, not colored, composed 
of suberect, somewhat interwoven, thin-walled, incrusted hyphae $21 / 2-3 \mu$ thick, occasionally nodose-septate; no glococystidia; cystidia not incrusted, tapering towards the apex, $3 \mu$ in diameter, protruding $10-30 \mu$ beyond the basidia; spores hyaline, cren, $4-5 \frac{1}{2} \times 3-4 \mu$.

Fructifications $3-10 \mathrm{~cm}$. long, 1-3 cm. wide, often surrounding small twigs.

On bark and wood of fallen Sambucus and other frondose species. In Europe and throughout North America. Throughout the year. Very common.

This species is very common, and has become so well known to mycologists early in their work, under its original name Corticium Sambuci that there has been a reluctance, which I feel also, to call it Peniophora Sambuci, which its structure really requires. Its cystidia have been termed sterile basidia and cystidioles, but they differ in no morphological respect from the cystidia of other species of Peniophora. The species occurs in especially fine condition on Sambucus, and it is well to use such specimens as standards for comparison.

Specimens examined:

Exsiccati: Bartholomew, Fungi Col., 3135, 4715; Brinkmann,

Westfälische Pilze, 10; Cavara, Fungi Longobardiae, 63, 213;

Cooke, Fungi Brit., 408; Ell. \& Ev., Fungi Col., 607, under the name Corticium scutellare; Krieger, Fungi Sax., 523; Romell, Fungi Scand., 35; Roumeguere, Fungi Gallici, 2911; Westendorp, Herb. Crypt. Belge, 588.

Sweden: Stockholm, L. Romell, 129, 200, and in Romell, Fungi Scand., 35.

Germany: Saxony, Krieger, Fungi Sax., 523; Westphalia, in Brinkmann, Westfälische Pilze, 10.

Austria: Tirol, Innsbruck, V. Litschauer.

Italy: Rome, G. Bresadola; Brixia, A. Marozzi, and Papia, F. Cavara, in Cavara, Fungi Longobardiae, 63 and 213 respectively.

England: Forden, E. Vize, in Cooke, Fungi Brit., 408.

Belgium: Courtrai, in Westendorp, Herb. Crypt. Belge, 588.

France: Fautrey, comm. by Lloyd Herb., 4326, 4357; Bois de Vincennes, N. Patouillard (in N. Y. Bot. Gard. Herb., and 
Mo. Bot. Gard. Herb., 55906); Rouen, in Roumeguere, Fungi Gallici, 2911.

Canada: J. Macoun, 21, 26; Lake Rosseau, E. T. \& S. A. Harper, 754; Ottawa, J. Macoun, 370.

Maine: F. L. Harvey (in N. Y. State Mus. Herb., and Mo. Bot. Gard. Herb., 55804).

New Hampshire: Chocorua, W. G. Farlow, 2, and C3 (in Mo. Bot. Gard. Herb., 43893).

Vermont: Grand View Mountain, E. A. Burt; Middlebury, E. A. Burt, 4 gatherings; Weybridge, E. A. Burt.

Massachusetts: East Wareham, C. L. Shear, 2903 (in Mo. Bot. Gard. Herb., 15448).

New York: Clarksville, C. H. Peck, comm. by N. Y. State Mus. Herb. (in Mo. Bot. Gard. Herb., 18281); Constableville, C. H. Peck, comm. by N. Y. State Mus. Herb., T4 (in Mo. Bot. Gard. Herb., 54571); Ithaca, G. F. Atkinson, 942, 4567, 8047, 22960; Lyndonville, C. E. Fairman, comm. by N. Y. State Mus. Herb. (in Mo. Bot. Gard. Herb., 57512); Marcellus, L. M. Underwood, 62 (in N. Y. Bot. Gard. Herb., and Mo. Bot. Gard. Herb., 61595); New York, W. A. Murrill (in N. Y. Bot. Gard. Herb., and Mo. Bot. Gard. Herb., 61595).

New Jersey: Newfield, J. B. Ellis, in Ell. \& Ev., Fungi Col., 607. Pennsylvania: Trexlertown, W. Herbst, 11 .

Louisiana: Baton Rouge, Edgerton \& Humphrey, comm. by C. J. Humphrey, 5662; St. Martinville, A. B. Langlois, dd, 37, comm. by Lloyd Herb., 2384, and 1944, comm. by W. G. Farlow (in Mo. Bot. Gard. Herb., 44065).

Michigan: Ann Arbor, C. H. Kauffman (in Mo. Bot. Gard. Herb., 5584); Gogebic County, E. A. Bessey, 372 (in Mo. Bot. Gard. Herb., 56636).

Missouri: Creve Coeur, L. O. Overholts (in Mo. Bot. Gard. Herb., 63704); St. Louis, E. A. Burt (in Mo. Bot. Gard. Herb., 63466, 58335).

Kansas: Stockton, E. Bartholomew, 5815, 8206 (in Mo. Bot. Gard. Herb., 16709, 62175), and in Bartholomew, Fungi Col., 4715; Rooks County, E. Bartholomew, 2045 (in Mo. Bot. Gard. Herb., 4827).

Washington: Bainbridge Island, E. Bartholomew, in Bartholo- 
mew, Fungi Col., 3135; Olympia, C. J. Humphrey, 6311; Sedro-Woolley, C. J. Humphrey, 7464.

California: Claremont, I. M. Johnston, comm. by L. O. Overholts, 3645 (in Mo. Bot. Gard. Herb., 54699); Santa Catalina Island, L. W. Nuttall, 522b (in Mo. Bot. Gard. Herb., 57622). Mexico: Guernavaca, W. A. \& E. L. Murrill, 391, comm. by N. Y. Bot. Gard. Herb. (in Mo. Bot. Gard. Herb., 54548); Orizaba, W. A. \& E. L. Murrill, 756, comm. by N. Y. Bot. Gard. Herb. (in Mo. Bot. Gard. Herb., 54644).

\section{P. Thujae Burt, n. sp.}

Type: in Burt Herb.

Fructifications effused, thin, closely adnate, white, sometimes becoming cartridge-buff in the herbarium, the margin thinning out; in section 40-150 $\mu$ thick, not colored, with the hyphae loosely arranged, suberect, interwoven, $2-3 \mu$ in diameter, nodose-septate, thin-walled, becoming incrusted in a subhymenial zone; no gloeocystidia; cystidia hair-like, not incrusted, $3 \mu$ in diameter at the base, tapering upward and sometimes somewhat capitate at apex, protruding $20-30 \mu$ beyond the basidia; spores white in a spore collection, $4-5 \times 3 \mu$.

Fructifications 2-6 cm. long, 1-2 cm. wide, on trunks of Thuja, more rarely on Juniperus and Pinus Strobus. Canada to Massachusetts, and westward to Missouri. July to October. Occasional.

$P$. Thujae may be recognized by its thin, white fructifications on white cedar, with microscopic structure as stated. It differs from Peniophora Sambuci in having thinner fructifications, not becoming granular and pruinose, cystidia numerous, and in occurrence on a coniferous substratum.

Specimens examined:

Canada: J. Macoun 62; St. Lawrence Valley, J. Macoun, 68, 80;

Ottawa, J. Macoun (in N. Y. State Mus. Herb., and Mo. Bot. Gard. Herb., 55813), and 45, and J. M. Macoun (in N. Y. State Mus. Herb., and Mo. Bot. Gard. Herb., 56078); Quebec, Hull, J. Macoun, 173.

Vermont: Middlebury, E. A. Burt, 3 gatherings, one of which is the type. 
Massachusetts: Magnolia, W. G. Farlow, f; Newton, W. G. Farlow.

New York: Ithaca, G. F. Atkinson, 14416; North River, C. H. Peck, comm. by N. Y. State Mus. Herb., T5 (in Mo. Bot. Gard. Herb., 54569).

Missouri: St. Louis, E. A. Burt.

20. P. montana Burt, n. sp.

Type: in Burt Herb.

Fructifications effused, thin, adnate, tender, whitish to ivoryyellow, widely cracked in drying and showing the loose subiculum on the sides of the crevices, the margin thinning out, somewhat floccose; in section 200-225 $\mu$ thick, not colored, composed of loosely interwoven, thin-walled, hyaline hyphae $4-5 \mu$ in diameter, not incrusted, not nodose-septate, of irregular outline; no gloeocystidia; cystidia hair-like, not incrusted, conical, tapering to a sharp apex, 6-9 $\mu$ in diameter at the base, protruding up to $40 \mu$; spores hyaline, even, cylindric, slightly curved, 12$14 \times 4-5 \mu$.

Fragmentary fructification $4 \mathrm{~cm}$. long, $1 \mathrm{~cm}$. wide.

On badly decayed coniferous wood at an altitude of 10,000 ft. Colorado. July. Rare.

$P$. montana is noteworthy by having spores as large as those of $P$. mutata, but the fructifications are thinner and more tender than those of $P$. mutata and occur on coniferous wood and have no gloeocystidia.

Specimens examined:

Colorado: Ouray, C. L. Shear, 1188, type.

21. P. terricola Burt, n. sp.

Type: in Burt Herb.

Fructifications effused, thin, closely adnate, somewhat membranaceous, white, not waxy, the margin indeterminate, thinning out; in section 100-200 $\mu$ thick, not colored, composed of suberect, branching hyphae $3-6 \mu$ in diameter, incrusted, densely interwoven and with more or less sand intermixed; no gloeocystidia; cystidia not incrusted, cylindric, 4-6 $\mu$ in diameter, protruding $20-50 \mu$ beyond the basidia; spores hyaline, even, 4-6 $\times 3-4 \mu$. 
Fructifications received in fragments but probably about 1-3 $\mathrm{cm}$. in diameter.

On ground in mixed woods. New York and Louisiana. April and June.

The fructifications of $P$. terricola contain so much of the sand from the earth substratum that it is difficult to secure sections or to distinguish the fructification proper from its vegetative mycelium. The occurrence in small white patches on the ground, and the characters of spores and cystidia may enable recognition of this species which is probably common.

Specimens examined:

New York: Ithaca, G. F. Atkinson, 22658, 22659, type.

Louisiana: St. Martinville, A. B. Langlois, bq.

\section{P. magnahypha Burt, n. sp.}

Type: in Mo. Bot. Gard. Herb. and Farlow Herb.

Fructifications interruptedly effused, thin, adnate, between pale drab-gray and pale vinaceous-fawn, contracting in drying into small, more or less completely separated masses, not waxy, the margin thinning out; in section . 150-180 $\mu$ thick, not colored, composed of erect hyphae $9-10 \mu$ in diameter which start from the substratum at points $30-100 \mu$ apart, branch repeatedly into branches of smaller diameter, are sparingly granule-incrusted, and terminate in large clusters of basidia and one or a few cystidia forming a hymenium; no gloeocystidia; cystidia not incrusted, septate, $9 \mu$ in diameter, protruding up to $60 \mu$ beyond the basidia; basidia with 4 sterigmata; spores hyaline, even, $9-10 \times 6 \mu$.

Fructifications up to $4 \mathrm{~cm}$. long, $2 \mathrm{~cm}$. wide.

On decaying wood of a frondose species. Florida. Autumn.

While preliminary inspection of $P$. magnahypha with a lens does not promise more than any one of the great number of littledifferentiated, perplexing, whitish resupinate species difficult to identify yet doing an important work in splitting up complex organic compounds, nevertheless its structural characters are unique. The combination of coarse, scattered, trunk-like, erect hyphae with the main trunk hypha or some of its principal branches protruding through and beyond the flat-topped cluster 
of basidia as a transversely septate cystidium should lead to the ready recognition of this species when sectional preparations are studied.

Specimens examined:

Florida: Cocoanut Grove, R. Thaxter, 5\%, type (in Mo. Bot.

Gard. Herb., 43947).

23. P. exilis Burt, n. sp.

Type: in Mo. Bot. Gard. Herb.

Fructifications longitudinally effused, very thin, closely adnate, pale olive-buff, even, somewhat velutinous, the margin thinning out, indeterminate; in section $30-60 \mu$ thick, not colored, composed of erect, bushy-branched hyphae $3 \mu$ in diameter, ascending from the substratum, soon terminating in basidia and cystidia, not nodose-septate, with very little, if any, incrustation; no gloeocystidia; cystidia hair-like, irregular, flexuous, $30 \times 41 / 2^{-}$ $5 \mu$, protruding up to $20 \mu$, few and scattered; basidia simple, with 4 short sterigmata; spores hyaline, even, $4 \frac{1}{2^{-5}} \times 2 \frac{1}{2}-3 \mu$.

Fructifications 1-6 cm. long, about $1 \mathrm{~cm}$. wide.

On bark of decaying branches of frondose species in moist virgin forest. Mexico. January.

The fructifications of $P$. exilis occur as a thin, downy, gray coating on very rotten branches $1-2 \mathrm{~cm}$. in diameter. The pale olive-buff color should be helpful in separating this species from the great number more white in color.

Specimens examined:

Mexico: Guernavaca, W. A. \& E. L. Murrill, 385, comm. by N. Y. Bot. Gard. Herb. (in Mo. Bot. Gard. Herb., 54467); Orizaba, W. A.\& E. L. Murrill, 757, type, and 780, comm. by N. Y. Bot. Gard. Herb. (in Mo. Bot. Gard. Herb., 54619, $54620)$.

24. P. livida Fries in herb. under Corticium, n. sp.

Peniophora serialis in part of v. Höhnel \& Litschauer, Bourdot \& Galzin, and Rea.-Not Corticium seriale Fries of Fries Herb.Not Xerocarpus Cacao Karsten, Hedwigia 29: 271. 1890.

Type: in Herb. Fries, determined by E. Fries as Corticium lividum. 
Fructifications longitudinally effused, closely adnate, waxysoft, variable in color, pale olive-gray and pale olive-buff to fawncolor in the herbarium, glabrous, even, not cracked usually, rarely with a few fissures from contraction in drying, the margin thinning out; in section 75-500 $\mu$ thick, not colored, composed of densely interwoven, rather erect hyphae about $3 \mu$ in diameter, indistinct, with the wall gelatinously modified; no gloeocystidia; cystidia not incrusted, tapering to a sharp apex, $31 / 2-6 \mu$ in diameter, protruding up to $40 \mu$ beyond the basidia; spores hyaline, even, $4-5 \times 1 \frac{1}{2}-2 \mu$.

Fructifications $3-12 \mathrm{~cm}$. long, 1-3 cm. wide.

Generally on old, decaying, coniferous wood, rarely on frondose wood. Europe, Louisiana, and British Columbia. Throughout the year.

$P$. livida may be best recognized by its close resemblance in aspect to even specimens of common Corticium lividum Pers., from which the presence of cystidia separate it. $P$. livida is one of the 3 species which European mycologists, following Bresadola, have been inclined to regard as sufficiently meeting the original description of Corticium seriale that one could ignore the fact that the species concerned do not agree in structure with one another, nor with any of the specimens in Kew Herbarium or Fries Herbarium, determined by Elias Fries as Corticium seriale. With regard to the appliability of the original description of Corticium seriale, it emphasizes rimose and testaceous fructifications which are not characters of $P$. livida. It might solve the problem of Corticium seriale Fr. to search in Sweden for a true Corticium which is testaceous and rimose and could be compared with the specimen in Kew Herbarium determined by Fries -something more like Corticium Cacao Karst, which has the hymenium somewhat deteriorated in my specimen so that I cannot be quite positive as to its genus from this specimen alone but seems to me to be a true Corticium.

Specimens examined:

Sweden: E. Fries, type, the thinner and paler of the specimens in Herb. E. Fries, determined by E. Fries as Corticium lividum; L. Romell, 108, 109; Femsjö, L. Romell, 410; Stockholm, L. Romell, 198, 326, 345, 362. 
Austria: Tirol, Innsbruck, V. Litschauer, 3 specimens under the name $P$. serialis.

Louisiana: Bogalusa, C. J. Humphrey, 5547.

British Columbia: Revelstoke, C. W. Dodge, 1639 (in Mo. Bot.

Gard. Herb., 58784); Sidney, J. Macoun, 9 (in Mo. Bot.

Gard. Herb., 5768); Victoria, J. Macoun, 541 (in Mo. Bot. Gard. Herb., 63728).

25. P. phyllophila Massee, Linn. Soc. Bot. Jour. 25: 150. 1889; Sacc. Syll. Fung. 9: 238. 1891; Rea, Brit. Basid., 697. 1922.

Asterostromella epiphylla v. Höhnel \& Litschauer, K. Akad. Wiss. Wien Sitzungsber. 116: 773. text f. 3. 1907.

Type: type distribution in Ravenel, Fungi Am., 457, under the name Corticium epiphyllum.

Fructification broadly effused, thin, closely adnate, not at all separable, whitish, becoming olive-buff in the herbarium, the margin thinning out; in section $40-80 \mu$ thick, not colored, composed of suberect, interwoven, branching, thin-walled hyphae $2 \mu$ in diameter, not incrusted, not nodose-septate, bearing clusters of basidia and branching paraphyses; also present occasional, tapering cystidia not incrusted, $30-45 \times 4-10 \mu$, usually immersed, occasionally protruding up to $32 \mu$ beyond the basidia; paraphyses colorless, branching at the hymenial surface into an antler-shaped form with very slender prongs; spores published by $v$. Höhn. \& Lits. as $10-22 \times 1 \frac{1}{2}-3 \mu$.

Fructifications up to $5 \mathrm{~cm}$. in diameter.

On fallen frondose leaves in South Carolina and on fallen decaying frondose limbs in Florida and Central America.

$P$. phyllophila is apparently a tropical species occurring more frequently on epidermis of small fallen twigs and ranging northward to South Carolina. I have studied specimens of the type distribution in the copies of Ravenel, Fungi Americana, of Farlow Herbarium, Missouri Botanical Garden Herbarium, United States Department of Agriculture Herbarium, and Burt Herbarium, and find these specimens to be the same in structure and all showing the distinctive antler-shaped paraphyses emphasized by v. Höhnel \& Litschauer, and also tapering, non- 
incrusted cystidia which are presumably what Massee really saw. I see no reason for displacing the specific name given by Massee for the later combination proposed by v. Höhnel \& Litschauer. The basidia are so young that I found none bearing sterigmata nor spores and only twice slender spores $12-15 \times$ $3 \mu$.

Specimens examined:

Exsiccati: Ravenel, Fungi Am., 457, type distribution, under the name Corticium epiphyllum.

South Carolina: Aiken, H. W. Ravenel, in Ravenel, Fungi Am., 457.

Florida: W. W. Calkins.

Central America: Panama Chagres, F. L. Stevens, 1900 (in Mo. Bot. Gard. Herb., 63521).

\section{P. piliseta Burt, n. sp.}

Type: in N. Y. Bot. Gard. Herb., Mo. Bot. Gard. Herb., and Burt Herb.

Fructifications longitudinally effused, thin, somewhat membranaceous, tender, small pieces separable when moistened, whitish cream-color in the herbarium, not cracked, not shining, the margin thinning out, with the hyphae interwoven; in section 100-120 $\mu$ thick, not colored, composed of ordinary, interwoven, thin-walled hyphae about $3 \mu$ in diameter, not incrusted nor nodose-septate, and of a system of hyaline tissue about $1 \mu$ in diameter, not taking stain, branching like the coarser tissue of Corticium investiens and with its delicate antler-shaped branches barely visible in the hymenial surface; no gloeocystidia; cystidia not incrusted, cylindric, obtuse, $41 / 2^{-6} \mu$ in diameter, protruding $30-45 \mu$, confined to the surface of the hymenium; spores hyaline, even, cylindric, biguttulate, $9-11 \times 4-4 \frac{1}{2} \mu$, copious.

Fructification $71 / 2 \mathrm{~cm}$. long, broken off at one end, $10-15 \mathrm{~mm}$. wide.

On a very rotten, small, frondose limb about $1 \mathrm{~cm}$. in diameter. Porto Rico. June.

$P$. piliseta is noteworthy by having in addition to an ordinary hyphal system in its fructification an additional system, intermixed with the first, of delicate, branching organs not taking 
stain, such as is more distinctly visible, because coarser, in $P$. phyllophila, Hypochnus pallescens, Corticium investiens and Grandinia granulosa, and whose peripheral branches are more or less visible in the surface of the hymenium as antler-shaped paraphyses. P. mexicana has coarser hyphae and more hypochnoid surface.

Specimens examined:

Porto Rico: Martin Piña, Rio Piedras, J. R. Johnston, 971 a, type (in N. Y. Bot. Gard. Herb., Mo. Bot. Gard. Herb., 63243, and Burt Herb.).

27. P. mexicana Burt, n. sp.

Type: in N. Y. Bot. Gard. Herb. and Mo. Bot. Gard. Herb.

Fructifications longitudinally effused, adnate, dry, hypochnoid, thin, cream color in the herbarium, even, velutinous under a lens, not cracked, the margin thinning out; in section $140 \mu$ thick, not colored, composed of even-walled, rather rigid, loosely arranged, branching hyphae $5-7 \mu$ in diameter, not incrusted, not nodose-septate, which ascend obliquely from the substratum and bear a dense hymenium containing numerous cystidia and branching, filiform paraphyses (or perhaps conidiophores); no gloeocystidia; cystidia minutely incrusted or rough, tapering, 60-100 $\times 5-9 \mu$, protruding $40-60 \mu$; spores (perhaps conidia) hyaline, even, $6-71 / 2 \times 4-5 \mu$, copious.

Fructifications $4 \mathrm{~cm}$. long and broken off at both ends, $6 \mathrm{~mm}$. wide.

In depressed places on very rotten frondose wood. Mexico. January.

The dry, cream color or buff fructifications of hypochnoid texture, very coarse hyphae, large cystidia, and branching paraphyses or conidiophores in the surface of the hymenium are characters which should make this species recognizable, although my inability to demonstrate basidia convinces me that the type is in a conidial stage somewhat comparable with that of Corticium roseum.

Specimens examined:

Mexico: Orizaba, Nuevo, altitude 3600 m., W. A. \& E. L. Murrill, 773, type (in Mo. Bot. Gard. Herb., 54633). 
28. P. ludoviciana Burt, n. sp.

Type: in Burt Herb., and Farlow Herb. probably.

Fructifications effused, adnate, very thin, buff-yellow, darkening to cinnamon-buff in the herbarium, hymenium subvelutinous, not waxy, not cracking, the margin thinning out, paler; in section $40-75 \mu$ thick, not colored, composed of suberect, branching, granule-incrusted, hyaline hyphae 3-4 $\mu$ in diameter; no gloeocystidia; cystidia hyaline, not incrusted, protruding 18-25 $\mu$ beyond the basidia; spores hyaline, even, $4-5 \times 21 / 2^{-}$ $31 / 2 \mu$, somewhat flattened on one side.

Fructifications $1-21 / 2 \mathrm{~cm}$. long, $1 / 2-11 / 2 \mathrm{~cm}$. broad, becoming confluent.

On rotting decorticated wood of frondose species. Louisiana and Michigan. August and April. Rare.

$P$. ludoviciana closely resembles in aspect $P$. flammea and, like the latter, is not separable from the substratum and gives no noteworthy color changes when the sections are treated with potassium hydrate solution. Prolonged search has failed to find any immersed cystidia. P. sulphurina has larger, cracked fructifications with shining hymenium and yellow subiculum.

Specimens examined:

Louisiana: St. Martinville, A. B. Langlois, 1919, type, comm. by W. G. Farlow.

Michigan: Vermilion, A. H. W. Povah, 369 (in Mo. Bot. Gard. Herb., 13921).

\section{P. fusca Burt, n. sp.}

Type: in Mo. Bot. Gard. Herb.

Fructifications effused, closely adnate, very thin, drying ecrudrab to drab, velvety, even, the margin not determinate, thinning out; in structure 35-45 $\mu$ thick, not colored, composed of loosely arranged, suberect, hyaline hyphae more or less incrusted, $31 / 2^{-}$ $4 \mu$ in diameter under the incrustation, not nodose-septate; no gloeocystidia nor conducting organs; cystidia hair-like, not incrusted, $7-12 \mu$ in diameter at the base, protruding $40-125 \mu$ beyond the basidia; basidia with 4 sterigmata; spores copious, hyaline, even, $6-7 \times 3 \frac{1}{2} \mu$.

Fructifications 2-6 cm. long, 1-2 cm. wide, becoming larger by confluence. 
On very rotten, decorticated and probably frondose wood. Alabama. June to October. Only 2 gatherings known.

$P$. fusca is a thin species of mucedinous aspect, like $P$. longispora but well characterized by its drab color, large cystidia, and moderately large spores. $P$. cinerea is sometimes of the same color but is less mould-like when viewed with a lens and with quite different structure and microscopic characters.

Specimens examined:

Alabama: Montgomery County, R. P. Burke, 508, type, and 836

(in Mo. Bot. Gard. Herb., 57301 and 63125 respectively).

30. P. gilvidula Bresadola, Mycologia 17: 70. 1925.

Type: in Weir Herb.

Fructifications broadly effused, closely adnate, waxy, pinkish buff in the herbarium, here and there somewhat cracked, pruinose, the margin thinning out; in section 150-250 $\mu$ thick, not colored, 2-layered, the layer next the substratum $75-150 \mu$ thick, composed of densely arranged hyphae about $4-5 \mu$ in diameter, not incrusted, which are longitudinally interwoven in the type, hymenial layer $75-100 \mu$ thick, composed of densely arranged, erect, coarse tissue; no gloeocystidia; cystidia not incrusted, 6-8 $\mu$ in diameter, protruding $30-60 \mu$ beyond the basidia, not numerous, confined to the hymenium; basidia with 4 sterigmata; spores white in the mass, even, $5-6 \times 2 \frac{1}{2}-3 \frac{1}{2} \mu$, copious.

Fructifications $8-15 \mathrm{~cm}$. long, $3-5 \mathrm{~cm}$. wide.

On wood of log of Pinus ponderosa. Montana. September.

$P$. gilvidula has no especially distinctive character. The occurrence on Pinus ponderosa wood, buff color, thick hymenial layer, coarse hyphae, and small spores constitute the group of distinguishing characters. I have included under $P$. gilvidula a specimen from the same place which has the layer next to the substratum composed of erect hyphae.

Specimens examined:

Montana: Evaro, J.R. Weir, 23305, type (in Weir Herb.) and 426 (in Mo. Bot. Gard. Herb.).

31. P. zonata Burt, n. sp.

Type: in Mo. Bot. Gard. Herb. 
Fructifications widely effused, closely adnate, thick, layered or zonate within, avellaneous, pruinose, contracting in drying and cracking into more or less connected masses about $1 \mathrm{~mm}$. in diameter, the margin thinning out; in section $700 \mu$ thick, probably stratose but perhaps with merely a hymenium of several (4 in the type) layers or zones, not colored, composed of densely arranged hyphae about $21 / 2-3 \mu$ in diameter, with somewhat gelatinously modified and indistinct, not sharply defined as tramal, and hymenial layers; no gloeocystidia; cystidia not incrusted, $3 \mu$ in diameter at the base, tapering to a sharp apex, protruding up to $30 \mu$, very numerous in the surface of the hymenium; spores hyaline, even, curved, $41 / 2 \times 21 / 2 \mu$, copious.

Portion of fructification $7 \mathrm{~cm}$. long, $4 \mathrm{~cm}$. wide, broken off at one end and on sides.

On decayed coniferous wood. Oregon. March.

The cystidia are so small and so very numerous in the hymenial surface and the season when collected-March-so early in the year that it is possible that this species is a stratose Corticium just starting a new outer stratum on its fructification, but I do not recognize it as a Corticium at present known to me. No matter what the genus may prove to be, the thick, somewhat liver-colored fructifications of layered or stratose structure, and notably cracked, should always make this species easy to recognize.

Specimens examined:

Oregon: Corvallis, S. M. Zeller, 2252, type (in Mo. Bot. Gard. Herb., 63030).

32. P. laminata Burt, n. sp.

Type: in Burt. Herb.

Fructifications broadly effused, thin, adnate, not separable, cream-buff to warm buff, pubescent, somewhat tubercular, at length cracking into small masses $2-3$ to a mm., the margin thinning out, fibrillose; in section $75-140 \mu$, rarely $200 \mu$, thick, not colored, becoming stratose, 1-6 strata, each composed of a supporting layer of loosely arranged, erect, hyaline hyphae 3$31 / 2 \mu$ in diameter, thin-walled, collapsing, not incrusted, and of a compact hymenial layer; no gloeocystidia; cystidia not incrusted, 
hair-like, cylindric, obtuse, $3-31 / 2 \mu$ in diameter, protruding up to $30 \mu$ beyond the basidia; basidia 4 -spored; spores hyaline, even, $41 / 2 \times 3-31 / 2 \mu$, copious.

Fructifications $2-8 \mathrm{~cm}$. in diameter.

On bark and wood of fallen decaying trunk of Pinus Strobus. Vermont. December. Rare.

$P$. laminata is so suggestive in color and general aspect of the very common Corticium investiens that it is possible $P$. laminata has been passed by as a thin, young specimen of $C$. investiens, but the structure of these two species is quite different. The color of P. laminata does not fade in the herbarium; my gathering of nearly thirty years ago still has the color originally noted.

Specimens examined:

Vermont: Middlebury, E. A. Burt, type.

33. P. guttulifera (Karst.) Sacc. Syll. Fung. 9: 240. 1891; Bourdot \& Galzin, Soc. Myc. Fr. Bul. 28: 400. 1913.

Gloeocystidium guttuliferum Karsten, Finska Vet. Soc. Bidrag Natur och Folk 48: 430. 1889.

Type: a portion in Burt Herb.

Fructifications broadly effused, closely adnate, thin, becoming light buff to pinkish buff and chamois-colored in the herbarium, more or less studded with minute, hard, globular masses of resinous color which are visible under a lens but dissolve and disappear in aqueous mounts, the margin indeterminate, thinning out; in section $50-160 \mu$ thick, not colored, with the hyphae erect, branching, $3-5 \mu$ in diameter, not incrusted; no gloeocystidia; cystidia heavily incrusted, often obtuse, $40-90 \times 10-15 \mu$, protruding up to $60 \mu$; spores white in a spore collection, even, depressed on one side, $7-10 \times 3-41 / 2 \mu$.

Fructifications $2-5 \mathrm{~cm}$. long, $1-21 / 2 \mathrm{~cm}$. wide.

On decaying wood of Populus, Betula, Acer, and undetermined frondose species. In Europe, and from Canada to Louisiana and westward to Oregon. May to January. Rare.

The type specimen of $P$. guttulifera differs from $P$. pubera in having no gloeocystidia whatever and in bearing on its surface minute, globular, shining masses of such aspect as occur on tips of the granules in Odontia sudans. Such masses are also borne 
on specimens from France communicated by Bourdot, and they are stated to be borne on the cystidia-this in addition to the usual incrustation of these cystidia. Since the resinous-colored masses disappear in the liquids to which they are subjected in sectioning and making aqueous preparations for microscopic study, I am inclined to regard the presence of these masses as perhaps due to weather conditions prevalent when the specimens bearing them were collected-a helpful, confirmatory specific feature when present, but not a necessary morphological character of $P$. guttulifera. Hence I have included under $P$. guttulifera, specimens which have spores $7-10 \times 3-41 / 2 \mu$, lack gloeocystidia, and have the aspect of $P$. pubera.

Specimens examined:

Finland: Mustiala, P.A. Karsten, type of Gloeocystidium guttuliferum, under the label Gloeocystis guttulifera.

Sweden: Femsjö, E. A. Burt; Göteberg, L. Romell, 295.

France: Allier, St. Priest, H. Bourdot, 6656, 8458.

Canada: Ottawa, J. Macoun, 130 a.

Maine: Kittery Point, R. Thaxter \& E. A. Burt, 2 gatherings.

New Hampshire: Shelburne, W. G. Farlow, 3.

Vermont: Middlebury, E. A. Burt.

New Jersey: Newfield, J. B. Ellis (in N. Y. Bot. Gard. Herb., and Mo. Bot. Gard. Herb., 61398).

Alabama: Montgomery County, R. P. Burke, 212, 478 (in Mo. Bot. Gard. Herb., 57083, 57295).

Louisiana: A. B. Langlois, 256, comm. by U. S. Dept. Agr. Herb. Ohio: Lancaster, W. A. Kellerman, 168, comm. by U. S. Dept. Agr. Herb.

British Columbia: Agassiz, J. Macoun, 129.

Oregon: Corvallis, W. A. Murrill, 940, comm. by N. Y. Bot. Gard. Herb., 55715.

34. P. flavido-alba Cooke, Grevillea 8: 21. pl. 125, f. 14. 1879; Sacc. Syll. Fung. 6: 644. 1888; Massee, Linn. Soc. Bot. Jour. 25: 151.1889.

Type: in Kew Herb.

Fructifications broadly effused, thin, closely adnate, cracking in drying, becoming cartridge-buff to pinkish buff in the her- 
barium, setulose with the large cystidia, the margin indeterminate, thinning out; in section 75-250 $\mu$ thick, not colored, composed of densely interwoven, hyaline hyphae about $3 \mu$ in diameter, not incrusted, and of very numerous large cystidia, many of which are often tilted in all directions; no gloeocystidia; cystidia heavily incrusted, cylindric-fusiform to conical, sharp-pointed, 60-120 $\times 12-18 \mu$, numerous in all regions to the substratum, protruding up to $50 \mu$ beyond the basidia; spores hyaline, even, white in a spore collection, $41 / 2^{-6} \times 2 \frac{1}{2}-31 / 2 \mu$.

Fructifications $5-15 \mathrm{~cm}$. or more long, $2-5 \mathrm{~cm}$. wide.

On bark of decaying limbs of Carya, Liguidambar, Myrica, Quercus, Salix, Vitis, and other frondose species. South Carolina to Louisiana, West Virginia and Ohio to Arkansas, and in the West Indies. July to April. Common.

$P$. flavido-alba resembles in aspect $P$. pubera with which it was confused by v. Höhnel \& Litschauer in their study of specimens distributed by Ravenel and by Ellis in their exsiccati, but differs sharply from $P$. pubera in absence of gloeocystidia and in having smaller spores. Its spores are smaller than those of $P$. guttulifera; it lacks layered structure, and the cystidia are much larger than in either $P$. Ravenelii or $P$. Roumeguerii. 'There may be observed in sectional preparations a curious tilting of many cystidia, some towards the right and some towards the left while most are erect and the tilting is at varying angles, being occasionally quite parallel with the substratum. Such tilting is unique among the species of Peniophora known to me and is best shown by the immersed cystidia in sections from the thicker fructifications. The type specimen in Kew Herbarium is on the same substratum, Myrica, as the specimens distributed in Ravenel, Fungi Am., 226, and impressed me as probably being from the same gathering.

Specimens examined:

Exsiccati: Bartholomew, Fungi Col., 4741; Ellis, N. Am. Fungi, 1209; Ell. \& Ev., N. Am. Fungi, 3412; Ravenel, Fungi Am., 226.

South Carolina: P. H. Rolfs, 1622, 1625.

Georgia: Atlanta, E. Bartholomew, 5677, 5689 (in Mo. Bot. Gard. Herb., 44253); Darien, H. W. Ravenel, 2529, type (in 
Kew Herb.) and specimens in Ravenel, Fungi Am., 226, and Ellis, N. Am. Fungi, 1209.

Florida: W. W. Calkins, comm. by W. G. Farlow (in Mo. Bot. Gard. Herb., 44634), and 628, comm. by W. G. Farlow (in Mo. Bot. Gard. Herb., 44641, 44254); New Smyrna, C. G. Lloyd, 212S; Tallahassee, E. Bartholomew, 5722 (in Mo. Bot. Gard. Herb., 44256).

Alabama: Auburn, F. S. Earle \& C. F. Baker, 2217 (in N. Y. Bot. Gard. Herb., and Mo. Bot. Gard. Herb., 61344); Montgomery County, R. P. Burke, 68, 147, 164, 169, 237, 444, 463, 465, 475, 667 (in Mo. Bot. Gard. Herb., 18395, 7552, 44963, 44959, 57105, 57271, 57284, 57286, 57293, 63089).

Louisiana: Abita Springs, A. B. Langlois, 2684; Baton Rouge, Edgerton \& Humphrey, comm. by C. J. Humphrey, 5665; New Orleans, E. Bartholomew, in Bartholomew, Fungi Col., 4741, and 5765 (in Mo. Bot. Gard. Herb., 44265); A. B. Langlois, 460 (in N. Y. Bot. Gard. Herb., and Mo. Bot. Gard. Herb., 61476); St. Martinville, A. B. Langlois, 2680, comm. by Lloyd Herb., 3529, and 1954, 2679, aq. bt, cm, and $\mathrm{cn}$.

West Virginia: Ellis Coll., 48 (in N. Y. Bot. Gard. Herb., and Mo. Bot. Gard. Herb., 61395).

Ohio: Cincinnati, C. G. Lloyd, 4515, 4526, 4806.

Kentucky: Crittenden, C. G. Lloyd, 3115; Mammoth Cave, C. G. Lloyd, 1602, and in Ell. \& Ev., N. Am. Fungi, 3412.

Arkansas: Bigflat, W. H. Long, 19894 (in Mo. Bot. Gard. Herb., 6387).

Cuba: San Antonio de los Baños, Havana Province, Earle \& Murrill, 88, comm. by N. Y. Bot. Gard. Herb.; Pinar del Rio Province, Earle \& Murrill, 241, comm. by N. Y. Bot. Gard. Herb.; Santiago de las Vegas, H. Hasselbring (in N. Y. Bot. Gard. Herb., and Mo. Bot. Gard. Herb., 61468).

Porto Rico: Rio Piedras, J. A. Stevenson, 3366, 5582, 6068 (in Mo. Bot. Gard. Herb., 7574, 6944, 54685).

Jamaica: Hall's Delight, F. S. Earle, 134, comm. by N. Y. Bot. Gard. Herb.

35. P. vernicosa Ellis \& Everhart in herb., n. sp.

Type: in N. Y. Bot. Gard. Herb., Mo. Bot. Gard. Herb., and Burt Herb. 
Fructifications long and broadly effused, very thin, closely adnate, pinkish buff in the herbarium, even, somewhat puberulent and setulose under a lens, not cracked, the margin thinning out, indeterminate; in section 30-45 $\mu$ thick, not colored, composed of densely interwoven, hyaline hyphae about $3 \mu$ in diameter, indistinct; no gloeocystidia; cystidia incrusted, fusiform, $40-50 \times 10-15 \mu$, protruding up to $50 \mu$ beyond the basidia; spores hyaline, even, $4-5 \times 3-31 / 2 \mu$.

Fructifications $10-12 \mathrm{~cm}$. long, $2-3 \mathrm{~cm}$. wide.

On dead pieces of Celtis. Florida and Louisiana. August and March.

The 3 gatherings under the name $P$. vernicosa in Ellis Collection of New York Botanical Garden and duplicates of these communicated to me directly by Langlois seem to be thin forms of 3 species, 2 of which are well known. The type of $P$. vernicosa shows the location of the fructification by the pinkish buff color of the area covered, somewhat varnish-like effect produced, and cystidia visible under a lens. There is the bare possibility that $P$. vernicosa may be demonstrated to be the very early stage of $P$. flavido-alba but my knowledge of the latter does not at present warrant such a conclusion.

Specimens examined:

Florida: Cutler Hammock, W. A. Murrill, 86, comm. by N. Y.

Bot. Gard. Herb. (in Mo. Bot. Gard. Herb., 62082).

Louisiana: St. Martinville, A. B. Langlois, 1965, type (in N. Y. Bot. Gard. Herb., Mo. Bot. Gard. Herb., 63726, and Burt Herb.).

\section{P. texana Burt, n. sp.}

Type: in Mo. Bot. Gard. Herb.

Fructifications long and broadly effused, adnate, thin, even, not shining, drying between cream-buff and pinkish buff and cracking transversely, the margin indeterminate, thinning out; in section about $100 \mu$ thick, not colored, with the hyphae indistinct, interwoven, $3-31 / 2 \mu$ in diameter, not incrusted; cystidia incrusted, conical, often tilted, not colored, 45-55 × 10-12 $\mu$, protruding beyond the basidia up to $45 \mu$; no gloeocystidia nor conducting organs; spores copious, hyaline, even, $4 \frac{1}{2} 2^{-6} \times 3-$ $4 \frac{1}{2} \mu$. 
Fructifications up to $25 \mathrm{~cm}$. long, $5 \mathrm{~cm}$. broad.

On bark of Juniperus sabinoides. Texas. October. Only the type collection known.

Although occurring on bark of Juniperus, $P$. texana is not at all related to $P$. laevigata and seems rather to belong in the group of species of which $P$. flavido-alba is best known. The occurrence on Juniperus, the large expanse of the fructifications, and large cystidia and spores should afford recognition of $P$. texana. Specimens examined:

Texas: Austin, W. H. Long, 21070, type (in Mo. Bot. Gard. Herb., 55134).

\section{P. flammea Burt, n. sp.}

Type: in Burt Herb. and N. Y. Bot. Gard. Herb.

Fructifications effused, adnate, very thin, olive-ocher to deep chrome, fading to clay color in the herbarium, hymenium often with some granules, the margin thinning out, paler; in section 50-90 $\mu$ thick, not colored and with no color changes by potassium hydrate solution, with hyphae $3 \mu$ in diameter, interwoven next to the substratum but suberect, branching and granuleincrusted towards the hymenium; no gloeocystidia; wholly immersed cystidia incrusted, $15-60 \times 5-10 \mu$, few and scattered; hair-like cystidia not incrusted, $3-5 \mu$ in diameter at base, protruding 20-30 $\mu$ beyond the basidia, are scattered in the surface of the hymenium; spores hyaline, even, $31 / 2-5 \times 1 \frac{1}{2}-21 / 2 \mu$.

Fructifications $1-10 \mathrm{~cm}$. long, $5 \mathrm{~mm} .-21 / 2 \mathrm{~cm}$. broad.

On rotting wood and bark of frondose species and on under side of rotting leaves of Sabal. Florida, Alabama, Texas, Cuba, and Bermuda. March to June. Probably rare.

$P$. flammea has the intense yellow color of Corticium chrysocreas and Odontia Wrightii but, unlike these species, its sections do not become vinaceous and then bleach when treated with potassium hydrate solution and the structural details of the sections are quite different also. Peniophora sulphurina is yellow and has small spores, but the fructification of $P$. flammea is as closely adnate to, and inseparable from, the substratum as that of $P$. cinerea.

Specimens examined: 
Florida: Tarpon Springs, W. A. Murrill, 216, comm. by N. Y. Bot. Gard. Herb. (in Mo. Bot. Gard. Herb., 62121).

Alabama: Montgomery, R. P. Burke, 3, 158 (in Mo. Bot. Gard. Herb., 17431, 44962).

Texas: Austin, W. H. Long, 524.

Cuba: C. G. Lloyd, 421 (in Mo. Bot. Gard. Herb., 55172); El Yunque Mt., Baracoa, L. M. Underwood \& F. S. Earle, 1215, type, comm. by N. Y. Bot. Gard. Herb.

Bermuda: Paget Swamp, H. H. Whetzel, Abe (in Mo. Bot. Gard.

Herb., 58905).

38. P. isabellina Burt, n. sp.

Type: in Burt Herb.

Fructifications longitudinally effused, very thin, closely adnate, not at all separable, between light pinkish cinnamon and avellaneous, not shining, becoming somewhat minutely cracked, the margin thinning out; in section 50-75 $\mu$ thick, not colored, composed of innumerable cystidia and densely arranged hyphae $21 / 2-3 \mu$ in diameter, indistinct; no gloeocystidia; cystidia incrusted, $30 \times 6 \mu$, protruding up to $12 \mu$, fusoid, usually starting from the substratum; spores $6 \times 3 \mu$ present but so few found that they may not belong.

Fructification $8 \mathrm{~cm}$. long and broken off at both ends, $1 \mathrm{~cm}$. broad.

On dead canes of blackberry (Rubus), and perhaps on other frondose wood. Virginia and Alabama. June to September.

$P$. isabellina is as closely adnate as $P$. cinerea and $P$. versicolor, from both of which it differs in not being colored in section. The occurrence of the type on blackberry stems may be helpful in recognizing this species, but several other species also occur on blackberry stems. The specimen from Alabama, referred to $P$. isabellina, is probably specifically distinct.

Specimens examined:

Virginia: Woodstock, C. L. Shear, 1191, type.

Alabama: Montgomery County, R. P. Burke, 62 (in Mo. Bot. Gard. Herb., 18207).

39. P. coccineo-fulva (Schw.) Burt, n. comb.

Phlebia coccineo-fulva Schweinitz, Am. Phil. Soc. Trans. N. S. 
4: 165. 1832; Sacc. Syll. Fung. 11: 112. 1895.-Corticium rhodellum Peck, N. Y. State Mus. Rept. 42: 122. 1889.-Peniophora rhodella (Peck) Sacc. Syll. Fung. 9: 239. 1891.-Peniophora Karstenii Massee, Linn. Soc. Bot. Jour. 25: 153. 1889. -Corticium calotrichum Karsten, Rev. Myc. 10: 73. 1888; Soc. pro Fauna et Fl. Fenn. Meddel. 16: 21. 1888; Icones Hym. Fenn. 3: 7. pl. 4, f. 71. 1891; Sacc. Syll. Fung. 6: 617. 1888; 9: 232. 1891.-Peniophora rhodochroa Bresadola, Mycologia 17: 70. 1925.-Peniophora leprosa Bourdot \& Galzin, Soc. Myc. Fr. Bul. 28: 394.1913.

Type: in Schweinitz Herb. and Farlow Herb.

Fructifications effused, adnate, becoming russet to Natal brown in the herbarium, sometimes cracked, the margin paler; in section typically vinaceous russet but sometimes not colored, 150-400 $\mu$ thick, 2-layered, the layer next to substratum 100$300 \mu$ thick, composed of loosely interwoven, thin-walled hyphae 4-8 $\mu$ in diameter, with many rough-walled or incrusted, the hymenial layer very dense, typically colored, bearing the cystidia; cystidia hyaline or slightly colored, incrusted, 40-80 $\times$ 10-14 $\mu$, protruding up to $50 \mu$; spores hyaline, even, $4-5 \times 2-$ $21 / 2 \mu$.

Fructifications $4-10 \mathrm{~cm}$. long, $2 \mathrm{~cm}$. broad.

On rotting wood and bark of Juglans, Quercus, and other frondose species, rarely on conifers. Canada to Alabama and westward to British Columbia and California, and in Mexico; occurs in Europe also. July to December. Frequent.

$P$. coccineo-fulva has been confused with $P$. velutina, from which it differs when best developed, in more intense color, the vinaceous subhymenial layer often showing this color on edges of cracks in the fructification, and in the incrusted hyphae. Paler specimens which are not otherwise distinguishable from $P$. velutina I have now referred to $P$. coccineo-fulva when they have the large, incrusted hyphae of the latter, for the European concept of $P$. velutina, as shown by specimens under this name in Kew Herbarium and communicated to me by Bourdot, Bresadola, Romell, and Litschauer, has the hyphae not incrusted, with the exception of additional specimens from Bresadola and Romell which they distinguished as different from $P$. velutina by labelling as "Peni- 
ophora velutina Fr. f. pallidior," and which I cite below as $P$. coccineo-fulva. These European specimens have exactly the same structure as the authentic specimen of Corticium calotrichum sent to me by Karsten, who noted the large rough hyphae in the description in Icones Hym. Fenn. 3: 7, but the hyphae are really granule-incrusted.

Specimens examined:

Exsiccati: Ell. \& Ev., N. Am. Fungi, 2019, under the name Peniophora velutina; Ell. \& Ev., Fungi Col., 707, under the name Peniophora velutina; Rabenhorst, Fungi Eur., 3231, under the name Corticium alneum, the type distribution of Peniophora Karstenii.

Finland: Mustiala, P. A. Karsten, authentic specimen of Corticium calotrichum, and in Rabenhorst, Fungi Eur., 3231. Sweden: Femsjö, L. Romell, 421; on Fagus, Hangnen, Femsjö, E. A. Burt.

Germany: Brinkmann, comm. by Bresadola as Peniophora velutina Fr. f. pallidior.

France: Aveyron, A. Galzin, 26563, comm. by H. Bourdot, 32878, authentic specimen of Peniophora leprosa.

Canada: Hull, Quebec, J. Macoun, 197; Lambeth, Ontario, J. Dearness, D $172 b$ (in Mo. Bot. Gard. Herb., 5482); Granton, J. Dearness, 966 (in Mo. Bot. Gard. Herb., 22582); Ottawa, J. Macoun 197, 291, and J. M. Macoun, 230 (in N. Y. State Mus. Herb., and Mo. Bot. Gard. Herb., 55756, 55920, 56081 respectively).

New Brunswick: Campobello, W. G. Farlow, 2 (in part).

Maine: Boarstone Mountain, Piscataquis County, W. A. Murrill, 2404 (in N. Y. Bot. Gard. Herb., and Mo. Bot. Gard. Herb., 61354).

New Hampshire: Chocorua, W. G. Farlow, 43 (in Mo. Bot. Gard. Herb., 43972); North Conway, A. S. Rhoads, 10 (in Burt Herb., and Mo. Bot. Gard. Herb., 56979).

Vermont: Middlebury, E. A. Burt, 2 gatherings.

New York: Albany, H. D. House (in N. Y. State Mus. Herb., and Mo. Bot. Gard. Herb., 59703); Alcove, C. L. Shear, 1309; Floodwood, C. H. Peck (in N. Y. State Mus. Herb., Burt Herb., and Mo. Bot. Gard. Herb., 55986); Hudson Falls, 
S. H. Burnham, 36 (in Mo. Bot. Gard. Herb., 54457); Ithaca Flats, G. F. Atkinson, 3090; Karner, H. D. House (in N. Y. State Mus. Herb., and Mo. Bot. Gard. Herb., 54368); Lyndonville, C. E. Fairman, type of Corticium rhodellum (in N. Y. State Mus. Herb.); Westport, C. H. Peck (in N. Y. State Mus. Herb., and Mo. Bot. Gard. Herb., 55968).

New Jersey: Belleplain, C. L. Shear, 1242; Newfield, J. B. Ellis, in Ell. \& Ev., N. Am. Fungi, 2019, and Fungi Col., 707, and (in Burt Herb., N. Y. Bot. Gard. Herb., and Mo. Bot. Gard. Herb., 57337, 63455).

Maryland: Takoma Park, C. L. Shear, 1335.

Pennsylvania: Nazareth, Schweinitz, type of Phlebia coccineo-fulva (in Herb. Schweinitz and Farlow Herb.).

Alabama: Auburn, comm. by Alabama Biological Survey; Montgomery, R. P. Burke, 72, 188, 635 (in Mo. Bot. Gard. Herb., 175\$2, 57068, 63072).

Ohio: Cincinnati, C. G. Lloyd, 2808.

Michigan: Ann Arbor, C. H. Kauffman, 35 (in Mo. Bot. Gard. Herb., 20025); New Richmond, C. H. Kauffman, 26 (in Mo. Bot. Gard. Herb., 16386); Vermilion, A. H. W. Povah, 5 (in Mo. Bot. Gard. Herb., 9225).

Wisconsin: Lake Geneva, E. T. \& S. A. Harper, 834, 961; Madison, C. J. Humphrey \& M. C. Jensen, 631 (in Mo. Bot. Gard. Herb., 10275).

Colorado: Pike's Peak, G. G. Hedgcock, comm. by C. J. Humphrey, 2554 (in Mo. Bot. Gard. Herb., 9782).

Idaho: Priest River, J. R. Weir, 131 (in Mo. Bot. Gard. Herb., 15762), and 16809, type of Peniophora rhodochroa (in Weir Herb. and Mo. Bot. Gard. Herb., 63690).

British Columbia: Kootenai Mts. near Salmo, J. R. Weir, 535 (in Mo. Bot. Gard. Herb., 21995).

California: Big Wash Cañon, Santa Catalina Island, L. W. Nuttall, 889, comm. by Field Mus. Nat. Hist. Herb. (in Mo. Bot. Gard. Herb., 57650).

Arizona: Coronado Nat. Forest, G. G. Hedgcock, comm. by C. J. Humphrey, 2547 (in Mo. Bot. Gard. Herb., 9906).

Mexico: Jalapa, W. A. \& E. L. Murrill, 144, comm. by N. Y. Bot. Gard. Herb. (in Mo. Bot. Gard. Herb., 6962). 
$1925]$

BURT-THE THELEPHORACEAE OF NORTH AMERICA. XIV 257

40. P. laevis (Fr.) Burt in R. Fries, R. Sci. Soc. Gothoburgens Actis IV. 3: [36]. 1900; in Peck, N. Y. State Mus. Bul. 54: 954. 1902; v. Höhnel \& Litschauer, K. Akad. Wiss. Wien Sitzungsber. 115: 1550. 1906; Bourdot \& Galzin, Soc. Myc. Fr. Bul. 28: 398. 1913; Rea, Brit. Basid. 692. 1922.

Thelephora laevis Fries, Elenchus Fung. 1: 206. 1828. Not T. laevis Persoon.-Corticium laeve Fries, Epicr. 560. 1838; Hym. Eur. 649. 1874.-Kneiffia laevis (Fries) Bresadola, Ann. Myc. 1: 99.1903.

Type: authentic specimen in Kew Herb.

Fructifications effused, membranaceous, adnate, separable from the substratum when moistened, drying light pinkish cinnamon to buff-pink and ochraceous buff, the margin radiately fibrillose; in section not colored, 300-400 $\mu$ thick, with the hyphae $3-4 \frac{1}{2} \mu$ in diameter, not colored, granule-incrusted, densely crowded together and running parallel with the substratum and then ascending obliquely into the hymenium; cystidia incrusted or not incrusted, $40-60 \times 41 / 2^{-9} \mu$, protruding up to $30 \mu$, confined to the hymenial layer; spores white in a spore collection, even, $4 \frac{1}{2}-6 \times 2 \frac{1}{2}-3 \mu$.

Fructifications $2-10 \mathrm{~cm}$. long, $2-4 \mathrm{~cm}$. broad.

On bark of frondose species. Europe, New Brunswick to Texas and westward to Washington and Oregon, in Cuba and in Island of Guam and in Japan. July to October. Not common.

Peniophora laevis is one of the species which Karsten understood as Corticium radiosum and sent under this name to Fries, as shown by the specimens in Herb. Fries determined by Karsten, and preserved by Fries without comment. Bresadola collected the species occasionally and communicated to me duplicates under the herbarium name Peniophora albo-gilvida. The above specimens agree in aspect with the authentic specimen of Corticium laeve from Fries in Kew Herb. and also agree with it in the details of microscopic structure including incrusted hyphae, smaller than those of Peniophora coccineo-fulva and more compactly and more longitudinally arranged than those of $P$. sanguinea. $P$. affinis does not have its hyphae at all incrusted.

Specimens examined: 
Sweden: authentic specimen (in Kew Herb.); on Betula, L. Romell, 122; Gottenburg, L. Romell, 120; Stockholm, L. Romell, 358 .

Finland: $P$. Karsten, 32 (in Fries Herb., under the name Corticium radiosum); Mustiala, $P$. Karsten, under the name $C$. radiosum, comm. by Bresadola, and also on Alnus under the name Peniophora velutina.

Russian Poland: Eichler, 10\%, comm. by Bresadola.

France: Allier, St. Priest, $H$. Bourdot, 8981, under the name $P$. Eichleriana.

Italy: Trient, Alps Mts., Bresadola, two specimens.

New Brunswick: Campobello, W. G. Farlow, 2.

New Hampshire: Chocorua, W. G. Farlow, 12 (in Burt Herb.) and $C$ 35, C 38, 40 (in Mo. Bot. Gard. Herb., 43963, 43967, 43971).

Vermont: Middlebury, E. A. Burt, three gatherings.

Massachusetts: Magnolia, W. G. Farlow; Williamstown, W. G. Farlow, 9.

New York: East Galway, E. A. Burt; East Schaghticoke, C. H. Peck (in N. Y. State Mus. Herb., and Mo. Bot. Gard. Herb., 55758); East Schodack, C. H. Peck, 12; Hague, C. H. Peck, 2; Ithaca, G. F. Atkinson, 4598; North Greenbush, H. D. House, 14.234 (in N. Y. State Mus. Herb., and Mo. Bot. Gard. Herb., 44733); Snyder, C. H. Peck, 16.

New Jersey: Newfield, J. B. Ellis, 2020, comm. by W. G. Farlow, 22 (in Mo. Bot. Gard. Herb., 7943).

Virginia: Crabbottom, W. A. Murrill, 169, 259 (in N. Y. Bot. Gard. Herb., 61557, 61568).

Alabama: Montgomery County, R. P. Burke, 129, 213, 813 (in Mo. Bot. Gard. Herb., 11034, 57085, 63115).

Texas: Gonzales, C. L. Shear, 1231.

Kentucky: Crittenden, C. G. Lloyd, 10113 (in Mo. Bot. Gard. Herb., 58689).

Ohio?: locality not stated, C. G. Lloyd, 4195.

Michigan: New Richmond, C. H. Kauffman, 47 (in Mo. Bot. Gard. Herb., 3259).

Wisconsin: Blue Mounds, E. T. \& S. A. Harper, 943; Lake Geneva, E. T. \& S. A. Harper, 836; Palmyra, A. O. Stucki, 53. 
Missouri: Perryville, R. A. Studhalter \& L. O. Overholts, 2706 (in Mo. Bot. Gard. Herb., 44290).

Nebraska: Lincoln, C. L. Shear, 540.

Idaho: Priest River, J. R. Weir, 608 (in Mo. Bot. Gard. Herb., 63196).

British Columbia: Sidney, J. Macoun, 10 (in Mo. Bot. Gard. Herb., 5728).

Washington: Bingen, W. N. Suksdorf, 764; Arlington, C. J. Humphrey, 7610.

Oregon: Eugene, C. J. Humphrey, 6061; Tidewater, S. M. Zeller, 1985 (in Mo. Bot. Gard. Herb., 58762).

Cuba: Ceballos, C. J. Humphrey, 2805.

Island of Guam: Edwards, comm. by J. R. Weir, 10765 (in Mo. Bot. Gard. Herb., 56238).

Japan: Mt. Mikuma, Prov. Awaji, A. Yasuda, 62 (in Mo. Bot. Gard. Herb., 56138).

\section{P. subiculosa Burt, n. sp.}

Type: in Mo. Bot. Gard. Herb. and N. Y. Bot. Gard. Herb.

Fructifications effused, somewhat membranaceous, tender, small pieces separable when moist, with the hymenium drying cartridge-buff, pulverulent, here and there cracked and showing the whitish subiculum which is pale chamois-colored next to the substratum and connected with chamois-colored marginal mycelial strands or cords; in section $400-500 \mu$ thick, not distinctly colored, with the hyphae loosely interwoven, hyaline, $4 \mu$ in diameter, not nodose-septate, granule-incrusted in all regions with large crystalline granules; cystidia heavily incrusted, 20-60 $\times 9 \mu$, protruding up to $15 \mu$, confined to the hymenium; spores hyaline, even, $3-31 / 2 \times 21 / 2 \mu$, borne 4 to a basidium.

Fructifications $2-3 \mathrm{~cm}$. long, $1 \mathrm{~cm}$. broad.

On humus of frondose wood. Mexico. December. Only one collection known.

$P$. subiculosa is related to $P$. Burtii but differs from it in having larger and incrusted cystidia and all hyphae heavily incrusted.

Specimens examined:

Mexico: Guernavaca, W. A. \& E. L. Murrill, 396, type (in N. Y.

Bot. Gard. Herb., and Mo. Bot. Gard. Herb., 54550). 
42. P. septocystidia Burt, n. sp.

Type: in N. Y. Bot. Gard. Herb., Mo. Bot. Gard. Herb., and Burt Herb.

Fructifications effused, the small patches becoming more or less confluent, membranaceous, separable, between warm buff and cinnamon-buff in the herbarium, somewhat tubercular through conforming to the irregularities of the substratum, the margin byssoid, with some mycelial strands; in section 250-400 $\mu$ thick, not colored, 2-layered, the layer next to the substratum much the thicker, composed of very loosely interwoven, incrusted hyphae $4-5 i \alpha$ in diameter under the incrustation, not nodose-septate, the hymenial layer dense, 35-45 $\mu$ thick; no gloeocystidia; cystidia incrusted with a few, large, somewhat colored granules, transversely septate, $5 \mu$ in diameter under the incrustation, protruding 30-35 $\mu$, scattered along surface of hymenium; spores hyaline, even, cylindric, curved, 5-7 $\times 2 \frac{1}{2}-$ $3 \mu$.

Fructifications $5 \mathrm{~mm} .-21 / 2 \mathrm{~cm}$. in diameter after confluence.

On decaying bark and humus. West Indies. January.

$P$. septocystidia is somewhat related to $P$. sanguinea, $P$. Burtii, and $P$. subiculosa, but is of different color, with very coarse hyphae and noteworthy cystidia.

Specimens examined:

Jamaica: Troy and Tyre, Cockpit Country, W. A. Murrill \&

W. Harris, 860, type (in Burt Herb., N. Y. Bot. Gard. Herb., and Mo. Bot. Gard. Herb., 61490).

\section{P. canadensis Burt, n. sp.}

Type: in Burt Herb.

Fructification effused, adnate, dry, hypochnoid, small pieces separable when moistened, cream-color in the herbarium, even, tomentose under a lens, not shining, the margin thinning out, of finely interwoven hyphae; in section 300-350 $\mu$ thick, not colored, stratose, each of the two strata composed of loosely arranged, erect, branching, nodose-septate, somewhat incrusted hyphae 4-6 $\mu$ in diameter, which are slightly colored near the substratum and hyaline elsewhere, and of a more compact hymenial layer containing cystidia; no gloeocystidia; cystidia incrusted, cylin- 
dric, $50-90 \times 6-9 \mu$, protruding up to $45 \mu$, very numerous in the hymenium; basidiospores hyaline, even, $7-8 \times 4-5 \mu$, copious, four to a basidium; other spherical spores $31 / 2-4 \mu$ in diameter are present in addition to immersed basidiospores in the buried hymenium.

Fructification $2 \frac{1}{2} \mathrm{~cm}$. long, $2 \mathrm{~cm}$. wide, broken off at both ends.

On wood of coniferous $\log$ and bark of Fraxinus. Canada and New York. September and October.

The type of $P$. canadensis somewhat resembles $P$. pubera in aspect but has texture more suggestive of Coniophora byssoidea. Such aspect, together with the coarse hyphae, large spores, and numerous large cystidia should fix the species. Unfortunately, the type consists of but a single piece of the dimensions stated, which was present in a packet of Corticium bombycinum. The New York gathering consists of a group of very small fructifications only one stratum thick.

Specimens examined:

Canada: locality not given, J. Macoun, 60 (in part), type. New York: Ithaca, G. F. Atkinson, Cornell Univ. Herb., 8282.

44. P. cremea Bresadola, Fungi Trid. 2: 63. pl. 173, f. 2 . 1898; Sacc. Syll. Fung. 16: 195. 1902; Bourdot \& Galzin, Soc. Myc. Fr. Bul. 28: 396. 1913; Wakefield, Brit. Myc. Soc. Trans. 5: 131. 1914; Rea, Brit. Basid. 691. 1922.

Kneiffia cremea Bresadola, Ann. Myc. 1: 100. 1903.-An Corticium Eichlerianum Bresadola, Ann. Myc. 1: 95. 1903?

Type: in Bresadola Herb. probably, authentic specimens in Burt Herb.

Fructifications broadly effused, membranaceous, separable, white or cream-color to ochraceous buff and darkening somewhat in the herbarium, sometimes cracking when dry and showing the white subiculum, the margin white and cobwebby; in section 100-300 $\mu$, rarely $500 \mu$, thick, not colored, composed of a broad layer next to the substratum of thick-walled, hyaline, erect hyphae $41 / 2^{-6} \mu_{\text {in }}$ diameter, branching at a wide angle, sometimes dichotomously, more or less granule-incrusted towards the hymenial layer; hymenial layer dense, bearing protruding cystidia evenwalled or incrusted about the apex and containing also immersed, 
incrusted cystidia when thickened; protruding cystidia cylindric or tapering towards the apex, $5-10 \mu$ in diameter at the base, protruding up to $60 \mu$ beyond the basidia; immersed cystidia $40-60 \times 9-10 \mu$; no gloeocystidia; spores white in a spore collection, even, $5-8 \times 2 \frac{1}{2}-31 / 2 \mu$.

Fructifications $4-15 \mathrm{~cm}$. long, 2-4 cm. wide.

On bark-covered and decorticated branches of frondose species on the ground. In Europe, Canada to Louisiana, and westward to the Pacific States and in Japan and in Natal, Africa. May to January. Infrequent but widely distributed.

$P$. cremea is readily recognizable among the species of the northern United States and Canada by its thick, white or creamy fructifications which have small spores, lack gloeocystidia, and are 2-layered with the thick under layer composed of coarse, loosely arranged, erect hyphae branching at an angle of towards $60^{\circ}$ and often dichotomously. These hyphae and their arrangement are distinctive. $P$. mutata has the same aspect and color but differs by much longer spores and the presence of gloeocystidia. $P$. velutina has its hyphae ascending obliquely to the hymenial layer.

Specimens examined:

Sweden: L. Romell, 196; Femsjö, L. Romell, 218.

Germany: Westphalia, Lengerich, Brinkmann, 341, determined and communicated by Bresadola.

Russian Poland: Eichler, determined and communicated by Bresadola.

Austria: Tirol, Gries, V. Litschauer; Innsbruck, V. Litschauer; Stiermark, V. Litschauer.

France: Aveyron, M. Galzin, 13292, comm. by H. Bourdot, 20856. England: Doncaster, E. M. Wakefield (in Mo. Bot. Gard. Herb., 57126).

Canada: J. Macoun, 24.

New Hampshire: Chocorua, E. A. Burt.

Vermont: Bristol, E. A. Burt, two gatherings; Middlebury, E. A. Burt, two gatherings.

Massachusetts: Magnolia, W. G. Farlow, a; Sharon, A. P. D. Piguet, comm. by W. G. Farlow.

New York: East Galway, E. A. Burt, three gatherings; Bergen 
Swamp, Genesee County, H. D. House (in N. Y. State Mus. Herb., and Mo. Bot. Gard. Herb., 57473).

New Jersey: Newfield, J. B. Ellis, 68 (in N. Y. Bot. Gard. Herb., and Mo. Bot. Gard. Herb., 63425).

District of Columbia: W. A. Murrill, 1496 (in N. Y. Bot. Gard. Herb., and Mo. Bot. Gard. Herb., 63453, 63465).

Alabama: Montgomery County, R. P. Burke, 800 (in Mo. Bot. Gard. Herb., 63108).

Louisiana: St. Martinville, A. B. Langlois, k, 1386, 1963, 2631 (in Burt Herb., N. Y. Bot. Gard. Herb., and Mo. Bot. Gard. Herb., 63456, 63503).

Michigan: Gogebic County, E. A. Bessey, 321 (in Mo. Bot. Gard. Herb., 56543).

Montana: Rexford, E. E. Hubert, comm. by J. R. Weir (in Weir Herb., and Mo. Bot. Gard. Herb., 63246).

Idaho: Coolin, J. R. Weir, 11499, 11575 (in Mo. Bot. Gard. Herb., 63261, 63303), and an unnumbered specimen (in Weir Herb., and Mo. Bot. Gard. Herb., 63247); Priest River, J. R. Weir, 609 (in Mo. Bot. Gard. Herb., 63197).

Manitoba: Swan River, G. R. Bisby, 1049 (in Mo. Bot. Gard. Herb., 59036); Winnipeg, G. R. Bisby, 1117 (in Mo. Bot. Gard. Herb., 59040).

British Columbia: Sidney, J. Macoun, 23, 28, 73, 82, 104, 834 (in Mo. Bot. Gard. Herb., 5757, 55335, 5758, 5759, 55337, 55334). Washington: Bingen, $W . N$. Suksdorf, 867; Chehalis, C. J. Humphrey, 6260; Everson, C. J. Humphrey, 7453; Kalama, C. J. Humphrey, 6205.

Oregon: Corvallis, S. M. Zeller, 1867 (in Mo. Bot. Gard. Herb., 56871); Eugene, C. J. Humphrey, 6088.

California: Palo Alto, W. A. Murrill, 1173, comm. by N. Y. Bot. Gard. Herb. (in Mo. Bot. Gard. Herb., 55706); Santa Catalina Island, Grand Canyon, L. W. Nuttall, 1060, comm. by Field Mus. Herb. (in Mo. Bot. Gard. Herb., 58883).

Japan: Sendai, A. Yasuda, 46 (in Mo. Bot. Gard. Herb., 56160); Mt. Mikuma, Prov. Awaji, A. Yasuda, 53 (in Mo. Bot. Gard. Herb., 56161).

Africa: Natal, Durban, P. A. van der Bijl,612 (in Mo. Bot. Gard. Herb., 59377). 
45. P. velutina (DC) Cooke, Grevillea 8: 21. pl. 125, f. 15. 1879; Sacc. Syll. Fung. 6: 644. 1888; Massee, Linn. Soc. Bot. Jour. 25: 152. 18S9; Bourdot \& Galzin, Soc. Myc. Fr. Bul. 28 : 39S. 1913; Rea, Brit. Basid. 692. 1922.

Thelephora velutina De Candolle, Fl. Fr. 6: 33. 1815; Fries, Elenchus Fung. 1: 203. 1828.-Corticium velutinum (DC) Fries, Epicr. 561. 1838; Hym. Eur. 650. 1874.-Kneiffia velutina (DC) Bresadola, Ann. Myc. 1: 100. 1903.

Fructifications broadly effused, membranaceous, separable, becoming vinaceous buff to fawn color in the herbarium, minutely velvety, the margin whitish, often extended in branching mycelial strands; in section not colored, $250-500 \mu$ thick, composed of loosely interwoven hyphae up to $5-8 \mu$ in diameter, not incrusted, only very rarely nodose-septate; cystidia incrusted, 40-100 $\times 8-15 \mu$, wholly immersed in the hymenial tissue or protruding up to $50 \mu$; spores white in spore falls, even, $41 / 2-51 / 2 \times$ $21 / 2-3 \mu$.

Fructifications $3-20 \mathrm{~cm}$. long, $2-15 \mathrm{~cm}$. broad.

On decaying limbs and logs of such frondose species as Fagus, Quercus, Castanea, Populus, etc., more rarely on coniferous wood. Throughout Canada and the United States and in Europe. May to December. Frequent.

$P$. velutina may be recognized by its large and rather thick fructifications of pinkish or vinaceous color when dry, separable from the substratum when moistened, by frequent presence of marginal mycelial strands, and by the coarse, non-incrusted hyphae - often up to $8 \mu$ in diameter-present in sectional preparations near the substratum.

Specimens examined:

Sweden: L. Romell, 121, 133; Stockholm, L. Romell, $13 \%$.

Poland: Eichler, from Bresadola.

Austria: Tirol, V. Litschauer.

France: Cormatin, F. Guillemin, 10, in part; St. Priest, Allier, H. Bourdot, 20859.

Canada: J. Macoun, 231, comm. by W. G. Farlow (in Mo. Bot. Gard. Herb., 14763); Ontario, Casselman, J. Macoun, 366.

New Hampshire: Chocorua, W. G. Farlow, 71 (in Mo. Bot. Gard. Herb., 43973). 
Vermont: Ripton, E. A. Burt.

Massachusetts: R. J. Blair, comm. by L. O. Overholts, 3812 b (in Mo. Bot. Gard. Herb., 54994).

New York: Alcove, C. L. Shear, 1198; East Galway, E. A. Burt, two gatherings: Floodwood, C. H. Peck (in N. Y. State Mus. Herb., and Mo. Bot. Gard. Herb., 55967), E. A. Burt; Karner, H. D. House (in N. Y. State Mus. Herb., and Mo. Bot. Gard. Herb., 54393).

New Jersey: Alpine, P. Wilson, 29 (in Mo. Bot. Gard. Herb., $54748)$.

Pennsylvania: State College, L. O. Overholts, 3326 (in Mo. Bot. Gard. Herb., 9533).

Alabama: Montgomery County, R. P. Burke, 419 (in Mo. Bot. Gard. Herb., 57259).

Tennessee: Elkmont, C. H. Kauffman, 73 (in Mo. Bot. Gard. Herb., 54330).

Michigan: New Richmond, C. H. Kauffman, 54 (in Mo. Bot. Gard. Herb., 11996); Seney, C. J. Humphrey, 1596 (in Mo. Bot. Gard. Herb., 17541).

Wisconsin: Madison, C. J. Humphrey, 2156 (in Mo. Bot. Gard. Herb., 6729).

Illinois: Anna, C. J. Humphrey, 2044 (in Mo. Bot. Gard. Herb., 21525).

Montana: Bernice, E. E. Hubert, comm. by J. R. Weir (in Mo. Bot. Gard. Herb., 63250); Yellowstone, F. S. Wolpert, comm. by J. R. Weir, 3934 (in Mo. Bot. Gard. Herb., 55179).

Colorado: Pike's Peak, G. G. Hedgcock, comm. by C. J. Humphrey, 2543 (in Mo. Bot. Gard. Herb., 20783).

Idaho: Priest River, J. R. Weir, 618 (in Mo. Bot. Gard. Herb., 63200).

British Columbia: Kootenai Mts., near Salmo, J. R. Weir, 512 (in Mo. Bot. Gard. Herb., 3772); Sidney, J. Macoun, 34, 42 (in Mo. Bot. Gard. Herb., 55341, 55345).

Washington: Bingen, W. N. Suksdorf, 703.

Oregon: Grant's Pass, J. R. Weir, 8687 (in Mo. Bot. Gard. Herb., 63199).

New Mexico: Tyom Experiment Station, W. H. Long, 21898 (in Mo. Bot. Gard. Herb., 55121). 
46. P. affinis Burt, n. sp.

Name without description in Peck, N. Y. State Mus. Bul. 54: 954. 1902 .

Type: in Burt Herb.

Fructifications broadly effused, membranaceous, adnate, separable when moistened, drying light buff to pinkish buff and light pinkish cinnamon, often cracked and showing the paler subiculum in the crevices, the margin paler, radiately fibrillose; in section not colored, $300-500 \mu$ thick, with the hyphae hyaline, $3-5 \mu$ in diameter, not at all incrusted, arranged densely and longitudinally in a broad layer along the substratum and then ascending obliquely into the hymenial laycr; cystidia incrusted or not incrusted, $30-60 \times 5-8 \mu$, protruding up to $30 \mu$, occurring in the hymenial layer only; spores white in a spore collection, even, $41 / 2-6 \times 21 / 2^{-3} \mu$.

Fructifications $3-20 \mathrm{~cm}$. long, 2-4 cm. broad.

On bark and decorticated logs and limbs of frondose species. Canada to New York and westward to Oregon, and also in Europe. July to October. Common.

$P$. affinis is related in aspect to $P$. laevis and has hyphae of the same diameter and arrangement as those of the latter species but not at all incrusted. The fructifications of $P$. affinis are usually thicker than those of $P$. laevis, less adnate to the substratum, paler and more cracked. Pale specimens of $P$. sanguinea crack into somewhat similar areas but show a somewhat colored, floccose subiculum in the fissures. The hyphae of $P$. affinis are of smaller diameter than those of $P$. velutina.

Specimens examined:

Exsiccati: Reliq. Farlowianae, 343, under the name Peniophora laevis.

Sweden: L. Romell, 123, 124, both under the name P. velutina. Austria: Tirol, $V$. Litschauer, under the name $P$. laevis. France: Allier, H. Bourdot, 8579, under the name $P$. laevis.

Canada: J. Macoun, 76, comm. by N. Y. State Mus. Herb. (in Mo. Bot. Gard. Herb., 57510).

Quebec: Hull, J. Macoun, 220.

Ontario: Jefferson, G. H. Graham, comm. by Univ. Toronto Herb., 674 (in Mo. Bot. Gard. Herb., 44924). 
Maine: Kittery Point, R. Thaxter \& E. A. Burt.

New Hampshire: Chocorua, W. G. Farlow, 35 and two unnumbered specimens in Burt Herb., Reliq. Farlowianae, 343, and C 36, 41, 69 (in Mo. Bot. Gard. Herb., 43964, 43969, 43970 respectively), E. A. Burt, three gatherings; North Conway, L. O. Overholts, 5106 (in Mo. Bot. Gard. Herb., 56356).

Vermont: Middlebury, E. A. Burt, type and another gathering. Massachusetts: North Scituate, W. G. Farlow.

New York: Albany, H. D. House (in N. Y. State Mus. Herb. and Mo. Bot. Gard. Herb., 14835); East Galway, E. A. Burt, six gatherings; Jamesville, L. M. Underwood (in N. Y. Bot. Gard. Herb., and Mo. Bot. Gard. Herb., 63419); Karner, H. D. House (in N. Y. State Mus. Herb., and Mo. Bot. Gard. Herb., 54348, 54352, 54371); Oneida, H. D. House (in N. Y. State Mus. Herb., and Mo. Bot. Gard. Herb., 59681); Snyder, C. H. Peck (in N. Y. State Mus. Herb., and Mo. Bot. Gard. Herb., 55757); Syracuse, L. M. Underwood, 116 (in N. Y. Bot. Gard. Herb., and Mo. Bot. Gard. Herb., 61485); West Fort Ann, S. H. Burnham, 12 (in Mo. Bot. Gard. Herb., 44002).

Tennessee: Elkmont, C. H. Kaufman, 68 (in Mo. Bot. Gard. Herb., 1680).

Illinois: Glencoe, E. T. \& S. A. Harper, 650, 820.

Wisconsin: Madison, C. J. Humphrey, 2159 (in Mo. Bot. Gard. Herb., 4597).

Oregon: Corvallis, W. A. Murrill, 1011, comm. by N. Y. Bot. Gard. Herb. (in Mo. Bot. Gard. Herb., 55714).

Jamaica: Farr, 1617 (in N. Y. Bot. Gard. Herb., and Mo. Bot. Gard. Herb., 61489). This reference is doubtful for the hymenium is in poor condition.

\section{P. inflata Burt, n. sp.}

Type: in Burt Herb. and probably in N. Y. Bot. Gard. Herb.

Fructifications effused, thin, tender, soft, membranaceous, separable, brittle when dry and cream color to cream-buff, the subiculum and margin white and cottony; in section $150 \mu$ thick, not colored, 2-layered, consisting of (1) a layer next to substratum $75 \mu$ thick of loosely arranged, thin-walled, lax, hyaline hyphae $21 / 2-3 \mu$ in diameter bearing short lateral branches, each with 2 
moniliform inflations, and of (2) a hymenial layer of erect hyphae densely arranged, and of numerous cystidia in all regions of this layer; no gloeocystidia ; cystidia incrusted or not incrusted, 15-24 $\times 3-31 / 2 \mu$, protruding up to $18 \mu$ beyond the basidia; spores colorless, even, $3 \times 2-21 / 2 \mu$, flat on one side, copious.

Fructifications $3-4 \mathrm{~cm}$. long, $1-1 \frac{1}{2} \mathrm{~cm}$. wide.

On very rotten wood. Jamaica. December. Probably rare.

$P$. inflata is so loosely attached to the substratum that careful handling is necessary to prevent fructifications from becoming detached from the wood during examination. The pair of moniliform inflations on short lateral branches of hyphae of the hyphal layer shows distinctly in sectional preparation and promises to be as helpful a character in the recognition of this species as the details of hyphal structure in Stereum purpureum, Corticium investiens, Grandinia granulosa, and others.

Specimens examined:

Jamaica: Hope Gardens, W. A. Murrill, 4, type, comm. by N. Y.

Bot. Gard. Herb.

\section{P. Sheari Burt, n. sp.}

Type: in Burt Herb.

Fructification effused, rather thick, membranaceous, drying pinkish buff, somewhat tubercular, somewhat velvety, not waxy, the margin becoming somewhat free and curling up in drying, separable from the substratum when moistened; in section 800 $1000 \mu$ thick, not colored, 2-layered, the layer next to the substratum up to 800-900 $\mu$ broad and composed of densely interwoven, hyaline hyphae not incrusted, not nodose-septate, thickwalled, $3 \mu$ in diameter, the hymenial layer $100-150 \mu$ broad, containing throughout great numbers of slender, rough-walled or minutely incrusted cystidia 30-45 × 4-6 $\mu$; no gloeocystidia; basidia with 4 sterigmata; spores hyaline, even, $10-12 \times 6-7 \mu$.

Fructifications $3 \mathrm{~mm} .-2 \mathrm{~cm}$. in diameter.

On dead Alnus. Blue Mt., Oregon. August. Probably rare and local.

The fructifications apparently originate as outgrowths from lenticels in the bark and spread laterally over more or less circular areas and become confluent. The occurrence on Alnus, tuber- 
cular surface, numerous and small cystidia confined to the hymenial layer, and spores $12 \times 6 \mu$ form a distinctive group of characters.

Specimens examined:

Oregon: Blue Mt., C. L. Shear, 797, type.

49. P. Ravenelii Cooke, Grevillea 8: 21. pl. 124, f. 12. 1879; Sacc. Syll. Fung. 6: 643. 1888; Massee, Linn. Soc. Bot. Jour. 25: 150.1889 .

Type: in Kew Herb.

Fructifications broadly effused, adnate, thin, small pieces separable when moistened, becoming pale pinkish buff to pinkish buff in the herbarium, and somewhat cracked, the margin thinning out; in section 100-300 $\mu$ thick, not colored, composed of erect and densely interwoven hyaline hyphae and very numerous cystidia in all regions of the fructifications and having a somewhat layered arrangement in thick specimens; no gloeocystidia; cystidia heavily and coarsely incrusted, conical, with apex obtuse or barely acute, $30-40 \times 12-18 \mu$ when deeply immersed, or $30 \times$ 8-10 $\mu$ in the hymenium; spores white in a spore collection, even, $4-5 \times 2-3 \mu$.

Fructifications 2-8 cm. long, 1-3 cm. wide.

On bark and wood of decaying logs of Quercus and other frondose species. District of Columbia to Mexico, in the Island of Guam, and in Japan. July to January. Frequent.

$P$. Ravenelii is distinguished by its small spores, coarsely incrusted, short cystidia with broad base, and absence of gloeocystidia. P. Roumeguerii is similar in aspect but becomes much thicker and has longer, slenderer, and more taper-pointed cystidia and is more distinctly layered.

Specimens examined:

Exsiccati: Ravenel, Fungi Am., 720, under the name Corticium laeve; Ravenel, Fungi Car. 2: 39, under the name Corticium laeve.

District of Columbia: Takoma Park, C. L. Shear, 1345.

South Carolina: H.W. Ravenel, type (in Kew Herb.), and in Ravenel, Fungi Car. 2: 39.

Georgia: Darien, H.W. Ravenel, in Ravenel, Fungi Am., 720; 
Tallulah Falls, A. B. Seymour, comm. by W. G. Farlow, 13 (in Mo. Bot. Gard. Herb., 44597).

Florida: Brooksville Hammock, W. A. Murrill, 166, comm. by N. Y. Bot. Gard. Herb. (in Mo. Bot. Gard. Herb., 62115); Cocoanut Grove, R. Thaxter, 96 (in Farlow Herb., and Mo. Bot. Gard. Herb., 43924); Daytona, R. A. Harper, 7 (in Mo. Bot. Gard. Herb., 54539); New Smyrna, W. A. Murrill, 6, comm. by N. Y. Bot. Gard. Herb., 62087.

Alabama: Auburn, F. S. Earle \& C. F. Baker (in N. Y. Bot.

Gard. Herb., and Mo. Bot. Gard. Herb., 61345).

Louisiana: Bogalusa, C. J. Humphrey, 5495 (in Mo. Bot. Gard. Herb., 13882); St. Martinville, A. B. Langlois, 2689, 2693 (in N. Y. Bot. Gard. Herb., and Mo. Bot. Gard. Herb., 61457, 61436), and 2692, ar, as, bp, bs, ci, and co.

Mexico: Orizaba, W. A. \& E. L. Murrill, 765, comm. by N. Y. Bot. Gard. Herb., 54647.

Island of Guam: Edwards, comm. by J. R. Weir, 10775 (in Mo.

Bot. Gard. Herb., 56239).

Japan: Prov. Awaji, Mt. Mikuma, A. Yasuda, 39, 56, 79 (in

Mo. Bot. Gard. Herb., 56156, 56159, 56313).

50. P. Roumeguerii Bresadola in litt., n. comb.

Corticium Roumeguerii Bresadola, Fungi Trid. 2: 36. pl. 144, f. 1. 1892; Roumeguère, Rèv. Myc. 15: 31 pag. sep. pl. 196, f. 13 b. 1893; Sacc. Syll. Fung. 11: 125. 1895.-Kneiffia Roumeguerii Bresadola, Ann. Myc. 1: 102. 1903.-Corticium Mollerianum Bresadola in Saccardo, Soc. Brot. Bol. 11: 13. 1892.-Peniophora Molleriana (Bres.) Saccardo, Soc. Brot. Bol. 11 : 13. 1892; Sacc. Syll. Fung. 11: 12S. 1895; v. Höhnel \& Litschauer, K. Akad. Wiss. Wien Sitzungsber. 117: 1092. 1908; Bourdot \& Galzin, Soc. Myc. Fr. Bul. 28: 401. 1913; Wakefield, Brit. Myc. Soc. Trans. 5: 132. 1915; Rea, Brit. Basid. 693. 1922.

Type: type distribution in Roumeguere, Fungi Gallici, 506.

Fructifications broadly effused, adnate, becoming rather thick, small pieces separable when moistened, whitish at first, becoming pale pinkish buff to pinkish buff in the herbarium, the margin thinning out; in section 100-700 $\mu$ thick, not colored, becoming 
layered in thick specimens, composed of erect and interwoven, closely agglutinate hyphae $2-3 \mu$ in diameter and of very numerous cystidia; no gloeocystidia; cystidia incrusted, $35-80 \times$ $8-12 \mu$, acute, numerous in all layers except next to the substratum; spores hyaline, even, 4-6 $42-3 \mu$.

Fructifications $3-8 \mathrm{~cm}$. long, 1-4 cm. wide.

On bark of logs of Quercus, Eucalyptus, Citrus, Ficus, and other frondose species, rarely on conifers. In Europe, and in Alabama, Louisiana, Missouri, Idaho, British Columbia to California, and in the West Indies. May to February. Not common.

$P$. Roumeguerii is possibly a synonym of $P$. Ravenelii, as I formerly regarded it, but the numerous specimens which have been studied lead me to believe that while of the same aspect, spore characters, and substratum, $P$. Roumeguerii eventually becomes twice as thick as $P$. Ravenelii, more closely agglutinate, and its cystidia longer and slenderer in proportion to their thickness. The error of v. Höhnel \& Litschauer, loc. cit., in misstating the year of publication of $P$. Molleriana as 1891 has probably led more recent European authors into reducing $P$. Roumeguerii to synonymy while it really has priority.

Specimens examined:

Locality not stated: G. Bresadola, authentic specimen under the name Peniophora Roumeguerii Bres.

Italy: Trient, G. Bresadola, authentic specimen of Peniophora Molleriana.

France: Aveyron, A. Galzin, 17908, comm. by H. Bourdot, 16898. England: Symond's Yat, E. M. Wakefield (in Mo. Bot. Gard. Herb., 44759).

Alabama: Montgomery County, R. P. Burke, 364 (in Mo. Bot. Gard. Herb., 57232).

Louisiana: Baton Rouge, Edgerton \& Humphrey, comm. by C. J. Humphrey, 5646, 5648; St. Martinville, A. B. Langlois, 1346, comm. by W. G. Farlow, 2675, 2683, 2970, cj, ck, and another specimen, comm. by Lloyd Herb., 3042.

Missouri: Creve Coeur Lake, L. O. Overholts, 3165 (in Mo. Bot. Gard. Herb., 5709).

Idaho: Santa, E. E. Hubert, comm. by J. R. Weir, 12001 (in Mo. Bot. Gard. Herb., 63363). 
British Columbia: Sidney, J. Macoun, 379 (in Mo. Bot. Gard. Herb., 55330).

Oregon: Tidewater, S. M. Zeller, 1983 (in Mo. Bot. Gard. Herb., 58760 ).

California: Berkeley, C.J. Humphrey, 5987, 5990; Redding, C. J. Humphrey, 6038; Santa Barbara, O. M. Oleson, 10.

Cuba: Horne (in N. Y. Bot. Gard. Herb., and Mo. Bot. Gard. Herb., 61464).

Porto Rico: Rio Piedras, J. A. Stevenson, 5792 (in Mo. Bot. Gard. Herb., 54693); Sabana Llana, J. A. Stevenson, 6058 (in Mo. Bot. Gard. Herb., 54686); Vega Baja, J. A. Stevenson, 5693 (in Mo. Bot. Gard. Herb., 54692).

\section{P. hiulca Burt, n. sp.}

Type: in Burt Herb. and probably in N. Y. Bot. Gard. Herb.

Fructifications long and widely effused, thick, membranaceous, separable when moistened, becoming light buff to warm buff in the herbarium, widely cracked, the margin determinate, somewhat tomentose; in section 250-1400 $\mu$ thick, not colored, 2layered, with a very thick layer next to the substratum of densely interwoven, longitudinally arranged and somewhat ascending thin-walled, hyaline hyphae $3-4 \mu$ in diameter, not incrusted, not nodose-septate and with the hymenial layer thinner - only 100-200 $\mu$ thick - and containing in all portions very numerous cystidia; no gloeocystidia; cystidia incrusted, somewhat conical, $30-50 \times 6-12 \mu$, very numerous, wholly immersed or protruding up to $30 \mu$; basidia with 4 sterigmata; spores hyaline, even, $4 \frac{1}{2}-5 \times 3 \mu$.

Fructifications 4-12 cm. long, 2-4 cm. wide-perhaps larger for all specimens received are fragmentary.

On bark and decaying wood of frondose species. Mexico and the West Indies. November to May.

$P$. hiulca has large, conspicuous fructifications with somewhat the color and aspect of $P$. mutata and $P$. Roumeguerii. The absence of gloeocystidia and the smaller spores distinguish it from the former, and the comparatively thin hymenial layer to which cystidia are restricted and the very thick layer of interwoven hyphae running in all directions, rather than predominantly erect, from $P$. Roumeguerii. 
Specimens examined:

Mexico: Jalapa, W. A. \& E. L. Murrill, 192, comm. by N. Y. Bot. Gard. Herb. (in Mo. Bot. Gard. Herb., 54549).

Bermuda: S. Brown, N. L. Britton \& F. J. Seaver, 150\%, comm. by N. Y. Bot. Gard. Herb.

Jamaica: Castleton Gardens, W. A. \& E. L. Murrill, 71, type, comm. by N. Y. Bot. Gard. Herb.; Mandeville, A. E. Wight, comm. by W. G. Farlow.

\section{P. phosphorescens Burt, n. sp.}

Type: in Burt Herb. and probably in Farlow Herb.

Fructifications effused, membranaceous, separable, becoming clay-color to avellaneous in the herbarium, and widely cracked into rectangular portions about $5 \mathrm{~mm}$. in diameter, which curl up somewhat from the substratum along the fissures and show the whitish, cottony subiculum, the hymenium waxy, somewhat tubercular and minutely spotted in the type, the margin thinning out; in section 300-500 $\mu$ thick, not colored, 2-layered, with the layer next to the substratum composed of loosely interwoven hyphae $3-3 \frac{1}{2} \mu$ in diameter, the hymenial layer up to $200 \mu$ thick, composed of densely arranged hyphae and cystidia; no gloeocystidia; cystidia incrusted, $70-100 \times 12-18 \mu$, fusiform, acute, sometimes tilted, immersed throughout the hymenial layer, few protruding; spores hyaline, even, subglobose, $4-5 \times 3-31 / 2 \mu$; said to be phosphorescent when collected.

Fructifications probably large, for collections consist of fragments $7 \times 1 \frac{1}{2} \mathrm{~cm}$., and $11 / 2-3 \mathrm{~cm}$. in diameter.

On rotten wood of fence post and decaying bark of frondose species. Jamaica. October to December.

$P$. phosphorescens may be recognized by the thick, clay-colored fructifications which contract in drying so as to crack into rectangular masses about $5 \mathrm{~mm}$. in diameter, separated from one another by rather wide fissures. The thick, hymenial portion of each mass is so weakly attached to the substratum by the loose subiculum that these masses curl upward along their edges and may occasionally become wholly detached. The cystidia are suggestive of those of $P$. flavido-alba but all other characters of these two species are different. Phosphorescence has been recorded for but few fungi. 
Specimens examined:

Jamaica: A. E. Wight, type, comm. by W. G. Farlow; Castleton Gardens, F. S. Earle, 240, comm. by N. Y. Bot. Gard. Herb.

53. P. sanguinea (Fr.) Bresadola in v. Höhnel \& Litschauer, K. Akad. Wiss. Wien Sitzungsber. 115: 1588, 1589. 1906; Bourdot \& Galzin, Soc. Myc. Fr. Bul. 28:395. 1913; Rea, Brit. Basid. 690. 1922.

Thelephora sanguinea Frics, Elenchus Fung. 1: $203.1828 .-$ Corticium sanguineum Fries, Epicr. 561. 1838; Hym. Eur. 650. 1874; Icones Hym. 2: 97. pl. 198, f. 2. 1877; Sacc. Syll. Fung. 6: 612. 1888; Wakefield, Brit. Myc. Soc. Trans. 4: 119. pl. 3, f. 18-20. 1913.-Kneiffia sanguinea (Fries) Bresadola, Ann. Myc. 1: 101. 1903.-Corticium glabrum Bcrkeley \& Curtis, Grevillea 1: 178. 1873; Sacc. Syll. Fung. 6: 620. 1888; Massee, Linn. Soc. Bot. Jour. 27: 142. 1890.-(In part) Corticium Petersii Berkeley \& Curtis, Grevillea 1: 177. 1873.

Fructification effused, somewhat membranaceous, tender, dragon's-blood red, substance arachnoid, the margin byssoid or fibrillose and often connected with mycelial strands of blood-red color which stain the wood red, hymenium drying light buff and pinkish buff to buff-pink; in section 200-500 $\mu$ thick, not colored, with the hyphae loosely arranged, $3-6 \mu$ in diameter, and with some granule-incrusted, rarely nodose-septate; cystidia hair-like, not incrusted usually, about $4 \frac{1}{2} \mu$ in diameter, protruding 20 $30 \mu$; spores white in spore collection, even, $4-5 \times 2-21 / 2 \mu$.

Fructifications 2-10 cm. long, 1-4 cm. wide.

On dead wood and fallen branches especially of conifers. Europe, New Hampshire to Louisiana, and in Oregon. July to January. Infrequent.

$P$. sanguinea and $P$. miniata may be recognized by the bloodred color of the young fructifications, the more or less numerous red mycelial strands, and the wood stained red. Later in fertile stage the hymenium tends toward a buff color with a tinge of red. In section $P$. sanguinea shows granule-incrusted hyphae more or less numerous among other even-walled hyphae, while $P$. miniata contains no incrusted hyphae.

Specimens examined: 
Exsiccati: Ell. \& Ev., Fungi Col., 1020, under the name Corticium radiosum.

Sweden: L. Romell, 130; Stockholm, L. Romell, 136.

Austria: Tirol, V. Litschauer.

France: F. Fautrey, from Lloyd Herb., 3308.

New Hampshire: Chocorua, W. G. Farlow, 10, E. A. Burt, 3, 4.

New York: Hudson Falls, S. H. Burnham, 21 (in Mo. Bot. Gard.

Herb., 54490); Karner, H. D. House, 14.157 (in Mo. Bot. Gard. Herb., 44704); Oneida, H. D. House (in N. Y. State Mus. Herb., and Mo. Bot. Gard. Herb., 57434); Wymantskill, C. H. Peck (in N. Y. State Mus. Herb., and Mo. Bot. Gard. Herb., 56051).

New Jersey: Newfield, J. B. Ellis, in Ell. \& Ev., Fungi Col., 1020. Pennsylvania: State College, L. O. Overholts, 3422 (in Mo. Bot. Gard. Herb., 54476).

South Carolina: Society Hill, types of Corticium glabrum, Curtis Herb., 2404 (in Curtis Herb.) and 3719 (in Kew Herb.).

Florida: W. W. Calkins, 845 (in Burt Herb., Farlow Herb., and Mo. Bot. Gard. Herb., 63421).

Alabama: Peters, 84\%, under the name Corticium miniatum (in

Curtis Herb., 5225), and Peters, 473, one of the types of Corticium Petersii (in Curtis Herb., 4509).

Louisiana: St. Martinville, A. B. Langlois, 2704.

Oregon: Corvallis, S. M. Zeller, 1860 (in Mo. Bot. Gard. Herb., 56868).

54. P. limonia Burt, n. sp.

Type: in Mo. Bot. Gard. Herb.

Fructifications broadly effused, compact, fleshy-membranaceous, small pieces separable when moistened, cream-buff, not cracked, the margin byssoid and with some radiating, cream-buff mycelial strands; in section $200 \mu$ thick, not perceptibly colored, 2-layered next to the substratum, with very coarse, heavily incrusted, loosely arranged, longitudinally interwoven hyphae 6-9 $\mu$ in diameter, and with the hymenial layer $75 \mu$ thick and composed of erect tissues; no gloeocystidia; cystidia not incrusted, $45 \times 41 / 2 \mu$, tapering to a sharp apex, protruding 20 $27 \mu$ beyond the basidia; spores hyaline, even, $3-4 \times 21 / 2 \mu$. 
Fructifications $2 \frac{1}{2}-4 \mathrm{~cm}$. long, $1-1 \frac{1}{2} \mathrm{~cm}$. wide.

On bark of decaying Robinia neo-mexicana. New Mexico. August.

$P$. limonia has the color of $P$. sulphurina and $P$. carnosa but differs from both by its occurrence on frondose bark and very coarse, heavily incrusted hyphae. The hymenial layer does not crack and flake away from the substratum like that of $P$. sulphurina. Treatment of sections with potassium hydrate solution causes no color changes.

Specimens examined:

New Mexico: Sulphur Canyon, W. H. Long, 21405, type (in Mo. Bot. Gard. Herb., 55146).

55. P. amoena Burt, n. sp.

Type: in Mo. Bot. Gard. Herb.

Fructifications long and broadly effused, thin, adnate, small pieces separable when moistened, cream-color in the herbarium, even, glabrous, the margin thinning out, of finely interwoven hyphae; in section $120 \mu$ thick, not colored, with the hyphae near the substratum compactly interwoven, about $3 \mu$ in diameter; an incrusted subhymenial zone present, formed of numerous incrusted bodies side by side; no gloeocystidia; cystidia of the hymenial surface not incrusted, $7-9 \mu$ in diameter, protruding up to $45 \mu$; basidia rather large, $25-30 \times 5-6 \mu$, with 4 sterigmata; spores hyaline, even, $12-15 \times 4-6 \mu$, copious.

Fructifications probably large, for pieces broken off at one end and one side are 5-6 cm. long, 11/2-2 cm. wide.

On a soft wood of a frondose species. British Columbia.

$P$. amoena forms cream-colored, somewhat waxy fructifications on decorticated logs of a pale soft wood-perhaps Populus. The spores are so large as to afford a valuable specific character.

Specimens examined:

British Columbia: Sidney, J. Macoun, 7, type (in Mo. Bot. Gard. Herb., 5766).

56. P. firma Burt, n. sp.

Type: in Burt Herb.

Fructifications effused, rather thick, dry, firm, membranaceous, 
small pieces separable when moistened, cream-buff in the herbarium, even, not cracked, the margin thinning out, fibrillose; in section $300-500 \mu$ thick, not colored, with the hyphae 4-6 $\mu$ in diameter near the substratum, densely interwoven, ascending and becoming finer, sometimes incrusted towards the hymenial layer; no gloeocystidia; cystidia not incrusted, tapering upward to a sharp point, 4-5 $\mu$ at base, protruding 20-35 $\mu$, confined to surface of hymenium, numerous; spores hyaline, even, 4-5 $\times$ $21 / 2-3 \mu$.

Fructifications $2-5 \mathrm{~cm}$. long in pieces broken off at both ends, 3-5 cm. wide.

On rotten wood of Alnus (?) and on bark of Robinia neomexicana. Washington and Arizona. September and October.

$P$. firma resembles $P$. Roumeguerii in general aspect but its cystidia are slenderer than those of $P$. Roumeguerii, not incrusted, and present in the hymenial surface only.

Specimens examined:

Washington: Arlington, C. J. Humphrey, \%609, type.

Arizona: Santa Catalina Mountains, Coronado National Forest,

G. G. Hedgcock \& W. H. Long, comm. by C. J. Humphrey, 2555 (in Mo. Bot. Gard. Herb., 12262).

57. P. miniata (Berk.) Burt, n. comb.

Thelephora miniata Berkeley in Hooker, Eng. Flora 22: 168. 1836; Brit. Fungi, No. 251. 1843. See v. Höhnel \& Litschauer, K. Akad. Wiss. Wien Sitzungsber. 115: 1588. 1906.

Type: authentic specimen in Berkeley, Brit. Fungi, 251.

Fructification effused, somewhat membranaceous, tender, English red, substance arachnoid, the margin byssoid or fibrillose and often connected with mycelial strands of blood-red color; hymenium drying pinkish buff to buff-pink and cinnamon-rufous; in section 150-300 $\mu$ thick, not colored, the hyphae loosely arranged, $3-6 \mu$ in diameter, not incrusted, rarely nodose-septate; cystidia few, hair-like, not incrusted, $31 / 2-41 / 2 \mu$ in diameter, protruding $20-30 \mu$; spores hyaline, even, $4-41 / 2 \times 2-21 / 2 \mu$.

Fructifications $2-10 \mathrm{~cm}$. Iong, $1-21 / 2 \mathrm{~cm}$. broad.

On fallen limbs, usually of conifers. In England, New Hampshire to Louisiana, and in Washington and Oregon. July to December. Infrequent. 
The twenty gatherings cited below have been separated from $P$. sanguinea by the absence of incrusted hyphae in their sectional preparations. In the original description of $T$. miniata, Berkeley stated, "This most elegant species differs so much from ' $T$ '. sanguinea $\mathrm{Fr}$, in being mos,t highly colored where exposed to light, while in the portions to which light has not free access it is nearly white, and in not tinging the wood whereon it grows with its own color, that an inspection of specimens renders it almost impossible to consider it the same." Fifteen of the twenty specimens referred below to $P$. miniata on account of absence of hyphal incrustation have the hymenium red and only five pinkish buff, while none of the twenty specimens show the wood stained red.

Specimens examined:

Exsiccati: Berkeley, Brit. Fungi, 251, authentic specimen of Thelephora miniata Berk.

England: Berkeley, Brit. Fungi, 251.

New Hampshire: Chocorua, E. A. Burt, 1, 2.

New York: Albany, H. D. House (in N. Y. State Mus. Herb., and Mo. Bot. Gard. Herb., 14830, 55201), and H. D. House \& J. Rubinger (in N. Y. State Mus. Herb., and Mo. Bot. Gard. Herb., 17797); Karner, H. D. House, comm. by N. Y. State Mus. Herb. (in Mo. Bot. Gard. Herb., 54347, 54357, 54377); Newtonville, C. H. Peck (in N. Y. State Mus. Herb., and Mo. Bot. Gard. Herb., 55969, 55989); North Elba, C. H. Kauffman, 5 (in Mo. Bot. Gard. Herb., 6719); Schuylerville, C. H. Peck, comm. by N. Y. State Mus. Herb., T 17, T 25 (in Mo. Bot. Gard. Herb., 54570, 54657).

Georgia: Tallulah Falls, A. B. Seymour, from Farlow Herb., D (in Mo. Bot. Gard. Herb., 44609).

Louisiana: St. Martinville, A. B. Langlois, bu.

Washington: Chehalis, C. J. Humphrey, 6273; Hoquiam, C. J. Humphrey, 6409.

Oregon: Granite Pass, J. R. Weir, 11183 (in Mo. Bot. Gard. Herb., 63252).

58. P. Burtii Romell, n. sp.

Type: in Burt Herb. and Romell Herb. 
Fructifications effused, somewhat membranaceous, tender, hymenium drying warm buff usually but sometimes whitish to cartridge-buff, sometimes cracked and showing the cottony substance, the margin byssoid or fibrillose and sometimes connected with antimony-yellow mycelial strands; in section 200-300 $\mu$ thick, not colored, with the hyphae loosely arranged, hyaline, rarely nodose-septate, with some incrusting granules in the subhymenium; cystidia hair-like, not incrusted, tapering, $3-4 \mu$ in diameter, protruding up to $25 \mu$, not numerous; spores hyaline, even, $4-41 / 2 \times 2-21 / 2 \mu$.

Fructifications 2-7 cm. long, 1-2 cm. broad.

On wood and fallen limbs of frondose species in woods. Vermont to Louisiana and in Ohio, Michigan, and Montana. July to October. Rare.

This species is noteworthy by the antimony-yellow or ochraceous mycelial strands or cords which grow from under the bark and connect with the fructifications. The presence of cystidia separates this species from Corticium sulphureum which has yellower fructifications and not as large mycelial cords when present.

Specimens examined:

Exsiccati: Ellis, N. Am. Fungi, 933, under the name Corticium radiosum.

Vermont: Middlebury, E. A. Burt.

Massachusetts: Sharon, A. P. D. Piguet, 136, comm. by Farlow Herb. (in Mo. Bot. Gard. Herb., 59627).

New York: Ithaca, H. H. Whetzel, comm. by Cornell Univ. Herb., 13760.

New Jersey: Newfield, J. B. Ellis, in Ellis, N. Am. Fungi, 933.

Virginia: Crabbottom, W. A. Murrill, 239 (in N. Y. Bot. Gard.

Herb., Burt Herb., and Mo. Bot. Gard. Herb., 61560).

Alabama: Auburn, Alabama Biological Survey.

Louisiana: Bogalusa, C. J. Humphrey, 5472; St. Martinville, A. B. Langlois, cl.

West Virginia: Paw Paw, C. L. Shear, 1179.

Ohio: C. G. Lloyd, 3823, type.

Michigan: New Richmond, C. H. Kauffman, 34 (in Mo. Bot. Gard. Herb., 23060). 
Montana: Evaro, J. R. Weir, 415 (in Mo. Bot. Gard. Herb., 14772).

59. P. subapiculata (Bres.) Burt, n. comb.

Corticium subapiculatum Bresadola, Mycologia 17:69. 1925. Type: in Weir Herb.

Fructifications broadly effused, adnate, small pieces separable when moistened, waxy, becoming ivory-yellow to pinkish buff in the herbarium, even, only rarely cracked, the margin thinning out, pruinate; in section about $150 \mu$ thick, not colored, composed of interwoven hyaline hyphae $3 \frac{1}{2}-4 \frac{1}{2} \mu$ in diameter, not incrusted, only rarely nodose-septate; no gloeocystidia; cystidia hair-like, not incrusted, cylindric, obtuse, $3-41 / 2 \mu$ in diameter, protruding $10-40 \mu$ beyond the basidia; spores hyaline, even, $4-6 \times 2-3 \mu$.

Fructifications $8-12 \mathrm{~cm}$. long, 1-4 cm. wide.

On decaying logs of Pinus, Abies, and Larix-usually on the wood. Idaho and British Columbia. June to September.

$P$. subapiculata resembles $P$. Weiri in color and general aspect but has no gloeocystidia and smaller cystidia and spores.

Specimens examined:

Montana: Evaro, J. R. Weir, 414 (in Mo. Bot. Gard. Herb., 63720); Kalispell, E. E. Hubert, comm. by J. R. Weir, 11957 (in Mo. Bot. Gard. Herb., 63312).

Idaho: Clarkia, A. S. Rhoades (in Weir Herb., 16928, type); Coolin, J. R. Weir, 11086 (in Mo. Bot. Gard. Herb., 63245); Priest River, J. R. Weir, 52, 130 (in Mo. Bot. Gard. Herb., 63718), and E. E. Hubert, comm. by J. R. Weir, 12020 (in Mo. Bot. Gard. Herb., 63375).

British Columbia: Kootenai Mountains, near Salmo, J. R. Weir, 4\%6 (in Mo. Bot. Gard. Herb., 63719).

60. P. sordida (Karst.) Burt-not in the sense of Brinkmann or Bresadola.

Corticium sordidum Karsten, Soc. pro Fauna et Flora Fennica Meddel. 9: 65. 1883; Finska Vet.-Soc. Bidrag Natur och Folk 48: 413. 1889; Sacc. Syll. Fung. 6: 631. 1888; Massee, Linn. Soc. Bot. Jour. 27: 140. 1890. Compare v. Höhnel 
\& Litschauer, K. Akad. Wiss. Wien Sitzungsber. 117: 1088. 1908.

Type: authentic specimen in Burt Herb.

Fructifications longitudinally effused, small portions separable when moistened, in the herbarium young specimen pale olivebuff and older specimen wood-brown, contracting in drying and cracking into small rectangular masses about $1 \mathrm{~mm}$. in diameter, separated by rather wide crevices and showing the paler floccose subiculum, the margin thinning out; in section 150-300 $\mu$ thick, not colored, becoming stratose, each stratum 2-layered, with the layer towards the substratum composed of loosely arranged, suberect, branching hyphae $41 / 2^{-5} \mu$, rarely $6 \mu$, in diameter, not incrusted, not nodose-septate, and the hymenial layer compact, $75 \mu$ thick; no gloeocystidia; cystidia not incrusted, cylindric, obtuse, $4-6 \mu$ in diameter, protruding up to $30 \mu$, none wholly immersed; spores copious, hyaline, even, $4 \frac{1}{2}-6 \times 2-3 \mu$.

Fructifications $3 \mathrm{~cm}$. $\times 7 \mathrm{~mm}$. and $21 / 2 \times 1 \mathrm{~cm}$. in the two fragmentary pieces from Karsten, 3-10 cm. long, 7-15 mm. wide in an American specimen.

On decorticated wood of $P$. sylvestris and $P$. Strobus on the ground. Finland and New York. October. Rare.

Brinkmann distributed in his "Westfälische Pilze," 8, under the name of Peniophora sordida (Karst.) Brinkmann, a specimen which was later referred by Bresadola to Peniophora serialis. I have not seen this specimen. Von Höhnel \& Litschauer accepted this reference, loc. cit., and placed Corticium sordidum Karst. as a synonym of $P$. serialis. The study of other specimens of the $P$. serialis complex shows that none of these others have the structure of authentic Corticium sordidum although somewhat resembling the old stage in general aspect. The problem with me for a time was whether $P$. cremea is distinct from $P$. sordida, but $P$. cremea occurs on frondose wood, is not cracked into rectangular, completely separated masses, and has larger cystidia, some of which are incrusted and wholly immersed. The Karsten specimens of $C$. sordidum are in some places composed of a single stratum $150 \mu$ thick of 2 layers and in others of 2 strata with thickness together of 240-300 $\mu$.

Specimens examined: 
Finland: Mustiala, P. A. Karsten, authentic specimen of Corticium sordidum.

New York: Karner, H. D. House, 14.188 (in Mo. Bot. Gard. Herb., 44722).

61. P. Burkei Burt, n. sp.

Type: in Mo. Bot. Gard. Herb.

Fructifications broadly effused, thin, adnate, membranaceous, tender, small pieces separable when moistened, cream-buff in the herbarium, somewhat tubercular, conforming to the inequalities of the rough bark upon which growing, somewhat eracked in drying, the margin thinning out, of finely interwoven hyphae; in section 120-180 $\mu$ thick, not colored, with the hyphae suberect, loosely interwoven, thin-walled, $3 \mu$ in diameter, nodose-septate, not incrusted; no gloeocystidia; cystidia not incrusted, subulate, $50 \times 4 \frac{1}{2}-5 \mu$, protruding up to $20 \mu$; spores hyaline, even, $6-7$ $\times 4-5 \mu$, copious.

Fructifications probably large $-4 \mathrm{~cm}$. long, $2-21 / 2 \mathrm{~cm}$. wide in pieces broken off at both ends and on one side.

On rough, frondose bark. Alabama. October.

$P$. Burke $i$ has some resemblance in aspect to $P$. cremea but has a more tubercular hymenium, slenderer and more erect hyphae, and larger spores.

Specimens examined:

Alabama: Montgomery County, R. P. Burke, 474, type (in Mo. Bot. Gard. Herb., 57292).

62. P. glebulosa Bresadola, Fungi Trid. 2: 61. pl. 1\%0, f. 2 . 1898; Sacc. Syll. Fung. 16: 195. 1902; Bourdot \& Galzin, Soc. Myc. Fr. Bul. 28: 384. 1913; Rea, Brit. Basid. 688. 1922.

Not Thelephora calcea Fries var. glebulosa Fries, Elenchus Fung. 1: 215. 1828.—Not Corticium calceum Fries, Epicr. 562. 1838; nor Hym. Eur. 652. 1874.

Type: in Bresadola Herb. and Burt Herb.

Fructifications widely effused, thin, closely adnate, whitish, pinkish buff, pale olive-buff, or cream color, pubescent with the cystidia, becoming cracked into small areas when dry, the margin thinning out; in section 50-200 $\mu$ thick, not colored, composed throughout of cystidia and rather erect, interwoven, hyaline, 
thin-walled hyphae $1-3 \mu$ in diameter, not incrusted; cystidia thick-walled, with very narrow lumen which is often much larger at apex of cystidium, even where immersed, or sometimes with some granular incrustation near protruding apex, 60-150 × 7$10 \mu$, protruding up to 50-100 $\mu$, very numerous throughout the fructification, not dissolved by treatment of sections with potassium hydrate; spores white, even, cylindric, slightly curved, $6-9 \times 1 \frac{1}{2}-2 \mu$.

Fructifications $3-15 \mathrm{~cm}$. long, 1-6 cm. wide.

On wood of decaying conifers, rarely on bark, and on frondose species. In Europe, from Canada to New Jersey, in Nebraska, Colorado, Montana and Manitoba to British Columbia and Oregon. May to November. Common locally.

$P$. glebulosa has distinctive cystidia to which Bourdot \& Galzin have given the term cystidioles. These cystidia are elongated, cylindric, even throughout their whole length usually, but sometimes with a little incrusting matter near the apex of the protruding part, and with a very thick wall-so thick that the axial lumen containing protoplasmic contents is merely a line which, however, is often greatly expanded at its peripheral end in the apex of the cystidium where the latter becomes thin-walled and fragile. The cystidia of $P$. glebulosa are not at all dissolved or only partially by the potassium hydrate treatment to which sections are subjected. In the original description Bresadola states that $P$. glebulosa is the same as authentic Corticium calceum var. glebulosum Fries. I believe this to be an error, for a fragment of authentic $C$. calceum var. glebulosum communicated to me by Bresadola and the original specimens so labelled in Fries Herbarium, all of which I studied, have no cystidia whatever and agree in all respects with a true Corticium collected at Femsjö, the original station, by Romell and myself.

Specimens examined:

Sweden: Femsjö, Romell \& Burt, three gatherings; Lappland,

L. Romell, 405; Stockholm, L. Romell, 199.

Austria: Stubai, Tirol, V. Litschauer.

Italy: Trient, G. Bresadola, type.

England: Symond's Yat, E. M. Wakefield (in Mo. Bot. Gard. Herb., 57120). 
Canada: Billings Bridge, J. Macoun, 113.

Quebec: Hull, J. Macoun, 246.

Maine: W. A. Murrill, 21391/2 (in N. Y. Bot. Gard. Herb., and Mo. Bot. Gard. Herb., 61424); Kittery Point, R. Thaxter \& E. A. Burt; Piscataquis County, W. A. Murrill, 2142, 2653 (in N. Y. Bot. Gard. Herb., and Mo. Bot. Gard. Herb., 61349, 61441).

New Hampshire: Chocorua, W. G. Farlow (in Mo. Bot. Gard. Herb., 19554) and 11.

Vermont: Middlebury, E. A. Burt, four gatherings.

New York: Altamont, E. A. Burt; East Galway, E. A. Burt, three gatherings; Farmington, E. Brown, 116 (in N. Y. Bot. Gard. Herb., and Mo. Bot. Gard. Herb., 61451); Ithaca, G. F. Atkinson, 8236, 8284; Sandlake, C. H. Peck, comm. by N. Y. State Mus. Herb., T 15 (in Mo. Bot. Gard. Herb., 54568).

New Jersey: Newfield, J. B. Ellis, under the herbarium name P. gracillima (in N. Y. Bot. Gard. Herb., and Burt Herb.).

Nebraska: Long Pine, C. L. Shear, 1056.

Colorado: Geneva Creek Canyon, alt. 8000-14000 ft., F. J. Seaver \& E. Bethel (in N. Y. Bot. Gard. Herb., and Mo. Bot. Gard. Herb., 61467); Golden, L. O. Overholts, 1752 (in Mo. Bot. Gard. Herb., 54881).

Montana: Bernice, J. R. Weir, 12000,12006 (in Mo. Bot. Gard. Herb., 63362, 63366); Darby, E. E. Hubert, comm. by J. R. Weir (in Mo. Bot. Gard. Herb., 6324S); Hecla, E. E. Hubert, comm. by J. R. Weir, 11416 (in Mo. Bot. Gard. Herb., 63263); Libby, E. E. Hubert, comm. by J. R. Weir, 11443 (in Mo. Bot. Gard. Herb., 63273).

Idaho: Coeur d'Alene, J. R. Weir, 11974, and E. E. Hubert, comm. by J. R. Weir, 11991 (both in Mo. Bot. Gard. Herb., 63328 and 63354 respectively); Coolin, J. R. Weir, 11562 (in Mo. Bot. Gard. Herb., 63301); Priest River, E. E. Hubert, comm. by J. R. Weir, 12029 (in Mo. Bot. Gard. Herb., 63381), and J. R. Weir, 350, 6362 (in Mo. Bot. Gard. Herb., 7853, 55952 ) and 54 .

Manitoba: Norway House, G. R. Bisby, 1458, 1464, 1476 (in Mo. Bot. Gard. Herb., 61640, 61646, 61658). 
British Columbia: Agassiz, J. R. Weir, 364 (in Mo. Bot. Gard. Herb., 16407); Comax, J. Macoun, 622 (in Mo. Bot. Gard. Herb., 55333); Kootenai Mts., Salmo, J.R. Weir, 485, 538 (in Mo. Bot. Gard. Herb., 17619, 1738); Sidney, J. Macoun, 22, 41, 64, 97 (in Mo. Bot. Gard. Herb., 5682, 55342, 5742, 55343); Squamish, J. Macoun (in Mo. Bot. Gard. Herb., 55180); Vancouver Island, J. Macoun, 356, 357 (in Mo. Bot. Gard. Herb., 55331, 55332); Victoria, J. Macoun, 576 (in Mo. Bot. Gard. Herb., 63502).

Washington: Bingen, W. N. Suksdorf, 699; Hoquiam, C. J. Humphrey, 6374; Kalama, C. J. Humphrey, 6139; Renton, C. J. Humphrey, 6633; Tacoma, W. A. Murrill, 145, comm. by N. Y. Bot. Gard. Herb. (in Mo. Bot. Gard. Herb., 55726). Oregon: Corvallis, S. M. Zeller, 1813 (in Mo. Bot. Gard. Herb., 56333); Eugene, C. J. Humphrey, 6086.

\section{P. verticillata Burt, n. sp.}

Type: in Mo. Bot. Gard. Herb.

Fructifications effused, thick, membranaceous, separable, whitish to ecru-drab in the herbarium, even the margin whitish, rather thick, cottony; in section $1300 \mu$ thick, not colored, consisting of (a) a layer $500 \mu$ thick next to the substratum of densely, longitudinally arranged hyaline hyphae about $3-31 / 2 \mu$ in diameter, and of (b) a zonate hymenial layer $800 \mu$ thick containing many elongated cystidia; no gloeocystidia; cystidia cylindric, $150-200 \times 6-7 \mu$, with 4-9 bands of incrusting matter, protruding up to $45 \mu$; no spores found.

Fructifications $1 \frac{1}{2}-21 / 2 \mathrm{~cm}$. long, $1-2 \mathrm{~cm}$. wide.

On rotten coniferous wood. Oregon. March.

The cystidia of $P$. verticillata are of the thick-walled cylindric type occurring in $P$. glebulosa but without as narrow a lumen, nor with the latter abruptly, greatly enlarged near the apex. The bands of incrusting matter on the cystidia are a unique character of the type but are not retained in glycerine mounts of sections. The very broad layer of longitudinally arranged hyphae along the substratum and the very thick, separable fructifications tending to ecru-drab are probably the more distinctive characters of this species, which is distinct from $P$. (Gloeocystidium) pallidula. 
Specimens examined:

Oregon: Waltersville, C. C. Epling \& J. B. Shorett, 600, type, comm. by S. M. Zeller, 2317 (in Mo. Bot. Gard. Herb., 63041).

64. P. crassa Burt, N. Y. State Mus. Rept. 54: 155. 1901. Stereum Karstenii Bresadola, I. R. Accad. Agiati Atti III. 3: 108. 1897; Bourdot \& Galzin, Soc. Myc. Fr. Bul. 37: 126. 1921.-Not Peniophora Karstenii Massee, Linn. Soc. Bot. Jour. 25: 153. 1889. - Not Phanerochaete odorata Karsten, Finska Vet.-Soc. Bidrag Natur och Folk 48: 427. 1889.-Corticium ochroleucum, in part, of Berkeley \& Curtis, Grevillea 1: 165. 1875, but not of Fries.

Type: in Burt Herb.

Fructifications broadly effused, becoming thick, somewhat fleshy, light buff to pinkish buff, separable from the substratum when moistened if thick, the margin somewhat tomentose, determinate; in section 500-1500 $\mu$ thick, not colored, 2-layered, with the layer next to the substratum 200-300 $\mu$ thick, composed of densely interwoven, rather thick-walled and stiff, non-incrusted hyphae $3-41 / 2 \mu$ in diameter, and with the hymenial layer 300$1200 \mu$ thick, more or less zonate, and composed of erect hyphae and cystidia; no gloeocystidia; cystidia even or sometimes somewhat incrusted, cylindric, flexuous, $100-500 \times 41 / 2-6 \mu$, protruding up to $30 \mu$ beyond the basidia, present in all parts of the hymenial layer, destroyed and dissolved by potassium hydrate treatment of sections; basidia 4-spored; spores white in spore collection, even, curved, $41 / 2-6 \times 1 \frac{1}{2}-2 \mu$.

Fructifications $3-20 \mathrm{~cm}$. long, 1-4 cm. wide.

On decorticated, decaying logs of Pinus, Abies, Picea, Tsuga, and Pseudotsuga. In Europe and from Canada to Alabama and westward to the Pacific states. Common.

$P$. crassa is certainly cogeneric with $P$. glebulosa, belongs in the same group of species, occurs on the same substrata and is probably equally destructive to wood. Its fructifications are thicker than those of $P$. glebulosa and crack into larger masses. The cystidia have thinner walls and larger lumen than those of $P$. glebulosa and are noteworthy for the destructive action of potas- 
sium hydrate on them, so that it can not be safely used in clearing and swelling the sections. Lactic acid should be used instead.

I have included under $P$. crassa the two European specimens of Stereum Karstenii cited below, because of agreement in all characters except the much greater thickness of the latter and their curling away from substratum at the margin and separation of the whole fructification in a sheet-like mass. American specimens of $P$. crassa range from 500 to $1000 \mu$ thick and have the margin closely adnate to the substratum. Perhaps there is specific difference between $P$. crassa and Stereum Karstenii.

Specimens examined:

Exsiccati: Ellis, N. Am. Fungi, 331, under the name Corticium ochroleucum var. spumeum; Ravenel, Fungi Car. 3: 33, under the name Corticium ochroleucum.

Hungary: A. Kmet, type of Stereum Karstenii from Bresadola.

France: Aveyron, A. Galzin, 20064, comm. by H. Bourdot, 20799. Canada: J. Macoun, 42; Quebec, J. Macoun, 260; Ottawa, J. Macoun, 248, in part.

New Hampshire: Chocorua, W. G. Farlow, 23, and an unnumbered specimen.

Vermont: Middlebury, E. A. Burt, two gatherings; Ripton, E. A. Burt, type.

Massachusetts: Magnolia, W. G. Farlow, e; Sharon, A. P. D. Piguet, 139, comm. by Farlow'Herb. (in Mo. Bot. Gard. Herb., 59360).

New York: Floodwood, E. A. Burt, C. H. Peck, 2; Ithaca, G. F. Atkinson, 8008; Keene, C. H. Peck, comm. by N. Y. State Mus. Herb., T 1 (in Mo. Bot. Gard. Herb., 54554); North Elba, C. H. Peck, comm. by N. Y. State Mus. Herb., T 9 (in Mo. Bot. Gard. Herb., 54555); Sylvan Beach, Oneida County, H. D. House (in N. Y. State Mus. Herb., and Mo. Bot. Gard. Herb., 7460, 8293).

New Jersey: Newfield, J. B. Ellis, in Ellis, N. Am. Fungi, 331. Pennsylvania: State College, L. O. Overholts, 3631 (in Mo. Bot. Gard. Herb., 54703).

North Carolina: H. W. Ravenel, 1521 (in Curtis Herb., 1763, under the name Corticium ochroleucum var. erimosum).

South Carolina: H.W. Ravenel, in Ravenel, Fungi Car. 3: 33, 
and (in Curtis Herb., 2169, under the name Corticium ochroleucum).

Alabama: Auburn, comm. by Alabama Biological Survey. Idaho: Addic, E. E. Hubert, comm. by J. R. Weir, 11976 (in Mo. Bot. Gard. Herb., 63329); Coolin, J. R. Weir, 11558 (in Mo. Bot. Gard. Herb., 63299); Priest River, J. R. Weir, 108, 378, 6351 (in Mo. Bot. Gard. Herb., 16060, 21353, 55951) and 3, 24, 46, 50, 56 .

British Columbia: Kootenai Mts., near Salmo, J. R. Weir, 455, 498 (in Mo. Bot. Gard. Herb., 8760, 21632); Revelstoke, C. W. Dodge, 1654 (in Mo. Bot. Gard. Herb., 58788); Sidney, $J$. Macoun, 63, 393 (in Mo. Bot. Gard. Herb., 5741, 55325).

Washington: Kalama, C. J. Humphrey, 6214 (in Mo. Bot. Gard. Herb., 20431).

Arizona: Flagstaff, W. H. Long, 21386 (in Mo. Bot. Gard. Herb., 55140); Fort Valley Experiment Station, W. H. Long, 19624 (in Mo. Bot. Gard. Herb., 20133).

65. P. subalutacea (Karst.) v. Höhnel \& Litschauer, K. Akad. Wiss. Wien Sitzungsber. 115: 1601. 1906; Bourdot \& Galzin, Soc. Myc. Fr. Bul. 28: 387. 1913; Wakefield, Brit. Myc. Soc. Trans. 5: 133. 1914; Rea, Brit. Basid. 688. 1922.

Corticium subalutaceum Karsten, Soc. pro Fauna et Flora Fennica Meddel. 9: 65. 1883; Finska Vet.-Soc. Bidrag Natur och Folk 48: 414. 1889; Sacc. Syll. Fung. 6: 636. 1888; v. Höhnel \& Litschauer, K. Akad. Wiss. Wien Sitzungsber. 115: 1560. 1906. - Kneiffia subalutacea (Karsten) Bresadola, Ann. Myc. 1: 104. 1903.

Type: authentic specimen or perhaps part of type in Burt Herb.

Fructifications long and widely effused, very thin, closely adnate, pale olive-buff to pinkish buff in the herbarium, hymenium loose and rather rough under a lens, the margin thinning out; in section 30-100 $\mu$ thick, not colored, with the hyphae interwoven, rather rigid and thick-walled, about $2 \frac{1}{2} \mu$ in diameter, not incrusted, cylindric, thin-walled, $4 \frac{1}{2}-6 \mu$, protruding up to $60 \mu$ beyond the basidia, often starting from the substratum, sometimes somewhat clustered at slight elevations of the hymenium: 
spores hyaline, even, narrowly cylindric, slightly curved, about $41 / 2-7 \times 1 \frac{1}{2} \mu$.

Fructifications $3-10 \mathrm{~cm}$. long, 1-3 cm. wide.

On decaying pine wood. Europe, New Jersey to Louisiana, and in Washington. July to March. Rare.

The cystidia of $P$. subalutacea place it in the group with $P$. glebulosa and $P$. crassa. It is thinner than either of these. It may be distinguished from thin forms of the former by the thinwalled cystidia which have a lumen of nearly uniform diameter which is not abruptly and greatly enlarged near the apex of the cystidium.

Specimens examined:

Sweden: Femsjö, E. A. Burt.

Finland: Mustiala, P. A. Karsten, authentic specimen.

Poland: Eichler, comm. by G. Bresadola.

Austria: Tirol, V. Litschauer.

England: Baslow Foray, A. D. Cotton, comm. by E. M. Wakefield (in Mo. Bot. Gard. Herb., 44583).

France: Aveyron, A. Galzin, 2444, comm. by H. Bourdot, 8007. New Jersey: Newfield, J. B. Ellis, 7510, comm. by W. G. Farlow (in Mo. Bot. Gard. Herb., 1794).

Maryland: Takoma Park, C. L. Shear, 1030.

Alabama: Montgomery County, R. P. Burke, 635 (in Mo. Bot. Gard. Herb., 63071).

Louisiana: St. Martinville, A. B. Langlois, 0 .

Washington: Mt. Paddo, W. N. Suksdorf, 726.

66. P. odorata (Karsten) Burt, n. comb.

Phanerochaete odorata Karsten, Finska Vet.-Soc. Bidrag Natur och Folk 48: 427. 1889. Not Stereum odoratum Fries, Epicr. 553. 1838.-Not Stereum Karstenii Bresadola, I. R. Accad. Agiati Atti III. 3: 108. 1897.

Type: in Burt Herb. from Karsten and probably in Karsten Herb.

Fructifications narrowly effused, small, pulvinate, somewhat convex, becoming longitudinally confluent, adnate, dry, felty, cartridge-buff to pale pinkish buff, velvety, the margin thick, entire; in section 500-1000 $\mu$ thick, not colored, at length zonate 
or stratose, composed of a layer next to the substratum of interwoven, tough, hyaline hyphae 3-4 $\mu$ in diameter, and of 1-4 hymenial layers; no glococystidia; cystidia not incrusted, cylindric, S0-150 × 6-9 $\mu$, protruding up to $80 \mu$ beyond the basidia, not destroyed by potassium hydrate treatment; basidia with 4 sterigmata; spores hyaline, even, $12-15 \times 4-6 \mu$, copious.

Fructifications $5 \mathrm{~mm} .-2 \frac{1}{2} \mathrm{~cm}$. long, 3-10 mm. wide, rarely $5-10 \mathrm{~cm}$. long by confluence.

On decorticated decaying wood and fence rails of Pinus albicaulis, $P$. contorta, P. flexilis, P. Murrayana, P. silvestris, Abies grandis, Larix, Pseudotsuga, and Thuja. In northern Europe, and in Wyoming, Montana, Idaho, British Columbia, Washington, and Arizona. Frequent.

$P$. odorata may be recognized by its small, thick, pulvinate, dry, velvety, pallid fructifications on old, weathered, blackened, coniferous wood, by large spores, and stratose fructifications which have even cystidia not affected by the potassium hydrate treatment of sections. Karsten referred his specimens to Stereum odoratum Fries, and Bresadola included the Karsten specimens under his Stereum Karstenii Bres., of which I regard the type to be a gathering made by Kmet in Hungary.

Specimens examined:

Finland: Mustiala, P.A. Karsten, type of Phanerochaete odorata. Sweden: Bedaro, L. Romell, 412; Lappland, L. Romell, 413; Stockholm, L. Romell, 369.

Montana: Anaconda, J. R. Weir, 583 (in Mo. Bot. Gard. Herb., 63173); Bernice, E. E. Hubert, comm. by J. R. Weir, 12011 (in Mo. Bot. Gard. Herb., 63322); Hecla, E. E. Hubert, comm. by J. R. Weir, 11405 (in Mo. Bot. Gard. Herb., 63260); Choteau, J. A. Hughes, comm. by J. R. Weir, 5824 (in Mo. Bot. Gard. Herb., 55649); Libby, E. E. Hubert, comm. by J. R. Weir, 11351 (in Mo. Bot. Gard. Herb., 63259); Melrose, E. E. Hubert, comm. by J. R. Weir, 11427, 11433, 11439 (in Mo. Bot. Gard. Herb., 63261, 63274, 63279); West Butte, J. A. Hughes, comm. by J. R. Weir, 5496 (in Mo. Bot. Gard. Herb., 55647). Wyoming: Fox Park, J. R. Weir, 10018 (in Mo. Bot. Gard. Herb., $55789)$.

Idaho: Bonanza, G. G. Hedgcock, comm. by C. J. Humphrey, 
2527, in part; Coolin, J. R. Weir, 11526 (in Mo. Bot. Gard. Herb., 63291); Priest River, E. E. Hubert, comm. by J. R. Weir (in Mo. Bot. Gard. Herb., 63258).

British Columbia: Kootenai Mts., Salmo, J. R. Weir, 536 (in Mo. Bot. Gard. Herb., 22598).

Washington: Mt. Paddo, W. N. Suksdorf, 729.

Arizona: Coronado National Forest, Santa Catalina Mountains, G. G. Hedgcock \& W. H. Long, comm. by C. J. Humphrey, 2544

(in Mo. Bot. Gard. Herb., 63534).

67. P. pilosa Burt, n. sp.

Type: in Burt Herb.

Fructifications effused, thin, closely adnate, hypochnoid, becoming pale olive-buff in the herbarium, the margin thinning out; in section 40-60 $\mu$ thick, not colored, composed of loosely arranged, thin-walled hyphae $2 \frac{1}{2}-3 \mu$ in diameter, not incrusted, and of cystidia starting from the substratum; no gloeocystidia; cystidia not incrusted, thin-walled, cylindric, $60-100 \times 4 \frac{1}{2}-7 \mu$, protruding up to $70 \mu$ beyond the basidia, often constricted near the tip and terminating in an ovoid-shaped body; basidia 4-spored; spores hyaline, even, $6-8 \times 4-41 / 2 \mu$, copious.

Fructifications fragmentary, with the largest fragment $21 / 2 \mathrm{~cm}$. long, $1 \mathrm{~cm}$. wide.

On decaying coniferous wood. New York and Alabama. Probably rare.

$P$. pilosa forms a gray, downy covering on old weathered pine wood, with the basidia not forming a compact hymenium. In aspect this species somewhat resembles $P$. tenuis but there are no gloeocystidia, and the numerous long, cylindric cystidia, sometimes terminating in a single spore-shaped end and sometimes in a short row of 2 or 3 , are distinctive.

Specimens examined:

New York: East Galway, E. A. Burt; Ithaca, G. F. Atkinson, 14415, type.

Alabama: Montgomery, R. P. Burke, 154 (in Mo. Bot. Gard. Herb., 3650).

68. P. Peckii Burt, n. sp.

Type: in Burt Herb. and probably in N. Y. State Mus. Herb. 
Fructifications broadly effused, somewhat membranaceous, separable from the substratum in small portions when moistened, thin, becoming cartridge-buff to cream-buff in the herbarium, not shining, cracking in drying, the margin thinning out; in section 60-360 $\mu$ thick, not colored, composed throughout of suberect hyphae about $4 \mu$ in diameter, not incrusted and occasionally nodose-septate, of elongated flexuous eystidia, and of great numbers of subglobose, even chlamydospores $4 \frac{1}{2}-5 \times 4 \mu$; cystidia not incrusted, flexuous, elongated, with somewhat the aspect of gloeocystidia, $30-100 \times 6-9 \mu$, in all regions of fructification, many starting from the substratum, tapering upward, protruding up to $40 \mu$ beyond the basidia; basidia with 4 sterigmata; basidiospores hyaline, even, subglobose, $5-6 \times 41 / 2 \mu$.

Fructifications $2-6 \mathrm{~cm}$. long, 1-3 cm. wide.

On bare ground in woods and on bark and wood of decaying Alnus, Betula, Populus, Quercus, and Ceanothus, rarely on a coniferous substratum. Canada to Massachusetts and westward to Washington. July to March. Occasional.

$P$. Peckii is placed in the species group with $P$. glebulosa on account of the large, even-walled cystidia which are more flexuous than those of the latter species and with more the aspect of gloeocystidia, but I have not yet demonstrated by granular contents that they are gloeocystidia. P. Peckii is distinguished by the great number of subglobose spores distributed throughout the whole fructification in sections studied.

Specimens examined:

Canada: J. Macoun, 18, 51; Lower St. Lawrence Valley, J. Macoun, 5.

Massachusetts: Cherry Brook, E. A. Burt \& A. B. Seymour; Magnolia, W. G. Farlow (in Burt Herb. and Mo. Bot. Gard. Herb., 44066); Sharon, A. P. D. Piguet, comm. by W. G. Farlow, 11 (in Mo. Bot. Gard. Herb., 55590) and by Farlow Herb., 132 (in Mo. Bot. Gard. Herb., 59622); Wellesley, L. W. Riddle, 11 .

New York: Ithaca, G. F. Atkinson, 5089; Karner, H. D. House, comm. by N. Y. State Mus. Herb. (in Mo. Bot. Gard. Herb., 54361, 55204); Westport, C. H. Peck, 6, type; White Plains, W. H. Ballou, 1 (in Mo. Bot. Gard. Herb., 55030). 
Michigan: Marquette, C. J. Humphrey, 1870 (in Mo. Bot. Gard. Herb., 11089).

Wisconsin: Blue Mounds, E. T.\& S. A. Harper, 895.

Washington: Bingen, W. N. Suksdorf, 741, $90 \%$.

69. P. heterocystidia Burt, n. sp.

Type: in Burt Herb.

Fructifications broadly effused, separable from the substratum when moistened, becoming cracked in drying and often loosening from substratum along the fissures, whitish when young, becoming light drab, cinnamon drab or vinaceous drab, the margin often paler; in section not colored or with only the hymenial layer clay-colored or brownish, 200-400 $\mu$ thick, 2-layered, the layer next to substratum usually broad, composed of loosely interwoven, somewhat ascending or longitudinally arranged, hyaline, nodoseseptate hyphae $3-4 \frac{1}{2} \mu$ in diameter, the hymenial layer $40-80 \mu$ thick, composed of cystidia, gloeocystidia, and erect hyphae usually slightly colored near plane of origin from the under layer; cystidia consisting of both usual incrusted cystidia 25-35 $\times$ 6-8 $\mu$, distributed in all parts of the outer layer, and of very large cystidia up to $40-100 \times 20-50 \mu$ which start from the baseoften somewhat colored-of the hymenial layer; gloeocystidia slender, flexuous, 40-60 $\times 5-6 \mu$, between the basidia; basidia with 4 sterigmata; spores from spore collection white, even, cylindric, $12-15 \times 31 / 2-41 / 2 \mu$.

Fructifications $2-7 \mathrm{~cm}$. in diameter.

On fallen limbs of gray birch, beech, maple, Carpinus, Magnolia, and other frondose species. Canada to Mississippi and westward to Missouri and in Mexico. June to March. Common.

$P$. heterocystidia resembles Corticium laeve Pers. $(=C$. evolvens Fr.) in color but is a true Peniophora, readily distinguished from our other separable species by having incrusted cystidia of the usual size, other very large cystidia up to $20-50 \mu$ in diameter, and gloeocystidia. Bresadola and von Höhnel \& Litschauer confused this species with $P$. carnea, from which it differs in being much thicker, separable from the substratum when moistened, and being colored within on the hymenial side instead of next 
to the substratum. Rarely a fructification may have the hymenium vary somewhat hydnaceous.

Specimens examined:

Exsiccati: Ellis, N. Am. Fungi, 716, under the name Corticium glabrum, 717a of some copies, under the name Corticium subgiganteum.

Canada: J. Macoun, 3, 10, 14, 46 .

Ontario: Lake Rosseau, E. T. \& S. A. Harper, 755; Ottawa, J. Macoun, 110.

Vermont: Middlebury, E. A. Burt, type, and 2 other gatherings. Connecticut: Central Village, J. L. Sheldon, 23, comm. by N. Y. Bot. Gard. Herb.

New York: Bemis Heights, C. H. Peck (in N. Y. State Mus. Herb., under the name Stereum albobadium); Bronx Park, Class in Mycology (in N. Y. Bot. Gard. Herb., Mo. Bot. Gard. Herb., 61392, 61430, and Burt Herb.); Kirkland, H. D. House (in N. Y. State Mus. Herb., Mo. Bot. Gard. Herb., 59685, and Burt Herb.); Snyders, C. H. Peck (in N. Y. State Mus. Herb., and Mo. Bot. Gard. Herb., 56018); Syracuse, L. M. Underwood, in some copies of Ell. \& Ev., Fungi Col., 221, under the name Corticium glabrum; White Plains, W. H. Ballou (in Mo. Bot. Gard. Herb., 55034).

New Jersey: Newfield, J. B. Ellis.

Pennsylvania: Meadville, E. C. Smith, comm. by L. O. Overholts, 8337 (in Mo. Bot. Gard. Herb., 59475); West Chester, Everhart, Haines, Jefferis \& Gray, in Ellis, N. Am. Fungi, 716. District of Columbia: Washington, C. L. Shear, $125 \%$ a, 1260.

Mississippi: Ocean Springs, L. M. Underwood (in N. Y. Bot. Gard. Herb., and Mo. Bot. Gard. Herb., 61484).

Ohio: Cincinnati, C. G. Lloyd, 191, 2790, 4518; Norwood, C. G. Lloyd, $22 \% 4$.

Indiana: Millers, E. T. \& S. A. Harper, 962; Union County, M. F. \& L. O. Overholts \& B. Fink, comm. by L. O. Overholts, 4204 (in Mo. Bot. Gard. Herb., 55636).

Illinois: Cypress, C. J. Humphrey, 1347 (in Mo. Bot. Gard. Herb., 42923); Glencoe, E. T. \& S. A. Harper, 662, 646.

Kentucky: Crittenden, C. G. Lloyd (in Lloyd Herb., 1411, and Mo. Bot. Gard. Herb., 55626). 
Missouri: Columbia, B. M. Duggar, 265, 288, 400, 472; Pacific, B. M. Duggar (in Mo. Bot. Gard. Herb., 63417); near St. Louis, E. A. Burt (in Mo. Bot. Gard. Herb., 63418).

Mexico: Tepeite Valley near Guernavaca, W. A. \& E. L. Murrill, 400, comm. by N. Y. Bot. Gard. Herb. (in Mo. Bot. Gard. Herb., 54551).

70. P. borealis (Peck) Burt, n. sp.

Peniophora disciformis (DC) Cooke var. borealis Peck in Harriman Alaska Exped. 5. The Fungi of Alaska, 43. 1904; Sacc. Syll. Fung. 17: 175. 1905.

Type: in Mo. Bot. Gard. Herb.

Fructifications effused, thick, membranaceous, separable, becoming light buff in the herbarium, velvety with the numerous cystidia, the margin thinner, entire, clay-color, free in some places; in structure $60 \mu$ thick, not colored, composed of hyaline hyphae $2 \mu$ in diameter, not incrusted, densely and longitudinally arranged along the substratum and then curving obliquely outward to form the hymenial layer, and of occasional slender gloeocystidial organs with enlarged clavate or pyriform tips up to $41 / 2^{-7} \mu$ in diameter; cystidia incrusted, cylindric, $60-75 \times 6-$ $9 \mu$, confined to the hymenial surface but in great numbers there, protruding nearly their whole length beyond the basidia; a single detached spore is hyaline, even, $10 \times 8 \mu$, but may be foreign.

Fructifications $5 \mathrm{~mm} .-21 / 2 \mathrm{~cm}$. long, $5 \mathrm{~mm}$. $-10 \mathrm{~mm}$. wide.

On bark of small decaying twigs of a frondose species-perhaps Alnus. Alaska. June.

$P$. borealis has aspect somewhat suggestive of $P$. aurantiaca but is more buff-colored, with darker margin becoming free, and with cystidia so long and numerous as to be very conspicuous when viewed with a lens. The abundance of these cystidia is so great as to be a very important character in the recognition of this species by preliminary inspection.

Specimens examined:

Alaska: Aqua Dulce River, Yakutat Bay, W. Trelease, 583, type (in Mo. Bot. Gard. Herb., 5006).

71. P. lepida Bresadola, Mycologia 17: 70. 1925.

Type: in Weir Herb. 
Fructifications broadly effused, thick, waxy-membranaceous, separable from the substratum, somewhat horn-like and requiring moistening for a short time before sectioning, pinkish buff to light ochraceous-buff in the herbarium, somewhat pulverulent, the margin finally free and rolling up from the substratum; in section 500-600 $\mu$ thick, not colored, composed of densely arranged hyphae $3-31 / 2 \mu$ in diameter, which run longitudinally along the substratum and then curve obliquely into the hymenium; between the hyphae occur numerous slightly more deeply staining elongated organs of the nature of conducting organs or slender gloeocystidia; cystidia incrusted, cylindric, $6-8 \mu$ in diameter, protruding up to $30 \mu$ beyond the basidia, very numerous in the hymenial surface, the incrusted part about $20-45 \mu$ long; no spores found.

Fructification $9 \mathrm{~cm}$. long, $31 / 2 \mathrm{~cm}$. wide.

On a dead stub about $2 \frac{1}{2} \mathrm{~cm}$. in diameter, of Salix sp. Idaho. June.

$P$. lepida has some resemblance to $P$. gigantea but is not quite as gelatinous in consistency as $P$. gigantea and occurs on Salix. The slender conducting hyphae or gloeocystidia should aid in recognizing the species. The broad layer of hyphae arranged longitudinally along the substratum and then curving outward into the hymenium is very like that of a resupinate Stereum but I recall no pileate Stereum of similar structure.

Specimens examined:

Idaho: National Forest, 50 miles east of Orofino, A. S. Rhoads (in Weir Herb., 16744, type).

\section{P. Kauffmanii Burt, n. sp.}

Type: in Mo. Bot. Gard. Herb., and probably in Kauffman Herb.

Fructifications long-effused, rather thin, adnate, small portions separable when moistened, between pale pinkish buff and tilleulbuff, not cracked, not waxy nor shining, the margin determinate, thinning out; in section 300-350 $\mu$ thick, 2-layered, with both layers of about equal thickness and the hymenial layer somewhat honey-yellow, the layer next to the substratum not colored, composed of loosely and longitudinally interwoven, thin-walled, 
hyaline hyphae about $3 \mu$ in diameter, of irregular outline; hymenial layer composed of densely arranged, erect hyphae, gloeocystidia, and cystidia; gloeocystidia flexuous, 45-100 $\times 4-7 \mu$; cystidia incrusted when wholly immersed, cylindric, obtuse, $30-45 \times 6-8 \mu$, protruding $20-30 \mu$ beyond the basidia in incrusted, or more usually, non-incrusted form, not abundant; spores hyaline, even, curved, $8-12 \times 2 \frac{1}{2}-3 \mu$, with pointed and tapering base, copious.

Fructifications $2-10 \mathrm{~cm}$. long but broken off at one end, 1-21/2 cm. wide.

On decaying limbs of Fagus. Kentucky. September. Probably local.

Among our few species of Peniophora which have gloeocystidia, $P$. Kauffmanii should be readily recognized by its occurrence on beech, buff color, structure of 2 equal layers, and small, incrusted cystidia.

Specimens examined:

Kentucky: Harlan, C. H. Kaufman, 69, type (in Mo. Bot. Gard. Herb., 22827).

73. P. alba Burt, n. sp.

Type: in Burt Herb.

Fructifications effused, very thin, somewhat membranaceous, small pieces separable when moistened, white, even, not shining, somewhat cracked by contraction in drying, the margin thinning out; in section 80-100 $\mu$ thick, not colored, with the hyphae loosely arranged near the substratum, suberect, branching, about $3 \mu$ in diameter, not incrusted, only rarely nodose-septate; gloeocystidia curved, $30-45 \times 31 / 2-41 / 2 \mu$, usually starting from the substratum; cystidia not incrusted or with some incrusting granules, thin-walled, $4-5 \mu$ in diameter, protruding up to $30 \mu$ beyond the basidia; spores hyaline, even, $4-5 \times 21 / 2 \mu$.

Fructifications fragmentary and not showing ends nor more than one side; such fragments $5 \mathrm{~cm}$. long, $10-15 \mathrm{~mm}$. wide.

On bark of dead cedar or spruce. Canada. September.

$P$. alba seems possible of recognition among our many whitish species of Peniophora by its pure white color, presence of gloeocystidia in addition to cystidia, and occurrence on coniferous bark. 
Specimens examined:

Canada: locality not given, J. Macoun, 57, type.

74. P. tenella Burt, n. sp.

Type: in Mo. Bot. Gard. Herb. and Farlow Herb.

Fructifications effused, white, tender, thin, loosely attached, separable when moistened, velvety, setulose with the large cystidia, the margin indeterminate, thinning out; in section 150-200 $\mu$ thick, not colored, composed of a dense hymenial layer 75-90 $\mu$ thick, borne on a loosely interwoven layer composed of thin-walled, hyaline hyphae $3-4 \mu$ in diameter, nodose-septate, sometimes granule-incrusted; hymenial layer composed of basidia, gloeocystidia, and incrusted cystidia; gloeocystidia numerous, flexuous, tapering from the base, $45-75 \times 5-8 \mu$; cystidia very large, heavily incrusted, conical, $60-100 \times 15-20 \mu$, wholly immersed, or protruding beyond the basidia up to $75 \mu$; spores copious, hyaline, even, $71 / 2-9 \times 3-4 \mu$.

Fructifications $1-2 \mathrm{~cm}$. in diameter.

On coniferous bark. New Hampshire and Massachusetts. September and October. Rare.

$P$. tenella is distinguished from $P$. pubera by occurrence on coniferous, rather than frondose, substratum, by being so loosely attached to the substratum that small portions needed for sectioning may be separated from the substratum when moistened, and by the loosely interwoven hyphal layer equalling or exceeding in thickness the hymenial layer and containing no gloeocystidia nor cystidia.

Specimens examined:

New Hampshire: Chocorua, W. G. Farlow, type (in Mo. Bot. Gard. Herb., 7617).

Massachusetts: Cambridge, A. P. D. Piguet, comm. by W. G. Farlow, 30 .

75. P. duplex Burt, n. sp.

Type: in Burt Herb.

Fructifications small, effused, thin, adnate, somewhat membranaceous, small pieces separable when moistened, becoming pale pinkish buff in the herbarium, even, not cracked, not shining, the 
margin narrow, radiate-fibrillose; in section $100-200 \mu$ thick, not colored, the hyphae with walls gelatinously modified, indistinct, about $3 \mu$ in diameter, ascending, densely crowded together and interwoven and with numerous gloeocystidia present; gloeocystidia sometimes pyriform but usually more elongated, $20-45 \times 6-9 \mu$, in all regions of the fructification; cystidia incrusted, cylindric, $25-30 \times 4 \frac{1}{2}-5 \mu$, protruding up to $20 \mu$ beyond the basidia, confined to the hymenium; spores hyaline, even, flattened on one side, $5 \times 2 \frac{1}{2} \mu$.

Fructifications received in fragments $1-2 \mathrm{~cm}$. long, 5-10 $\mathrm{mm}$. wide.

On bark of Pinus austriaca (cult.). New York. October.

In general aspect $P$. duplex suggests small fructifications of $P$. gigantea but not curling away from the substratum at all. The cystidia are smaller than those of $P$. gigantea and the latter does not have gloeocystidia.

Specimens examined:

New York: Shelter Island, W. G. Farlow, type.

76. P. mutata (Peck) Bresadola in Bourdot \& Galzin, Soc. Myc. Fr. Bul. 28: 399. 1913.

Corticium mutatum Peck, N. Y. State Mus. Rept. 43:67. 1890. Type: in N. Y. State Mus. Herb.

Fructifications broadly effused, membranaceous, fleshy, thick, separable when moistened, drying white to pinkish buff, sometimes centrally tuberculose or with raduloid teeth and occasionally with radial folds, sometimes cracking in drying and showing the white, fibrillose subiculum in the fissures, the margin white, radially byssoid; in structure 300-1000 $\mu$ thick, composed of loosely arranged, ascending, thin-walled, hyaline hyphae 3-4 $\mu$ in diameter, occasionally nodose-septate; gloeocystidia pyriform, $15 \times 7 \mu$, more or less numerous, sometimes grown out into elongated, flexuous form up to $100 \times 4-5 \mu$, occurring as hyphal ends or branches in the sybhymenium; cystidia incrusted or not incrusted, $50-100 \times 6-15 \mu$, sometimes not protruding beyond the basidia and sometimes so few present as to be found only after examination of several sections; basidia 4-spored, with short, thick, knob-like sterigmata; spores hyaline, even, cylindric, 8-16 $\times 3-4 \mu$. 
Fructifications $3-7 \mathrm{~cm}$. long, 1-3 cm. broad, sometimes larger by confluence.

Common on bark of decaying logs and fallen branches of Populus and also on Tilia, Quercus, Acer, and other frondose species. Canada to Alabama, westward to Idaho, in Europe and in Japan. July to November and in April.

P. mutata is a thick, somewhat fleshy, white, or whitish species occurring usually on bark of fallen poplar and basswood and showing in sectional preparations pyriform gloeocystidia, cystidia, and spores usually about $12 \times 31 / 2 \mu$. This species approaches the genus Radulum in thickness of the fructification, its obliquely ascending hyphae, and in occasional specimens having some raduloid teeth; such specimens have the aspect of Radulum orbiculare but differ from it by presence of the pyriform bodies and cystidia.

Specimens examined:

Exsiccati: Ellis, N. Am. Fungi, 717 a, under the name Corticium subgiganteum, 719, under the name Corticium laeve; Ell. \& Ev., Fungi Col., 308, under the name Corticium laeve.

Austria: Langenschönbich, $F$. v. H*hnel, comm. by V. Litschauer. Canada: J. Macoun, 7, 52; Lower St. Lawrence Valley, $J$. Macoun, 11, 81; Ottawa, J. Macoun, 40, 41, and 136 (in N. Y. State Mus. Herb., and Mo. Bot. Gard. Herb., 55924); Ontario, Harraby, E. T. \& S. A. Harper, 685.

Maine: Piscataquis County, W. A. Murrill, 2451 (in N. Y. Bot. Gard. Herb., and Mo. Bot. Gard. Herb., 61402); Portage, L. W. Riddle, 16 .

Vermont: Middlebury, E. A. Burt, two gatherings.

New York: Ithaca, G. F. Atkinson, 22965; Karner, H. D. House, $14.153,14.160$ (in part), and two unnumbered specimens (in Mo. Bot. Gard. Herb., 44712, 44706, 54367, 55215); Sevey, C. H. Peck, type (in N. Y. State Mus. Herb.); Shokan, C. H. Peck, T24 (in Mo. Bot. Gard Herb., 54660); Slingerlands, C. H. Peck, T 23 (in Mo. Bot. Gard. Herb., 54659); Syracuse, L. M. Underwood, 48 (in N. Y. Bot. Gard. Herb., and Mo. Bot. Gard. Herb., 61409, 61433); White Plains, W. H. Ballou (in Mo. Bot. Gard. Herb., 10458).

New Jersey: Newfield, J. B. Ellis, in Ellis, N. Am. Fungi, 717a, 719, and Ell. \& Ev., Fungi Col., 308. 
Florida: $W . W$. Calkins.

Alabama: Montgomery, R. P. Burke, 13 (in Mo. Bot. Gard. Herb., 17193).

Ohio: Preston, C. G. Lloyd, 1555; West Elkton, L. O. Overholts, 3164 (in Mo. Bot. Gard. Herb., 5712).

Indiana: Crawfordsville, D. Reddick, 6, 8, 13, 14 . Illinois: River Forest, E. T. \& S. A. Harper, 631.

Michigan: Ann Arbor, C. H. Kauffman.

Wisconsin: Blue Mounds, E. T. \& S. A. Harper, 871.

Minnesota: Princeton, C. J. Humphrey, 899 (in Mo. Bot. Gard. Herb., 21044).

Missouri: Columbia, B. M. Duggar, 561; Meramec Highlands, P. Spaulding (in Mo. Bot. Gard. Herb., 63746); Pickering, E. Bartholomew, 6425 (in Mo. Bot. Gard. Herb., 55195); St. Louis, N. M. Glatfelter, 1377, comm. by N. Y. Bot. Gard. Herb.; E. A. Burt (in Mo. Bot. Gard. Herb., 44073).

South Dakota: Custer, J. R. Weir, 10019 (in Mo. Bot. Gard. Herb., 55799).

Idaho: Priest River, J. R. Weir, 37; St. Maries, J. R. Weir, 560 (in Mo. Bot. Gard. Herb., 63179).

Japan: Bungo, A. Yasuda, 107 (in Mo. Bot. Gard. Herb., $57024)$.

77. P. Allescheri Bresadola, Fungi Trid. 2: 62. pl. 172. 1898; Sacc. Syll. Fung. 16: 194. 1902.-But not as understood by Bourdot \& Galzin and by Wakefield.

Kneiffia Allescheri Bresadola, Ann. Myc. 1: 100. 1903.Gloeopeniophora Allescheri (Bres.) v. Höhnel \& Litschauer, K. Akad. Wiss. Wien Sitzungsber. 117: 1082. 1908.

Type: in Bresadola Herb. and Burt Herb.

Fructifications broadly effused, membranaceous, fleshy, thick, drying white to pinkish buff, sometimes contracting in drying, curling away from the substratum more or less at the fissures and showing the white, fibrillose subiculum, the margin white, byssoid; in structure 300-1000 \& thick, composed of obliquely ascending and interwoven, hyaline hyphae more or less incrusted, 3-6 $\mu$ in diameter; gloeocystidia elongated, flexuous, $40-100 \times$ 4-7 $\mu$, often continued beyond the deeply staining portion as an 
undifferentiated hypha, numerous in the subhymenium; cystidia incrusted or not incrusted, 30-60 × 6-10 $\mu$; spores hyaline, even, 10-13 × 3-4 $\mu$.

Fructifications 2-10 cm. long, 1-3 cm. broad.

On bark of fallen limbs of Populus and other frondose species. Canada to New York and westward to Washington, in West Indies, and in Europe.

The type of $P$. Allescheri and specimens of similar structure cited below differ so slightly from $P$. mutata that I have separated them from the latter only by all their gloeocystidia being of slender elongated form and perhaps specially differentiated middle portions of hyphae, while the gloeocystidia of P. mutata are terminal portions of hyphae and hyphal branches which are in many cases pyriform and in others afford indication by a pyriform base of having finally grown out from a pyriform body into an elongated gloeocystidium. It may be that when someone can keep under observation and examination a specimen of $P$. mutata during its season, he may find that pyriform gloeocystidia are present abundantly up to the time of copious spore production and then finally all become elongated so that the fructification would be referable to $P$. Allescheri. In this event $P$. Allescheri will become a synonym of $P$. mutata by priority of the latter.

While $P$. mutata has become correctly understood in Europe through my exchanges with Bresadola there is a misunderstanding there concerning $P$. Allescheri. Von Höhnel \& Litschauer studied the original specimen of $P$. Allescheri in Bresadola Herb. and state, loc. cit., that this consists of a mixture of fructifications of $P$. cremea and $P$. Allescheri, the latter as described by Bresadola and figured in his plate. The specimen shared with me by Bresadola is in such close agreement with the plate that the colored drawing of the upper figure may have been made from it, and it agrees also with the description. Its data as to collection is given "ad corticem Fagi silv. Bavaria. Allescher." The portions of the original specimens communicated to Bourdot \& Galzin and to Miss Wakefield are apparently of the $P$. cremea component, referred to by v. Höhnel \& Litschauer.

Specimens examined: 
Sweden: L. Romell, 439 (in Mo. Bot. Gard. Herb., 44305) ; Stockholm, L. Romell, 102.

Germany: Bavaria, Allescher, comm. by Bresadola, part of type. Canada: Rideau Park, J. Macoun, 325; Ottawa, J. Macoun, 133, in part; Quebec, Ironsides, J. Macoun, 256.

New Hampshire: Jackson, W. H. Snell, 624 (in Mo. Bot. Gard. Herb., 59246).

Vermont: Middlebury, E. A. Burt.

New York: Glasco, Ulster County, P. Wilson, 40 (in Mo. Bot. Gard. Herb., 54747); Ithaca, H. E. Stork, 6 (in Mo. Bot. Gard. Herb., 56643), G. F. Atkinson, 8031, 22761, D. Reddick, by Cornell Univ. Herb., 20567, Van Hook, Cornell Univ. Herb., 8011, and Wright, Cornell Univ. Herb., 8353.

Ohio: C. G. Lloyd, 3920; College Hill, C. G. Lloyd, 3121 (in Lloyd Herb., Burt Herb., N. Y. Bot. Gard. Herb., and Mo. Bot. Gard. Herb., 61419).

Indiana: Crawfordsville, A. R. Bechtel, 10 (in Mo. Bor. Gard. Herb., 59648).

Michigan: Ann Arbor, C. H. Kauffman, 12; New Richmond, C. H. Kauffman, 31 (in Mo. Bot. Gard. Herb., 9864).

British Columbia: Vancouver Island, J. Macoun, 355 (in Mo. Bot. Gard. Herb., 55323).

Washington: Bingen, W. N. Suksdorf, 702.

West Indies: Grenada, Grand Etang, $R$. Thaxter, comm. by W. G. Farlow, 4.

78. P. subcremea v. Höhnel \& Litschauer, K. Akad. Wiss. Wien Sitzungsber. 115: 1600. text f. 6. 1906; Sacc. Syll. Fung. 21 : 408. 1912.

Type: type distribution in Rabenhorst, Fungi Eur., 3230, under the name Corticium lacteum.

Fructifications effused, thin, closely adnate, becoming cartridgebuff to ivory-yellow in the herbarium, not cracked, the margin thinning out; in section 40-150 $\mu$ thick, not colored, composed of suberect, bushy-branched hyphae $2-3 \mu$ in diameter, not incrusted, only occasionally nodose-septate, and of flexuous gloeocystidia $40 \times 4 \mu$, starting from the substratum in the type; cystidia not incrusted, $4 \frac{1}{2-6} \mu$ in diameter, protruding up to 
$40 \mu$ beyond the basidia; spores hyaline, cylindric, $3 \frac{1}{2}-41 / 2 \times$ $2-21 / 2 \mu$, copious.

Fructifications $1 \frac{1}{2}-8 \mathrm{~cm}$. long, $1 \frac{1}{2}-5 \mathrm{~cm}$. wide.

On bark and wood of Pinus. Finland, Montana, and Manitoba. September to November. Rare.

The specimen from Manitoba is on bark of a frondose species, but agrees well in other respects with the specimens on pine. The small spores are a distinguishing character of $P$. subcremea.

Specimens examined:

Exsiccati: Rabenhorst, Fungi Eur., 3230, type distribution, under the name Corticium lacteum.

Finland: Mustiala, P. A. Karsten, in Rabenhorst, Fungi Eur., 3230.

Montana: Anaconda, E. E. Hubert, comm. by J. R. Weir, 12010 (in Mo. Bot. Gard. Herb., 63370).

Manitoba: Winnipeg, G. R. Bisby \& I. L. Conners, 1183 (in Mo. Bot. Gard. Herb., 59047).

79. P. admirabilis Burt, n. sp.

Type: in Burt Herb.

Fructifications broadly effused, adnate, thin, membranaceous, small pieces separable, becoming cartridge-buff in the herbarium, fibrillose, not shining, even, with but few small cracks, the margin thinning out, with its hyphae loosely interwoven; in section 180-240 $\mu$ thick, not colored, composed of suberect, thin-walled hyphae $3 \frac{1}{2}-4 \mu$ in diameter, not incrusted, of gloeocystidia both elongated and vesicular, and of large chlamydospores; cystidia cylindric, incrusted, up to $105 \times 9 \mu$, confined to the hymenium, somewhat disorganized by potassium hydrate solution; vesicular gloeocystidia and vesicular spaces up to $45 \times 30 \mu$; chlamydospores as seen singly on hyphal branches are up to $15 \times 9 \mu$; basidiospores white in spore collection, even, 6-7 $73 \mu$, borne 4 to a basidium.

Fructifications $3-10 \mathrm{~cm}$. long, 1-2 $\mathrm{cm}$. wide.

On decaying wood of stump of Ulmus. New York. May.

$P$. admirabilis is well marked among our species which have gloeocystidia by the presence of large imbedded spores. 
Specimens examined:

New York: Oneonta, E. A. Burt.

80. P. versata Burt, n. sp.

Type: in Burt Herb.

Fructifications effused, thin, membranaceous, small pieces separable when moistened, becoming pinkish buff in the herbarium, not waxy, the margin thinning out, fibrillose; in section 150-300 $\mu$ thick, not colored, composed of suberect, interwoven hyphae about $3 \mu$ in diameter, with walls somewhat gelatinously modified, and of gloeocystidia; gloeocystidia numerous, flexuous, $35-55 \times 6-8 \mu$; cystidia not incrusted, tapering towards the apex, $6 \mu$ in diameter, protruding up to $40 \mu$, scarcely or perhaps not at all distinguishable from gloeocystidia; basidia with 4 sterigmata; spores hyaline, even, $4-5 \times 21 / 2-3 \mu$.

Fructifications $2-5 \mathrm{~mm}$. long, $5-15 \mathrm{~mm}$. wide.

On slightly decayed red fir planks and cross-ties. Washington. September and October.

The fructifications of $P$. versata stand out conspicuously against the blackened timber upon which they occur. The resemblance of the protruding cystidia to gloeocystidia and the possibility that they have the function of gloeocystidia or may be gloeocystidia functioning as cystidia should enable this species to be readily distinguished from species containing cystidia and gloeocystidia quite distinct from each other.

Specimens examined:

Washington: Chehalis, C. J. Humphrey, 6285; Edmonds, C.J. Humphrey, 7623, type.

81. P. albo-straminea Bresadola, Mycologia 17: 69. 1925.

Type: in Weir Herb.

Fructifications orbicular, finally confluent and broadly effused, thin, very tender, small pieces separable when moistened, becoming between cartridge-buff and ivory-yellow in the herbarium, somewhat cracked, even, the margin pruinate; in section 60-90 $\mu$ thick, not colored, composed of somewhat loosely arranged hyphae $3-5 \mu$ in diameter, occasionally nodose-septate, and of gloeocystidia; gloeocystidia flexuous to zigzag, $40-60 \times 41 / 2-6 \mu$, 
usually starting from the substratum and wholly immersed, sometimes protruding beyond the basidia; cystidia, if really distinct from gloeocystidia, not incrusted, $41 / 2-8 \mu$ in diameter, protruding up to $30 \mu$ beyond the basidia; spores hyaline, even, $5-71 / 2 \times 3-4 \mu$.

Fructifications $2-8 \mathrm{~cm}$. long, $11 / 2-3 \mathrm{~cm}$. wide.

On wood and bark of decaying Alnus tenuifolia and Quercus californica. Idaho and California. October.

The gloeocystidia, sometimes of zigzag form, and cystidia, which are possibly only protruding portions of gloeocystidia, are marked characters of the type specimen which should afford recognition of $P$. albo-straminea if these are constant specific characters. However, the buff color, Alnus substratum, and presence of gloeocystidia should suffice. In No. 17069 a foreign mycelium of coarse hyphae is underneath the fructification proper.

Specimens examined:

Idaho: Priest River, J. R. Weir, 17069, type, and 16818 (both in Weir Herb.).

California: Massack, Plumas National Forest, A. S. Rhoads, 17 (in Mo. Bot. Gard. Herb., 56986).

82. P. Taxodii Burt, n. sp.

Type: in Burt Herb.

Fructifications effused, very thin, closely adnate, whitish to pale olive-buff in the herbarium, the hymenium loose and rather hypochnoid under a lens, the margin indeterminate, thinning out; in section $45-60 \mu$ thick, not colored, composed of erect, branching hyphae $2-21 / 2 \mu$ in diameter, not incrusted, not nodoseseptate, and of numerous cystidia, gloeocystidia, and crystalline matter; cystidia not incrusted, thin-walled, tapering to a sharp apex, $6-8 \mu$ in diameter, protruding $20-40 \mu$ beyond the basidia, often starting from the substratum; gloeocystidia often not distinguishable from the cystidia except by granular, deeply staining contents, protruding up to $20-40 \mu$ beyond the basidia; spores hyaline, even, $7-71 / 2 \times 3-31 / 2 \mu$.

Fructification $7 \mathrm{~cm}$. long, $11 / 2^{-2} \mathrm{~cm}$. wide.

On decorticated top limb of prostrate top of Taxodium dis- 
tichum left in the swampy woods. Texas. September. Probably local.

$P$. Taxodii has thin grayish fructifications on the blackened, weathered wood of a prostrate tree top left in lumbering operations. It is difficult to distinguish cystidia from gloeocystidia in the sections unless the organs lacking contents which take the stain are cystidia and the deep-staining and more numerous bodies gloeocystidia, for both start from the substratum, protrude beyond the hymenium, and taper to a sharp point.

Specimens examined:

Texas: Beaumont, C. J. Humphrey, 5947, type.

\section{P. investiens Burt, n. sp.}

Type: in N. Y. Bot. Gard. Herb., Mo. Bot. Gard. Herb., and Burt Herb.

Fructifications longitudinally effused, thin, adnate, small pieces separable when moistened, becoming cartridge-buff in the herbarium, even, not cracked, not shining, the margin thinning out, minutely tomentose; in section $180 \mu$ thick, not colored, with a broad layer of densely interwoven hyphae $2 \frac{1}{2}-3 \mu$ in diameter, thin-walled, not incrusted, not nodose-septate; gloeocystidia flexuous, $25-40 \times 4-5 \mu$, immersed in the hymenium; cystidia not incrusted, $9 \mu$ in diameter, protruding up to $60 \mu$ beyond the basidia ; basidia with 4 prominent sterigmata; spores hyaline, even, $12-13 \times 3-31 / 2 \mu$-one spore seen is $15 \times 6 \mu$ but perhaps does not belong.

Fructifications $8 \mathrm{~cm}$. long, $1 \mathrm{~cm}$. wide.

On decaying stem of palmetto. Bermuda. December.

The presence of the gloeocystidia in the hymenial layer and not also in the interwoven hyphae near the trama, together with the long spores and occurrence on palmetto, should enable the recognition of $P$. investiens.

Specimens examined:

Bermuda: Stewardson Brown, N. L. Britton \& F. J. Seaver, 1924, type (in N. Y. Bot. Gard. Herb., Mo. Bot. Gard. Herb., 63730, and Burt Herb.).

84. P. incarnata (Pers.) Karsten, Hedwigia 1889: 27. F. 1889; Finska Vet.-Soc. Bidrag Natur och Folk 48: 424. 1889; 
Massee, Linn. Soc. Bot. Jour. 25: 147. Jl. 1889; Sacc. Syll. Fung. 9: 241. 1891; Bourdot \& Galzin, Soc. Myc. Fr. Bul. 28 : 404. 1913; Rea, Brit. Basid. 694. 1922.

Thelephora incarnata Persoon, Syn. Fung. 573. 1801; Myc. Eur. 1: 130. 1822 (Corticium); Fries, Syst. Myc. 1:444. 1821; Elenchus Fung. 1: 219. 1828.-Corticium incarnatum (Pers.) Fries, Epicr. 564. 1838; Hym. Eur. 654. 1874; Berkeley, Brit. Fung. 275. 1860; Berk. \& Curtis, Grevillea 2: 4. 1873; Peck, N. Y. State Mus. Rept. 24: 80. 1872; Morgan, Cincinnati Soc. Nat. Hist. Jour. 10:201. 1888; Sacc. Syll. Fung. 6: 625. 18s8.-Kneiffia incarnata (Pers.) Bresadola, Ann. Myc. 1: 103. 1903.-Gloeopeniophora incarnata (Pers.) v. Höhnel \& Litschauer, K. Akad. Wiss. Wien Sitzungsber. 116:816. 1907.Peniophora aemulans Karsten, Finska Vet-Soc. Bidrag Natur och Folk 48:425. 1889; Sacc. Syll. Fung. 9: 239. 1891.

Fructifications effused, closely adnate, drying pinkish cinnamon to warm buff, cracking, the margin sometimes paler, thinning out; in section 100-250 $\mu$ thick, not colored, composed of hyaline, thin-walled hyphae $2-3 \mu$ in diameter, densely interwoven along the substratum and then becoming suberect and extending between more or less numerous gloeocystidia and some cystidia; gloeocystidia sometimes broadly ovoid, $30-45 \times 10-15 \mu$, usually more cylindric and narrower, $30-60 \times 6-10 \mu$; cystidia becoming incrusted, $30-45 \times 6-10 \mu$, rarely protruding beyond the basidia; basidia with 4 sterigmata; spores hyaline, even, cylindric, flattened on one side, $6-10 \times 3-41 / 2 \mu$.

Fructifications $2-10 \mathrm{~cm}$. long, 1-2 cm. broad, sometimes in scattered, small, tubercular growths $2-5 \mathrm{~mm}$. in diameter on lenticels of small limbs.

On wood and bark of fallen limbs of frondose species usually. Europe, Canada to Alabama, and westward to the Pacific states, and in Japan. Throughout the year. Common.

$P$. incarnata is recognizable by its closely adnate, reddish fructifications, spores $6-9 \times 3-4 \mu$, and abundant gloeocystidia. Sometimes one has to search several sections before finding an incrusted cystidium. The spores run slightly smaller in most American gatherings than in the fewer European specimens which I have seen and are with us usually only about $6-8 \times 3 \mu$. 
Specimens examined:

Exsiccati: Cooke, Fungi Brit., 7; Reliq. Farlowianae, 342; Ravenel, Fungi Am., 140; Romell, Fungi Scand., 33.

Sweden: Stockholm, L. Romell, 67, 100, 101, and in Romell, Fungi Scand., 33.

Finland: Mustiala, $P . A$. Karsten, authentic specimen of $P$. aemulans.

Austria: Tirol, V. Litschauer, four specimens.

Italy: locality not given, $G$. Bresadola, two specimens.

England: Knys Lynn, C. B. Plowright, in Cooke, Fungi Brit., 7;

Yorkshire, E. M. Wakefield (in Mo. Bot. Gard. Herb., 57124). Newfoundland: Bay of Islands, A. C. Waghorne, 5, 165 (in Mo. Bot. Gard. Herb., 43987, 5010).

Ontario: Harraby, Lake Rosseau, E. T. \& S. A. Harper, 791.

Maine: Piscataquis County, W. A. Murrill, 1861 (in N. Y. Bot.

Gard. Herb., Burt Herb., and Mo. Bot. Gard. Herb., 61591); Orono, P. L. Ricker, 621.

New Hampshire: Chocorua, W. G. Farlow, c89 (in Mo. Bot. Gard. Herb., 43974), and in Reliq. Farlowianae, 342.

Vermont: Middlebury, E. A. Burt, six gatherings; Ripton, E. A. Burt, two gatherings.

Massachusetts: W. G. Farlow, 4; Sharon, A. P. D. Piguet, 5, two unnumbered specimens, comm. by W. G. Farlow (in Mo. Bot. Gard. Herb., 55220, 55446, 55600).

New York: Albany, H. D. House, six gatherings (in Mo. Bot. Gard. Herb., 57412, 57457, 57519, 59684, 59700, 63448); Alcove, C. L. Shear, 246; Fulton, A. E. Fivaz, comm. by A. H. W. Povah, 136 (in Mo. Bot. Gard. Herb., 58158); Ithaca, G. F. Atkinson, 3034, C. J. Humphrey, C. O. Smith, comm. by G. F. Atkinson, 8225, Van Hook, comm. by G. F. Atkinson, 8066, H. H. Whetzel, Plant Path. Herb., 12228 (in Mo. Bot. Gard. Herb., 60599); Orient, R. Latham, 144 (in Mo. Bot. Gard. Herb., 44230); Orient Point, R. Latham, comm. by N. Y. State Mus. Herb. (in Mo. Bot. Gard. Herb., 55815, 55922); Syracuse, L. M. Underwood, 2, 89 (in N. Y. Bot. Gard. Herb., and Mo. Bot. Gard. Herb., 61567, 61598); Vaughns, S. H. Burnham, 14 (in Mo. Bot. Gard. Herb., 54500).

Pennsylvania: Center Hall, E. West, comm. by L. O. Overholts, 
3661 (in Mo. Bot. Gard. Herb., 54702); State College, L. O. Overholts, 4807 (in Mo. Bot. Gard. Herb., 56340); Trexlertown, W. Herbst, 23, and comm. by Lloyd Herb., 3611.

Maryland: Takoma Park, C. L. Shear, 1337.

District of Columbia: Washington, C. L. Shear, 1257, 1267.

West Virginia: Paw Paw, C. L. Shear, 1174.

South Carolina: Aiken, H. W. Ravenel, in Ravenel, Fungi Am., 140.

Florida: Royal Palm Hammock, W. A. Murrill, 123, 136, comm. by N. Y. Bot. Gard. Herb. (in Mo. Bot. Gard. Herb., 62098, 62099).

Alabama: Auburn, F. S. Earle, 2299 (in N. Y. Bot. Gard. Herb., and Mo. Bot. Gard. Herb., 61416); Montgomery County, R. P. Burke, 19, 275, 630, 664, 666, 679, 699 (in Mo. Bot. Gard. Herb., 16700, 57158, 63099, 63076, 63101, 63097, 63103). Kentucky: C. G. Lloyd, 1878.

Ohio: College Hill, Aiken, comm. by C. G. Lloyd, 2327.

Wisconsin: Madison, W. Trelease (in Mo. Bot. Gard. Herb., 44314); Palmyra, A. O. Stucki, 39.

Iowa: Woodbine, C.J. Humphrey \& C. W. Edgerton, comm. by C. J. Humphrey, 6566 (in Mo. Bot. Gard. Herb., 20691).

Missouri: Bismarck, L. O. Overholts (in Mo. Bot. Gard. Herb., 63454); Perryville, L. O. Overholts, 2687 (in Mo. Bot. Gard. Herb., 44287).

Kansas: Phillips County, E. Bartholomew; Rooks County, E. Bartholomew, 2046 (in Mo. Bot. Gard. Herb., 4842, 44313).

Colorado: Mancos, G. G. Hedgcock, comm. by C. J. Humphrey, 2551 (in Mo. Bot. Gard. Herb., 9783).

New Mexico: Tyom Experiment Station, W. H. Long, 21564 (in Mo. Bot. Gard. Herb., 55142).

Alaska: Farragut Bay, W. Trelease, 582 (in Mo. Bot. Gard. Herb., 4852).

Washington: Bingen, W. N. Suksdorf, 715, 745, 760, 765, 881, 882, 904.

Japan: Prov. Bungo, A. Yasuda, 119, 123 (in Mo. Bot. Gard. Herb., 59470, 59474).

85. P. aurantiaca Bresadola in Bourdot \& Galzin, Soc. Myc. Fr. Bul. 28: 402. 1913; Rea, Brit. Basid. 694. 1922. 
Corticium aurantiacum Bresadola, Fungi Trid. 2: 37. pl. 144, f. 2. 1892; Sacc. Syll. Fung. 11: 126. 1895.-Kneiffia aurantiaca Bresadola, Ann. Myc. 1: 103. 1903.-Gloeopeniophora aurantiaca (Bres.) v. Höhnel \& Litschauer, K. Akad. Wiss. Wien Sitzungsber. 117: 1094.1908.

Type: probably in Bresadola Herb.; authentic specimen in Burt Herb.

Fructifications effused, beginning as small, convex outgrowths at lenticels of the bark, spreading so as to form circular patches which become confluent, adnate, bright orange-pink to orangechrome, fading in the herbarium to light pinkish cinnamon and light buff, the margin white at first, radiating; in section not colored, 150-250 $\mu$ thick, with the hyphae densely and longitudinally arranged in a rather broad layer next to the substratum except at the points of emergence from the lenticels, hyaline, thin-walled, 3-4 $\mu$ in diameter; gloeocystidia 30-60 $\times 6-9 \mu$, abundant in the convex portions; cystidia rough-walled, pointed, up to $45 \times 8 \mu$, sometimes protruding $30 \mu$ beyond the basidia, more often wholly immersed and $30 \times 4-5 \mu$; basidia large, $60 \times 10-12 \mu$, often protruding beyond the immature basidia when fruiting and bearing 4 sterigmata; spores hyaline, even, $12-16 \times 6-12 \mu$.

Fructifications 1-5 mm. in diameter at first, then laterally confluent over areas $1-10 \mathrm{~cm}$. long, $1 / 2-2 \mathrm{~cm}$. broad.

On dead Alnus of various species. Labrador to North Carolina, westward to northern United States and Canada to British Columbia and Oregon, and in Europe. August to November. Common.

$P$. aurantiaca is easily recognized by its occurrence on dead twigs of alder, in bright incarnate or orange-red fructifications with large spores up to $15 \times 10 \mu$. These spores are usually borne copiously and show well in crushed preparations. To demonstrate the gloeocystidia and cystidia it is necessary to examine sections cut through the convex or papilliform points of origin of the fructifications. Sometimes examination of many sections is necessary for demonstration of the cystidia. Failure to cut the sections from places above stated led me to refer gatherings of this species to Corticium laetum for some of my cor- 
respondents. C. laetum may occur on Alnus and has color and spores like $P$. aurantiaca.

Specimens examined:

Exsiccati: de Thümen, Myc. Univ., 112, under the name Corticium incarnatum; Linhart, Fungi Hung., 438, under the name Peniophora incarnata.

Sweden: L. Romell, 62.

Austria: Tirol, V. Litschauer, three specimens, E. Rehm, in Myc. Univ., 112.

Hungary: Petrozsény, G. Linhart, in Linhart, Fungi Hung., 438. Italy: Trient Alps, G. Bresadola, authentic specimen.

England: Lyndhurst, Hamp., E. M. Wakefield (in Mo. Bot. Gard. Herb., 57127).

Labrador: The Strait, A. C. Waghorne, 5 (in Mo. Bot. Gard. Herb., 43986).

Newfoundland: Bay of Islands, A. C. Waghorne, 341 (in Mo. Bot. Gard. Herb., 5012).

New Brunswick: Campobello, W. G. Farlow, 1.

Canada: J. Macoun, 17, 116; Carleton's Place, J. Macoun, 158; Ottawa, J. Macoun, 25.

Maine: Costigan, W. A. Murrill, 1766 (in N. Y. Bot. Gard. Herb., and Mo. Bot. Gard. Herb., 61407); Kittery Point, $R$. Thaxter \& E. A. Burt; Portage, L. W. Riddle, 13; Westbrook, P. L. Ricker, $97 \%$.

New Hampshire: Chocorua, W. G. Farlow, c6 (in Mo. Bot. Gard. Herb., 44124); Hanover, G. R. Lyman, 24 (in N. Y. Bot. Gard. Herb., and Mo. Bot. Gard. Herb., 61587).

Massachusetts: Weston, A. B. Seymour, T34 (in Mo. Bot. Gard. Herb., 15759).

New York: Childwold, G. F. Atkinson \& B. M. Duggar, Cornell Univ. Bot. Dept. 5056; Hudson Falls, S. H. Burnham, 28 (in Mo. Bot. Gard. Herb., 54491); Karner, H. D. House, 14.164 and another specimen, comm. by N. Y. State Mus. Herb. (in Mo. Bot. Gard. Herb., 44713, 54372).

Pennsylvania: Bear Meadows, L. O. Overholts, 2677 (in Mo. Bot. Gard. Herb., 20277).

North Carolina: Chapel Hill, W. C. Coker, 4705 (in Mo. Bot. Gard. Herb., 57425). 
Michigan: Gogebic County, E. A. Bessey, 184 (in Mo. Bot. Gard. Herb., 56581); Vermilion, A. H. W. Povah (in Mo. Bot. Gard. Herb., 18274).

Montana: Evaro, J. R. Weir, 410 (in Mo. Bot. Gard. Herb., 21617); Missoula, J. R. Weir, 349, 425 (in Mo. Bot. Gard. Herb., 6105, 14765).

Idaho: Addie, J. R. Weir, 12005 (in Mo. Bot. Gard. Herb., 63321).

Manitoba: Norway House, G. R. Bisby, 1460 (in Mo. Bot. Gard. Herb., 61642).

British Columbia: J. Macoun, 752, comm. by J. Dearness (in Mo. Bot. Gard. Herb., 12027); Agassiz, J. R. Weir, 359 (in Mo. Bot. Gard. Herb., 16760); Salmo, J. R. Weir, 515 (in Mo. Bot. Gard. Herb., 14170); Sidney, J. Macoun, 1, 72, 752 (in Mo. Bot. Gard. Herb., 5755, 55339, 55318).

Washington: Kalama, C. J. Humphrey, 6134; Nympia, C. J. Humphrey, 6304; Seattle, W. A. Murrill, 141, and an unnumbered specimen, comm. by N. Y. Bot. Gard. Herb. (in Mo. Bot. Gard. Herb., 55731, 55733).

Oregon: Corvallis, S. M. Zeller, 1906 (in Mo. Bot. Gard. Herb., $56882)$.

86. P. pubera (Fr.) Sacc. Syll. Fung. 6: 646. 1888; Massee, Linn. Soc. Bot. Jour. 25: 149. 1889; Bourdot \& Galzin, Soc. Myc. Fr. Bul. 28: 400. 1913; Rea, Brit. Basid. 693. 1922.

Thelephora pubera Fries, Elenchus Fung. 1:215. 1828.-Corticium puberum Fries, Epicr. 562. 1838; Hym. Eur. 652. 1874; Patouillard, Tab. Anal. Fung. 1: 66. f. 152. 1883; Bresadola, Fungi Trid. 2: 38. pl. 145. f. 1. 1892.-P. pubera forma villosa Bresadola, I. R. Accad. Agiati Atti 3: 113. 1897.-Kneiffia pubera (Fr.) var. villosa Bresadola, Ann. Myc. 1: 101. 1903.

Fructifications effused, closely adnate, white, becoming dirty whitish to light buff and pinkish buff in the herbarium, and widely cracked, the hymenium even, setulose with the large cystidia, the margin indeterminate, thinning out; in section $45-400 \mu$ thick, not colored, composed of rather crowded, erect hyphae 2-4 $\mu$ in diameter, thin-walled, not incrusted, and of gloeocystidia and incrusted cystidia; gloeocystidia flexuous, $30-60 \times 4 \frac{1}{2}-9 \mu$; 
cystidia incrusted, conical, pointed, fusiform, 50-90 $\times 8-20 \mu$, wholly immersed or protruding up to $50 \mu$; spores hyaline, even, depressed on one side.

Fructifications 2-6 cm. long, 1-3 cm. wide.

On decaying wood, logs and limbs of frondose species, rarely on conifers. In Europe and from Canada to Louisiana and westward to British Columbia and Oregon. May to January. Common.

P. pubera is characterized by having gloeocystidia, large, conical, heavily incrusted cystidia, and spores usually $7-9 \times 31 / 2-4 \mu$. The gloeocystidia show well in my permanent mounts in glycerine, after the sections have been stained with eosin and stood for a few hours in glycerine. I did not find an authentic specimen of $P$. pubera in Kew or Fries Herbaria but specimens received under this name from Bresadola, Litschauer, Romell, and Miss Wakefield have gloeocystidia in every specimen and other characters as stated and show agreement in the European concept of this species. Specimens with the other characters of $P$. pubera but lacking gloeocystidia should be compared with $P$. guttulifera. In North America, $P$. pubera forms thinner fructifications than in Europe and is sometimes paler, drying rarely whitish or with a slight yellowish tint.

Specimens examined:

Sweden: Göteborg, L. Romell, 174.

Germany: Westphalia, Lengerich, W. Brinkmann, authentic specimen of P. pubera Fr. f. villosa from Bresadola.

Austria: Tirol, Innsbruck, $V$. Litschauer, two specimens; Stubai, $V$. Litschauer.

Italy: Trient, G. Bresadola.

Great Britain: S. Wales, Swansea, E. M. Wakefield (in Mo. Bot. Gard. Herb., 57123).

Canada: Quebec, Hull, J. Macoun, 388.

New Hampshire: Chocorua, W. G. Farlow, 6, 6b, 27, and 29 (in

Burt Herb.), and an unnumbered specimen and 152 (in Mo. Bot. Gard. Herb., 7843, 55244).

Massachusetts: Magnolia, W. G. Farlow, two specimens.

Rhode Island: Woonsocket, W. H. Snell, $7 M, 8 M$ (in Mo. Bot. Gard. Herb., 56805, 56806). 
New York: Ithaca, G. F. Atkinson, 8227, 14363, and C. Thom, comm. by G. F. Atkinson, 14372; Karner, H. D. House, 14.165 in part (in Mo. Bot. Gard. Herb., 44715).

New Jersey: Newfield, J. B. Ellis, three specimens (in N. Y. Bot. Gard. Herb., and Mo. Bot. Gard. Herb., 61401, 61443, 63467). Maryland: Takoma Park, C. L. Shear, 1129, 1158.

District of Columbia: Takoma Park, C. L. Shear, 964.

Virginia: Crabbottom, W. A. Murrill (in N. Y. Bot. Gard. Herb.). Florida: W. W. Calkins, 860 (in N. Y. Bot. Gard. Herb., and Mo. Bot. Gard. Herb., 61455).

Alabama: Montgomery County, R. P. Burke, 207, 208, 277, 347, 375, 376, 377, 424, 460, 468, 658, 662, 806, 807 (in Mo. Bot. Gard. Herb., 57080, 57081, 57159, 57218, 57245, 57244, 57243, 57261, $57282,57287,63085,63087,63109$, and 63110 respectively).

Louisiana: St. Martinville, A. B. Langlois, 2685, cl.

Kentucky: Harlan, C. H. Kauffman, 66 (in Mo. Bot. Gard. Herb., 16346).

Wisconsin: Blue Mounds, Miss A. C. Stucki, 38; Madison, C. J. Humphrey, 2488 (in Mo. Bot. Gard. Herb., 11277).

Missouri: Creve Coeur Lake, L. O. Overholts, 3166, 661 (in Mo. Bot. Gard. Herb., 5708, 5710).

Montana: Anaconda, Mt. Hagan, J. R. Weir, 11253 (in Mo. Bot. Gard. Herb., 63256).

Idaho: Coolin, J. R. Weir, 11505, 11516 (in Mo. Bot. Gard. Herb., 63286, 63289).

Manitoba: Winnipeg, G. R. Bisby, 1945 (in Mo. Bot. Gard. Herb., 60555).

British Columbia: Cormac, J. Macoun, 658 (in Mo. Bot. Gard. Herb., 55328); Sidney, J. Macoun, 788 (in Mo. Bot. Gard. Herb., 55329); Vancouver Island, Oak Bay, J. Macoun, 600 (in Mo. Bot. Gard. Herb., 55327); Victoria, J. Macoun, 564 (in Mo. Bot. Gard. Herb., 55326).

Washington: Chehalis, C. J. Humphrey, 627\%.

Oregon: Corvallis, S. M. Zeller, 1851, 1855, 1904 (in Mo. Bot. Gard. Herb., 56863, 56864, 56880).

87. P. pertenuis (Karsten) Burt, n. comb.

Corticium pertenue Karsten, Hedwigia 29: 270. 1890; Finska 
Vet.-Soc. Bidrag Natur och Folk 51: 226. 1892; Sacc. Syll. Fung. 9: 234. 1891; v. Höhnel \& Litschauer, K. Akad. Wiss. Wien Sitzungsber. 115: 1556. 1906-(In part) Gloeocystidium praetermissum (Karst.) v. Höhnel \& Litschauer, K. Akad. Wiss. Wien Sitzungsber. 115: 1565. 1906.-An Peniophora praetermissa Karsten, Finska Vet.-Soc. Bidrag Natur och Folk 48: 423. 1889 ?

Type: probably in Karsten Herb. and fragment in Burt Herb.

Fructifications long-effused, closely adnate, not separable when moist, very thin, waxy, even, white or whitish, drying pale pinkish buff to cream color, the margin thinning out; in section $60-150 \mu$ thick, not colored, with the hyphae $3-4 \mu$ in diameter, erect, branching, not incrusted, bearing the compact hymenium; gloeocystidia numerous, variable in form, often tapering, 20-60 $\times 6-8 \mu$; cystidia hair-like, not incrusted, $4-5 \mu$ in diameter, protruding up to $20 \mu$ beyond the basidia, few and scattered; spores copious, hyaline, even, curved, 7-10 $\times 4-5 \mu$.

Fructifications 2-10 cm. long, 1-2 cm. wide.

On decaying coniferous wood. In Europe, in Canada to District of Columbia, and in Oregon, Jamaica and Bermuda. July to November. Rare in North America.

The principal characteristics of $P$. pertenuis aiding in its recognition are occurrence in thin, whitish, waxy fructifications on old decaying coniferous wood, presence of gloeocystidia, and hairlike non-incrusted cystidia which are not destroyed in any degree by the treatment of the sections with potassium hydrate solution, and the curved spores. $P$. tenuis differs in having its cystidia incrusted at the tip. I have not seen an authentic specimen of $P$. praetermissa but the specimen sent to me under this name by Bresadola and one of the two specimens from Litschauer have their cystidia almost completely disintegrated by the potassium hydrate treatment in clearing and swelling the tissues of sections, as occurs also in $P$. glebulosa. Hence, I think that $P$. praetermissa may eventually be regarded by European mycologists as specifically distinct from $P$. pertenuis.

Specimens examined:

Finland: Mustiala, P. A. Karsten, portion of type, comm. by Bresadola, also authentic specimen on Picea from Karsten. 
Sweden: Stockholm, L. Romell, 116, 138, 162, 163, 164, 183, 191, 193, 203, 212, 215.

Austria: Natters, Tirol, V. Litschauer, under the name Gloeocystidium praetermissum.

Canada: Ottawa, J. Macoun, 42, 318; St. Lawrence Valley, $J$. Macoun, 41 .

New Hampshire: Chocorua, W. G. Farlow, 5.

New Jersey: Newfield, J. B. Ellis (in N. Y. Bot. Gard. Herb. and Mo. Bot. Gard. Herb.).

District of Columbia: Washington, C. J. Humphrey, 2525 (in Mo. Bot. Gard. Herb., 20383).

Montana: Trego, J. R. Weir, 11969 (in Mo. Bot. Gard. Herb., 63227 ).

Idaho: Coolin, J. R. Weir, 11512 (in Mo. Bot. Gard. Herb., 63287); Priest River, J. R. Weir, 139 (in Mo. Bot. Gard. Herb., 63468).

Oregon: Portland, C. J. Humphrey, 6127.

Washington: Falcon Valley, W. N. Suksdorf, 724.

Bermuda: Paget Marsh, on Sabal, H. H. Whetzel, Ao, Abd (in Mo. Bot. Gard. Herb., 58719, 58906).

Jamaica: Troy and Tyre, W. A. Murrill \& W. Harris, 1053, in part, comm. by N. Y. Bot. Gard. Herb.

88. P. tenuis (Pat.) Massee, Linn. Soc. Bot. Jour. 25: 149. 1889.

Corticium tenue Patouillard, Rev. Myc. 7: 152 . 1885; Tab. Anal. Fung. 1: 203. f. 462. 1886; Sacc. Syll. Fung. 6: 632. 1889.-Kneiffia tenuis (Pat.) Bresadola, Ann. Myc. 1: 105. 1903. -Gloeocystidium tenue (Pat.) v. Höhnel \& Litschauer, Wiesner Festschr. Wien, 70. 1908; Bourdot \& Galzin, Soc. Myc. Fr. Bul. 28: 364.1913.

Fructifications effused, closely adnate, thin, white, drying whitish to pale pinkish buff, somewhat pruinose, the margin thinning out; in section $60-180 \mu$ thick, not colored, with the hyphae erect, branching, $3-4 \mu$ in diameter, thin-walled, not incrusted; gloeocystidia $20-60 \times 6-8 \mu$, flexuous; cystidia hairlike, cylindric, $4-6 \mu$ in diameter, protruding $20-45 \mu$ beyond the basidia, incrusted about the tip; spores hyaline, even, curved, $8-10 \times 4-41 / 2 \mu$.

Fructifications 2-6 cm. long, 1-2 cm. wide. 
On decaying wood and bark of frondose species more usually. Europe and Massachusetts. July to December. Rare.

$P$. tenuis is doubtfully distinct from $P$. pertenuis, having the same aspect and microscopical characters except that some of the cystidia have incrusting granules at the tips, as shown in the figures by Patouillard cited above.

Specimens examined:

Germany: Westphalia, Lengerich, W. Brinkmann, comm. by Bresadola.

Austria: Tirol, V. Litschauer.

France: Allier, St. Priest, H. Bourdot, 6530; Aveyron, A. Galzin, 11689, comm. by H. Bourdot, 18554 .

Massachusetts: Brookline, Hammond's Pond, G. R. Lyman, 189.

89. P. serialis (Bres.) v. Höhnel \& Litschauer, K. Akad. Wiss. Wien Sitzungsber. 116: 777. 1907.

Kneiffia serialis Bresadola, Ann. Myc. 1:101. 1903 (in part); Sydow, Myc. Germ., 1. 1903.-Not Xerocarpus Cacao Karsten, Hedwigia 29: 271. 1890.-An Corticium seriale Fries, Epicr. 563. 1838?-Corticium seriale (Bres.) Bourdot \& Galzin, Soc. Myc. Fr. Bul. 27: 253. 1911 (Forme 2).

Type: type distribution in Sydow, Myc. Germ., 1.

Fructifications long and widely effused, thin, closely adnate, very variable in color, smoke-gray and pale olive-buff to woodbrown in the herbarium, even, sometimes cracked; the margin thinning out, indeterminate; in section $60-180 \mu$ thick, not colored, composed of densely arranged, erect hyphae about $3 \mu$ in diameter, with the outer portion of the wall gelatinously modified and indistinct, and of some scattered, yellowish or brownish, somewhat spherical masses 9-12 $\mu$ in diameter, immersed near the substratum; gloeocystidia in the unusual form of irregular, immersed spherical masses 9-12 $\mu$ in diameter; cystidia not incrusted, tapering to a sharp apex, $3-5 \mu$ in diameter, protruding up to $30 \mu$; spores hyaline, even, curved, 4-6 $\times 1-2 \mu$.

Fructifications 3-12 cm. long, 2-5 cm. wide.

On decaying wood of logs of Pinus, Abies, Tsuga, and Thuja. Europe, New York, and Washington. August to May.

$P$. serialis resembles in aspect $P$. Cacao and Corticium lividum; 
from the latter, the more common species, it is distinguished by its cystidia and from both by the immersed, spherical, colored masses near the substratum, such as were described and figured for another species with larger spores as gloeocystidia by von Höhnel \& Litschauer in K. Akad. Wiss. Wien Sitzungsber. 116: 838. 1907.

Specimens examined:

Exsiccati: Sydow, Myc. Germ., 1.

Sweden: Femsjö, E. A. Burt, two gatherings.

Germany: Brandenburg, P. Sydow, type distribution, in Sydow,

Myc. Germ., 1, and comm. by Bresadola.

New York: Floodwood, C. H. Peck, 8.

Washington: Sedro Woolley, C. J. Humphrey, 7538.

90. P. typhicola Burt, n. sp.

Type: in Burt Herb.

Fructifications effused, thin, adnate, somewhat membranaceous, tender, between whitish and pale olive-buff in the herbarium, even, not shining, not cracked, the margin thinning out, indeterminate; in section 60-75 $\mu$ thick, not colored near the substratum, composed of suberect, densely interwoven, thin-walled hyphae $2-3 \mu$ in diameter, indistinct, and of incrusted cystidia and a few gloeocystidia; gloeocystidia flexuous, 25-30 × 4-6 $\mu$, few present; cystidia incrusted, $40 \times 15 \mu$, immersed, starting from the substratum; paraphyses with filiform tips about $1 / 2^{-1} \mu$ in diameter, with 1 or 2 lateral branches but not antler-shaped, in surface of hymenium; spores hyaline, even, $8-12 \times 31 / 2-4 \mu$, two to a basidium.

Fructifications 2-10 $\mathrm{mm}$. in diameter.

On dead Typha latifolia. New York.

This specimen was at first doubtfully referred to $P$. phyllophila which it resembles in aspect and somewhat in structure, but it is thicker, more dense, has gloeocystidia, and does not have conspicuous antler-shaped paraphyses. Reference to Epithele Typhae, which I have been unable to find in our North American species, is precluded by the absence of hyphal fascicles.

Specimens examined:

New York: Ithaca, G. F. Atkinson, 261, type. 
91. P. filamentosa (Berk. \& Curtis) Burt in Coker, Elisha Mitchell Scientif. Soc. Jour. 36: 162. pl. 32, f. 5, 6. 1921.

Corticium filamentosum Berkeley \& Curtis, Grevillea 1: 178. 1S73; Sacc. Syll. Fung. 6: 619. 1888; Massee, Linn. Soc. Bot. Jour. 27 : 154. 1890.-(In part) Corticium Petersii Berkeley \& Curtis, Grevillea 1: 177. 1873.-Peniophora unicolor Peck, N. Y. State Mus. Rept. 43: 66. 1890; Sacc. Syll. Fung. 9: 239. 1891.-An Corticium radicatum P. Hennings, Pilze Ostafrikas, 54. 1895; Sacc. Syll. Fung. 14: 222. 1899? See v. Höhnel \& Litschauer, K. Akad. Wiss. Wien Sitzungsber. 117: 1093. 1908.

Type: in Kew Herb. and Curtis Herb.

Fructifications broadly effused, membranaceous, loosely adnate, separable when moistened, soft, drying Isabella color to buffy citrine, the margin and subiculum concolorous with, or a little paler than, the hymenium, often extended into, or connected with, branching mycelial strands or cords; in section 150-400 $\mu$ thick, colored, with the hyphae loosely interwoven, thin-walled, $3-4 \mu$ in diameter, densely incrusted with ochraceous granules which are not soluble in lactic acid preparations, but dissolve quickly when sections are treated with potassium hydrate solution and leave the sections bleached, after first becoming vinaceous; cystidia incrusted, $40-50 \times 6-8 \mu$, protruding up to $40 \mu$, confined to the hymenial layer; spores white in spore collection, even, $3-5 \times 2-3 \mu$.

Fructifications $2-10 \mathrm{~cm}$. long, $1-3 \mathrm{~cm}$. broad; sometimes much larger on logs by confluence longitudinally.

On decaying wood and logs and fallen limbs of frondose species. Germany, Canada to Alabama, and westward to Arizona, in Mexico, the West Indies, and Japan. July to January. Common.

Although colored like a Coniophora, $P$. filamentosa is easily recognized by its marginal mycelial strands, small and white spores, and hyphae incrusted with ochraceous granules which are soluble in the 7 per cent solution of potassium hydrate with which sections are usually treated. Since the original description of Corticium Petersii combines the characters of both Peniophora sanguinea and $P$. filamentosa, and one of the types is of one species 
and the other of the other, $C$. Petersii has been reduced to synonymy and $C$. filamentosum of the same authors adopted for the present species.

Specimens examined:

Exsiccati: Ravenel, Fungi Car. 5: 28, the type distribution of Corticium Petersii.

Germany: Hannover, Engelke (in Mo. Bot. Gard. Herb., 43481, under the name Peniophora radicata).

Canada: J. Macoun, 298; Lower St. Lawrence Valley, J. Macoun, $6,28,38$.

New Hampshire: Franconia, W. G. Farlow, 26.

Vermont: Middlebury, E. A. Burt, two gatherings.

New York: Albany, L. O. Overholts, 3389 (in Mo. Bot. Gard. Herb., 10179); Altamont, C. H. Peck (in N. Y. State Mus. Herb., and Mo. Bot. Gard. Herb., 55211); Bolton, C. H. Peck, 15; Bolton Landing, C. H. Peck (in N. Y. State Mus. Herb., and Mo. Bot. Gard. Herb., 55975, 56021); Cazenovia, L. M. Underwood, 46 (in N. Y. Bot. Gard. Herb., and Mo. Bot. Gard. Herb., 61405); East Berne, C. H. Peck (in N. Y. State Mus. Herb., and Mo. Bot. Gard. Herb., 56016); East Galway, E. A. Burt, two gatherings; East Schagticoke, C. H. Peck (in N. Y. State Mus. Herb., and Mo. Bot. Gard. Herb., 56022); North Elba, C. H. Kauffman, 9 (in Mo. Bot. Gard. Herb., 16769); North Greenbush, H. D. House, 14.235 (in N. Y. State Mus. Herb., and Mo. Bot. Gard. Herb., 14840, 44734); Hudson Falls, S. H. Burnham, 23 (in Mo. Bot. Gard. Herb., 54487); Ithaca, G. F. Atkinson, 7892; Staten Island, W. H. Ballou (in Mo. Bot. Gard. Herb., 10276); Syracuse, L. M. Underwood, type of Peniophora unicolor (in N. Y. State Mus. Herb.).

New Jersey: J. B. Ellis, comm. by W. G. Farlow (in Mo. Bot. Gard. Herb., 44645); Newfield, J. B. Ellis, 1518, comm. by W. G. Farlow (in Mo. Bot. Gard. Herb., 14645); Orange, L. M. Underwood (in N. Y. Bot. Gard. Herb., and Mo. Bot. Gard. Herb., 61576).

Maryland: Takoma Park, C. L. Shear, $109 \%$.

North Carolina: Chapel Hill, J. N. Couch, Univ. N. C. Herb., 4607 (in Mo. Bot. Gard. Herb., 57423).

Alabama: Peters, type (in Kew Herb., and Curtis Herb., 6119), 
and in Ravenel, Fungi Car. 5: 28; Montgomery County, R. P. Burke, 425, 660 (in Mo. Bot. Gard. Herb., 57270, 63086).

Kentucky: Crittenden, C. G. Lloyd (in Lloyd Herb., 10113, and Mo. Bot. Gard. Herb., 65627).

Ohio: C. G. Lloyd, 3883; Cincinnati, C. G. Lloyd, 4504.

Michigan: New Richmond, C. H. Kauffman, 49 (in Mo. Bot. Gard. Herb., 3734).

Illinois: Riverside, E. T. \& S. A. Harper, 852.

Missouri: Columbia, B. M. Duggar, $44 \%$.

Arizona: Fort Valley Experiment Station, W. H. Long, 21121 (in Mo. Bot. Gard. Herb., 55138).

Mexico: Jalapa, W. A. \& E. L. Murrill, 178, 327, comm. by N. Y.

Bot. Gard. Herb. (in Mo. Bot. Gard. Herb., 44969, 54496).

Cuba: C. G. Lloyd, 420 (in Mo. Bot. Gard. Herb., 55173); Omaja,

C. J. Humphrey, 2782 (in Mo. Bot. Gard. Herb., 14850).

Jamaica: Troy and Tyre, W. A. Murrill \& W. Harris, 911, comm.

by N. Y. Bot. Gard. Herb.

Japan: Prov. Bunga, A. Yasuda, 113 (in Mo. Bot. Gard. Herb., 59463).

92. P. viticola (Schw.) v. Höhnel \& Litschauer, K. Akad. Wiss. Wien Sitzungsber. 116: 779. text f. 4. 1907.

Thelephora viticola Schweinitz, Naturforsch. Ges. Leipzig Schrift. 1:107. 1822; Am. Phil. Soc. Trans. N. S. 4:168. 1832; Fries, Elenchus Fung. 1: 205. 1828.-Corticium viticola Fries, Epicr. 561. 1838; Sacc. Syll. Fung. 6: 617. 1888; Massee, Linn. Soc. Bot. Jour. 27: 146. 1890; Coker, Elisha Mitchell Scientif. Soc. Jour. 36: 172. pl. 33, f. 6. 1921.-Corticium crocicreas Berkeley \& Curtis, Grevillea 1: 178. 1873; Sacc. Syll. Fung. 6: 616. 1888. Not C. crocicreas Massee nor v. Höhnel \& Litschauer.-Corticium subaurantiacum Peck, N. Y. State Mus. Rept. 43:67. 1890; Sacc. Syll. Fung. 9: 230. 1891.

Type: in Schweinitz Herb.

Fructifications effused, thin, adnate, soft, small portions separable when moistened, the tomentose subiculum and margin ochraceous orange, the hymenium even, grayish to buff-yellow and pruinose; in section 150-400 $\mu$ thick, with the denser and broader subhymenial region ochraceous orange and the more 
loosely interwoven region next to the substratum yellow, the loosely interwoven hyphae thin-walled, $2-4 \mu$ in diameter, not nodose-septate, incrusted with colored granules which give the color to the fructification, and are destroyed and dissolved by the action of potassium hydrate solution leaving the sections bleached; no gloeocystidia; cystidia not incrusted, thin-walled, cylindric, 6-9 $\mu$ in diameter, protruding $25-40 \mu$ beyond the basidia; basidia with 4 sterigmata; spores white in collection on slide, even, $7-8 \times 4-5 \mu$.

Fructifications $1-2 \mathrm{~cm}$. in diameter, becoming confluent over areas $3-8 \mathrm{~cm}$. long, $2-5 \mathrm{~cm}$. wide.

On bark and wood of decaying Vitis, Abies, Acer, and Fagus. Vermont to North Carolina, Kentucky, and Arkansas. July to October. Abundant locally.

$P$. viticola is conspicuous by the large, brilliant orange fructifications with paler, pruinose fertile hymenium which occur on rotting large stems of the wild grape and on logs in deep mountain forests. The bleaching of the sections through destruction and solution of the incrusting pigment granules is common also to $P$. filamentosa, from which $P$. viticola differs in more orange color and larger spores.

Specimens examined:

Exsiccati: Ravenel, Fungi Car. 3: 34 .

Vermont: Bread Loaf, E. A. Burt; Little Notch, E. A. Burt; Middlebury, E. A. Burt, determination as Corticium subaurantiacum confirmed by Peck.

New York: Ampersand, C. H. Peck (in N. Y. State Mus. Herb., T 20, and Mo. Bot. Gard. Herb., 54638); Clear Water, G. F. Atkinson, 5043 (in Cornell Univ. Herb.); Floodwood, E. A. Burt; Lake Placid, W. A. \& E. L. Murrill, 104 (in N. Y. Bot. Gard. Herb., and Mo. Bot. Gard. Herb., 57344); Long Lake, A. H. W. Povah, 13 (in Mo. Bot. Gard. Herb., 9084); Marcy Trail, C. H. Peck (in N. Y. State Mus. Herb., T 19, and Mo. Bot. Gard. Herb., 54637); North Elba, C. H. Kauffman, 3 (in Mo. Bot. Gard. Herb., 6686); Ray Brook, C. H. Peck (in N. Y. State Mus. Herb., T 21, and Mo. Bot. Gard. Herb., 54639); Undercliff, comm. by Univ. Wis. Herb., 45.

North Carolina: Salem, Schweinitz, type (in Herb. Schweinitz). 
Alabama: Peters, in Ravenel, Fungi Car. 3: 34, and as Corticium crocicreas Berk. \& Curtis, type (in Kew Herb. and in Curtis Herb., 4542).

Kentucky: Mammoth Cave, C. G. Lloyd, 1601, 2661, and another specimen comm. by Ellis Herb.

Arkansas: Fordyce, C. J. Humphrey, 5799.

93. P. sulphurina (Karst.) v. Höhnel \& Litschauer, K. Akad. Wiss. Wien Sitzungsber. 115: 1573. 1906.

Tomentella sulphurina Karsten, Finska Vet.-Soc. Bidrag Natur och Folk 48:420. 1889.-Hypochnus sulphurinus (Karst.) Sacc. Syll. Fung. 9: 243. 1891.

Type: authentic specimen-perhaps part of type--in Burt Herb.

Fructifications effused, adnate, the hymenium drying clay color, thin, brittle, even, here and there cracked and showing the mustard-yellow subiculum, the margin fibrillose-byssoid, mustard-yellow; in section $150-400 \mu$ thick, pale yellow, with the hyphae loosely arranged, thin-walled, 4-6 $\mu$ in diameter, occasionally nodose-septate, some hyphae granule-incrusted; cystidia hair-like, not incrusted, $3-6 \mu$ in diameter, protruding up to $30 \mu$, not numerous; spores hyaline, even, $3-4 \times 2-21 / 2 \mu$.

Fructifications 2-6 cm. long, 1-2 cm. broad.

On coniferous bark usually. In Finland, from New Hampshire to Alabama and westward to British Columbia and Oregon. August to November. Rare.

The American gatherings referred to $P$. sulphurina are a little paler than the European and the sections lose most of their color when floated on alcohol in sectioning so as to become not distinctly colored in section. In other respects our specimens agree so well with the authentic specimen that I believe they should be included in this species. Potassium hydrate solution does not change the color of the sections to vinaceous and bleach them as it does sections of $P$. filamentosa.

Specimens examined:

Finland: Jalasjärvi, authentic specimen from $P$. A. Karsten. New Hampshire: Chocorua, W. G. Farlow (in Mo. Bot. Gard. Herb., 7872).

New York: Fall Creek, G. F. Atkinson, 7993; Ithaca, E. J. Petey, comm. by C. J. Humphrey, 471; Rainbow, C. H. Peck (in 
N. Y. State Mus. Herb., T 32, and Mo. Bot. Gard. Herb., 54656); Yates, C. H. Peck, 33.

Pennsylvania: Delaware Water Gap, W. A. Murrill, comm. by

N. Y. Bot. Gard. Herb. (in Mo. Bot. Gard. Herb., 61469).

New Jersey: Newfield, J. B. Ellis, comm. by W. G. Farlow (in Mo. Bot. Gard. Herb., 7764, 14290, 14770).

District of Columbia: Takoma Park, C. L. Shear, 1348.

Alabama: Montgomery, R. P. Burke, 145 (in Mo. Bot. Gard. Herb., 10359).

Kentucky: Crittenden, C. G. Lloyd, 8120.

South Dakota: Sylvan Lake, Custer, J. R. Weir, 10011 (in Mo.

Bot. Gard. Herb., 55792).

Idaho: Priest River, $J . R$. Weir, 30.

British Columbia: Squamish, J. Macoun, 497, 534 (in Mo. Bot. Gard. Herb., 55182, 55181).

Oregon: Eugene, C. J. Humphrey, 1051.

\section{P. carnosa Burt, n. sp.}

Type: in Burt Herb., Mo. Bot. Gard. Herb., and N. Y. State Mus. Herb.

Fructifications long and broadly effused, thick, fleshy-membranaceous, adnate, barium-yellow to honey-yellow, of the same color within where cracked, the margin determinate, thinning out, somewhat radiate-fibrillose; in section $400-700 \mu$ thick, colored like the hymenium in thick sections but very thin sections hyaline, somewhat zoned, composed of a very broad hyphal layer bearing a hymenial layer 50-60 $\mu$ thick, the hyphae hyaline, $5-6 \mu$ in diameter; no gloeocystidia; eystidia hair-like, not incrusted, tapering to a sharp tip, $4 \mu$ in diameter at the base, protruding up to $30 \mu$ beyond the basidia, very numerous in the hymenial surface; basidia 4-spored; spores white in spore collection, even, $4-5 \times 2-21 / 2 \mu$.

Fructifications 3-12 cm. long, 11/2-6 cm. wide.

On bark and wood of coniferous logs such as Pinus, Abies, Picea, Pseudotsuga, Juniperus, and Larix, rarely on frondose species. In mountains of New England, New York, Minnesota, and British Columbia and Montana to New Mexico. May to October. Common in the Rocky Mountain forests. 
$P$. carnosa may be recognized at sight by its large, thick, yellow fructifications occurring on coniferous logs in forests of the White Mountains, Adirondacks, and the Rocky Mountains. The abundant cystidia are too small to be visible with a lens, hence it is necessary to examine sections with a microscope to recognize the species as a Peniophora rather than a Corticium. It does not have the mustard-yellow subiculum of $P$. sulphurina nor does its hymenial layer flake away from the substratum as in the latter.

Specimens examined:

Maine: Piscataquis County, W. A. Murrill, 2311 (in N. Y. Bot.

Gard. Herb., and Mo. Bot. Gard. Herb., 61596).

New Hampshire: Chocorua, E. A. Burt; Intervale, L. O. Overholls, 5039 (in Mo. Bot. Gard. Herb., 56351); North Conway, L. O. Overholts, 4732 (in Mo. Bot. Gard. Herb., 56117).

New York: Hague, C. H. Peck, type (in Burt Herb., N. Y. State Mus. Herb., and Mo. Bot. Gard. Herb., 56019); North Elba, C. H. Kauffman, 4 (in Mo. Bot. Gard. Herb., 21307).

Minnesota: Cass Lake, J. R. Weir, 392 (in Mo. Bot. Gard. Herb., 12436).

Montana: Fortine, E. E. Hubert, comm. by J. R. Weir, 12013 (in Mo. Bot. Gard. Herb., 63323); Missoula, J. R. Weir, 383 (in Mo. Bot. Gard. Herb., 20892).

Idaho: Meadow Creek, E. E. Hubert, comm. by J. R. Weir, 11669, 11671 (in Mo. Bot. Gard. Herb., 63308, 63310); Priest River, E. E. Hubert, comm. by J. R. Weir, 11738 (in Mo. Bot. Gard. Herb., 63311), J. R. Weir, 355, 9100 (in Mo. Bot. Gard. Herb., 10883, 55955), and 26, 32, 51, 5\%, 62, 69.

British Columbia: Kootenai Mts. near Salmo, J. R. Weir, 450, 458, 464, 467, 468, 469, 479, 523, 530 (in Mo. Bot. Gard. Herb., $8767,9121,12613,12287,8766,12534,12907,20976$, and 16078 respectively).

Washington: Olympia, C. J. Humphrey, 6291.

New Mexico: Cienega Canyon, W. H. Long, 21470, 21515, 21561 (in Mo. Bot. Gard. Herb., 55148, 55149, 55150); Sulphur Canyon, W. H. Long, 21411 (in Mo. Bot. Gard. Herb., 55147); Tyom Experiment Station, W. H. Long, 21935 (in Mo. Bot. Gard. Herb., 55151). 
95. P. citrinella (B. \& C.) Burt, n. comb.

Corticium citrinellum Berkeley \& Curtis, Iinn. Soc. Bot. Jour. 10 : 336.1868 ; Sacc. Syll. Fung. 6: 616. 1888; Massee, Linn. Soc. Bot. Jour. 27: 147. 1890.

Type: in Curtis Herb. and probably in Kew Herb.

Fructifications effused, thin, tender, small pieces separable when moistened, barium-yellow, cracked and showing a byssoid, barium-yellow subiculum, the margin thinning out, sometimes with barium-yellow mycelial strands; in section 120-300 $\mu$ thick, barely barium-yellow when but slightly magnified but not perceptibly colored under high magnification and wholly bleached by treatment with potassium hydrate solution, 2-layered, with the broader layer next to the substratum and composed of loosely interwoven hyphae $21 / 2^{-3} \mu$ in diameter under the incrustation of scattered, coarse granules, not nodose-septate, and with the hymenial layer $90 \mu$ thick, compact; no gloeocystidia; wholly immersed cystidia few, incrusted, $15 \times 9 \mu$; protruding cystidia hair-like, short, $3-4 \frac{1}{2} \mu$ in diameter, protruding up to $12 \mu$; spores hyaline, even, $3-4 \times 2-3 \mu$.

Fructifications $1-3 \mathrm{~cm}$. long, $1 / 2-1 \mathrm{~cm}$. wide.

On bark of logwood limb on the ground. West Indies. October to March.

$P$. citrinella belongs in the group of species with $P$. sulphurina, $P$. limonia, $P$. Burtii, and $P$. subiculosa, and appears distinct from each of these when specimens are compared with one another. It has priority over all the others as a species. Its distinguishing combination of characters is barium-yellow color, cracked hymenium showing subiculum of the same color, color bleached by treatment with potassium hydrate solution, short cystidia, and occurrence on frondose bark.

Specimens examined:

Cuba: C. Wright, 844, type (in Curtis Herb.); Pinar del Rio

Province, Earle \& Murrill, 381, comm. by N. Y. Bot. Gard. Herb.; Santa Clara Province, Earle \& Murrill, 427, comm. by N. Y. Bot. Gard. Herb.

Jamaica: Hope Gardens, F. S. Earle, 164, comm. by N. Y. Bot. Gard. Herb. 
96. P. Sacchari Burt, n. sp.

Type: in Mo. Bot. Gard. Herb.

Fructifications longitudinally effused, adnate, thin, somewhat membranaceous, noted as yellow when growing but now clay color in the herbarium, even, cracking into polygonal masses about $1 / 2 \mathrm{~mm}$. in diameter which may curl away from the substratum more or less and show the exposed tissue colored like the hymenium, the margin thinning out, of finely interwoven hyphae; in section 75-110 $\mu$ thick, with the thin sections not colored appreciably, composed of densely arranged, suberect hyphae about $3 \mu$ in diameter, not incrusted, not nodose-septate; no gloeocystidia; cystidia not incrusted, tapering towards the apex, 5-6 $\mu$ in diameter, protruding up to $30 \mu$; spores hyaline, even, $31 / 2^{-4} \times 2 \frac{1}{2}-3 \mu$.

Fructifications $8 \mathrm{~cm}$. long, 10-13 mm. wide.

On cane trash of Saccharum officinarum. Porto Rico. January.

$P$. Sacchari was listed by Johnston \& Stevenson, Dept. of Agr. Porto Rico Jour. 1: 227. 1917, as Peniophora sp. It has not been received from other sources and is apparently a species local to Porto Rico or with a preference for a sugar-cane substratum. It should be conspicuous by its yellow color. $P$. citrinella is thicker and has incrusted cystidia.

Specimens examined:

Porto Rico: Rio Piedras, J. A. Stevenson, 1204, type (in Mo. Bot. Gard. Herb., 11787).

97. P. medioburiensis Burt, n. sp.

Type: in Burt Herb.

Fructifications effused, thin, felty, small pieces separable when moistened, becoming in the herbarium between light grayish olive and deep olive-buff, the margin thinning out and sometimes paler; in section 200-300 $\mu$ thick, colored like the surface, somewhat zonate, composed of suberect, thin-walled, evenwalled hyphae $3 \mu$ in diameter and of incrusted hyphae $5 \mu$ in diameter over the incrustation; no gloeocystidia; cystidia usually not incrusted, sometimes granule-incrusted, cylindric, obtuse, $6-8 \mu$ in diameter, protruding up to $30 \mu$ beyond the basidia; basidia with 4 large sterigmata up to $6 \mu$ long; spores white in spore collection, cylindric, $8-14 \times 41 / 2-6 \mu$. 
Fructifications $5 \mathrm{~mm} .-3 \mathrm{~cm}$. long, $5 \mathrm{~mm} .-1 \frac{1}{2} \mathrm{~cm}$. wide.

On wood and bark of fallen, rotten limbs of Carya. Middlebury, Vermont. July. Seen but once.

This species is of felty or fibrillose structure like some species of Hypochnus, not at all waxy, and of dull, olivaceous color so as to be very inconspicuous on the fallen decaying limbs on which found. So few species of Peniophora have spores up to $14 \mu$ long that the spore dimensions should prove in this instance an important character for recognition of $P$. medioburiensis.

Specimens examined:

Vermont: Battell Ledge, Middlebury, E. A. Burt, type.

98. P. subsulphurea (Karst.) v. Höhnel \& Litschauer, K. Akad. Wiss. Wien Sitzungsber. 115: 1580, 1592. 1906; Bourdot \& Galzin, Soc. Myc. Fr. Bul. 28: 388. 1913.

Corticium subsulphureum Karsten, Soc. pro Fauna et Fl. Fennica Meddel. 6: 12. 1881; Sacc. Syll. Fung. 6: 632. 1888; Massee, Linn. Soc. Bot. Jour. 27: 148. 1890.-Xerocarpus subsulphureus Karsten, Finska Vet.-Soc. Bidrag Natur och Folk 37: 138. 1882; 48: 417. 1889. See v. Höhnel \& Litschauer, K. Akad. Wiss. Wien Sitzungsber. 117: 1093. 1908.-Corticium subincarnatum Peck, N. Y. State Mus. Rept. 42: 122.1889 ; Sacc. Syll. Fung. 9: 232. 1891.

Type: authentic specimen in Burt Herb., and specimen cited by Karsten in Roumeguere, Fungi Gall., 4307.

Fructifications longitudinally effused, adnate, at first citronyellow, soon cinnamon-buff, even, pulverulent, the margin thinning out, citron-yellow; in section $150-400 \mu$ thick, with the hymenial layer and that next to the substratum usually slightly colored, the hyphae suberect and branching or loosely interwoven, thin-walled, hyaline, 3-4 $\mu$ in diameter, nodose-septate, not incrusted except perhaps with a few minute grains in the subhymenium; hymenium becoming 2-layered; cystidia hair-like, thin-walled, even or with a few incrusting granules, $4-5 \mu$ in diameter, protruding up to $40 \mu$; spores white in spore-collection, $4-51 / 2 \times 2-21 / 2 \mu$.

Fructifications $4-10 \mathrm{~cm}$. long, 1-3 cm. broad.

On decaying decorticated wood of Pinus and Abies in mountain 
forests. Europe and northern United States and Canada westward to Idaho and Manitoba. July to October. Uncommon.

This species may be recognized by its cinnamon-buff, yellowmargined, closely adnate fructifications which occur, so far as known at present, only on bare wood of spruce and pine. I cannot understand how von Höhnel \& Litschauer, loc. cit., could have regarded $P$. subsulphurea as perhaps not specifically distinct from the Hannover specimens of $P$. radicata ( $P$. filamentosa) which have their hyphae heavily incrusted with a yellow matter soluble in potassium hydrate solution, and much larger, more incrusted cystidia, and fructifications only loosely adnate when present on decorticated wood and margined with conspicuous mycelial strands.

Specimens examined:

Finland: Mustiala, P. A. Karsten, authentic specimen of Xerocarpus subsulphureus.

Sweden: L. Romell, 182.

France: Aveyron, A. Galzin, 21033, comm. by H. Bourdot, 18426.

Canada: Lower St. Lawrence Valley, J. Macoun, 62.

New York: Cascade, C. H. Peck (in N. Y. State Mus. Herb., T. 31, and Mo. Bot. Gard. Herb., 56072); Clear Lake, G. F. Atkinson, 5048; Floodwood, E. A. Burt, C. H. Peck, 5, and an unnumbered specimen (in N. Y. State Mus. Herb., and Mo. Bot. Gard. Herb., 56017); North Elba, C. H. Peck, type of Corticium subincarnatum (in N. Y. State Mus. Herb.).

Minnesota: Vermilion Lake, E. W. D. Holway, 155, the Corticium epichlorum of Geol. \& Nat. Hist. Survey of Minn. but not $C$. epichlorum Berk. \& Curtis (in U. S. Dept. Agr. Herb. and Burt Herb.).

Montana: Melrose, E. E. Hubert, comm. by J. R. Weir, 11431 (in Mo. Bot. Gard. Herb., 63270).

Idaho: Priest River, J. R. Weir, 14.

Manitoba: Norway House, G. R. Bisby, 1478 (in Mo. Bot. Gard. Herb., 61660).

99. P. martiana (Berk. \& Curtis) Burt, n. comb.

Corticium martianum Berkeley \& Curtis, Grevillea 1: 179. 
1873; Peck, N. Y. State Mus. Rept. 30:48. 1879; 40 : 76. 1887; Sacc. Syll. Fung. 6: 633. 1888; Massee, Linn. Soc. Bot. Jour. 27: 144.1890.

Type: type distribution in Ravenel, Fungi Car. 5: 30.

Fructifications widely effused, rather thick, somewhat tubercular or rugose, waxy, drying cinnamon to liver-brown and burnt umber and so hard as to require prolonged moistening before sectioning, the margin thinning out; in section $200-400 \mu$ thick, colored like the hymenium, becoming dark vinaceous when treated with potassium hydrate solution, 2-layered, with the layer next to the substratum composed of longitudinally arranged, honey-yellow hyphae $3 \mu$ in diameter, and with the hymenial layer thicker, denser, darker, and composed of densely interwoven hyphae and scattered cystidia; no gloeocystidia; cystidia incrusted, conical, 30-45 $\times 8-12 \mu$, wholly immersed or protruding up to $30 \mu$ beyond the basidia; spores hyaline, even, $4-4 \frac{1}{2} \times 2 \frac{1}{2}-3 \mu$.

Fructifications $1-10 \mathrm{~cm}$. long, $1-4 \mathrm{~cm}$. wide.

On very rotten wood of frondose species-Betula and Populus noted. Massachusetts to Alabama and in Ohio and Idaho. September to November. Rare.

$P$. martiana is usually blood-red in color, with substance of the same color, and with surface so tubercular or with so irregular folds as to suggest a Phlebia. It is likely to be confused with Phlebia hydnoidea Schw., from which it is sharply distinct by the more toothed surface and slightly colored cystidia of the latter.

Specimens examined:

Exsiccati: Ravenel, Fungi Car. 5: 30, type distribution.

Massachusetts: Murray (in Curtis Herb., 6251).

New York: Ithaca, H. L. Jackson, comm. by Cornell Univ.

Herb., 18659; Keene Valley, Adirondack Mts., W. G. Farlow. West Virginia: Eglon, C. G. Lloyd, 02678.

Florida: R. Thaxter, 14 (in Mo. Bot. Gard. Herb., 43934).

Alabama: Peters, in Ravenel, Fungi Car. 5: 30.

Ohio: College Hill, C. G. Lloyd, 1659.

Idaho: Coolin, J. R. Weir, 11116 (in Mo. Bot. Gard. Herb.. 63251). 
100. P. alutaria Burt, n. sp.

Type: in Burt Herb.

Fructifications effused, closely adnate, very thin, not at all separable, clay color in the herbarium, somewhat lacunose in some places, somewhat granular where thickest, the margin thinning out; in section 120-160 $\mu$ thick, showing a little color when only little magnified and giving the characteristic color to the fructification but hyaline under high magnification, composed of densely arranged, interwoven, suberect hyphae 3-31/2 $\mu$ in diameter, not incrusted; no gloeocystidia; cystidia of two kinds: cylindric, hair-like, flexuous cystidia $3-31 / 2 \mu$ in diameter, not incrusted protrude up to $30 \mu$ beyond the basidia and sometimes have capitate tips; smaller incrusted cystidia $10 \times 3 \mu$ are present at surface of hymenium; basidia 4-spored; spores white in spore collection, even, subglobose, $3-31 / 2 \times 3 \mu$.

Fragmentary pieces of fructifications are up to $5 \mathrm{~cm}$. long, $2 \mathrm{~cm}$. wide.

Type on wood of hardwood log of a frondose species in mountain woods, also on Larix. Vermont and Michigan. November. Rare.

$P$. alutaria seems possible of recognition by its clay color, closely adnate fructifications, and small spores and cystidia.

Specimens examined:

Vermont: Little Notch, Bristol, E. A. Burt, type.

Michigan: pole yard, Escanaba, C. J. Humphrey, 1783 (in Mo. Bot. Gard. Herb., 42931).

101. P. separans Burt, n. sp.

Type: in Mo. Bot. Gard. Herb. and Dodge Herb.

Fructifications broadly effused, adnate, somewhat membranaceous, small pieces separable when moistened, between pale ochraceous buff and avellaneous in the herbarium, even, somewhat cracked and showing the darker substance in the sides of the fissures, the margin thinning out, slightly darker, some-

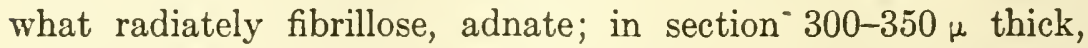
colored, stratose, each stratum 2-layered, the supporting layer composed of densely and longitudinally interwoven, slightly colored hyphae $3-31 / 2 \mu$ in diameter, the hymenial layer 75- 
$120 \mu$ thick, composed of densely arranged, erect tissue; no gloeocystidia nor conducting organs; cystidia incrusted, $40-50 \times$ 8-15 $\mu$, numerous, immersed, starting from the base of the hymenial layer; spores hyaline, even, 8-10 $\times 2-3 \mu$.

Fructifications probably large, for those studied are $4 \mathrm{~cm}$. long by $4 \mathrm{~cm}$. wide and broken off on three sides.

On bark of coniferous log. British Columbia. September.

$P$. separans has some resemblance in color and aspect to $P$. ciliata and resupinate Stereum sanguinolentum, but the stouter, wholly immersed cystidia distinguish $P$. separans from the former species, and the presence of cystidia and lack of conducting organs from the latter. The type has two strata, the other specimen only a single stratum of two layers.

Specimens examined:

British Columbia: Porcupine Creek, south of Beavermouth, C. W.

Dodge, 1702, type, and 1704 (in Mo. Bot. Gard. Herb., 58797, 58798, and in Dodge Herb.).

\section{P. stratosa Burt, n. sp.}

Type: in Mo. Bot. Gard. Herb.

Fructifications broadly effused, adnate, thick, stratose, somewhat cartilaginous-coriaceous, hard when dry, becoming pinkish buff to light ochraceous buff in the herbarium, cracking in drying and showing the stratose context, the margin thinning out; in section $700 \mu$ thick, pale yellowish, composed of 8 strata in the type, with the hyphae hyaline, densely interwoven and conglutinate, about $2-21 / 2 \mu$ in diameter; cystidia incrusted, conical, $45-55 \times 10-13 \mu$, protruding up to $40 \mu$, present in all strata but more abundant and conspicuous in the outer half of the fructification and less distinct and perhaps becoming absorbed in the more deeply buried strata; spores copious, hyaline, even, $4-5 \times$ $2-21 / 2 \mu$.

Fructification $8 \mathrm{~cm}$. long, $31 / 2 \mathrm{~cm}$. wide in the single piece constituting the type, which has natural margin on one side only and was broken from a larger mass.

On Quercus densiflora and Eucalyptus. California and Mexico. September.

$P$. stratosa is related to $P$. similis but has larger cystidia and spores. 


\section{Specimens examined:}

California: Pinehurst, E. E. Bethel, 26273 (in Mo. Bot. Gard. Herb., 55437); Redwood Park, W. H. Long, 18514, type (in Mo. Bot. Gard. Herb., 55065).

Mexico: A. Dampf, comm. by J. R. Weir, 63537 (in Mo. Bot. Gard. Herb., 63710).

\section{P. tabacina Burt, n. sp.}

Type: in Burt Herb.

Fructifications effused, adnate, tawny olive to snuff-brown, the hymenium becoming cracked and showing in the fissures the concolorous subiculum, the margin thinning out, colored like the hymenium; in structure 150-400 $\mu$ thick, tawny olive throughout, 2-layered, with the layer next to the substratum composed of loosely interwoven, even-walled, colored hyphae $3-31 / 2 \mu$ in diameter, nodose-septate, not incrusted, and the hymenial layer about equal in thickness to the other, with its hyphae densely crowded together in a palisade layer and bearing basidia and sterigmata and containing some somewhat colored spores; cystidia not incrusted, cylindric, $6-8 \mu$ in diameter, protruding up to $80 \mu$; basidiospores hyaline, even, $6-9 \times 2 \frac{1}{2}-3 \mu$, copious; slightly colored spores $9 \times 3 \mu$ are present in the deeper portion of the hymenial layer of the type specimen.

Fructifications $2-9 \mathrm{~cm}$. long, $1-21 / 2 \mathrm{~cm}$. broad.

On decaying coniferous wood and bark of logs. Wisconsin, Colorado, Washington, and Oregon. July to November. Rare.

$P$. tabacina is distinguished by its tobacco color throughout and hyphae and cystidia lacking incrustation. It lacks the radiate filamentous margin of $P$. filamentosa of somewhat similar color as well as the hyphal incrustation of the latter. The presence of colored spores in the subhymenium is suggestive of Stereum rugisporum, a species of the same color, occurring on coniferous substrata in the same regions, and more abundant material may show that $P$. tabacina is the thin, first-stratum stage of the latter, but the fructifications at hand are closely adnate to the substratum rather than loosely connected with it by the tomentose layer characteristic of many resupinate Stereums.

Specimens examined: 
Wisconsin: Oconto Falls, C. J. Humphrey, 9445 (in Mo. Bot. Gard. Herb., 57176).

Colorado: Ouray, C. L. Shear, 1185, type.

British Columbia: Agassiz, J. R. Weir, 390 (in Mo. Bot. Gard. Herb., 63728); Sidney, J. Macoun, 19 (in Mo. Bot. Gard. Herb., 5734).

Washington: Olympia, C. J. Humphrey, 6343; Seattle, C. J. Humphrey, 6456; Sedro-Woolley, C. J. Humphrey, 7578 (in Mo. Bot. Gard. Herb., 10753).

Oregon: Corvallis, on prune bark, Mrs. E. B. Zeller, comm. by

S. M. Zeller, 1871 (in Mo. Bot. Gard. Herb., 56872); Eugene,

C. J. Humphrey, 6096.

104. P. fusco-marginata Burt, n. sp.

Type: in Burt Herb. and probably in Lloyd Herb.

Fructifications long-effused, membranaceous, separable, becoming pinkish buff to warm buff in the herbarium, not waxy nor cracked, the extreme margin byssoid, fuscous, colored like the supporting hyphal layer next to the substratum; in section 300$320 \mu$ thick, colored next the substratum, 2-layered with (1) the layer next to the substratum composed of longitudinally arranged hyphae 4-5 $\mu$ in diameter, not incrusted, not nodoseseptate, fuscous along the substratum, becoming colorless above, and (2) the hymenial layer of equal thickness, composed of colorless, erect hyphae somewhat granule-incrusted in an incrusted zone; no gloeocystidia; cystidia not incrusted, $6 \mu$ in diameter at base, tapering to the apex, protruding up to $30-40 \mu$ beyond the basidia; spores hyaline, even, $5-6 \times 3-31 / 2 \mu$.

Fructifications 1-10 cm. long, the largest broken off at both ends, $1 / 2-21 / 2 \mathrm{~cm}$. wide.

On bark of fallen decaying frondose limbs. Florida and Louisiana. June and July. Local.

$P$. fusco-marginata has the unusual character of a colored layer of coarse, fuscous hyphae running over the substratum and only more or less completely covered by the buff, fertile portion of the fructification, so that the protruding colored portion forms a distinctive fuscous margin. The Florida specimen is sterile and too young for confident reference. 
Specimens examined:

Florida: Snapper Creek Hammock, W. A. Murrill, 226, comm. by N. Y. Bot. Gard. Herb. (in Mo. Bot. Gard. Herb., 62083). Louisiana: St. Martinville, A. B. Langlois, 1947 and 100, type, comm. by Lloyd Herb., 2771.

105. P. similis (B. \& C.) Massee, Linn. Soc. Bot. Jour. 25: 147. 1889.

Corticium simile Berk. \& Curtis, Linn. Soc. Bot. Jour. 10:337. 1868; Sacc. Syll. Fung. 6: 631. 1888.

Type: in Kew Herb. and Farlow Herb., and a fragment in Burt Herb.

Fructifications broadly effused, adnate, becoming light buff to cream color in the herbarium, somewhat velutinous, cracked, the margin thin; in section marguerite-yellow and darker next to the substratum but with yellow color bleached by action of potassium hydrate solution on the sections, $200-500 \mu$ thick in the type but finally up to $2 \mathrm{~mm}$. thick, composed of densely arranged, erect hyphae $3 \mu$ in diameter, and of great numbers of cystidia; cystidia incrusted, not colored, conical or fusiform, 15-25 $\times 6-8 \mu$, very numerous in all regions; spores hyaline, even, allantoid, $4 \times 1 \mu$, borne 4 to a basidium.

Fructifications "spreading for several inches." Fragmentary specimens examined are $1-4 \mathrm{~cm}$. in diameter.

On under side of frondose logs and fallen limbs. Florida, Mexico, West Indies, and Japan. October to March. Probably common.

$P$. similis closely resembles Corticium portentosum in aspect, and I am unable to distinguish it from the latter except by examination with the microscope which reveals the abundant, small, colorless cystidia. $P$. tephra is closely related but does not form as thick fructifications, and its fructifications are less cracked, darker-colored in section, with darker, thicker-walled, more erect and more crowded hyphae, and slightly larger spores.

Specimens examined:

Florida: Cutler Hammock, W. A. Murrill, 63, comm. by N. Y. Bot. Gard. Herb. (in Mo. Bot. Gard. Herb., 62093); Royal Palm Hammock, W. A. Murrill, 112, 113, 119, 122, 125, all 
comm. by N. Y. Bot. Gard. Herb. (in Mo. Bot. Gard. Herb., 62094-62098, 62110).

Mexico: Guernavaca, W. A. \& E. L. Murrill, 537, comm. by N. Y. Bot. Gard. Herb. (in Mo. Bot. Gard. Herb., 54553); Orizaba, W. A. \& E. L. Murrill, 777, comm. by N. Y. Bot. Gard. Herb. (in Mo. Bot. Gard. Herb., 54612); Xuchiles, near Cordoba, W. A. \& E. L. Murrill, 1211, comm. by N. Y. Bot. Gard. Herb. (in Mo. Bot. Gard. Herb., 54600).

Cuba: C. Wright, 543, type (in Kew Herb., Farlow Herb., and Burt Herb.), C. G. Lloyd, 482 (in Mo. Bot. Gard. Herb., 55171); Alto Cedro, Earle \& Murrill, 483, 553, both comm. by N. Y. Bot. Gard. Herb.; Ceballos, C. J. Humphrey, 2678, 2813, 2834 (in Mo. Bot. Gard. Herb., 9087, 14855, 14837); Managua, Earle \& Murrill, 42, comm. by N. Y. Bot. Gard. Herb.; San Diego de los Baños, Earle \& Murrill, 203, 260, 303, all comm. by N. Y. Bot. Gard. Herb.

Porto Rico: Rio Piedras, J. A. Stevenson \& R. C. Rose, 6530 (in Mo. Bot. Gard. Herb., 55072).

Bermuda: B. \& J. Dodge, comm. by N. Y. Bot. Gard. Herb. Jamaica: Cinchona, W. A.\& E. L. Murrill, 598, 658, comm. by N. Y. Bot. Gard. Herb.; Troy and Tyre, W. A. Murrill \& W. Harris, 886, 1053, in part, comm. by N. Y. Bot. Gard. Herb. Grenada: Grand Etang, $R$. Thaxter, comm. by W. G. Farlow, $7,8$.

Japan: Mt. Tsukikuma, Prov. Bungo, A. Yasuda, 100 (in Mo. Bot. Gard. Herb., 57018).

\section{P. Seymouriana Burt, n. sp.}

Type: type in Mo. Bot. Gard. Herb. and probably in Farlow Herb.

Fructifications long and broadly effused, thin, closely adnate, small portions separable when moistened, Verona brown to mummy-brown or fuscous, somewhat velvety, cracking into small areas, the margin determinate, entire; in structure 60$180 \mu$ thick, colored throughout like the hymenium, composed of erect, colored, densely interwoven hyphae $3 \mu$ in diameter, not incrusted, not nodose-septate, and of cystidia in all regions; no gloeocystidia; hymenial surface velvety through very numerous 
branched paraphyses having final branches $1 \mu$ in diameter; cystidia incrusted, $20-35 \times 12-15 \mu$, usually wholly immersed; spores not found.

Fructifications $12 \mathrm{~cm}$. long and broken off at ends, $3 \mathrm{~cm}$. wide.

On fallen decaying branches of undetermined frondose species. Georgia and Cuba. August and April. Probably rare.

$P$. Seymouriana has general aspect suggestive of a resupinate Hymenochaete or the effused stroma of an Hypoxylon. The fructifications are thinner than those of $P$. tephra, with less numerous cystidia and with the much darker hymenium becoming cracked like that of Hymenochaete corrugata.

Specimens examined:

Georgia: Glen Ella, Tallulah Falls, A. B. Seymour, type, comm.

by Farlow Herb., G (in Mo. Bot. Gard. Herb., 44613). Cuba: C. G. Lloyd, 145 (in Mo. Bot. Gard. Herb., 55495).

107. P. laevigata (Fr.) Massee, Linn. Soc. Bot. Jour. 25: 149. Je. 1889; Karsten, Finska Vet.-Soc. Bidrag Natur och Folk 48: 426. O. 1889; Bourdot \& Galzin, Soc. Myc. Fr. Bul. 28: 408. 1913; Rea, Brit. Basid. 696.1922.

Thelephora laevigata Fries, Elenchus Fung. 1: 224. 1828.Corticium laevigatum Fries, Epicr. 565. 1838; Hym. Eur. 656. 1874; Sacc. Syll. Fung. 6: 628. 1888.-Xerocarpus Juniperi Karsten, Rev. Myc. $3^{9}$ : 22. 1881.-Kneiffia laevigata (Fr.) Bresadola, Ann. Myc. 1: 104. 1903.

Fructifications effused, thin, snuff-brown, drab, or pale drabgray, adnate, small pieces separable from the bark when moistened, becoming cracked when dry, the margin at length free; in section brown, $200 \mu$ thick, composed of very numerous, colored cystidia and thin-walled, hyaline hyphae $2-4 \mu$ in diameter; cystidia colored, cylindric-clavate or fusiform, $25-50 \times 5-6 \mu$, thick-walled and rough above or perhaps somewhat incrusted, very numerous in all regions and giving their color to the trama as a whole; spores hyaline, even, $7-8 \times 3-4 \mu$.

Fructifications $21 / 2^{-12} \mathrm{~cm}$. long, $1 / 2-4 \mathrm{~cm}$. broad.

On bark of Juniperus. Canada, New York, and Europe. April and September. Rare.

This species may be recognized by its occurrence on Juniperus, 
brown color within, and abundance of colored cystidia. European authors record it on bark of living Juniperus communis, but the data with the two American specimens which I have seen gave merely the kind of substratum, one of these being Juniperus virginiana.

Specimens examined:

Exsiccati: de Thümen, Myc. Univ., 2014, authentic specimen from Karsten of Xerocarpus Juniperi.

Sweden: L. Romell, 104, 105, 106; Femsjö, L. Romell, 407.

Finland: Mustiala, P. Karsten, in de Thümen, Myc. Univ., 2014. Italy (?): locality not given, G. Bresadola.

England: Buckden, Yorkshire, E. M. Wakeficld (in Mo. Bot. Gard. Herb., 57119).

Canada: J. Macoun, 24.

New York: Orient, Long Island, R. Latham (in Mo. Bot. Gard. Herb., 58907, and Burt Herb.).

108. P. tephra (B. \& C.) Cooke, Grevillea 8: 20. pl. 123, f. 6 . 1879; Sacc. Syll. Fung. 6: 643. 1888; Massee, Linn. Soc. Bot. Jour. 25: 143.1889.

Corticium tephrum Berk. \& Curtis, Linn. Soc. Bot. Jour. 10 : 336. 1868.

Type: in Kew Herb., and in Curtis Herb. mounted on left of card, that on the right is Stereum albobadium.

Fructifications effused, adnate, between tilleul-buff and drab, becoming drab in the herbarium, somewhat velutinous, the margin thin, adnate, concolorous; in section brown throughout, zonate, 400-550 $\mu$ thick, composed of erect, flexuous, thick-walled, somewhat colored hyphae $3-4 \mu$ in diameter, densely crowded together, and of very numerous cystidia; cystidia coarsely incrusted, conical, sometimes fusiform, 15-25 × 6-9 $\mu$, protruding up to 9-12 $\mu$, not colored, very numerous, throughout the whole fructification; spores hyaline, even, $5 \times 21 / 2-3 \mu$.

Fructifications $2-6 \mathrm{~cm}$. long, $1 / 2-2 \mathrm{~cm}$. broad.

On dead wood of frondose species. Mexico, Cuba, Porto Rico, and Bermuda. October to January.

Former accounts of $P$. tephra are erroneous because they were partly based on a gathering of resupinate Stereum albobadium. 
$P$. tephra belongs in the group with $P$. laevigata and $P$. pruinata but does not have the colored cystidia of the former nor the pruinose hymenium of the latter. The Australian specimen from Berkeley under the name P. tephra, in N. Y. Botanical Garden Herbarium, has colored cystidia and is more probably $P$. laevigata.

Specimens examined:

Mexico: Motzorongo, near Cordoba, W. A. \& E. L. Murrill, 997, comm. by N. Y. Bot. Gard. Herb. (in Mo. Bot. Gard. Herb., 54623).

Cuba: C. Wright, type (specimen in Curtis Herb. mounted on left side of card); Ceballos, C. J. Humphrey, 2692 (in Mo. Bot. Gard. Herb., 21942); Ciego de Avila, Earle \& Murrill, 592, comm. by N. Y. Bot. Gard. Herb.; Herradura, Earle \& Murrill, 143, comm. by N. Y. Bot. Gard. Herb.

Porto Rico: Bayamon, J. A. Stevenson, 6760 (in Mo. Bot. Gard. Herb., 55059).

Bermuda: Agricultural Station, H. H. Whetzel, Ak (in Mo. Bot. Gard. Herb., 58909).

109. P. pruinata (B. \& C.) Burt, n. comb.

Stereum pruinatum Berk. \& Curtis, Linn. Soc. Bot. Jour. 10: 332. 1868; Sacc. Syll. Fung. 6:583. 1888; Massee, Linn. Soc. Bot. Jour. 27 : 198.1890.

Type: in Kew Herb. and Farlow Herb.

Effused, adnate, drying pale neutral gray to drab-gray, pruinose, cracking when thick, the margin very thin; in section fuscous throughout, becoming zonate and finally $1 \mathrm{~mm}$. thick, composed of densely arranged, erect, colored hyphae $3 \mu$ in diameter and of very numerous cystidia in all regions of the section; cystidia incrusted, fusiform, 18-22 $\times 6-12 \mu$; spores hyaline, even, subglobose, about $3-4 \frac{1}{2} \times 2 \frac{1}{2}-3 \mu$ in the few found.

Fructifications probably cover large areas, for those are 5-10 $\times 1-5 \mathrm{~cm}$. and fractured on 3 or all sides in the specimens seen.

On rotting hardwood logs. Florida, Alabama, Mexico, and the West Indies. June to March. Occasional.

Dried specimens have the livid or cinereous color of some forms of $P$. cinerea but with surface of rather more velvety tex- 
ture, often not cracked at all or, when cracked, into areas ranging down to about $5 \mathrm{~mm}$. in diameter. The fructifications of $P$. pruinata are much thicker than those of $P$. cinerea and darker throughout. When moistened, small pieces may be separated from the bark for sectioning.

Specimens examined:

Florida: Cocoanut Grove, R. Thaxter, 77 (in Farlow Herb., and Mo. Bot. Gard. Herb., 43897); Otter Creek, C. J. Humphrey, 6703 (in Humphrey Herb.); Palm Beach, H. von Schrenk (in Mo. Bot. Gard. Herb., 43043).

Alabama: Montgomery County, R. P. Burke, 374 (in Mo. Bot.

Gard. Herb., 57242).

Mexico: Motzorongo, near Cordoba, W. A. \& E. L. Murrill, 988 (in Mo. Bot. Gard. Herb., 54621); Orizaba, W. A. \& E. L. Murrill, 764, in part, comm. by N. Y. Bot. Gard. Herb. (in Mo. Bot. Gard. Herb., 54635).

Cuba: C. Wright, 193, type (in Farlow Herb., and Kew Herb.); Alto Cedro, Santiago de Cuba Province, Earle \& Murrill, 516, 518, 544, 555, comm. by N. Y. Bot. Gard. Herb.; Ceballos, C. J. Humphrey, 2815.

Porto Rico: Mount Morales, near Utuado, Mrs. E. G. Britton \& D. W. Marble, 1204, comm. by N. Y. Bot. Gard. Herb. (in Mo. Bot. Gard. Herb., 61486).

Jamaica: Hope Gardens, W. A. Murrill, 2, comm. by N. Y. Bot. Gard. Herb.; Moneague to Union Hill, W. A. Murrill, 1176 , comm. by N. Y. Bot. Gard. Herb.

110. P. rimosissima (B. \& C.) Burt, n. comb.

Corticium rimosissimum Berkeley \& Curtis, Am. Acad. Arts \& Sci. Proc. 4: 124. 1858; Sacc. Syll. Fung. 6: 639. 1888; Massee, Linn. Soc. Bot. Jour. 27: 122. 1890.-An Stereum umbrinum Berk. \& Curtis?

Type: type distribution in C. Wright, Plants of U. S. North Pacific Expl. Exp., 110.

Fructifications broadly effused, rather thick, dry, membranaceous, separable in rather large pieces, pliant when dry, now bister in the herbarium, not shining, even, cracking through the colored hymenium into polygonal masses $1-4$ to $\mathrm{a} \mathrm{mm}$. and 
showing the underlying pale substance, the true margin unknown; in section 360-450 $\mu$ thick, colored in the hymenial layer, with the basal layer composed of obliquely ascending, loosely interwoven, thin-walled, hyaline hyphae $3-4 \mu$ in diameter, not incrusted, not nodose septate, and of thick-walled, non-staining, hyaline organs $41 / 2 \mu$ in diameter, not incrusted, whose pointed tips protrude as cystidia up to $12 \mu$ beyond the basidia; spores hyaline, even, $6 \times 41 / 2 \mu-$ few found and may not belong.

Fragmentary fructifications not having margin are $4 \mathrm{~cm}$. long, $2 \mathrm{~cm}$. wide.

On dead cane. Nicaragua.

$P$. rimosissima is closely related in color and structure to Stereum umbrinum but has colorless cystidia not incrusted and only $4 \frac{1}{2}-6 \mu$ in diameter, and thinner fructifications which are not known yet to occur reflexed.

Specimens examined:

Nicaragua: C. Wright, type (in U. S. Dept. Agr. Herb.).

\section{P. Weiri Bresadola, Mycologia 17: 70.1925.}

Type: in Weir Herb.

Fructifications long and broadly effused, thin, closely adnate, becoming cream-buff to chamois in the herbarium, even, somewhat cracked, the margin thinning out; in section $150 \mu$ thick, concolorous with, and giving the color to, the fructification, composed of densely interwoven, rigid, slightly colored hyphae $2-31 / 2 \mu$ in diameter, not incrusted; gloeocystidia flexuous or sometimes filamentous, $30-75 \times 3-5 \mu$; cystidia not incrusted, thin-walled, cylindric, obtuse, $6-8 \mu$ in diameter, protruding up to $40-50 \mu$ beyond the basidia, not numerous; basidia with 4 sterigmata; spores hyaline, even, cylindric, $6-8 \times 3-31 / 2 \mu$, copious.

Fructifications 5-12 cm. long, 2-4 cm. wide.

On wood of decaying logs of Pinus monticola. Idaho. September.

The gloeocystidia of $P$. Weiri are unusual in their position, since they are occasionally oblique or parallel with the substratum, and more elongated then than when in the more usual, erect position, nor did they become visible in my sections stained with 
eosin until the sections have cleared somewhat in the permanent glycerine mount. The color of the densely interwoven tissue of the fructification should aid in recognition of the species.

Specimens examined:

Idaho: Priest River, J. R. Weir, 23345, type (in Weir Herb.).

\section{P. Farlowii Burt, n. sp.}

Type: in Burt Herb.

Fructifications effused, closely adnate, rather thick, pale olive-buff in the herbarium, even, somewhat cracked and showing the tissue to be horn-like and somewhat resin-colored (pecanbrown) where exposed on sides of the fissures, the margin thinning out, composed of finely interwoven hyphae; in section 250$350 \mu$ thick, somewhat colored, inclosing some portions of the substratum, composed of densely interwoven and conglutinate hyphae $2-3 \mu$ in diameter, not incrusted, not nodose-septate, indistinct; no gloeocystidia; cystidia incrusted, 30-70 $\times 12-15 \mu$, protruding up to $30 \mu$, few and scattered; spores hyaline, even, $4 \times 2 \mu$.

Fructifications in fragments $2-3 \mathrm{~cm}$. long, $2 \mathrm{~cm}$. wide.

On very rotten frondose wood. New Hampshire. September.

$P$. Farlowii shows in the dried specimen a pale olive-buff hymenium covering a horn-like, somewhat resin-colored underlying layer; the cystidia are so large as to be a good distinctive character.

Specimens examined:

New Hampshire: Chocorua, Bowditch Swamp, W. G. Farlow, 16, type.

113. P. colorea Burt, n. sp.

Type: in Burt Herb.

Fructifications longitudinally effused, very thin, closely adnate, light drab, not shining, even, the margin thinning out, indeterminate; in section 70-80 $\mu$ thick, light drab, 2-layered, with a layer along the substratum about $30 \mu$ thick, of densely longitudinally interwoven, somewhat colored hyphae about $3 \mu$ in diameter, indistinct, conglutinate, and with a colored hymenial layer of erect basidia, paraphyses, and cystidia; no gloeocystidia; 
cystidia incrusted, slightly colored, fusiform, 24-33 × 12-15 $\mu$, few, immersed in the hymenial layer; spores of a crushed preparation cylindric, hyaline, even, curved, $8-10 \times 2-3 \mu$.

Fructifications $3-9 \mathrm{~cm}$. long, $1-1 \frac{1}{2} \mathrm{~cm}$. wide.

On bark of dead branches about $1-1 / 2 \mathrm{~cm}$. in diameter, of frondose species. Louisiana. December.

$P$. colorea belongs near the $P$. cinerea group of very variable species. It may well prove that $P$. colorea is not a specifically distinct member of this group when more abundant material from southern Louisiana is available, but it seems to me distinct now by the longitudinal layer next to the substratum, light drab color throughout, few, large, slightly colored cystidia which are confined to the hymenial layer, and by the slender, elongated spores.

Specimens examined:

Louisiana: St. Martinville, A. B. Langlois, ch, type.

\section{P. decorticans Burt, n. sp.}

Type: in Burt Herb.

Fructifications long-effused, closely adnate, very thin, growing on the wood, spreading longitudinally and laterally between the wood and bark, loosening the latter, pale pinkish buff and pale gull-gray to whitish, pruinose, with occasional tubercules in some specimens; in section brownish throughout, $50-90 \mu$ thick, not zonate, composed of densely arranged, interwoven, slightly colored, erect hyphae $3 \mu$ in diameter, with no darker and opaque zone next to the substratum; cystidia few, incrusted, ovoid to subglobose, up to $20-25 \times 15 \mu$, seen only in the region next to the substratum; paraphyses with slender, antler-shaped branches protrude from hymenium; spores hyaline, even, slightly curved, $8-9 \times 3 \mu$, few seen.

Fructifications 1-2 cm. wide, $2 \mathrm{~cm}$. $-6 \mathrm{~m}$. long, on under side of dead branches along which the loosened bark curls back laterally.

On Quercus Garryana, Acer macrophyllum, and Rhus diversiloba. Washington and Oregon. February to December. Common locally.

$P$. decorticans differs from $P$. cinerea, $P$. nuda, $P$. caesia, and $P$. violaceo-livida in not being so dark as to be opaque next to the 
substratum. Its most noteworthy character, by which it may be recognized at a glance, is its curious habit of forming the fructification on bark-covered limbs between the bark and the wood, so that the loosened bark-very noticeable on Quercus limbs-curls back, disclosing the fructification closely adnate on the wood. The antler-shaped branching paraphyses occur in $P$. phyllophida also.

Specimens examined:

Washington: Bingen, W. N. Suksdorf, 910, type, 756, 757, 758.

Oregon: Corvallis, C. Epling (in Mo. Bot. Gard. Herb., 60183),

S. M. Zeller, 1769, 2258 (in Mo. Bot. Gard. Herb., 56846, 63028).

115. P. nuda (Fr.) Bresadola, I. R. Accad. Agiati Atti III. 3 : 114. 1897; Bourdot \& Galzin, Soc. Myc. Fr. Bul. 28: 405. 1913; Rea, Brit. Basid. 695. 1922.

Thelephora nuda Fries. Syst. Myc. 1: 447. 1821.-Corticium nudum Fries, Epicr. 564. 1838; Patouillard, Tab. Anal. Fung. 2: 33. f. 582. 1887; Sacc. Syll. Fung. 6: 626. 1888.-Peniophora ochracea Massee, Linn. Soc. Bot. Jour. 25: 150. 1889, but not Corticium ochraceum Fries.

Illustrations: Patouillard, loc. cit.

Fructification effused, closely adnate, very thin, pale drabgray, pale purplish gray or pale gull-gray, pruinose, waxy, cracking in drying; in section brownish, darker and opaque next the substratum, 75-160 $\mu$ thick, the hyphae densely interwoven, rather erect, $3 \mu$ in diameter, somewhat colored; cystidia incrusted, in all regions of the fructification, usually about 20-25 $\times 6 \mu$, larger near the substratum and sometimes up to $15 \mu$ in diameter; spores hyaline, even, curved, $41 / 2-9 \times 21 / 2^{-3} \mu$, reported larger by European authors.

Fructifications 2-6 $\times 1-2 \mathrm{~cm}$.

On fallen limbs of frondose species such as Acer, Quercus, Populus, etc. Canada to Texas, in Europe and Japan. April to January. Occasional.

I have seen no authentic specimens of $P$. nuda, but the European concept of this species differs from $P$. cinerea in having the fructifications more whitish gray in color, more broadly effused, 
and less evidently formed by confluence of several small fructifications and with some cystidia near the substratum of greater diameter than those elsewhere. I have seen no spore collections, and it is possible that the spore measurements given above are too small, since they are based on spores found in preparations of sections.

Specimens examined:

Exsiccati: Ravenel, Fungi Am., 454, under the name Corticium ochraceum.

Canada: Ottawa, J. Macoun, 26.

Vermont: Middlebury, E. A. Burt.

New York: Alcove, C. L. Shear, 1306; Altamont, E. A. Burt.

New Jersey: Newfield, J. B. Ellis (in N. Y. Bot. Gard. Herb., and Mo. Bot. Gard. Herb., 61338).

Maryland: Takoma Park, C. L. Shear, 1358.

Virginia: C. L. Shear, 1181.

South Carolina: Pinopolis, in Ravenel, Fungi Am., 454.

Georgia: Atlanta, E. Bartholomew, 8981 (in Mo. Bot. Gard. Herb., 63459).

Florida: Daytona, R. A. Harper, 5 (in Mo. Bot. Gard. Herb., 54538).

Alabama: Auburn, F. S. Earle (in N. Y. Bot. Gard. Herb., and Mo. Bot. Gard. Herb., 63415).

Louisiana: Baton Rouge, C. W. Edgerton, 830.

Texas: Beaumont, C. J. Humphrey, 5936.

Japan: Province Bungo, N. Nakayma, comm. by A. Yasuda, 125 (in Mo. Bot. Gard. Herb., 59471).

116. P. argentea Ellis \& Everhart in herb., n. sp.

Type: in N. Y. Bot. Gard. Herb. and Mo. Bot. Gard. Herb.

Fructifications effused, closely adnate, thin, pallid mouse-gray to drab-gray, pruinose, cracked in drying, the margin darker and thinning out; in section brown and opaque with exception of the hyaline hymenial layer, $150 \mu$ thick, with the hyphae densely interwoven, thick-walled, stiff, $3-31 / 2 \mu$ in diameter, colored as in Hymenochaete, not incrusted; cystidia not incrusted, partially destroyed and rendered nearly invisible by potassium hydrate solution, tapering upward to a point, protruding up to $30 \mu$, 
6-7 $\mu$ in diameter, often colored for $20 \mu$ at the base and there with the aspect of buried setae; basidia deteriorated; no spores found.

Fructifications 4-8 cm. long, 1-11/2 cm. broad.

On bark and decorticated wood of decaying Fraxinus. Louisiana. January. Probably rare.

This species has the color and aspect of $P$. nuda and $P$. caesia but differs from both of these and also from $P$. cinerea in having its opaque basal layer $120 \mu$ thick, comprising the whole thickness of the fructification except the hymenium, and in having its hyphae thick-walled and distinct and colored as in Hymenochaete. The cystidia differ from those of the species just named and also $P$. pruinata in not being incrusted and are noteworthy by being attacked and partially dissolved by 7 per cent solution of potassium hydrate to such a degree that they are best studied when sections are mounted in lactic acid.

Specimens examined:

Louisiana: St. Martinville, A. B. Langlois, 1758, type (in N. Y.

Bot. Gard. Herb., and Mo. Bot. Gard. Herb., 63416).

117. P. violaceo-livida (Sommf.) Bresadola in Bourdot \& Galzin, Soc. Myc. Fr. Bul. 28: 405. 1913; Rea, Brit. Basid. 695. 1922.

Thelephora violaceo-livida Sommerfelt, Fl. Lapp. Suppl. 283. 1826.-Corticium violaceo-lividum (Sommf.) Fries, Epicr. 564. 1838; Hym. Eur. 655. 1874; Sacc. Syll. Fung. 6:627. 1888.

Fructifications somewhat effused, closely adnate, rather thick, tubercular, pale mouse-gray to drab-gray, often round; in section brownish, 100-300 $\mu$ thick, becoming zonate within, darker and opaque next to the substratum, the hyphae somewhat colored, densely arranged, erect; cystidia incrusted, $20-30 \times 6-9 \mu$, distributed in all regions, very numerous; spores hyaline, even, curved, $6-9 \times 2 \frac{1}{2}-4 \mu$, as found with sections.

Fructifications $1-4 \times 1 / 2^{-2} \mathrm{~cm}$., often with the component masses rounded, 5-7 $\mathrm{mm}$. in diameter.

On fallen limbs of Salix, Prunus, Fraxinus Castanea, and Quercus. Canada to Louisiana. March to October. Rare.

The concept of this species presented by Bresadola, which has 
become generally accepted in Europe, is followed here except that I have referred to this species effused fructifications with tuberculate surface, thick and zonate within, as well as fructifications consisting of aggregations of small, round masses. The specimen received from Bresadola has the latter form and is on Prunus Cerasus; one from Romell on Salix, the substratum first cited for the species, has a similar zonate structure within and a tubercular surface but is more effused than that from Bresadola.

Specimens examined:

Lappland: Sommerfelt, authentic specimen under the name Thelephora fallax var. violaceo-livida (in Herb. Fries).

Sweden: L. Romell, 71 .

Austria: Hall in Tirol, V. Litschauer.

Italy probably: locality not stated, G. Bresadola.

Canada: Ontario, Ottawa, J. Macoun, 27, 131.

Vermont: Middlebury, E. A. Burt, two gatherings.

Massachusetts: near Boston, E. A. Burt.

New Jersey: Newfield, J. B. Ellis (in Mo. Bot. Gard. Herb., 61339).

Maryland: Takoma Park, C. L. Shear, $102 \%$.

District of Columbia: Soldiers Home, C. L. Shear, 1116.

Louisiana: Baton Rouge, Edgerton \& Humphrey, comm. by C. J. Humphrey, 2521.

118. P. cinerea (Pers.) Cooke, Grevillea 8: 20. pl. 123, f. 8. 1880; Sacc. Syll. Fung. 6: 643. 1888; Bourdot \& Galzin, Soc. Myc. Fr. Bul. 28: 407. 1913; Rea, Brit. Basid., 696. 1922.

Corticium cinereum Persoon, Roemer Neues Mag. Bot. 1: 111. 1894; Fries, Epicr. 563. 1838; Hym. Eur. 654. 1874.Thelephora cinerea § Corticium Persoon, Syn. Fung. 579. 1801; Myc. Eur. 1: 148. 1822; Fries, Elenchus Fung. 1:221. 1828.Kneiffia cinerea (Fr.) Bresadola, Ann. Myc. 1: 103. 1903.Corticium fumigatum de Thümen, Torr. Bot. Club Bul. 6: 95. 1876; Myc. Univ., 513. 1876.-Thelephora lilacina Schweinitz, Am. Phil. Soc. Trans. N. S. 4: 168. 1832.-Peniophora lilacina (Schw.) Massee, Linn. Soc. Bot. Jour. 25: 147. 1889.

Illustrations: Fries, Icones Hym., pl. 198, f. 4; Cooke, loc. cit.; Patouillard, Tab. Anal. Fung. f. 251. 
Fructifications effused, closely adnate, very thin, in small patches becoming confluent, lurid, ashy in various shades as pale drab-gray, pale mouse-gray, and cinnamon-drab, pruinose, waxy, becoming cracked in drying; in section $50-100 \mu$ thick usually, brownish, darker and opaque near the substratum, the hyphae densely interwoven, $3 \mu$ in diameter, somewhat colored; cystidia incrusted, $25-40 \times 4 \frac{1}{2}-9 \mu$, distributed throughout the section; spores hyaline, even, cylindric, $6-9 \times 2-3 \mu$, borne 4 to a basidium.

Fructifications $2-5 \times 1 / 2^{-1} \mathrm{~cm}$. ; when scattered $2-5 \mathrm{~mm}$. in diameter.

On fallen limbs of Alnus, Acer, Prunus, Pyrus, Quercus, and most other frondose and coniferous species. Throughout North America, West Indies, Europe, southern Africa, and Japanprobably cosmopolitan. Our commonest species. Throughout the year.

$P$. cinerea may be recognized by its resemblance to a thin coat of ashy gray or slightly tinted paint on the bark of fallen limbs; the substance of the sections is brownish when viewed with a hand lens, and dark and opaque next the substratum under the compound microseope. P. caesia, $P$. nuda, and P. violaceo-livida must be cautiously separated from $P$. cinerea, for all are closely related.

Specimens examined:

Exsiccati: Berkeley, Brit. Fungi, 63, 64; Ellis, N. Am. Fungi, 21, under the name Corticium fumigatum, 610; Ell. \& Ev., Fungi Col., 610, 805, under the name C. fumigatum; de Thümen, Myc. Univ., 513, type distribution of C. fumigatum, 1206; Sydow, Myc. Germ., 205.

Sweden: L. Romell, 69, 70.

England: in Berkeley, Brit. Fungi, 63, 64; Kew Gardens, E. M.

Wakefield (in Mo. Bot. Gard. Herb., 57121).

Germany: Brandenburg, in Sydow, Myc. Germ., 205; Berlin, P. Magnus (in N. Y. State Mus. Herb., and Mo. Bot. Gard. Herb., 55803).

Austria: Lengerich, Brinkmann, comm. by G. Bresadola; Tirol, three specimens, comm. by V. Litschauer.

Italy: Trento, G. Bresadola; Vallambrosa, Cavara, comm. by G. Bresadola. 
Newfoundland: Bay of Islands, A. C. Waghorne, 989 (in Mo. Bot. Gard. Herb., 5009).

Canada: J. Macoun, 8, 9, 50 .

Quebec: Hull, J. Macoun.

Ontario: London, J. Dearness, 169a, 169c (in Mo. Bot. Gard. Herb., 11350, 5629); Ottawa, J. Macoun, 394.

Maine: Portage, L. W. Riddle.

New Hampshire: Chocorua, W. G. Farlow, 147 (in Mo. Bot. Gard. Herb., 55262) and three specimens in Burt Herb.; North Conway, A. S. Rhoads, 8 (in Mo. Bot. Gard. Herb., 56977), W. H. Snell, 627 (in Mo. Bot. Gard. Herb., 59294).

Vermont: Middlebury, E. A. Burt, nine gatherings.

Massachusetts: Arlington, E. A. Burt, A. P. D. Piguet, comm. by W. G. Farlow (in Mo. Bot. Gard. Herb., 43959); Billerica, E. A. Siegler (in Mo. Bot. Gard. Herb., 55035); Boston, E. A. Burt; Stoneham, C. L. Shear, 1239.

Connecticut: Portland, G. P. Clinton (in Mo. Bot. Gard. Herb., 43945).

New York: Albany, H. D. House (in N. Y. State Mus. Herb., and Mo. Bot. Gard. Herb., 15955, 57517, 59673, 59690, 59695), L. O. Overholts, 3988 (in Mo. Bot. Gard. Herb., 6989), C. H. Peck (in N. Y. State Mus. Herb., and Mo. Bot. Gard. Herb., 55987, 57516, 57518); Alcove, C. L. Shear, 248, 1006, 1100, 1198, 1216, 1900; Carrollton, C. H. Peck (in Mo. Bot. Gard. Herb., 56012); East Galway, E. A. Burt; Greenbush, C. H. Peck (in N. Y. State Mus. Herb., 74, and Mo. Bot. Gard. Herb., 55776); Hudson Falls, S. H. Burnham, 19 (in Mo. Bot. Gard. Herb., 54504); Ithaca, G. F. Atkinson, 674, 8218, H. S. Jackson, Cornell Univ. Herb., 14394, C. O. Smith, comm. by G. F. Atkinson, 8223; Karner, H. D. House (in N. Y. State Mus. Herb., and Mo. Bot. Gard. Herb., 54369); Knox, C. H. Peck (in N. Y. State Mus. Herb., and Mo. Bot. Gard. Herb., 55751); Menands, C. H. Peck (in N. Y. State Mus. Herb., and Mo. Bot. Gard. Herb., 55805); Middle Grove, E. A. Burt; Van Cortland Park, New York City, C. H. Peck (in N. Y. State Mus. Herb., and Mo. Bot. Gard. Herb., 55977); Orient, R. Latham, 181 (in Mo. Bot. Gard. Herb., 44227); Selkirk, C. H. Peck (in N. Y. State Mus. Herb., and Mo. Bot. Gard. 
Herb., 55773); Van Etten, Tioga County, W. C. Barbour, 1365 (in N. Y. Bot. Gard. Herb., and Mo. Bot. Gard. Herb., 61400); West Albany, C. H. Peck (in N. Y. State Mus. Herb., and Mo. Bot. Gard. Herb., 55749); Westport, C. H. Peck (in N. Y. State Mus. Herb., and Mo. Bot. Gard. Herb., 55750); White Plains, L. M. Underwood (in N. Y. Bot. Gard. Herb., and Mo. Bot. Gard. Herb., 61588); Willsboro Point, C. O. Smith; West Fort Ann, S. H. Burnham, 17 (in Mo. Bot. Gard. Herb., 44046).

New Jersey: Newark, H. S. Jackson; Newfield, J. B. Ellis (in Mo. Bot. Gard. Herb., 4818), 1076, 1078, comm. by W. G. Farlow (in Mo. Bot. Gard. Herb., 14762, 7459), comm. by N. Y. Bot. Gard. Herb. (in Mo. Bot. Gard. Herb., 61448), in Ellis, N. Am. Fungi, 21, 610, in Ell. \& Ev., Fungi Col., 610, 805, and de Thümen, Myc. Univ., 513, 1206; Belleplain, C. L. Shear, 1165.

Pennsylvania: Bethlehem, Schweinitz, type of Thelephora lilacina (in Farlow Herb. and Kew Herb.).

Maryland: Takoma Park, C. L. Shear, 962, 1028, 1076, 1162, 1349. District of Columbia: Takoma Park, C. L. Shear, 515 (in N. Y. State Mus. Herb., and Mo. Bot. Gard. Herb., 55808), 1353; Washington, C. L. Shear, 1200, 1258.

Virginia: Park Lane, W. H. Long, 18509 (in Mo. Bot. Gard. Herb., 55061).

North Carolina: Blowing Rock, G. F. Atkinson, 4328, 8030.

Georgia: Atlanta, E. Bartholomew, 5676 (in Mo. Bot. Gard. Herb., 44252).

Florida: New Smyrna, W. A. Murrill, 5, comm. by N. Y. Bot. Gard. Herb. (in Mo. Bot. Gard. Herb., 62085).

Alabama: Auburn, F. S. Earle, unnumbered specimens and 42 (in N. Y. Bot. Gard. Herb., and Mo. Bot. Gard. Herb., 61399, 61452), and F. S. Earle \& C. F. Baker (in N. Y. Bot. Gard. Herb., and Mo. Bot. Gard. Herb., 61428); Montgomery and Montgomery County, R. P. Burke, 9, 11, 42, 120, 449, 455, 458, 461, 469, 513, 818 (in Mo. Bot. Gard. Herb., 16360, 22340, $21100,19555,57277,57280,57283,57288,57303,63117)$.

Louisiana: Baton Rouge, Edgerton \& Humphrey, 5727a, 5666. Tennessee: J. R. Weir, 7558 (in Mo. Bot. Gard. Herb., 55464). 
Ohio: Norwood, C. G. Lloyd, 1576.

Indiana: Crawfordsville, A. R. Bechtel, 12 (in Mo. Bot. Gard. Herb., 59660); Millers, E. T. \& S. A. Harper, 939.

Illinois: Barry, H.W. Anderson (in Mo. Bot. Gard. Herb., 55966); Cypress, C. J. Humphrey, 1359 (in Mo. Bot. Gard. Herb., 22522); River Forest, E. T. \& S. A. Harper, 676, 757; Riverside, E. T. \& S. A. Harper, $67 \%$.

Michigan: Ann Arbor, C. H. Kauffman (in N. Y. Bot. Gard. Herb., and Mo. Bot. Gard. Herb., 61396); Gogebic County, E. A. Bessey, 56, 78, 183, 216, 236, 371 (in Mo. Bot. Gard. Herb., 56545, 56549, 56580, 56546, 56590, 56635); Michigan Agricultural College, B. O. Longyear (in Mo. Bot. Gard. Herb., 55704); New Richmond, E. W. Hartwell (in Mo. Bot. Gard. Herb., 58163); Vermilion, A. H. W. Povah, 242 (in Mo. Bot. Gard. Herb., 58163).

Wisconsin: Blue Mounds, comm. by Univ. Wis. Herb., 28; Madison, E. Bartholomew 6652 (in Mo. Bot. Gard. Herb., 57039), M. C. Jensen, comm. by C. J. Humphrey, 2432 (in Mo. Bot. Gard. Herb., 4835), and W. Trelease (in Mo. Bot. Gard. Herb., 4816, 43988, 43989).

Minnesota: Lake Itaska, E. L. Jensen, 5 (in Mo. Bot. Gard. Herb., 12530); Univ. Farm Campus, St. Paul, E. L. Jensen, 3 (in Mo. Bot. Gard. Herb., 4203).

Missouri: Columbia, B. M. Duggar, 572, 574; Creve Coeur Lake, L. O. Overholts, 3159 (in Mo. Bot. Gard. Herb., 5714).

Nebraska: Lincoln, C. L. Shear, 1054, 1058, 1342.

Colorado: Golden, E. Bethel \& L. O. Overholts, 1744 (in Mo. Bot. Gard. Herb., 54870).

Manitoba: Winnipeg, A.H. R. Buller, comm. by G. R. Bisby, 878, and G. R. Bisby, 1348 (in Mo. Bot. Gard. Herb., 58995, and 60554 respectively).

British Columbia: Salmo, J. R. Weir, 444 (in Mo. Bot. Gard. Herb., 6243); Sidney, J. Macoun, 6, 775 (in Mo. Bot. Gard. Herb., 5765, 55324).

Washington: Bingen, W. N. Suksdorf, 700, 701, 721, 744, 759, 861, 885, 918, 954, 960, 963; Corvallis, S. M. Zeller, 2262 (in Mo. Bot. Gard. Herb., 63033); Chelan, J. R. Weir, 5490 (in Mo. Bot. Gard. Herb., 58260); Kalama, C. J. Humphrey, 6219; 
Washougal, R. H. Turk, comm. by S. M. Zeller, 2630 (in Mo. Bot. Gard. Herb., 63057).

California: Berkeley, comm. by W. A. Setchell, 1032 (in Mo. Bot. Gard. Herb., 44241); Stanford University, C. F. Baker, 12; Sierra Nevada Mountains, W. H. Harkness, 1025 (in Kew Herb., under the name Peniophora carnea Berk. \& Cke.).

Mexico: Guernavaca, W. A. \& E. L. Murrill, 358, 407 (in N. Y. Bot. Gard. Herb., and Mo. Bot. Gard. Herb., 54470, 54532).

Cuba: San Antonio de los Baños, Havana Province, Earle \& Murrill, 73, comm. by N. Y. Bot. Gard. Herb.

Porto Rico: Rio Piedras, J. A. Stevenson, 2451, 2920, 3067, 5581, 5638 (in Mo. Bot. Gard. Herb., 9185, 3125, 9055, 6957, 54585). Jamaica: Chester Vale, W. A. \& E. L. Murrill, 334, comm. by N. Y. Bot. Gard. Herb.; Cinchona, W. A. \& E. L. Murrill, 596 , comm. by N. Y. Bot. Gard. Herb.; Troy and Tyre, W. A. \& E. L. Murrill, 894, comm. by N. Y. Bot. Gard. Herb.

Africa: Stellenbosch, Cape Colony, P. A.van der Bijl, 326 (in Mo. Bot. Gard. Herb., 63397).

Japan: Mt. Mikuma, Province Awaji, A. Yasuda, 4 (in Mo. Bot. Gard. Herb., 55666).

119. P. caesia Bresadola in Bourdot \& Galzin, Soc. Myc. Fr. Bul. 28: 406. 1913; Rea, Brit. Basid., 695. 1922.

Corticium caesium Bresadola, Fungi Trid. 2: 39. pl. 145, f. 2. 1892; Sacc. Syll. Fung. 11: 126.1895.

Illustrations: Bresadola, loc. cit.

Type: authentic specimen in Burt Herbarium.

Fructifications broadly effused, closely adnate, very thin, pale mouse-gray to pale purplish-gray, delicately pruinose, cracked in drying, the margin similar; in section brownish, $40-90 \mu$ thick, dark and opaque next to substratum; hyphae densely interwoven, somewhat colored; cystidia near the substratum 15-25 × 10-20 $\mu$, incrusted, becoming slightly colored, not numerous; spores hyaline, even, curved, $6-8 \times 21 / 2^{-3} \mu$ as found in preparations of sections, probably larger in spore falls.

Fructifications 2-10 × 1-2 cm.

On fallen limbs of Syringa, Betula, Quercus, and other frondose 
species. Vermont to District of Columbia, in Missouri, and in Europe. March to December. Rare.

$P$. caesia is more widely effused than $P$. cinerea, is not formed by confluence of many small fructifications, and has much the color and aspect of $P$. nuda but differs from the latter in absence of the numerous, small cystidia.

Specimens examined:

Exsiccati: Roumeguère, Fungi Gallici, 2910, under the name Corticium incarnatum, 3213, under the name Corticium cinereum. Austria: Vienna, comm. by V. Litschauer.

Italy: Trient, G. Bresadola, authentic specimen.

France: in Roumeguère, Fungi Gallici, 2910, 3213.

Vermont: Lake Dunmore, E. A. Burt.

District of Columbia: Washington, Department Grounds, on Syringa vulgaris, C. L. Shear, 1264, in part, and an unnumbered specimen.

Missouri: Columbia, B. M. Duggar, 448.

120. P. carnea (Berk. \& Cooke) Cooke, Grevillea 8: 21. pl. 124, f. 11. 1879; Sacc. Syll. Fung. 6: 644. 1888; Massee, Linn. Soc. Bot. Jour. 25: 151. 1889.

Corticium carneum Berkeley \& Cooke, New York Acad. Sci. Ann. 1: 179. 1878; Linn. Soc. Bot. Jour. 17: 141. 1878.

Type: in Kew Herb.

Fructification effused, closely adnate, thin, ochraceous fleshcolor, drying avellaneous and cracked, the margin whitish and fibrillose; in section brownish, 100-120 $\mu$ thick, with a dark, semi-opaque zone next to the substratum; hyphae densely interwoven, $3-31 / 2 \mu$ in diameter, slightly colored, somewhat longitudinally interwoven next to the substratum; cystidia incrusted, of two kinds - very large cystidia resembling conical or subglobose crystalline masses $45-75 \times 30-75 \mu$ are seated on the opaque zone, other cystidia $25-35 \times 6-8 \mu$ are scattered throughout the region between the dark zone and the surface of the hymenium; gloeocystidia flexuous, $40-50 \times 4-41 / 2 \mu$, not numerous; spores hyaline, even, slightly curved, 8-12 $\times 3-4 \mu$.

Fructifications $1-6 \mathrm{~cm}$. long, $1 / 2-2 \mathrm{~cm}$. broad.

On logs and fallen, decaying, frondose limbs. Texas and Cuba. March. Rare. 
The thin, closely adnate fructifications of $P$. carnea, brownish within and with a broad, dark, opaque zone next to the substratum, place this species in the $P$. cinerea group. It is remarkable by having, in addition to the ordinary kind of cystidia, very much larger cystidia which finally become, by the accretions of mineral matter, very large masses of mineral nature with very coarse grains on the exterior of the mass. In the Cuban gathering which I have referred to this species, when a small portion of the hymenial surface was moistened with alcohol and then with water preparatory to removal of a bit of the fructification for sectioning, the moist hymenium became punctate with minute depressions, probably by presence at those points of the large buried cystidia. This may prove a useful test for preliminary sorting out, without examination by the microscope, of the rare $P$. carnea from the more common $P$. cinerea of nearly similar aspect. $P$. heterocystidia has cystidia of two kinds, like those of $P$. carnea but thicker, readily separable from the substratum when moistened, and with a narrow brown zone in the middle of its sectional preparations and with a loosely interwoven hyaline zone next to the substratum. The specimen in Kew Herbarium, collected on fir in the Sierra Nevada Mountains, California, by Harkness, 1025 , and referred by Cooke to $P$. cinerea does not have the large cystidia of his type and is $P$. cinerea instead.

Specimens examined:

Texas: Galveston Bay, H. W. Ravenel, 78, type (in Kew Herb.). Cuba: San Diego de los Baños, Pinar del Rio Province, Earle \& Murrill, 333, comm. by N. Y. Bot. Gard. Herb.

SPECIES TOO INCOMPLETELY DESCRIBED FOR LOCATION AMONG PRECEDING SPECIES

Peniophora convolvens Bresadola, Ann. Myc. 18: 48. 1920.

"Elongato-effusa, ceraceo-membranacea, pallida vel avellanea, ambitu similari, demum libero-convoluto; hymenio demum late rimoso, interstitiis fibrillosis; sporis hyalinis, obovatis, 6-7 $\times 5-$ $6 \mu$; basidiis clavatis, $40-45 \times 6-7 \mu$; cystidiis saepe immersis vel usque ad $45 \mu$ prominentibus, $9-12 \mu$ crassis.

"Hab. ad ligna, St. Croix, Americae centralis. Raunkiaer." 
P. gigaspora Massee, Linn. Soc. Bot. Jour. 25: 152. 1889; Sacc. Syll. Fung. 9: 23S. 1891.

"Latissime effusa, ambitu fimbriata albicans; hymenio pallido, velutino, sicco indurato, contiguo; cystidia fusoidea, 80-120 $\times$ 30-40 $\mu$; sporae oblongo-ellipsoideae, 18-20 × $10 \mu$.

"N. Providence, Bahamas.

"On decorticated wood, forming thin, continuous, broadly effused patches, somewhat resembling $P$.velutina, but differing in cystidia and spores."

(To be concluded)

INDEX TO SPECIES OF PENIOPHORA

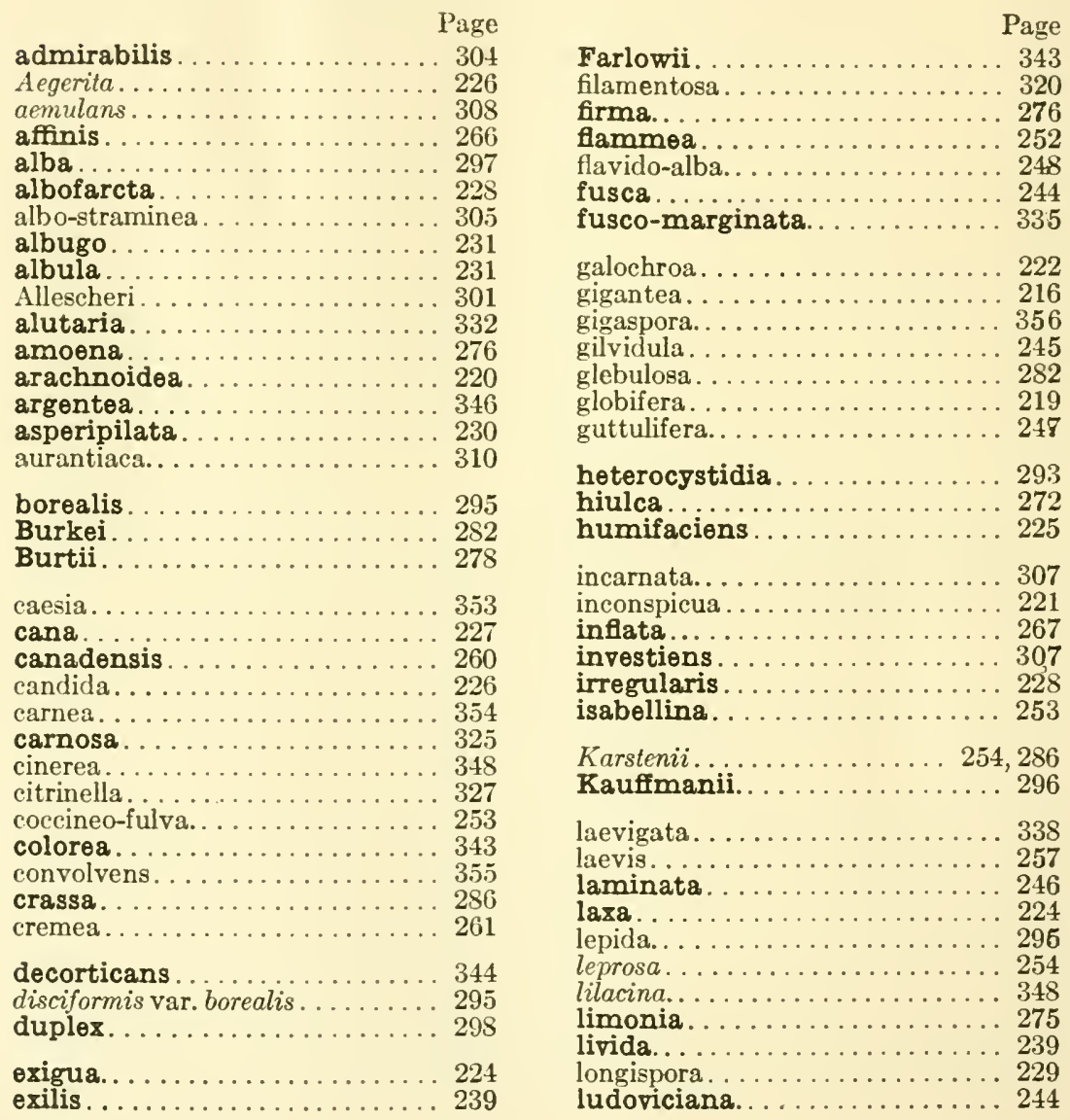




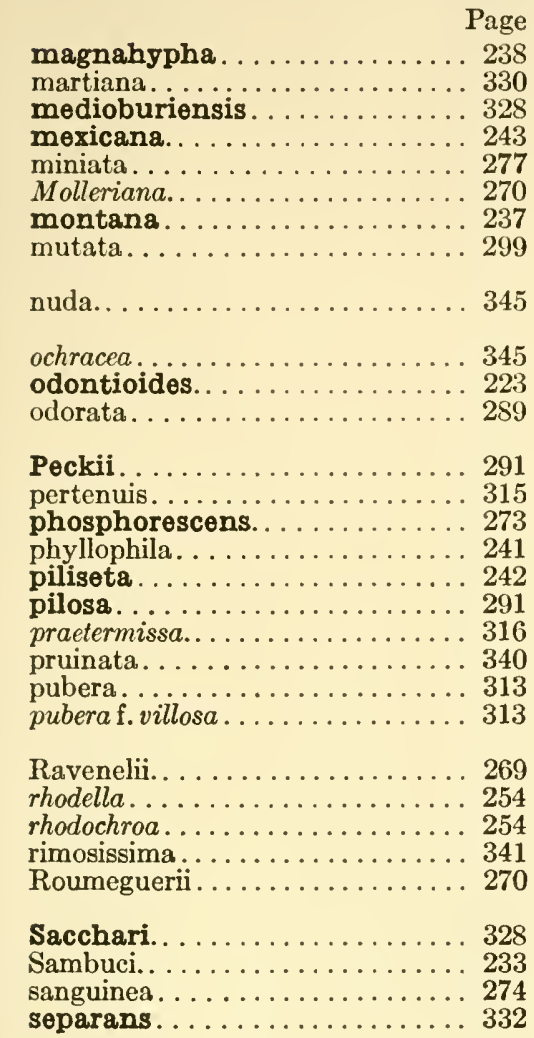

Page

serialis........................... 318

Seymouriana........... 337

Sheari................. 268

similis..................... 336

sordida.................. 280

stratosa............... 333

subalutacea................. 288

subapiculata............. 280

subcremea.............. 303

subiculosa............... 259

subsulphurea. . . . . . . . . . 329

sulphurina.............. 324

tabacina. . . . . . . . . . . 334

Taxodii................. 306

tenella................ 298

tenuis................... 317

tephra.................. 339

terricola. . . . . . . . . . . . . 237

texana............... 251

Thujae................ 236

typhicola................ 319

unicolor. . . ........... 320

velutina................... 264

vernicosa.............. 250

versata................. 305

verticillata.............. 285

violaceo-livida. . . . . . . . . . 347

viticola................. 322

Weiri................ 342

zonata.............. 245 

The Thelephoraceae of North America. XV

Corticium

EDWARD ANGUS BURT

Reprinted from ANNALS OF THE Missoum BotanicaL

GARDEN 13: 173-354. September, 1926 


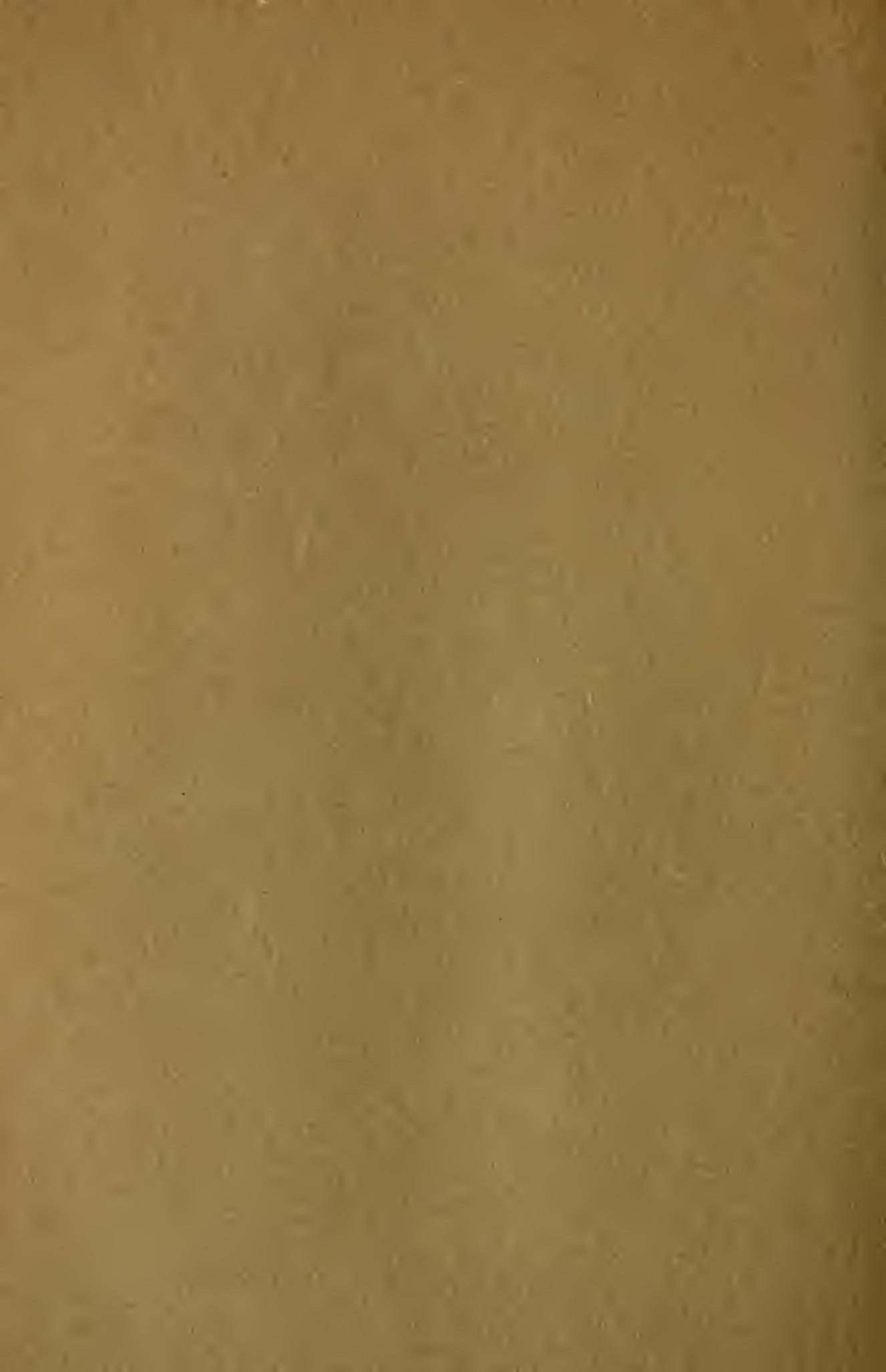


THE THELEPHORACEAE OF NORTH AMERICA. XV ${ }^{1}$ (Conclusion, With Supplement and General Index) EDWARD ANGUS BURT Mycologist and Librarian to the Missouri Botanical Garden

\section{CORTICIUM}

Corticium Persoon, Roemer Neues Mag. Bot. 1: 110. 1794; Obs. Myc. 1: 37. 1796; Fries, Gen. Hym. 15. 1836; Epicr. 556. 1838; Hym. Eur. 646. 1874; Berkeley, Outl. Brit. Fung. 272. 1860; Morgan, Cincinnati Soc. Nat. Hist. Jour. 10: 198. 1888; Sacc. Syll. Fung. 6: 603. 1888; Karsten, Vet.-Soc. Bidrag Natur och Folk 48: 408. 1889; Massee, Linn. Soc. Bot. Jour. 27: 117. 1890; Bresadola, I. R. Accad. Agiati Atti III. 2: 110. 1897; Ann. Myc. 1: 93 . 1903; Engl. \& Prantl, Nat. Pflanzenfam. $\left(\mathrm{I}: 1^{* *}\right): 118$. 1898; Bourdot \& Galzin, Soc. Myc. Fr. Bul. 27: 224. 1911; Rea, Brit. Basid. 14, 672. 1922.-Includes Gloeocystidium v. Höhnel \& Litschauer, Weisner Festschr. Wien, 58. 1908, and Bourdot \& Galzin, Soc. Myc. Fr. Bul. 28: 354. 1913. -Not Gloeocystidium Karsten, Finska Vet.-Soc. Bidrag Natur och Folk 48: 429. 1889. See Burt, Mo. Bot. Gard. Ann. 12: 247. 1926. - Includes Vararia Karsten, Finska Vet.-Soc. Bidrag Natur och Folk 52: 96. 1898; Asterostromella v. Höhnel \& Litschauer, K. Akad. Wiss. Wien Sitzungsber. 116: 773. 1907; Weisner Festschr. Wien, 58. 1908; Bourdot \& Galzin, Soc. Myc. Fr. Bul. 27: 265. 1911.-Includes Xerocarpus and Lyomyces of Karsten, Finska Vet.-Soc. Bidrag Natur och Folk 48: 417, 418. 1889.Includes in part Hypochnus Sacc. Syll. Fung. 6:653. 1888, and Engl. \& Prantl, Nat. Pflanzenfam. (I: $\left.1^{* *}\right)$ : 116. 1898.-Not Hypochnus Fries emend. Karsten, Rev. Myc. $3^{9}$ : 23. 1881. See Burt, Mo. Bot. Gard. Ann. 3: 203. 1916.

${ }^{1}$ Issued September 20, 1926.

Ann. Mo. Bot. Gard., Vol. 13, 1926 
Fructifications waxy, crustaceous or floccose, fleshy, cartilaginous, coriaceous or membranaceous, always resupinate, effused; hymenium even, or somewhat tubercular in a few species; basidia simple with $2-8$ sterigmata, usually 4 , the sterigmata not greatly thickened; basidiospores white, even-green in $C$. atrovirens; substance variously differentiated but not containing colored, stellate organs. Distinguished from Peniophora by not having cystidia.

The species described as belonging in Corticium upon publication of the genus are Corticium polygonium, C. laeve, C. roseum, $C$. Sambuci, C. cinereum, and $C$. aurantium, in the order given, no one of which was designated as the type species. C. Sambuci and $C$. cinereum are now included in Peniophora and $C$. aurantium in Aleurodiscus.

Von Höhnel and Litschauer and Bourdot and Galzin have segregated under Gloeocystidium Karsten all species of Corticium which have gloeocystidia. I have not followed them in this, because I regard gloeocystidia as but one of the several differentiations of tissue which afford helpful distinctive characters for recognition of the species of this genus. In fact, I feel that closer observation of the tissues and structure of the fructification and accurate record of such structure should give important, and often decisive, characters of all the species. My own study has already gone so far in this direction that I attach but slight regard to a specific determination which is based merely upon obvious external characters and the substratum upon which growing. A sufficient objection to Gloeocystidium for the species which have gloeocystidia is that one of the two species upon which Karsten founded the genus is Peniophora guttulifera, a true Peniophora with no gloeocystidia whatever, and the other is Odontia sudans.

Asterostromella as a genus to include Corticium investiens, a species with helpful hyphal differentiation, is antedated by Karsten's Vararia, having $C$. investiens as its type species.

What was shown in the preceding part about the distribution of our species of Peniophora is true also for Corticium. Of the 107 species of Corticium herein presented, 46 are described as new species. The color of the exterior of the fructification and of its internal substance and the presence of tissues of somewhat unusual form have afforded a basis for the arrangement of our 
species into 4 workable groups nearly equal in numbers, as presented in the following key to the species. Each of these groups is subdivided to such degree as seems desirable-largely by spore characters-into minor groups of so few species that the characters of the component species of any group may, and should, all be considered in determining the probable species of the specimen in course of identification. The extensive lists of specimens studied, with their localities where collected, and present preservation in published exsiccati and herbaria, afford material for checking up one's own determinations. Determinations as published should correct earlier tentative determinations communicated to my correspondents.

Throughout this work technical color terms are those of Ridgway's 'Color Standards and Nomenclature.' 'There was little knowledge available as to the color of specimens when growing, but since the time-consuming task of determination is usually with dried specimens collected many years ago and often more or less faded or yellowed, my record of the color of the dried specimens should be the more helpful to the chief users of this work.

Accounts of the species of the genera Tremellodendron, Eichleriella, Sebacina and Septobasidium were included to set off more sharply the true Thelephoraceae to which the species of these four genera are so similar in aspect that they were commonly known under their original names as species of Thelephoraceae. By treating these genera and Lachnocladium in the present work, the student had at hand a systematic account of all North American fungi of thelephoraceous aspect. The matter on those genera could otherwise have been included in my recent publications: 'Some North American Tremellaceae, Dacryomycetaceae and Auriculariaceae' and 'North American species of Clavaria.'

To all whose names have been recorded as collectors and contributors of specimens and to botanical institutions whose specimens are cited and which have afforded me facilities for the study of their herbaria I am deeply indebted. Without their aid but little could have been done. 


\section{Key to THe Species}

I. Substance not appreciably colored, no gloeocystidia.

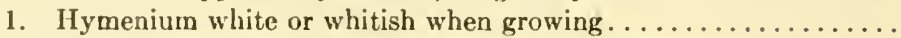

*With antler-shaped paraphyses or color change from yellow to white in fruiting ................. 1,2

**Spores globose or subglobose.

a. Imbedded spores (chlamydospores) usually present. ......

b. Imbedded spores not yet observed............... ***Spores more elongated.

a. Spores large, more than $6 \mu$ long. ..............11, ss

b. Spores small, hyphae incrusted or among obscuring mineral matter.

c. Spores small, hyphae not incrusted...............

2. Hymenium colored when dry and not known to be white at firstusually some shade of buff, yellow, red, brown or blue.......

*Spores globose or subglobose, less than $5 \mu$ in diameter.......

**Spores globose or subglobose, more than $5 \mu$ in diameter..... ***Spores more elongated.

a. Spores very large, $10-18 \mu$ long............... 30,81

b. Spores large, $6-12 \mu$ long. .................. $32-44,90$

c. Spores small, hyphae somewhat incrusted . . . . . . . 12, 45-48

d. Spores small, hyphae not incrusted, fructifications separable.

e. Spores small, hyphae not incrusted, fructifications closely

adnate or only small pieces separable................
dia present or structure vesicular, or some tissue note-

II. Gloeocystidia present or structure vesicular,
worthy, substance colored or not colored.

* Gloeocystidia present or shown by vesicular structure or by colored,

resinous-appearing masses................ $5 \gamma_{-86,107}$

a. Gloeocystidia not colored, elongated, imbedded spores numerous. . . . . ........................ $57-58$

b. Gloeocystidia not colored, elongated, lacking chlamydospores.

†Spores globose, subglobose or broadly ovoid........ $59-66$

††Spores more elongated................66-71, 79

c. Gloeocystidia not colored, pyriform to globose......... 72-79

d. Gloeocystidia colored, elongated.............. 80-83

e. Gloeocystidia colored, subangular or globose, resinous-appearing........................ 86,86

**Distinguished by antler-shaped branching of some hyphae or paraphyses, or other branching of paraphyses, or unusual form of other tissues.......1, $17,23,29,36,38-40,60,72,76,80,87,88,92-94,107$ ***Numerous imbedded spores or other than basidiospores... $3,4,11,37,57,58$

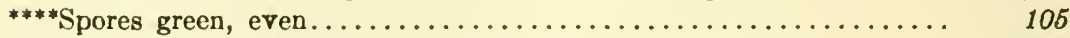

**** Spores usually white but finally becoming ochraceous........... 34

III. Substance colored, no gloeocystidia................ 87-106

*Fructifications ranging from gray to drab.

a. With paraphyses having slender branches, spores small.... 87, 88

b. Paraphyses not noteworthy, spores larger, 7-10 $\mu$ long.... 89-91

**Fructifications ochraceous to wax-yellow and red. 
a. With some hyphae or paraphyses having antler-shaped or racemose branching. ................... 92-94

b. Tissues not having antler-shaped or racemose branching. . . . 2, 95-99 ***Fructifications darker, tending to brown and vinaceous.

a. Parasitic species. ...................... 100-102

b. Always saprophytic.................... 103, 104

${ }^{* * * *}$ Fructifications green or blue . . . . . . . . . . . . . . . 106

1. Corticium paraphysatum Burt, n. sp.

Type: in Mo. Bot. Gard. Herb.

Fructifications effused, thin, closely adnate, white to pale cartridge-buff in the herbarium, even, velutinous, not shining, not cracked, the margin similar, thinning out; in section $45-75 \mu$ thick, not colored, composed of somewhat scattered, deeply staining, clavate organs-probably basidia-immersed among great numbers of slender, erect, non-staining, branching organs which approach antler-form in branching and form the layer of paraphyses at the surface of the hymenium; no gloeocystidia; no basidia bearing sterigmata nor spores found.

Fructifications $1-5 \mathrm{~cm}$. long, $1 / 2-21 / 2 \mathrm{~cm}$. wide. Small fructifications become confluent.

Beneath prostrate, decaying, hardwood limbs of a frondose species. Cuba. Still immature in December.

Although the specimens at hand of C. paraphysalum are still so immature that it has not been possible to demonstrate their mature basidia and spores, the species is distinct from others of the genera Aleurodiscus, Sebacina, and Corticium which are known to me. It should be readily recognizable by its thin, closely adnate, white fructifications on small hardwood limbs and by the abundance of the non-staining paraphyses.

Specimens examined:

Cuba: Ceballos, C. J. Humphrey, 2848, type, and 2776, 2800 (in Mo. Bot. Gard. Herb., 63769, 63768, and 63770 respectively), and 2586; Omaja, C. J. Humphrey, 2698 (in Mo. Bot. Gard. Herb., 43063).

2. C. sulphureum Fries, Epicr. 561. 1838; Hym. Eur. 650. 1874; Berkeley, Outl. Brit. Fung. 274. 1860; Sacc. Syll. Fung. 6: 612 . 1888 .

Thelephora sulphurea Fries, Syst. Mcy. 1:452. 1821 ; Elenchus 
Fung. 1:204. 1828.-Corticium croceum Bresadola, I. R. Accad. Agiati Atti III. 3: 112.1897 ; Bourdot \& Galzin, Soc. Myc. Fr. Bul. 27: 242. 1911; Rea, Brit. Basid. 676. 1922.-An Sporotrichum croceum Kunze \& Schmidt, Myk. Heft. 1: 81. 1817?Not Corticium sulphureum Persoon, which is a synonym of Hypochnus fumosus Fries. See Burt, Mo. Bot. Gard. Ann. 3: 239. 1916.

Type: authentic specimen in Kew Herb.

Fructifications effused, fibrillose-byssoid, sulphur-yellow to wax-yellow when a sterile mycelium, becoming whitish throughout when forming the hymenium, the margin yellow or whitish, running out into sulphur-yellow to wax-yellow branching rhizomorphic strands; when fertile $200-300 \mu$ thick in section, not appreciably colored, the hyphae loosely arranged, ascending, branching, $2 \frac{1}{2} \mu$ in diameter, rough-walled or somewhat incrusted with small crystals; no gloeocystidia; spores hyaline, even, $3 \times 2 \mu$, copious.

Fructifications $3-10 \mathrm{~cm}$. long, 2-4 cm. wide.

Under side of decaying Fagus and other species. Europe, Maryland, Missouri, Montana, and Idaho. Common in Europe but rare in North America. August to October.

The mycelium of $C$. sulphureum is conspicuous by its brilliant wax-yellow color, but in fruiting this yellow color is lost throughout the fructification, persisting only about the margin and in the rhizomorphic strands. By this curious character and by the pruinose or velvety hymenium one may distinguish $C$. sulphureum from $C$. bicolor. The International Botanical Rules afford no ground for the displacement by Bresadola of the well-established name Corticium sulphureum by $C$. croceum.

Specimens examined:

Sweden: authentic specimen from E. Fries (in Kew Herb.); Femsjö, E. A. Burt, 2 gatherings; Stockholm, L. Romell, 151, 152.

Germany: Brinkmann, comm. by G. Bresadola.

Austria: Innsbruck, V. Litschauer; Tirol, V. Litschauer.

Maryland: Takoma Park, C. L. Shear, 1069.

Missouri: Meramec Highlands, F. P. McWhorter (in Mo. Bot. Gard. Herb., 57359). 
Montana: Bernice, E. E. Hubert, comm. by J. R. Weir, 12008 (in Mo. Bot. Gard. Herb., 63368).

Idaho: Priest River, E. E. Hubert, comm. by J. R. Weir, 12021 (in Mo. Bot. Gard. Herb., 63376).

3. C. punctulatum Cooke, Grevillea 6: 132. 1878; Sacc. Syll. Fung. 6: 614. 1888; Massee, Linn. Soc. Bot. Jour. 27: 129. 1890.

Type: type distribution in Ravenel, Fungi Am., 128.

Fructifications broadly effused, thin, somewhat hypochnoid, only fragments separable, white at first, becoming between pinkish buff and cream-color in the herbarium, punctulate at first, at length even and continuous in spots, fibrillose, the margin thinning out, concolorous, indeterminate; in section about $135 \mu$ thick, not colored, with hyphae loosely interwoven, $4-41 / 2 \mu$ in diameter, not incrusted, occasionally nodose-septate; no gloeocystidia; spores imbedded in all regions of the fructification are probably chlamydospores; basidia bearing sterigmata or spores not demonstrated; spores at surface of hymenium hyaline, even, perhaps becoming minutely rough, $6 \times 4 \frac{1}{2}-5 \mu$, copious.

Fructifications up to $6 \mathrm{~cm}$. long, 1-2 cm. wide.

On rotten pine logs and on small splinters and rubbish consolidated by the mycelium. New Jersey and South Carolina.

The punctulate hymenium of $C$. punctulatum is distinctive in the several specimens from the original collection now in three herbaria; the presence of imbedded spores in all regions of the fructification should prove another helpful character for the recognition of this species.

Specimens examined:

Exsiccati: Ravenel, Fungi Am., 128.

New Jersey: Belleplain, C. L. Shear, 1248.

South Carolina: Aiken, H. W. Ravenel, 2334, type (in Kew Herb. and in Ravenel, Fungi Am., 128).

4. C. vellereum Ellis \& Cragin, Jour. Myc. 1 : 58.1885 ; Sacc. Syll. Fung. 6:615. 1888; Massee, Linn. Soc. Bot. Jour. 27: 137. 1890; Wakefield, Brit. Myc. Soc. Trans. 5: 128.1914.

Corticium Bresadolae Bourdot, Rev. Sci. Bourb. 23: 6. 1910; Bourdot \& Galzin, Soc. Myc. Fr. Bul. 27: 233. 1911. 
Type: in N. Y. Bot. Gard. Herb.

Fructifications widely effused, adnate, rather thick, tender, small pieces separable when moistened, white, cream-buff or pinkish buff, even, pulverulent or waxy, rarely cracked, the margin white, byssoid; in section 200-500 $\mu$ thick, not colored, composed of loosely interwoven, thin-walled, nodose-septate hyphae 3-5 $\mu$ in diameter and usually numerous chlamydospores; no gloeocystidia; basidiospores white in spore collection, even, subglobose, $5-7 \times 41 / 2-6 \mu$; chlamydospores of about the same dimensions.

Fructifications $3-10 \mathrm{~cm}$. in diameter.

On bark and wood of frondose species decaying on the ground. In Europe, from Canada to Texas, westward to British Columbia and California, and in Mexico and Japan. July to March. Common.

C. vellereum is distinguished among our species of Corticium by the presence usually of very numerous chlamydospores and by the absence of gloeocystidia. This is true of C. punctulatum, but the latter is more hypochnoid in surface and occurs on pine.

Specimens examined:

Sweden: L. Romell, 404.

France: St. Priest, H. Bourdot, 15\%49, authentic specimen of C. Bresadolae.

England: Winchester, F. Escombe, comm. by E. M. Wakefield (in Mo. Bot. Gard. Herb., 4038).

Canada: J. Macoun, 652, comm. by W. G. Farlow (in Mo. Bot.

Gard. Herb., 7457); Ottawa, J. Macoun, 8, 49, 180, and 281 (in N. Y. State Mus. Herb., and Mo. Bot. Gard. Herb., 57455);

St. Lawrence Valley, J. Macoun, 25.

New Hampshire: Chocorua, E. A. Burt.

Vermont: Middlebury, E. A. Burt; Abby Pond, Ripton, E. A. Burt.

Massachusetts: Magnolia, W. G. Farlow.

New York: Albany, H. D. House (in N. Y. State Mus. Herb., and

Mo. Bot. Gard. Herb., 59689); Hudson Falls, S. H. Burnham, 13 (in Mo. Bot. Gard. Herb., 44004); Ithaca, G. F. Atkinson, 22971; Jordan, E. Brown, 179 (in N. Y. Bot. Gard. Herb., and Mo. Bot. Gard. Herb., 61451); Van Cortland Park, New York 
City, W. A. Murrill (in N. Y. Bot. Gard. Herb., and Mo. Bot. Gard. Herb., 61429); Westport, C. H. Peck, 2 (in N. Y. State Mus. Herb., T 24, and Mo. Bot. Gard. Herb., 56070).

Pennsylvania: State College, L. O. Overholts, 4811 (in Mo. Bot. Gard. Herb., 56125).

Georgia: Savannah, C. J. Humphrey, 5109 (in Mo. Bot. Gard. Herb., 11953).

Alabama: Auburn, F. S. Earle, 115 (in N. Y. Bot. Gard. Herb., and Mo. Bot. Gard. Herb., 61561).

Texas: Quitman, W. H. Long, comm. by C. J. Humphrey, 2545 (in Mo. Bot. Gard. Herb., 9920).

Ohio: C. G. Lloyd, 3738, 3825; Linwood, C. G. Lloyd, 1880.

Michigan: Ann Arbor, C. H. Kauffman, 11, 16.

Wisconsin: Superior, C. J. Humphrey, 1548 (in Mo. Bot. Gard. Herb., 10744).

Illinois: River Forest, E. T. \& S. A. Harper, 627, 629.

Missouri: Upper Creve Coeur, E. A. Burt (in Mo. Bot. Gard. Herb., 58345); St. Louis, S. M. Zeller (in Mo. Bot. Gard. Herb., 55642); Valley Park, E. A. Burt (in Mo. Bot. Gard. Herb., 44074).

Kansas: Rooks County, E. Bartholomew, 2 specimens under the herbarium name C. globiferum (in Burt Herb., and Mo. Bot. Gard. Herb., 4848, 4849); Strong City, G. G. Hedgcock, comm. by C. J. Humphrey, 2541 (in Mo. Bot. Gard. Herb., 11043); Topeka, F. W. Cragin, 560, type, 583 (in N. Y. Bot. Gard. Herb.).

South Dakota: Black Hills, J. R. Weir, 10014 (in Mo. Bot. Gard. Herb., 55795).

Idaho: Priest River, E. E. Hubert, comm. by J. R. Weir, 11633 (in Mo. Bot. Gard. Herb., 63306).

Manitoba: Winnipeg, A.H. R. Buller, 720, 845 (in Mo. Bot. Gard. Herb., 58984, 58993); G. R. Bisby, 1341, 1347 (in Mo. Bot. Gard. Herb., 60550, 60557).

British Columbia: G. M. Dawson, comm. by W. G. Farlow (in Mo. Bot. Gard. Herb., 44690).

California: Berkeley, W. T. Horne, comm. by W. A. Setchell, 1031 (in Mo. Bot. Gard. Herb., 44239).

Mexico: Guernavaca, W. A.\& E. L. Murrill, 361,371 , comm. by 
N. Y. Bot. Gard. Herb. (in Mo. Bot. Gard. Herb., 54464, 54459); Parral, Chihuahua, E. O. Mathews, 19 (in Mo. Bot. Gard. Herb., 44127).

Japan: Kogura Prov., Kozuka, A. Yasuda, 154 (in Mo. Bot. Gard. Herb., 62956).

5. C. granulare Burt, Mo. Bot. Gard. Ann. 10: 187. 1923.

Type: in Mo. Bot. Gard. Herb.

Fructification effused, adnate, snow-white, pulverulent under a lens, very thin, only $15-30 i$ thick, not bearing a continuous hymenium but consisting of bushy branched, suberect hyphal clusters standing out from the substratum and near together, with their main trunks up to $6 \mu$ in diameter and short-celled; no cyrtidia nor gloeocystidia; basidia simple, $15 \times 4 \frac{1}{2} \mu$, with 4 sterigmata; spores hyaline, even, flattened on one side, 4-41/2 $\times 3-4 \mu$, copious.

Fructifications scattered along the substratum, 1-3 cm. long, 4-8 mm. wide.

On dead herbaceous stems. Hawaiian Islands, F. L. Stevens, 381, type (in Mo. Bot. Gard. Herb., 60603).

6. C. ermineum Burt, n. sp.

Type: in Mo. Bot. Gard. Herb.

Fructifications effused, thin, closely adnate, white, not shining, not cracked, the margin similar, thinning out, fimbriate; in section $200 \mu$ thick, not colored, with some hyphae densely arranged along the substratum but becoming suberect and more loosely arranged towards the hymenium, $3 \mu$ in diameter, incrusted, not nodose-septate; no gloeocystidia; spores hyaline, even, $7-9 \times 5-6 \mu$, copious.

Fructifications up to $12 \mathrm{~cm}$. long, $3 \mathrm{~cm}$. wide.

On decorticated, very rotten wood of logs of Thuja plicata and spruce. Vermont and Idaho. August and October.

C. ermineum is distinct among our white species of Corticium by its ermine-white color, well-incrusted hyphae, large spores and occurrence on coniferous wood. C. amylaceum of France, of which I have a cotype, is a related species but thinner, more farinose, and less compact. 
Specimens examined:

Vermont: Middlebury, E. A. Burt.

Idaho: Priest River, E. E. Hubert, comm. by J. R. Weir, 12026, type (in Mo. Bot. Gard. Herb., 63379).

7. C. Berkeleyi Cooke in Massee, Linn. Soc. Bot. Jour. 27 : 133. 1890; Sacc. Syll. Fung. 11: 127. 1895.

Type: type distribution in Ravenel, Fungi Am., 225.

Fructifications broadly effused, thin, membranaceous-arachnoid, small pieces separable when moistened, whitish at first, becoming light buff to pinkish buff in the herbarium, even or minutely granular, not waxy nor shining, cracked, the margin thinning out, with hyphae interwoven; in section 100-200 $\mu$ thick, not colored, with hyphae nodose-septate, not incrusted, 4-5 $\mu$ in diameter along the substratum and sending out ascending, loosely arranged branches which become smaller and densely arranged in the hymenium; no gloeocystidia; basidia 4-spored; spores hyaline, even, subglobose and 4-8 $\times 4-6 \mu$, or globose and 4-6 $\mu$ in diameter.

Fructifications $3-10 \mathrm{~cm}$. in diameter.

On bark and wood of conifers-usually pine. Canada to Texas and in Michigan, Idaho, British Columbia, and New Mexico. April to November. Infrequent.

C. Berkeleyi probably covers large areas on bark of pine logs. It is white or very nearly white, with the hymenium barely continuous, spores globose or subglobose, and hyphae coarse and mostly erect, like those of $C$. bombycinum but with not as thick fructifications and a very inconspicuous margin in comparison with $C$. bombycinum.

Specimens examined:

Exsiccati: Ellis, N. Am. Fungi, 934; Ravenel, Fungi Am., 225, type distribution.

Canada: J. Macoun, 32; Lower St. Lawrence Valley, J. Macoun, 74.

Ontario: Ottawa, J. Macoun, 35.

New Hampshire: Chocorua, W. G. Farlow, 9.

Vermont: Middlebury, E. A. Burt.

New York: Newtonville, C. H. Peck (in N. Y. State Mus. Herb., and Mo. Bot. Gard. Herb., 14854). 
North Carolina: Chapel Hill, J. N. Couch, comm. by W. C. Coker, 4257 (in Mo. Bot. Gard. Herb., 57419).

South Carolina: Aiken, H. W. Ravenel, in Ellis, N. Am. Fungi, 934.

Georgia: Darien, H.W. Ravenel, in Ravenel, Fungi Am., 225; Savannah, C. J. Humphrey, 5109 (in Mo. Bot. Gard. Herb., 11953).

Alabama: Montgomery County, R. P. Burke, 519 (in Mo. Bot. Gard. Herb., 57305).

Texas: Quitman, W. H. Long, comm. by C. J. Humphrey, 2545 (in Mo. Bot. Gard. Herb., 9920).

Michigan: Ann Arbor, C. H. Kauffman, 34.

Idaho: Kooskia, J. R. Weir, 997 (in Mo. Bot. Gard. Herb., 13544);

Priest River, J. R. Weir, 6360 (in Mo. Bot. Gard. Herb., 58449). British Columbia: Kootenai Mts., near Salmo, J.R. Weir, 478 (in Mo. Bot. Gard. Herb., 63274).

New Mexico: Clouderoft, W. H. Long, 19523 (in Mo. Bot. Gard.

Herb., 44767); Mogollen, G. G. Hedgcock \& W. H. Long, comm. by C. J. Humphrey, 2559 (in Mo. Bot. Gard. Herb., 9781).

8. C. arachnoideum Berkeley, Ann. \& Mag. Nat. Hist. 13: 345. pl. 9, f. 3. 1844; Outl. Brit. Fung. 273. 1860; Berk. \& Curtis, Grevillea 2: 4. 1873; Fries, Hym. Eur. 649. 1874; Sacc. Syll. Fung. 6: 611. 1888; Massee, Linn. Soc. Bot. Jour. 27: 135. 1890; Bresadola, Ann. Myc. 1: 93.1903.

Not probably $C$. arachnoideum as understood by v. Höhnel \& Litschauer, and Rea.

Type: in Kew Herb.

Fructifications effused, thin, arachnoid, tender, snow-white, forming an even hymenial pellicle in the older, more central portions, supported on the loosely arranged arachnoid subiculum which protrudes as a sterile, delicate, web-like margin; in section 100-200 $\mu$ thick, not colored, with hyphae very loosely interwoven, $3-4 \mu$ in diameter, nodose-septate, not incrusted; no gloeocystidia; spores hyaline, even, globose, or subglobose, 4-6 $\mu$ in diameter or $6 \times 5 \mu, 5 \times 4 \mu, 4-41 / 2 \times 3-4 \mu$.

Fructifications $2-6 \mathrm{~cm}$. long, 1-3 cm. wide.

On humus of leaf fragments and decaying wood, running over 
mosses and lichens and on rotten wood. Rare in Europe, common in North America from Canada to Louisiana and westward to the Pacific, in the West Indies and the Hawaiian Islands. May to November.

C. arachnoideum is globose-spored and separated from $C$. lacteum by white color, more arachnoid subiculum, and thinner and less compact hymenium. C. centrifugum, which is common in Europe and infrequent in North America, has narrower spores than $C$. arachnoideum, is less arachnoid, more inclined to ashy white color, more widely eff used, and on decaying wood preferably. Our American specimens of $C$. arachnoideum agree perfectly with those of Berkeley in Kew and with the Berkeley \& Curtis specimens also determined by Berkeley.

Specimens examined:

Exsiccati: Brinkmann, Westfälische Pilze, 103; Ellis, N. Am.

Fungi, 411; Ell. \& Ev., Fungi Col., 918.

Sweden: L. Romell, 77; Stockholm, L. Romell, 161.

England: on moss, 437 , authentic specimen, perhaps type, $M . J$. Berkeley (in Kew Herb.).

Scotland: Glamis, J. Stevenson (in Berkeley Herb. of Kew Herb.). Germany: Westphalia, W. Brinkmann, comm. by Bresadola, and in Brinkmann, Westfälische Pilze, 103 (in Mo. Bot. Gard. Herb., 63441).

Austria: Stubai, Tirol, V. Litschauer, under the name Corticium centrifugum var. macrosporum.

Canada: J. Macoun, 47, 63; Lower St. Lawrence Valley, $J$. Macoun, 12, 64, 89; London, Ontario, J. Dearness, 1146 (in Mo. Bot. Gard. Herb., 18762); Ottawa, J. Macoun, 400.

Newfoundland: Bay of Islands, A. C. Waghorne, 1014 (in Mo. Bot. Gard. Herb., 4813).

Massachusetts: Sharon, A. P. D. Piguet, comm. by W. G. Farlow, and 135, comm. by Farlow Herb. (in Mo. Bot. Gard. Herb., 59626).

Vermont: Middlebury, E. A. Burt, 4 gatherings.

New York: Albany, H. D. House (in N. Y. State Mus. Herb., and Mo. Bot. Gard. Herb., 57509); Bolton, C. H. Peck, 17; Bolton Landing, C. H. Peck (in N. Y. State Mus. Herb., and Mo. Bot. Gard. Herb., 55769); East Galway, E. A. Burt; Ithaca, G. F. 
Atkinson, 2125, 8054, 8240, 14956; H. S. Jackson, 18658; C. Thom, 14367; Karner, H. D. House, comm. by N. Y. State Mus. Herb. (in Mo. Bot. Gard. Herb., 55193).

New Jersey: Newfield, J. B. Ellis, in Ellis, N. Am. Fungi, 411, Ell. \& Ev., Fungi Col., 918, and 1374, comm. by W. G. Farlow (in Mo. Bot. Gard. Herb., 14652).

Maryland: Takoma Park, C. L. Shear, 1029, 1105.

North Carolina: Blowing Rock, G. F. Atkinson, 4325; Chapel Hill, J. N. Couch, comm. by W. C. Coker, 4235a (in Mo. Bot. Gard. Herb., 57418).

South Carolina: M. A. Curtis, 2513 (in Farlow Herb.).

Mississippi: Ocean Springs, L. M. Underwood (in N. Y. Bot.

Gard. Herb., and Mo. Bot. Gard. Herb., 61482).

Louisiana: Plaqueminas County, A. B. Langlois, 998.

Illinois: Riverside, E. T. \& S. A. Harper, 738.

Montana: Hecla, E. E. Hubert, comm. by J. R. Weir, 11408 (in Mo. Bot. Gard. Herb., 63264); Missoula, J. R. Weir, 402 (in Mo. Bot. Gard. Herb., 11256); Rock Hill, J. R. Weir, 11963 (in Mo. Bot. Gard. Herb., 63224); Yellow Bay, J. A. Hughes, comm. by J. R. Weir, 7035 (in Mo. Bot. Gard. Herb., 55466). Idaho: Coolin, J. R. Weir, 11540 (in Mo. Bot. Gard. Herb., 63295); Ruby Creek, E. E. Hubert, comm. by J. R. Weir, 12009 (in Mo. Bot. Gard. Herb., 63369); Sandpoint, E. E. Hubert, comm. by J. R. Weir, 12024 (in Mo. Bot. Gard. Herb., 63377). Manitoba: Norway House, G. R. Bisby, 1465 (in Mo. Bot. Gard. Herb., 57912).

Washington: Falcon Valley, W. N. Suksdorf, 725; Mt. Paddo, W. N. Suksdorf, 734; Sedro-Woolley, C. J. Humphrey, 1045 (in Mo. Bot. Gard. Herb., 10901).

Oregon: Wallowa Lake, C. L. Shear, 798.

California: Redding, C. J. Humphrey, 1045; Santa Catalina Island, L. W. Nuttall, 1092 (in Mo. Bot. Gard. Herb., 58871).

Cuba: San Diego de los Baños, Earle \& Murrill, 361, comm. by N. Y. Bot. Gard. Herb.

Porto Rico: Rio Piedras, J. A. Stevenson, 6557 (in Mo. Bot. Gard. Herb., 55080).

Hawaiian Islands: F. L. Stevens, 964 (in Stevens Herb., Mo. Bot. Gard. Herb., 60602, and Burt Herb.). 
9. C. portentosum Berk. \& Curtis, Grevillea 2: 3. 1873; Morgan, Cincinnati Soc. Nat. Hist. Jour. 10: 201. 1888; Sacc. Syll. Fung. 6: $636 . \quad$ 1888; Massee, Linn. Soc. Bot. Jour. $27: 129$. 1890; Bourdot \& Galzin, Soc. Myc. Fr. Bul. 27: 235. 1911.

Corticium diminuens Berk. \& Curtis, Grevillea 2: 3. 1873; Sacc. Syll. Fung. 6: 631. 1888; Massee, Linn. Soc. Bot. Jour. 27: 158. 1890. —Stereum portentosum (Berk. \& Curtis) v. Höhnel \& Litschauer, K. Akad. Wiss. Wien Sitzungsber. 116: 743. 1907. -Corticium portentosum crystallophorum Ell. \& Ev. Torr. Bot. Club Bul. 24: 125. 1897.-Corticium Aluta Bresadola in v. Höhnel \& Litschauer, Wiesner Festschr. Wien, 62. 1908.—An Corticium grammicum P. Hennings, Engl. Bot. Jahrb. 38: 106. 1905? Compare v. Höhnel \& Litschauer, K. Akad. Wiss. Wien Sitzungsber. 116: 743. 1907.

Type: in Kew Herb. and Curtis Herb.

Fructifications long and widely effused, thick, coriaceous-soft, small pieces separable when moistened, white, becoming light buff to warm buff in the herbarium, even, only rarely cracked, the margin often whitish, pubescent-villose; in section 150$1000 \mu$ thick, colored like the hymenium, becoming zonate or stratose when thick, composed of very densely interwoven, tough hyphae about $1-2 \mu$ in diameter, not incrusted, not nodoseseptate, protruding in the hymenial surface as curved paraphyses; more or less numerous aggregations of mineral matter may be immersed in the substance; no gloeocystidia; basidia few; spores hyaline, even, spherical, $41 / 2-7 \mu$ in diameter, few present usually.

Fructifications 4-12 cm. long, 2-4 cm. wide.

On bark and wood of logs of frondose species. In Europe, South Africa, throughout North America and the West Indies, in South America, and in the Philippine Islands. Common.

C. portentosum is well named and may be recognized by its large, whitish, coriaceous fructifications on frondose logs, which become zonate within in thick specimens, and have globose spores $6 \mu$ in diameter, and the slender branches of the interwoven hyphae exceeding the basidia and forming the hymenial surface. This species was formerly confused in Europe with Stereum alneum and was communicated to me under this name by both Karsten and Bresadola. It also occurs from Lindblad in Kew 
Herb. and from Blytt in Fries Herb. under the name of Stereum odoratum, from another specimen of which, determined by $\mathbf{E}$. Fries, it differs by the elongated spores and occurrence on Pinus of the latter.

Specimens examined:

Exsiccati: Ellis, N. Am. Fungi, 718; Ell. \& Ev., N. Am. Fungi, 1715; Ravenel, Fungi Car. 3: 31; de Thuemen, Myc. Univ., 2013, under the name Corticium radiosum.

Finland: Mustiala, P. A. Karsten, in de Thuemen, Myc. Univ., 2013; Vasa, P. A. Karsten, under the name Stereum alneum.

Sweden: Stockholm, L. Romell, 26, 159, both under the name Stereum alneum.

Germany: Feldkirch, Rick, comm. by Bresadola, under the name Stereum alneum.

Hungary: Kmet, comm. by Bresadola, under the name Stereum odoratum.

Italy: locality not stated, Bresadola, comm. under the name Stereum alneum; Trento, Bresadola.

France: Aveyron, A. Galzin, 14990, comm. by H. Bourdot, 15750. Canada: Ontario, London, J. Dearness, 1287 (in Mo. Bot. Gard. Herb., 19057).

New York: Ithaca, G. F. Atkinson, 3406; Poughkeepsie, W. R. Gerard, 316 (in N. Y. Bot. Gard. Herb., and Mo. Bot. Gard. Herb., 61385).

Pennsylvania: Michener, type (in Kew Herb., and Curtis Herb., 3620); West Chester, Everhart, Haines, Jefferis \& Gray, in Ellis, N. Am. Fungi, 718.

Florida: W. W. Calkins, in Ell. \& Ev. N. Am. Fungi, 718, and (in N. Y. Bot. Gard. Herb., Mo. Bot. Gard. Herb., 61488, and Burt Herb.); H. von Schrenk (in Mo. Bot. Gard. Herb., 44202); Cocoanut Grove, R. Thaxter, 99 (in Mo. Bot. Gard. Herb., 43926); Cutler Hammock, W. A. Murrill, 76, 252, 253, comm. by N. Y. Bot. Gard. Herb. (in Mo. Bot. Gard. Herb., 62101, 62129, and 62128, respectively); Miami, W. H. Long, 12290 (in Mo. Bot. Gard. Herb., 55051); Palm Beach, R. Thaxter, 15 (in Mo. Bot. Gard. Herb., 43928).

Alabama: Peters, type distribution of Corticium diminuens, in Ravenel, Fungi Car. 3 : 31, and (in Curtis Herb., 4009) ; Mont- 
gomery County, R. P. Burke, 464 (in Mo. Bot. Gard. Herb., 57285).

Louisiana: A. B. Langlois, 244, comm. by U. S. Dept. Agr. Herb. ; St. Martinville, A. B. Langlois, 1762, 2098, and 1247, comm. by W. G. Farlow (in Mo. Bot. Gard. Herb., 44075), and 2438, type of Corticium portentosum crystallophorum.

Texas: San Antonio, W. H. Long, 21187 (in Mo. Bot. Gard. Herb., 55132); Uvalde, W. H. Long, 21686 (in Mo. Bot. Gard. Herb., $55133)$.

Kentucky: Mammoth Cave, C. G. Lloyd, 2568.

Ohio: Cincinnati, A. P. Morgan (in Lloyd Herb., 2604, and under the name Corticium subgiganteum); Loveland, D. L. James (in U. S. Dept. Agr. Herb.); West Elkton, L. O. Overholts, 4208 (in Mo. Bot. Gard. Herb., 55637); Waynesville, F. G. Lea, the C. ochraceum of Lea's Cat. Plants of Ohio (in Berkeley Herb. at Kew).

Indiana: Scottsburg, J. R. Weir, 369 (in Mo. Bot. Gard. Herb., 17771); Weirtown, J. R. Weir, 353 (in Mo. Bot. Gard. Herb., 9933).

Wisconsin: Lake Geneva, E. T. \& S. A. Harper, 848; Star Lake, Miss Stucki, 56 .

Missouri: Columbia, B. M. Duggar, 569.

British Columbia: Sidney, J. Macoun, 24, 37, 86, 88, 105, 165 (in Mo. Bot. Gard. Herb., 5685, 55348, 8109, 11350, 55349, 20477); Squamish, J. Macoun, 537, 570 (in Mo. Bot. Gard. Herb., 55192, 55185); Vancouver Island, J. Macoun, 144, 295, 537 (in Mo. Bot. Gard. Herb., 18865, 55320, 55319).

Mexico: Jalapa, W. A. \& E. L. Murrill, 115, 191, 346, comm. by N. Y. Bot. Gard. Herb. (in Mo. Bot. Gard. Herb., 10854, 54437, 54481); Orizaba, W. A.\& E. L. Murrill, 750, comm. by N. Y. Bot. Gard. Herb. (in Mo. Bot. Gard. Herb., 54636).

Bermuda: Paget Swamp, H. H. Whetzel, Abf (in Mo. Bot. Gard. Herb., 58910).

Cuba: Baracoa, L. M. Underwood \& F. S. Earle, 784, comm. by N. Y. Bot. Gard. Herb. (in Mo. Bot. Gard. Herb., 61556); Camaguey (in Mo. Bot. Gard. Herb., 56123); Havana Province, Earle \& Murrill, 24, 103, comm. by N. Y. Bot. Gard. Herb.; Omaja, C. J. Humphrey, 2709, 2830 (in Mo. Bot. Gard. Herb., 
13740, 14847); Oriente, comm. by J. R. Weir 10617 (in Mo. Bot. Gard. Herb., 56235); Pinar del Rio Province, Earle \& Murrill, 196, 201, 208, 295, 312, comm. by N. Y. Bot. Gard. Herb., P. Wilson, $115 \% 0$, comm. by N. Y. Bot. Gard. Herb. (in Mo. Bot. Gard. Herb., 61494); Puerto Principe Province, Earle \& Murrill, 582, 602, comm. by N. Y. Bot. Gard. Herb.; Santiago de Cuba Province, Earle \& Murrill, 460, 467, comm. by N. Y. Bot. Gard. Herb.

Porto Rico: Ponce, F. S. Earle, 117; Rio Piedras, J. R. Johnston, 982, 982a, 972a (in Mo. Bot. Gard. Herb., 9849, 61355, 61356), J. A. Stevenson, 3597, 5158 (in Mo. Bot. Gard. Herb., 12720, 6807); Utuado, N. L. Britton \& J. F. Cowell, 999 (in N. Y. Bot. Gard. Herb., and Mo. Bot. Gard. Herb., 61492).

Jamaica: W. A. \& E. L. Murrill, 40, comm. by N. Y. Bot. Gard. Herb. (in Mo. Bot. Gard. Herb., 56288); Castleton Gardens and Chester Vale, W. A. \& E. L. Murrill, 52, 314, respectively, comm. by N. Y. Bot. Gard. Herb.; Hope Gardens, F. S. Earle, 178 , comm. by N. Y. Bot. Gard. Herb.

Montserrat: Roches, J. A. Shafer, 915 (in N. Y. Bot. Gard. Herb., and Mo. Bot. Gard. Herb., 61473).

Argentina: R. Fries, 138, comm. by L. Romell, 333 .

Philippine Islands: comm. by C. G. Lloyd, 11215 (in Mo. Bot. Gard. Herb., 58688).

Africa: Natal, Durban, P. A. van der Bijl, 2, 36 (in Mo. Bot. Gard. Herb., 58800, 58834); Unkomaas, P. A. van der Bijl, 1151 (in Mo. Bot. Gard. Herb., 62079).

10. C. bombycinum (Sommerf.) Bresadola, I. R. Accad. Agiati Atti III. 3: 111. 1897; Bourdot \& Galzin, Soc. Myc. Fr. Bul. 27: 233. 1911; Wakefield \& Pearson, Brit. Myc. Soc. Trans. 6: 138. text f. 1919; Rea, Brit. Basid. 674. 1922.

Thelephora bombycina Sommerfelt, Fl. Lapp. Suppl. 284. 1826; Fries, Elench. Fung. 1: 211. 1828.

Type: in Sommerfelt Herb., in Univ. of Christiania Herb., a fragment in Burt Herb.

Fructifications irregularly effused, thick, membranaceous-soft, pieces separable, at first white, becoming pinkish buff to creambuff in the herbarium, even or varying rough to a hydnoid sur- 
face, somewhat cracked, the margin and subiculum floccose to fibrillose and sometimes hirsute; in section 200-1000 $\mu$ thick, with the hyphae suberect, loosely interwoven, thick-walled, 4-5 $\mu$ in diameter, nodose-scptate; no gloeocystidia; spores hyaline, even, $6-10 \times 5-6 \mu$.

Fructifications $3-10 \mathrm{~cm}$. long, $2-3 \mathrm{~cm}$. wide.

On bark of living and dead Salix and Alnus usually, but also on Betula, Acer, Tilia, Populus, and Pinus. In Europe and from Canada to Massachusetts and westward to Washington and Arizona, and in Texas. July to March. Uncommon.

C. bombycinum is a thick species with description somewhat suggestive of $C$. cremoricolor, but it does not crack radially, and tend to brown color like the latter, is more spongy and with more pelliculose hymenium and with a broader, thicker, and very conspicuous margin, and favors Salix as a substratum.

Specimens examined:

Exsiccati: Brinkmann, Westfälische Pilze, 11; Jaczewski, Fungi Rossiae, 232, under the name Hypochnus Sambuci; Romell, Fungi Scand., 35, under the name Corticium serum.

Norway: Saltd, Sommerfelt, fragment of type comm. by L. Romell.

Sweden: Stockholm, L. Romell, 63, 64, 65, 201, 344, and in Romell, Fungi Scand., 35; Upsala, L. Romell, two unnumbered specimens.

Russia: in Jaczewski, Fungi Rossiae, 232.

Germany: Lengerich, in Brinkmann, Westfälische Pilze, 11. Austria: Feldkirch, Rick, comm. by Bresadola.

Canada: J. Macoun, 56, 60, in part, 157; Lower St. Lawrence Valley, J. Macoun, 30.

Ontario: Port Credit and Toronto, J. H. Faull, 655 and 380 , respectively (in Mo. Bot. Gard. Herb., 44943, 44948).

Vermont: Middlebury, E. A. Burt.

Massachusetts: on beams in cotton mill, R. J. Blair, 248, in part, comm. by L. O. Overholts, 3812a (in Mo. Bot. Gard. Herb., 54995).

New York: Alcove, C. L. Shear, 1317; Clear Water, G. F. Atkinson, 5050; East Galway, E. A. Burt; Hudson Falls, S. H. Burnham, 14 (in Mo. Bot. Gard. Herb., 44007); Kenwood, S. H. 
Burnham, comm. by N. Y. State Mus. Herb. (in Mo. Bot. Gard. Herb., 56048).

Texas: Quitman, W. H. Long, 12092 (in N. Y. Bot. Gard. Herb., and Mo. Bot. Gard. Herb., 61343).

Michigan: Ann Arbor, C. H. Kauffman, 18.

Minnesota: Princeton, C. J. Humphrey, 1030 (in Mo. Bot. Gard. Herb., 21779).

Washington: Bingen, W. N. Suksdorf, 905, 915.

Arizona: Flagstaff, W. H. Long, 19449 (in Mo. Bot. Gard. Herb., $55141)$.

11. C. sociatum Burt, n. sp.

Type: in Mo. Bot. Gard. Herb.

Fructifications effused, small, closely adnate, very thin, white, becoming continuous and somewhat waxy at the center, even, barely cracked, the margin thinning out, with hyphae interwoven; in section $70-90 \mu$ thick, not colored, with the hyphae loosely interwoven near the substratum, $3 \mu$ in diameter, not incrusted, not nodose-septate; no gloeocystidia; basidia with 4 sterigmata; spores hyaline, even, $101 / 2-12 \times 5-6 \mu$, copious; a few imbedded spores present.

Fructifications $2-10 \mathrm{~mm}$. long, $1-3 \mathrm{~mm}$. wide -24 on an area $9 \mathrm{~cm}$. long, $2 \mathrm{~cm}$. wide.

On bark of decaying logs of Thuja plicata. Manitoba and British Columbia. August.

C. sociatum is a white species belonging in the group with $C$. arachnoideum, $C$. centrifugum, and $C$. pelliculare but distinct by the many small fructifications arranged near together, large spores, and hyphae neither nodose-septate nor incrusted.

Specimens examined:

Manitoba: Norway House, G. R. Bisby, 1466 (in Mo. Bot. Gard. Herb., 61649).

British Columbia: Kootenai Mts. near Salmo, J. R. Weir, 529, type (in Mo. Bot. Gard. Herb., 21596).

12. C. scutellare Berk. \& Curtis, Grevillea 2: 4. 1873; Sacc. Syll. Fung. 6: 634. 1888; Massee, Linn. Soc. Bot. Jour. 27: 128. 1890. 
Type: in Kew Herb. and Farlow Herb.

Fructifications long and widely effused, thin, adnate, from white becoming cream-buff to warm buff in the herbarium, waxy, often granular, finally very much cracked into minute areolae, 1-3 to a mm., which flake away from the substratum-sometimes leaving some of the white subiculum on the latter, the margin thinning out; in section 120-250 $\mu$ thick, not colored, composed of suberect, interwoven, thin-walled hyphae $2 \frac{1}{2}-31 / 2 \mu$ in diameter, incrusted in the subhymenial region so as to form a conspicuous subhymenial zone of mineral matter; no cystidia nor gloeocystidia; spores hyaline, even, $4-6 \times 2-3 \mu$.

Fructifications $2-8 \mathrm{~cm}$. long, $1-4 \mathrm{~cm}$. wide.

On fallen decaying limbs of frondose species. New York to Louisiana and westward to Kansas, in the West Indies, Japan, and South Africa. June to January. Common in the southern states.

C. scutellare, when fully mature in the southern states, may be recognized at sight by the very numerous areolae wholly separated from one another by fissures, but less mature and more northern specimens may be cracked into more rectangular masses up to $2 \mathrm{~cm}$. in diameter and more or less connected together. In such specimens the subhymenial zone of mineral matter is a helpful character, for this zone is constant and conspicuous when sections are examined and, together with the small spores, afford sharp distinctive characters.

Specimens examined:

New York: Albany County, S. H. Burnham, 29 (in Mo. Bot. Gard. Herb., 54484); Alcove, C. L. Shear, 998; Fort Ann, S. H. Burnham, 43, in part (in Mo. Bot. Gard. Herb., 54453); Hudson Falls, S. H. Burnham, 16, 35 (in Mo. Bot. Gard. Herb., 54499, 54451); Ithaca, H. S. Jackson, C. Thom, comm. by Cornell Univ. Herb., 18201 and 14371, respectively; Karner, H. D. House (in N. Y. State Mus. Herb., and Mo. Bot. Gard. Herb. 54380), and C. H. Peck, comm. by N. Y. State Mus. Herb., T6 (in Mo. Bot. Gard. Herb., 54640); Meadowdale, C. H. Peck, comm. by N. Y. State Mus. Herb., T6 (in Mo. Bot. Gard. Herb., 54640); North Elba, C. H. Peck (in N. Y. Bot. Gard. Herb., and Mo. Bot. Gard. Herb., 55973); Port Jefferson, 
C. H. Peck (in N. Y. Bot. Gard. Herb., and Mo. Bot. Gard. Herb., 55981).

New Jersey: Newfield, J. B. Ellis, 418, 2052, 2475, and 2 unnumbered specimens comm. by W. G. Farlow (in Mo. Bot. Gard. Herb., 16061, 14255, 7657, 7456 and 44642, respectively). Pennsylvania: Philadelphia, A. S. Rhoads, comm. by L. O. Overholts, 2680 (in Mo. Bot. Gard. Herb., 5918); Trexlertown, W. Herbst, 40.

District of Columbia: Takoma Park, E. M. Williams (in N. Y. State Mus. Herb., and Mo. Bot. Gard. Herb., 55812).

Virginia: Chain Bridge, A. S. Rhoads, comm. by L. O. Overholts, 3968 (in Mo. Bot. Gard. Herb., 54985).

South Carolina: type (in Curtis Herb., 2473).

Georgia: Tallulah Falls, A. B. Seymour, comm. by Farlow Herb., E (in Mo. Bot. Gard. Herb., 44610).

Florida: Mr. Curtiss, comm. by W. G. Farlow.

Alabama: Auburn, Ala. Biol. Survey; Montgomery, R. P. Burke, 6, 84, 143, 148, 239 (in Mo. Bot. Gard. Herb., 22316, 20508, 10673, 44907, 57104, respectively).

Mississippi: Ocean Springs, F. S. Earle, 183 (in Mo. Bot. Gard. Herb., 4838).

Louisiana: A. B. Langlois, 134, comm. by U. S. Dept. Agr. Herb.; St. Martinville, A. B. Langlois, aa, 856, 2632, and a specimen comm. by Lloyd Herb., 4128.

Kentucky: Mammoth Cave, C. G. Lloyd, 2562.

Indiana: Crawfordsville, D. Reddick, 9.

Illinois: Glencoe, E. T. \& S. A. Harper, 821.

Missouri: Columbia, B. M. Duggar, 589.

Kansas: Rooks County, E. Bartholomew.

Jamaica: Chester Vale, W. A. \& E. L. Murrill, 290, 329, 341, comm. by N. Y. Bot. Gard. Herb.; Hope Gardens, F. S. Earle, 192, comm. by N. Y. Bot. Gard. Herb.; Monkey Hill, W. A. \& E. L. Murrill, 783, comm. by N. Y. Bot. Gard. Herb.; New Haven Gap, W. A. \& E. L. Murrill, 766, comm. by N. Y. Bot. Gard. Herb.; St. Margaret's Bay, A. E. Wight, comm. by W. G. Farlow, 4 (in Mo. Bot. Gard. Herb., 44076).

Japan: Shinokubi, Prov. Harima, A. Yasuda, 6 (in Mo. Bot. Gard. Herb., 55664). 
Africa: Erhove, Zululand, P. A. van der Bijl, 26 (in Mo. Bot. Gard. Herb., 58824); Houtbos, Transvaal, P. A. van der Bijl, 1482.

13. C. tuberculatum Karsten, Hedwigia 35:45. 1896; Krit. Öfvers. Finl. Basidsv. Tilläg 3:29. 1898; Sacc. Syll. Fung. 14: 221. 1899 ; v. Höhnel \& Litschauer, K. Akad. Wiss. Wien Sitzungsber. 115: 1561. 1906.

Type: authentic specimen or part of type in Burt Herb.

Fructifications orbicular or longitudinally effused, rather thick, somewhat membranaceous, small pieces separable when moistened, white at first, becoming light buff to warm buff in the herbarium, somewhat colliculose or tuberculate, waxy, the margin radiately fibrillose; in section 200-300 $\mu$ thick, not colored, with the hyphae densely interwoven in a narrow layer next to the substratum and then ascending obliquely and not crowded to the compact hymenial layer, $31 / 2-41 / 2 \mu$ in diameter, somewhat incrusted in the type, not nodose-septate; no gloeocystidia; spores hyaline, even, $4-6 \times 2 \frac{1}{2}-31 / 2 \mu$, copious.

Pieces of fructification $2 \frac{1}{2} \mathrm{~cm}$. in diameter in the specimen seen.

On bark and wood of fallen branches of Populus, Fraxinus, and other frondose species. Finland, Pennsylvania to Wisconsin. Rare.

C. tuberculatum approaches Radulum in having a middle layer of loosely arranged, ascending hyphae and a somewhat colliculose surface and some small tubercules in the authentic specimen communicated to me by Karsten and which agrees closely with his description of the species. The general aspect somewhat resembles that of Peniophora mutata. 'The American gatherings cited below have a more even hymenium and hyphae not incrusted and are doubtfully referred to $C$. tuberculatum.

Specimens examined:

Finland: Mustiala, P. A. Karsten, probably part of type.

Pennsylvania: Trexlertown, W. Herbst, $7 \%$.

Michigan: East Tower, J. R. Weir, 370 (in Mo. Bot. Gard. Herb., 17074).

Wisconsin: Madison, A. O. Stucki, 44, comm. by Univ. Wis. Herb. 
14. C. crustaceum (Karsten) v. Höhnel \& Litschauer, K. Akad. Wiss. Wien Sitzungsber. 115: 1566. 1906.

Xerocarpus crustaceus Karsten, Hedwigia 35: 45. 1896.Stereum crustaceum Karsten in Sacc. Syll. Fung. 14: 215. 1899.

Type: in Karsten Herb. and Burt Herb.

Fructifications effused, thin, crustaceous-adnate, somewhat grumose, not at all separable, white or whitish, even or somewhat granular, conforming to inequalities of the substratum, somewhat cracked; in section 40-100 $\mu$ thick, not colored, composed of densely arranged hyphae $2 \mu$ in diameter, not well shown, with crystalline masses intermixed; no gloeocystidia; spores hyaline, even, $4 \frac{1}{2}-5 \times 3 \mu$, copious.

Fructifications 2-6 cm. long, 1-3 cm. wide.

On rough bark of Acer, Crataegus, Populus, Salix, Ulmus, and Abies. Finland and Canada to Florida. July to November. Probably common.

C. crustaceum is so similar in aspect to Peniophora Sambuci that it is necessary to distinguish it from the latter by the microscopic characters of sectional preparations. C. crustaceum has no cystidia, has more densely arranged hyphae and a good deal of obscuring crystalline matter intermixed.

Specimens examined:

Finland: Mustiala, P. A. Karsten, authentic specimen on Populus. Canada: J. Macoun, 1, 2; St. Lawrence Valley, J. Macoun, 27, 49,51 .

Ontario: Ottawa, J. Macoun (in N. Y. State Mus. Herb., and Mo.

Bot. Gard. Herb., 55902), and 4.

Quebec: Hull, J. Macoun, 82.

Vermont: Middlebury, E. A. Burt.

West Virginia: Paw Paw, C. L. Shear, 1176.

Florida: Jacksonville, W. W. Calkins, comm. by Farlow Herb. (in Mo. Bot. Gard. Herb., 44637).

15. C. pelliculare Karsten, Finska Vet.-Soc. Bidrag Natur och Folk 48: 411. 1889; Hedwigia 35: 46. 1896; Sacc. Syll. Fung. 9: 232. 1891; Bourdot \& Galzin, Soc. Myc. Fr. Bul. 27: 239. 1911.-Cf. v. Höhnel \& Litschauer, K. Akad. Wiss. Wien Sitzungsber. 115: 1556.1906. 
Type: fragment of type and authentic specimen in Burt Herb.

Fructifications broadly effused, thin, membranaceous, tender, small pieces separable, white when fresh, becoming ivory-yellow to cream-buff in the herbarium, even, somewhat cracked and showing a loose, cottony subiculum which extends out beyond the hymenium as a fimbriate, white margin; in section 100-300 $\mu$ thick, not colored, composed of loosely interwoven and ascending, thin-walled hyphae $2 \frac{1}{2}-3 \frac{1}{2} \mu$ in diameter, sparingly nodoseseptate, rarely incrusted in the subhymenium; no gloeocystidia; spores hyaline, even, $4-6 \times 2-3 \mu$.

Fructifications 2-6 cm. long, 1-3 cm. wide.

On decaying limbs of both coniferous and frondose species. In Europe and from New Hampshire to Pennsylvania, in Illinois, British Columbia to Mexico, and in Bermuda. June to December. Infrequent.

$P$. pelliculare has delicate white to creamy fructifications distinguishable from those of $C$. lacteum by the small spores not at all globose.

Specimens examined:

Exsiccati: Thümen, Myc. Univ., 1607, under the name Corticium laeve.

Finland: Mustiala, P. A. Karsten, fragment of type comm. by Karsten to Bresadola and by Bresadola to Romell and by Romell to Burt.

Sweden: K. Starback, authentic specimen comm. by Karsten; $L$. Romell, 319; Femsjö, E. A. Burt, two gatherings; Stockholm, L. Romell, 298A, 320.

New Hampshire: Chocorua, W. G. Farlow, C37 (in Mo. Bot. Gard. Herb., 43968).

Vermont: Middlebury, E. A. Burt.

New York: Albany, H. D. House (in N. Y. State Mus. Herb., and in Mo. Bot. Gard. Herb., 57490); Orient Point, R. Latham, 3 (in N. Y. State Mus. Herb., and Mo. Bot. Gard. Herb., 55700). New Jersey: Belleplain, C. L. Shear, 1237; Newfield, J. B. Ellis, in Ell. \& Ev. Fungi Col., 1207.

Pennsylvania: Bear Meadows, L. O. Overholts, 2890 (in Mo. Bot. Gard. Herb., 5717); Trexlertown, W. Herbst, 15.

Michigan: Ann Arbor, C. H. Kauffman, 19. 
Illinois: Helleydayboro, C. J. Humphrey, 1351 (in Mo. Bot. Gard. Herb., 59017); Port Byron, E. T. \& S. A. Harper, 733. British Columbia: Kootenai Mts., Salmo, J. R. Weir, 456 (in Mo. Bot. Gard. Herb., 13043) ; Sidney, J. Macoun, 11 (in Mo. Bot. Gard. Herb., 5729).

Washington: Bingen, W. N. Suksdorf, 879, 919.

Arizona: Flagstaff, W. H. Long, 19491 (in Mo. Bot. Gard. Herb., 44738, 55135); First Valley Experiment Station, W. H. Long, 21119 (in Mo. Bot. Gard. Herb., 55136).

Mexico: Chihuahua, Parral, E. O. Mathews, 2, 26 (in Mo. Bot. Gard. Herb., 44126, 44125); Guernavaca, W. A. \& E. L. Murrill, 418, comm. by N. Y. Bot. Gard. Herb. (in Mo. Bot. Gard. Herb. 54512).

Bermuda: on cornstalks, S. Brown, N. L. Britton \& F. J. Seaver, 11248 (in N. Y. Bot. Gard. Herb. and Mo. Bot. Gard. Herb., $4809)$.

16. C. Auberianum Montagne in La Sagra, Hist. de Cuba 9²: 226. 1845; Syll. Crypt. 178. 1856; Sacc. Syll. Fung. 6: 616. 1888; Massee, Linn. Soc. Bot. Jour. 27: 135. 1890.

Type: part of type in Kew Herb.

Fructifications effused, orbicular at first, becoming longitudinally elongated, adnate, very thin, white, floccose-farinaceous, even, sometimes somewhat cracked, the margin thinning out, floccose; in section $45-120 \mu$ thick, not colored, composed of suberect, branching, interwoven, thin-walled hyphae about $2 \mu$ in diameter, not nodose-septate; no gloeocystidia; no cystidia; spores hyaline, even, flattened on one side, $4-5 \times 2-3 \mu$.

Fructifications at first $2-10 \mathrm{~mm}$. in diameter, finally up to 10 cm. long, $1 \mathrm{~cm}$. broad.

On small decaying, fallen twigs of frondose species. Vermont to Louisiana, and in the West Indies. August to March. Rare.

C. Auberianum may be recognized by its very thin, snow-white fructifications having a farinose hymenial surface, small spores, and slender, thin-walled hyphae throughout. No gloeocystidia are present nor coarse hyphae near substratum. The occurrence of several small fructifications near together when young is characteristic. The hyphae are probably somewhat incrusted, but this needs confirmation. 
Specimens examined:

Vermont: $E$. A. Burt, two gatherings.

North Carolina: Blowing Rock, G. F. Atkinson, 4330.

South Carolina: On Carya, Curtis Herb., 2497 (in Kew Herb.).

Georgia: Tallulah Falls, A. B. Seymour, comm. by Farlow Herb.,

DD (in Mo. Bot. Gard. Herb., 44595).

Florida: Sands Key, R. A. Harper, 6 (in Mo. Bot. Gard. Herb., 54537).

Louisiana: St. Martinville, A. B. Langlois, Q, R.

Arkansas: Womble, W. H. Long, 19823, 19821, in part (in Mo. Bot. Gard. Herb., 8633, 17801).

Bermuda: Walsingham, H. H. Whetzel, Aat (in Mo. Bot. Gard. Herb., 58718).

Cuba: presumable part of type from Montagne to Berkeley (in Kew Herb.); Managua, Earle \& Murrill, 26, comm. by N. Y. Bot. Gard. Herb.; San Antonio de los Baños, Havana Province, Earle \& Murrill, 46, comm. by N. Y. Bot. Gard. Herb.; San Diego de los Baños, Havana Province, Earle \& Murrill, 332, comm. by N. Y. Bot. Gard. Herb.; locality not stated, C. G. Lloyd, 480 (in Mo. Bot. Gard. Herb., 55176).

\section{C. galactinum (Fr.) Burt, in Moffatt, Chicago Acad.} Sci. Bul. $7: 137.1909$.

Thelephora galactina Fries, R. Soc. Sci. Upsal. Acta III. 1: 136. 1851; Sacc. Syll. Fung. 6: 541. 1888; von Schrenk, Bot. Gaz. 34: 65 . 1902. - An Corticium rigescens Berk. \& Curtis in Cooke, Grevillea $20: 12$. 1891?

Type: in Fries Herb. and Curtis Herb.

Fructifications long and broadly effused, becoming rather thick, coriaceous-soft, closely adnate, small pieces separable, white to cream-color, waxy, even, not cracked, the margin indeterminate, thinning out, with the hyphae interwoven; in section 200-1000 $\mu$ thick, not colored, composed of suberect, densely interwoven, hyaline hyphae about 1-2 $\mu$ in diameter, not incrusted; no gloeocystidia; curved ends of the hyphae or their branches form the surface of the hymenium and are about $1 / 2-1 \mu$ in diameter; spores white in spore collection, $4-51 / 2 \times 2-3 \mu$.

Fructifications $4-12 \mathrm{~cm}$. long, 2-4 cm. wide. 
On roots of living apple and blackberry plants, on the ground, and broadly effused on rotting logs of frondose and coniferous species. Canada to Texas and westward to the Pacific coast, in West Indies and in Japan. Throughout the year. Common.

C. galactinum resembles $C$. portentosum in aspect but has a more erect hyphal structure and is usually not at all stratose and with substance not colored. Both species have a hymenial surface composed of fine, curved hyphal branches, but the spores of $C$. galactinum are smaller and ellipsoid and those of $C$. portentosum spherical. The mycelium of $C$. galactinum was collected as a parasitic root rot on the roots of young apple trees and blackberry bushes and developed mature fructifications. The collector's data on the type specimen of this species is "In radicibus ad latera fossarum."

Specimens examined:

Exsiccati: Ravenel, Fungi Car. 4: 15, under the name Corticium calceum.

Canada: J. Macoun, 26, 31, 111; Lower St. Lawrence Valley, J. Macoun, 4, 9, 35, 83 .

Ontario: Lake Rosseau, E. T. \& S. A. Harper, 638, 640; Nixon, J. Dearness, 1023 (in Mo. Bot. Gard. Herb., 22732); Ottawa, J. Macoun, 56, 248, in part; Temagami, H. von Schrenk (in Mo. Bot. Gard. Herb., 57053).

Maine: New Limerick, H. von Schrenk, 62 (in U. S. Dept. Agr. Herb. and Burt Herb.); Piscataquis County, W. A. Murrill, 1881 (in N. Y. Bot. Gard. Herb., Mo. Bot. Gard. Herb., 61423, and Burt Herb.).

New Hampshire: Chocorua, W. G. Farlow (in Mo. Bot. Gard. Herb., 19544); North Conway, L. O. Overholts, 4555, 4584 (in Mo. Bot. Gard. Herb., 55635, 55634).

Vermont: Grand View Mt., E. A. Burt; Little Notch, E. A. Burt; Middlebury, E. A. Burt, five gatherings.

New York: Arkville, W. A. Murrill (in N. Y. Bot. Gard. Herb., and Mo. Bot. Gard. Herb., 61362, 61363); Cranberry Lake, A. H. W. Povah, 772 (in Mo. Bot. Gard. Herb., 3730); East Galway, E. A. Burt; Floodwood, E. A. Burt, C. H. Peck, 12; Forestburgh, C. H. Peck, comm. by N. Y. State Mus. Herb. (in Mo. Bot. Gard. Herb., 56049); Freeville, G. F. Atkinson, 
18186; Gansevoort, C. H. Peck, comm. by N. Y. State Mus. Herb. (in Mo. Bot. Gard. Herb., 55982) ; Ithaca, G. F. Atkinson, 2869, 4898; Jenkinsville, S. H. Burnham, 40 (in Mo. Bot. Gard. Herb., 54452); Karner, H. D. House, comm. by N. Y. State Mus. Herb. (in Mo. Bot. Gard. Herb., 55197); Lake Placid, W. A. \& E. L. Murrill, 270 (in N. Y. Bot. Gard. Herb., and Mo. Bot. Gard. Herb., 61578); North Elba, C. H. Peck, 12, and (in N. Y. State Mus. Herb., T 26, and Mo. Bot. Gard. Herb., 54652); Oneida, H. D. House, comm. by N. Y. State Mus. Herb. (in Mo. Bot. Gard. Herb., 57414); Pompey, L. M. Underwood, 25, 107, $35 \%$ (in N. Y. Bot. Gard. Herb., and Mo. Bot. Gard. Herb., 61432, 61431, 61575); West Fort Ann, S. H. Burnham, 13, in part (in Mo. Bot. Gard. Herb., 54505); White Plains, L. M. Underwood (in N. Y. Bot. Gard. Herb., and Mo. Bot. Gard. Herb., 61574).

Pennsylvania: Mt. Gretna, E. A. Burt; State College, L. O. Overholts, 4711 (in Mo. Bot. Gard. Herb., 56116).

Virginia: Woodstock, C. L. Shear, 1195.

South Carolina: H.W. Ravenel, in Ravenel, Fungi Car. 4: 15, on pine, and type (in Fries Herb., and Curtis Herb., 1601).

Florida: W. W. Calkins (in U. S. Dept. Agr. Herb., and Burt Herb.); Starke, C. L. Shear, 2904 (in Mo. Bot. Gard. Herb., 15311); Tallahassee, E. Bartholomew, 5708 (in Mo. Bot. Gard. Herb., 44255).

Louisiana: Bogalusa, C. J. Humphrey, 5516; St. Martinville, A. B. Langlois, 607 (in U. S. Dept. Agr. Herb., and Burt Herb.), $1762, X$.

Texas: Houston, H. W. Ravenel, 268 (in U. S. Dept. Agr. Herb., and Burt Herb.).

West Virginia: Eglon, C. G. Lloyd, 02643.

Ohio: Cincinnati, A. P. Morgan, comm. by Lloyd Herb., 2604. Illinois: on apple roots, H. von Schrenk; River Forest, E. T. \& S. A. Harper, 655 .

Michigan: Mass, C. J. Humphrey, 1583 (in Mo. Bot. Gard. Herb., 10743); Three Lakes, C. J. Humphrey, 1602 (in Mo. Bot. Gard. Herb., 17883); Vermilion, A. H. W. Povah, 203 (in Mo. Bot. Gard. Herb., 15326).

Missouri: Grandin, H. von Schrenk (in Mo. Bot. Gard. Herb., 
43022); St. Louis, on apple roots, H. von Schrenk, three gatherings.

Arkansas: on blackberry roots, G. M. Darrow (in Mo. Bot. Gard. Herb., 63734); on apple roots, H. von Schrenk; Fordyce, C. J. Humphrey, 5812; Womble, W. H. Long, 19816, 19898, 19864, 21104 (in Mo. Bot. Gard. Herb., 8958, 8634, 8635, 55144).

Colorado: Golden, L. O. Overholts, 1745 (in Mo. Bot. Gard. Herb., 54874).

Montana: Como, E. E. Hubert, comm. by J. R. Weir, 11959 (in Mo. Bot. Gard. Herb., 63316); Evaro, J. R. Weir, 437 (in Mo. Bot. Gard. Herb., 14387); Rexford, E. E. Hubert, comm. by J. R. Weir, 11977 (in Mo. Bot. Gard. Herb., 63330).

Idaho: Coeur d'Alene, E. E. Hubert, comm. by J. R. Weir, 12002 (in Mo. Bot. Gard. Herb., 63364); Coolin, J. R. Weir, 11504 (in Mo. Bot. Gard. Herb., 63285); Priest River, J. R. Weir, 15, and 133, 346 (in Mo. Bot. Gard. Herb., 12119, 7561), and E. E. Hubert, comm. by J. R. Weir, 12025 (in Mo. Bot. Gard. Herb., 63378 ) ; St. Maries, J. R. Weir, comm. by C. J. Humphrey, 2556 (in Mo. Bot. Gard. Herb., 13030), and E. E. Hubert, comm. by J. R. Weir, 11997 (in Mo. Bot. Gard. Herb., 63360).

Manitoba: Winnipeg, G. R. Bisby \& I. L. Conner, 1102 (in Mo. Bot. Gard. Herb., 59038).

British Columbia: Kootenai Mts., near Salmo, J. R. Weir, 457, 500, 508, 531, 542 (in Mo. Bot. Gard. Herb., 9122, 21631, 20270, 23118, 14254).

Washington: Chehalis, C. J. Humphrey, 6289 (in Mo. Bot. Gard. Herb., 10751); Lake Wilderness, C. H. Kauffman, 17 (in Mo. Bot. Gard. Herb., 4674); Renton, C. J. Humphrey, 6640; Sedro Woolley, C. J. Humphrey, 7568 (in Mo. Bot. Gard. Herb., 10775).

Cuba: Ceballos, C. J. Humphrey, 2790 (in Mo. Bot. Gard. Herb., 9083).

Porto Rico: Rio Piedras, J. A. Stevenson, 1195, 3224 (in Mo. Bot. Gard. Herb., 6949, 7734).

Japan: Hiroto-Mura, Prov. Awaji, A. Yasuda, 24 (in Mo. Bot. Gard. Herb., 55662); Mt. Mikuma, Prov. Awaji, A. Yasuda, 17 (in Mo. Bot. Gard. Herb., 55661). 
18. C. calceum Fries emend. Romell \& Burt

C. calceum Fries, Epicr. 562. 1838, in part; Hym. Eur. 652. 1874, in part; Sacc. Syll. Fung. 6:622. 1888, in part.-Thelephora calcea Fries var. glebulosa Fries, Elench. Fung. 2: 215. 1828. - Not Peniophora glebulosa Bresadola, Fungi Trid. 2: 61 pl. 170, f. 2. 1898.

Type: in Fries Herb. and a fragment in Burt Herb.

Fructifications broadly effused, very thin, closely adnate, not at all separable, floccose-membranaceous, white, sometimes becoming ivory-yellow in the herbarium, even, cracking to the substratum into small rectangular masses 1-4 to a mm., the margin farinose; in section 100-200 $\mu$ thick, not colored, with the hyphae erect, densely crowded together and interwoven, somewhat conglutinate, short-celled, $1-11 / 2 \mu$ in diameter, sometimes with algal cells imbedded; no gloeocystidia nor cystidia; spores hyaline, even, $3-51 / 2 \times 1 \frac{1}{2}-2 \mu$.

Fructifications $3-20 \mathrm{~cm}$. long, 1-5 cm. wide.

Under side of decaying rails of Pinus sylvestris and P. Strobus, and on decaying wood of logs of $P$. monticola and Thuja. In Sweden and from Vermont and New Jersey to Idaho and British Columbia. July to November. Abundant when found.

Since $C$. calceum var. glebulosum is all that now remains under C. calceum after the segregation under other names of all other components, no confusion should result from the present proposed restriction of the species $C$. calceum. It may be added that the original description of $C$. calceum applies better to the emended species than to any of the other components withdrawn. Bresadola studied the Friesian type of Thelephora calcea var. glebulosa and identified it with Peniophora glebulosa, a species very common throughout Europe. He shared a portion of his Friesian type with me and accompanied it with notes on microscopic details in which he stated, "Cystidia adsunt sed collapsa." However, no cystidia are present in this fragment, nor in the type in Fries Herb., nor in ample collections of the species made by Romell and myself at the type station, Femsjö. I have not been able to recognize this species in the extensive series of Corticiums received from countries of Europe other than Sweden. Since the species is widely distributed and abundant in northern United 
States, it is possible that it is a North American endemic species which became established in Sweden as an outlying station, comparable with cases of Stereum rufum, Stereum Murrayi, etc.

Specimens examined:

Exsiccati: Ell. \& Ev., N. Am. Fungi, 2807, under the name Corticium scutellare; Ell. \& Ev., Fungi Col., 104, under the name Corticium scutellare.

Sweden: Femsjö, E. Fries, type of Thelephora calcea var. glebulosa (in Fries Herb., and fragment in Burt Herb.), L. Romell, 185, 211, and Romell \& Burt, two gatherings; Stockholm, L. Romell, 321, 322, 324, 325 .

Canada: J. Macoun, 1, 34; Lower St. Lawrence Valley, J. Macoun, $5 \%$.

Vermont: Middlebury, E. A. Burt, two gatherings.

New York: Bolton, C. H. Peck, 9; Clearwater, G. F. Atkinson, 5046; Floodwood, C. H. Peck, 11; Ithaca, G. F. Atkinson, 941, 22972; Schuylerville, C. H. Peck, 20.

New Jersey: Newfield, J. B. Ellis, in Ell. \& Ev., N. Am. Fungi, 2807, and in Ell. \& Ev., Fungi Col., 104.

Pennsylvania: State College, L. O. Overholts, 4809 (in Mo. Bot. Gard. Herb., 56119).

Michigan: Mass, C. J. Humphrey, 1662 (in Mo. Bot. Gard. Herb., 17607).

Wisconsin: Lake Glencoe, E. T. \& S. A. Harper, 853.

Idaho: Priest River, J. R. Weir, 40, 64, and 6350 (in Mo. Bot. Gard. Herb., 58387).

British Columbia: Kootenai Mts., near Salmo, J. R. Weir, 461, 463, 533 (in Mo. Bot. Gard. Herb., 9119, 12631, 20973).

\section{C. vescum Burt, n. sp.}

Type: in Mo. Bot. Gard. Herb.

Fructifications effused, closely adnate, very thin, not at all separable, from white to pale drab-gray in the herbarium, even, not shining, not cracked, the margin thinning out, indeterminate; in section 20-30 $\mu$ thick, not colored, very compact, composed of very short, erect hyphae which terminate in basidia; no gloeocystidia; spores hyaline, even, allantoid, $4 \frac{1}{2} \times 1 / 2^{-1} \mu$.

Fructifications up to $6 \mathrm{~cm}$. long, $3 \mathrm{~cm}$. wide. 
On decorticated pine limb completely decayed by a brittle, brown rot. Maryland and Alabama. October.

C. vescum looks like a thin, whitish or somewhat cinereous wash in water color on the surface of the weathered pine limb. No interwoven hyphal structure is visible under a lens, for the short basal hyphae start out vertically from the substratum and terminate in basidia packed closely together in the hymenium.

Specimens examined:

Maryland: Takoma Park, C. L. Shear, 961.

Alabama: Montgomery, R. P. Burke, 476, type (in Mo. Bot.

Gard. Herb., 57294).

\section{C. incanum Burt, n. sp.}

Type: in Burt Herb.

Fructifications effused, very thin, closely adnate, not separable, becoming pearl-gray to mineral-gray in the herbarium, even, waxy, not cracked, the margin thinning out, indeterminate; in section 20-75 $\mu$ thick, not colored, composed of densely interwoven, hyaline hyphae $21 / 2^{-3} \mu$ in diameter, rarely nodose-septate, not incrusted; no gloeocystidia; basidia simple, with 4 short, blunt sterigmata; spores hyaline, even, about $31 / 2^{-4} \times 11 / 2^{-3} \mu$.

Fructifications 4-8 cm. long, 1-2 cm. wide.

On bark and wood of dead Acer and other frondose limbs. Canada to North Carolina. October and November.

C. incanum forms a thin, inseparable coating of mineral-gray color over bark and wood of frondose species usually. The aspect is so similar to that of common Peniophora cinerea that it is likely to be passed by as the latter, if examination of microscopic structure is not made.

Specimens examined:

Canada: J. Macoun, 36; Ottawa, J. Macoun, 32, 34.

Vermont: Middlebury, E. A. Burt.

New York: Karner, H. D. House, comm. by N. Y. State Mus. Herb. (in Mo. Bot. Gard. Herb., 54384).

New Jersey: Belleplain, C. L. Shear, 1249, type.

North Carolina: Chapel Hill, J. N. Couch, 4225, comm. by W. C.

Coker, under the name C. ochraceo-niveum (in Mo. Bot. Gard. Herb., 57412). 
21. C. canum Burt, n. sp.

Type: in Burt Herb.

Fructifications effused, thin, hypochnoid, tender, not separable, whitish to pale pinkish buff in the herbarium, even, with the hymenium fibrillose under a lens rather than in the form of a continuous pellicle, the margin thinning out, arachnoid; in section 100-180 $\mu$ thick, not colored, composed of lax, loosely interwoven hyphae $21 / 2 \mu$ in diameter, thin-walled, nodose-septate, not incrusted, bearing a more compact hymenium; no gloeocystidia: spores hyaline, even, $3-4 \times 1 \frac{1}{2}-2 \mu$.

Fructifications $3-5 \mathrm{~cm}$. long, $1 / 2-11 / 2 \mathrm{~cm}$. wide.

On decaying wood and bark of conifers. Canada to Louisiana and in Washington. September to October. Infrequent.

$C$. canum belongs in the group with $C$. centrifugum and $C$. pelliculare but differs from both in more hypochnoid structure and smaller spores. The hyphae are nodose-septate and not incrusted.

Specimens examined:

Canada: J. Macoun, 13, type, and 86 , in part.

New York: Ithaca, G. F. Atkinson, 2568.

Maryland: Takoma Park, C. L. Shear, 1063.

Louisiana: St. Martinville, A. B. Langlois, 168, comm. by Lloyd Herb., 3046.

Idaho: Coolin, J. R. Weir, 11101 (in Mo. Bot. Gard. Herb., 63391); Priest River, J. R. Weir, 21.

British Columbia: Salmo, Kootenai Mts., J. R. Weir, 447 (in

Mo. Bot. Gard. Herb., 21800).

Washington: Hoquiam, C. J. Humphrey, 6375, 6413.

22. C. centrifugum (Lév.) Bresadola, Ann. Myc. 1:96. 1903; v. Höhnel, Ann. Myc. 3: 188. 1905; Bourdot \& Galzin, Soc. Myc. Fr. Bul. $27: 240.1911$.

Rhizoctonia centrifuga Léveillé, Ann. Sci. Nat. Bot. II. 20 : 225. 1843.-Hypochnus centrifugus Tulasne, Fung. Carp. 1: 113. 1861; Sacc. Syll. Fung. 6: 654. 1888.-Corticium decipiens v. Höhnel \& Litschauer, K. Akad. Wiss. Wien Sitzungsber. 117: 1116.1908.

Fructifications effused, very thin, arachnoid, forming a con- 
tinuous hymenial pellicle, fragile, white, becoming pale olivebuff in the herbarium, even, the margin arachnoid or byssoid; in section $75-150 \mu$ thick, not colored, with the hyphae loosely interwoven, thin-walled, not incrusted, usually $2-3 \mu$ in diameter, sometimes with a few coarser and up to $6 \mu$ in diameter along the substratum, only rarely nodose-septate; no gloeocystidia; spores hyaline, even, ellipsoidal, $4-8 \times 21 / 2-4 \mu$.

Fructifications 2-6 cm. long, 1-3 cm. wide.

On decaying wood and leaves and fallen branches. Common in Europe, infrequent from Canada to Louisiana and westward to the Pacific and in the West Indies. June to February.

C. centrifugum is related to $C$. arachnoideum and C. pelliculare. Its more elongated spores, thinner and less arachnoid fructifications, and hyphae with only very few clamp connections separate it from $C$. arachnoideum, while $C$. pelliculare becomes more yellow in the herbarium, is likely to show some hyphal incrustation, and has rather smaller spores and a more compact hymenium. According to the original description $C$. decipiens differs by not having clamp connections but they are certainly present in the authentic specimen communicated by Litschauer.

Specimens examined:

Exsiccati: Ell. \& Ev., Fungi Col., 309, under the name Corticium arachnoideum.

Sweden: L. Romell, 76; Stockholm, L. Romell, 60, 61, 168, 296, 348.

Germany: W. Brinkmann, comm. by Bresadola.

Austria: Klosterberg, Tirol, V. Litschauer, and another specimen under the name $C$. decipiens, determined and comm. by Litschauer.

Canada: Ottawa, J. Macoun, 49, 52.

Maine: Kittery Point, R. Thaxter (in Mo. Bot. Gard. Herb., $57606)$.

New Hampshire: Chocorua, W. G. Farlow; Shelburne, W. G. Farlow, 2.

New York: East Galway, E. A. Burt; Ithaca Flats, C. O. Smith, comm. by G. F. Atkinson, 8226; Karner, H. D. House (in N. Y. State Mus. Herb., and Mo. Bot. Gard. Herb., 54350).

New Jersey: Newfield, J. B. Ellis, in Ell. \& Ev., Fungi Col., 309. 
Pennsylvania: State College, L. O. Overholts, 3630 (in Mo. Bot. Gard. Herb., 54698).

District of Columbia: Takoma Park, C. L. Shear, 1947.

Louisiana: St. Martinville, A. B. Langlois, ay.

Manitoba: Stony Mountain, A. H. R. Buller, 900 (in Mo. Bot. Gard. Herb., 58999); Winnipeg, G. R. Bisby, 1342 (in Mo. Bot. Gard. Herb., 60551).

Washington: Bingen, W. N. Suksdorf, 914.

Oregon: Corvallis, S. M. Zeller, 2066 (in Mo. Bot. Gard. Herb., $58767)$.

California: Massack, A. S. Rhoads, 18 (in Mo. Bot. Gard. Herb., 56987).

Jamaica: Castleton Gardens, W. A. \& E. L. Murrill, 67, comm. by N. Y. Bot. Gard. Herb.; Chester Vale, W. A. \& E. L. Murrill, 372, comm. by N. Y. Bot. Gard. Herb.

\section{C. Atkinsonii Burt, n. sp.}

Type: in Burt Herb.

Fructifications effused, adnate, thin, small pieces separable when moistened, white, even, waxy, not cracked, the margin thinning out, with hyphae interwoven; in section about $150 \mu$ thick, not colored, composed of interwoven, branching, thinwalled, occasionally nodose-septate hyphae $3 \mu$ in diameter, not incrusted, which have in the middle and subhymenial region an additional branched system of branches not more than $1 \mu$ in diameter and bearing short acicular branchlets; no gloeocystidia; basidia simple, usually 4 sterigmata but rarely 5 or 6 ; spores hyaline, even, $41 / 2 \times 2-21 / 2 \mu$.

Fructifications 1-3 cm. long, 1-2 cm. wide.

On decaying, charred frondose wood and on Populus. New York and Louisiana. November and January.

C. Atkinsonii has snow-white color, waxy surface and small spores. The noteworthy character separating it from other white species is the system of delicate hyphal branches, so abundant in the middle and subhymenial regions of the fructification that they mask the outlines of the usual hyphae there and so fine that on first impression they seem to be the walls of collapsed hyphae. The mode of branching is not exactly that of $C$. in- 
vestiens and $C$. jamaicense but a comparable type of hyphal differentiation. The great distance between the two stations leads me to suspect that $C$. Atkinsonii is more frequent than indicated by the collections in which the distinctive branching was observed.

Specimens examined:

New York: Altamont, E. A. Burt; Ithaca, G. F. Atkinson, 2558, type.

Louisiana: A. B. Langlois, 246, comm. by U. S. Dept. Agr. Herb.

\section{C. subnullum Burt, n. sp.}

Type: in Mo. Bot. Gard. Herb.

Fructifications effused, closely adnate, very thin, cartridgebuff to olive-buff in the herbarium, hypochnoid, not forming a continuous hymenium but with the basidia in more or less connected tufts of about 3-5 to the mm., farinaceous, the margin similar; in section 30-45 $\mu$ thick, not colored, composed of loosely arranged, hyaline hyphae $2-21 / 2 \mu$ in diameter, thin-walled, not incrusted, not nodose-septate; no gloeocystidia; spores hyaline, even, globose, $21 / 2 \mu$ in diameter, borne 4 to a basidium.

Fructifications $3-7 \mathrm{~cm}$. long, 2-3 cm. wide.

On bark of decaying logs of Populus sp. British Columbia. July.

When C. subnullum becomes better known from additional collections, it may become necessary to transfer it to another genus, but the present gathering favors the view that it is a Corticium somewhat lacking basidia so that the hymenium becomes discontinuous. This character, occurrence on poplar bark, small spores, and general aspect of an olive-buff Hyphomycete are good distinctive characters.

Specimens examined:

British Columbia: Sidney, J. Macoun, 30, type (in Mo. Bot. Gard. Herb., 63776).

25. C. crustulinum Burt, n. sp.

Type: in Mo. Bot. Gard. Herb.

Fructifications effused, thin, tender, separable, with the substance whitish, dry, soft and cottony, and the hymenium warm 
buff in the herbarium, even, pelliculose, brittle, not shining, the margin whitish, continuous with the substance, fimbriate; in section $160 \mu$ thick, not colored, composed of a layer next the substratum of loosely interwoven, hyaline, thin-walled hyphae $2 \mu$ in diameter, nodose-septate, not incrusted, and of a compactly interwoven, thin hymenium; no gloeocystidia; basidia $6 \times 3 \mu$, with 4 sterigmata; spores hyaline, even, subglobose, $3 \times 2-3 \mu$, copious.

Fructifications $5 \mathrm{~cm}$. long, $2-3 \mathrm{~cm}$. wide.

On very rotten frondose wood. Porto Rico. July.

C. crustulinum is characterized by the loosely attached, whitishmargined fructifications with yellowish hymenium borne on a white, cottony substance. The small hyphae, small basidia, and small spores are good confirmatory characters. We have no closely related species.

Specimens examined:

Porto Rico: Rio Piedras, J. A. Stevenson, 2914, type (in Mo. Bot. Gard. Herb., 3130).

26. C. tessulatum Cooke, Grevillea 6:132. 1878; Sacc. Syll. Fung. 6:619. 1888; Massee, Linn. Soc. Bot. Jour. 27: 136. 1890.

Type: type distribution in Ravenel, Fungi Am., 127.

Fructifications effused, adnate, thin, somewhat membranaceous, tender, small pieces separable, in the herbarium becoming naphthalene-yellow, with central parts light ochraceous buff, even, contracting greatly in drying, and cracking into rectangular masses 1-4 mm. in diameter separated by fissures 1-2 mm. wide, with some of the white silky subiculum clinging to the substratum, the margin whitish, fibrillose; in section 150-200 $\mu$ thick, not colored, composed of loosely interwoven, very thin-walled and collapsing hyphae $4 \mu$ in diameter, abundantly nodose-septate, not incrusted; no gloeocystidia; spores hyaline, even, $4-4 \frac{1}{2} \times$ $3 \mu$, few found.

Fructifications $2-4 \mathrm{~cm}$. in diameter.

On pine and spruce bark on the ground. Canada to South Carolina, and in Idaho and Arizona. May to October. Infrequent.

C. tessulatum is somewhat suggestive of $C$. Berkeleyi in aspect 
but is colored differently, tending towards light ochraceous-buff in the more central parts of the fructification; this color, occurrence on old pine and spruce, the wide cracks from drying, and loose attachment to substratum and tendency to scale away from it of the rectangular masses of the dried fructification are helpful characters in recognizing the species. C. illaqueatum, occurring on Castanea in France, is closely related.

Specimens examined:

Exsiccati: Ravenel, Fungi Am., 127, type distribution.

Canada: Lower St. Lawrence Valley, J. Macoun, 71, 75; Ontario, Temagami, H. von Schrenk (in Mo. Bot. Gard. Herb., 57051). Maine: Penobscot County, W. A. Murrill, 1821 (in N. Y. Bot. Gard. Herb., Burt Herb., and Mo. Bot. Gard. Herb., 59676). New Hampshire: Chocorua, W. G. Farlow, 10, and two other gatherings.

Vermont: Middlebury, E. A. Burt.

New York: Osceola, C. H. Peck (in N. Y. State Mus. Herb., and Mo. Bot. Gard. Herb., 59674, 59676).

Maryland: Takoma Park, C. L. Shear, 1066. South Carolina: Aiken, H.W. Ravenel, in Ravenel, Fungi Am., 127.

Idaho: Addie, E. E. Hubert, comm. by J. R. Weir, 11989 (in Mo. Bot. Gard. Herb., 63352).

Arizona: Flagstaff, W. H. Long, 19494 (in Mo. Bot. Gard. Herb., 44768, 44769); Interior Basin, San Francisco Peaks, W. $H$. Long, 21309, in part (in Mo. Bot. Gard. Herb., 54890).

27. C. Stevensonii Burt, n. sp.

Type: in Mo. Bot. Gard. Herb.

Fructifications effused, rather thick, fleshy-membranaceous, small pieces separable, becoming cartridge-buff to cream-buff in the herbarium, perhaps white when growing, ceraceous, slightly colliculose, becoming somewhat cracked in drying, the margin narrow, similar; in section $400-450 \mu$ thick, not colored, with an incrusted subhymenial zone, the hyphae $3-31 / 2 \mu$ in diameter, not nodose-septate, rather thick-walled and rigid, loosely interwoven and rising obliquely to the base of the compact subhymenium, conspicuously incrusted for a length of about $30 \mu$ in the incrusted 
zone and about $6 \mu$ in diameter over the incrustation; no gloeoeystidia; spores copious, hyaline, even, $6 \times 4-41 / 2 \mu$.

Fructifications in fragments $1-3 \mathrm{~cm}$. long, $1-2 \mathrm{~cm}$. wide.

On badly decayed frondose wood. Porto Rico. December.

This species resembles in aspect Peniophora cremea and $P$. mutata, and its hyphae are similarly coarse and loosely arranged but both cystidia and gloeocystidia are lacking. The incrusted zone at the base of the subhymenium is about $30 \mu$ thick and very characteristic. Each hypha assumes incrustation upon entering this zone, has position parallel to the other hyphae, and is devoid of incrustation beyond the zone.

Specimens examined:

Porto Rico: Rio Piedras, Palo Seco, La Isabell Grove, J. A. Stevenson, 3523, type (in Mo. Bot. Gard. Herb., 6635).

28. C. lacteum Fries, Epicr. 560. 1838; Hym. Eur. 649. 1874; Sacc. Syll. Fung. 6: 610. 1888; Massee, Linn. Soc. Bot. Jour. 27: 132. 1890.-Not C. lacteum of Bresadola, v. Höhnel \& Litschauer, nor probably of Bourdot \& Galzin, and Rea.

Thelephora lactea Fries, Syst. Myc. 1: 452. 1821; Elenchus Fung. 1: 205. 1828.-Corticium pellicula (Fr. ?) Karsten, Soc. pro Fauna et Fl. Fenn. Meddel. 11: 5. 1885.

Type: in Fries Herb.-the specimen determined by E. Fries. Authentic specimen in better condition in Kew Herb.- the cream-colored fructification collected by Lbd., Svex. Soderm, Oct.

Fructifications effused, thin, membranaceous, tender, small pieces separable, becoming cream-colored to cinnamon-buff in the herbarium, even, more or less cracked, the margin whitish, fibrillose; in section 150-300 $\mu$ thick, not colored, with the hyphae densely and longitudinally arranged along the substratum and then curving upward to the hymenium, $21 / 2-4 \mu$ in diameter, incrusted in the subhymenial region, occasionally nodose-septate; no gloeocystidia nor vesicular bodies; spores hyaline, even, subglobose, about 5-61/2 $\times 5-6 \mu$, pointed at the base.

Fructifications $3-8 \mathrm{~cm}$. long, $2-5 \mathrm{~cm}$. wide.

On decaying wood and limbs of coniferous and frondose species and on the ground. In Europe and in northern United States 
and Canada from Massachusetts westward to the Pacific states. May to November. Occasional.

It has been necessary to depart from the conflicting concepts of C. lacteum, and base the species on the presumably oldest existing specimen collected and determined by Fries and preserved in his herbarium under the name of Thelephora lactea. Other and more recent specimens were referred by Fries to Corticium lacteum, the genus Corticium not being used by Fries until the publication of his 'Epicrisis.' These more recent specimens are of various species as might be expected, for the exact methods of the present day in the study of resupinate Hymenomycetes were not then used, and it is probable that these later specimens have caused the confusion in current concepts of C. lacteum. It is fortunate that one of these later specimens, named by Fries, agrees with the original specimen, is in better condition than the original specimen, and is preserved in Kew Herbarium where it is convenient for comparison. C. lacteum, as understood from these specimens, belongs in a group of species of similar aspect having globose spores about $6 \mu$ in diameter. The other members of this group are C.radiosum, and C. abeuns. C. pelliculare has the same aspect as the others named but its spores are not globose. When one knows any one of the above group of species the other species should be readily recognized as they are found, for $C$. lacteum has rather coarse, loosely arranged, more or less granule-incrusted hyphae, and lacks gloeocystidia and vesicular bodies; $C$. abeuns has wholly immersed gloeocystidia of the usual kind; and $C$. radiosum has vesicular organs which are at first like those of $C$. polyonium but become much more inflated and with highly attenuated wall, and finally perhaps are shown only by vesicular spaces between the massed hyphae.

Specimens examined:

Sweden: type, under the name Thelephora lactea (in Herb. Fries);

Svex. Söderm., Lindblad, determined by E. Fries as Corticium lacteum (in Kew Herb.); Stockholm, L. Romell, 114, 179, 327.

Finland: Mustiala, P. Karsten, comm. by Karsten under the name Corticium pellicula Fr.?

France: Fautrey, determination as Corticium lacteum approved by Patouillard for Lloyd, comm. by C. G. Lloyd, 4368. 
Canada: J. Macoun, 29, and an unnumbered specimen from Ellis Herb., comm. by W. G. Farlow (in Mo. Bot. Gard. Herb., 44640); Ironsides, J. Macoun, 286 (in N. Y. Bot. Gard. Herb., and Mo. Bot. Gard. Herb., 61348); Lower St. Lawrence Valley, J. Macoun, 45, 47, 90; Ottawa, J. Macoun, 57, and 165 and 349 (in N. Y. State Mus. Herb., and Mo. Bot. Gard. Herb., 56052,55921 ).

Vermont: Middlebury, E. A. Burt, 2 gatherings.

Massachusetts: Magnolia, W. G. Farlow.

New York: Albany, H. D. House \& J. Rubinger, comm. by N. Y. State Mus. Herb. (in Mo. Bot. Gard. Herb., 7462); Altamont, E. A. Burt; Freeville, G. F. Atkinson, 2586; Hague, C. H. Peck, 11; Ithaca, G. F. Atkinson, 2870, 14100; Sandlake, C. H. Peck (in N. Y. State Mus. Herb., and Mo. Bot. Gard. Herb., 55748); Warrensburg, C. H. Peck, comm. by N. Y. State Mus. Herb. (in Mo. Bot. Gard. Herb., 55976).

Pennsylvania: Carbondale, E. A. Burt.

Alabama: Montgomery, R. P. Burke, 220 (in Mo. Bot. Gard. Herb., 57094).

Ohio: Cincinnati, A. P. Morgan, comm. by Lloyd Herb., 2617. Michigan: Ann Arbor, C. H. Kauffman, 24, 38 (in Mo. Bot. Gard. Herb., 17172, 18617); New Richmond, C. H. Kauffman, 25, 33, 42 (in Mo. Bot. Gard. Herb., 17035, 20030, 22870).

Wisconsin: Blue Mounds, A. O. Stucki, 37.

Illinois: Peoria, C. J. Humphrey, 1990 (in Mo. Bot. Gard. Herb., 17518).

Idaho: Bonanza, G. G. Hedgcock, comm. by C. J. Humphrey, 2557, in part; Coolin, J. R. Weir, 11574 (in Mo. Bot. Gard. Herb., 63302).

Colorado: Uncompaghre National Forest, G. G. Hedgcock, comm. by C. J. Humphrey, 2546.

British Columbia: Sidney, J. Macoun, 84 (in Mo. Bot. Gard. Herb., 55346).

Washington: Chiquash Mountains, W. N. Suksdorf, 842; Seattle, W. A. Murrill, 151, comm. by N. Y. Bot. Gard. Herb. (in Mo. Bot. Gard. Herb., 55727).

California: Massack, A. S. Rhoads, 21 (in Mo. Bot. Gard. Herb., 56990). 
29. C. subgiganteum Berkeley, Grevillea 2: 3 . 1873; Sacc. Syll. Fung. 6: 632. 1888; Lyman, Boston Soc. Nat. Hist. Proc. 33: 151. pl. 18, f. 2-21, pl. 26, f. 137. 1907.

Peniophora subgigantea (Berk.) Massee, Linn. Soc. Bot. Jour. 25: 142. 1889.-Michenera artocreas Berk. \& Curtis, Linn. Soc. Bot. Jour. 10: 333. 1868; Sacc. Syll. Fung. 6: 653. 1888; Patouillard, Soc. Myc. Fr. Bul. 7: 42. pl. 4, f. 1-5. 1891; Essai Taxon. 67. 1900; Peirce, Torr. Bot. Club Bul. 17: 305. pl. 110, f. k-n. 1890; Lyman, Boston Soc. Nat. Hist. Proc. 33: 157. pl. 18, f. 6-21, pl. 26, f. 137. 1907.-An Corticium gilvidum Bresadola, Ann. Myc. 18: 46. 1920?

Type: in Kew Herb. and Farlow Herb.

Basidiosporic stage broadly effused, adnate, thick, membranaceous, separable in small pieces when moist, drying light buff to light ochraceous-buff, even, glabrous, not cracked, the margin whitish, sometimes buff when old; in section 500-1000 $\mu$ thick, not colored, with the hyphae densely interwoven, about $2-21 / 2 \mu$ in diameter, not incrusted, not nodose-septate; no gloeocystidia; paraphyses with pointed tips; basidia large with 4 sterigmata usually; basidiospores hyaline, even, globose or subglobose, 14-19 $\mu$ in diameter or 14-19 $\times 12-16 \mu$.

Chlamydosporic or Michenera fructifications disk-shaped, concave, drying snuff-brown, cracked, the margin acute, thick, white on its elevated side; in section 1-2 mm. thick, composed of a thick basal layer of densely interwoven hyphae about $2 \mu$ in diameter which terminate in sporiferous ends and branches densely crowded together in the concave layer at surface of the fructifications; sporophores consist of each a single chlamydospore terminating in a slender, flexuous, tapering terminal appendage up to 10-50 $\mu$ long; chlamydospores ovoid, even, 12-20 × 10-15 $\mu$.

Basidiosporic fructifications $2-15 \mathrm{~cm}$. long, $1-4 \mathrm{~cm}$. wide; Michenera fructifications $6-8 \mathrm{~mm}$. in diameter.

On bark of dead limbs of Acer rubrum, Magnolia, and Liriodendron. In swamps in the Atlantic states from Canada to Cuba. July to February. Occasional.

Fructifications of the perfect stage bear some resemblance in general aspect to those of $C$. portentosum but are readily distinguished by the much larger spores. When growing on the 
same twigs the perfect fructifications occur normally on the under side of the twigs with the imperfect ones opposite on the upper side.

Specimens examined:

Exsiccati: Ell. \& Ev., N. Am. Fungi, 3102, under the name Corticium ochroleucum var. resupinatum.

Canada: Quebec, Hull, J. Macoun, 149; Ontario, Ottawa, J. Macoun, comm. by N. Y. State Mus. Herb. (in Mo. Bot. Gard. Herb., 55802).

Maine: Kittery Point, $R$. Thaxter, comm. by G. R. Lyman.

New Hampshire: Chocorua, W. G. Farlow (in Mo. Bot. Gard. Herb., 55580) ; North Conway, comm. by L. O. Overholts, 5062 (in Mo. Bot. Gard. Herb., 56354).

Vermont: Middlebury, C. G. Lloyd, 10623 (in Mo. Bot. Gard. Herb., 44639).

Connecticut: near Moosup River, J. L. Sheldon, comm. by C. J. Humphrey, 2526 (in Mo. Bot. Gard. Herb., 18559).

New York: Karner, C. H. Peck (in N. Y. State Mus. Herb., and Mo. Bot. Gard. Herb., 55782).

New Jersey: Newfield, J. B. Ellis, comm. by Lloyd Herb., 1442, by. Farlow Herb. (in Mo. Bot. Gard. Herb., 55584), and in Ell. \& Ev., N. Am. Fungi, 3102.

Virginia: Clarendon, W. H. Long, 12715 (in Mo. Bot. Gard. Herb., 55060).

North Carolina: Transylvania County, W. A. Murrill \& H. D. House, 423, comm. by N. Y. Bot. Gard. Herb. (in Mo. Bot. Gard. Herb., 56586).

South Carolina: Aiken, H. W. Ravenel, 1669, type (in Kew Herb. and Farlow Herb.).

Alabama: Auburn, G. F. Atkinson, 2364.

Cuba: C. Wright, type of Michenera artocreas (in Farlow Herb.).

30. C. ceraceum Berk. \& Rav. in Ravenel, Fungi Car. Exs. 3. 29. 1855, without description; Massee, Linn. Soc. Bot. Jour. 27: 150. 1890; v. Höhnel \& Litschauer, K. Akad. Wiss. Wien Sitzungsber. 116: 785. text f. 6. 1907.

Corticium molle Berk. \& Curtis, Linn. Soc. Bot. Jour. 10: 336. 1868; Grevillea 1: 180. 1873.-Not Corticium molle Fries.C. armeniacum Sacc. Syll. Fung. 6: 637. 1888. 


\section{Type: type distribution in Ravenel, Fungi Car. 3: 29.}

Fructifications broadly effused, ceraceous-fleshy, drying membranaceous, small pieces separable when moistened, becoming cinnamon-buff to army-brown in the herbarium, even, shining, not cracking, the margin paler, narrow, with hyphae interwoven; in structure $100-400 \mu$ thick, not colored, composed of erect, densely interwoven, agglutinate, thick-walled hyphae $2 \frac{1}{2}-3 \mu$ in diameter, not incrusted, rarely, if at all, nodose-septate; no gloeocystidia; spores hyaline, even, flattened on one side, 10-16 $\times 41 / 2-7 \mu$.

Fructifications 1-10 cm. long, 1-3 cm. wide; sometimes confluent over areas up to $1 \mathrm{~m}$. long.

On decaying trunks of frondose species. New Jersey to Mexico, in the West Indies, and in South Africa. Throughout the year. Uncommon.

C. ceraceum varies in the thickness of its fructifications which are usually cinnamon to ochraceous-orange in color and sometimes become very large. The spores are so very large that they afford a good distinctive character but are most likely to be found in crushed preparations of the hymenium.

Specimens examined:

Exsicatti: Ellis, N. Am. Fungi, 607; Ravenel, Fungi Am., 453;

Fungi Car. 3: 29, type distribution.

New Jersey: Newfield, J. B. Ellis, comm. by Lloyd Herb.

Virginia: Woodstock, C. L. Shear, 1193.

North Carolina: Biltmore Estate, W. A. Murrill (in N. Y. Bot. Gard. Herb., and Mo. Bot. Gard. Herb., 61351).

South Carolina: H. W. Ravenel, in Ellis, N. Am. Fungi, 607, and type in Ravenel, Fungi Car. 3: 29; Aiken, H. W. Ravenel, in Ravenel, Fungi Am., 453; Black Rock, H.W. Ravenel, 1261 (in Curtis Herb.).

Alabama: Montgomery, R. P. Burke, 133 (in Mo. Bot. Gard. Herb., 10951).

Louisiana: Lafayette County, A. B. Langlois, 1467; St. Martinville, A. B. Langlois, 41, comm. by Lloyd Herb., and 2709, and $G$.

Mexico: Orizaba, W. A. \& E. L. Murrill, 789, comm. by N. Y. Bot. Gard. Herb. (in Mo. Bot. Gard. Herb., 54615). 
Cuba: C. Wright, type of Corticium molle B. \& C. (in Curtis Herb., 202); Alto Cedro, Earle \& Murrill, comm. by N. Y. Bot. Gard. Herb.

Africa: locality not given, P. A. van der Bijl, 19 (in Mo. Bot. Gard. Herb., 58810).

\section{C. Bambusae Burt, n. sp.}

Type: in Burt Herb., and Farlow Herb.

Fructifications small, becoming confluent, effused, adnate, very thin, tender, small pieces separable, cartridge-buff, even, not shining, somewhat cracked, the margin free in some places; in section 80-120 $\mu$ thick, not colored, with the hyphae about $21 / 2 \mu$ in diameter, not incrusted, not nodose-septate, arranged longitudinally along the substratum and sending out lateral branches to form the hymenium; no gloeocystidia; basidia simple, $40 \times$ $10 \mu$, with 4 sterigmata; spores hyaline, even, $14-18 \times 8-9 \mu$, pointed at both ends, copious.

Fructifications 1-3 mm. in diameter, becoming confluent over an area $4 \mathrm{~cm}$. long, $1-11 / 2 \mathrm{~cm}$. wide.

On bamboo. West Indies and Venezuela. Very common.

The small, cartridge-buff fructifications clustered together and becoming confluent over the hard cortex of culms of bamboo and the unusually large spores are good distinctive characters for recognition of this species.

Specimens examined:

Trinidad: Maravel, $R$. Thaxter, type, comm. by W. G. Farlow, 19.

32. C. cremoricolor Berk. \& Curtis, Grevillea 1: 180. 1873; Sacc. Syll. Fung. 6: 615. 1888.-Massee, Linn. Soc. Bot. Jour. 27: 133. 1890 (spelled cremicolor).

Type: in Kew Herb. and Farlow Herb., labelled Corticium cremicolor B. \& C.

Fructifications broadly effused, rather thick, membranaceous, small pieces separable when moistened, becoming cream-colored and pinkish buff to wood-brown in the herbarium, cracking into areolae $2-3 \mathrm{~mm}$. in diameter and with a distinctly radial arrangement of the principal cracks frequently, more or less colliculose with broad, slightly elevated granules, the margin narrow, fibril- 
lose, sometimes radiate; in section $200-800 \mu$ thick, not colored, with hyphae somewhat longitudinally interwoven and then ascending to a compact hymenium, $2-3 \mu$ in diameter, rarely larger, not incrusted but mixed with more or less mineral matter; no gloeocystidia; spores hyaline, even, flattened on one side, 8-12 $\times 5-8 \mu$.

Fructifications $2-10 \mathrm{~cm}$. long, $11 / 2^{-3} \mathrm{~cm}$. wide, often confluent.

On bark of decaying Quercus and other frondose species. Throughout Canada and the United States. April to December. Frequent.

$C$. cremoricolor is so similar to $C$. hydnans in aspect that the much larger spores of $C$. cremoricolor afford the best character for separation of these two species. C. cremoricolor is less tubercular, however, thicker, and usually with cracks radiating from the center of the fructification. C. anthracophilum Bourd. is closely related in structure.

Specimens examined:

Canada: J. Macoun, 19.

Massachusetts: Cambridge, L. M. Underwood, 1001 (in N. Y. Bot. Gard. Herb., and Mo. Bot. Gard. Herb., 57340).

New York: Ithaca, H. S. Jackson, comm. by Cornell Univ. Herb., 14391; Onondaga Valley, L. M. Underwood (in N. Y. Bot. Gard. Herb., and Mo. Bot. Gard. Herb., 61388).

New Jersey: Belleplain, C. L. Shear, 124\%, Newfield, J. B. Ellis, comm. by Farlow Herb. (in Mo. Bot. Gard. Herb., 44636).

Pennsylvania: Ohio Pyle, W. A. Murrill, 10\%6, 1133 (in N. Y. Bot. Gard. Herb., and Mo. Bot. Gard. Herb., 61586, 61579); Reitz Gap, L. O. Overholts, 4633 (in Mo. Bot. Gard. Herb., 56118); State College, L. O. Overholts \& C. R. Orton, comm. by L. O. Overholts, 4723 (in Mo. Bot. Gard. Herb., 56115); 'Trexlertown, W. Herbst, comm. by Lloyd Herb., 2227; Whitehaven, G. F. Atkinson, 8654 .

Maryland: Takoma Park, C. L. Shear, $10 \% 5$.

District of Columbia: Washington, C. L. Shear, $1240,1259$.

Florida: W. W. Calkins, comm. by Farlow Herb. (in Mo. Bot. Gard. Herb., 44633).

Alabama: Peters, type (in Kew Herb., and Curtis Herb., 5205). Texas: Houston, H.W. Ravenel, 271, comm. by U. S. Dept. Agr. 
Herb. This is the Corticium lactescens of Cooke's Fungi of Texas; Quitman, W. H. Long, 12092 (in Mo. Bot. Gard. Herb., $55047)$.

Ohio: C. G. Lloyd, 3821, comm. by Farlow Herb., 166 (in Mo. Bot. Gard. Herb., 55261), and 3821 and $390 \%$.

Indiana: Scottsburg, $J . R$. Weir, 976 (in Mo. Bot. Gard. Herb., 17186).

Illinois: Christopher, C. J. Humphrey, 2092 (in Mo. Bot. Gard. Herb., 21145); Lombard, E. T. \& S. A. Harper, 952.

Michigan: Ann Arbor, C. H. Kauffman, 27; New Richmond, Demmon, comm. by A. H. W. Povah, 6 (in Mo. Bot. Gard. Herb., 20198), and C. H. Kauffman, 29 (in Mo. Bot. Gard. Herb., 20304).

Wisconsin: Madison, M. C. Jensen, and another comm. by C. J. Humphrey, 2439 (in Mo. Bot. Gard. Herb., 43839 and 22376, respectively); Stevens Point, C. J. Humphrey, 1802 (in Mo. Bot. Gard. Herb., 17910).

Minnesota: Univ. Minn. Myc. Herb., comm. by E. L. Jensen, 8 (in Mo. Bot. Gard. Herb., 10565).

Missouri: Bismarck, L. O. Overholts (in Mo. Bot. Gard. Herb., 58322 ).

British Columbia: Sidney, J. Macoun, 12 (in Mo. Bot. Gard. Herb., 5730).

New Mexico: Cienega Springs, W. H. Long, 21596 (in Mo. Bot. Gard. Herb., 55120); Cloudcroft, W. H. Long, 19665, 19529 (in Mo. Bot. Gard. Herb., 55044, 55045); Tyom Canyon, $W$. $H$. Long, 21895 (in Mo. Bot. Gard. Herb., 55119); Tyom Exp. Sta., W. H. Long, 21877 (in Mo. Bot. Gard. Herb., 55118).

33. C. confluens Fries, Epicr. 564. 1838; Hym. Eur. 655. 1874; Berkeley, Outl. Brit. Fung. 276. 1860; Sacc. Syll. Fung. 6: 626 . 1888; Massee, Linn. Soc. Bot. Jour. 27: 133. 1890; Bresadola, I. R. Accad. Agiati Atti III. 3: 112. 1897; Bourdot \& Galzin, Soc. Myc. Fr. Bul. 27: 252. 1911; Rea, Brit. Basid. 679.1922.

Thelephora confluens Fries, Syst. Myc. 1: 447. 1821.-Corticium confluens var. subcalceum Karsten, Rev. Myc. 10:74. 1888.

Fructifications effused, rather thick, waxy-membranaceous, 
small pieces separable when moistened, whitish to cartridge-buff and light pinkish cinnamon in the herbarium, even, with few cracks, the margin indeterminate, thinning out; in section 200$500 \mu$ thick, not colored, composed of ascending, densely interwoven and agglutinate, thin-walled hyphae $21 / 2-3 \mu$ in diameter, not incrusted, occasionally nodose-septate; no gloeocystidia; spores hyaline, even, ovoid, $5-9 \times 3 \frac{1}{2}-6 \mu$, copious.

Fructifications $2-8 \mathrm{~cm}$. long, 1-3 cm. wide.

On bark of fallen decaying limbs of Betula, Alnus, Salix, and other frondose species. In Europe, from Newfoundland to Louisiana and westward to Manitoba and Washington, in Mexico, the West Indies, Japan, and South Africa. April to December. Common.

$C$. confluens may be recognized among our species by its occurrence on frondose bark in closely adnate fructifications with somewhat the aspect of pale Peniophora incarnata but of different structure, which is distinctive by not being stratose and by having the hyphae agglutinate, and by the presence of large spores. The authentic specimen from Karsten of $C$. confluens var. subcalceum has spores $9 \times 6 \mu$ and does not have cystidia, differing in both respects from the statement by Bresadola in Ann. Myc. 1: 102. 1903.

Specimens examined:

Sweden: L. Romell, 80, 81, 82, 83, 84.

Finland: Mustiala, authentic specimen, perhaps part of type of Corticium confluens var. subcalceum Karst. from Karsten.

Germany: Lengerich, W. Brinkmann, Westfälische Pilze, 13 (in Mo. Bot. Gard. Herb., 63430).

Austria: Tirol, Hall, V. Litschauer; Stubai, V. Litschauer.

Italy: G. Bresadola.

Newfoundland: Bay of Islands, A. C. Waghorne, 983 (in Mo. Bot. Gard. Herb., 63747).

Canada: Lower St. Lawrence Valley, J. Macoun, 65.

Ontario: Eastman's Springs, J. Macoun, 532; Ottawa, J. Macoun, 29; Woodstock, E. Bartholomew, 6713 (in Mo. Bot. Gard. Herb., 57041).

New Hampshire: Camp, Ellis R., Underwood \& C., 22 (in N. Y. Bot. Gard. Herb., Burt Herb., and Mo. Bot. Gard. Herb., 61585); Chocorua, W. G. Farlow. 
Vermont: Middlebury, E. A. Burt, 2 gatherings.

New England: W. G. Farlow.

Massachusetts: Waverly, G. R. Lyman, 164.

New York: Albany, H. D. House (in N. Y. State Mus. Herb., and Mo. Bot. Gard. Herb., 57446, 57472, 57670, 59680); Altamont, E. A. Burt; East Galway, E. A. Burt; Hudson Falls, S. H. Burnham, 48 (in Mo. Bot. Gard. Herb., 54465); Ithaca, C. $H$. Kauffman, C. O. Smith, Van Hook, comm. by G. F. Atkinson, 14384, 8045, and 8048, respectively; Karner, H. D. House (in N. Y. State Mus. Herb., and Mo. Bot. Gard. Herb., 54374, 55206); New York, Class in Mycology (in N. Y. Bot. Gard. Herb., and Mo. Bot. Gard. Herb., 61346); North Elba, C. H. Peck, comm. by N. Y. State Mus. Herb. (in Mo. Bot. Gard. Herb., 56111); Oneida, H. D. House, comm. by N. Y. State Mus. Herb. (in Mo. Bot. Gard. Herb., 59705); Seventh Lake, Hamilton County, H. E. Stork, 2 (in Mo. Bot. Gard. Herb., 56639); West Park, New York City, F. S. Earle, 1596 (in N. Y. Bot. Gard. Herb., and Mo. Bot. Gard. Herb., 61425); West Troy, C. H. Peck (in N. Y. State Mus. Herb., and Mo. Bot. Gard. Herb., 55781).

New Jersey: Belleplain, C. L. Shear, 1255.

Pennsylvania: Carbondale, E. A. Burt; Germantown, E. A. Burt; State College, L. O. Overholts, 2620 (in Mo. Bot. Gard. Herb., 20278).

Maryland: Silver Springs, D. G. Fairchild, comm. by U. S. Dept. Agr. Herb.

District of Columbia: Takoma Park, C. L. Shear, 1354; Washington, C. L. Shear, 1238, in part.

Florida: Daytona, R. A. Harper, 9 (in Mo. Bot. Gard. Herb., 54536).

Alabama: Auburn, F. S. Earle \& C. F. Baker, and 43 (in N. Y. Bot. Gard. Herb., and Mo. Bot. Gard. Herb., 61558).

Louisiana: Baton Rouge, Edgerton \& Humphrey, comm. by C. J. Humphrey, 5729, 5733; St. Martinville, A. B. Langlois, i, dh, and 472 (in N. Y. Bot. Gard. Herb., and Mo. Bot. Gard. Herb., 614788), and 1761a, comm. by W. G. Farlow (in Mo. Bot. Gard. Herb., 42600).

Illinois: Duquoin, C. J. Humphrey, 1309, 1394 (in Mo. Bot. Gard. Herb., 10324, 10352); Riverside, E. T. \& S. A. Harper, 675. 
Wisconsin: Blue Mounds, Miss Stucki, 12, 13.

Iowa: Ames, H. H. Hume, 3 (in N. Y. Bot. Gard. Herb., and Mo. Bot. Gard. Herb., 61583); Fort Dodge, O. M. Oleson, 438 (in Mo. Bot. Gard. Herb., 44077).

Manitoba: Winnipeg, G. R. Bisby, 62 (in Mo. Bot. Gard. Herb., 57898).

Washington: Puyallup, C. J. Humphrey, 7649.

Porto Rico: Campo Alegre, J. A. Stevenson, 6585 (in Mo. Bot. Gard. Herb., 55078).

Jamaica: Troy, A.E. Wight, 420, comm. by W. G. Farlow (in Mo. Bot. Gard. Herb., 14558).

Mexico: Guernavaca, W. A. \& E. L. Murrill, 541, 549, 548, comm.

by N. Y. Bot. Gard. Herb. (in Mo. Bot. Gard. Herb., 54558, 54559,54560 ).

Japan: Prov. Shinauo, A. Yasuda, 133 (in Mo. Bot. Gard. Herb., 62060).

Africa: Natal, Pietermaritzburg, P. A. van der Bijl, 583 (in Mo. Bot. Gard. Herb., 69371).

34. Coniophora corrugis Burt, Mo. Bot. Gard. Ann. 13: 310. 1926.

This species occurs on living trees, logs and dead limbs of conifers in forests of the Rocky Mountain region and from British Columbia to Arizona in the Pacific states. The fructifications are somewhat coriaceous, loosely attached to the substratum, and vinaceous in color. The spores in most specimens are colorless, even, 6-10 $\times 4-7 \mu$, not copious-fully mature and colored in only one of the specimens received during 14 years.

35. C. laetum (Karst.) Bresadola, Ann. Myc. 1: 94. 1903; v. Höhnel \& Litschauer, K. Akad. Wiss. Wien Sitzungsber. 115: 1552. 1906; Bourdot \& Galzin, Soc. Myc. Fr. Bul. 27:237. 1911.

Hyphoderma laetum Karsten, Rev. Myc. 11:206. 1889; Sacc. Syll. Fung. 10: 530. 1892.-Corticium hypnophilum Karsten, Rev. Myc. 12: 126. 1890; Sacc. Syll. Fung. 9: 234.1891.

Fructifications effused, thin, membranaceous-waxy, soft, small pieces separable when moist, orange-pink to rose color, fading in the herbarium to cartridge-buff, even, not cracked, the margin 
thinning out, somewhat arachnoid; in section 100-200 $\mu$ thick, not colored, composed of interwoven, hyaline hyphae 5-8 $\mu$ in diameter, not incrusted, no clamp connections found; no gloeocystidia; spores hyaline, even, $6-12 \times 4-8 \mu$.

Fructifications $5 \mathrm{~mm} .-2 \mathrm{~cm}$. long, 5-10 mm. wide.

On living mosses and on bark of dead Alnus and Betula. In Europe and in New York, Michigan, and North Dakota.

This species may be recognized by bright rose color when fresh, occurrence on living moss and dead alders, large spores, coarse hyphae, and absence of gloeocystidia. The three American specimens cited below seem referable to $C$. laetum except that their hyphae are more numerous and of smaller diameter-4-6 $\mu$ - than those of the European specimens with which compared. Peniophora aurantiaca has much the same aspect and occurs on Alnus also but has gloeocystidia and cystidia.

Specimens examined:

Sweden: L. Romell, 145 .

Finland: Mustiala, authentic specimen of C. hypnophilum from Karsten.

Italy: specimen on Alnus of $C$. laetum collected and determined by Bresadola.

New York: Karner, H. D. House (in N. Y. State Mus. Herb., and Mo. Bot. Gard. Herb., 44708).

Michigan: Isle Royale, Allen \& Stuntz, 42, comm. by Univ. Wis. Herb.

North Dakota: Brenckle, comm. by V. Litschauer, 2.

36. C. roseum Persoon, Roemer Neues Mag. Bot. 1: 111. 1794; Fries, Epicr. 560. 1838; Hym. Eur. 650. 1874; Berkeley, Outl. Brit. Fung. 273. 1860; Sacc. Syll. Fung. 6: 611. 1888; Bourdot \& Galzin, Soc. Myc. Fr. Bul. 27: 233. 1911; Coker, Elisha Mitchell Scientif. Soc. Jour. 36: 171. pl. 33, f. 3-5. 1921; Rea, Brit. Basid. 673. 1922.

Thelephora rosea Persoon, Syn. Fung. 575. 1801; Myc. Eur. 1: 131. 1822; Fries, Syst. Myc. 1: 451. 1821; Elench. Fung. 1: 203. 1828.-Corticium roseolum Massee, Linn. Soc. Bot. Jour. 27: 140. pl. 6, f. 2. 1890.-C. polygonoides Karsten, Soc. pro Fauna et Fl. Fenn. Meddel. 6: 12. 1881; Sacc. Syll. Fung. 6: 
638. 1888; Bourdot \& Galzin, Soc. Myc. Fr. Bul. 27: 232. 1911. - Lyomyces polygonoides Karsten, Finska Vet.-Soc. Bidrag Natur. och Folk 48: 419. 1889.-Aleurodiscus roseus (Pers.) v. Höhnel \& Litschauer, K. Akad. Wiss. Wien Sitzungsber. 115: 1568. 1906.

Fructification effused, rather thick, adnate, somewhat membranaceous, small pieces separable when moist, drying pinkish buff to buff-pink, pruinose, finally cracked, the margin whitish, more or less byssoid; in section 200-280 $\mu$ thick, with the hymenial layer perhaps slightly colored, 2-layered, with the basal layer composed of longitudinally arranged, densely interwoven hyphae $3-31 / 2 \mu$ in diameter, not incrusted, the hymenial layer composed of erect hyphae, basidia, and slender, slightly brownish, short-branched paraphyses; no gloeocystidia; basidia at first exceeded by the paraphyses, finally protruding; spores hyaline, even, $6-12 \times 41 / 2-8 \mu$.

Fructifications sometimes $2-3 \mathrm{~mm}$. in diameter and becoming laterally confluent, more usually 1-10 cm. long, 1-3 cm. wide.

On bark and wood of logs and branches of frondose species such as Populus, Betula, Alnus, Acer, Carya, Ulmus, etc., rarely on coniferous wood. In Europe, from Canada to Alabama, westward to Manitoba and Washington, in New Mexico and Mexico, and in Japan. Throughout the year. Common.

C. roseum is well named, for its pale rose-color is distinctive and is confirmed, when sections are examined, by the slender, slightly brownish, short-branched organs which are probably paraphyses but have seemed to me when in young vigorous condition to have the branches tipped by very minute spherical bodies. C. polygonoides is the early stage with the paraphyses exceeding the young basidia.

Specimens examined:

Exsiccati: Ell. \& Ev., Fungi Col., 609, under the name Corticium incarnatum; de Thümen, Myc. Univ., 2012.

Sweden: L. Romell, 47, 127, 146; Stockholm, L. Romell, 147 . Finland: Mustiala, P. A. Karsten, in de Thümen, Myc. Univ., 2012, and authentic specimen of Lyomyces polygonoides. Austria: Stubai, Tirol, V. Litschauer. Italy: Trient, G. Bresadola. 
England: Apthorpe, Norths, 12, type of C. roseolum (in Kew Herb.).

Canada: J. Macoun, 85.

Ontario: London, J. Dearness, D1078c (in Mo. Bot. Gard. Herb., 18666); Ottawa, J. Macoun, 135, 451.

Maine: Freeport, O. O. Stover, comm. by P. L. Ricker.

Vermont: Middlebury, E. A. Burt, 3 gatherings; Ripton, E. A. Burt, 2 gatherings; Smugglers' Notch, Mt. Mansfield, E. A. Burt.

Massachusetts: Newton, W. G. Farlow; Willow Brook, H. Webster, comm. by Boston Myc. Club Herb., E.; Waverly, G. $R$. Lyman, 120, 164.

New York: Alcove, C. L. Shear, 1204, 1313; Altamont, E. A. Burt; Ithaca, G. F. Atkinson, 2120, and H. S. Jackson, comm. by Cornell Univ. Herb., 14389; Minnewaska, C. H. Peck (in N. Y. State Mus. Herb., and Mo. Bot. Gard. Herb., 55980); Orient, R. Latham, 223 (in Mo. Bot. Gard. Herb., 44226); Poughkeepsie, R. C. Poppey, in Gerard Herb. (in N. Y. Bot. Gard. Herb., and Mo. Bot. Gard. Herb., 61559); Syracuse, L. M. Underwood, 18 (in N. Y. Bot. Gard. Herb., and Mo. Bot. Gard. Herb., 44312); White Plains, L. M. Underwood (in N. Y. Bot. Gard. Herb., and Mo. Bot. Gard. Herb., 61410).

New Jersey: Newfield, J. B. Ellis, in Ell. \& Ev., Fungi Col., 609. Pennsylvania: Center Hall, E. West, comm. by L. O. Overholts, 3659 (in Mo. Bot. Gard. Herb., 54700); State College, J. Ellis, comm. by L. O. Overholts, 5207 (in Mo. Bot. Gard. Herb., 56360).

District of Columbia: Takoma Park, C. L. Shear, 953.

North Carolina: W. C. Coker, 4703 (in Mo. Bot. Gard. Herb., 57424).

Alabama: Auburn, C. F. Baker (in N. Y. Bot. Gard. Herb., Mo. Bot. Gard. Herb., 61397, and Burt Herb.); Montgomery, R. P. Burke, 2, in part, 160, 305 (in Mo. Bot. Gard. Herb., 22073, 44961, 57195).

Ohio: College Hill, Aiken, comm. by Lloyd Herb., 2341; Linwood, C. G. Lloyd, 1870; Preston, C. G. Lloyd, 1561.

Indiana: Indianapolis, $H$. von Schrenk (in Mo. Bot. Gard. Herb., 19805). 
Illinois: Cairo, E. Bartholomew, 9234.

Minnesota: Brickton, C. J. Humphrey, 1124 (in Mo. Bot. Gard. Herb., 10276).

Iowa: Decorah, E. W. D. Holway.

Missouri: Creve Coeur Lake, F. P. McWhorter (in Mo. Bot. Gard. Herb., 57334).

Montana: Monarch, J. R. Weir (in Mo. Bot. Gard. Herb., 20736). Idaho: J. R. Weir, 366 (in Mo. Bot. Gard. Herb., 15165).

Manitoba: River Park, A. H. R. Buller, 873 (in Mo. Bot. Gard. Herb., 58994); Stony Mountain, A. H. R. Buller, 897 (in Mo. Bot. Gard. Herb., 58989); Winnipeg, A. H. R. Buller, 936 (in Mo. Bot. Gard. Herb., 59025).

Washington: Bingen, W. N. Suksdorf, 685, 720; Columbia River, W. Klickitat County, W. N. Suksdorf, 106.

New Mexico: Mogollon, G. G. Hedgcock \& W. H. Long, comm. by

C. J. Humphrey, 2540 (in Mo. Bot. Gard. Herb., 21660).

Mexico: Parral, Chihuahua, E. O. Mathews, 4 (in Mo. Bot. Gard. Herb., 44419).

Japan: Sendai, A. Yasuda, 60 (in Mo. Bot. Gard. Herb., 56144).

37. C. salmonicolor Berk. \& Broome, Linn. Soc. Bot. Jour. 14: 71. 1873; Sacc. Syll. Fung. 6: 620. 1888; Massee, Linn. Soc. Bot. Jour. 27: 122. 1890; Petch, Phys. and Dis. of Hevea brasiliensis, 209. 1911; Rorer, Trinidad Dept. Agr. Bul. 15³: 1. f. 1, 2. 1917; Lee \& Yates, Philippine Jour. Sci. 14: 657. pl. $1-\% .1919$.

Necator decretus Massee, Kew Bul. Misc. Inf. 1898: $119 . \quad$ 1898; Sacc. Syll. Fung. 16: 1094. 1902.-Corticium javanicum Zimmermann, Centralbl. f. Bakt. Abt. 2, 7 : 103. textf. 3. 1901.-C. Zimmermanni Sacc. \& Syd. in Sacc. Syll. Fung. 16: 1117. 1902; 17: 169.1905.

Type: in Kew Herb.

Fructifications broadly effused, thin, adnate, membranaceoussoft, separable when moist, pale ochraceous buff to orange-pink when fresh, fading in the herbarium to pale olive-buff and cartridge-buff, pulverulent, even, cracking a little in drying, the margin thinning out; in section 100-200 $\mu$ thick, composed of hyphae running longitudinally over the substratum and bearing 
a broad layer of suberect, branching, loosely interwoven hyphae 4-7 $\mu$ in diameter, not incrusted, not nodose-septate; no gloeocystidia; basidiospores hyaline, even, $9-12 \times 6-8 \mu$. The conidia of the imperfect Necator stage are catenulate, $14-18 \times 7-8 \mu$, according to Massee.

Fructifications 2-20 cm. long, 1-3 cm. wide.

Parasitic on bark of branches 1-3 cm. in diameter and young trees of Cacao, Citrus, Hevea, Amherstia, tea and coffee plants in tropical regions, and on Ficus and pear and apple shoots in Florida and Louisiana. In West Indies, Philippine Islands, East Indies, and Ceylon.

C. salmonicolor is a species very destructive to important economic species of shrubs and trees, causing the Pink Disease where the climate is warm and moist for sufficiently long periods that the mycelium can run over the bark of young shoots and penetrate into the deeper tissues. Its parasitic occurrence on living woody plants, bright color, coarse hyphae, and large spores render it easy to recognize in tropical regions.

Specimens examined:

Florida: Gainesville, J. Matz (in Mo. Bot. Gard. Herb., 44822, 54934).

Louisiana: Baton Rouge, C. W. Edgerton, 702, 990a.

Porto Rico: Bayamon, J. A. Stevenson, 2827 (in Mo. Bot. Gard. Herb., 9689); Pueblo Vigo, J. A. Stevenson, 5436 (in Mo. Bot. Gard. Herb., 7820); Trujillo Alto, J. A. Stevenson, 3819, and W. C. Drier, comm. by J. A. Stevenson, 6770 (in Mo. Bot. Gard. Herb., 9059 and 55054, respectively).

Dominica: W. Norwell, comm. by J. B. Rorer (in Mo. Bot. Gard. Herb., 18560).

Trinidad: J. B. Rorer (in Mo. Bot. Gard. Herb., 20429); Guaico, J. B. Rorer, four gatherings (in Mo. Bot. Gard. Herb., 14023, 17934, 20295, 44770); Port of Spain, J. B. Rorer (in Mo. Bot. Gard. Herb., 9008).

Ceylon: a portion of 3 authentic specimens determined by Berkeley in Kew Herb. (in Mo. Bot. Gard. Herb., 8891), T. Petch, comm. by Kew Herb. (in Mo. Bot. Gard. Herb., 8890); Peradeniya, T. Petch, 8640 (in Mo. Bot. Gard. Herb., $56245)$. 
38. C. spretum Burt, n. sp.

Type: in Burt Herb.

Fructifications effused, adnate, rather thick, somewhat coriaceous, cinnamon-buff in the herbarium, even, not shining, in drying cracking to the substratum into polygonal masses about $1 \mathrm{~mm}$. in diameter, the margin similar, narrow, entire; in section 200-300 $\mu$ thick, colored like the hymenium, composed of ascending, densely interwoven, thin-walled hyphae $3-31 / 2 \mu$ in diameter, not incrusted, not nodose-septate; no gloeocystidia; slender paraphyses about $1 \mu$ in diameter, with short branches near the tips, are present between the basidia; spores hyaline, even, $8-10 \times 5-6 \mu$.

Fructifications probably large, for received in fragments up to $5 \mathrm{~cm}$. long, $2 \mathrm{~cm}$. wide.

On decorticated wood of a decaying stump of Fraxinus oregona. Washington. September.

C. spretum has conspicuous fructifications resembling Hymenochaete spreta in aspect. The deeply cracked fructifications cinnamon-buff externally and throughout, large spores, slender paraphyses, and occurrence on ash stumps should enable the species to be recognized confidently.

Specimens examined:

Washington: Bingen, W. N. Suksdorf, 962, type.

39. C. rubropallens (Schw.) Massee, Linn. Soc. Bot. Jour. 27 : 145. 1890.

Thelephora rubropallens Schweinitz, Am. Phil. Soc. Trans. N. S. 4: 168. 1832.-Stereum rubropallens (Schw.) Cooke, Grevillea 20: 35. 1891; Sacc. Syll. Fung. 11 : 121. 1895.-Not C. rubropallens Bresadola, Ann. Myc. 1: 97. 1903, nor Bourdot \& Galzin, Soc. Mye. Fr. Bul. 27: 258. 1911.

Type: in Schweinitz Herb. and probably in Farlow Herb. and Kew Herb.

"'T. effusa, indeterminatim effigurata, ambitu marginibus latissimis albis; versus centrum subroseo-incarnata, crebre sporidifera aut pulverulenta. Pelliculam efficit ex arcte intertextis filis. UInarem longitudinem explet.

"Longe lateque effusa in corticibus et lignis Bethlehem.". 
In section 100-150 $\mu$ thick, not colored, with the hyphae suberect, branched, rather loosely interwoven, about $2 \frac{1}{2}-3 \mu$ in diameter, not incrusted but bearing imbedded crystalline matter, with very slender, colorless, hair-like paraphyses protruding beyond the basidia and, in my opinion, with short branches near the tips; no gloeocystidia; spores noted by Massee as 8-9 93 u, and by Cooke as $6-7 \times 3 \mu$, none found in my preparations of the type.

I regret that a Corticium on Fagus, Ripton, Vermont, Nov. 4, 1896, which I misdetermined as C. rubropallens, relying too largely on general aspect and coloration in comparison with the type, and communicated to Bresadola, Romell, and Karsten under that name, should have led both Bresadola and Bourdot into error concerning $C$. rubropallens. The names of those specimens should be changed to C.roseopallens Burt, as described in the present work.

C. rubropallens belongs in the group of species with $C$. rubrocanum, C. albido-carneum, and C. Atkinsonii. Each species of this group lacks gloeocystidia and has the very slender and numerous paraphyses protruding beyond the basidia and masking the latter. The only recent gathering which I can now refer to C. rubropallens on the basis of agreement in internal structure is now white in herbarium condition and doubtful therefore. Its few spores are $9-10 \times 4 \mu$.

Specimens examined:

Pennsylvania: Bethlehem, Schweinitz, type (in Schweinitz Herb.). Alabama: Montgomery, R. P. Burke, 118 (in Mo. Bot. Gard. Herb., 19557).

40. C. rubrocanum de Thümen, Myc. Univ., 409, with description. 1876; Torr. Bot. Club Bul. 6: 95. 1876; Sace. Syll. Fung. 6: 632.1888.

Type: type distribution in de Thümen, Myc. Univ., 409.

Fructifications broadly effused, thin, adnate, membranaceous, small pieces separable when moist, becoming tilleul-buff in the herbarium, hoary, glabrous, finally cracking at the center into polygonal masses 1-2 to a mm., the margin determinate or indeterminate and thinning out, of the same color; in section 
$100-150 \mu$ thick, not colored or only very slightly in the subhymenium, with the hyphae longitudinally and densely interwoven next to the substratum, then becoming erect, bushybranched in the hymenial layer, short-celled, of irregular outline, about $3-31 / 2 \mu$ in diameter, not incrusted but with some imbedded crystalline matter; paraphyses slightly brownish below, protruding beyond the basidia as very slender hairs about $1 / 2-1 \mu$ in diameter with short lateral branches; no gloeocystidia; the only spore found is hyaline, even, $9 \times 3 \frac{1}{2} \mu$ but may not belong.

Fructifications $2-10 \mathrm{~cm}$. long, 1-2 cm. wide.

On fallen twigs of Quercus coccinea. New Jersey to Louisiana. November to April. Not common.

$P$. rubrocanum is distinguished by its occurrence in thin, hoary, nearly white fructifications with a tint of pink on small fallen branches of oak, and by the absence of gloeocystidia and the presence of delicate hair-like paraphyses in the hymenial surface. Spore collections should be made to determine the spore dimensions, for the spores have not been retained well in any specimen examined. It is probable that $C$. rubrocanum will be found to be a synonym of $C$. rubropallens when the type of the latter can be studied more critically than by me twenty-six years ago.

Specimens examined:

Exsiccati: Ellis, N. Am. Fungi, 22; de Thümen, Myc. Univ., 409, type.

New Jersey: Newfield, J. B. Ellis, in Ellis, N. Am. Fungi, 22, in de Thümen, Myc. Univ., 409, and (in Mo. Bot. Gard. Herb., 4846, 44638).

South Carolina: H. W. Ravenel, 37\%, comm. under the name $C$. Auberianum by N. Y. Bot. Gard. Herb.

Alabama: Montgomery, R. P. Burke, 105 (in Mo. Bot. Gard. Herb., 11280).

Louisiana: Natchitoches, G. D. Harris, comm. by Cornell Univ. Herb., 5111; St. Martinville, A. B. Langlois, 1939

41. C. cultum Burt, n. sp.

Type: in Burt Herb.

Fructifications usually a thin, whitish, cottony mycelium along the sides of tunnels of a bark beetle but sometimes bearing a 
hymenium and in those places effused, small, thin, closely adnate, somewhat membranaceous-fleshy, ivory-yellow when growing, fading to white in the herbarium, even, not cracked, the margin continuous with the sterile mycelium; in section 100-150 $\mu$ thick, not colored, composed of suberect, branching, densely arranged and somewhat interwoven hyphae $3-31 / 2 \mu$ in diameter, short-celled, occasionally nodose-septate; no gloeocystidia; basidia simple, eylindric, $27 \times 3 \frac{1}{2}-41 / 2 \mu$, with 4 knob-shaped sterigmata; spores hyaline, even, $6-8 \times 3 \frac{1}{2}-41 / 2 \mu$, copious; some imbedded spores present.

Fructifications 5-10 mm. long, 1-2 mm. wide.

In thick bark of coniferous logs on side walls of tunnels made by a bark-boring beetle. Idaho probably.

C. cultum is one of the species which should be considered in connection with the fungous flora of burrows of bark-boring insects. The term "ambrosia fungi" has been used for some other fungi growing in such places. The type specimen of C. cultum is scanty but well fruited. The species has not been received from any source as growing on the exterior of bark or wood.

Specimens examined:

Idaho: probably Idaho but only general locality stated, $J . R$.

Weir, comm. by W. G. Farlow, type (in Mo. Bot. Gard. Herb., 44655).

42. C. rubellum Burt, n. sp.

Type: in Burt Herb.

Fructifications broadly effused, adnate, thin, somewhat membranaceous, small pieces separable when moist, vinaceous-fawn, becoming wood-brown in the herbarium, even, not waxy, the margin thinning out; in section $120-500 \mu$ thick, not colored when thin but somewhat colored in thick fructifications and then stratose, with the hyphae arranged longitudinally and crowded together parallel with the substratum in each stratum, more loosely interwoven towards the hymenium, $21 / 2^{-3} \mu$ in diameter, not incrusted, rarely nodose-septate; no gloeocystidia; spores copious, hyaline, even, $6-9 \times 5-6 \mu$, flattened on one side, with a small apiculus on the flattened side near the base. 
Fructifications 5-10 $\mathrm{cm}$. long, 1-5 cm. wide.

On decorticated wood of dead Vitis and on decaying bark of Quercus Gambelii and Tilia. Florida, Illinois, Colorado, and Manitoba. July to October.

C. rubellum differs from $C$. rubicundum in becoming finally stratose and somewhat colored, having larger and more subglobose spores, and occurring on dead grape vines, oak, and basswood. The Florida specimen lacks spores and may be incorrectly referred here. C. confluens has similar spores.

Specimens examined:

Florida: New Smyrna, W. A. Murrill, 27, comm. by N. Y. Bot.

Gard. Herb. (in Mo. Bot. Gard. Herb., 62081).

Illinois: Glencoe, E. T. \& S. A. Harper, 941, type; River Forest, E. T. \& S. A. Harper, 661 .

Colorado: Deer Creek Park, E. Bartholomew, 9149, 9150.

Manitoba: Winnipeg, A. H. R. Buller, comm. by G. R. Bisby, 724 (in Mo. Bot. Gard. Herb., 58987).

\section{C. hydnans (Schw.) Burt, n. comb.}

Radulum hydnans Schweinitz, Am. Phil. Soc. Trans. N. S. 4: 164. 1832; Sacc. Syll. Fung. 11:112. 1895.-Corticium colliculosum Berk. \& Curtis, Grevillea 2: 3. 1873; Peck, N. Y. State Mus. Rept. 28: 52. 1876; Sacc. Syll. Fung. 6: 618. 1888: Massee, Linn. Soc. Bot. Jour. 27: 134. 1890.

Type: in Farlow Herb. and probably in Schweinitz Herb.

Fructifications long and widely effused, adnate, thin, membranaceous, small pieces separable when moistened, pinkish buff to cinnamon-buff in the herbarium, becoming more or less colliculose or somewhat tuberculate, cracking into polygonal masses 1-2 $\mathrm{mm}$. in diameter, the margin whitish, with hyphae interwoven; in structure $100-300 \mu$ thick, not colored, with the hyphae longitudinally arranged next the substratum and then ascending and interwoven to the hymenium, $2-3 \mu$ in diameter, not incrusted; no gloeocystidia; spores hyaline, even, $5-8 \times 2 \frac{1}{2}-3 \frac{1}{2} \mu$.

Fructifications 1-10 cm. long, 1-3 cm. wide.

On decaying frondose limbs on the ground. Canada to Texas and westward to Washington and British Columbia. April to November. Occasional. 
C. hydnans is intermediate between Corticium and Radulum with granules rather too broad at base, too little elevated and too convex to be a typical Radulum in configuration, and yet always leading one to search for more raduloid teeth. It is well named as $C$. hydnans or by its later name $C$. colliculosum. It may be distinguished from Radulum orbiculare in doubtful cases by its lack of gloeocystidia.

Specimens examined:

Exsiccati: Ellis, N. Am. Fungi, 329 and 717 b, the latter under the name Corticium subgiganteum; Ravenel, Fungi Am., 126, 227 , both under the name Corticium calceum; de Thümen, Myc. Univ., 605.

Canada: Gaspé, J. Macoun, 530.

Ontario: London, J. Dearness, 1178 (in Mo. Bot. Gard. Herb., 18773).

New Hampshire: North Conway, A. S. Rhoads, 7 (in Mo. Bot. Gard. Herb., 56893).

Vermont: Middlebury, E. A. Burt.

Massachusetts: Sprague, 96, type of Corticium colliculosum (in Curtis Herb., 5297).

New York: Albany, H. D. House (in N. Y. State Mus. Herb., and Mo. Bot. Gard. Herb., 14834); Alcove, C. L. Shear, 1011, 1212, 1219; East Galway, E. A. Burt; Grand View, H. von Schrenk (in Mo. Bot. Gard. Herb., 42817); Ithaca, H. S. Jackson, comm. by Cornell Univ. Herb., 14390, and W. H. Long (in Mo. Bot. Gard. Herb., 62987); New Baltimore, C. H. Peck, comm. by N. Y. State Mus. Herb., T 30 (in Mo. Bot. Gard. Herb., 56071); Trenton Falls, C. H. Peck, comm. by N. Y. State Mus. Herb., T 9 (in Mo. Bot. Gard. Herb., 54572).

New Jersey: Newfield, J. B. Ellis, and (in N. Y. Bot. Gard. Herb., and Mo. Bot. Gard. Herb., 61636) and in Ellis, N. Am. Fungi, $717 \mathrm{~b}$, and de Thümen, Myc. Univ., 605.

Pennsylvania: Bethlehem, Schweinitz, type of Radulum hydnans (in Schweinitz Herb. and Farlow Herb.); Center County, C. R. Orton, comm. by L. O. Overholts, 2940 (in Mo. Bot. Gard. Herb., 8265); State College, L. O. Overholts, 3040 (in Mo. Bot. Gard. Herb., 5689); Trexlertown, W. Herbst, 3.

Maryland: Rock Creek, C. L. Shear, 1046. 
District of Columbia: Washington, C. L. Shear, 1261 .

North Carolina: Biltmore Estate, W. A. Murrill (in N. Y. Bot. Gard. Herb., and Mo. Bot. Gard. Herb., 61382).

Georgia: Darien, H.W. Ravenel, in Ravenel, Fungi Am. 227.

Florida: Gainesville, H.W. Ravenel, in Ravenel, Fungi Am., 126. Louisiana: Baton Rouge, Edgerton \& Humphrey, comm. by C. J. Humphrey, 5642; St. Martinville, A. B. Langlois, comm. by U. S. Dept. Agr. Herb.

Texas: Lindheimer, 40 (in Mo. Bot. Gard. Herb., 4819).

West Virginia: Paw Paw, C. L. Shear, 1175.

Kentucky: Crittenden, C. G. Lloyd, 2365, 3118.

Ohio: Cincinnati, comm. by Lloyd Herb., 2792; Loveland, D. $L$. James, comm. by U. S. Dept. Agr. Herb.

Illinois: Glen Ellyn, E. T. \& S. A. Harper, 955; River Forest, $E$. T. \& S. A. Harper, 794 .

Michigan: Ann Arbor, C. H. Kauffman, 48 (in Mo. Bot. Gard. Herb., 8083); Gogebic County, E. A. Bessey, 248 (in Mo. Bot. Gard. Herb., 56613).

Missouri: Grandin, H. von Schrenk (in Mo. Bot. Gard. Herb., 43021).

Nebraska: Long Pine, C. L. Shear, 1065.

British Columbia: Yoho Valley, J. Macoun, 6.

Washington: Bellingham, $J$. R. Weir, 545 (in Mo. Bot. Gard. Herb., 5899).

California: Santa Catalina Island, L.W. Nuttall, 402, in part (in Mo. Bot. Gard. Herb., 57614).

\section{C. rubicundum Burt, n. sp.}

Type: in Burt Herb.

Fructifications broadly effused, rather thick, membranaceous, loosely attached, separable, drying buff-pink to light vinaceouscinnamon, slightly tubercular, pruinose, the margin radiating, whitish; in section $200-500 \mu$ thick, not colored, with a hymenial layer $60 \mu$ thick borne on a broad layer reaching to the substratum and composed of interwoven, thick-walled, hyaline hyphae $3-4 \mu$ in diameter, not incrusted, occasionally nodoseseptate; no gloeocystidia; basidia 4-spored; spores hyaline, even, $4-7 \times 3-4 \frac{1}{2} \mu$, copious. 
Fructifications 6-8 $\mathrm{cm}$. long, $2-5 \mathrm{~cm}$. wide.

On bark of logs of Tsuga canadensis, Picea and Pinus. Canada, Colorado and Washington. September.

C. rubicundum has large, sheet-like, loosely attached fructifications with somewhat the aspect of those of Peniophora velutina but lacking cystidia. The thick, membranaceous, loosely attached fructification is suggestive of a resupinate Stereum but I have seen no Stereum of which this may be the resupinate stage. The occurrence on hemlock bark should help in identifying future gatherings.

Specimens examined:

Canada: Lake Rosseau, Ontario, E. T. \& S. A. Harper, 637, type. Colorado: near Mancos, G. G. Hedgcock, comm. by C. J. Humphrey, 2560.

Washington: Mt. Paddo, W. N. Suksdorf, 735, 736.

45. C. granulatum Burt, n. sp.

Type: in Burt Herb.

Fructifications effused, thin, closely adnate, central portions fawn-color, becoming wood-brown in the herbarium, dull rather than shining, with some scattered, small granules, not cracked, the margin fimbriate, fading from ochroleucous to whitish; in section $120-240 \mu$ thick, not colored, with a narrow incrusted zone, the hyphae densely interwoven, $3 \mu$ in diameter, somewhat incrusted, not nodose-septate; no gloeocystidia; basidia protruding slightly when mature, with 4 sterigmata; spores hyaline, even, $4-5 \times 2-3 \mu$.

Fructifications $3-5 \mathrm{~cm}$. long, 1-2 cm. wide.

On very rotten wood of Populus trichocarpa. Idaho. September and October.

This species should be readily recognized by its color when fresh, somewhat granular hymenium, and occurrence on decaying poplar wood. The incrustation of the hyphae is a good available character for separation from $C$. subceraceum and $C$. deflectens.

Specimens examined:

Idaho: Priest River, J. R. Weir, 33, type, and 106.

46. C. illaqueatum Bourdot \& Galzin, Soc. Myc. Fr. Bul. 27 : 238. 1911. 
Type: authentic specimens in Burt Herb.

Fructifications effused, adnate, membranaceous-thin, loosely attached to the substratum, small pieces separable when moist, becoming cream-buff in the herbarium, even, not cracked regularly, the margin somewhat arachnoid; in section 150-300 $\mu$ thick, not colored, composed of loosely interwoven, thin-walled hyphae $3-4 \mu$ in diameter, nodose-septate, with some incrustation next to the substratum; no gloeocystidia; spores hyaline, even, $4 \frac{1}{2}-6 \times 3 \mu$, borne 4 to a basidium.

Fructifications $1-3 \mathrm{~cm}$. long, $1 / 2-11 / 2 \mathrm{~cm}$. wide.

On bark of decaying Castanea and other frondose species. France and Louisiana. September to January.

C. illaqueatum has color somewhat like that of $C$. ceraceum and $C$. hydnans but is loosely attached to the substratum and has smaller spores than the former and does not crack in drying like the latter.

Specimens examined:

France: Aveyron, H. Bourdot, 16063, and M. Galzin, 12684, 12689, 15107, comm. by H. Bourdot, 18548, 16092, 12623. Louisiana: St. Martinville, A. B. Langlois, 203.

\section{C. Rosae Burt, n. sp.}

Type: in Mo. Bot. Gard. Herb.

Fructifications effused, adnate, rather thick, membranaceous, separable, drying Rood's brown, ceraceous, even, contracting in drying and cracking through the hymenial layer into rectangular masses 2-4 $\mathrm{mm}$. in diameter and showing the thick, white, cottony subiculum in the crevices, the margin white, cottony; in section $400-600 \mu$ thick, not colored, with the hyphae about $3 \mu$ in diameter, more or less incrusted in the middle region, not nodose-septate, densely crowded together and arranged longitudinally in a broad layer along the substratum, then ascending obliquely and becoming densely interwoven in a thick hymenial layer; no gloeocystidia; spores hyaline, even, $4-7 \times 2 \frac{1}{2}-3 \mu$ as seen attached to the basidia.

Fructifications received in fragments $2-2 \frac{1}{2} \mathrm{~cm}$. long, $1 \mathrm{~cm}$. wide-broken off on three sides.

On bark of dead wild rose-Rosa sp. British Columbia. February. 
C. Rosae has thick fructifications which are conspicuous by their reddish brown color and prominent white margin. The occurrence on wild rose bushes should aid in recognition of the species. The loose attachment to the substratum by a broad layer of longitudinally arranged hyphae is suggestive of the genus Stereum but the specimens do not have the margin reflexed in the least degree; I know of no Stereum of which this may be the resupinate stage.

Specimens examined:

British Columbia: Sidney, J. Macoun, 275, type (in Mo. Bot. Gard. Herb., 63772) and another specimen of the same number comm. by J. Dearness (in Mo. Bot. Gard. Herb., 63773).

\section{C. apiculatum Bresadola, Mycologia 17:68. 1925.}

C. areolatum Bresadola, Mycologia 17:68. 1925.

Type: in Weir Herb.

Fructifications broadly effused, thin, membranaceous, tender, small portions separable when moistened, between ivory-yellow and cream color, even, contracting in drying and cracking into angular masses about $1 \mathrm{~mm}$. in diameter more or less completely separated by fissures which show the floccose subiculum along their sides, the margin thinning out, fibrillose; in section $90-130 \mu$ thick, not colored, composed of loosely interwoven, thin-walled hyphae $21 / 2-41 / 2 \mu$ in diameter, with an occasional incrusting granule, occasionally nodose-septate; no gloeocystidia; spores hyaline, even, $4 \frac{1}{2}-5 \times 2 \frac{1}{2}-3 \mu$.

Fructifications $2-5 \mathrm{~cm}$. long, $11 / 2-3 \mathrm{~cm}$. wide.

On decaying branches of Alnus tenuifolia. Alabama to Idaho, and British Columbia to Mexico. October and December.

$C$. apiculatum belongs in the $C$. lacteum group of species. It should be recognized in its region by occurrence on Alnus, cream color, and small, somewhat elliptical spores. C. areolatum has a fructification with the areolate masses separated from one another by rather wide fissures but of same color as type of $C$. apiculatum, spores the same size, and fructification separable to the same degree-certainly not closely adnate.

Specimens examined:

Alabama: Montgomery, R. P. Burke, 199, 202, 671 (in Mo. Bot.

Gard. Herb., 57075, 57078, 63102). 
Missouri: near St. Louis, L. O. Overholts, 3167 (in Mo. Bot. Gard. Herb., 5711).

Idaho: Priest River, J.R. Weir, 23904, type (in Weir Herb.), and 23387, type of $C$. areolatum (in Weir Herb.).

British Columbia: Sidney, J. Macoun, 99 (in Mo. Bot. Gard. Herb., 6767).

Washington: Seattle, W. A. Murrill, 181, comm. by N. Y. Bot.

Gard. Herb. (in Mo. Bot. Gard. Herb., 55742).

Mexico: Jalapa, W. A. \& E. L. Murrill, 12S, comm. by N. Y. Bot.

Gard. Herb. (in Mo. Bot. Gard. Herb., 10748).

49. C. subceraceum Burt, n. sp.

Type: in Burt Herb.

Fructifications broadly effused, adnate, membranaceous, separable when moist, tawny to hazel in the herbarium, even or with some small obtuse granules, waxy, not cracking, the margin somewhat fimbriate, whitish; in section 200-300 $\mu$ thick, not colored, 2-layered, the layer next to the substratum thick, composed of loosely arranged, suberect hyaline hyphae not incrusted, not nodose-septate, mostly $4-41 / 2 \mu$ in diameter but with a few up to $6 \mu$, the hymenial layer dense, thin, undulating; no gloeocystidia; spores hyaline, even, $4-41 / 2 \times 2-21 / 2 \mu$.

Fructifications $3-8 \mathrm{~cm}$. long, $1-3 \mathrm{~cm}$. wide.

On wood and bark of fallen frondose limbs, rarely on pine. July to October. Pennsylvania to Alabama and westward to Illinois. Infrequent.

C. subceraceum resembles in general aspect $C$. ceraceum but has small spores. This species should be compared with Grandinia mucida when the problem of the latter is being solved; the only European specimen of G. mucida which I have studied was shared with me by Bresadola and is distinct, having aspect of the illustration in Fries, Icones Hym., pl. 195, f. 3.

Specimens examined:

Pennsylvania: Trexlertown, W. Herbst, 76, type, and an unnumbered specimen, both received under the name Corticium laeve of Herbst, Fung. Fl. Lehigh Valley.

Maryland: Takoma Park, C. L. Shear, 1275.

District of Columbia: W. A. Murrill, 1446 (in N. Y. Bot. Gard. Herb., and Mo. Bot. Gard. Herb., 61491). 
North Carolina: Salem, Schweinitz, the Thelephora aurantia of Schweinitz, Fungi Car. and Thelephora (Grandinia) mucida of Schweinitz, Syn. N. An. Fungi, 708 (in Schweinitz Herb.).

Alabama: Montgomery, R. P. Burke, 191 (in Mo. Bot. Gard. Herb., 57070).

Kentucky: Crittenden, C. G. Lloyd, 1684, 3123.

Ohio: C. G. Lloyd, 4177, 4179; Cincinnati, C. G. Lloyd, 4496; Madisonville, C. G. Lloyd, $01 \% 1$.

Illinois: Cerro Gordo, L. O. Overholts, 3121 (in Mo. Bot. Gard. Herb., 5715); River Forest, E. T. \& S. A. Harper, 658.

50. C. roseo-pallens Burt in Lyman, Boston Soc. Nat. Hist. Proc. 33: 173. pl. 20, f. 56-73. 1907.

Type: in Burt Herb.

Fructifications broadly effused, thin, adnate, membranaceous, tender, small pieces separable when moist, flesh-pink when fresh, fading to ivory-yellow in the herbarium, at first with the hymenium interrupted, at length continuous, waxy, even, the margin thinning out, with the hyphae interwoven; in section 100-200 $\mu$ thick, not colored, with the hyphae suberect, interwoven, more loosely arranged near the substratum, $3-31 / 2 \mu$ in diameter, not incrusted, occasionally nodose-septate; no gloeocystidia; basidia 4-spored; spores pale rose when first collected, fading to white, even, cylindric, slightly curved, $4-5 \times 1 \frac{1}{2}-2$.

Fructifications 3-12 cm. long, 2-6 cm. wide.

On bark and wood of decaying logs of Fagus, Populus, Quercus, etc. Maine to Louisiana and in Missouri. October. Occasional.

This species may be recognized by its broadly effused, thin, flesh-pink or pale rosy salmon fructifications, fading upon drying to nearly white and by the small allantoid spores. In his discussion of a portion from my type, comm. to Bresadola under the name C. rubropallens, Bourdot \& Galzin, Soc. Myc. Fr. Bul. 27: 258. 1911, regard their $C$. subtestaceum as a synonym and $C$. incrustans v. Höhn. \& Litsch. as scarcely distinct. I have not seen specimens of the latter species and those of the former, communicated to me by Bourdot, are hardly convincing.

Specimens examined: 
Maine: Kittery Point, $R$. Thaxter, comm. by W. G. Farlow, 7 (in Mo. Bot. Gard. Herb., 55291).

Vermont: Grand View Mountain, E. A. Burt; Middlebury, E. A. Burt; Ripton, E. A. Burt, type; Weybridge, E. A. Burt.

Massachusetts: Stony Brook, G. R. Lyman, 142; Waverly, G. R. Lyman, 142 .

New York: Albany, H. D. House, 14.170 and H. D. House \& $J$. Rubinger (in Mo. Bot. Gard. Herb., 44721, 8732); Ithaca, G. F. Atkinson, 2559a; Sylvan Beach, H. D. House (in N. Y. State Mus. Herb., and Mo. Bot. Gard. Herb., 9089).

Louisiana: Lafayette, A. B. Langlois, 1764 , comm. by W. G. Farlow.

Missouri: Creve Coeur, B. M. Duggar (in Mo. Bot. Gard. Herb., 44821).

51. C. ochraceum Fries, Epicr. 563. 1838; Hym. Eur. 652. 1874; Berkeley, Outl. Brit. Fung. 275. 1860; Sacc. Syll. Fung. 6: 624 . 1888; Bresadola, Fungi Trid. 2: 60. pl. 170, f. 1. 1898; Bourdot \& Galzin, Soc. Myc. Fr. Bul. 27: 256. 1911; Rea, Brit. Basid. 680. 1922.

Thelephora calcea var. argillacea Fries, Elench. Fung. 1: 215. 1828.

Type: in Fries Herb.

Fructifications broadly effused, closely adnate, rather thick, becoming pinkish buff to wood-brown in the herbarium, waxy, even or somewhat papillose, contracting in drying and cracking to the substratum into rectangular masses about $1 / 2-1 \mathrm{~mm}$. in diameter, and showing sides of the fissures composed of firm, dense, agglutinate structure, the margin at first whitish, soon concolorous, thinning out; in section 300-500 $\mu$ thick, becoming somewhat zonate or stratose, not colored, composed of erect hyphae densely crowded, interwoven, and so closely glued together that the deeply staining lumen is the distinguishable part; gloeocystidia, if present at all, so similar to the hyphae in form and diameter that there is no indication of them except in aqueous mounts; spores hyaline, even, $4-6 \times 2 \frac{1}{2}-31 / 2 \mu$.

Fructifications $3-10 \mathrm{~cm}$. long, $1-4 \mathrm{~cm}$. wide.

On decorticated and sometimes charred limbs on the ground of 
Pinus Strobus and other conifers. In Europe and in Vermont, Alabama, Idaho, and Washington. September and October. Rare in North America.

$C$. ochraceum somewhat resembles in general aspect $C$. lactescens and is, in my opinion, related to the latter by hyphae in barely the beginning of differentiation into gloeocystidia. C. ochraceum of American plant lists is based on misdetermined specimens.

Specimens examined:

Sweden: Femsjö, E. Fries, type (in Fries Herb.); North Sweden,

L. Romell, 403; Smöland, E. Fries, authentic specimen of

Corticium calceum var. argillaceum (in Fries Herb.).

Austria: Innsbruck, Tirol, V. Litschauer.

Italy: on Abies excelsa in Alps Mts., G. Bresadola.

Vermont: Middlebury, E. A. Burt.

Alabama: Montgomery, R. P. Burke, 606 (in Mo. Bot. Gard. Herb., 57471).

Montana: Rexford, E. E. Hubert, comm. by J. R. Weir, 12017 (in Mo. Bot. Gard. Herb., 63373).

Idaho: Priest River, J. R. Weir, 59.

Washington: Hoquiam, C. J. Humphrey, 6373; Seattle, C. J. Humphrey, 6454, and W. A. Murrill, 135, comm. by N. Y. Bot. Gard. Herb. (in Mo. Bot. Gard. Herb., 55737).

52. C. furfuraceum Bresadola, Mycologia 17:69. 1925.

Type: in Weir Herb.

Fructifications broadly effused, closely adnate, thin, furfuraceous, ivory-yellow to pinkish buff in the herbarium, becoming somewhat cracked, the margin thinning out, pruinate; in section 60-140 $\mu$ thick, not colored, composed of suberect, thin-walled hyphae about $3 \mu$ in diameter, somewhat collapsed and irregular in outline, indistinct, not incrusted; no gloeocystidia nor conducting organs; spores hyaline, even, 4-51/2 $\times 21 / 2 \mu$.

Fructifications more than $10 \mathrm{~cm}$. long, for broken off at both ends, $6 \mathrm{~cm}$. wide.

On decaying wood of logs of Abies grandis, Pinus monticola, $P$. contorta, $P$. ponderosa, and Larix occidentalis. Montana, Idaho, Washington, and British Columbia. August and September. Probably common. 
C. furfuraceum may be recognized on the substrata given by the very thin, closely adnate fructifications of ivory-yellow to pinkish buff color, which crack slightly by contraction in drying and have small spores.

Specimens examined:

Montana: Evaro, J. R. Weir, 439 (in Mo. Bot. Gard. Herb., 63714); Missoula, J. R. Weir, 401, 409 (in Mo. Bot. Gard. Herb., 11316, 63717).

Idaho: Coolin, J. R. Weir, 17211, type, 16764 and 16927 (in Weir Herb.).

British Columbia: Kootenai Mountains, near Salmo, J. R. Weir, 481, 501, 526 (in Mo. Bot. Gard. Herb., 63725, 63716, 63715). Washington: Kalama, C. J. Humphrey, 6225.

53. C. lividum Persoon, Obs. Myc. 1: 38. 1796; Fries, Epicr. 563. 1838; Hym. Eur. 652. 1874; Berkeley, Outl. Brit. Fung. 275. 1860; Sacc. Syll. Fung. 6:623. 1888; Massee, Linn. Soc. Bot. Jour. 27: 152. 1890; Bourdot \& Galzin, Soc. Myc. Fr. Bul. 27: 253. 1911; Rea, Brit. Basid. 680. 1922.

Thelephora livida Persoon, Myc. Eur. 1: 148. 1822; Fries, Syst. Myc. 1:447. 1821; Elench. Fung. 1:218. 1828.-Phlebia livida (Pers.) Bresadola, I. R. Accad. Agiati Atti III. 3: 105. 1897.-Grandinia ocellata Fries, Epicr. 527. 1838; Hym. Eur. 626. 1874; Sacc. Syll. Fung. 6: 501. 1888.-An Corticium hepaticum Berk. \& Curtis, Grevillea 1: 180. 1873?

Fructifications broadly effused, agglutinated, sometimes becoming rather thick, somewhat waxy-gelatinous, not separable, varied in color, gray or tinged reddish or bluish, becoming pale smoke gray, cinnamon-buff, and raisin-black in the herbarium, pruinose, even or sometimes radiately wrinkled or tuberculate by aggregations of imbedded crystalline matter, the margin thinning out, similar or whitish; in section $100-500 \mu$ thick, not colored usually, rarely slightly brownish, composed of densely interwoven, suberect hyphae about $2-3 \mu$ in diameter, with the walls gelatinously modified and glued together; no gloeocystidia; spores hyaline, even, $3-5 \times 11 / 2-2 \mu$.

Fructifications $2-10 \mathrm{~cm}$. long, 1-5 cm. wide.

On rotting logs, usually decorticated, of coniferous species, 
more rarely on frondose logs. In Europe, Canada to Texas, and westward to British Columbia and California, and in Venezuela and East Indies. June to December. Probably common.

C. lividum may be recognized by its livid fructifications of gray, reddish, or bluish tinge and of somewhat gelatinous consistency, somewhat suggestive of those of Peniophora gigantea in aspect but destitute of cystidia. C. hepaticum seems to me referable to C. lividum but I need to study the type again in the feature of the slightly reflexed margin, which I now suspect may be that of a different species overrun by $C$. lividum. Since the tubercules of the Grandinia ocellata form are due to heaps of imbedded crystals, it has seemed to taxonomists that this species is a Corticium rather than a Grandinia.

Specimens examined:

Sweden: Femsjö, L. Romell, 214, E. A. Burt, 3 gatherings, L. Romell, comm. by Bresadola.

Austria: Steiermark, $N$. Rechinger, comm. \& det. by V. Litschauer; Tirol, V. Litschauer.

Hungary: Kmet, comm. by Bresadola.

Italy: G. Bresadola.

England: Mulgrave Woods, E. M. Wakefield (in Mo. Bot. Gard. Herb., 57115).

Canada: J. Macoun, 94, and 350, comm. by W. G. Farlow (in Mo. Bot. Gard. Herb., 8269) ; J. Dearness (in Mo. Bot. Gard. Herb., 56797); Ottawa, J. Macoun, 2, 46, 53.

New Hampshire: Chocorua, W. G. Farlow.

Vermont: Middlebury, E. A. Burt.

New York: Ampersand, C. H. Peck (in N. Y. State Mus. Herb., and Mo. Bot. Gard. Herb., 56102); Catskill Mts., C. H. Peck (in N. Y. State Mus. Herb., and Mo. Bot. Gard. Herb., 55792). Pennsylvania: State College, L. O. Overholts, 3425 (in Mo. Bot. Gard. Herb., 54471).

Maryland: Takoma Park, C. L. Shear, 1269.

Louisiana: St. Martinville, A. B. Langlois, comm. by W. G. Farlow (in Mo. Bot. Gard. Herb., 44693), and comm. by Ellis Herb. (in Burt Herb.).

Texas: Silsbee, W. H. Long, 21227 (in Mo. Bot. Gard. Herb., $55127)$. 
Wisconsin: Lake Geneva, E. T. \& S. A. Harper, 899.

Montana: Anaconda, E. E. Hubert, comm. by J. R. Weir, 12007 (in Mo. Bot. Gard. Herb., 63367); Como, E. E. Hubert, comm. by J. R. Weir, 11958 (in Mo. Bot. Gard. Herb., 63315); Evaro, J. R. Weir, 421 (in Mo. Bot. Gard. Herb., 14764); Kalispell, E. E. Hubert, comm. by J. R. Weir, 11972 (in Mo. Bot. Gard. Herb., 63333); Libby, E. E. Hubert, comm. by J. R. Weir, 11347, 11360, 12041 (in Mo. Bot. Gard. Herb., 63701, 63702, 63391) ; Missoula, E. E. Hubert, comm. by J. R. Weir, 11981 (in Mo. Bot. Gard. Herb., 63334); Radnor, E. E. Hubert, comm. by J. R. Weir, 11645 (in Mo. Bot. Gard. Herb., 63707). Idaho: Coeur d'Alene, E. E. Hubert, comm. by J. R. Weir, 11993 (in Mo. Bot. Gard. Herb., 63356); Priest River, J. R. Weir, 6364 (in Mo. Bot. Gard. Herb., 58373), and 13, 76, 84; Santa, E. E. Hubert, comm. by J. R. Weir, 11755, 12003, 12042 (in Mo. Bot. Gard. Herb., 63313, 63365, 63392).

British Columbia: Kootenai Mts. near Salmo, J. R. Weir, 527 (in Mo. Bot. Gard. Herb., 20903); Sidney, J. Macoun, 85, 380 (in Mo. Bot. Gard. Herb., 63693, 63764); Vancouver Island, J. Macoun, comm. by J. Dearness, V 85 (in Mo. Bot. Gard. Herb., 22729).

Washington: Kalama, C. J. Humphrey, 6138.

Oregon: Philomath, S. M. Zeller, 2159 (in Mo. Bot. Gard. Herb., 58774).

California: Requa, $R$. Kelly, comm. by A. S. Rhoads, 16 (in Mo. Bot. Gard. Herb., 56985).

Venezuela: La Guayra, A. F. Blakeslee, comm. by W. G. Farlow (in Mo. Bot. Gard. Herb., 55294).

East Indies: Batavia, Rick, comm. by Bresadola under the name Phlebia livida (Pers.) Bres.

54. C. Overholtsii Burt, n. sp.

Type: in Mo. Bot. Gard. Herb.

Fructifications effused, closely adnate, thin, somewhat membranaceous, at first between pale salmon and pale grayish vinaceous, becoming tilleul-buff in the herbarium, even, pruinose, not cracked, the margin thinning out, somewhat fimbriate; in section $160 \mu$ thick, not colored, composed of suberect, densely inter- 
woven, conglutinate hyphae up to $3 \mu$ in diameter, not incrusted, with wall gelatinously modified, the outline not well defined; no gloeocystidia; spores hyaline, even, $5-6 \times 2-21 / 2 \mu$, copious.

Fructifications $1 \frac{1}{2}-3 \mathrm{~cm}$. long, $1-2 \mathrm{~cm}$. wide.

On thick bark of dead Pinus rigida. Pennsylvania. October.

$C$. Overholtsii has the livid color of $C$. vinaceo-scabens but nothing else in common with that species. In structural details it is related to $C$. lividum but does not have the appearance of dried cartilage or resin, characteristic of all specimens of the latter known to me.

Specimens examined:

Pennsylvania: Reitz Gap, L. O. Overholts, 4656, type (in Mo. Bot. Gard. Herb., 57155).

\section{C. Pseudotsugae Burt, n. sp.}

Type: in Mo. Bot. Gard. Herb.

Fructifications effused, closely adnate, very thin, not at all separable, light buff in the herbarium, even, not shining, not cracked, the margin similar, thinning out, pulverulent; in section 45-55 $\mu$ thick, not appreciably colored, composed of densely interwoven hyphae about $1 \frac{1}{2}-2 \mu$ in diameter, not incrusted, conglutinate; no gloeocystidia; basidia with 4 sterigmata; spores hyaline, even, $3-5 \times 2-3 \mu$.

Fructifications $5-8 \mathrm{~cm}$. long, $1-2 \mathrm{~cm}$. wide.

On decorticated, decaying wood of Pseudotsuga taxifolia and Tsuga canadensis. New York and Idaho. August to November.

C. Pseudotsuga is almost exactly the avellaneous color of Saccardo's 'Chromotaxia.' This color, occurrence on hemlock, and very thin fructifications are the most available characters for recognition of the species.

Specimens examined:

New York: Freeville, G. F. Atkinson, 2627.

Idaho: Sandpoint, E. E. Hubert, comm. by J. R. Weir, 11617, type (in Mo. Bot. Gard. Herb., 63305).

56. C. confine Bourdot \& Galzin, Soc. Myc. Fr. Bul. 27: 260. 1911.

Type: authentic specimen in Burt Herb. 
Fructifications broadly effused, thin, closely adnate, pale pinkish buff to pale olive-buff in the herbarium, not shining, hypochnoid, rimose-granular into areas or granules about $2-3$ to a $\mathrm{mm}$., the margin thinning out, byssoid; in section 75-150 $\mu$ thick, not colored, composed of erect, thin-walled, hyaline hyphae $21 / 2-3 \mu$ in diameter, of irregular outline, collapsing, nodoseseptate; no gloeocystidia; spores hyaline, even, $3-5 \times 2 \frac{1}{2} \mu$, copious.

Fructifications $4-10 \mathrm{~cm}$. long, $2-4 \mathrm{~cm}$. wide.

On decaying frondose wood. France and Vermont. May to August.

This species is related to Grandinia by its granular aspect but the granules seem to have originated so largely from the cracking of the fructification to the substratum that I concur in the inclusion in Corticium. It has a more hypochnoid surface than C. scutellare.

Specimens examined:

France: Allier, H. Bourdot, 16064, 16065.

Vermont: Middlebury, Battell Ledge, E. A. Burt.

57. C. analogum (B. \& G.) Burt, n. comb.

Gloeocystidium analogum Bourdot \& Galzin, Soc. Myc. Fr. Bul. 28: 366.1913.

Type: authentic specimen in Burt Herb.

Fructifications broadly effused, thick, adnate, fleshy-membranaceous, small pieces separable when moistened, becoming maizeyellow to chamois in the herbarium, somewhat colliculose, not cracked or but little cracked, not shining, the margin thinning out; in section 500-1000 $\mu$ thick, colored like the hymenium, becoming zonate or somewhat stratose, composed of hyphae 3-4 $\mu$ in diameter, densely interwoven, conglutinate and poorly defined, of great numbers of imbedded spores and gloeocystidia; gloeocystidia immersed in many zones or layers, $40-80 \times 6-8 \mu$, becoming dissolved by potassium hydrate solution; imbedded spores subglobose, $5-6 \times 5 \mu$, minutely rough, slightly colored in the deeper portions of the fructification, hyaline at the surface of the hymenium; spores on basidia not demonstrated.

Fructifications in fragments up to $8 \mathrm{~cm}$. long, $3 \mathrm{~cm}$. wide. 
On decaying wood of Quercus and Fraxinus in France, of Quercus in Maine, and of Populus trichocarpa in Idaho. July to October. Probably rare.

$C$. analogum has general aspect and color of C. galactinum and C. portentosum and structure related to that of $C$. effuscatum. The thick, stratose fructifications, containing great numbers of imbedded spores and gloeocystidia, afford good additional distinctive characters. The Maine specimens are doubtfully referred here as a young first-stratum stage.

Specimens examined:

France: Aveyron, A. Galzin, 12435, authentic specimen, comm. by $\mathrm{H}$. Bourdot, 16164 .

Maine: Kittery Point, R. Thaxter \& E. A. Burt.

Idaho: Priest River, J. R. Weir, 25.

58. C. effuscatum Cooke \& Ellis, Grevillea 9: 103. 1881; Sacc. Syll. Fung. 6: 633. 1888; Massee, Linn. Soc. Bot. Jour. 27 : 142. 1890; Lyman, Boston Soc. Nat. Hist. Proc. 33: 176. pl. 21, f. 74-95, pl. 22, f. 96-105. 1907.

Type: in Kew Herb.

Fructifications broadly effused, rather thick, membranaceous, small pieces separable when moistened, honey-yellow to russet when fresh, fading to cream-buff in the herbarium, even, pulverulent, the margin thinning out; in section $200-500 \mu$ thick, composed of very densely arranged, suberect, interwoven hyphae about $2 \mu$ in diameter, gloeocystidia, and chlamydospores; gloeocystidia flexuous, $40-150 \times 5-9 \mu$, starting from the substratum; imbedded chlamydospores very numerous, globose, $5-6 \mu$ in diameter, sometimes comprising nearly the whole fructification; basidiospores hyaline, even, $6 \mu$ in diameter.

Fructifications $3-10 \mathrm{~cm}$. long, $2-4 \mathrm{~cm}$. wide.

On under side of decaying wood and bark of frondose species. Newfoundland and Canada to Louisiana and westward to Washington. September to November. Widely distributed and common locally.

C. effuscatum is conspicuous when fresh by its large salmon to brick-red fructifications. It soon fades in the herbarium to the pallid or buff color assumed in the herbarium by many species and 
must then be cautiously separated from C. confluens and Hypochnus pallescens which may have the same aspect. The very numerous imbedded chlamydospores and elongated gloeocystidia of $C$. effuscatum are its characters for such separation.

Specimens examined:

Exsiccati: Ellis, N. Am. Fungi, 1208.

Newfoundland: Bay of Islands, A. C. Waghorne, 1014 (in Mo. Bot. Gard. Herb., 4805).

Canada: J. Macoun, 16; Lower St. Lawrence Valley, J. Macoun, 3. Ontario: Ottawa, J. Macoun, 455.

Quebec: Ironsides, J. Macoun, 280.

New Hampshire: Chocorua, W. G. Farlow, E (in Mo. Bot. Gard. Herb., 55001).

New York: Ithaca, G. F. Atkinson, 1002, 2113; North Greenbush, H. D. House, 14.236 (in Mo. Bot. Gard. Herb., 44735); Staten Island, W. H. Ballou; Tyre, C. H. Peck (in N. Y. State Mus. Herb., and Mo. Bot. Gard. Herb., 57718); Westport, C. H. Peck (in N. Y. State Mus. Herb., and Mo. Bot. Gard. Herb., 57770), and 1; White Plains, W. H. Ballou, 1, 2 (in Mo. Bot. Gard. Herb., 55623, 55628).

Pennsylvania: West Chester, Everhart \& Haines, in Ellis, N. Am. Fungi, 1208.

District of Columbia: Washington, C. L. Shear, 1262.

Georgia: Tipton, C. J. Humphrey, 162.

Louisiana: A. B. Langlois, 249; St. Martinville, A. B. Langlois, Z. Ohio: C. G. Lloyd, 3824.

Illinois: Bluff Lake, L. H. Pammel (in Mo. Bot. Gard. Herb., 60655).

Missouri: Creve Coeur, E. A. Burt (in Mo. Bot. Gard. Herb., 19458, 44071); Rose Hill, L. H. Pammel (in Mo. Bot. Gard. Ilerb., 60656); St. Louis, L. H. Pammel, comm. by Farlow Herb.; Upper Creve Coeur, E. A. Burt (in Mo. Bot. Gard. Herb., 54775).

Idaho: Priest River, J. R. Weir, 53.

British Columbia: Vancouver Island, Cedar Hill, J. Macoun. Washington: Arlington, C. J. Humphrey, 7611 (in Mo. Bot. Gard. Herb., 10750); Kalama, C. J. Humphrey, 6160. 
59. C. abeuns Burt, n. sp.

Type: in Burt Herb.

Fructification broadly effused, thin, membranaceous, tender, small pieces separable when moistened, whitish to ivory-yellow and cream-buff in the herbarium, even, not cracked or but little eracked, the margin whitish, thinning out, composed of interwoven hyphae; in section 100-240 $\mu$ thick, not colored, composed of somewhat erect, interwoven hyphae $2 \frac{1}{2}-3 \mu$ in diameter, not incrusted, and of slender gloeocystidia; gloeocystidia 30-60 $\times$ 4-7 $\mu$, numerous, immersed; spores hyaline, even, subglobose, 6-7 $\times 4-6 \mu$, copious.

Fructifications 4-13 cm. long, 2-5 cm. wide.

On decaying coniferous wood, rarely on bark of frondose species. Maine to Alabama, in British Columbia and New Mexico, and in Japan and South Africa. July to October. Infrequent.

$C$. abeuns has the aspect of $C$. lacteum and $C$. radiosum and spores of nearly the same size as in these species but not quite as globose and further notably distinct from both by its slender, flexuous gloeocystidia.

Specimens examined:

Maine: Piscataquis County, W. A. Murrill, 1938 (in N. Y. Bot. Gard. Herb., and Mo. Bot. Gard. Herb., 63765).

New Hampshire: North Conway, W. H. Snell, 626 (in Mo. Bot. Gard. Herb., 59293).

New York: Alcove, C. L. Shear, 1215; Freeville, G. F. Atkinson, 2595; Karner, C. H. Peck, comm. by N. Y. State Mus. Herb., T 7 (in Mo. Bot. Gard. Herb., 54557) and another specimen (in N. Y. State Mus. Herb., and Mo. Bot. Gard. Herb., 55784). Alabama: Goldbranch, J. R. Weir, 10958 (in Mo. Bot. Gard. Herb., 63240); Montgomery, R. P. Burke, 229, type, and 471 (in Mo. Bot. Gard. Herb., 57100, 57289).

Wisconsin: Madison, M. C. Jensen, comm. by C. J. Humphrey, 617 (in Mo. Bot. Gard. Herb., 44785).

British Columbia: Sidney, J. Macoun, 490, 812 (in Mo. Bot. Gard. Herb., 55314, 62117); Squamish, J. Macoun, 496 (in Mo. Bot. Gard. Herb., 55184).

New Mexico: Datil National Forest, W. H. Long, 21046 (in Mo. Bot. Gard. Herb., 55145). 
Japan: Awaji, A. Yasuda, 12, 80 (in Mo. Bot. Gard. Herb., 55660, 56311).

Africa: Houtbos, Transvaal, P. A. van der Bijl, 1495.

60. C. ravum Burt, n. sp.

Type: in Burt Herb.

Fructifications broadly effused, closely adnate, thin, not separable, becoming pale pinkish buff to light buff in the herbarium, even, not shining, becoming cracked at the center, the margin thinning out, concolorous; in section 45-150 $\mu$ thick, not colored, composed of densely arranged hyphae, interwoven near substratum but erect towards the hymenium, of numerous gloeocystidia, and of very slender paraphyses; gloeocystidia 20-80 $\times 7-11 \mu$, the more ovoid ones nearer the substratum; paraphyses more or less numerous in the hymenial surface, very slender, hyaline, curved, $1 / 2^{-1} \mu$ in diameter; spores white in spore collection, even, $6-8 \times 4-4 \frac{1}{2} \mu$.

Fructifications up to $10 \mathrm{~cm}$. long, $2 \mathrm{~cm}$. wide, broken off at both ends.

On fallen frondose limbs. Florida to Louisiana, in Missouri, Cuba, and Brazil. August to February.

C. ravum has grayish fructifications closely resembling welldeveloped ones of $C$. rubrocanum in general aspect but distinct by gloeocystidia.

Specimens examined:

Florida: C. G. Lloyd, 4832.

Alabama: Montgomery, R. P. Burke, 126 (in Mo. Bot. Gard. Herb., 5282).

Louisiana: St. Martinville, A. B. Langlois, 1765 and $N$, type.

Missouri: Creve Coeur, E. A. Burt (in Mo. Bot. Gard. Herb., 44045).

Cuba: Omaja, C. J. Humphrey, 3056.

Brazil: Rio de Janeiro, J. N. Rose, 21462, comm. by N. Y. Bot. Gard. Herb.

61. C. mexicanum Burt, n. sp.

Type: in Mo. Bot. Gard. Herb., and N. Y. Bot. Gard. Herb. Fructifications adnate, small, circular, becoming confluent, 
rather thick, fleshy-membranaceous, separable when moist, cream color to cream-buff in the herbarium, somewhat velvety or fibrillose, not cracked, the margin concolorous, fimbriate; in section $400 \mu$ thick, not colored, with hyphae next to the substratum longitudinally and densely arranged, thick-walled, not incrusted, not nodose-septate, curving outward obliquely into the hymenium; gloeocystidia numerous in the hymenium and subhymenium, clavate or cylindric, $60-120 \times 9-12 \mu$; spores few, even, hyaline, not seen attached to basidia, $9-11 \times 6-7 \mu$.

Fructifications at first $2-3 \mathrm{~mm}$. in diameter, becoming confluent into a mass $2 \mathrm{~cm}$. long, $5 \mathrm{~mm}$. wide.

On very rotten wood. Mexico. January.

On account of the loose attachment of the fructification to the substratum and the broad layer of longitudinally arranged hyphae it is possible that $C$. mexicanum may be the resupinate stage of a Stereum, but if so, it is distinct from any Stereum known to me.

Specimens examined:

Mexico: Xuchiles, near Cordoba, W. A. \& E. L. Murrill, 1196, type, comm. by N. Y. Bot. Gard. Herb. (in Mo. Bot. Gard. Herb., 54604).

62. C. epigaeum Ell. \& Ev. Jour. Myc. 1: 88. 1885; Sacc. Syll. Fung. 6: 631. 1888.

Type: in N. Y. Bot. Gard. Herb.

Fructifications effused, thin, membranaceous, tender, small pieces separable when moistened, white, becoming somewhat pinkish buff in the herbarium, not cracked, the margin concolorous, thinning out; in section 175-250 $\mu$ thick, not colored, 2layered, the layer next to the substratum about $75 \mu$ thick, consisting of densely interwoven hyphae about $21 / 2-3 \mu$ in diameter, not showing characters clearly in the type; hymenial layer 100$150 \mu$ thick, composed of densely arranged hyphae, gloeocystidia, and basidia; gloeocystidia elongated; spores hyaline, even, 51/2$6 \times 5 \mu$, confined to hymenial surface.

Fructifications 2-5 cm. long, 1-3 cm. wide.

On bare ground and rotten wood on the ground. New Hampshire to British Columbia, Washington, and Oregon. August to April. Rare. 
C. epigaeum is characterized by white color, 2-layered structure, elongated gloeocystidia, and large, subglobose spores. It is related to $C$. lactescens but does not become stratose nor cracked nor as hard and compact as the latter. The type specimen itself should be used for comparison rather than the specimens from widely separated localities which seem to me probably to be $C$. epigaeum.

Specimens examined:

New Hampshire: Chocorua, W. G. Farlow (in Mo. Bot. Gard. Herb., 13954).

New York: Karner, H. D. House, comm. by N. Y. State Mus. Herb., 14.160 (in Mo. Bot. Gard. Herb., 44705).

Ohio: Cincinnati, C. G. Lloyd, $451 \%$.

Michigan: New Richmond, C. H. Kauffman, 20 (in Mo. Bot. Gard. Herb., 9905).

British Columbia: Hastings, J. Macoun, 129.

Washington: Bingen, W. N. Suksdorf, 896, 754.

Oregon: Carpenter, 100, type (in N. Y. Bot. Gard. Herb.).

63. C. lactescens Berkeley, Outl. Brit. Fung. 274. 1860; Fries, Hym. Eur. 650. 1874; Sacc. Syll. Fung. 6: 612. 1888; Massee, Linn. Soc. Bot. Jour. 27: 138. 1890; Bresadola, Ann. Myc. 1: 95. 1903; Wakefield, Brit. Myc. Soc. Trans. 4: 118. pl. 3, f. 6-8. 1913; Rea, Brit. Basid. 685. 1922.

Thelephora lactescens Berkeley in Hooker, Eng. Fl. 2²: 169. 1836. -Gloeocystidium lactescens (Berk.) v. Höhnel. \& Litschauer, K. Akad. Wiss. Wien Sitzungsber. 116: 784 . 1907; Bourdot \& Galzin, Soc. Myc. Fr. Bul. 28: 366. 1913.-Corticium Brinkmanni Bresadola in Brinkmann, Westfälische Prov.-Vereins f. Wiss. u. Kunst Jahresber. 26: 128. 1898.

Type: in Kew Herb.

Fructifications broadly effused, rather thick, closely adnate, waxy-fleshy, small pieces separable, whitish to flesh color and buff-pink when fresh, becoming light buff to avellaneous in the herbarium, even, contracting greatly in drying and forming in thick fructifications very numerous short fissures with somewhat resin-colored sides, the margin whitish, narrow, when fresh exuding a watery white milk where wounded; in section $200-1000 \mu$ 
thick, pale avellaneous, becoming stratose when old and thick, with a narrow layer of hyphae arranged longitudinally along the substratum and the remainder of the fructification composed, according to age, of one or more strata of erect, agglutinated hyphae, basidia, and gloeocystidia; gloeocystidia very numerous, flexuous, 60-120 $\times$ 4-9 $\mu$; spores hyaline, even, flattened on one side, $4-8 \times 3-6 \mu$, copious.

Fructifications $4-10 \mathrm{~cm}$. long, $1-4 \mathrm{~cm}$. wide.

On decaying wood of logs of frondose species. In Europe, Canada to Louisiana, and westward to the Pacific states, in the West Indies, and in Mexico. Throughout the year. Widely distributed but not common.

C. lactescens is best recognized in thick stratose fructifications by their cracking into short and usually disconnected fissures, stratose and agglutinated structure, occurrence on frondose wood, very numerous gloeocystidia, and rather large spores.

Specimens examined:

Exsiccati: Berkeley, Brit. Fungi, 21.

Sweden: Stockholm, L. Romell, 176; Tyresö, L. Romell, C.

Germany: Westfalia, Lengerich, W. Brinkmann, part of type of Corticium Brinkmanni from Bresadola.

Austria: Innsbruck, Tirol, V. Litschauer, 2 specimens; $N$. Austria, V. Litschauer.

Italy: Trent, G. Bresadola; Pisa, T. Archangeli, comm. by Herb. Horti Pisani (in Mo. Bot. Gard. Herb., 44564).

France: Bois de Boulogne, Paris, G. F. Atkinson.

England: $M$. J. Berkeley, in Berkeley, Brit. Fungi, 21; West Farleigh, M. J. Berkeley (in Kew Herb.); West Walling, M. J. Berkeley (in Kew Herb.).

Canada: J. Macoun, 12, 20, 81; Hemlock Lake, Beechwood, J. Macoun, 450; Billings Bridge, J. Macoun, 55; Carleton Place, J. Macoun, 91; Lower St. Lawrence Valley, J. Macoun, 26, 32, 36; Ontario, Belleville, J. Macoun, 531.

Newfoundland: Bay of Islands, A. C. Waghorne, 477 (in Mo. Bot. Gard. Herb., 4833).

Maine: Kittery Point, R. Thaxter \& E. A. Burt.

Vermont: Middlebury, E. A. Burt; Silver Lake, Leicester, E. A. Burt. 
Massachusetts: Arlington, A. P. D. Piguet, comm. by W. G. Farlow, 34.

New York: Kirkville, L. M. Underwood, 55 (in N. Y. Bot. Gard. Herb., and Mo. Bot. Gard. Herb., 61566); Ithaca, Thom, comm. by Cornell Univ. Herb., 13725; Vaughns, Hudson Falls, $S$. $H$. Burnham, 26 (in Mo. Bot. Gard. Herb., 54492).

North Carolina: Biltmore Estate, W. A. Murrill (in N. Y. Bot. Gard. Herb., Mo. Bot. Gard. Herb., 61564, and Burt Herb.).

Louisiana: Baton Rouge, Edgerton \& Humphrey, comm. by C. J. Humphrey, 5650.

Tennessee: Unaka Springs, W. A. Murrill, 623 (in N. Y. Bot. Gard. Herb., and Mo. Bot. Gard. Herb., 61565).

Michigan: Mass, C. J. Humphrey, 1698 (in Mo. Bot. Gard. Herb., 14228).

British Columbia: Sidney, J. Macoun, 76, 978, 496 (in Mo. Bot. Gard. Herb., 5752, 55316, 55317).

Washington: Bingen, W. N. Suksdorf, 909, 911.

Oregon: Corvallis, S. M. Zeller, 1771, 1905 (in Mo. Bot. Gard. Herb., 56848, 56881).

California: Pasadena, A. J. McClatchie, 786 (in N. Y. Bot. Gard. Herb., and Mo. Bot. Gard. Herb., 61461).

Mexico: Jalapa, W. A. \& E. L. Murrill, 68, comm. by N. Y. Bot.

Gard. Herb. (in Mo. Bot. Gard. Herb., 1682).

Porto Rico: Rio Piedras, J. A. Stevenson, 3957, 5576 (in Mo. Bot.

Gard. Herb., 7688, 11346).

Grenada: Grand Etang, $R$. Thaxter, comm. by W. G. Farlow, 16.

64. C. salmoneum Burt, n. sp.

Type: in Burt Herb. and in Farlow Herb.

Fructifications broadly effused, adnate, rather thick, somewhat membranaceous, small pieces separable when moist, "orangesalmon" when fresh, becoming vinaceous-buff in the herbarium, even, somewhat velvety, not shining, not at all cracked, the margin similar, determinate, thinning abruptly; in section $360 \mu$ thick, not colored, composed of densely interwoven hyphae 3-6 $\mu$ in diameter, thin-walled, not incrusted, glued together so that the outline is not clearly defined; gloeocystidia cylindric, up to $100 \times 8-9 \mu$, very numerous, confined to the hymenium; spores hyaline, even, $5 \times 31 / 2 \mu$. 
Fructifications 4-6 cm. long, $11 / 2-21 / 2 \mathrm{~cm}$. wide, and broken off on three sides in the specimens seen. Probably large.

On bark of decaying frondose wood. West Indies.

This tropical species is somewhat related to $C$. lactescens but differs in not becoming eracked nor stratose and in having its gloeocystidia of nearly equal length and arranged side by side in palisade manner in the hymenial layer.

Specimens examined:

Grenada: Chilly Brook, Grand Etang, R. Thaxter, type, comm. by W. G. Farlow, 16.

65. C. Macounii Burt, n. sp.

Type: in Burt Herb.

Fructifications widely effused, closely adnate, soft and fleshy when fresh, drying somewhat cartilaginous, small pieces separable when moistened, white, becoming ivory-yellow in the herbarium, even, sometimes cracking in drying, the margin thinning out; in section 60-150 $\mu$ thick, not colored, with the hyphae suberect, branching, $2 \frac{1}{2}-3 \mu$ in diameter; gloeocystidia, or perhaps conducting organs, very slender, 30-90 $\times 3-31 / 2 \mu$, starting from the substratum; spores hyaline, even, subglobose, slightly flattened on one side, 8-10 $\times 6-9$ i, pointed at base, copious.

Fructifications $3-8 \mathrm{~cm}$. long, 1-2 $\mathrm{cm}$. wide.

On decorticated, decaying pine wood. Canada, and perhaps New Hampshire and New York. October. Rare.

C. Macounii is much thinner than C. Berkeleyi and contracts in drying to a horn-like coating on the wood. The gloeocystidia or conducting organs are distinctive but inconspicuous. The specimens from New Hampshire and New York are a little thicker than the Canadian specimens by the presence of a layer of hyphae densely arranged, parallel with the substratum.

Specimens examined:

Canada: Lower St. Lawrence Valley, J. Macoun, 86.

Quebec: Hull, J. Macoun, 368, type.

New Hampshire: Chocorua, W. G. Farlow.

New York: Ithaca, G. F. Atkinson, 14102.

66. C. argentatum Burt, n. sp.

Type: in Burt Herb. 
Fructifications long-effused, thin, closely adnate, not at all separable, pale drab-gray, even, somewhat pruinose, becoming cracked, the margin similar or whitish, thinning out; in section $150 \mu$ thick, colored buffy brown, composed of densely arranged, interwoven, erect hyphae and gloeocystidia; the hyphae about $3 \mu$ in diameter, incrusted near the substratum; gloeocystidia very numerous in all regions, usually flexuous, $40-50 \times 8-12 \mu$, but some $6-12 \mu$ in diameter in the form of spherical brown masses; spores hyaline, even, $4-6 \times 3 \mu-$ few found and may not belong.

Fructification $10 \mathrm{~cm}$. long, $1 \mathrm{~cm}$. wide.

On under side of small branches of Salix. Nebraska. February. Apparently local.

C. argentatum has aspect so similar to Peniophora cinerea and $C$. subcinerea that microscopic examination of sections is necessary to separate it from these more common species. Distinguishing characters are the silvery color externally and brown color within and numerous gloeocystidia, some of which have the form of brown spherical masses such as occur in Peniophora serialis.

Specimens examined:

Nebraska: Long Pine, C. L. Shear, 1094, type.

\section{C. septentrionale Burt, n. sp.}

Type: in Mo. Bot. Gard. Herb.

Fructifications broadly effused, adnate, thin, small pieces separable when moist, drying snow-white, waxy, pulverulent, cracking by wide fissures into rectangular masses about $3 \times 2 \mathrm{~mm}$., the margin similar, composed of interwoven hyphae; in section 150-200 $\mu$ thick, not colored, composed of hyphae loosely arranged below, suberect, bushy-branched, nodose-septate, $3-31 / 2 \mu$ in diameter, not incrusted; gloeocystidia flexuous, up to $45 \times 6 \mu$, sometimes capitate or moniliform at apex, confined to the hymenial layer; spores hyaline, even, cylindric, $6-8 \times 2-21 / 2-3 \mu$, not numerous; basidia with 4 sterigmata.

Fructifications $5 \mathrm{~cm}$. long, $2 \mathrm{~cm}$. wide, broken off at both ends.

On decaying, weathered, frondose wood. Alabama and Manitoba. October.

Among the species having gloeocystidia $C$. septentrionale is 
noteworthy by its snow-white color; the long spores and gloeocystidia with occasionally capitate or moniliform apex may be helpful, confirmatory characters.

Specimens examined:

Alabama: Montgomery Co., R. P. Burke, 672 (in Mo. Bot. Gard. Herb., 63092).

Manitoba: Winnipeg, G. R. Bisby, 1346, type (in Mo. Bot. Gard. Herb., 60556).

68. C. stramineum Bresadola, Hedwigia 39: (221). 1900; Sacc. Syll. Fung. 16: 193. 1902.

Gloeocystidium stramineum Bresadola in Brinkmann, Westfälische Pilze, 18; Bourdot \& Galzin, Soc. Myc. Fr. Bul. 28: 361. 1913.-See Wakefield, Brit. Myc. Soc. Trans. 4: 341. 1918.

Type: type distribution in Brinkmann, Westfälische Pilze, 18.

Fructifications broadly effused, adnate, thin, somewhat membranaceous, small pieces separable when moist, becoming cartridge-buff to cream-buff in the herbarium, even, becoming somewhat cracked, the margin thinning out, pruinose, similar; in section 100-200 $\mu$ thick, not colored, composed of suberect, interwoven hyaline hyphae $2-3 \mu$ in diameter, not incrusted, and of elongated gloeocystidia; gloeocystidia flexuous, tapering towards apex, 40-100 × 41/2-9 $\mu$; spores hyaline, even, 4-6 62 $3 \mu$, not copious.

Fructifications 2-8 cm. long, 1-3 cm. wide.

On bark of decaying Alnus, Acer rubrum, and Carya. In Europe, and from Canada to South Carolina and westward to British Columbia and in Mexico. September to January. Rare.

C. stramineum may be recognized among our species having gloeocystidia, by its thin, whitish to straw-colored fructification on Acer rubrum.

Specimens examined:

Sweden: L. Romell, 419.

Germany: Lengerich, Westphalia, W. Brinkmann, part of type from Bresadola.

Austria: Tirol, V. Litschauer, 4 specimens from Innsbruck, Klosterberg, Stubai, and Volders, respectively.

Canada: J. Macoun, 28; Ontario, Ottawa, J. Macoun, 18. 
New Hampshire: Chocorua, W. G. Farlow, 31 and unnumbered specimen.

Vermont: Middlebury, E. A. Burt.

New York: Bronx Park, L. M. Underwood (in N. Y. Bot. Gard. Herb., and Mo. Bot. Gard. Herb., 61594); Ithaca, G. F. Atkinson, 3087; Karner, H. D. House (in N. Y. State Mus. Herb., and Mo. Bot. Gard. Herb., 54365, 54362).

New Jersey: Newfield, J. B. Ellis, comm. by N. Y. Bot. Gard. Herb.

Maryland: Takoma Park, C. L. Shear, 1338.

South Carolina: Hartsville, W. C. Coker, 3947 (in Mo. Bot. Gard. Herb., 57415).

Kentucky: Crittenden, C. G. Lloyd, 3124.

Missouri: Creve Coeur, F. P. McWhorter (in Mo. Bot. Gard. Herb., 57451).

British Columbia: Sidney, $J$. Macoun, 74, 80, in part (in Mo. Bot. Gard. Herb., 5749, 5750).

Mexico: Orizaba, W. A. \& E. L. Murrill, r63, comm. by N. Y. Bot. Gard. Herb., 54634.

\section{C. Litschaueri Burt, n. sp.}

Type: in Burt Herb.

Fructifications broadly effused, adnate, thin, somewhat membranaceous, small pieces separable when moistened, between ivory-yellow and olive-buff in the herbarium, even, becoming somewhat cracked, not shining, the margin thinning out; in section $200 \mu$ thick, not colored, composed of loosely interwoven, thick-walled hyphae $3 \mu$ in diameter, nodose-septate, not incrusted; gloeocystidia flexuous, 45-120 $\times 41 / 2^{-6} \mu$, in all regions of the fructification; spores hyaline, even, cylindric, flattened on one side, $9-10 \times 3-31 / 2 \mu$, four to a basidium.

Fragments of fructification $2 \mathrm{~cm}$. long, 1-11/2 $\mathrm{cm}$. wide, broken off on three sides.

On bark of Alnus and apple. North Dakota and Oregon.

$C$. Litschaueri has the aspect of $C$. stramineum and occurs on a frequent substratum of the latter but the spores of $C$. Litschaueri are the larger and the hyphae are thicker-walled than those of C. stramineum and more like those of $P$. cremea. 
Specimens examined:

North Dakota: Brenckle, comm. by V. Litschauer, 1, type.

Oregon: Corvallis, S. M. Zeller, 2219 (in Mo. Bot. Gard. Herb., 63029).

\section{C. protrusum Burt, n. sp.}

Type: in Mo. Bot. Gard. Herb.

Fructifications broadly effused, rather thick, dry, felty-membranaceous, separable, drying between light buff and cream color, even, conforming to irregularities of the substratum, not cracked, the margin a little paler than the hymenium, thinning out, with the hyphae interwoven; in section $500 \mu$ thick, not colored, 2layered, with (1) a broad layer next to the substratum of very densely and longitudinally arranged hyphae, and with (2) a somewhat more loosely arranged layer of interwoven, suberect, hyaline hyphae $4-41 / 2 \mu$ in diameter, not incrusted, and occasional gloeocystidia; gloeocystidia flexuous, up to $60 \times 4 \frac{1}{2}-5 \mu$; basidia 4-spored, not side by side and adhering together in a compact palisade layer but very numerous and protruding individually 6-15 $\mu$; spores attached to basidia are hyaline, even, $6 \times 2 \frac{1}{2}-3 \mu$, tapering towards the base, not copious.

Fructification $6 \mathrm{~cm}$. long, $5 \mathrm{~cm}$. wide, broken off on one side and at one end-probably large.

On bark of a badly decayed frondose log in a moist virgin forest. Mexico. December.

C. protrusum has a large fructification of general aspect and color of that of $C$. portentosum and $C$. galactinum but softer than these, of quite different structure, and having gloeocystidia. The basidia protrude beyond the general level of the fructification in the manner of cystidia; the presence of spores at the apex shows convincingly their real nature.

Specimens examined:

Mexico: Jalapa, W. A. \& E. L. Murrill, 157, comm. by N. Y. Bot. Gard. Herb. (in Mo. Bot. Gard. Herb., 10354).

71. C. livido-caeruleum Karsten, Notiz ur Sällsk. pro Faun. et Fl. Fenn. Förh. 9: 370. 1868; Finska Vet.-Soc. Bidrag Natur och Folk 25: 315 . 1876; 48: 415. 1889; Icones Hym. Fenniae 
3: 8. f. 75. 1889; Fries, Hym. Eur. 652. 1874; Sacc. Syll. Fung. 6: 623. 1888; Massee, Linn. Soc. Bot. Jour. 27: 152.1890.

Gloeocystidium livido-caeruleum (Karst.) v. Höhnel \& Litschauer, K. Akad. Wiss. Wien Sitzungsber. 115: 1554. 1906; Bourdot \& Galzin, Soc. Myc. Fr. Bul. 28: 355. 1913.-An Corticium plumbeum Fries, Hym. Eur. 653. 1874?

Type: studied from Karsten Herb. in Helsingfors by v. Höhnel \& Litschauer, loc. cit.

Fructifications long-effused, agglutinate, waxy-soft, not separable, white at first, then darkening in spots, finally more or less completely slate-gray to dark plumbeous, white, pruinose, rarely cracked; in section 100-250 $\mu$ thick, colored within when mature by 1-3 bluish black layers whose color is unchanged in lactic acid mounts but becomes at first vinaceous and is then dissolved and the sections bleached by potassium hydrate solution; very young fructifications not colored within; hyphae about $3 \mu$ in diameter, glued together so that the outline is not clearly shown; gloeocystidia elongated, flexuous, 30-60 $\times 3-6 \mu$; spores hyaline, even, $4 \frac{1}{2}-6 \times 2 \frac{1}{2}-31 / 2 \mu$.

Fructifications $1-10 \mathrm{~cm}$. long, $2 \mathrm{~mm} .-3 \mathrm{~cm}$. wide.

Under side of decaying coniferous rails, boards, and shingles, recorded on Abies, Pinus and Thuja. In Europe and in Canada, Vermont, New York, Montana, and Manitoba. April to September. Infrequent.

The dark lead color of one or more layers in the interior of the fructifications and the destruction of the coloring pigment by seven per cent potassium hydrate solution, together with the presence of gloeocystidia, afford a group of characters by which C. livido-caeruleum may be confidently recognized. Karsten did not send me an authentic specimen of his C. livido-caeruleum but he sent a specimen with the same characters under the name Corticium plumbeum Fr.

Specimens examined:

Sweden: L. Romell, 107; Lappland, L. Romell, 409.

Finland: Mustiala, P. A. Karsten, under the name C. plumbeum Fr.

Austria: Tirol, Innsbruck, V. Litschauer; Stubai, V. Litschauer. Canada: J. Macoun, 87 . 
Vermont: Middlebury, E. A. Burt, 2 gatherings.

New York: Altamont, E. A. Burt.

Montana: Fontine, E. E. Hubert, conm. by J. R. Weir (in Mo. Bot. Gard. Herb., 63234); Missoula, J. R. Weir, 420 (in Mo. Bot. Gard. Herb., 14767), and E. E. Hubert, comm. by J. R. Weir, 11961 (in Mo. Bot. Gard. Herb., 63318); Trego, E. E. Hubert, comm. by J. R. Weir, 11975 (in Mo. Bot. Gard. Herb., $63331)$.

Idaho: Avery, E. E. Hubert, comm. by J. R. Weir, 11987 (in Mo. Bot. Gard. Herb., 63320).

Manitoba: Norway House, G. R. Bisby, 1462 (in Mo. Bot. Gard. Herb., 61644).

British Columbia: Kootenai Mts., near Salmo, J.R. Weir, 466 (in Mo. Bot. Gard. Herb., 14936).

72. C. pilosum Burt, n. sp.

Type: in Mo. Bot. Gard. Herb.

Fructifications effused, becoming confiuent, closely adnate, very thin, not separable, pale pinkish buff, becoming pale olivebuff and pale smoke-gray in the herbarium, even, not shining, but little or not at all cracked, the margin of the same color, thinning out; in section 30-75 $\mu$ thick, not colored, composed of densely interwoven, hyaline hyphae $2-21 / 2 \mu$ in diameter, not incrusted, of gloeocystidia, and of delicate, branching paraphyses; gloeocystidia near the substratum, spherical or pyriform, $16-30 \mu$ in diameter or up to $30 \times 15 \mu$, narrower gloeocystidia may be present also; paraphyses with slender branching tips about $1 \mu$ in diameter occur in the surface of the hymenium; spores hyaline, even, curved, $6-9 \times 3-41 / 2 \mu$.

Fructifications becoming confluent over areas up to $8 \mathrm{~cm}$. long and $1-2 \mathrm{~cm}$. wide.

On bark of fallen limbs of Alnus, Vitis, and Tsuga. Georgia, Alabama and Missouri. October and April. Not common.

C. pilosum has general aspect and color suggestive of the Peniophora cinerea group of species but has no cystidia. The slender branching paraphyses have been noted also in Peniophora phyllophila, C. albido-carneum, C. Atkinsonii, and C. jamaicense. Perhaps C. pilosum is mature C. albido-carneum. 
Specimens examined:

Georgia: Atlanta, E. Bartholomew, 8982, type (in Mo. Bot. Gard. Herb., 63463).

Alabama: Auburn, Earle \& Baker (in N. Y. Bot. Gard. Herb., and

Mo. Bot. Gard. Herb., 63709, 61479); Montgomery, R. P.

Burke, 16, 217, 350, 452, 613 (in Mo. Bot. Gard. Herb., 4738,

$57089,57221,57275,57443)$.

Missouri: Baden, E. A. Burt (in Mo. Bot. Gard. Herb., 18864).

73. C. radiosum Fries, Epicr. 560. 1838; Icones Hym. 2: 97. pl. 198, f. 1. 1884; Hym. Eur. 649. 1874; Sacc. Syll. Fung. 6 : 611. 1888; Bresadola, I. R. Accad. Agiati Atti III. 3 : 110.1897 ; Rea, Brit. Basid. 685. 1922.

Thelephora radiosa Fries, Obs. Myc. 2: 277. 1818; Elench. Fung. 1: 206. 1828; Persoon, Myc. Eur. 1: 130.1822. Corticium pellicula (Fr.) Karsten, Soc. pro Fauna et Fl. Fenn. Meddel. 11:5. 1885.-Corticium alutaceum (Schrad.) Bresadola, I. R. Accad. Agiati Atti III. 3: 110. 1897; v. Höhnel \& Litschauer, K. Akad. Wiss. Wien Sitzungsber. 115: 1556. 1906. -Gloeocystidium alutaceum (Schrad.) Bourdot \& Galzin, Soc. Myc. Fr. Bul. 28: 367. 1913.-An Thelephora alutacea Schrader, Spic. Fl. Germ. 1: 187. 1794?

Type: type illustration is Fries, Icones Hym. 2: pl. 198, f. 1. 1884. No authentic specimen determined, by E. Fries as Thelephora (or Corticium) radiosa is known.

Fructifications broadly effused, thin, membranaceous, tender, small pieces separable, from whitish to ivory-yellow and creambuff in the herbarium, even, but little cracked, the margin white, broad, radiating, fibrillose; in section 100-300 $\mu$ thick, not colored, composed of densely interwoven, ascending hyphae rather crowded together except where separated by vesicular bodies which become greatly inflated and thin-walled and are finally up to $20-60 \times 15 \mu$; spores hyaline, even or slightly rough, subglobose, $4 \frac{1}{2} 2^{-7} \mu$ in diameter or $6 \times 4 \frac{1}{2}-5 \mu$.

Fructifications $3-15 \mathrm{~cm}$. long, 1-7 cm. wide.

On decaying wood of coniferous species usually. In Europe, Canada to Pennsylvania, and westward to Alaska, British Columbia, and Washington. 
C. radiosum may be recognized by its occurrence on coniferous wood, whitish or ivory-yellow color, white fimbriate margin, subglobose spores about $6 \mu$ in diameter, and presence of very large vesicular bodies when sections are examined. These bodies are often so inflated and with walls so tenuous that their location is shown by vesicular spaces between the otherwise crowded hyphae.

No authentic specimen of $C$. radiosum determined by E. Fries is known to be in existence, although there are four specimens so determined by Karsten in Herb. Fries; two of these specimens are Peniophora laevis, another is very immature but may be Stereum odoratum, while the fourth specimen, Karsten, No. 32, has globose spores $6-8 \times 5-6 \mu$ but does not show vesicular bodies in my mount. However, these four specimens present the Karsten idea of $C$. radiosum as to aspect. The colored illustration of $C$. radiosum in Fries' Icones, pl. 198, f. 1, is excellent, and taken in connection with the good original description by Fries and his critical comment on the close resemblance to his Peniophora laevis, seems to me to afford a more secure foundation for the concept of this species as $C$. radiosum than as Corticium alutaceum, for Schrader's description of Thelephora alutacea consists of the following five words, viz., "Supra exalbida, subtus tomentosa nivea." This vague description is not supplemented by an illustration, and I have not been able to learn of the existence of an authentic specimen. Any statement as to synonymy in the case of resupinate Hymenomycetes by mycologists of a former century is of slight value when a nice feature of internal structure is decisive.

Specimens examined:

Exsiccati: Ell. \& Ev., Fungi Col., 1211, under the name Corticium Petersii.

Sweden: Femsjö, L. Romell, 177; Stockholm, L. Romell, 113, 178, 181.

Austria: Innsbruck, Tirol, V. Litschauer; Stubai, Tirol, V. Litschauer, 2 specimens-all as C. alutaceum.

Hungary: Tatra Magna, V. Greschik, from Bresadola, under the name C. alutaceum.

Canada: Lower St. Lawrence Valley, J. Macoun, 87; Ontario, Ottawa, J. Macoun, 139, 204. 
Vermont: Bethel, P. Spaulding, comm. by U. S. Path. \& Myc. Coll., 2708; Middlebury, E. A. Burt, 2 gatherings.

Massachusetts: Sharon, A. P. D. Piguet (in Farlow Herb., 127, and Mo. Bot. Gard. Herb., 55234).

New York: Albany, H. D. House (in N. Y. State Mus. Herb., and Mo. Bot. Gard. Herb., 59672); Constableville, C. H. Peck, comm. by N. Y. State Mus. Herb., T 3 (in Mo. Bot. Gard. Herb., 54556, 55774); Fort Ann, S. H. Burnham, 11 (in Mo. Bot. Gard. Herb., 54508); Freeville, G. F. Atkinson, 2585; Ithaca, G. F. Atkinson, 2527, 14186; Schuylerville, C. H. Peck, 19 , and an unnumbered specimen (in N. Y. State Mus. Herb., $55772)$.

New Jersey: Newfield, J. B. Ellis (in N. Y. Bot. Gard. Herb., and Mo. Bot. Gard. Herb., 54450).

Pennsylvania: Bellefonte, L. O. Overholts, 9729 (in Mo. Bot. Gard. Herb., 55098); State College, C. R. Orton, 2, comm. by L. O. Overholts (in Mo. Bot. Gard. Herb., 44041).

West Virginia: Nuttallburg, L. W. Nuttall, in Ell. \& Ev., Fungi Col., 1211.

Tennessee: Elkmont, C. H. Kauffman, 89 (in Mo. Bot. Gard. Herb., 44990).

Michigan: Ann Arbor, C. H. Kauffman, 36 (in Mo. Bot. Gard. Herb., 19327); East Lansing, E. A. Bessey (in Mo. Bot. Gard. Herb., 56178); New Richmond, C. H. Kauffman, 50 (in Mo. Bot. Gard. Herb., 18523).

Missouri: Creve Coeur L. O. Overholts (in Mo. Bot. Gard. Herb., 42602).

Arkansas: Fordyce, C. J. Humphrey, 2528 (in Mo. Bot. Gard. Herb., 14057).

Washington: Bellingham, J. R. Weir, 546 (in Mo. Bot. Gard. Herb., 63744); Olympic Mts., comm. by W. G. Farlow, 3 (in Mo. Bot. Gard. Herb., 44588); Sedro-Woolley, C. J. Humphrey, 7483.

British Columbia: Sidney, J. Macoun, 25 (in Mo. Bot. Gard. Herb., 5686).

Alaska: Ketchikan, J. R. Weir, 329 (in Mo. Bot. Gard. Herb., 16437). 
74. C. vesiculosum Burt, n. sp.

Type: in Burt Herb.

Fructifications broadly effused, closely adnate, thin, between ivory-yellow and cream color in the herbarium, waxy, even, not cracked, the margin thinning out; in section $150-240 \mu$ thick, not colored, somewhat stratose, with the 3 strata or layers of the type separated by narrow zones of hyphae glued together; hyphae about $2 \mu$ in diameter, thin-walled, collapsing, poorly defined, densely interwoven; gloeocystidia up to $40 \times 8 \mu$; many vesicular bodies, presumably gloeocystidia, are present and are 5-7 $\mu$ in diameter-also larger vesicular spaces; spores hyaline, even, 4-8 $\times 2 \frac{1}{2}-4 \mu$, borne on protruding basidia having 4 sterigmata.

Fructifications in fragments up to $4 \mathrm{~cm}$. long, $11 / 2 \mathrm{~cm}$. wide.

On decaying, frondose wood. Canada and New York. October.

C. vesiculosum is colored like C. radiosum but is closely adnate, does not have a radiating, fibrillose margin, and has smaller spores.

Specimens examined:

Canada: J. Macoun, 71, type.

New York: East Galway, E. A. Burt.

75. C. globosum Burt, n. sp.

Type: in Mo. Bot. Gard. Herb.

Fructifications effused, thick, adnate, spongy-soft, white, becoming cartridge-buff, somewhat granular, not waxy, cracked only rarely, the margin determinate, thick, with hyphae interwoven; in section 600-700 $\mu$ thick, grayish olive near the substratum, stratose, each stratum composed of slightly colored, thinwalled, suberect, curving and branching hyphae $1 / 2-1 \mu$ in diameter, and of scattered, conspicuous, rather thick-walled, globose vesicular bodies $12-13 \mu$ in diameter; no other gloeocystidia; no cystidia; spores hyaline, even, $3 \times 2 \mu$.

Largest fragments of fructifications are $3 \mathrm{~cm}$. in diameter and $4 \mathrm{~cm}$. long, $2 \mathrm{~cm}$. wide.

On rotten frondose wood. West Indies. November. Probably local.

C. globosum forms thick, pulvinate fructifications suggestive in 
aspect of those of resupinate Stereum Murrayi but soft and spongy when moistened. The abundant, slender, curving hyphae show structural relationship with Corticium investiens and $\mathrm{Hy}$ phochnus pallescens, but I find no antler-shaped branches either at the hymenial surface or in the interior. The globose vesicular bodies are conspicuous and a valuable distinctive character.

Specimens examined:

Cuba: Omaja, C. J. Humphrey, 2842.

Porto Rico: Rio Piedras, J. A. Stevenson, 5793, type (in Mo. Bot.

Gard. Herb., 54690), and J. A. Stevenson \& R. C. Rose, 6531

(in Mo. Bot. Gard. Herb., 55652).

76. C. subalbum Burt, n. sp.

Type: in N. Y. Bot. Gard. Herb., Mo. Bot. Gard. Herb., an Burt Herb.

Fructifications effused, very thin, closely adnate, whitish to cartridge-buff in the herbarium, even, not shining, but little cracked, the margin similar, thinning out; in section $75 \mu$ thick, not colored, composed of densely interwoven hyphae about $2 \mu$ in diameter, and of very numerous gloeocystidia which are broadly ovoid to subglobose, up to $30 \times 15-18 \mu$, or $20 \mu$ in diameter; very slender paraphyses with branched tips protrude slightly beyond the basidia; spores hyaline, even, $101 / 2^{-13} \times$ $4-5 \mu$, copious.

Fructifications $3-5 \mathrm{~mm}$. in diameter, clustered near together and becoming confluent in a mass $5 \mathrm{~cm}$. long, $11 / 2 \mathrm{~cm}$. wide.

On small dead limbs of Alnus. Georgia and Alabama. November.

C. subalbum is distinct from other gloeocystidial species by thin, whitish fructifications, rather large spores, abundant gloeocystidia, and the slender paraphyses.

Specimens examined:

Georgia: Atlanta, E. Bartholomew, 8983 (in Mo. Bot. Gard. Herb., 63462).

Alabama: Auburn, F. S. Earle, 2300, type (in N. Y. Bot. Gard. Herb., Mo. Bot. Gard. Herb., 63375, and Burt Herb.).

77. C. vinososcabens Burt, n. sp.

Type: in Burt Herb. 
Fructifications broadly effused, adnate, rather thick, membranaceous, separable when moistened, vinaceous-buff or pale avellaneous when fresh, becoming deep purplish vinaceous where bruised, finally between pale olive-buff and pale pinkish buff in the herbarium, even, waxy, not cracking, the margin whitish, fimbriate; in section $150-450 \mu$ thick, pale-colored, with a compact hymenial layer containing numerous thin-walled, vesicular bodies $15-75 \times$ $12-45 \mu$, and with a very broad supporting layer consisting of thinwalled, nodose-septate hyphae $2-3 \mu$ in diameter, not incrusted and loosely arranged except in thick fructifications where 1 or 2 dense narrow zones are present between substratum and hymenial layer; basidia 2-spored; spores white in spore collection, even, subglobose, 6-9 $\times 5-7 \mu$, slightly pointed at the base.

Fructifications $3-9 \mathrm{~cm}$. long, $11 / 2-3 \mathrm{~cm}$. wide.

On bark of fallen trunk of Abies rubra and Tsuga canadensis. Vermont to Wisconsin. September and November. Rare.

C. vinososcabens dries a characteristic livid color, occurs on bark of conifers, and has large subglobose spores and a vesiculose hymenial layer. These vesicular organs are presumably gloeocystidia but so highly inflated that they appear empty under the microscope, and with their scanty cell contents adhering to the cell wall.

Specimens examined:

Vermont: Little Notch, Ripton, E. A. Burt, type.

New York, Karner, H. D. House, 14.210 (in Mo. Bot. Gard. Herb., 44730).

Wisconsin: Ladysmith, C. J. Humphrey, 1773 (in Mo. Bot. Gard. Herb., 14242).

78. C. polygonium Persoon, Roemer Neues Mag. Bot. 1: 110. 1794; Fries, Epicr. 564. 1838; Hym. Eur. 655. 1874; Berkeley, Outl. Brit. Fung. 276. 1860; Sacc. Syll. Fung. 6: 627. 1888; Massee, Linn. Soc. Bot. Jour. 27 : 144. 1890; Bresadola, Ann. Myc. 1: 97. 1903; Rea, Brit. Basid. 684. 1922.

Thelephora polygonia Persoon, Syn. Fung. 574. 1801; Myc. Eur. 1: 132. 1822; Fries, Syst. Myc. 1: 444 . 1821; Elench. Fung. 1: 222. 1828.-Gloeocystidium polygonium (Pers.) v. Höhnel \& Litschauer, Wiesner Festschr. Wien, 69. 1908; 
Bourdot \& Galzin, Soc. Myc. Fr. Bul. 28: 363. 1913.-G. polygonium (Pers.) var. fulvescens Bresadola, Mycologia 17:69. 1925.

Fructifications orbicular, soon confluent and broadly effused, closely adnate, thin, pale ecru-drab to brownish drab, pruinose, even or somewhat tubercular, waxy, the margin whitish; in section 150-250 $\mu$ thick, not colored, composed of suberect, interwoven hyphae $3-5 \mu$ in diameter, occasionally nodose-septate, and of pyriform gloeocystidia 10-25 $\times 5-20 \mu$; spores hyaline, even, cylindric, slightly curved, $71 / 2^{-10} \times 21 / 2^{-3} \mu$.

Fructifications $3-5 \mathrm{~mm}$. in diameter, becoming by confluence up to $8 \mathrm{~cm}$. long, $1-2 \mathrm{~cm}$. wide.

On fallen branches of Populus. In Europe and in Colorado, Idaho, Manitoba, and Washington.

American specimens of $C$. polygonium are not as heavily pruinose as the European specimens which I have seen and may be recognized by the light grayish vinaceous color of the fructifications, occurrence on poplar bark, large, scattered gloeocystidia, and slender, cylindric spores.

Specimens examined:

Exsiccati: Cooke, Fungi Brit., 6; Romell, Fungi Scand., 128.

Sweden: Stockholm, L. Romell, 118, 119, and in Romell, Fungi

Scand., 128, and W. A. Murrill, comm. by N. Y. Bot. Gard.

Herb. (in Mo. Bot. Gard. Herb., 61477); Svex, Söderm.,

Lindblad, from E. Fries (in Kew Herb.).

Germany: Brinkmann, comm. by Bresadola.

Austria: Tirol, V. Litschauer.

England: Batheaston, C. E. B., in Cooke, Fungi Brit., 6.

Colorado: Geneva Creek Canyon, F. J. Seaver \& E. Bethel (in

N. Y. Bot. Gard. Herb., and Mo. Bot. Gard. Herb., 61474);

Lake Eldora, F. J. Seaver \& E. Bethel (in N. Y. Bot. Gard.

Herb., and Mo. Bot. Gard. Herb., 56793).

Idaho: J. R. Weir, 16824, type of Gloeocystidium polygonium var.

fulvescens (in Weir Herb.); Coolin, J. R. Weir, 11551 (in Mo.

Bot. Gard. Herb., 63703); Priest River, J.R. Weir, 14946 (in Mo. Bot. Gard. Herb., 56803).

Manitoba: I. L. Conners \& J. F. Higham, comm. by G. R. Bisby, 394 (in Mo. Bot. Gard. Herb., 58969).

Washington: Bingen, W. N. Suksdorf, 719, 902. 
79. C. chrysocreas Berk. \& Curtis, Grevillea 1: 178. 1873; Sacc. Syll. Fung. 6:618. 1888.

Corticium crocicreas Massee, Linn. Soc. Bot. Jour. 27: 151. 1890; v. Höhnel \& Litschauer, K. Akad. Wiss. Wien Sitzungsber. 116: 776. 1907.-Not C. crocicreas Berk. \& Curtis.

Type: type distribution in Ravenel, Fungi Car. 5:27, under the name Corticium crocicreas.

Fructifications broadly effused, rather thick, closely adnate, not at all separable, apricot-yellow and olive-ocher to dark olive-buff, even or becoming somewhat papillate, cracked in drying, the margin thinning out, indeterminate; in section $120-300 \mu$ thick, olive-ocher throughout, composed of erect, densely interwoven and conglutinate colored hyphae about $2 \mu$ in diameter, of very numerous vesicular organs $15-21 \times 6-9 \mu$; coloring matter of the sections becomes vinaceous upon treatment with potassium hydrate solution and the sections are finally bleached; spores white in a spore collection, even, $4 \frac{1}{2}-5 \times 21 / 2 \mu$.

Fructifications $3-8 \mathrm{~cm}$. long, $1-3 \mathrm{~cm}$. wide.

On wood and bark of decaying logs of frondose species. South Carolina to Louisiana and Missouri, in Mexico, in West Indies, and in Japan. July to April. Occasional.

C. chrysocreas has olive-ocher fructifications of the same color throughout which make it one of the most conspicuous species of the region bordering on the Gulf of Mexico. Several other Gulf species have a northern station in Missouri or Illinois. The vesicular structure in section is an important distinctive character for separation of this species from Odontia Wrightii, which has the same color and geographical range but angular granules in the hymenium.

Specimens examined:

Exsiccati: Ell. \& Ev., N. Am. Fungi, 2021, under the name Corticium crocicreas - in some copies this, and in others a different species; Ravenel, Fungi Car. 5:27, under the name $C$. crocicreas. South Carolina: H.W. Ravenel, Curtis Herb., 2933, type (in Kew Herb.) and in Ravenel, Fungi Car. 5: 27.

Florida: W. W. Calkins, in some copies of Ell. \& Ev., N. Am. Fungi, 2021; New Smyrna, C. G. Lloyd, 2072.

Alabama: Peters, 418 (under the name $C$. crocicreas in Curtis Herb., 4027). 
Mississippi: Hattiesburg, C. J. Humphrey, 5454.

Louisiana: Baton Rouge, Edgerton \& Humphrey, comm. by C. J. Humphrey, 5601; St. Martinville, A. B. Langlois, bm, H. 2612, and 35 - the last comm. by Lloyd Herb., 2386-and 1950a, comm. by W. G. Farlow (in Mo. Bot. Gard. Herb., 42601).

Missouri: Creve Coeur, E. A. Burt (in Mo. Bot. Gard. Herb., 1757, 14199).

Mexico: Jalapa, W. A. \& E. L. Murrill, 180, comm. by N. Y. Bot. Gard. Herb. (in Mo. Bot. Gard. Herb., 44968).

Cuba: Baracoa, L. M. Underwood \& F. S. Earle, 1210, comm. by N. Y. Bot. Gard. Herb.

Japan: Hida-Machi, Prov. Bungo, N.Nakayama, comm. by A. Yasuda, 96, under the name Corticium Nakayamae Yasuda.

80. C. involucrum Burt, n. sp.

Type: in Burt Herb.

Fructifications broadly effused, closely adnate, thin, somewhat gelatinous, not at all separable, drying olive-buff to snuff-brown, even, conforming to inequalities of the substratum, pruinose, not cracked except where bridging a depression, the margin indeterminate, thinning out; in section $60-80 \mu$ thick when composed of 1 stratum, $120-150 \mu$ when 2 strata are present, colored like the hymenium by the color of the numerous gloeocystidia, each stratum composed of erect, densely arranged hyphae and gloeocystidia; hyphae $3 \mu$ in diameter, with outer wall somewhat gelatinously modified, clothed with short lateral branches up to $6 \mu$ long which are clustered in an involucral cup at the base of the basidium; gloeocystidia brownish-colored, irregular, flexuous, 30$45 \times 4-41 / 2 \mu$, very numerous; basidia simple, bearing 4 spores; spores hyaline, even, spherical, 3-4 $\mu$ in diameter.

Fructifications 2-10 cm. long, 1-3 cm. wide.

Under side of decorticated, decaying logs of frondose species usually-one gathering on coniferous wood. Canada, New Hampshire, Vermont, and Cuba. September to December.

C. involucrum forms a thin brown coating on decaying wood, with aspect somewhat suggestive of a Sebacina or C. lividum but so near the color of the wood and so inconspicuous that it is probably often overlooked; the colored gloeocystidia are addi- 
tional confirmatory characters which should identify the species. The hyphal structure is unique but not likely to be observed unless close study is made.

Specimens examined:

Canada: Ottawa, J. Macoun, 4, 23.

New Hampshire: Chocorua, W. G. Farlow, 7.

Vermont: Middlebury, E. A. Burt, type.

Cuba: Ceballos, C. J. Humphrey, 2793 (in Mo. Bot. Gard. Herb., 20200).

81. C. luridum Bresadola, Fungi Trid. 2: 59. pl. 169. 1898; Sacc. Syll. Fung. 16: 119. 1902.

Gloeocystidium luridum (Bres.) v. Höhnel \& Litschauer, K. Akad. Wiss. Wien Sitzungsber. 116: 770. 1907; Bourdot \& Galzin, Soc. Myc. Fr. Bul. 28: 360. 1913.

Type: part of type in Burt Herb.

Fructifications broadly effused, adnate, sometimes rather thick, small pieces separable when moistened, becoming cinnamon-buff to avellaneous in the herbarium, not shining, even, sometimes somewhat cracked with age, the margin similar; in section 150 $300 \mu$ thick, slightly colored, composed of densely arranged hyphae $2-31 / 2 \mu$ in diameter and not incrusted, which run parallel with the substratum in a narrow layer and then become erect and mixed with gloeocystidia in a broad layer which bears the hymenium; gloeocystidia numerous, slightly colored, flexuous, 50$100 \times 6-7 \mu$; spores hyaline, even, $6-8 \times 3-5 \mu$.

Fructifications $3-4 \mathrm{~cm}$. long, 1-4 cm. wide and broken off at both ends in the fragments received.

On bark and wood of frondose species. In Europe, Ohio, and Manitoba. Autumn. Rare.

C. luridum may be recognized among our species by its slightly colored gloeocystidia and resemblance in general aspect and color to Peniophora velutina. The spores were published by Bresadola as 10-17 $\times 6-8 \mu$ but I have found none so large in the specimen received.

Specimens examined:

Italy: Florentia, Martelli, type, from Bresadola.

Ohio: Preston, C. G. Lloyd, 1558. 
Manitoba: Winnipeg: A. H. R. Buller, 744 (in Mo. Bot. Gard. Herb., 57913).

82. C. jamaicense Burt, n. sp.

Type: in Burt Herb.

Fructifications broadly effused, adnate, thick, somewhat membranaceous, small pieces separable when moistened, becoming buff-brown to tawny olive in the herbarium, even, pulverulent, not cracked, the margin probably thick and entire but not well shown by the fragments; in section $150-600 \mu$ thick, concolorous with the hymenium, composed of even, suberect hyphae $3 \mu$ in diameter, of interwoven organs $2 \mu$ in diameter with antlershaped branching, of colored gloeocystidia, and of imbedded, globose, slightly colored, rough-walled spores $6-7 \mu$ in diameter, very numerous in all regions; gloeocystidia becoming dark-colored, irregular, flexuous, 35-60 × 5-7 $\mu$, scattered throughout the fructifications, none found protruding; basidia simple, with 4 sterigmata; basidiospores spherical, hyaline, even, $6 \mu$ in diameter as seen attached to basidia.

Fructifications received in fragments, of which the largest is 7 $\mathrm{cm}$. long, $2 \mathrm{~cm}$. wide.

On decaying wood. Jamaica. December to January.

The general aspect and antler-shaped branching of one kind of its hyphal components show relationship to Hypochnus peniophoroides, H. pallescens, Stereum induratum, S. duriusculum, Asterostromella dura, and $A$. rhodospora. Could I have found uneven basidiospores this species would have been included in Hypochnus near $H$. pallescens and H. peniophoroides; such basidiospores may eventually be demonstrated when this species becomes better known.

Specimens examined:

Jamaica: Cinchona, W. A.\& E. L. Murrill, 456, type, comm. by N. Y. Bot. Gard. Herb.; Morce's Gap, W. A. \& E. L. Murrill, 677,740 , comm. by N. Y. Bot. Gard. Herb.

83. C. debile Berk. \& Curtis in Massee, Linn. Soc. Bot. Jour. 27: 131. 1890; Sacc. Syll. Fung. 11: 127. 1895.

Type: in Kew Herb. and Farlow Herb. 
Fructifications broadly effused, thin, closely adnate, becoming palc ivory-yellow to buffy brown in the herbarium, even, waxy, not cracked, the margin whitish; in section $150 \mu$ thick, yellowish by presence of numerous colored gloeocystidia, with the hyphae about $2 \frac{1}{2}-3$ in diameter, with walls gelatinously modified and poorly defined, longitudinally arranged along substratum and then ascending to the hymenium; gloeocystidia somewhat colored, flexuous, 30-60 × 3-5 $\mu$; some colorless vesicular bodies present also; spores hyaline, even, subglobose, $4-5 \mu$ in diameter in Burt preparation but noted by Massee as $7 \times 3-4 \mu$.

Fructifications $1-3 \mathrm{~cm}$. in diameter.

Under side of decaying frondose limbs on the ground. Louisiana, California, West Indies, and Venezuela. June and December. Rare.

C. debile has gloeocystidia which are numerous and conspicuous by their yellowish color; these gloeocystidia and the brown fructifications afford good distinguishing characters.

Specimens examined:

Louisiana: St. Martinville, A. B. Langlois, bb, 2674 (in N. Y. Bot. Gard. Herb., and Mo. Bot. Gard. Herb., 58327).

California: Preston's Ravine, Palo Alto, W. A. Murrill \& L. S. Abrams, 1195, comm. by N. Y. Bot. Gard. Herb. (in Mo. Bot. Gard. Herb., 55709).

Cuba: near Havana, C. J. Humphrey, 2963. Porto Rico: Bayamon, J. A. Stevenson, 6762 (in Mo. Bot. Gard. Herb., 55053); Rio Piedras, J. A. Stevenson, 5620, and J. A. Stevenson \& R. C. Rose, 6529 (in Mo. Bot. Gard. Herb., 44864, 55082); Martin Peña, J. A. Stevenson, 3719 (in Mo. Bot. Gard. Herb., 7091).

Jamaica: Constant Spring Hotel grounds, W. A. \& E. L. Murrill, 26, comm. by N. Y. Bot. Gard. Herb.

Venezuela: Fendler, type (in Curtis Herb., 204).

84. C. venosum Berk. \& Ravenel, Grevillea 1: 177. 1873; Sacc. Syll. Fung. 6 : 620. 1888; Massee, Linn. Soc. Bot. Jour. 27 : 147. 1890.

Type: in Kew Herb. and Farlow Herb.

Fructifications broadly effused, rather thick, waxy-gelatinous 
when moistened, becoming vinaceous-brown in the herbarium, even; in section 500-600 $\mu$ thick, with a layer $300 \mu$ broad towards the substratum composed of longitudinally and densely arranged hyphae, with the outer walls so gelatinously modified that only the stained lumen and contents of each hypha are now visible as to outline; hymenial portion zonate, composed of 2 layers, each containing numerous curved, slender, flexuous, deeply staining organs $30-75 \times 3-4 \mu$, which may be elongated gloeoeystidia or perhaps basidia of the transversely septate kind; a few scattered, brownish spherical organs resembling gloeocystidia of Peniophora serialis; spores hyaline, even, $12-13 \times 4-5 \mu$, few seen and may not belong.

On decaying logs. South Carolina.

In the original description it was stated that there is a thin, tomentose subiculum composed of interwoven threads. If so, it is not retained in my mounts of sections from the specimens in Kew and Farlow Herbaria made 26 and 24 years ago respectively. I did not decide from the type specimens whether this species is a Corticium or Stereum having elongated gloeocystidia or an Auricularia with transversely septate basidia. I noted the presence of the word "Auricularia" on the specimen in Kew Herbarium but the species was published as a Corticium. $\mathrm{My}$ thin Corticium argentatum is of too different structure to be a synonym of this. While writing this account it occurs to me that the specimens distributed in Ellis, N. Am. Fungi, 1109, under the name Phlebia spilomea, should have been compared with a type of $C$. venosum.

Specimens examined:

South Carolina: Black Oak, H.W. Ravenel, 1321, type (in Kew Herb. and in Farlow Herb.).

85. C. ochrofarctum Burt, n. sp.

Type: in Mo. Bot. Gard. Herb.

Fructifications effused, closely adnate, very thin, hypochnoid, tilleul-buff in the herbarium, even, not shining, not cracked, the margin whitish, thinning out, with hyphae interwoven; in section 100-150 $\mu$ thick, not colored, composed of hyphae and numerous scattered, spherical, ochraceous gloeocystidia; hyphae rather 
loosely arranged near the substratum, suberect, incrusted, $41 / 2 \mu$ in diameter under the incrustation and up to $6 \mu$ over it, not incrusted and more densely arranged towards the hymenium; gloeocystidia in the form of brown or ochraceous, resinous, spherical or somewhat angular masses 9-20 $\mu$ in diameter; spores white in a spore collection, even, cylindric, somewhat curved, $8 \times 2 \frac{1}{2} \mu$.

Fructifications $2-6 \mathrm{~cm}$. long, $5 \mathrm{~mm} .-3 \mathrm{~cm}$. wide.

On decorticated, very rotten logs of Populus trichocarpa. Idaho. September.

The specific name ochrofarctum has reference to the colored, resinous gloeocystidia which are so large and so deep colored that they may be seen by inspection of the fructification with a lens and give, when so viewed, a minutely speckled appearance to the fructification. The large, coarsely incrusted hyphae are distinctive also. C. coroniferum is a related European species.

Specimens examined:

Idaho: Coolin, J. R. Weir, 11120, type, and 11122 (in Mo. Bot.

Gard. Herb., 63695 and 63696 respectively).

86. C. Tsugae Burt, n. sp.

Type: in Mo. Bot. Gard. Herb.

Fructifications effused, thin, dry, hypochnoid, downy, avellaneous, with the surface white-pruinose, even, not cracked, the margin similar, indeterminate; in section $30 \mu$ thick, not colored, composed of hyphae and numerous colored gloeocystidia; hyphae hyaline, thin-walled, $3 \mu$ in diameter, not incrusted, not nodoseseptate, ascending from the substratum; gloeocystidia in the form of brown or ochraceous, resinous-appearing, subspherical masses up to $18 \mu$ in diameter; not more than 4 sterigmata to a basidium demonstrated; spores hyaline, even, $6-71 / 2 \times 3-31 / 2 \mu$, copious.

Fructifications in fragments up to $21 / 2 \mathrm{~cm}$. long, $11 / 2 \mathrm{~cm}$. wide.

On very rotten wood of Tsuga canadensis. New Hampshire. September.

The color of the fructification of this species is so nearly that of the rotten substratum that close inspection is necessary to detect the presence of the fungus, whose color is probably due to the 
gloeocystidia. This aspect, together with uncommon gloeocystidia and non-incrusted hyphae, are good distinctive characters.

Specimens examined:

New Hampshire: Chocorua, W. G. Farlow, 148, type (in Mo. Bot.

Gard. Herb., 55248).

87. C. subcinereum Burt, n. sp.

Type: in Burt Herb.

Fructifications long-effused, closely adnate, thin, not at all separable, pale gull-gray to pale drab-gray, slightly granular, somewhat pruinose, becoming cracked in drying, the margin similar or paler, thinning out; in section $60-100 \mu$ thick, slightly colored, with the hyphae densely interwoven, $1-2 \mu$ in diameter, so grown together as to show structure indistinctly, but probably not nodose-septate nor incrusted; no cystidia nor gloeocystidia; branched paraphyses about $1 \mu$ in diameter are present in the hymenium; spores hyaline, even, $5-8 \times 3-31 / 2 \mu$.

Fructifications 2-10 cm. long, 1-2 cm. wide.

On bark of fallen, decaying limbs of Betula, Cornus, and Syringa. Canada, Massachusetts, and Kansas. February to October. Local.

C. subcinereum closely resembles Peniophora cinerea, P. caesia, and $C$. argentea in aspect but is distinct from each by its lack of cystidia and gloeocystidia.

Specimens examined:

Canada: Ottawa, J. Macoun, 37, type.

Massachusetts: Sharon, A. P. D. Piguet, comm. by W. G. Farlow, 8 (in Mo. Bot. Gard. Herb., 55289).

Kansas: Rockport, E. Bartholomew; Rooks County, comm. by Lloyd Herb., 2301; Stockton, E. Bartholomew, 8620, 8702 (in Mo. Bot. Gard. Herb., 62491, 63749, and Burt Herb.).

88. C. albido-carneum (Schw.) Massee, Linn. Soc. Bot. Jour. $27: 142$. 1890 .

Thelephora albido-carnea Schweinitz, Am. Phil. Soc. Trans. N. S. 4: 169. 1832.-Corticium albido-carneum (Schw.) Ravenel, Fungi Car. 4: 14, was a misdetermination by Ravenel.

Type: in Schweinitz Herb., Farlow Herb., and Kew Herb. 
Fructifications effused, small, becoming confluent longitudinally but very narrow, closely adnate, thin, becoming pale drabgray to pinkish buff in the herbarium, pruinose, cracking transversely in drying, the margin paler; in section $60-120 \mu$ thick, composed of 3 equal layers, of which that next to substratum consists of densely, longitudinally interwoven, slightly colored hyphae $11 / 2^{-2} \mu$ in diameter, not incrusted nor nodose-septate; the middle layer contains numerous pyriform bodies $12 \times 6 \mu$ which are presumably basidia; the outer layer is composed of bushy-branched paraphyses $3 \mu$ in diameter with final branchlets and lateral prongs about $1 / 2 \mu$ in diameter; detached spores 5-8 $\times 3-4 \mu$, few present and may not belong.

Fructifications 6-10 $\mathrm{mm}$. long, 1-2 $\mathrm{mm}$. wide, becoming more or less confluent over areas up to $5 \mathrm{~cm}$. long and $3 \mathrm{~cm}$. wide.

In crevices of the bark of dead wood of wild species of Vitis. Pennsylvania, Virginia, and Michigan. February and May. Rare.

C. albido-carneum is a very rare species which has been collected but few times and in small quantity for critical study. The specimens seem immature and the tissues of the fructifications are so minute and the covering of paraphyses so troublesome that I have been unable to make out the detailed structure of the basidia. The plan of structure is suggestive of a Sebacina but I have been unable to demonstrate longitudinal septa in any of the pyriform organs. The somewhat smoky color of the sections, their 3-layered structure, and occurrence on bark of dead wild grape trunks are a combination of characters which should afford ready recognition of this species. The dates of collection of the specimens seem to indicate that the species may fruit in winter. If some of the pyriform organs are gloeocystidia, $C$. pilosum may prove not specifically distinct.

Specimens examined:

Pennsylvania: Bethlehem, Schweinitz, type (in Schweinitz Herb.,

Kew Herb., and Farlow Herb.).

Virginia: Arlington Farm, C. L. Shear, 2810 (in Mo. Bot. Gard.

Herb., 15310).

Michigan: Paw Paw, L. A. Hawkins, comm. by C. L. Shear. 
89. C. adhaesum Burt, n. sp.

Type: in Mo. Bot. Gard. Herb.

Fructifications effused, closely adnate, rather thick, not separable, between drab and deep olive-buff, somewhat granular, pulverulent, cracked at intervals of 1-2 mm., the margin abrupt; in section $250-350 \mu$ thick, chamois-colored within, composed of densely arranged, thick-walled, erect and interwoven hyphae 3$31 / 2 \mu$ in diameter, not incrusted, not nodose-septate, conglutinate and not showing structure well; no gloeocystidia; spores hyaline, even, flattened on one side, $31 / 2^{-6} \times 21 / 2^{-3} \mu$, copious.

Fructifications $6 \mathrm{~cm}$. long, $2 \mathrm{~cm}$. wide.

On rough surface of badly decayed wood of a frondose species. Mexico and West Indies. Probably rare.

C. adhaesum is separated from the most of our species by having its fructifications colored within to such a degree that the thin sections are somewhat chamois-colored. The drab color of the hymenium and gluing together of the hyphae in sections are other distinctive characters.

Specimens examined:

Mexico: Jalapa, W. A. \& E. L. Murrill, 64, comm. by N. Y. Bot. Gard. Herb. (in Mo. Bot. Gard. Herb., 16479).

Porto Rico: Rio Piedras, J. A. Stevenson, 5577 (in Mo. Bot. Gard. Herb., 11059).

Jamaica: A. E. Wight, comm. by W. G. Farlow, C 1, type (in Mo. Bot. Gard. Herb., 44005).

Trinidad: Port of Spain, R. Thaxter, comm. by W. G. Farlow, 22. Grenada: Grand Etang, R. Thaxter, comm. by W. G. Farlow, 121.

90. C. leptaleum Ell. \& Ev. in Millsp. \& Nutt. Field Mus. Publ. Bot. 1: 170. 1896; Sacc. Syll. Fung. 14: 220. 1899.

Type: in N. Y. Bot. Gard. Herb.

Fructifications effused, adnate, membranaceous-soft, contracting in drying so that only one-half the original area is covered, cracking into masses $2-3 \mathrm{~mm}$. in diameter and curling up from substratum so as to resemble cups of a Peziza, grayish white, becoming pinkish buff in the herbarium, pulverulent; in section $300 \mu$ thick, composed of densely interwoven hyphae $3-31 / 2 \mu$ in diameter, incrusted in the subhymenium, only rarely nodoseseptate; no gloeocystidia; spores hyaline, even, 8-10 $\times 3-4 \mu$. 
On under side of dead Magnolia Fraseri. West Virginia. April.

In the original description it is stated, "The membrane on which the hymenium stands where exposed on the incurved margin of the pezizoid areas is pale brown." Some twenty years ago at the time my sections of the type were made, I did not record whether the sections were colored within or not. They are now colorless but may have faded. The large spores preclude reference to $C$. hydnans.

Specimens examined:

West Virginia: L. W. Nuttall, 690, type (in N. Y. Bot. Gard. Herb.).

91. C. laeve Persoon, Roemer Neues Mag. Bot. 1: 110. 1794; Sacc. Syll. Fung. 6: 611. 1888; Bresadola, Ann. Myc. 1: 94. 1903; Bourdot \& Galzin, Soc. Myc. Fr. Bul. 27: 232. 1911; Rea, Brit. Basid. 673. 1922.

Thelephora laevis Persoon, Syn. Fung. 575. 1801 (under Corticium); Myc. Eur. 1: 130. 1822.-T. evolvens Fries, Obs. Myc. 1: 254. pl. 4, f. 5. 1815; Syst. Myc. 1: 441. 1821; Elench. Fung. 1: 181. 1828.-Corticium evolvens Fries, Epicr. 557. 1838; Hym. Eur. 646. 1874; Sacc. Syll. Fung. 6: 604. 1888; Massee, Linn. Soc. Bot. Jour. 27: 118. pl. 6, f. 4. 1890.-Not Corticium laeve Fries, which is a Peniophora.

Type: in Herb. Mougeot, according to Bresadola in letter. Fragment of type from Quelet to Bresadola in Burt Herb.

Fructifications usually widely effused, rarely small and diskshaped, very rarely slightly reflexed, thick, membranaceous, tender, small pieces separable when moist, becoming cream color and light pinkish cinnamon to wood-brown and drab in the herbarium, waxy, even, more or less undulate, sometimes coarsely tuberculate, cracking in drying and showing on the sides of the fissures a thick, crust-like hymenial layer of about the same color as the surface of the hymenium and connected with the substratum by a thicker layer of whitish floccose or loose tissue, the margin white, silky, radiating, but sometimes free when the fructifications are pezizaeform and 1-3 $\mathrm{mm}$. in diameter; in section 200-500 $\mu$ thick, 2-layered, with the hymenial layer usually 
somewhat colored but concolorous with the surface of the hymenium, very compact, supported by the broad layer of loosely arranged, obliquely ascending, thin-walled hyphae $3-4 \mu$ in diameter, sometimes conspicuously guttulate, nodose-septate, not incrusted; no gloeocystidia; spores hyaline, even, 7-10 × 4$6 \mu$, flattened on one side, tapering towards the pointed base, usually glued together on the flattened side at ends of the protruding basidia.

Fructifications $1-10 \mathrm{~cm}$. long, $1-5 \mathrm{~cm}$. wide, rarely only $1-3$ mm. in diameter.

On bark of fallen decaying limbs of many frondose species. Europe and northern United States and Canada. Throughout the year. Very common.

C. laeve is a very common species on fallen limbs of poplar, maple, beech, etc., whose usually drab fructifications crack when dried and show the dark hymenial crust supported on a whitish subiculum. The absence of paraphyses and presence of spores 7-10 $\times 4-6 \mu$, shaped like apple seeds and glued together in groups of 2-4, are important additional characters. In the large number of gatherings cited below there are only 2 American specimens which have a slightly reflexed margin and would be referred to Stereum, where the species really belongs.

Specimens examined:

Exsiccati: Brinkmann, Westfälische Pilze, 9 ; Cooke, Fungi Brit., 10; Ell. \& Ev., Fungi Col., 221, under the name Corticium glabrum; Libert, PI. Crypt. Ard., 20; Romell, Fungi Scand., 124; Sydow, Myc. Germ., 355, under the name Peniophora laevis; de Thümen, Myc. Univ., 1109.

Sweden: Svex. Söderm., Lindblad, authentic specimen of C. evolvens from Fries (in Kew Herb.); Stockholm, L. Romell, 89, 90, 91, 92, 93, 94, 95, and in Romell, Fungi Scand., 124.

Finland: Mustiala, P. A. Karsten, in de Thümen, Myc. Univ., 1109.

Germany: Brandenburg, H. Sydow, in Sydow, Myc. Germ., 355; Westphalia, W. Brinkmann, in Brinkmann, Westfälische Pilze, 9.

Austria: Innsbruck, Tirol, V. Litschauer, 3 specimens. Italy: Trient, G. Bresadola, 3 specimens; Vallambrosa, Cavara, comm. by Bresadola. 
France: A. Libert, in Libert, Pl. Crypt. Ard., 20; Paris, Persoon, original specimen of $C$. laeve, comm. by Bresadola; Strassburg, L. Maire.

England: E. M. Wakefield (in Mo. Bot. Gard. Herb., 58691); Hampstead, in Cooke, Fungi Brit., 10.

Canada: Lower St. Lawrence Valley, J. Macoun, 17, 50.

Ontario: Granton, J. Dearness, 1040 E (in Mo. Bot. Gard. Herb., 23107); London, J. Dearness, 945 h (in Mo. Bot. Gard. Herb., 14252).

Newfoundland: Bay of Islands, A. C. Waghorne, 517, 1027.

New Hampshire: Chocorua, W. G. Farlow, 2 (in Mo. Bot. Gard. Herb., 44594).

Vermont: Middlebury, E. A. Burt, 5 gatherings, Ripton, E. A. Burt, 4 gatherings.

New York: Adirondack Mts., G. F. Atkinson, C; Albany, H. D. House (in N. Y. State Mus. Herb., and Mo. Bot. Gard. Herb., 14829, 19456); Alcove, C. L. Shear, 1210, 1214; Altamont, E. A. Burt; Bronx Park, Class in Mycology (in N. Y. Bot. Gard. Herb., and Mo. Bot. Gard. Herb., 61389); Hague, C. H. Peck (in N. Y. State Mus. Herb., and Mo. Bot. Gard. Herb., 56110), and 13; Ithaca, C. O. Smith, comm. by G. F. Atkinson, 8046, and G. F. Atkinson, d, 2813, 4899; Lyndonville, C. E. Fairman, 138 (in Mo. Bot. Gard. Herb., 61438); New York, F. S. Earle (in N. Y. Bot. Gard. Herb., and Mo. Bot. Gard. Herb., 61677); Newcomb, H. D. House (in N. Y. State Mus. Herb., and Mo. Bot. Gard. Herb., 59666); Oneida, H. D. House (in N. Y. State Mus. Herb., and Mo. Bot. Gard. Herb., 59679, 59699); Sylvan Beach, H. D. House (in N. Y. State Mus. Herb., and Mo. Bot. Gard. Herb., 7461); Syracuse, L. M. Underwood, 51, 126 (in N. Y. Bot. Gard. Herb., and Mo. Bot. Gard. Herb., 61571, 61394), and in Ell. \& Ev., Fungi Col., 221.

District of Columbia: Takoma Park, C. L. Shear, 1038.

Michigan: Michigan Agricultural College, B. O. Longyear, 9 (in N. Y. State Mus. Herb., and Mo. Bot. Gard. Herb., 55787).

Missouri: St. Louis, E. A. Burt (in Mo. Bot. Gard. Herb., 58334). British Columbia: Sidney, J. Macoun, 65, 77, 78 (in Mo. Bot. Gard. Herb., 5743, 5753, 9778), and $35,288,319,350$, 424 (in Macoun Herb.); Squamish, J. Macoun, 318, 536 (in Mo. Bot. 
Gard. Herb.); Victoria, J. Macoun, 577 (in Macoun Herb.); Vancouver Island, J. Macoun, 419 (in Mo. Bot. Gard. Herb., 55315), and comm. by J. Dearness, V 35 (in Mo. Bot. Gard. Herb., 19573).

Washington: Bingen, W. N. Suksdorf, 714, 755, 872, 886, 898, 899, 901, 955, 961; Olympia, C. J. Humphrey, 6293, 6330; Seattle, A. M. Parker, 177 (in N. Y. Bot. Gard. Herb., and Mo. Bot. Gard. Herb., 61475).

Oregon: Seattle, W. A. Murrill, 988, comm. by N. Y. Bot. Gard. Herb. (in Mo. Bot. Gard. Herb., 55703).

92. C. investiens (Schw.) Bresadola, I. R. Accad. Agiati Atti III. 3 : 110. 1897; Ann. Myc. 1: 95. 1903.

Radulum? investiens Schweinitz, Am. Phil. Soc. Trans. N. S. 4: 165. 1832; Sacc. Syll. Fung. 11: 112. 1895.-Vararia investiens (Schw.) Karsten, Krit. Öfvers. Finl. Basidsv. Tilläg 3: 32. 1898. - Asterostromella investiens (Schw.) v. Höhnel \& Litschauer, K. Akad. Wiss. Wien Sitzungsber. 117: 1083. 1908.-Corticium alutarium Berk. \& Curtis, Grevillea 2: 4. 1873; Sacc. Syll. Fung. 6: 634. 1888; Massee, Linn. Soc. Bot. Jour. 27 : 137. 1890.Thelephora subochracea Peck, N. Y. State Mus. Rept. 46: 109. 1893; Sacc. Syll. Fung. 11: 116. 1895.-Xerocarpus alutarius (Berk. \& Curtis) Karsten, Finska Vet.-Soc. Bidrag Natur och Folk 48: 418. 1889.

Type: in Schweinitz Herb., Farlow Herb., Fries Herb., and probably in Kew Herb.

Fructifications broadly effused, usually thin, tough, dry, adnate, small pieces separable when moist, warm buff to light orange-yellow, conforming to inequalities of the substratum, somewhat tomentose, not cracked, the margin thinning out; in section $150-600 \mu$ thick, concolorous with the hymenium, composed of a few even-walled, hyaline hyphae $21 / 2 \mu$ in diameter, and of a great number of yellowish, stiff hyphae with dichotomous and antler-shaped branching and short, acicular, prong-like terminal branchlets, which extend beyond the basidia in the hymenial surface; no gloeocystidia; basidia 4-spored; spores hyaline under the microscope but slightly straw-colored in the mass, even, $12 \times 4 \mu$, tapering downward to the slender, apiculate base. 
Fructifications 2-20 cm. long, 1-5 cm. wide.

On rotten logs and fallen branches of both frondose and coniferous species and sometimes running over fallen leaves and the ground. In Europe, throughout North America, West Indies, Venezuela, and in Japan. July to December. Very common.

$C$. investiens is readily recognized by chamois color and surface texture like that of chamois leather. Under the microscope the antler-shaped branching of its principal hyphal component is well shown. This mode of hyphal branching seems to me a useful specific character for the various other species which have it, e. g., Lachnocladium brasiliense, Grandinia granulosa, Stereum induratum, S. duriusculum, Hypochnus peniophoroides, H. pallescens, Peniophora phyllophila, P. piliseta, P. mexicana, and Corticium jamaicense but not of greater importance than other hyphal modifications which are useful specific characters, hence I can not accept as helpful Karsten's genus Vararia, of which the type species is Corticium investiens, nor its synonym Asterostromella of v. Höhnel \& Litschauer.

Specimens examined:

Exsiccati: Ellis, N. Am. Fungi, 517.

Sweden: Femsjö, L. Romell, 157, and C. G. Lloyd, 09149 (in Mo. Bot. Gard. Herb., 55619).

Hungary: Kmet, comm. by Bresadola.

Canada: J. Macoun, 91 .

Ontario: Niagara, J. Dearness, D586 (in Mo. Bot. Gard. Herb., 3727); Temagami, C. G. Lloyd, 07633 (in Mo. Bot. Gard. Herb., 55618).

Maine: Kittery Point, R. Thaxter \& E. A. Burt.

New Hampshire: Chocorua, W. G. Farlow; Shelburne, W. G. Farlow.

Vermont: Grand View Mt., E. A. Burt, 2 gatherings; Lake Dunmore, E. A. Burt; Little Notch, E. A. Burt; Middlebury, E. A. Burt.

Massachusetts: Lincoln, A. B. Seymour, T40 (in Mo. Bot. Gard. Herb., 12955); Magnolia, W. G. Farlow (in Farlow Herb.).

New York: Albany, H. D. House (in N. Y. State Mus. Herb., and Mo. Bot. Gard. Herb., 6324, 54358, 54359); Alcove, C. L. Shear, 1121, 1123, 1203, 1322; Arkville, W. A. Murrill (in N. 
Y. Bot. Gard. Herb., and Mo. Bot. Gard. Herb., 61361); East Galway, E. A. Burt; Floodwood, E. A. Burt, C. H. Peck, 4a; Fort Ann, S. H. Burnham, 25 (in Mo. Bot. Gard. Herb., 54495); Freeville, G. F. Atkinson, 2812; Gansevoort, C. H. Peck (in N. Y. Bot. Gard. Herb., and Mo. Bot. Gard. Herb., 55974); Ithaca, G. F. Atkinson, 8200, 22758, 22763, 23278, and C. J. Humphrey, 548, 22563; Karner, H. D. House, 14.154, comm. by N. Y. State Mus. Herb. (in Mo. Bot. Gard. Herb., 44711); Lake Placid, W. A. \& E. L. Murrill, 282 (in N. Y. State Mus. Herb., and Mo. Bot. Gard. Herb., 61673); North Elba, C. H. Kauffman, 6 (in Mo. Bot. Gard. Herb., 21464); North Greenbush, C. H. Peck (in N. Y. State Mus. Herb., and Mo. Bot. Gard. Herb., 55783, 56109); Oneida, H. D. House (in N. Y. State Mus. Herb., and Mo. Bot. Gard. Herb., 57474, 59682); Onondaga Valley, L. M. Underwood, 11 (in N. Y. Bot. Gard. Herb., and Mo. Bot. Gard. Herb., 61580); Sandlake, C. H. Peck (in N. Y. State Mus. Herb., and Mo. Bot. Gard. Herb., 55779); Shokan, C. H. Peck, type of Thelephora subochracea (in N. Y. State Mus. Herb.); Snyders, C. H. Peck (in N. Y. State Mus. Herb., and Mo. Bot. Gard. Herb., 55780); Westport, C. H. Peck, 4 .

Pennsylvania: Michener, type of Corticium alutarium (in Curtis Herb., 6349); Bethlehem, Schweinitz, type of Radulum? investiens (in Schweinitz Herb. and Farlow Herb.) and under the name Thelephora ochracea of Schweinitz (in Curtis Herb. from Schweinitz Herb.); Ohio Pyle, W. A. Murrill, 1047 (in N. Y. Bot. Gard. Herb., and Mo. Bot. Gard. Herb., 61553); State College, L. O. Overholts (in Mo. Bot. Gard. Herb., 54701); Trexlertown, W. Herbst, 33, 42; West Chester, Everhart \& Haines, in Ell. N. Am. Fungi, 517; no locality given, H. Jackson, Gentry (in N. Y. State Mus. Herb., and Mo. Bot. Gard. Herb., 55809, 55905, respectively).

Delaware: Newark, H. S. Jackson, B7.

District of Columbia: Takoma Park, C. L. Shear, 960 .

Louisiana: St. Martinville, C. J. Humphrey, 2519 (in Mo. Bot. Gard. Herb., 42937).

West Virginia: Eglon, C. G. Lloyd, 1408 (in Mo. Bot. Gard. Herb., 55610); Nuttallburg, L. W. Nuttall, 189, comm. by U. S. Dept. Agr. Herb.; Paw Paw, C. L. Shear, $117 \%$. 
Ohio: C. G. Lloyd, 4197 (in N. Y. Bot. Gard. Herb., and Mo. Bot. Gard. Herb., 61593); Cincinnati, A. P. Morgan, the Corticium ochraceum of Morgan Herb., comm. by Lloyd Herb., 2639.

Indiana: Millers, E. T. \& S. A. Harper, 830.

Michigan: Ann Arbor, C. H. Kaufman, 41 (in Mo. Bot. Gard. Herb., 22930); Whitmore Lake, A. H. W. Povah, 10 (in Mo. Bot. Gard. Herb., 9228).

Montana: Trego, E. E. Hubert, comm. by J. R. Weir, 12039 (in Mo. Bot. Gard. Herb., 63389).

Idaho: Priest River, J. R. Weir, $38 ; E$. E. Hubert, comm. by J. R. Weir, 11998 (in Mo. Bot. Gard. Herb., 63361).

British Columbia: Sidney, J. Macoun, 14 (in Mo. Bot. Gard. Herb., 5732); Vancouver Island, J. Macoun, comm. by J. Dearness, V148 (in Mo. Bot. Gard. Herb., 21138).

Mexico: Orizaba, Barrio Nuevo, W. A. \& E. L. Murrill, 762, comm. by N. Y. Bot. Gard. Herb. (in Mo. Bot. Gard. Herb., 54646).

Jamaica: Castleton Gardens, W. A. \& E. L. Murrill, 129 (in N. Y. Bot. Gard. Herb., Mo. Bot. Gard. Herb., 61365, and Burt Herb.); Cinchona, W. A. \& E. L. Murrill, 648 (in N. Y. Bot. Gard. Herb., and Mo. Bot. Gard. Herb., 61458); Morces Gap, W. A. \& E. L. Murrill, 734 (in N. Y. Bot. Gard. Herb., and Mo. Bot. Gard. Herb., 61466).

Porto Rico: Rio Piedras, J. A. Stevenson, 3474 (in Mo. Bot. Gard. Herb., 6732).

Venezuela: Fendler (in Curtis Herb., 190, under the herbarium name Corticium xanthellum).

Japan: Nakada-mura, Prov. Awaji, A. Yasuda, 44 (in Mo. Bot. Gard. Herb., 56169).

\section{C. pectinatum Burt, n. sp.}

Type: in Mo. Bot. Gard. Herb. and Farlow Herb.

Fructifications broadly effused, thin, closely adnate, not separable, warm buff to wood-brown in the herbarium, cracking into polygonal masses about 2 to the $\mathrm{mm}$., not shining, the margin unknown; in section 60-90 $\mu$ thick, concolorous with the hymenium, composed of densely interwoven, colorless or slightly colored hyphae about $1 \mu$ in diameter, not incrusted, not nodose- 
septate, and of comb-shaped or antler-shaped branching, slightly colored masses of about $5-10 \mu$ in diameter each and having many prongs; no gloeocystidia; basidia 6-12 $\times 4-5 \mu$, immature, immersed in the antler-shaped paraphyses which form the surface of the hymenium; no spores found.

Fructification $1-6 \mathrm{~cm}$. Iong, $1 / 2-11 / 2 \mathrm{~cm}$. wide.

On bark of dead frondose limbs. Florida and West Indies. October to March.

C. pectinatum has the general aspect and color of $C$. scutellare and structure of $C$. investiens but with much smaller and more delicate hyphae and antler-shaped organs than the latter.

Specimens examined:

Florida: Cocoanut Grove, R. Thaxter, 76, type (in Mo. Bot. Gard. Herb., 43898); Royal Palm Hammock, W. A. Murrill, 191, comm. by N. Y. Bot. Gard. Herb., 63762).

Cuba: Omaja, C. J. Humphrey, 2596 (in Mo. Bot. Gard. Herb., 8730).

94. C. racemosum Burt, n. sp.

Type: in Burt Herb.

Fructifications broadly effused, closely adnate, thin, dry, not separable, drying cream-buff, even, not shining, becoming transversely cracked in the central portions, the margin thinning out, indeterminate, concolorous; in section 70-140 $\mu$ thick, colored cream-buff, composed of very densely arranged, erect, branching and interwoven hyphae $2-21 / 2 \mu$ in diameter; no gloeocystidia; paraphyses in hymenial surface with tips branched sometimes racemosely, sometimes in antler-shaped manner, often irregularly, these branches about $1 / 2 \mu$ in diameter; spores hyaline, even, flattened on one side, 4-6 $42-3 \mu$.

Fructifications 2-12 cm. long, 1-4 cm. wide.

On bark and wood of decaying logs of Thuja plicata, Larix occidentalis, Abies grandis, and Pseudotsuga taxifolia. Idaho, British Columbia, and Washington. July to September.

The slender branched paraphyses of C. racemosum and lack of gloeocystidia locate this species in the group with $C$. Atkinsonii, C. albidocarneum, C. rubropallens, and C.rubrocanum. The antlershaped branching of occasional paraphyses connects this species 
with the $C$. investiens group also. Radulum Pini-canadense Schw. should also be considered here.

Specimens examined:

Idaho: Priest River, J. R. Weir, 39, type, and 137 (in Mo. Bot. Gard. Herb., 9852).

British Columbia: Salmo, J. R. Weir, 465 (in Mo. Bot. Gard. Herb., 11777).

Washington: Stanwood, C. J. Humphrey, 7360 (in Mo. Bot. Gard. Herb., 7825).

95. C. subcontinuum Berk. \& Curtis, Linn. Soc. Bot. Jour. 10 : 337. 1868; Sacc. Syll. Fung. 6: 635. 1888; Massee, Linn. Soc. Bot. Jour. 27 : 128.1890.

Type: in Kew Herb. and Farlow Herb.

Fructifications effused, adnate, rather thick, small pieces separable, becoming chamois-colored in the herbarium, ceraceous, even, sometimes cracking in drying but the cracks not running together, showing the Isabella-colored tissue on the sides of the cracks, the margin thinning out; in section 200-400 $\mu$ thick, Isabella-colored, 2-layered, with a broad layer next to the substratum of brown hyphae $2-3 \mu$ in diameter, not incrusted, not nodose-septate; spores hyaline, even, subglobose, $3-4 i \mathrm{in}$ diameter or $4 \times 3 \mu$.

Fructifications recorded as "spreading for several inches." The fragmentary pieces in herbaria are $2-3 \mathrm{~cm}$. long, $1 \mathrm{~cm}$. wide.

On bark and decaying wood. Louisiana, Texas, and West Indies. February to June. Rare.

The fructifications of $C$. subcontinuum resemble in general aspect, thickness, and consistency those of $C$. confluens, but are of different structure from those of the latter and are sharply distinct by the colored substance of the interior. The Louisiana specimens are doubtfully referred to this species.

Specimens examined:

Louisiana: Ruston, C. J. Humphrey, 2532 (in Mo. Bot. Gard. Herb., 12495); St. Martinville, A. B. Langlois, 1761 b, comm. by W. G. Farlow (in Mo. Bot. Gard. Herb., 42598, and Burt Herb.) and $1 \% 61 a$, in part.

Texas: locality not given, C. Wright, comm. by U. S. Dept. Agr. Herb., under the name $C$. calceum. 
Cuba: C. Wright, 587, type (in Kew Herb. and Curtis Herb.); Omaja, C. J. Humphrey, 2575.

Porto Rico: Rio Piedras, J. A. Stevenson \& R. C. Rose, 6528 (in Mo. Bot. Gard. Herb., 55083).

\section{C. Murrilli Burt, n. sp.}

Type: in Mo. Bot. Gard. Herb.

Fructifications broadly effused, thick, soft, spongy, dry, flexible, separable in sheets which have the hymenium between light buff and cream-buff and the under side Van Dyke brown, hymenium velutinous, not cracked, the margin concolorous with the hymenium, tomentose; in section $600-900 \mu$ thick, colored, with the hyphae of the under layer brown, loosely, longitudinally interwoven, rough, nodose-septate, $4-41 / 2 \mu$ in diameter, and with hymenial layer $75-450 \mu$ thick with hyaline, interwoven hyphae; no gloeocystidia; basidia simple, with 4 sterigmata; spores hyaline, even, cylindric, $25-35 \times 6-9 \mu$.

Fructification $7 \mathrm{~cm}$. long, $31 / 2 \mathrm{~cm}$. wide in the piece seen which is broken off at one end and on one side.

On bark of decaying $\log$ of an apparently frondose species in a moist virgin forest. Mexico. December.

C. Murrilli is probably a species with large, soft, dry fructification separable from the bark in a pliant, sheet-like mass and having the hymenium buff color and the under side a rich Van Dyke brown. The very large spores are another distinguishing character. C. Langloisii is thinner and has smaller spores.

Specimens examined:

Mexico: Jalapa, W. A.\& E. L. Murrill, 182, type, comm. by N. Y. Bot. Gard. (in Mo. Bot. Gard. Herb., 44967).

97. C. subochraceum Bresadola, Hedwigia 35: 290. 1896; Sacc. Syll. Fung. 14: 221. 1899.

Type: part of type in Burt Herb.

Fructifications broadly effused, closely adnate, very thin, not separable, becoming light pinkish cinnamon to wood-brown in the herbarium, glabrous, even, not shining, not cracking, the margin thinning out, whitish at first, becoming colored like the hymenium; in section $45-100 \mu$ thick, only slightly colored in the hy- 
menium and subhymenium but giving the color to the fructification, composed of densely interwoven, distinct hyphae $3-31 / 2 \mu$ in diameter, not incrusted, not nodose-septate; no gloeocystidia; spores hyaline, even, $3-41 / 2 \times 2-2 \frac{1}{2}[$, copious.

Fructifications 1-8 cm. long, 1-2 cm. wide.

On bark and decaying wood of frondose species. Alabama, I ouisiana, Nebraska, and Brazil. May and June.

C. subochraceum occurs on decaying frondose wood and bark in closely adnate, thin fructifications of wood-brown color due to the pale color of the superficial tissue. The spores were published by Bresadola as $6-8 \times 4-41 / 2 \mu$ and the hyphae as conglutinate, but in the original specimen from Bresadola the spores are copious, flattened on one side, and not larger than $41 / 2 \times 21 / 2 \mu$ and the hyphae not conglutinate.

Specimens examined:

Alabama: Auburn, Earle \& Baker (in N. Y. Bot. Gard. Herb., and Mo. Bot. Gard. Herb., 58325); Montgomery Co., R. P. Burke, 398 (in Mo. Bot. Gard. Herb., 57212).

Louisiana: St. Martinville, A. B. Langlois, $a b$, w, and 1345, comm.

by W. G. Farlow (in Mo. Bot. Gard. Herb., 42603).

Nebraska: Lincoln, C. L. Shear, 1341.

Brazil: Blumenau, A. Möller, part of type from Bresadola.

98. C. canadense Burt, n. sp.

Type: in Burt Herb., Mo. Bot. Gard. Herb., and N. Y. State Mus. Herb.

Fructifications broadly effused, adnate, rather thick, membranaceous, small pieces separable when moistened, light buff, even, ceraceous, cracking but little in drying, the margin narrow, sulphur-yellow, with its hyphae interwoven; in section 600-800 $\mu$ thick, colored, stratose, the buried strata becoming fuscous; hyphae of each stratum $3 \mu$ in diameter, not incrusted, occasionally nodose-septate, erect, loosely arranged below, forming a compact hymenium; no gloeocystidia; spores white in spore collection, cylindric, even, $41 / 2-6 \times 1 \frac{1}{2}-2 \mu$.

Fructifications $3-10 \mathrm{~cm}$. long, 1-5 cm. wide.

On decaying wood of logs of Pinus Strobus. Canada and New Hampshire. July to September. Rare. 
C. canadense has beautiful fructifications with buff hymenium and sulphur-colored margin. The occurrence on pine, stratose structure in section, and the buried strata fuscous in color afford more ample confirmatory distinctive characters than we usually find in resupinate species.

Specimens examined:

Canada: Ontario, Ottawa, J. Macoun, 26, type (in Burt Herb.,

N. Y. State Mus. Herb., and Mo. Bot. Gard. Herb., 55909).

New Hampshire: Chocorua, W. G. Farlow (in Mo. Bot. Gard.

Herb., 6766), 8, and E. A. Burt.

99. C. bicolor Peck, Buffalo Soc. Nat. Hist. Bul. 1:62. 1873; N. Y. State Mus. Rept. 26: 72. 1874; Sacc. Syll. Fung. 6: 630 . 1888; Massee, Linn. Soc. Bot. Jour. 27: 157. 1890.

Type: in N. Y. State Mus. Herb.

Fructifications widely effused, thin, membranaceous, tender, small pieces separable when moist, white, becoming pale pinkish buff to cream color in the herbarium, even, continuous, not cracked, the subiculum wax-yellow throughout, byssoid, the margin yellow to wax-yellow, often running out into wax-yellow rhizomorphic strands; in section 200-300 $\mu$ thick, yellow near the substratum and usually throughout, color not changed by lactic acid but bleached by potassium hydrate solution; the hyphae loosely interwoven, delicate, $21 / 2 \mu$ in diameter, somewhat rough or incrusted with small crystals; no gloeocystidia; spores hyaline, even, subglobose, $2 \mu$ in diameter or $3 \times 2 \mu$, copious.

Fructifications $3-8 \mathrm{~cm}$. long, $2-3 \mathrm{~cm}$. wide.

On under side of fallen limbs and decaying wood on the ground, usually on pine and other conifers but also on Populus. New Hampshire to New Jersey and in Montana and Washington. August to November. Uncommon.

$C$. bicolor is a beautiful species related to $C$. sulphureum, from which it constantly differs in occurring nearly always in fertile condition with a compact whitish, even hymenium borne on the brilliant, wax-yellow subiculum. The hyphae and spores are similar to those of $C$. sulphureum.

Specimens examined:

New Hampshire: Chocorua, A. P. D. Piguet, comm. by W. G. 
Farlow, 176, and W. G. Farlow (in Mo. Bot. Gard. Herb., 55249 and 13630 , respectively).

New York: Karner, H. D. House, comm. by N. Y. State Mus. Herb., 14.152; Oneida, H. D. House (in N. Y. State Mus. Herb., and Mo. Bot. Gard. Herb., 57452, 57476); Warrensburg, C. H. Peck, type (in N. Y. State Mus. Herb.) and (in N. Y. State Mus. Herb., and Mo. Bot. Gard. Herb., 55771).

New Jersey: Newfield, J. B. Ellis, 88, comm. by W. G. Farlow (in Mo. Bot. Gard. Herb., 7944).

Montana: Evaro, J. R. Weir, 419, 435 (in Mo. Bot. Gard. Herb., 14768, 6707).

Washington: Hoquiam, C. J. Humphrey, 6400.

100. C. koleroga (Cooke) v. Höhnel, K. Akad. Wiss. Wien Sitzungsber. 119: 395. 1910; Burt, Mo. Bot. Gard. Ann. 5: 123. f. 1. 1918.

Pellicularia koleroga Cooke, Grevillea 4: 116, 134. 1876; Pop. Sci. Rev. 15 : 164. pl. 135, f. $a-c .1876$; Linn. Soc. Bot. Jour. 18 : 461. 1881; Sacc. Syll. Fung. 4: 149. 1886; Fawcett, G. L., Porto Rico Agr. Exp. Sta. Ann. Rept. 1910: 35. 1911; Jour. Agr. Res. 2: 231. text f. 1-3. 1914; Porto Rico Agr. Exp. Sta. Bul. 17: 8. pl. 1. 1915.-Erysiphe scandens Ernst, A., Estudios sobre las Deformaciones, Enfermedades y Enemigos del Arbol de Cafe in Veneizuela, 16. pl.f. 5. 1878.

Type: in Kew Herb.

The parasitic vegetative mycelium forms long, slender, mycelial strands of rather uniform diameter, whitish or pallid at first, finally fuscous, running along the branches and midrib and veins of the leaves, infecting the leaves and ramifying between the cells of the leaf parenchyma, finally emerging at many points on the under side of the leaf to form minute fructifications which give a mottled appearance to the leaf; fructifications soon laterally confluent into a thin, arachnoid, perforate membrane covering the under surface of the leaf between midrib and principal veins, drying pale smoke-gray, separable in small pieces, composed of loosely interwoven, hyaline or slightly colored, thin-walled, even, rigid hyphae $41 / 2^{-6} \mu$ in diameter, not nodose-septate, running parallel with the substratum, and about 1-3 hyphae thick, branching at right angles; basidia scattered along the hyphae, simple, ovoid, 10- 
$12 \times 7-8 \mu$, with short sterigmata; spores hyaline, even, flattened or slightly concave on one side, $10-13 \times 31 / 2^{-5} \mu$.

Mycelial strands in the specimens received are $35 \mathrm{~cm}$. long and broken with the branch at the lower end, $1 / 2-1 \mathrm{~mm}$. in diameter, not swollen into sclerotia; fructifications $9 \mathrm{~cm}$. long, 4 $\mathrm{cm}$. broad, $30-45 \mu$ thick, more or less divided by the midrib and principal veins.

Parasitic on branches and leaves of the coffee plant. India, and the Antilles and neighboring regions of South America.

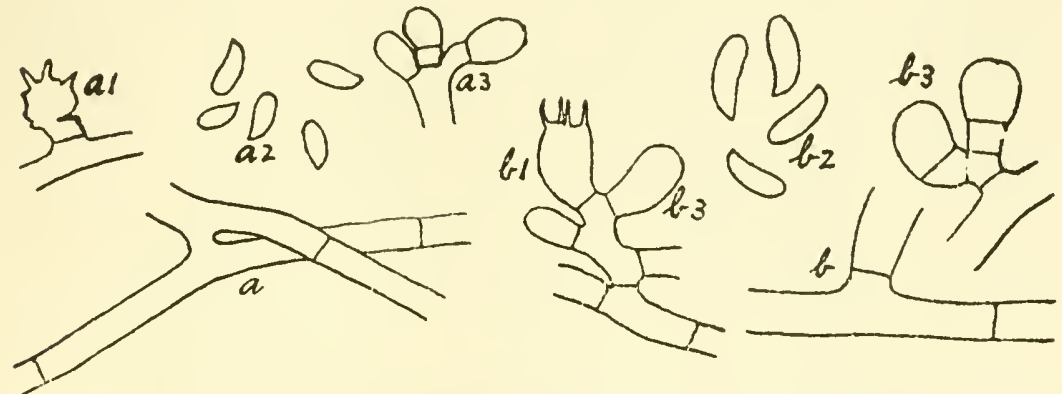

Fig. 1. C. koleroga. $a-a s$, from sketches by Miss Wakefield of structure of type in Kew Herbarium; magnification not stated but computed from spore dimensions at about 630 . $a$, hypha; $a 1$, collapsed basidium; $a 2$, spores; $a 3$, young basidia. $b-b 3$, from Porto Rican specimen, $\times 870$. $b$, hypha; $b 1$, basidium; $b 8$, spores; $b \$$, young basidia.

Specimens examined:

India: Mysore, preparation from the type (in Kew Herb.).

Porto Rico: Mayaguez, F. L. Stevens, 9488 (in Stevens Herb., and

in Mo. Bot. Gard. Herb., 54510); H. E. Thomas (in Mo. Bot.

Gard. Herb., 55397).

Colombia: H. T. Dawe, fragment (in Mo. Bot. Gard. Herb. from specimen in Kew Herb.).

Venezuela: A. Ernst, fragments showing mottled stage and continuous fructification respectively (in Mo. Bot. Gard. Herb. from specimens in Kew Herb., determined by Ernst as Candelillo, Erysiphe scandens); H. Peltier, comm. by U. S. Dept. Agr., Path. \& Myc. Coll., 1713 (in Mo. Bot. Gard. Herb., 62168 ).

101. C. Stevensii Burt, Mo. Bot. Gard. Ann. 5: 125. text f. 2 . 1918. 
Hypochnopsis ochroleuca Noack, Boletim do Instituto Agronomico Sao Paulo em Campinas 9: 80. 1898.-Hypochnus ochroleucus Noack in Sacc. Syll. Fung. 16: 197. 1902; Stevens, Science N. S. 26: 724. 1907; Stevens \& Hall, Ann. Myc. 7: 49-59. text f. 1-8. 1909.-Not Corticium ochroleucum Bresadola, Fungi Trid. 2: 58. $p l .16 \%$, f. 2. 1892.

Vegetative mycelium forms on the twigs roundish or oblong, chestnut-brown sclerotia $3-4 \mathrm{~mm}$. in diameter, and also slender mycelial strands white when young, becoming chestnut-brown, rumning along the twigs and petioles to the leaves and fructifying there; fructifications at first downy and barely visible, soon thickening into a dirty pinkish buff, felty membrane covering the whole under side of the leaf and frequently separable from it as a
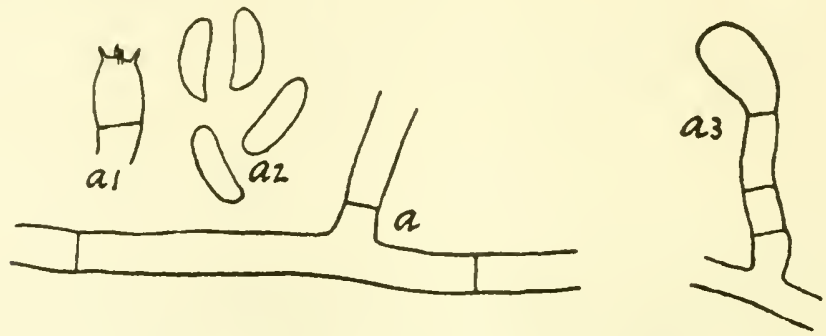

Fig. 2. C. Stevensii. From specimen from Trinidad, $\times 870$. $a$, hypha; a1, basidium; a2, spores; $a 3$, young basidium.

whole by mere handling; hyphae hyaline or slightly colored, giving their color to the fructifications, even, thin-walled, not incrusted, not nodose-septate, $41 / 2-71 / 2 \mu$ in diameter; basidia scattered along the hyphae on short lateral branches, simple, $11 \times 7-8 \mu$, with four short sterigmata; spores hyaline, flattened or slightly concave on one side, $8-11 \times 3-4 \mu$.

Fructification $11 \mathrm{~cm}$. long, 3-4 cm. broad, 45-60 $\mu$ thick, unbroken over whole under surface of leaves; sclerotia $3-4 \mathrm{~mm}$. in diameter; mycelial strands $1 / 2-1 \mathrm{~mm}$. in diameter, many $\mathrm{cm}$. long.

On apple, pear, and quince, in Brazil and southern United States, causing the leaves to dry and fall, and on Codiaeum in Trinidad.

This species differs from Corticium koleroga by having sclerotia and thicker, darker-colored, and more felted fructifications which are but feebly attached to the leaf and form an unbroken covering 
over the whole under surface of the leaf from margin to margin. Fruiting specimens of this fungus have been available for study from only two localities, but these specimens agree in the characters stated above.

Specimens examined:

North Carolina: Horseshoe, J. G. Hall, comm. by F. L. Stevens, sclerotial stage on pear twigs; Mt. Airy, F. C. Reimer, comm. by F. L. Stevens, fertile stage on pear leaves.

Georgia: A. L. Quaintance, comm. by F. S. Earle, sclerotial stage on apple twigs.

Florida: C. G. Lloyd, sclerotial stage on pear twigs.

Texas: Dickson, F. W. Mally, comm. by U. S. Dept. Agr., sclerotial stage on pear twigs.

Trinidad: Diego Martei, J. B. Rorer, fertile stage on leaves of Codiaeum variegatum (in Mo. Bot. Gard. Herb., 44771); Petit Valley, J. B. Rorer, sclerotial and fruiting stages on leafy twigs of Codiaeum variegatum (in Mo. Bot. Gard. Herb., 11960, 19786, 19810, and 20062).

102. C. vagum Berk. \& Curtis, Grevillea 1: 179. 1873; Sacc. Syll. Fung. 6: 616. 1888; Massee, Linn. Soc. Bot. Jour. 27 : 148. 1890; Duggar, Mo. Bot. Gard. Ann. 2: 445. 1915; Peltier, Univ. Ill. Agr. Exp. Sta. Bul. 189: 285. 1915; Burt, Mo. Bot. Gard. Ann. 5: 128. text f. 3. 1918; Coker, Elisha Mitchell Scientif. Soc. Jour. 36: 173. pl. 33, f. 9, 10. 1921.

Corticium vagum Berk. \& Curtis var. Solani Burt in Rolfs, Science N. S. 18 : 729 . 1903; Colo. Agr. Exp. Sta. Bul. 91: 1-20. pl. 1-5. 1904.-Hypochnus Solani Prill. \& Del. Soc. Myc. Fr. Bul. 7: 220. text f. 1891; Sacc. Syll. Fung. 11: 130. 1895.Corticium Solani Prill. \& Del. in Bourdot \& Galzin, Soc. Myc. Fr. Bul. 27: 248. 1911.-Corticium botryosum Bresadola, Ann. Myc. 1: 99. 1903; Sacc. Syll. Fung. 17: 173. 1905; Bourdot \& Galzin, Soc. Myc. Fr. Bul. 27: 248. 1911.-Rhizoctonia Solani Kühn, Krankheiten d. Kulturgewächse, 224. 1858; Duggar, Mo. Bot. Gard. Ann. 2: 424. 1915.

Type: in Kew Herb. and in Curtis Herb.

Vegetative mycelium saprophytic in the soil and in wood in contact with the ground, and parasitic as the Rhizoctonia Solani stage 
in underground portions of various plants and forming at their surface underground minute sclerotia; fructification a thin, arachnoid, perforate membrane more or less separable, pale olive-buff to cream color; in structure $60-100 \mu$ thick, composed of a few looscly interwoven hyphae running along the substratum and scnding out short branches which bear the basidia; hyphae in contact with substratum may be slightly brownish, hyaline elsewhere, not incrusted, not nodose-septate, up to 6-10 $\mu$ in diameter, with branches smaller; basidia not forming a compact hymenium, $10-20 \times 71 / 2^{-11} \mu$, with $4-6$ sterigmata $6-10 \mu$ long
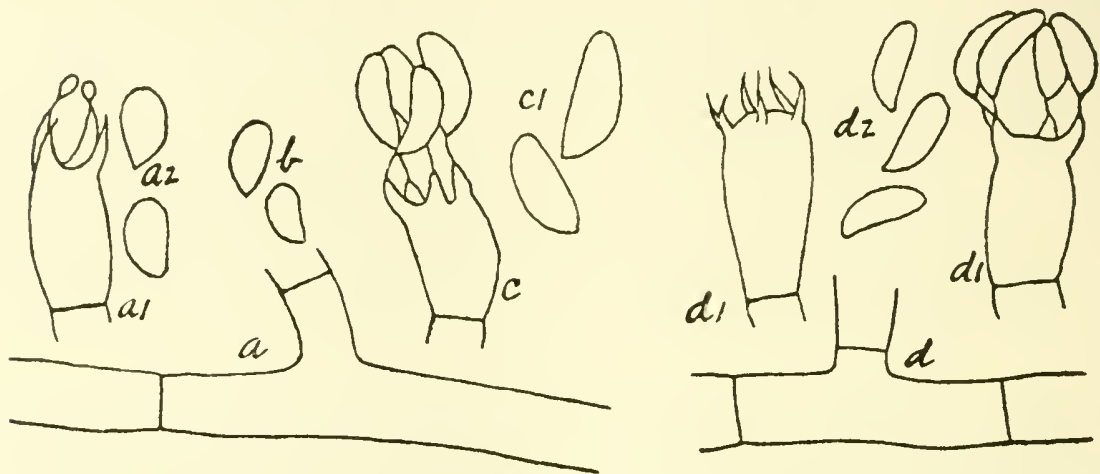

Fig. 3. C. vagum, $\times 870$. $a-a \&$, from specimen on potato in Colorado. $a$, hypha; $a 1$, basidium; $a 2$, spores. $b$, spores of specimen on Plantago in Illinois. $c-c 1$, from specimen on earth in Massachusetts. $c$, basidium; $c 1$, spores. $d-d \mathscr{2}$, from specimen on wood in British Columbia. $d$, hypha; $d 1$, basidia; $d \mathscr{Z}$, spores.

and more or less swollen towards the basidium; spores hyaline, even, flattened on one side, 8-14 $\times 4-6 \mu$.

Fructifications $5-15 \mathrm{~cm}$. long on logs, $5-10 \mathrm{~cm}$. broad; in a collar 1-10 $\mathrm{cm}$. long, sheathing the base of living stems.

On bare earth, wood and bark lying on the ground, and on living stems of potatoes, beans, rhubarb, horseradish, tomatoes, Amaranthus, etc., at or near the ground. New Brunswick to Florida and westward to Vancouver and Washington, in West Indies, Europe, India, and Australia. Common.

Corticium vagum differs from $C$. koleroga and $C$. Stevensii in having its mycelium and sclerotia subterranean when parasitic, in having its fructifications at the surface of the ground or merely sheathing small herbaceous stems for only a few centimeters up from the ground and never spreading out on the under side of 
broad leaves at a considerable distance above ground, by having larger hyphae, larger basidia, and the basidia with larger sterigmata which are more thickened in the lower portion and sometimes six to a basidium; the spores are somewhat larger in $C$. vagum also. The examination of the large amount of $C$. vagum which has come to hand does not afford ground for regarding the collar-like fructifications on small living herbaceous stems as worthy of varietal separation. As common as this species now is in the United States, it is rather surprising that a collection of it under some name has not been found in Herb. Schweinitz.

Specimens examined:

Exsiccati: Ellis, N. Am. Fungi, 330; Ravenel, Fungi Am., 132, 577

- the latter under the name Zygodesmus pannosus.

Sweden: Stockholm, L. Romell, 204.

Russian Poland: Eichler, comm. by Bresadola, portion of type of Corticium botryosum Bres.

New Brunswick: Campobello, W. G. Farlow, 3.

Canada: J. Macoun, 2, 84, 340 .

Ontario: Ottawa, J. Macoun, 327.

Massachusetts: Brookline, G. R. Lyman, 180; Magnolia, W. G. Farlow.

New York: Albany, H. D. House \& J. Rubinger (in Mo. Bot. Gard. Herb., 8734); East Galway, E. A. Burt, 2 collections; Ithaca, Van Hook, comm. by G. F. Atkinson, 8092; Karner, H. D. House, 14.162, and 3 other collections (in N. Y. State Herb. and Mo. Bot. Gard. Herb., 44709, 54349, 55199, 55203); Tripoli, S. H. Burnham, 13, in part (in Mo. Bot. Gard. Herb., $54506)$.

New Jersey: Belleplain, C. L. Shear, 1244; Newfield, J. B. Ellis, in Ellis, N. Am. Fungi, 330.

Pennsylvania: Carbondale, E. A. Burt; Trexlertown, W. Herbst, 95.

Maryland: Takoma Park, C. L. Shear, 1164, 1334.

District of Columbia: Takoma Park, C. L. Shear, 965, 1041 (the former in Mo. Bot. Gard. Herb. also).

South Carolina: Curtis Herb., 3240, type (in Kew Herb. and in Curtis Herb.); Aiken, H.W. Ravenel, in Ravenel, Fungi Am., 132, 577. 
Alabama: Montgomery, R. P. Burke, 170 (in Mo. Bot. Gard. Herb., 43162).

West Virginia: Paw Paw, C. L. Shear, 1171.

Ohio: Cincinnati, C. G. Lloyd, 4508.

Illinois: Urbana, G. L. Peltier, 14 collections, on living stems of beans, carrot, tomato, radish, rhubarb, horseradish, potato, winter vetch, spinach, Amaranthus, Campanula, and Plantago major (in Mo. Bot. Gard. Herb., 6264, 8761-8765, 8816, 43836, 44677-44682).

Montana: Evaro, J. R. Weir, 434 (in Mo. Bot. Gard. Herb., 17725).

Idaho: Coolin, J. R. Weir, 11545 (in Mo. Bot. Gard. Herb., 63298). Priest River, J. R. Weir, 140, 89 in part (Mo. Bot. Gard. Herb., 8197, 11349).

Colorado: Fort Worth, F.M. Rolfs, 2 collections, on living stems of potatoes.

Manitoba: Norway House, G. R. Bisby, 1475, 1477 (in Mo. Bot. Gard. Herb., 61657, 61659).

British Columbia: Sidney, J. Macoun, 4, 20, 83, 85, 87, 26, 154 (in Mo. Bot. Gard. Herb., 5764, 5735, 7068, 7024, 7833, 55347, 55350 , respectively) and $39 a, 151,172$ (in Macoun Herb.); Vancouver Island, J. Macoun, V89, V90, V151, V154, V172 (in Mo. Bot. Gard. Herb., 22815, 22927, 20357, 20507, 20728, respectively).

Washington: Bingen, W. N. Suksdorf, 846, 852, 863.

India: Ceylon, T. Petch, 5675 (in Mo. Bot. Gard. Herb., 56035). Japan: Prov. Awaji, A. Yasuda, 111 (in Mo. Bot. Gard. Herb., 57027).

103. C. vinaceum Burt, n. sp.

Type: in Burt Herb.

Fructifications effused, very thin, closely adnate, drying between light pinkish cinnamon and vinaceous-buff, even, not shining, not cracked, the margin similar, thinning out; in section 75-100 $\mu$ thick, colored near the substratum, with the hyphae $21 / 2 \mu$ in diameter, densely longitudinally interwoven and conglutinate, not incrusted, bearing a hymenium $25 \mu$ thick; no gloeocystidia; basidia not protruding; spores white in spore collection, even, subglobose, $7-8 \times 6-7 \mu$. 
Fructifications 5-10 mm. in diameter, near together and becoming irregularly confluent over areas up to $4 \mathrm{~cm}$. long, 1-2 cm. wide.

Under side of decaying coniferous plank. Alabama and Louisiana. March.

The distinguishing characters of this species are occurrence on coniferous wood in closely adnate, vinaceous fructifications, which are somewhat colored next to the substratum and have large spores.

Specimens examined:

Alabama: Montgomery, R. P. Burke, 271 (in Mo. Bot. Gard. Herb., 57156).

Louisiana: St. Martinville, A. B. Langlois, $d f$, type.

104. C. fuscostratum Burt, n. sp.

Type: in N. Y. State Mus. Herb., Mo. Bot. Gard. Herb., and Burt Herb.

Fructifications broadly effused, thin, tender, forming a thin, fragile, cartridge-buff to pale smoke-gray hymenial pellicle on an arachnoid or fibrillose, wood-brown subiculum, the hymenium cracking into small polygonal masses about $1 \mathrm{~mm}$. in diameter, the margin colored like the substance, fimbriate; in section 120$300 \mu$ thick, wood-brown, with the hyphae pale brownish, $21 / 2 \mu$ in diameter, nodose-septate, sometimes incrusted; no gloeocystidia; spores hyaline, even, flattened on one side, $3-4 \times 2 \mu$.

Fructifications $3-6 \mathrm{~cm}$. long, 2-3 cm. wide.

On bark of decaying Pinus Strobus and other conifers. Canada to Maryland and westward to British Columbia. August to December. Uncommon.

The fructifications of $C$. fuscostratum are characterized by a hymenial layer as thin, fragile, and cracked as that of $C$. arachnoideum or of $C$. centrifugum and a supporting layer underneath as colored as that of $C$. subcontinuum. Compare $C$. ochroleucum Bres. and $C$. olivaceo-album.

Specimens examined:

Canada: J. Macoun, 15; St. Lawrence Valley, J. Macoun, 29.

New York: Albany, H. D. House, type (in N. Y. State Mus. Herb.,

Mo. Bot. Gard. Herb., 63750, and Burt Herb.), and H. D. 
House \& J. Rubinger (in N. Y. State Mus. Herb., and Mo. Bot. Gard. Herb., 7766); Round Lake, C. H. Pech, (in N. Y. State Mus. Herb., and Mo. Bot. Gard. Herb., 42930).

Pennsylvania: Freeland, C. R. Orton \& G. E. Broadbent, comm. by L. O. Overholts, 5166 (in Mo. Bot. Gard. Herb., 56359).

Maryland: 'Takoma Park, C. L. Shear, 963.

Michigan: East Tawas, J. R. Weir, 317 (in Mo. Bot. Gard. Herb., 6961); New Richmond, C. H. Kauffman, 86 (in Mo. Bot. Gard. Herb., 54327).

Wisconsin : Star Lake, J. J. Neumann, comm. by H. von Schrenk (in Mo. Bot. Gard. Herb., 42734).

British Columbia: Kootenai Mountains near Salmo, J. R. Weir, 503, 511 (in Mo. Bot. Gard. Herb., 63722, 5900).

105. C. atrovirens Fries, Epicr. 562. 1838; Hym. Eur. 651. 1874; Berkeley, Outl. Brit. Fung. 274. 1860; Sacc. Syll. Fung. 6: 614. 1888; Massee, Linn. Soc. Bot. Jour. 27: 155. 1890; Bresadola, Ann. Myc. 1: 96. 1903; Maire, Brit. Myc. Soc. T'rans. 3: 172. pl. 16. 1910; Bourdot \& Galzin, Soc. Myc. Fr. Bul. 27: 243. 1911; Rea, Brit. Basid. 677. 1922.

Thelephora atrovirens Fries, Elenchus Fung. 1: 202. 1828.Lyomyces caerulescens Karsten, Finska, Vet.-Soc. Bidrag Natur och Folk 37: 154. 1882.-Hypochnus chalybaeus Schroeter, Krypt.-Fl. Schlesien 3: 416. 1888.

Fructifications irregularly effused, thin, floccose-fibrillose or arachnoid, greenish glaucous blue to deep bluish gray-green, even, not cracked, the margin thinning out, with hyphae interwoven; in section $150-250 \mu$ thick, colored like the hymenium, composed of long, slender, interwoven, colored hyphae $2-3 \mu$ in diameter, not nodose-septate, not incrusted; no gloeocystidia; spores colored like the fructification, even, subglobose, $3-4 \times$ $2 \frac{1}{2}-31 / 2 \mu$, borne 4 to a basidium.

Fructifications $1-4 \mathrm{~cm}$. long, 1-2 cm. wide.

On under side of decaying bark and fallen branches. In Europe, and from New Brunswick to South Carolina and in Illinois. September to December. Infrequent.

C. atrovirens is conspicuous by its fructifications blue-green in all parts. It is intermediate between Corticium and Hypochnus, being included in the former on account of the even spores. 
Specimens examined:

Exsiccati: Sydow, Myc. Germ., 1432.

Finland: Mustiala, P. A. Karsten, authentic specimen of Hypochnopsis caerulescens.

Germany: Brandenburg, P. Vogel, in Sydow, Myc. Germ., 1432. Poland: Russian Poland, Eichler, comm. by G. Bresadola.

Great Britain: Coed Coch (in Berkeley Herb. of Kew Herb.).

New Brunswick: Campobello, W. G. Farlow.

Vermont: Middlebury, E. A. Burt, 2 gatherings.

Massachusetts: Beverly, C. W. Dodge \& D. H. Linder, A (in Mo. Bot. Gard. Herb., 63451); Stony Brook, G. R. Lyman, 129.

New York: Cascadilla, A. J. Pieters, comm. by Cornell Univ. Herb., 5256; Ithaca, G. F. Atkinson, 8202; Karner, H. D. House, 14.205 and an unnumbered specimen (in Mo. Bot. Gard. Herb., 44727, 54394); Syracuse, L. M. Underwood, 44 (in N. Y. State Mus. Herb., and Mo. Bot. Gard. Herb., 56088). North Carolina: Blowing Rock, G. F. Atkinson, 4301.

South Carolina: Gourdin, C. J. Humphrey, 2586 (in Mo. Bot. Gard. Herb., 43119).

Illinois: Hallidayboro, C. J. Humphrey, 2125 (in Mo. Bot. Gard. Herb., 22086).

106. C. caeruleum (Schrad.) Fries, Epicr. 562. 1838; Hym. Eur. 651. 1874; Berkeley, Outl. Brit. Fung. 274. 1860; Berk. \& Curtis, Grevillea 1 : 178. 1873; Sacc. Syll. Fung. 6: 614. 1888; Massee, Linn. Soc. Bot. Jour. 27: 151. 1890; Bourdot \& Galzin, Soc. Myc. Fr. Bul. 27: 232. 1911; Wakefield, Brit. Myc. Soc. Trans. 4: 119. pl. 3, f. 26. 1913; Coker, Elisha Mitchell Scientif. Soc. Jour. 36: 169. pl. 33, f. 1. 1921; Rea, Brit. Basid. 673. 1922.

Thelephora caerulea Schrader in De Candolle, Fl. Fr. 2: 107. 1815; Persoon, Myc. Eur. 1: 147. 1822; Fries, Elench. Fung. 1: 202. 1828.-Auricularia phosphorea Sowerby, Eng. Fungi, pl. 350. 1802.-Thelephora Indigo Schweinitz, Naturforsch. Ges. Leipzig Schrift. 1: 107. 1822.

Fructifications somewhat round, broadly effused, adnate, rather thick, membranaceous, separable when moist, indigoblue to induline blue, even, somewhat velvety, the margin thin- 
ning out, concolorous or whitish ; in section 200-500 $\mu$ thick, thickening by becoming stratose, the outer stratum deep blue, the hyphae thick-walled, interwoven, nodose-septate, not incrusted, $3-41 / 2 \mu$ in diameter; no gloeocystidia; spores even, $6-10 \times$ $41 / 2-5 \mu$.

Fructifications $3-10 \mathrm{~cm}$. in diameter.

On under side of decaying limbs of Quercus and other frondose species. In Europe, southern United States, Illinois, and Japan. August to November. Probably in quantity where found.

C. caeruleum is easily recognized by its deep blue color and occurrence on fallen oak limbs.

Specimens examined:

Exsiccati: Cavara, Fungi Longobardiae, 13; Cooke, Fungi Brit., 221, and ed. II, 5; Libert, Pl. Crypt. Ard., 22; Ravenel, Fungi Am., 451; Ravenel, Fungi Car. 3: 27; de Thümen, Myc. Univ., 1207; Westendorp, Crypt. Belge, 767.

Denmark: Skarup, E. Rostrup, in de Thümen, Myc. Univ., 1207. Italy: Cavara, in Cavara, Fungi Longobardiae, 13.

Belgium: in Westendorp, Crypt. Belge, 767.

France: Libert, in Libert, Pl. Crypt. Ard., 22; Corrombles, F.

Fautrey, comm. by Lloyd Herb.

England: Chichester, in Cooke, Fungi Brit., ed. II, 5.

South Carolina: H. W. Ravenel, in Ravenel, Fungi Car. 3: 27;

Aiken, H.W. Ravenel, Fungi Am., 451.

Georgia: Atlanta, E. Bartholomew, 5679 (in Mo. Bot. Gard. Herb., 44218).

Florida: Sanford, C. L. Shear, 5204 (in Mo. Bot. Gard. Herb., 62164).

Alabama: Auburn, F. S. Earle (in Lloyd Herb., 3450, Burt Herb., and Mo. Bot. Gard. Herb., 4851), Earle \& Baker, comm. by A.B. Seymour (in Mo. Bot. Gard. Herb., 16394); G. L. Peltier (in Mo. Bot. Gard. Herb., 4684), A. H. W. Povah, 906 (in Mo. Bot. Gard. Herb., 58692), and F. A. Wolf (in Mo. Bot. Gard. Herb., 43983); Montgomery County, R. P. Burke (in N. Y. Bot. Gard. Herb., and Mo. Bot. Gard. Herb., 61562), and 14 (in Mo. Bot. Gard. Herb., 16983).

Illinois: Anna, C. J. Humphrey, 1356 (in Mo. Bot. Gard. Herb., 42932). 
Arkansas: Womble, W. H. Long, 19769 (in Mo. Bot. Gard. Herb., 8961).

Japan: Sendai, A. Yasuda (in Mo. Bot. Gard. Herb., 58236).

\section{Extra Limital Species}

107. C. paniculatum Burt, n. sp.

Type: in Burt Herb.

Fructifications effused, thin, adnate, somewhat membranaceous, small pieces separable, pinkish cinnamon in the herbarium, even, not shining, not cracked, the margin narrow, thinning out, with hyphae interwoven; in section $200 \mu$ thick, not colored, composed of loosely interwoven, hyaline hyphae $3 \mu$ in diameter, not incrusted, not nodose-septate, and of irregularly arranged gloeocystidia or conducting organs up to $30-75 \times 3-6 \mu$, flexuous or irregular in form; paraphyses brownish, giving their color to the hymenium, paniculately branched, with the ultimate branches very slender, projecting beyond the basidia and forming the hymenial surface; basidia cylindric-clavate, $30-40 \times 41 / 2-6 \mu$; no spores found.

Fructifications $2 \mathrm{~cm}$. long, $5 \mathrm{~mm}$. wide, confluent longitudinally.

On small, decaying, frondose limbs. Paraguay. August.

C. paniculatum is distinguished among the Corticiums which have gloeocystidia by its pinkish cinnamon color and hymenial surface composed of conspicuous, somewhat colored, bushybranched paraphyses.

Specimens examined:

Paraguay: Paraguari, Malme, 1081, type, comm. by L. Romell, 331.

\section{Species too Incompletely Described for Location among Preceding Species}

108. C. dendriticum P. Hennings, Hedwigia 41 : Beiblatt, 102. 1902; Sacc. Syll. Fung. 17: 168. 1905; v. Höhnel \& Litschauer, K. Akad. Wiss. Wien Sitzungsber. 116: 742. 1907.

Type: in Berlin Herb.

"Carnoso-ceraceum, pallide carneum, dendroideo-ramosum vel radiato-effusum, margine sicco reflexo, albo-villosulo; hymenio 
ceraceo, pruinoso carneo, sicco rimoso, basidiis clavatis, 2-4sterigmatibus, $20-28 \times 7-8 \mu$; sporis subglobosis, subroseis, levibus, $4-5 \mu$.

"San Jose de Costa Rica auf Stämmen von Orangen.-H. Pittier.

"Der Pilz bildet fleischige, dendritisch verzweigte, fleischrothe Lager, derselbe soll eine Krankheit der Stämme verursachen. Mit. C. salicinum Fr. und C. sarcoides Fr. verwandt."

Von Höhnel and Litschauer, in their study of the type specimen of $C$. dendriticum, found the spores 10-11 $\times 8 \mu, 4$ sterigmata constantly, and the fructifications seated upon a lichen instead of directly on the trunk of Citrus aurantium.

\section{Excluded Species}

Corticium ferax Ell. \& Ev. Am. Nat. 31 : 339, 1897; Sacc. Syll. Fung. 14: 219. 1899.

Sections of the type specimen in Ellis Coll. in N. Y. Bot. Gard. Herb. show this to be a Hyphomycete. A specimen under this name collected on coniferous wood, Beaver Meadow, Hull, Quebec, was communicated by J. Macoun as the Corticium ferax Ell. \& Ev. of Canadian Cryptogams, 246, Nat. Hist. Survey of Canada Herb.; this is Peniophora glebulosa.

\section{SUPPLEMENT}

Since the publication of the earlier parts, the following species have been received which were not included in those parts or require further notice.

\section{ALEURODISCUS}

See also account of species of Aleurodiscus by Lloyd, Myc. Writ. 6: Myc. Notes 62: 926. f. 1666-1688. 1920; 65: 1066. f. 2009-2012. 1921.

Aleurodiscus cerussatus (Bres.) v. Höhnel \& Litschauer, K. Akad. Wiss. Wien Sitzungsber. 116: 807. pl. 4, f. 1. 1907; Bourdot \& Galzin, Soc. Myc. Fr. Bul. 28: 351. 1913.

Corticium cerussatum Bresadola, Fungi Trid. 2: 37. pl. 144, f. 3 . 
1892; I. R. Accad. Agiati Atti III. $3: 112.1897$; Sacc. Syll. Fung. 11: 126. 1895.-Kneiffa cerussata Bresadola, Ann. Myc. 1: 104. 1903.

Type: in Burt Herb., an authentic specimen which is probably a part of the type.

Fructifications effused, closely adnate, thin, waxy, white at first, becoming between pinkish buff and cream-buff in the herbarium, even, somewhat pruinose under a lens, cracking at right angles when old into masses about 3-4 to a mm., the margin similar, thinning out; in section 100-150 $\mathrm{e}$ thick; not colored, composed of suberect, interwoven, densely crowded hyphae about $2 \mu$ in diameter and of very numerous gloeocystidia; gloeocystidia flexuous, $40-60 \times 4-6 \mu$; bottle-brush paraphyses form the hymenial surface; spores hyaline, even, $12-15 \times 7-8 \mu$.

Fructifications 1-7 cm. long, 2-10 mm. wide.

On old, weathered, coniferous wood. Europe, Manitoba, and Oregon. June to October.

C. cerussatus is distinguished from our other species of Aleurodiscus with the exception of $A$. succineus, by having both gloeocystidia and bottle-brush paraphyses and from the latter by being effused.

Specimens examined:

Italy: Trient, G. Bresadola, part of type probably.

Manitoba: Binscarth, G. R. Bisby, 1050 (in Mo. Bot. Gard. Herb., 59037); Winnipeg, G. R. Bisby, 65 (in Mo. Bot. Gard. Herb., 57899), and comm. by L. O. Overholts, 7027 (in Mo. Bot. Gard. Herb., 57475).

Oregon: Granite Pass, J. R. Weir, 8682 (in Mo. Bot. Gard. Herb., 36743).

A. disciformis (DC.) Patouillard, Soc. Myc. Fr. Bul. 10:80. text f. 1894; v. Höhnel \& Litschauer, K. Akad. Wiss. Wien Sitzungsber. 116: 798. pl. 1, f. 1. 1907; Bourdot \& Galzin, Soc. Myc. Fr. Bul. 28: 350. 1913; Rea, Brit. Basid. 671. 1922.

Thelephora disciformis De Candolle, Fl. Fr. 6: 31. 1915; Fries, Syst. Myc. 1: 443. 1821.-Stereum disciforme (DC.) Fries, Epicr. 551. 1838; Hym. Eur. 642. 1874; Patouillard, Tab. Anal. Fung. 112. f. 250. 1884.-Peniophora disciformis (DC.) Cooke, 
Grevillea 8: 20. pl. 122, f. 2. 1879; Sacc. Syll. Fung. 6: 642. 1888 .

Fructifications effused, disciform, rather thick, pale olive-buff to cartridge-buff in the herbarium, pulverulent to velutinous, even, becoming somewhat cracked, the margin free, narrow, somewhat elevated, somewhat ochraceous on the under side; in section 150-800 $\mu$ thick, not colored, composed of erect, densely arranged hyphae $3-4 \mu$ in diameter, with a great deal of crystalline matter intermixed; paraphyses $41 / 2-6 \mu$ in diameter, cylindric, sometimes becoming irregularly swollen, sometimes somewhat moniliform toward the apex; spores hyaline, even, 15-20 $\times 11-15 \mu$.

Fructifications $1 / 2-21 / 2 \mathrm{~cm}$. in diameter, or $1 / 2-21 / 2 \mathrm{~cm}$. long, $1 / 2-1 \mathrm{~cm}$. wide.

On bark of Quercus. Europe, Mexico, and Africa. August to May.

A. disciformis is a species whose large fructifications resemble in aspect those of $A$. candidus although not as white as the latter and with paraphyses related in form to those of $A$. amorphus.

Specimens examined:

Austria: Vienna, V. Litschauer.

Italy: Trentino, G. Bresadola.

France: Aveyron, M. Galzin, 9503, comm. by H. Bourdot, 18550; locality not stated, Mougeot (in Farlow Herb.).

Mexico: locality not stated, A. Dampf (in Weir Herb.).

Africa: Union of South Africa, Stellenbosch, P. A. van der Bijl, 658 (in Mo. Bot. Gard. Herb., 59358).

A. helveolus Bresadola, Mycologia 17:71. 1925.

Type: in Weir Herb.

Fructifications erumpent, pulvinate to short-clavate, sessile, rugulose, waxy, somewhat gelatinous, Hay's brown, drying somewhat fuscous; hyphae hyaline, not incrusted, $4 \frac{1}{2}-6$ in in diameter; no conducting organs; basidia simple, large, $45-80 \times 6$ $8 \mu$, with $2-4$ sterigmata; spores hyaline, even, $18-21 \times 6-9 \mu$ according to Bresadola; hymenium surrounds the clubs on all sides.

Fructifications about $2 \mathrm{~mm}$. high and $1 \mathrm{~mm}$. in diameter when moistened. 
On bark of dead Salix lasiandra. Washington. November.

The dried fructifications of $A$. helveolus have some resemblance in aspect to those of Stereum rufum but swell on softening and rise to a height of $2 \mathrm{~mm}$. above the bark. The paraphyses were described by Bresadola as "paraphysibus irregularibus, undulatorestrictis, moniliformibus, laevibus, $3-\mathbf{b} \mu$ crassis, apice interdum subcapitatis" but they do not show clearly in my preparation.

Specimens examined:

Washington: Spokane, alt. 576 m., J.R. Weir, 16312, type (in Weir Herb.).

A. macrodens Coker, Elisha Mitchell Scientif. Soc. Jour. 36: 155. pl. 15, upper figs., pl. 31, f. 7-9. 1921.

Type: part of type in Mo. Bot. Gard. Herb.

"Forming irregular, often somewhat elongated patches about $2 \mathrm{~mm}$. to $2 \mathrm{~cm}$. long with well-defined margins and with much the aspect of $A$. candidus; surface minutely pulverulent, pure white, or pale cream when old and weathered; entire thickness only about $150-190 \mu$, the structure in section much obscured by very small crystals and the densely branched paraphyses. Basidia entirely embedded, $12-15 \mu$ thick, irregular and bent, with 4 long, stout sterigmata, which only reach the surface by their tips. Spores commonly rectangular in outline, the surface set with a few large, irregularly placed, bluntly pointed spines which are up to $4 \mu$ long; body of spore $111 / 2-15 \times 181 / 2^{-27} \mu . "$

On bark of living trees of Fraxinus and Salix. New Hampshire to North Carolina. May to December. Probably common.

"In passing the plant would be taken for A. candidus, but when examined is seen to be much thinner with the closely pressed margin not showing a dark underside. The spores are remarkable and unlike any others in the genus."

Specimens examined:

New Hampshire: Chocorua, W. G. Farlow, 1.

New York: Alcove, C. L. Shear, 1302, 1305; East Galway, E. A. Burt; Poughkeepsie, W. R. Gerard, 294, comm. by N. Y. Bot. Gard. Herb.

North Carolina: Chapel Hill, W. C. Coker, 4734, type, comm. by Univ. North Carolina Herb. (in Mo. Bot. Gard. Herb., 57427). 
A. subcruentatus (Berk. \& Curtis) Burt, Mo. Bot. Gard. Ann. 7: 237. 1920; Zeller, Mycologia 14: 179. 1922.

Stereum subcruentatum Berk. \& Curtis, Am. Acad. Arts \& Sci. Proc. 4: 123. 1858; Sacc. Syll. Fung. 6:567. 1888.

Type: in Farlow Herb.

Fructifications small, sometimes effuso-reflexed, with the reflexed portion up to 1-2 $\mathrm{mm}$. broad but more frequently resupinate, somewhat discoid, with the margin free all around and slightly elevated-in one fructification grown out so as to be attached by the vertex; upper side of reflexed pileus whitish at the margin, avellaneous nearer the substratum, somewhat radiately rugose, mealy; hymenium even, white or becoming pinkish buff; pulverulent; in section 500-1000 $\mu$ thick, not colored, composed of suberect, densely interwoven hyphae among a great amount of obscuring crystalline and mineral matter which is often in masses up to $45 \times 15 \mu$; hyphae about $2 \mu$ in diameter; hymenial portion up to $600 \mu$ thick, composed of several layers, containing more or less numerous imbedded spores resembling the basidiospores; paraphyses simple, filiform, probably torulose, about $2-3 \mu$ in diameter, basidiospores copious at surface of hymenium, hyaline, even, somewhat flattened on one side, 12$18 \times 9-12 \mu$.

Fructifications 2-15 mm. in diameter.

On bark of Tsuga Sieboldii in Japan and on bark of living trunks of Picea sitchensis and Douglas fir in California and Oregon. August and September.

A. subcruentatus has hymenial surface and spores suggestive of A. disciformis but is a very distinct species by having its fructifications effuso-reflexed when on the bark of standing trunks, by occurrence on conifers, thick and zonate hymenial portion, and presence of imbedded spores.

Specimens examined:

Oregon: Corvallis, S. M. Zeller, 1809 (in Mo. Bot. Gard. Herb., 56330).

California: Requa, W. H. Snell (Mo. Bot. Gard. Herb., 55860) and E. E. Hubert, comm. by J. R. Weir, 9946 (in Mo. Bot. Gard. Herb., 56229).

Japan: C. Wright, 265, type, Fungi U. S. Pac. Expl. Exp. (in 
Farlow Herb.); Mt. Akayu, Prov. Echègo, A. Yasuda, 22 (in Mo. Bot. Gard. Herb., 55659).

A. succineus Bresadola, Mycologia 17: 71. 1925.

Type: in Weir Herb.

Fructifications small, flattened, becoming disk-shaped by slight elevation of the margin, mouse-gray, pruinose, with the margin thick, entire, becoming free, under side pale; in section $500 \mu$ thick, composed of densely arranged, ascending, thin-walled, hyaline hyphae 3-5 $\mu$ in diameter and of numerous gloeocystidia; gloeocystidia flexuous, $75-100 \times 8-10 \mu$; paraphyses cylindric, of bottle-brush form, very numerous in the surface of the hymenium; basidia with 4 sterigmata; spores hyaline, even, ellipsoidal, 10 $\times 5 \mu$.

Fructifications 1-3 mm. long, 1-2 mm. wide.

On old weathered wood of Arbutus Menziesii. Oregon. September.

A. succineus is readily recognized by its discoid fructifications which have both gloeocystidia and bottle-brush paraphyses.

Specimens examined:

Oregon: Grants Pass, J. R. Weir, 8682, type (in Weir Herb.).

A. Zelleri Burt, n. sp.

Type: in Burt Herb.

Fructifications resupinate, gregarious, erumpent, pulvinate, convex, pinkish buff to tawny; in section about $600 \mu$ thick, composed of a broad layer of erect, somewhat interwoven hyphae $3-31 / 2 \mu$ in diameter, not incrusted, bearing a hymenial layer; no cystidia; gloeocystidia flexuous, $30-40 \times 4 \mu$, confined to the hymenial layer; basidia protruding, with 4 sterigmata; spores hyaline, even, $6-9 \times 4-41 / 2 \mu$, copious.

Fructifications $1 / 2-11 / 2 \mathrm{~mm}$. in diameter, about $1 / 2 \mathrm{~mm}$. thick10 on an area about $1 \mathrm{~cm}$. square.

On small dead twigs of a frondose species-perhaps Alnus. Oregon. December.

A. Zelleri may be recognized by its small, tawny, convex fructifications, erumpent from lenticels in the bark and having somewhat the aspect of a Tubercularia. 
Specimens examined:

Oregon: Corvallis, S. M. Zeller, 6800, type.

\section{CONIOPHORA}

Coniophora corrugis Burt, n. sp.

Type: in Burt Herb.

Fructifications broadly effused, coriaceous-membranaceous, loosely attached, separable when moist, between fawn color and salmon-pink to russet-vinaceous, even when dry, somewhat wrinkled when moist, cracking in drying, the margin whitish, byssoid; in section $300 \mu$ thick, not colored, with a broad layer next to the substratum of slender, loosely interwoven, thickwalled, nodose-septate hyphae about $31 / 2-4 \mu$ in diameter, not incrusted, and with a very compact hymenial layer; no gloeocystidia nor cystidia; basidia with 4 sterigmata; spores even, 6-10 $\times 4-7$, usually hyaline but when fully mature some at least are colored.

Fructifications 2-10 cm. long, 1-3 cm. wide.

On logs and dead limbs and on living trees of Pinus ponderosa, Abies lasiocarpa, Picea Engelmannii, Juniperus, and Ribes. In mountain forests. Wyoming to Colorado and British Columbia to Arizona. May to October. Common.

This species is most likely to be referred to Corticium, for it does not produce spores copiously and the few found in preparations may be full-sized and hyaline. It was 14 years after the type collection was received before it was demonstrated from a more mature specimen that the spores become colored finally. Several other collections with hyaline spores were received in the interval. $C$. corrugis may be recognized among our alpine species by its occurrence on the hosts stated, somewhat coriaceous, loosely attached, vinaceous fructifications, and large spores. The occurrence on living trees, as noted by Dr. Weir on Idaho specimens, is almost sufficient to identify this species when so found. $C$. corrugis seems related to $C$. polyporoidea.

Specimens examined:

Exsiccati: Baker, Pacific Slope Fungi, 3570, under the name Corticium corruge Burt.

Wyoming: Jackson Hole, E. B. Payson, 2369 (in Mo. Bot. Gard. Herb., 57369). 
Colorado: Arapahoe region, B. M. Duggar (in Mo. Bot. Gard. Herb., 63771); Tolland, L. O. Overholts, 1801 (in Mo. Bot. Gard. Herb., 43785, 54873), and E. Bethel (in N. Y. Bot. Gard. Herb., and Mo. Bot. Gard. Herb., 61447).

Idaho: St. Joe National Forest, J. R. Weir (in Mo. Bot. Gard. Herb., 43759, 63761); Victor, E. B. Payson, 2353, 2362 (in Mo. Bot. Gard. Herb., 57358, 57362).

British Columbia: Sidney, J. Macoun, 83 (in Mo. Bot. Gard. Herb., 55354).

Washington: Mt. Paddo, W. N. Suksdorf, 792, type.

Oregon: Austin, J. R. Weir, 5242 (in Mo. Bot. Gard. Herb., $55944)$.

California: Mt. Shasta, E. B. Copeland, in Baker, Pacific Slope Fungi, 3570; Santa Barbara, W. H. Morse, comm. by C. J. Humphrey, 860 (in Mo. Bot. Gard. Herb., 19314).

Arizona: Mt. Humphrey, near Flagstaff, W. H. Long, 21323 (in

Mo. Bot. Gard. Herb., 55130); Peak Agassiz, near Flagstaff, W. H. Long, 19489 (in Mo. Bot. Gard. Herb., 44737, 55129).

C. flavomarginata Burt, n. sp.

Type: in Burt Herb.

Fructifications effused, thick, membranaceous, separable, when growing avellaneous, with the margin flavous, fading in the herbarium to pinkish buff with margin whitish, even or somewhat colliculose, velvety, the margin radiate-fimbriate; in section $500 \mu$ thick, chamois-colored, becoming stratose, the hyphae suberect, densely arranged and interwoven, slightly colored, thinwalled, collapsing, $3-31 / 2 \mu$ in diameter, not incrusted, not nodoseseptate; no cystidia nor gloeocystidia; spores slightly colored, even, cylindric, $12-15 \times 4 \frac{1}{2}-6 \mu$.

Fructifications 1-3 cm. long, $1 / 2-3 \mathrm{~cm}$. wide.

In crevices of the rough bark of large branches of Quercus Garryana. Washington. December and March.

The faded herbarium specimens of $C$. flavomarginata have aspect similar to those of $C$. polyporoidea but very different tissues and spores. The yellow margin of the thick, tan-colored fructifications composed of 3 strata, should make this species conspicuous in its region, and it is rather surprising that it has not been received except from Mr. Suksdorf. 


\section{Specimens examined:}

Washington: Bingen, W. N. Suksdorf, 912, 913; W. Klickitat County, W. N. Suksdorf, 888, type, and 889.

\section{Sistotremoides (Sehw.) Massee}

Thelephora Sistotremoides Schweinitz, Naturforsch. Ges. Leiprig Schrift. 1: 109. 1822.-Corticium suffocatum Peck, N. Y. State Mus. Rept. 30:48. 1879.

Type: under the name Odontia Sistotremoides of Curtis Herb. in Farlow Herb. and probably also in Berkeley Herb. at Kew and Schweinitz Herb.

I was misled as to $C$. Sistotremoides in my presentation of the species in Mo. Bot. Gard. Ann. 4: 249. 1917, by having to base the work on the descriptions formerly published. I have since found in Farlow Herb. a piece $12 \times 6 \mathrm{~mm}$. of the authentic specimen from Schweinitz Herb. This specimen is in excellent preservation; a preparation from it wholly changes the concept of C. Sistotremoides, whose description should become:-

Fructifications effused, thin, membranaceous, not fleshy, somewhat separable, becoming sepia in the herbarium, even, not papillate; in section $200-300 \mu$ thick, colored like the hymenium, composed of colored hyphae $4-4 \frac{1}{2} \mu$ in diameter, incrusted, not nodose-septate, loosely arranged and interwoven, rather irregular in form; no cystidia present or not distinguishable from immature basidia; spores colored, even, 9-10 $\times 6 \mu$.

Authentic specimen is on reddish brown coniferous bark.

The type specimen of $C$. Sistrotremoides is darker than that of $C$. suffocata but not specifically distinct in my opinion. The account and distribution published for the latter in my earlier work applies to $C$. Sistotremoides. The deseriptive matter published there for $C$. Sistotremoides should be struck out.

\section{CRATERELLUS}

Craterellus subundulatus Peck, N. Y. State Mus. Bul. 67: 27. 1903.

Thelephora subundulata Peck, Torr. Bot. Club Bul. 22: 492. 1895; Sacc. Syll. Fung. 14: 214.1899.

Type: in N. Y. Bot. Gard. Herb. 
Fructifications gregarious or cespitose; pileus thin, coriaceousfleshy, depressed or subinfundibuliform, sometimes split on one side, slightly floccose-squamulose or fibrillose, grayish or grayish brown, becoming light drab in the herbarium, wavy or lobed on the margin, the lobes often overlapping; stem equal, solid, colored like the pileus; hymenium uneven or shallowly radiately venose, decurrent, drying light pinkish cinnamon; no setae nor cystidia; basidia with 4 sterigmata; spores hyaline, even, flattened on one side, $6-9 \times 41 / 2-6 \mu$.

Fructifications when dried $11 / 2-2 \mathrm{~cm}$. high; pileus $4-13 \mathrm{~mm}$. in diameter; stem 8-14 mm. long, 1-11/2 mm. thick.

On ground under trees of Fagus. New York and Delaware. July and August.

Peck noted this species as related to $C$. sinuosus, from which it differs in smaller size, solid and darker-colored stem, and slightly smaller spores. The fructifications are apparently plentiful when found, for some 30 fructifications of various sizes comprise each gathering.

Specimens examined:

New York: New York Botanical Garden, New York, Peck \& Earle, 1064 (in N. Y. Bot. Gard. Herb., Mo. Bot. Gard. Herb., and Burt Herb.).

Delaware: Wilmington, A. Commons, 2718, type (in N. Y. Bot. Gard. Herb.).

\section{C. turbinatus Burt, n. sp.}

Type: in Mo. Bot. Gard. Herb.

Pileus solitary, stipitate, coriaceous-corky, cylindric-turbinate, solid, with the margin erect, lobed, thinner, and the disk depressed, drying snuff-brown to Prout's brown, glabrous, even; flesh drying pale Saccardo's umber, and with a fragrant, pronounced odor, and taste not noteworthy; lamellae decurrent, distant, narrow, about $1 \mathrm{~mm}$. broad in the dried specimen, thin, about $2-4 \mathrm{~mm}$. apart, not connected nor with venose interspaces, concolorous with the pileus, with colored conducting organs in the subhymenial tissue; basidia simple, with at least 2 sterigmata demonstrated; spores slightly colored, even, globose, 5-6 $\mu$ in diameter; stem not sharply differentiated from the pileus, solid, contracting abruptly below, glabrous. 
Fructifications $10 \mathrm{~cm}$. high; pileus $7 \mathrm{~cm}$. high, $3-4 \mathrm{~cm}$. in diameter, with lobes up to $3 \mathrm{~cm}$. long; stem $3 \mathrm{~cm}$. long.

On stump of Quercus. California. March.

I have seen of this species only a dricd specimen which was collected by Lieutenant McWhorter at a military training camp and I am not sure that the species may not be transferred eventually to perhaps Paxillus on account of the thin lamellae, which are, however, very narrow and distant. The species is distinguished by its thick, solid, snuff-brown, glabrous fructifications drying with fragrant odor, by globose, colored spores, and by occurrence on an oak stump.

Specimens examined:

California: near Base Hospital, Camp Stewart, Palo Alto, F. P. McWhorter, type (in Mo. Bot. Gard. Herb., 57269).

Craterellus (?) Zelleri Burt, n. sp.

Type: in Mo. Bot. Gard. Herb.

Pileus fleshy when growing, thin, tubaeform, drying Prout's brown, with the erect, spreading margin deeply lacerate-in some cases to the stem and rarely splitting the stem on one side nearly to the ground; stem short, perforate, hollow, even, glabrous, Prout's brown; hymenium drying chamois to Naples yellow, even or reticulately plicate and with the larger pores subdivided into smaller, shallow pits more completely covering the under surface of the pileus but present also, although less well-developed, in patches on the upper side; no gloeocystidia; basidia simple, with 6 , or perhaps more, sterigmata; spores colored, even, 8-9 $\times$ $41 / 2-6 \mu$.

Fructifications up to $6 \mathrm{~cm}$. high; pileus $3-4 \mathrm{~cm}$. broad; stem 2 $\mathrm{cm}$. long, $3 \mathrm{~mm}$. thick.

On the ground in a dense forest. Oregon. March.

I have included this species in Craterellus because of the similarity of the subhymenial hyphae to the longitudinally arranged hyphae of the pileus and my inability to detect any evidence of an underlying hymenium. The aspect of the fungus is that of Craterellus cornucopioides. It is my opinion that this species will eventually be demonstrated to be a Merulius parasitic or saprophytic on the pilei of Craterellus cornucopioides. I know no Merulius to which this species is referable. 
Specimens examined:

Oregon: Corvallis, S. M. Zeller, 2093, type (in Mo. Bot. Gard. Herb., 58770).

\section{CYPHELLA}

Cyphella alboviolascens (Alb. \& Schw.) Karsten, Finska Vet.Soc. Bidrag Natur och Folk 37: 133. 1882; 48: 400. 1889; Sacc. Syll. Fung. 6: 669 . 1888; Bourdot \& Galzin, Soc. Myc. Fr. Bul. 26: 225. 1910; Rea, Brit. Basid., 698. 1922; Pilat, Ann. Myc. 22: 211. 1924; Monogr. Cyphellacearum Czechoslov. 2: 45. pl. 1, f. 2. 1925.

Pcziza alboviolascens Albertini \& Schweinitz, Consp. Fung. 322. pl. 8, f. 4. 1805. - Cyphella Curreyi Berk. \& Broome, Not. Brit. Fungi, 935, Ann. \& Mag. Nat. Hist. III. 7: 379. 1861.

Fructifications gregarious or scattered, somewhat spherical at first, becoming flattened at the pore and somewhat hemispherical, white, densely villose, sessile or subsessile, soft throughout and easily sectioned, the margin inrolled; hairs white, rough, $6 \mu$ in diameter, up to $120 \mu$ long; hymenium concave, often violaceous; spores hyaline, even, flattened on one side, the convex side nearly subangular, $9-12 \times 6-9 \mu$.

Fructifications up to $1 \mathrm{~mm}$. broad in American gatherings, up to $1 / 2 \mathrm{~mm}$. high.

On dead twigs of Syringa vulgaris and Sambucus. Europe and Maine. July to October.

C. alboviolascens differs from C. Tiliae by softer fructifications, shorter, nearly 3 -angled spores, and shorter hairs. C. villosa is closely related.

Specimens examined:

Exsiccati: Sydow, Myc. Germ., 353.

Germany: Brandenburg, P. Vogel, in Sydow, Myc. Germ., 353.

Czecho-Slovakia: A. Pilat.

Maine: Kittery Point, R. Thaxter (in Mo. Bot. Gard. Herb., 58742, and Burt Herb.), comm. by W. G. Farlow (in Mo. Bot. Gard. Herb., 55573).

C. fasciculata (Schw.) Berk. \& Curtis

Collections made on Alnus oregana extend the range of $C$. fas- 
ciculata to Oregon. 'These specimens have the spores up to 8-10 $\times 5-6 \mu$-twice the diameter of the spores of specimens of eastern United States-and somewhat larger basidia, but their other characters are so similar to those of eastern specimens that it now seems best to refer them to C. fasciculata.

These specimens are:

Oregon: Corvallis, F. D. Bailey (in Mo. Bot. Gard. Herb., 44144, 44199).

C. galeata (Schum.) Fr.

To my description of this species in Mo. Bot. Gard. Ann. 1: 362. 1915, it should be added that the spores are tawny, rough to verrucose, $7-9 \times 6-8 \mu$, or subglobose, $8-10 \mu$ in diameter, according to Bourdot \& Galzin, Soc. Myc. Fr. Bul. 26: 227. 1910, and Rea, Brit. Basid., 704. 1922.

C. marginata McAlpine, Fung. Dis. Stone-fruit Trees in Australia, 120. f. 229-232. 1902; Sacc. Syll. Fung. 17: 192. 1905; Zeller, Mycologia 14: 179. 1922.

Fructifications gregarious, fleshy-gelatinous, sessile, globose, somewhat ochraceous, drying drab and hoary, the pore distinct when full grown but nearly closed by the inrolled margin; hairs curved, honey-yellow, even, up to $120 \times 4 \mu$; basidia simple, 40-45 × 6-8 $\mu$, with 4 sterigmata; spores hyaline, even, 10-12 $\times 6-7 \mu$.

Fructifications usually $1 / 2 \mathrm{~mm}$. in diameter, reported up to 1 $\mathrm{mm}$. in diameter.

On small "die back" twigs of peach, almond, and apple. Australia and Oregon. July.

The small, grayish drab fructifications were very numerous on the small twigs received. Up to 30 were counted on an area $1 \mathrm{~mm}$ square.

Specimens examined:

Oregon: Corvallis, S. M. Zeller, 1830, 1831 (in Mo. Bot. Gard. Herb., 56334, 56335).

C. muscicola Fries, Syst. Myc. 2: 202. 1823; Hym. Eur. 663. 1874; Patouillard, Tab. Anal. Fung. 19. f. 31. 1883; Sacc. Syll. Fung. 6: 682. 1888. 
Phaeocyphella muscicola (Fr.) Rea, Brit. Basid., 704. 1922; Pilat, Monogr. Cyphellacearum Czechoslov. 2: 67. text f. 16. 1925.

Fructifications gregarious, sessile or subsessile, cup-shaped, thin, membranaceous, the margin slightly downy, at length somewhat flaring; hymenium concave, even, snuff-brown with the copious spores; spores colored, even, spherical, $6-61 / 2 \mu$ in diameter, so copious that they conceal the basidia.

Fructifications up to $1 \mathrm{~mm}$. in diameter in American specimens, equalling the diameter in height.

On mosses. West Indies. November.

I have seen no European specimens of this species but the single gathering from Grenada agrees well with the concept of the species as more definitely described by the recent European mycologists. The occurrence on mosses, ashy white, open cups which become slightly flaring at the margin, and brown hymenium and spores are distinctive characters.

Specimens examined:

Grenada: $R$. Thaxter, comm. by W. G. Farlow, 5 .

C. patens A. L. Smith, Linn. Soc. Bot. Jour. $35: 10 . p l .1, f .6-8$. 1891; Sacc. Syll. Fung. 17: 192. 1905.

Type: in Brit. Mus. Herb. presumably.

"Sparsa, tubaeformis, dein elongata, fere ad basim fissa et expansa, margine superiore incurvata, circa $5 \mathrm{~mm}$. longa, $2 \mathrm{~mm}$. lata, extus flava tomentosa; hymenio brunneo, lamellis paucis angustis lamelliformis instructis; sporis globosis, minute asperulis, $5 \mu$ diam., hyalinis.

"On bark of tree, Morne Niger Maron [Dominica]. Sept. 1892. No. 323.

"This species seems to form a transition between the forms with a rugulose hymenium such as C. Malbranchei, Pat., and genera with regular gills such as Lentinus; the incurving margin and the shape of the immature specimens have decided the placing it in Cyphella."

C. sessilis Burt, n. sp.

Type: in Mo. Bot. Gard. Herb. 
Fructifications gregarious, sessile, closely adnate, white, very thin, membranaceous-fleshy, applanate, even, ceraceous, the margin slightly elevated, narrow, white, fibrillose; in section $60 \mu$ thick, not colored, with the hyphae ascending, thin-walled, $2-3 \mu$ in diameter; no gloeocystidia; basidia simple, $12 \times 41 / 2 \mu$, with 4 sterigmata; spores becoming pale-colored, even, $6-7 \times 3 \frac{1}{2}$ $4 \mu$.

Fructifications $200-400 \mu$ in diameter.

On fallen palm leaves. Bermuda. January.

The small, circular fructifications are rather near together and numerous, 17 having been counted on an area $1 \mathrm{~cm}$. square. They are adnate by the whole under surface, with the hymenium flat and bordered by the narrow, white, fibrillose margin. Most of the spores are hyaline; some, however, are somewhat colored. The aspect is that of a minute Discomycete.

Specimens examined:

Bermuda: H. H. Whetzel, Ajj, type, comm. by R. Thaxter (in Mo. Bot. Gard. Herb., 58708), and duplicate from H. H. Whetzel.

C. tela (B. \& C.) Massee, Jour. Myc. 6: 179. pl. 7, f. 12, 13. 1891.

Peziza tela Berk. \& Curtis, Grevillea 3: 156 . 1875.-Tapesia tela (B. \& C.) Sace. Syll. Fung. 8: 373. 1889.-An Peziza Daedalea Schw.?

Type: in Farlow Herb. and Kew Herb., under the name Peziza tela.

"Gregarious on a dense white subiculum; cups minute, 150$180 \mu$ diameter, subglobose; mouth at first small, becoming expanded, but the acute margin always remains more or less incurved; externally blackish brown, frosted with glistening crystals of oxalate of lime; hymenium concave, even, naked, blackish brown; basidia clavate, tetrasperous; spores subglobose or broadly pyriform, smooth, pale brown, 7 by 5 .

"On wood. Lower Carolina. (Type in Herb. Berk., Kew, No. 7724).

"The present species, owing to its dark color and gregarious habit, also being furnished with a dense, white, broadly effused, 
superficial mycelium, suggests the genus Peziza when examined under a low power, but is a true Cyphella."

I have examined superficially the type of Peziza tela B. \& C. in Farlow Herb. and the aspect is so similar to that of Solenia poriaeformis that Massee's statement about the spores of $P$. tela being colored should be confirmed. I was unable to make such examination of the spores. The type of Peziza Daedalea Schw. has the same aspect as $P$. tela.

\section{Thaxteri Burt, n. sp. \\ Type: in Burt Herb.}

Fructifications very small, gregarious, stipitate, cup-shaped with the mouth open, drying between avellaneous and light pinkish cinnamon, merely farinose under a lens but really hairy when highly magnified, the margin inrolled when dry; hairs Isabella color, even, flexuous, $25-30 \times 4-41 / 2 \mu$; hymenium Isabella color; basidia simple, $16 \times 4-6 \mu$; spores ochraceous, even, $7-8 \times 5 \mu$; stem central, cylindric, with surface like the pileus.

Fructifications about $1 / 4 \mathrm{~mm}$. in diameter; stem about $140 \mu$ long, 60-80 $\mu$ thick.

On bark. West Indies. November.

About 30 of the small, goblet-shaped fructifications are present on an area about $1 / 2 \mathrm{~cm}$. long, $1 / 4 \mathrm{~cm}$. wide. The farinose surface of the exterior of the cups and stem is probably due to granular matter on the hairs, but no trace of such matter is found when the hairs are examined in permanent glycerine mounts by the compound microscope.

Specimens examined:

Grenada: Grand Etang, R. Thaxter, type, comm. by W. G. Farlow.

\section{HYPOCHNUS}

Hypochnus albus Burt, n. sp.

Type: in Mo. Bot. Gard. Herb.

Fructifications effused, small, circular, closely adnate, very thin, snow-white, even, velutinous under a lens with the large cystidia, not shining, the margin similar; in section 30-60 $\mu$ thick, not colored, composed of loosely interwoven, hyaline hyphae $11 / 2-2 \mu$ in diameter, not nodose-septate, incrusted in the sub- 
hymenium; no gloeocystidia; cystidia somewhat incrusted, 75$120 \times 9-15 \mu$, of greatest diameter at the base, usually seated on the incrusted zone, more rarely on the substratum; paraphyses delicate, branching in antler-shaped form; spores hyaline, globose, $71 / 2 \mu$ in diameter, even at first, finally minutely echinulate, borne 4 to a basidium.

Fructifications 1-4 mm. in diameter, 3 present on an area $12 \times 15 \mathrm{~mm}$.

On bark of a frondose species among mosses and lichens in a moist, virgin forest. Mexico. January.

The small, white fructifications, conspicuous cystidia, antlershaped paraphyses, and echinulate spores form a unique group of characters distinguishing $H$. albus. But for the echinulate spores this species could have been placed in Peniophora next to P. phyllophila.

Specimens examined:

Mexico: Orizaba, Nuevo, W. A. \& E. L. Murrill, $749 a$, type, comm. by N. Y. Bot. Gard. Herb. (in Mo. Bot. Gard. Herb., $54654)$.

H. epiphyllus (Schw.) Burt, n. comb.

Hydnum epiphyllum Schweinitz, Am. Phil. Soc. Trans. N. S. 4: 163. 1832.-Hypochnus granulosus (Peck) Burt, Mo. Bot. Gard. Ann. 3:218. textf. 9. 1916, where additional synonymy is given.

Type: in Farlow Herb. from Schweinitz Herb. and probably in Schweinitz Herb. and at Kew, under the name Hydnum epiphyllum.

In Curtis Herb. of Farlow Herb. there are specimens of this species under the name Hydnum epiphyllum, collected in Alabama, Peters, 1124, and also under the herbarium name, Odontia grandinia, collector Peters, 1116.

H. filamentosus Burt, n. sp.

Type: in Mo. Bot. Gard. Herb.

Fructifications effused, small, closely adnate, very thin, hypochnoid-arachnoid, Mars-brown but this color completely soluble in dilute potassium hydrate solution; hymenium not continuous and showing many ends of fibrils under a lens, the margin thinning out; 
in section up to $90 \mu$ thick in some places but with much thinner connecting portions and mycelial strands in the same section, colored but wholly bleached by action of potassium hydrate solution, the hyphae incrusted, $4-5 \mu$ in diameter, often together in rope-like strands up to $18 \mu$ in diameter with crystalline matter on the outer surface of the strands; basidia $15 \times 5 \mu$, with 4 sterigmata, protruding from the covering matter of the strands, few observed; spores attached to the basidia are hyaline (after treatment of the sections with potassium hydrate solution), subglobose, rough, $3 \mu$ in diameter; no cystidia.

Fructifications 1-4 mm. in diameter, somewhat confluent for a length of $2 \mathrm{~cm}$.

On small fragments of blackened, decaying wood of a frondose species-apparently on the under side next to the ground. Cuba. March.

The specimen upon which the description is based is scantily developed; collections with normal continuous hymenium will probably eventually be made. The distinguishing characters seem to be Mars-brown color, complete bleaching by potassium hydrate solution, numerous rope-like strands, hyphae thinwalled, incrusted, collapsing, and small subglobose spores.

Specimens examined:

Cuba: locality not stated, C. G. Lloyd, 424, type (in Mo. Bot. Gard. Herb., 55174).

\section{H. fumosus Fr.}

To the synonymy of this species in Mo. Bot. Gard. Ann. 3:239. 1916, should be added Odontia tenuis Peck, N. Y. State Mus. Rept. 44: 134. 1891. Study of the type in N. Y. State Mus. Herb. shows the outer surface overrun with the intricate, branching, anastomosing, mycelial threads, and the spores white, minutely echinulate, $4-4 \frac{1}{2} \times 2 \frac{1}{2} \mu$-both characteristic of $H$. fumosus.

H. pallidofulvus (Peck) Burt, n. comb.

Zygodesmus pallidofulvus Peck, N. Y. State Mus. Bul. 105: 30. 1906; Sacc. Syll. Fung. 22: 1358. 1913.-Hypochnus subferrugineus Burt, Mo. Bot. Gard. Ann. 3:210. 1916. 
Study of the type of Zygodesmus pallidofulous in N. Y. State Mus. Herb. shows the species to be an Hypochnus specifically the same as $H$. subferrugineus, which therefore becomes a synonym.

H. Rhacodium Berk. \& Curtis in herb. under Stereum, n. sp.

'Type: in Mo. Bot. Gard. Herb., Farlow Herb., and Kew Herb.

Fructifications effused, very thick, crust-like and brittle when dry and fuscous or dusky drab externally and throughout, colliculose, not cracked, the margin unknown; in section $11 / 2^{-3} \mathrm{~mm}$. thick, fuscous, composed (1) of a layer $1 / 2-2 \mathrm{~mm}$. thick next to the substratum, fibrous and tow-like, composed of loosely interwoven, thick-walled, rigid hyphae up to $6 \mu$ in diameter, not incrusted, rarely nodose-septate, and (2) of a crust-like hymenial portion, composed of 1 or 2 layers with hyphae erect, densely crowded, colored, $4-5 \mu$ in diameter, not incrusted, not nodose-septate, bearing basidia; no gloeocystidia nor cystidia; basidia with at least 2 sterigmata demonstrated; spores concolorous with the hyphac, aculeate-tuberculate, somewhat angular, the body 6-7 $\mu$ in diameter.

Fructifications probably large-known from fragments up to $2 \mathrm{~cm}$. long, $1 / 2 \mathrm{~cm}$. wide.

On under side of decaying logs of apparently a frondose species. Pennsylvania.

H. Rhacodium has the aspect of a thick, dark fuscous, effused Hypoxylon. The hyphae of the under layer are brittle when dry so that the hymenial crust is very likely to split away from the substratum through this brittle layer. The specimens in Kew and Farlow Herbaria, communicated by Michener through Curtis, consist of the hymenial crust. Michener's own specimen, now in the Mo. Bot. Gard. Herb., has the whole fructification to the woody substratum. This species is related to $H$. umbrinus.

Specimens examined:

Pennsylvania: E. Michener, type, No. 1435 to M. A. Curtis (in Mo. Bot. Gard. Herb., 5095, in Farlow Herb., and Kew Herb. as Curtis Herb., 4061, under the herbarium name Stereum Rhacodium). 
H. subviolaceus Peck, N. Y. State Mus. Rept. 47: 151. 1894; Sacc. Syll. Fung. 11: 130. 1895.

Type: in N. Y. State Mus. Herb. and Mo. Bot. Gard. Herb.

Fructifications effused, closely adnate, very thin, violet-gray at first, becoming drab in the herbarium, even, velutinous, the margin whitish at first, fibrillose; in section $90 \mu$ thick, colored, composed of suberect and interwoven, densely arranged, thinwalled hyphae $2 \mu$ in diameter, some hyaline and many colored and bushy-branched; spores nearly hyaline, globose, rough or minutely aculeate, $4-41 / 2 \mu$ in diameter.

Fructification $2 \frac{1}{2} \mathrm{~cm}$. long, $11 / 2 \mathrm{~cm}$. wide, broken off at both ends and on one side.

On badly decayed coniferous wood. Canada. September.

The aspect of $H$. subviolaceus is not hypochnoid but rather that of a very thin Coniophora. The occurrence on decorticated coniferous wood, drab color, system of bushy-branched, colored tissue in addition to, and somewhat masking, the usual hyphae, and the small nearly hyaline spores should aid in recognition of this species.

Specimens examined:

Canada: J. Macoun, type (in N. Y. State Mus. Herb.), and comm. by N. Y. State Mus. Herb., T 34 (in Mo. Bot. Gard. Herb.).

H. umbrinus (Fr.) Quelet, Fl. Myc. 2. 1888.

The above combination has priority over that in Mo. Bot. Gard. Ann. 3: 213. 1916, according to Wakefield, Brit. Myc. Soc. Trans. 6: 132. 1919. I have not access to a copy of the Quelet.

Upon reexamination of the sections in my preparation from the type of Thelephora arachnoidea Berk. \& Br., I think that this is a Septobasidium as stated by Bresadola, Ann. Myc. 14:241. This species should therefore be struck out in my work where given as a synonym of $H$. umbrinus.

Caldesiella viridis (Alb. \& Schw.) Pat. Essai Taxon. 120. 1900; Rea, Brit. Basid. 651. 1922; Bourdot \& Galzin, Soc. Myc. Fr. Bul. 40: 128. 1924.-Odontia viridis (Alb. \& Schw.) Quelet, Fl. Myc. 434. 1888; Bresadola, I. R. Accad. Agiati Atti III. 3: 97. 
1S97.-Hydnum viride (Alb. \& Schw.) Fries, Syst. Myc. 1: 421. 1821 ; Hym. Eur. 614, 1874.

This species has hypochnoid texture, color deep grape-green at first, fading to Vetiver green in the herbarium, and minutely echinulate spores slightly colored, about $31 / 2^{-5} \times 3-31 / 2 \mu$. I have seen American collections from Vermont, Missouri, and British Columbia. 'The fructifications are sometimes so even that they might be referred to Hypochnus.

\section{PENIOPHORA}

Peniophora populnea (Peck) Burt, n. comb.

Stereum populneum Peck, N. Y. State Mus. Rept. 47: 145. 1894.

Type: in N. Y. State Mus. Herb. and Burt Herb.

Fructifications effused, often confluent, adnate, rather thin, small pieces separable when moist, brown tinged with liver color when fresh, becoming between Natal brown and Mars brown in the herbarium, not shining, somewhat colliculose, contracting in drying and cracking into angular masses $1 / 2-11 / 2 \mathrm{~mm}$. in diameter, the margin thin, radiate-dentate, pale, drying slightly free in some places; in section 250-300 $\mu$ thick, colored, 2-layered, with a broad layer next to the substratum composed of longitudinally arranged, crowded and densely interwoven, nearly hyaline hyphae $2 \frac{1}{2}-3 \mu$ in diameter, and with an equal, colored hymenial layer composed of erect, densely crowded and interwoven, brownish hyphae and brownish paraphyses and cystidia; no gloeocystidia; cystidia heavily incrusted, very large, up to 60-100 $\times 20-25 \mu$, at the surface of the hymenium but not protruding; paraphyses hair-like, colored, slender, $1-1 \frac{1}{2} \mu$ in diameter, branching at or near the tips into 2 or 3 short branches; basidia cylindric, 70$90 \times 3-4 \mu$, probably simple and with 4 very short sterigmata; spores hyaline, even, $12-15 \times 4 \mu$.

Fructifications $3 \frac{1}{2} \mathrm{~cm}$. long, $3 \mathrm{~cm}$. wide.

On bark of decaying Populus tremuloides. New York. August.

$P$. populneum should be recognized by its occurrence on poplar logs, liver color externally and colored substance, cracked hymenium, very large cystidia, and long and slender basidia. The 
layer of hyphae longitudinally arranged along the substratum and the very long and slender basidia have made me question whether this species is not an Auricularia but $\mathrm{I}$ have been unable to demonstrate transverse septation in any of the basidia.

Specimens examined:

New York: Ray Brook, Essex County, C. H. Peck, type (in N. Y. State Mus. Herb., under the name Stereum populneum, and in Burt Herb.).

\section{STEREUM}

Stereum aculeatum (B. \& C.) Burt, n. comb.

Thelephora aculeata Berk. \& Curtis, Grevillea 1: 149.1873 ; Sacc. Syll. Fung. 6: 523. 1888; Burt, Mo. Bot. Gard. Ann. 7 : 232. 1920.

I now refer to $S$. aculeatum a small specimen received since the publication of the part on Stereum. This specimen has the component fructifications central-stemmed, laterally confluent, and resembling in aspect $S$. pallidum, but differing from the latter by the presence of gloeocystidia and the absence of cystidia; the spores are hyaline, even, $5 \times 3 \frac{1}{2}-4 \mu$.

Fructifications $4 \mathrm{~cm}$. high, $21 / 2 \mathrm{~cm}$. wide.

On the ground. South Carolina and Missouri. June and August.

Specimens examined:

South Carolina: Santee Swamp, H.W. Ravenel, \%64, type (Curtis Herb., 2009, in Kew Herb., and Farlow Herb.); Clemson College, P. H. Rolfs, 1835 .

Missouri: locality not stated, Dr. Emig, comm. by J. R. Weir, 18820 (in Mo. Bot. Gard. Herb., 58744, and Burt Herb.).

S. atrorubrum Ell. \& Ev. Acad. Nat. Sci. Philadelphia Proc. 1890 : 219. 1890; Sacc. Syll. Fung. 9: 225. 1891.

Type: in N. Y. Bot. Gard. Herb., and a fragment in Burt Herb.

"Fan-shaped or reniform, 1-3 cm. broad and long, coriaceous, thin, narrowed behind into a sessile base, hollow at first (about the same color as $S$. complicatum) and tomentose-pubescent with a few narrow faint zones, but when mature of a dull dark red (about the color of the pileus of Pol. lucidus) with the surface 
glabrous and densely radiate-rugose, margin lobed and crisped and in some specimens proliferous, young hymenium yellow, becoming when old brick color when moist, paler when dry. In the mature state the 3-5 concentric zones are more distinct and slightly elevated. 'The specimens roll up in drying and become hard and brittle."

We have but very few strictly sessile or reniform species of Stereum, although sessile specimens of common effuso-reflexed species were deseribed as distinct species; more collections of $S$. atrorubrum are needed to clear up this important eharacter in this case. The upper surface of the fragment seen by me is now dusky brown to bone-brown, glabrous, shining, strongly radiately rugose and shallowly concentrically suleate; hymenium even, glabrous, avellaneous; in structure about $800 \mu$ thick, composed of (1) an intermediate layer of longitudinal, densely arranged, thick-walled, rigid hyphae $3-31 / 2 \mu$ in diameter, (2) bordered on the upper side by an opaque, brown layer $60 \mu$ thick which gives the color to the pileus, and (3) eurving on the lower side into a hymenial layer $300 \mu$ thick; no cystidia, gloeocystidia, nor conspicuous conducting organs; spores up to $7 \times 2-21 / 2 \mu$ present but may not belong for only 2 seen.

The date of the collection-May-and appearance of the hymenium suggest a specimen of the preceding season which has held over through the winter and may have had somewhat different characters when growing. The very dark-colored, strongly radiating rugose upper side of the pileus is noteworthy.

Specimens examined:

British Columbia: on old logs, $J$. Macoun, 86 , type, a fragment examined.

S. radicans (Berk.) Burt, Mo. Bot. Gard. Ann. 7: 108. pl. 3, f. 16. 1920 .

In a collection of this species from Porto Rico, in Mo. Bot. Gard. Herb., 7585, the spores have become slightly colored, showing that this species belongs in Thelephora. The species is really an intermediate between Stereum and Thelephora, having the dense, intermediate layer of Stereum and also vesicular gloeocystidia in the hymenial layer. The spores are still hyaline in 3 of the 4 gatherings which I have studied. 
S. Underwoodii Burt, n. sp.

An Stereum induratum Berkeley, Linn. Soc. Bot. Jour. 16: 44. 1877 ?

Type: in Burt Herb.

Fructifications corky, not hard nor indurated, adnate, resupinate and effused, sometimes narrowly reflexed, the reflexed surface drab in the herbarium where young, nearly black where oldest, somewhat concentrically sulcate, fibrillose, not shining, the margin entire; hymenium warm buff to honey-yellow in the herbarium, even, velutinous; in section $1 / 2-2 \mathrm{~mm}$. thick, colored warm buff to tawny olive throughout, stratose, composed of densely interwoven, colored, rigid hyphae $1 \frac{1}{2}-2 \frac{1}{2} \mu$ in diameter, highly branched and with many branches of more or less antlershaped form; no cystidia, gloeocystidia, conducting organs nor imbedded spores; spores hyaline, even, $10 \times 5 \mu$ but may not belong, only 1 seen.

Fructifications effused over areas $6 \mathrm{~mm} .-5 \mathrm{~cm}$. long, $6 \mathrm{~mm} .-2$ $\mathrm{cm}$. wide, the reflexed margin $2-3 \mathrm{~mm}$. broad.

On bark of Xolisima. West Indies and Brazil. September and April.

This species has the antler-shaped branching of hyphae characteristic of Hypochnus pallescens, H. peniophoroides, Asterostromella dura, and Stereum duriusculum. The narrowly reflexed margin is well shown by the specimens from Jamaica and is important for location of S. Underwoodii in Stereum. The Brazilian specimen was received from Bresadola under the name Stereum induratum Berk.- - a species known only from a single collection made by the Challenger Expedition in the East Indies and described as pileate, conchiform, 3 inches across, and very hard. S. Underwoodii is soft, not at all hard, and does not turn the edge of the razor in sectioning. I have not yet been able to study the type of S. induratum.

Specimens examined:

Jamaica: base of John Crow Peak, L. M. Underwood, 2432, type, comm. by N. Y. Bot. Gard. Herb.; Cinchona, L. M. Underwood, 3128, comm. by N. Y. Bot. Gard. Herb.

Brazil: Blumenau, Dr. Möller, comm. by Bresadola under the name of Stereum induratum. 


\section{THELEPHORA}

Thelephora lutosa Schw. Sce Burt, Mo. Bot. Gard. Ann. 1: 216.1914.

This rare species has been known only from the type collection from Salem, North Carolina. 'There is now an additional gathering by Dr. W. A. Murrill, 404, from Mountain Lake, Virginia, July 8-14, of which a specimen is in the Mo. Bot. Gard. Herb. The specimen grew in clay ground in mixed woods; a fragment of buried rotten wood is attached to the short, radicated base. This specimen does not necessitate any change in the description. In the dried fructification the soft, fine pubescence of the upper side, and cream color externally and within are distinctive characters. The older portion of the hymenium has assumed a light drab color with the spores, which are slightly colored, angular, $4-6 \times 4-41 / 2 \mu$.

\section{TULASNELLA}

Tulasnella calospora (Boud.) Juel, K. Svenska Vet.-Akad. Bihang till Handl. Afd. III. 23 ${ }^{12}$ : $23 . \quad$ 1897; Bresadola, Ann. Myc. 1: 114.1903.

Prototremella calospora Boudier, Jour. de Bot. 10: 85. text $f$. 1-4. 1896. - An Tulasnella rosella Bourdot \& Galzin, Soc. Myc. Fr. Bul. 39: 263. 1924?

Fructifications effused, very thin, waxy, whitish in the herbarium, somewhat perforate, the margin thinning out; in section 100-150 $\mu$ thick, with the hyphae about $3 \mu$ in diameter, thinwalled; spores hyaline, even, fusiform, flexuous, $20-27 \times 3-31 / 2 \mu$, often with a lateral branch.

Covering as a cluster of small fructifications the terminal portions of dead mosses on an area $2 \mathrm{~cm}$. long, about $1 \mathrm{~cm}$. wide.

On wood in Europe, on dead mosses in Maine.

$T$. calospora has fructifications rather more membranaceous than those of our other species, and longer spores, which are noteworthy by having frequently a branch stand out at right angles from the body of the spore. I figured such a branched spore in Mo. Bot. Gard. Ann. 6: 258. text f. 3. 1919.

Specimens examined:

Maine: Kittery Point, R. Thaxter (in Mo. Bot. Gard. Herb., 57477). 


\section{VELUTICEPS}

Veluticeps fusca Humphrey \& Long, n. sp.

Type: in Humphrey Herb. and Mo. Bot. Gard. Herb.

Fructifications coriaceous-corky, resupinate, effuso-reflexed, or conchiform, laterally confluent, with the reflexed part somewhat concentrically sulcate, tomentose, at first nearly auburn or tawny, finally becoming dusky drab and weathering hoary, the margin clay-colored when young, entire, becoming somewhat crisped; hymenium plane, avellaneous, velutinous, thickly studded with protruding fascicles of colored hyphae which have the appearance of teeth of a Hydnum when little magnified; in section 1-3 mm. thick, wood-brown, composed of densely arranged, suberect and interwoven, rigid, colored hyphae $3-41 / 2 \mu$ in diameter, not incrusted, not nodose-septate; hyphal fascicles 12$25 \mu$ in diameter, protruding through and beyond the hymenium up to 90-150 $\mu$ and composed of flexuous, parallel, colored hyphae $31 / 2^{-7} \mu$ in diameter; basidia simple, with 4 slender, conspicuous sterigmata up to $6 \mu$ long; spores white, even, usually unequilateral, $9-10 \times 31 / 2^{-4} \mu$.

Confluent over areas up to $12 \mathrm{~cm}$. long and $2-3 \mathrm{~cm}$. wide, the reflexed margin 6-12 $\mathrm{mm}$. broad.

On decorticated, decaying logs of Pinus ponderosa. Washington, Arizona, and New Mexico. October.

It is probable that $V$. fusca occurs more frequently than its few, widely separated, recorded stations indicate, for gatherings are likely to be referred by collectors to Hydnum on account of the superficial resemblance of the hymenial fascicles to teeth of Hydnum. The fructifications are large and conspicuous, somewhat resembling in aspect those of Stereum sulcatum but quite distinct by the hymenial fascicles.

Specimens examined:

Washington: Spokane, J. R. Weir, 611 (in Mo. Bot. Gard. Herb., 36749).

Arizona: Fort Valley Experiment Station, near Flagstaff, $W . H$. Long, 19688, type (in Mo. Bot. Gard. Herb., 20084).

New Mexico: Gila National Forest, near Pinos Altos, G. G. Hedgcock \& W. H. Long, 9851, comm. by C. J. Humphrey, 2572 (in Mo. Bot. Gard. Herb., 11200). 


\section{Auriculariaceae}

\section{SEPTOBASIDIUM}

Septobasidium mexicanum Sydow, Ann. Myc. 18: 154. 1920; Sacc. Syll. Fung. 23:567. 1925.

"Omnino resupinatum, matrici arete adhaerens, tenuissimum, centro circiter $1 / 2-3 / 4 \mathrm{~mm}$. crassum, ca. 1-3 cm. longum, $1-2 \mathrm{~cm}$. latum, ferrugineum, centro dein cinereo-ferrugineum, ad anbitum anguste sed distincte albido-cinereo fimbriatum, leve, haud rimosum; contextus ex hyphis flavo-brunneis crasse tunicatis $3-4$ i crassis sparse ramosis remote septatis compositus; basidia non visa.

"Hab. ad ramos vivos Cupressi spec., Mexico, 1918, leg. Reiche no. $46 . "$

S. pedicellatum Patouillard, Jour. de Bot. 6: 61. text f. 1892; Burt, Mo. Bot. Gard. Ann. 3: 323. 1916.

Type: in Museum of Paris.

Since my account of this species I have studied specimens of both the Cuban collections distributed by C. Wright under the name Thelephora pedicellata and find that the collection, $C$. Wright, 798, distributed in Wright, 'Fungi Cubenses Wrightiani' is in condition to afford the structural details figured by Patouillard and therefore must be the type distribution of his species.

The general description of this species, which could not be given before, is:

Fructifications resupinate, dry, avellaneous, pulverulent, occurring in small, interrupted patches, each about $2-3 \mathrm{~mm}$. in diameter; in structure $500-600 \mu$ thick, colored, stratose, composed of 2 strata, each consisting of a hymenial crust supported on pillars or pedicels about $15 \mu$ in diameter, with their component hyphae about $3 \mu$ in diameter; probasidia borne at the surface of the hymenial layer.

On living bushes among, and on, mosses and lichens. Cuba.

S. pinicola Snell, Mycologia 14: 58. pl. 11-13. 1922; Overholts, Mycologia 16: 233. 1924.

Type: in Snell Herb., Mo. Bot. Gard. Herb., and Forest Path. Herb. 
"Fructification resupinate, effused, coriaceous, in general circular in shape, more or less concentrically sulcate, separable from substratum, roughly tomentose to strigose, army-brown to Natal-brown when dry, the margin light drab to cinnamon-drab, strigose; in structure lacunar, spongy, 1-1.8 mm. thick, individual hyphae under the microscope clay-color to tawny olive, thickwalled, even, 3-3.5 $\mu$ in diameter, loosely interwoven so as to form a spongy structure with locules, branching to form a lighter colored hymenium about $80-110 \mu$ thick; probasidia terminal or lateral, hyaline, pyriform to subglobose, $10-15 \times 15-17 \mu$, throughout hymenium; spore-bearing organs straight, hyaline, 54-66 × 6-7 $\mu, 3$-septate, growing from probasidia and projecting above hymenium; spores hyaline, simple, curved, 14-17.5 $\times 3-3.5 \mu$, borne singly from each of 3 cells of spore-bearing organ, acropetally as far as observed.

"Fructification 3-60 mm. but more commonly 10-35 $\mathrm{mm}$. in diameter, 1-1.8 mm. thick."

On bark of living Pinus Strobus in New England, New York, and Pennsylvania, and probably co-extensive with the habitat of this host; also on Pinus monticola in Idaho. Found sporulating after prolonged moist and rainy period in August.

S. Spongia (Berk. \& Curtis) Patouillard, Soc. Myc. Fr. Bul. 16: 181. 1900; Burt, Mo. Bot. Gard. Ann. 3: 339. text f. 11. 1916.

From several collections of this species made by Dr. J. A. Stevenson in Porto Rico and San Domingo, additional characters have been secured for completion of the description.

Fructifications on leaves and stems of Citrus decumana and $C$. sinensis dry, warm sepia to Benzo-brown; probasidia at the hymenial surface of a few filaments are hyaline, globose, $9 \mu$ in diameter; spore-bearing organs straight, cylindric-clavate; spores simple, hyaline, curved, 9-10 $\times 3-4 \mu$, observed on the outer cells of the organs.

Sterile fructifications have been received from Dr. A. T. Speare, collected on Citrus, at Okeechobee, Florida. 


\section{Exotic Species}

S. album Burt, n. sp.

Type: in Mo. Bot. Gard. Herb.

Fructifications resupinate, effused, adnate, thick, fleshy, white, somewhat colliculose, pulverulent, contracting in drying and forming a few large fissures at $2-3 \mathrm{~mm}$. apart, the margin somewhat tomentose; in structure $600-700 \mu$ thick, not colored, composed of densely interwoven and ascending, even-walled, hyaline hyphae $3-4 \mu$ in diameter, occasionally nodose-septate, not incrusted; no probasidia seen; spore-bearing organs straight, 3septate, $75 \times 6 \mu$, confined to the outer $150 \mu$ of the hymenium, only rarely reaching the surface and protruding; spores simple hyaline, even, $10-12-15 \times 7-9 \mu$, borne singly on the outer 3 cells of the spore-bearing organs so far as observed; surface of the hymenium composed of slender, hyaline, matted and coiled paraphyses or hyphal branches $2 \mu$ in diameter.

Fructifications 1-3 cm. long, $1-11 / 2 \mathrm{~cm}$. wide.

On bark of dead, fallen branches of Nothofagus. New Zealand. December.

S. album somewhat resembles Corticium portentosum and is exceptional, if there is no error in the collector's data, by its occurrence on dead, fallen branches. The hymenial surface of coiled paraphyses, absence of probasidia, and hyphae extending from all parts of the substratum into the fructification without consolidation into supporting pillars are additional characters for recognition of the species.

Specimens examined:

New Zealand: Queenstown, Otago, G. H. Cunningham, 542, type, comm. by J. R. Weir (in Mo. Bot. Gard. Herb., 59315).

S. cinnamomeum Burt, n. sp.

Type: in Farlow Herb. and Mo. Bot. Gard. Herb.

Fructifications resupinate, effused, dry, hypochnoid, small pieces separable when moist, Brussels brown, somewhat colliculose, somewhat velutinous, the margin concolorous, with surface irregular, somewhat raduloid; in section $210 \mu$ thick, colored, stratose, consisting of 2 strata, each composed of suberect, loosely interwoven, rigid hyphae $3 \mu$ in diameter, colored 
like the hymenium, not incrusted, not nodose-septate; probasidia spherical, $6 \mu$ in diameter; spore-bearing organs numerous, cylindric, $30 \times 6 \mu$; spores simple, hyaline, curved, $13 \times 31 / 2 \mu$.

Fructifications probably large, for the one seen covered an area $71 / 2 \mathrm{~cm}$. long, $5 \mathrm{~cm}$. wide.

On moss-covered bark of an apparently frondose species. Chile. December.

Distinguished by bright Brussels brown color, stratose structure consisting of 2 strata in the type, and absence of supporting pillars for the hymenial crust. The hyphae arise uniformly into the fructification from all points in the substratum.

Specimens examined:

Chile: Corral, $R$. Thaxter, $b$, type (in Farlow Herb., and Mo. Bot.

Gard. Herb., 57896).

S. spiniferum Burt, n. sp.

Type: in Farlow Herb. and Mo. Bot. Gard. Herb.

Fructifications resupinate, effused, adnate, coriaceous, blackish brown (3) in the herbarium, not shining, surface somewhat veined and with the veins extended into occasional, cylindric teeth or spines $2-5 \mathrm{~mm}$. long, $2 / 5 \mathrm{~mm}$. in diameter, extending obliquely from the veins and the hymenial surface in the marginal region, the margin fimbriate; in section $400 \mu$ thick, colored, composed of loosely interwoven, rigid hyphae $4 \frac{1}{2} \mu$ in diameter, concolorous with the fructification; probasidia $9-12 \mu$ in diameter; no spores nor spore-bearing organs seen.

Fructification $9 \mathrm{~cm}$. long, surrounding a living hardwood branch $12 \mathrm{~mm}$. in diameter.

On living, frondose branches. Chile. November.

The veined hymenium of $S$. spiniferum locates this species in the group with $S$. retiforme. The extension of the veins in the form of large hydnoid teeth is a unique character, if constantly present in future collections.

Specimens examined:

Chile: San Pedro, Concepcion, R. Thaxter, a, type (in Farlow Herb., and Mo. Bot. Gard. Herb., 57895). 


\section{Tremellaceae}

\section{EICHLERIELLA}

Eichleriella mexicana Burt, n. sp.

Type: in Mo. Bot. Gard. Herb. and N. Y. Bot. Gard. Herb.

Fructifications coriaceous, separable, effuso-reflexed, with the reflexed portion narrow, snuff-brown, and concentrically sulcate on the upper side, fibrillose, the margin entire; hymenium light vinaceous-cinnamon in the herbarium, pruinose, even; in section $600 \mu$ thick, (1) with the layer at surface of pileus and next to substratum up to $100 \mu$ thick and having its hyphae Saccardo's umber, loosely interwoven, thick-walled, 3-4 $\mu$ in diameter, and (2) with a broad intermediate layer composed of densely interwoven, hyaline hyphae $4 \mu$ in diameter which passes into (3) the hymenial layer composed of basidia and slender branched paraphyses bearing granules; basidia immersed about $30 \mu$ below the surface of the hymenium, longitudinally septate, 16$21 \times 10-11 \mu$; spores simple, hyaline, even, $12 \times 4-5 \mu$.

Fructification resupinate over an area $4 \mathrm{~cm}$. long, $11 / 2 \mathrm{~cm}$. wide, and broken off at both ends; the reflexed portion $2 \mathrm{~mm}$. broad.

On bark of a decaying, frondose limb. Mexico. December.

$E$. mexicana is related to $E$. alliciens but is thicker, browner above, with branched paraphyses bearing granules, and with larger spores.

Specimens examined:

Mexico: Guernavaca, W. A. \& E. L. Murrill, 399, type (in Mo. Bot. Gard. Herb., 54547, and N. Y. Bot. Gard. Herb.).

\section{SEBACINA}

Sebacina (?) Cokeri Burt, n. sp.

Sebacina sp. Coker, Elisha Mitchell Scientif. Soc. Jour. 35: 157. pl. 47, 61, f. 1-5. 1920.

Type: in Univ. of North Carolina Herb. and Mo. Bot. Gard. Herb.

"Forming low, crowded and anastomosing, nodulated masses and pustules looking very like a Myxomycete; patches $9 \mathrm{~cm}$. or more long and up to $1.5 \mathrm{~cm}$. wide in our collection (probably quite indefinite as to size and form of area covered); height only up to 
1 or $1.5 \mathrm{~mm}$. ; color a pallid creamy yellow or dusky cream; surface glabrous, shining unless getting rather dry. Texture succulent but not gelatinous in the usual sense, but firmly waxy. Fibers of the flesh slender and regular, about 1.5-2 $\mu$ thick, sparingly branched.

"Spores oval, flattened on one side, yellowish under microscope, very variable in size, 6.3-9 $\times 7.7-12.2 \mu$, sprouting into threads by one or two germ tubes, which may arise at any point. Basidia oval, 13.7-14.4 $\times 16.3 \mu$, irregularly four-celled, collapsing soon after formation of spores. Sterigmata much thickened upward, some very long and slender. Paraphyses slender, densely packed, curved over, and mostly branched a little at the ends, the branches crooked and rhizoid-like and more slender and set with very minute crystals. Much larger, roughly globular or angular crystals with slender, spine-like, hyaline projections also occur rather abundantly through the hymenium; they are mostly about $7-9 \mu$ thick.

"This species is markedly distinct from all others we have seen. The peculiar color, pustulate, anastomosing form and plump spores and large crystals separate it easily from our other Sebacinas. The projections on the crystals do not seem to be of the same nature and after drying reappear very obscurely if at all. They may be the stubs of hyphae that took part in the formation of the crystals. So thickly interwoven are the tips of the paraphyses and so dense the little crystals that there is formed a distinct and darker crust over the surface."

The thickest portion of the fructification has dried Dresden brown.

Specimens examined:

North Carolina: Chapel Hill, on under side of old, hard heart of an oak branch, February, W. C. Coker, 4116, type (in Mo. Bot. Gard. Herb., 56719).

S. fibrillosa Burt, n. sp.

Type: in Mo. Bot. Gard. Herb. and N. Y. Bot. Gard. Herb.

Fructifications effused, incrusting, adnate, rather thin, fibrillose-hypochnoid, drying whitish, somewhat velutinous, surface irregular and conforming to the elevations and depressions of the 
surface upon which growing, the margin somewhat fimbriate; in section 200-400 $\mu$ thick, not colored, composed of densely interwoven, hyaline hyphae about $21 / 2 \mu$ in diameter, with the wall gelatinously modified, much foreign matter present; cystidia not incrusted, cylindric, obtuse, $3 \frac{1}{2}-7 \mu$ in diameter, protruding up to $30 \mu$; basidia longitudinally septate, pyriform, $15 \times 9 \mu$, present in the surface of the hymenium; spores simple, hyaline, curved, $7-8 \times 3^{1}-4 \mu$, copious.

Fructification $3 \mathrm{~cm}$. long, $2 \mathrm{~cm}$. wide.

Running over wood humus on the forest floor at 7000 feet altitude. Mexico. December.

S. fibrillosa is a small, whitish, incrusting species running over the irregular surface of wood humus. Its distinguishing character is the presence of cystidia, which are conspicuous and as distinct as in a Peniophora, and locate this species in the subgenus Heterochaetella of Sebacina.

Specimens examined:

Mexico: Tepeite River region, near Guernavaca, W. A. \& E. L. Murrill, 515, type (in N. Y. Bot. Gard. Herb., and Mo. Bot. Gard. Herb., 54514).

\section{S. lactescens Burt, n. sp.}

Type: in Mo. Bot. Gard. Herb. and Farlow Herb.

Fructifications effused, rather thick when moist, thin when dry, gelatinous, separable, loosely attached, drying between drab and wood-brown, even, the margin thinning out; in section $1000 \mu$ thick, not colored, composed of densely arranged, ascending and interwoven hyphae with walls so completely modified gelatinously that only the protoplasmic contents of the lumen can be followed; gloeocystidia somewhat colored, clavate, $54 \times 5$ $71 / 2 \mu$, abundant in the hymenium; basidia longitudinally cruciately septate, $15 \times 12 \mu$, immersed about $25-35 \mu$ below the surface of the hymenium; spores hyaline, even, curved, $12 \times 6 \mu$.

Fructifications $2 \mathrm{~cm}$. long, $1 / 2^{-1} \mathrm{~cm}$. wide.

Longitudinally confluent on the under side of a frondose limb. West Indies.

S. lactescens may be recognized by its wood-brown color when dry, gelatinous consistency, and numerous and conspicuous, 
slightly colored gloeocystidia. The latter locate this species in the subgenus Bourdotia of Sebacina.

Specimens examined:

Grenada: Grant Etang, R. Thaxter, comm. by W. G. Farlow, 153, type (in Mo. Bot. Gard. Herb., 55236).

S. plumbescens Burt, Mo. Bot. Gard. Ann. 3:241. 1916.

S. plumbea Burt, Mo. Bot. Gard. Ann. 2: 765. text f. 6, pl. 27, f. 20. 1915, but not of Bresadola \& Torrend, Broteria 11: 87. f. 8. 1913.-S. Burti Trotter in Sacc. Syll. Fung. 23: 573. 1925.

S. murina Burt, n. sp.

Type: in Mo. Bot. Gard. Herb.

Fructifications effused, closely adnate, very thin, pallid mousegray and somewhat pulverulent when dry, even, the margin similar; in section $30 \mu$ thick, not colored, composed chiefly of longitudinally septate basidia starting almost directly from the substratum, $15 \times 8 \mu$, and of immersed, white, incrusted masses up to $25 \times 7 \mu$ as seen in lactic acid preparations, densely covered with spiculose granules which clothe a short, cylindric, flexuous, hyphal axis for each mass; spores simple, hyaline, even, $9 \times 6 \mu$.

Fructifications 5-6 cm. long, 11/2-2 cm. wide.

On decorticated, weathered, badly decayed wood on mountain side at altitude 800-1500 feet. Mexico. January.

S. murina is noteworthy by the small, erect, cylindric, incrusted, white masses between its basidia. These masses are evidently homologous with the paraphyses of $S$. calcea but differ from the latter by being unbranched, as shown when their spiculose, incrusting matter is cleared away by potassium hydrate solution; the central axis of each mass then becomes visible as a cylindric, flexuous rod somewhat olivaceous in color in preparations stained with eosin and very similar in appearance then to the organs termed gloeocystidia by Bourdot \& Galzin in the subgenus Bourdotia of Sebacina.

Specimens examined:

Mexico: Motzorongo, near Cordoba, W. A.\& E. L. Murrill, 986, type, comm. by N. Y. Bot. Gard. Herb. (in Mo. Bot. Gard. Herb., 54609). 
S. polyschista Berk. \& Curtis, n. sp., in herb. under Corticium. 'Type: in Farlow Herb. and probably in Kew Herb.

Fructifications effused, rather thin, loosely attached to the substratum, separable, fleshy, avellaneous in the herbarium, even, cracking in drying and showing through the cracks the whitish, fibrous subiculum, the margin thinning out, whitish, arachnoid; in section $400-500 \mu$ thick, slightly colored, with the hyphae near the substratum loosely interwoven, thick-walled, $4 \frac{1}{2}-6 \mu$ in diameter, not nodose-septate, not incrusted, and with the hymenial layer $200 \mu$ thick, composed of densely interwoven hyphae $3 \mu$ in diameter; no cystidia ; basidia cylindric, apparently longitudinally septate, at the surface of the hymenium; spores hyaline, even, curved, $10 \times 4 \frac{1}{2} \mu$.

On under side of limb of dead Pyrus Malus. South Carolina. July.

This species should be recognized by the avellaneous color of its fructifications which shrink greatly and crack in drying. It is related to $S$. adusta.

Specimens examined:

South Carolina: Society Hill, M. A. Curtis, 4950, type (in Farlow Herb.).

S. Sheari Burt, Mo. Bot. Gard. Ann. 2: 758. text f. 2. 1915. This species was transferred to the genus Heterochaete, in Mo. Bot. Gard. Ann. 8: 377. 1921, under the name Heterochaete Sheari Burt.

\section{Exotic Species}

S. africana Burt, n. sp.

Type: in Mo. Bot. Gard. Herb.

Fructifications effused, closely adnate, thin, fleshy-gelatinous, drying cartridge-buff, contracting in drying and cracking, even, not shining, the margin not present; in section $240 \mu$ thick, not colored, composed of suberect, densely arranged hyphae with walls gelatinously modified, somewhat granule-incrusted; gloeocystidia not colored, flexuous, $75 \times 4-6 \mu$, confined to the hymenial region between the basidia; basidia pyriform, at the surface of the hymenium; spores simple, hyaline, curved, $6-71 / 2 \times 3 \mu$. 
Fructifications probably large, for specimen received is $9 \mathrm{~cm}$. long, about $1 \mathrm{~cm}$. wide, and broken off on all sides.

On decorticated, rotten, frondose log. South Africa. January.

S. africana resembles in aspect Corticium ochraceum but is a Sebacina in structure. It is further distinguished by its buff color, sparingly granule-incrusted, gelatinous-walled hyphae, small spores, and colorless, flexuous gloeocystidia which are in all respects like those present in some species of Corticium and Peniophora. The gloeocystidia locate $S$. africana in the subgenus Bourdotia of Sebacina.

Specimens examined:

South Africa: Knyna, Cape Colony, P. A. van der Bijl, 1342, type (in Mo. Bot. Gard. Herb., 63405).

\section{TREMELLODENDRON}

Tremellodendron simplex Burt, Mo. Bot. Gard. Ann. 2: 742. pl. 26, f. 5. 1915.

Another collection of this species, affording a more accurate description, consists of 2 infundibuliform fructifications with black, rugose, compressed stems; the pilei are olive-buff, even, glabrous; hymenium inferior, testaceous, with the margin oliveocher.

Fructifications $3 \mathrm{~cm}$. high; stem $2 \mathrm{~cm}$. long, $11 / 2 \mathrm{~mm}$. in diameter; pileus $1 \mathrm{~cm}$. in diameter, about $1 \mathrm{~cm}$. long.

This gathering was made at El Yunque, Cuba, in March, 1903, by Underwood \& Earle, 1087 A, and is now in N. Y. Bot. Gard. Herb.

T. tenax (Schw.) Burt, Mo. Bot. Gard. Ann. 7: 67. pl. 11, f. 105, 106. 1922.

Clavaria tenax Schweinitz, Am. Phil. Soc. Trans. N. S. 4: 182. 1832.-Merisma tenax (Schw.) Léveillé, Ann. Sci. Nat. Bot. III. 5: 157. 1846.-Pterula tenax (Schw.) Sacc. Syll. Fung. 6: 742. 1888.-Tremellodendron Hibbardi Lloyd, Myc. Writ. 6. Myc. Notes 65: 1049. pl. 179, f. 1947. 1921.

Type: in Schweinitz Herb. and a fragment in Farlow Herb.

Fructifications fascicled, with substance very tough, at length somewhat horn-like, soon ramose-divided from the base; branches 
compressed, dilated at the apex into almost a membrane; branchlets minute, irregularly extended and then fimbriate. Color alutaceous red. Does not exceed an inch in height.

The specimen in Schweinity Herb. is compressed, not fleshy when moistened, and has the hymenium fuscous; basidia longitudinally septate; spores hyaline, even, flattened on one side, $9 \times 5 \frac{1}{2} \mu$. T. tenax has somewhat the aspect of some forms of $T$. pallidum but is readily separable from the latter by the very dark hymenium of T. tenax.

Specimens examined:

Massachusetts: West Roxbury, Miss A. Hibbard, under the name

T. Hibbardi (in Mo. Bot. Gard. Herb., 58736).

Pennsylvania: Bethlehem, Schweinitz, type (in Herb. Schweinitz and Farlow Herb.).

\section{INDEX TO GENERA}

New scientific names and combinations are printed in bold face type; synonyms in ilalics; and previously published names, in ordinary type.

THELEPHORACEAE

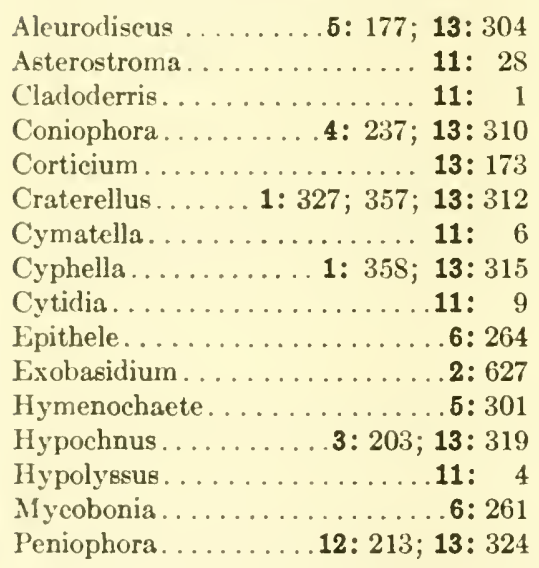

Skepperia............. 11: 8

Solenia............... 11: 13

Stereum......... 7: 81; 13: 325

Thelephora.........1: 185; 13: 328

Tulasnella........6: 253; 13: $32 S$

Veluticeps........6: 259; 13: 329

CLAVARIACEAE

Lachnocladium......... 6: 266

AURICULARIACEAE

Septobasidium....... 3: 319; 13: 330

TREMELLACEAE

Eichleriella........ 2: 731; 13: 334

Sebacina ......... 2: 731; 13: 334

Tremellodendron..... 2: 733; 13: 339

\section{INDEX to Species}

abeuns (Corticium)....... 13: 250

abretina (Hymenochaete)..... 7: 186

abietinum (Stereum) ....... 7: 186

abietis (Corticium) ........ 2: 760

abnormis (Hymenochaete).... acerinum (Corticium)...... 5: 196

acerinum (Stereum) ....... $5: 196$

acerinum v. nivosum (Stereum) 6: 193

acerinus (Aleurodiscus)...... 5: 196

aculeata (Thelephora). 7: 232; 13: 325 
aculeatum (Stereum)....... 13: 325

adhaesum (Corticium)... .. 13: 279

admirabilis (Peniophora)... 12: 304

adusta (Sebacina) ........ 2: 764

Aegerita (Peniophora) ...... 12: 226

Aegerita (Sclerotium) ...... 12: 226

aemulans (Peniophora)...... 12: $30 \mathrm{~S}$

affinis (Peniophora) ...... 12:226

affinis (Thelephora) ....... 7: 96

africana (Sebacina)....... 13: 338

agglutinans (Hymenochaete). . . 5: 344

alba (Peniophora)........ 12: 297

albido-brunnea (Thelephora)... 1: 214

albido-carnea (Theleplora).... 13: 277

albido-carneum (Asterostroma). 11: 29

albido-carneum (Corticium)... 13: 277

albobadia (Thelephora)...... 7: 216

albobadium (Stereum)...... 7: 216

albofarcta (Peniophora)...... 12: 223

alboftavescens (Coniophora)... 4 4:248

alboflavescens (Corticium).... 4: 217

albo-marginata (Peniophora)... 7:216

albo-marginata (Thelephora)... 7:216

albo-straminea (Peniophora)... 12: 305

alboviolascens (Cyphella).... 13: 315

alboviolascens (Peziza)...... 13: 315

albugo (Peniophora)....... 12: 231

albula (Peniophora)....... 12: 231

album (Septobasidium).... . 13: 332

albus (Hypochnus) ........ 13: 319

albus (Microstroma) . . . . . . 11: 27

Allescheri (Gloeopeniophora). . 12: 301

Allescheri (Kneiffia) . ....... 12: 301

Allescheri (Peniophora) ..... 12: 301

alliciens (Eichleriella)...... . 2: 746

alliciens (Stereum)........ 2: 740

Aluta (Corticium).......... 13: 187

alutaceum (Corticium)...... 13: 263

alutaceum (Gloeocystidium)... 13: 263

alutaria (Peniophora)....... 12: 332

alutarium (Corticium) . . . . . . 13: 283

alutarius (Xerocarpus)...... 13: 283

ambiens (Hymenochaete)..... 5: 344

ambigua (Hymenochaete)..... 7: 200

ambiguum (Stereum)....... 7: 190

ambiguus (Trichocarpus)..... 7: 200

ambiguus (Xerocarpus)...... 7:200

americanorum (Microstroma). 11: 27

amoena (Peniophora)...... 12: 276

amorpha (Cyphella) ........ 5: 180 amorphum (Corticium)....... 5: 180

amorphus (Aleurodiscus)..... 5: 150

ampla (Auriculariopsis)...... 11: 10

ampla (Cyphella).......... 11: 9

analogum (Corticium)....... 13: 217

analogum (Gloeocystidium)... 13: 247

anastomosans (Stereum)..... 7: 115

anastomosans (Thelephora).... 7: 115

Andromedae (Exobasidium) . . 2: 649

angustata (Thelephora)...... 1: 205

anomala (Hymenochaete).... 5: 358

anomala (Peziza) . . . . . . . 11: 19

anomala (Solenia) . . . . . . . 11: 19

anomala v. orbicularis (Solenia). 1: 373

anomaloides (Solenia)....... 11: 19

anthocephala (Thelephora).... 1: 203

anthochroa (Thelephora) .... 7: 229

anthracophilum (Corticium). .. 13: 219

apiculatum (Corticium) ..... 13: 2:38

apiculatus (Aleurodiseus)... $5: 186$

arachnoidea (Cyphella)...... 1: 363

arachnoidea (Peniophora) . . 12: 220

arachnoidea (Thelephora) 3: 213; 13: 323

arachnoideum (Corticium) . . . 13: 1 44

arcticum (Stereum)........ 7:155

Arctostaphyli (Exobasidium) . . 2: 649

arenicolum (Stereum)...... 7:232

areolatum (Corticium)....... 13: 238

areolatum (Stereum)...... 7: 202

argentatum (Corticium).... 13: 256

argentea (Peniophora)....... 12: 346

argillaceus (Hypochnus) ..... 3: 222

arida (Coniophora)........ 4: 244

arida (Hymenochaete)....... 5: 340

arida (Hymenochaetella) .... 5 : 340

aridum (Corticium)........ 4: 244

armeniacum (Corticium)..... 13: 216

artocreas (Michenera) ...... 13:215

aschistum (Corticium) ...... 7: 203

aspera (Hymenochacte) ..... 5: 511

asperata (Hymenochacte) .... $5: 3 \pi 1$

asperipilata (Peniophora)... 12: 230

Atkinsonii (Corticium)..... 13: 208

Atkinsonii (Lachnocladium)... 6:277

Atkinsonii (Peniophora)..... 7: 200

atrata (Sebacina) ........ 2: 765

atratum (Septobasidium).... 3: 3:34

atrocinerea (Coniophora) ..... 4:260

atrocinerea (Coniophorella) . . . 4: 260

atroruber (Hypochnus) ..... 3: 230 
atroruber (Zygodesmus)...... 3: 230

atrorubrum (Stereum)

at rovirens (Corticium)

13: 325

13: 300

13: 300

6: 317

attenuata (Hymenochaete).

Auberianum (Corticium)

13: 198

aurantiaca (Gloeopeniophora)

aurantiaca (Peniophora)

aurantiaca (Podoseypha)

aurantiaca ('Thelephora)

aurantiaca ('Tomentella)

aurantiacum (Corticium)

aurantiacum (Stereum)

aurantiacus (Hypoclinus).

aurantium (Tremellodendron) .

australe (Stereum)..........

avellanea (Coniophora).......

avellanum (Stereum).

avellaneus (Hypochnus).....

Azaleae (Exobasidium)......

badia (Thelephora).

badio-ferruginea (Hynieno-

chaete) .

badio-ferrugineum (Stereum)...

balsaineum (Stereum).

balsamicola (Nodularia)

Bambusae (Corticium)

Bananae (Cyphella)

basale (Corticium)

Berkeleyana (Hymenochaete) .

Berkeleyanum (Stereum)......

Berkeleyi (Corticium)........

Berkeleyi (Peniophora).......

Berkeleyi (Veluticeps)........

Bertolonii (Stereum) ...........

bicolor (Asterostroma) . . . . . 11: 32

bicolor (Clavaria) ...... 9: 67; 6: 274

bicolor (Corticium) . . . . . . 13: 291

bicolor (Hypochnus)........ 3: 229

bicolor (Lachnocladium) . 9: 65; 6: 274

bicolor (Stereum) . ........ 7:117

bicolor (Thelephora)........ 7:117

bicolor (Zygodesmus)....... 3: 227

biennis (Thelephora). 1: 215, 216; 5:213

bizonatum (Stereum)....... 7: 216

bombycina (Thelephora) ..... 13: 190

bombycinum (Corticium)... . 13: 190

borealis (Craterellus) ....... 1: 357

borealis (Hymenochaete) .... 5: 317 borealis (Peniophora)..... 12: 295

botryoides (Hypochnus) . . . . 3: 226

botryoides (Thelephora)...... 3: 226

botryosum (Corticium)...... 13: 295

botryosus (Aleurodiscus).... . 5: 198

brasiliense (Lachnocladium). . . 6:268

Bresadolae (Corticium) . . . . . 13: 179

brevipes (Craterellus)........ 1: 329

Brinkmanni (Corticium)... . . 13: 253

brunneola (Coniophora)...... 4: 257

brunneoleuca (Mycobonia).... 6: 263

brunncoleucum (Hydnum) .... 6 6: 263

brunneolum (Corticium) ..... 4: 257

Burkei (Peniophora) . . . . . . 12: 282

Burti (Sebacina) . . . . . . . . 13: 337

Burtianum (Stereum).........7: 93

Burtii (Peniophora) ......... 12: 278

byssoidea (Coniophora)....... 4: 263

byssoidea (Coniophorella).... 4: 463

byssoidea (Peniophora)...... 4:263

byssoideum (Corticium)...... 4: 263

Cacao (Hymenochaete)...... 5: 310

Cacao (Stereum).......... 5: 310

Cacao (Xerocarpus) . . . . . . 12: 239

caerulea (Thelephora)....... 13: 301

caerulescens (Lyomyces)..... 13: 300

caeruleum (Corticium)...... 13: 301

caesia (Peniophora)........ 12: 353

caesium (Corticium)........ 12: 353

caespitosum (Stereum)..... 7:116

caespitulans (Thelephora).... 1: 204

calcea (Sebacina) . ........ 2: 759

calcea (Thelephora)....... 2: 759

calcea v. argillacea (Thelephora) 13: 241

calcea v. glebulosa (Thelephora). 13: 203

calceum (Corticium)....... 13: 203

calospora (Prototremella) ... . 13: 328

calospora (Tulasnella)...... 13: 328

calotrichum (Corticium)...... 12: 254

calyculus (Craterellus)...... 1: 338

calyculus (Stercum)........ 1: 338

campanula (Peziza)........ 1: 360

cana (Peniophora)........ 12: 227

canadense (Corticium) ..... 13: 290

canadensis (Hypochnus).... 3: 211

canadensis (Peniophora).... 12: 260

candida (Aegerita) ........ 12: 226

candida (Cyphella)......... 1: 377

candida (Merisma)......... 2: 737 
candida (Peniophora)

12: 226

candida (Solenia).

11: 14

candida (Thelephora) ...2: 737; 5: 188 candidissima (Thelephora) ... 5: 188 candidum (Stereum)........ 5: 188 candidum (Tremellodendron).. 2: 737 candidus (Aleurodiscus) . . . . . 5: 188 Candolleana (Cladoderris)..... 11: 2 canescens (Septobasidium) ... 3: 312 Cantharella (Thelephora) ..... 1: 330 Cantharellus (Craterellus) ... 1: 330 canum (Corticium) ........ 13: 206 caperata (Thelephora)....... 7: 87 caperatum (Stereum) ........ 7: 87 capnoides (Coniophora) ..... 4: 267 capula (Cyphella).......... 1: 366 capula (Peziza) ........... 1: 366 caricina (Cyphella) ........ 1: 366 carnea (Peniophora).

12: 354 carneum (Corticium). 12: 354 carnosa (Peniophora). 12: 325 carolinense (Stereum). 7: 236 cartilagineum (Lachnocladium) caryophyllea (Thelephora).... Cassandrae (Exobasidium).... Cassiopes (Exobasidium)..... castanoum (Septobasidium).. centrifuga (Rhizoctonia).

6: 269

1: 209

2: 649

2: 649

3: 330

13: 206

centrifugum (Corticium) ..... 13: 206

centrifugus (Hypochnus)..... 13: 206

ceraceum (Corticium)...... 13: 216

cerebella (Coniophora)...... 4: 240

cerebella (Thelephora)....... 4: 240

cerrusatus (Aleurodiscus).... 13: 304

cerrusatum (Corticium)....... 13: 304

cervicolor (Asterostroma) . . . . 11: 28

cervicolor (Corticium)....... 11: 28

cervina (Clavaria)......... 6: 273

cervina (Hymenochaete)..... $5: 363$

cervinum (Lachnocladium)....

cervinus (Hypochnus).......

Chailletii (Stereum)

6: 273

3: 232

7: 200

chalybaeus (Hypochnus) ..... 13: 300

chlorascens (Sebacina)...... 2: 756

chlorinum (Corticium)...... 4: 265

chrysocreas (Corticium) ..... 13: 270

cinerascens (Hymenochaete)... 7: 203

cinerascens (Hypochnus) .... 3: 233

cinerascens (Peniophora)..... 7: 203

cinerascens (Stereum)...... 7: 203 cinerascens (Thelephora)..... $7: 203$

cinerascens (Tomentella)..... 3: 233

cinerea (Peniophora)....... 12: 348

cinerea (Solenia) . . . . . . . . 11: 22

cinereo-fusca (Cyphella)...... 1: 377

cinereo-fusca (Lachnella)...... 1:377

cinereo-fusca (Peziza)....... 1:377

cinereum (Corticium)....... 12: 348

cinnamomea (Hymenochaete) . 5: 345

cinnamomea (Septobasidium) 2: 763

cinnamoneum (Corticium) .... 5: 345

cinnamomoum (Septobasidi-

um)................ 13: 332

cirratum (Septobasidium).... 3: 334

citrinella (Peniophora) ...... 12: 327

citrinellum (Corticium) ...... 12: 327

Cladonia (Merisma)........ 2: 738

Cladonia (Thelephora)...... 2: 738

Cladonia (Tremellodendron)... 2: 738

clavatus (Cantharcllus) . . . . . 1: 329

clavatus (Craterellus)....... 1: 329

clavatus (Nevrophyllum)..... 1: 329

coccineo-fulva (Peniophora) . . 12: 253

coccineo-fulva (Phlebia) . . . . . 12: 253

Coffearum (Stereum) ....... 7: 216

coffeatum (Stereum) ......... 7: 117

Cokeri (Sebacina)... . . . . . 13: 334

colliculosum (Corticium)..... 13: 233

colorea (Peniophora)........ 12: 343

complicatum (Stereum)...... 7: 169

concolor (Stereum)........ 7: 163

conferta (Solenia) ........ 11: 17

confine (Corticium) ........ 13: 246

confluens (Corticium)...... 13: 220

confluens (Craterellus)....... 1:331

confluens v. subcalceum (Cortic-

ium) . . . . . . . . . . . . 13: 220

confusa (Solenia)......... 11: 19

conglobata (Cyphella)...... 1: 373

conicum (Stereum) . . . . . 7: 179

convoluta (Cyphella) ........ 1: 380

convolvens (Peniophora)..... 12: 355

Cookei (Coniophora)........ 4: 244

corbiformis (Thelephora) .... 1:211

coriaria (Grandinia)........ 3: 228

coriarius (Hypochnus)...... 3: 228

cornucopioides (Cantharellus). . 1:333

cornucopioides (Craterellus)... 1: 333

cornucopioides (Thelephora)... 1:212

corrugata (Hymenochaete).... $5: 358$ 
corrugata ('Thelephoris).

corrugatum (Corticium). corrugis (Coniophora)

corrugis (Crutedellus)

corticola (Asterostroma)

rorticolor (Hymenochate).

(ruspedia ('Thelephora)

(raspedium (Stereum).

crassa (Cladoderris) .

crasise (Hymenochate) . 5: 367; 7: 192

crassa (l'cniophora)

crissa (Thelephora).

crassum (Actinostroma) ..... 11: 2

crassum (Stereum).

crateriformis (Hymenochaete).

crenca (lineiffia)

cremea (P'eniophora)

cremeus (Aleurodiscus)

eremoricolor (Corticium)

cristata ('Thelephora).

cristatum (Stereum)

cristulatum (Stcreum)

crocea (Coniophora).

croceum (Corticium)

croceum (Sporotrichum).

crocicreas (Corticium). 12: 322; 13: 270

crustaceum (Corticium)...... 13: 196

crustaceum (Stereum).

crustulinum (Corticium).

cubensis (Hymenochaete).....

cultum (Corticium)

cuneatum (Stereum)

Cupressi (Cyphella)

13: 196

13: 209

5: 337

13: 231

7: 233

1: 380

cupulaeformis (Cyphclla).... 1: 369

cupulatum (Stereum).... 7: 179, 233

Curreyi (Cyphella).......... 13: 315

Curtisii (Hymenochaete) .... 5 5: 320

Curtisii (Stereun)......... 5: 320

cuticularis (Thelephora)..... 1: 216

cyphelloides (Stereum) ...... 7:112

Daedalea (Peziza).....11: 23; 13: 319 damaccornis (Hymenochaete) . 5: 306 damicorne (Stereum) . . . . . . 5 5: 306 dealbata (Clavaria)........ 9: 72

dealbatum (Lachnocladium)... 9: 72

debile (Corticium).

13: 273

decipiens (Corticium)....... 13: 206

decolorans (Exobasidium).... 2: 656

$d^{\text {ccolorans (Podoscypha)..... 7: } 107}$ decolorans (Stereum)....... 7: 107

decolorans ('Thelephora)..... 7: 107

decorticans (Peniophora) ... 12: 344

decretus (Necator) . . . . . . 13: 227

deglubers (Corticium)....... 2: 755

deglubens (Fichleriella) ...... 2:747

deglubens (Radulum) . . . . . . 2: 747

deglubens (Sebaeina)....... 2: 755

delitescens (Craterellus).... 1: 339

dendritica (Cladoderris) ..... 11: 2

dendriticum (Corticium)..... 13: 303

dentosa (Thelephora)....... 1: 224

diaphana (Thelephora). . . . . 7: 98

diaphanum (Stereum) ...... 7: 97

digitata (Hymenochaete) .... 5: 347

dilatus (Craterellus)....... 1: 343

diminuens (Corticium) ...... 13:187

disciforme (Stereum)....... 13: 305

disciformis (Aleurodiscus) .... 13: 305

disciformis (Peniophora) ..... 13: 305

disciformis v. borealis (Penio-

phora) ............. 12: 295

discoideum (Exobasidium).... 2: 649

dissecta (Thelephora)........ 7:113

dissita (Peniophora)........ 7: 203

dissitum (Stereum)......... 7:203

dryina (Coniophora) ....... 4: 253

dryinum (Corticium)....... 4: 253

dryophila (Collybia) . . . . . . 2: 656

dubius (Craterellus)......... 1: 335

duplex (Peniophora) ........ 12: 298

dura (Hymenochaete)....... 5: 352

duriusculum (Stereum) . ..... 7: 236

durum (Stereum) . . . . . . 7: 226

Dussii (Epithele).......... 6: 26.5

Dussii (Hypochnus) . . . . . . 6 6: 265

Dussii (Peniophora)....... 6: 66.5

Earlei (Stereum) ......... 7: 199

echinosporus (Hypochnus) ... 3: 3:237

echinosporum (Corticium).... 3: 237

effuscatum (Corticium) ....... 13: 248

Eichleriana (Tulasnella)..... 6: 255

Eichlerianum (Corticium).... 12: 261

clacodes (Hypochnus)....... 3: $21 \mathrm{~S}$

elegans (Stereum).......... 7: 105

clegans (Thelephora)....... 7: 105

elegantissima (Hymenochaete). 5: 314

elegantissimun (Stereum).... $5: 314$

Ellisii (Coniophora)....... 4: 25i 
Ellisii (Corticium)

$4: 25 \pi$

Ellisii (Hymenochacte)

4: 257

Ellisii (Peniophora).

7: 222

endophila (Cyphella)

11: 25

endophila (Solenia).

11: 25

ephebia (Peniophora).

7: 204

ephebium (Corticium)........

7: 204

epichlora (Hymenochacte)....

5: 351

epichlorum (Corticium)

5: 351

epigaeum (Corticium)

13: 252

epigaeus (Hypochnus)

3: 226

epiphylla (Asterostromella).... 12: 241

epiphyllum (Hydnum) ....... 13: 320

epiphyllus (Hypochnus) ..... 13: 320

episphaeria (Hymenochaete) .. 5: 362

episphaeria (Thelephora) ..... 5: 362

erectum (Lachnocladium)

ermineum (Corticium)

erumpens (Stereum)

evolvens (Corticium)

exigua (Peniophora)

exigua (Thelephora)

exiguum (Stereum)

exilis (Peniophora)

6: 276

13: 182

7: 209

13: 280

12: 224

7: 99

7: 99

12: 239

farinellus (Xerocarpus)

2: 760

farinosa (Íneiffia)

12: 226

Farlowii (Aleurodiscus).

5: 182

Farlowii (Peniophora)

12: 343

fasciatum (Stereum) .

7: 155

fasciculata (Cyphella). 1: 373; 13: 315

fasciculata (Solenia) . ....... 11: 15

fasciculatus (Cantharellus).... 1: 373

ferax (Corticium).

13: 304

ferreum (Stereum).

7: 202

5: 332

3: 208

ferruginea (Tomentella).

ferrugiveum (Corticium)

ferrugineum (Stereum).

3: 208

5: 332

3: 207

3: 212

3: 208

3: 212

ferruginosus (Hypochnus).

fibrillosa (Sebacina)

13: 335

fibrillosus (Hypochnus)

3: 238

filamentosa (Peniophora)

12: 320

filamentosum (Corticium)

12: 320

filamentosus (Hypochnus). .

filicina (Solenia).

13: 320

11: 18

filicola (Cyphella). fimbriata (Hymenochaete) . . . 7: 186

funbriata (Thelephora) . . . . . 1: 222

fimbriatum (Stereum)....... 7: 234

firma (Peniophora) ....... 12: 276

fissum (Stereum) ......... 7: 111

flabellate (Podoscypha)...... 7: 111

flabellatum (Stereum) ...... 7: 111

flammea (Peniophora) . . . . . 12: 252

flava (Bonia) . . . . . . . . . . . 6: 262

flava (Coniophora)........ 4: 261

flava (Mycobonia) . . . . . . . 6: 6: 262

flava (Peziza) ........... 6: 262

flavido-alba (Peniophora) ..... 12: 248

flavomarginata (Coniophora) 13: 311

flavum (Grandiniodes) ......6: 262, 264

flavim (Hydnum) . . . . . . . . . 6: 262

floceulenta (Cytidia)........ 11: 9

flocculentum (Corticiun)..... 11: 9

floridana (Cladoderris) . . . . . 11: 4

foetidus (Hypolyssus)....... 11: 5

foetidum (Merisma)........ 1: 201

formosa (Hymenochaete). . 5: 307, 308

fragile (Stereum) . . . . . . . . . 7: 233

fragrans (Clavaria) ......... 6: 270

frustulosa (Hymenochacte)... . 3: 337

frustulosum (Septobasidium) . . 3: 337

frustulosum (Stereum) ..... 7: 227

fuligineus (Hypochnus) . . . . 3: 232

fuliginosa (Hymenochaete).5: 342, 365

fuliginosum (Stereum)....... 5: $\mathbf{5 6 5}$

fulva (Cyphella)........... 1: 373

fulva (Hymenochaete)...... 5: 354

fulvella (Hymenochaete)..... 5: $5: 318$

fulvo-cinctus (Hypochnus)..... 3: 228

fulvo-nitens (Stereum)....... 7: 91

fulvo-olivacea (Coniophora).... 4: 258

funigatum (Corticium)...... 12: 348

fumigatum (Septobasidium) . 3: 240

fumosa (Cyphella)......... 1: 376

fumosum (Corticium)....... 3: 239

fumosus (Hypochnus). . 3: 239; 13: 321

furcata (Cyphella)......... 1: 373

furccllata (Clavaria)........ 6: 274

furcellatum (Lachnocladiun). . 6: 274

furfuraceum (Corticium) ..... 13: 242

fusca (Iymenochaete)...... 5: 565

fusca (Hymenochaetella)..... Б $5: 366$

fusca (Odontia) . . . . . . . . . 3: 239

fusca (Peniophora)........ 12: 244

fusca (Tomentella)......... 3: 215 
fuser ("Thelephora)

7: 117

fusca (Veluticeps).

13: 329

fuscata (Hypochnopsis).

3: 213

fuscatus (Hypochnus)

3: 213

fuscomarginata (Peniophora) 12: 235

fuscostratum (Corticium) ... 13: 299

fusco-violacea (Tulasnella).... 6: $25 \mathrm{~S}$

fuscum (Corticium)........ 3: 215

fuscum (Stereum)......... 7:117

fuscus (Hypochnus) ....... 3: 215

fusispora (Coniophora)...... 4: 243

fusisporum (Corticium)..... 4: 243

galactine ('Thelephora)....... 13: 199

galactinum (Corticium)...... 13: 199

galeata (Cyphella) .....1: 362; 13: 316

galcatus (Cantbarelius) ...... 1: 362

Galeottii (Stereum)....... 7: 234

galochroa (Peniophora)...... 12: 222

gausapata (Thelephora)...... 7: 136

gausapatum (Stereum) ...... 7: 136

gelatinosa (Eichleriella) .... 2: 748

gigantea (Peniophora)...... 12: 216

giganteum (Corticium)...... 12: 216

gigaspora (Peniophora)..... 12: 356

gilvidula (Peniophora)...... 12: 245

gilvidum (Corticium)....... 13: 215

glabrescens (Stereum)...... 7: 110

glabrum (Corticium)........ 12: 274

glaucescens (Stereum)...... 7: 186

glebulosa (Peniophora)...... 12: 282

globifera (Peniophora)...... 12: 219

globosum (Corticium)...... 13: 266

gracile (Asterostroma)...... 11: 34

gracilis (Solenia).........11: 15, 26

gracilis (Thelephora)....... 2: 738

grammicum (Corticium)..... 13: 187

granosa (Thelephora)....... 3: 227

granosus (Hypochnus)...... 3: 227

granulare (Corticium)....... 13: 182

granulatum (Corticium) ... 13: 236

granulosus (Hypochnus). 3: 218; 13: 320

granulosus (Zygodesmus) .... 3: 218

grisco-pallida (Cyphella)..... 1: 367

griseo-zonata (Thelephora).... 1: 221

griseum (Stcreum)........ 7: 234

guadelupense (Lachnocladium). $\quad 6: 277$

guadelupense (Merisma) . .... 6: 6:277

guadelupense (Stercum) ..... 7: 236

guadelupensis (Pterula)...... guttulifera (Peniophora)..... 12: 247

gutluliferum (Glococystidium) . 12:247

Harperi (Coniophora) ...... 4: 252

Hartmanni (Stereum)....... 7: 112

Hartmanni (Thelephora) .... 7: 713

Haydeni (Stereum)....... 7: 236

Helvelloides (Corticium)...... 2: 757

Helvelloides (Sebacina)...... 2: 756

Helvelloides (Thelephora).... 2: 757

helveolus (Aleurodiscus) ..... 13: 306

hepaticum (Corticium)...... 13: 243

heterocystidia (Peniophora) . 12: 293

heterosporum (Stereum)... 7:220

Hibbardi (Tremellodedron)

$7: 67 ; 13: 340$

hirsuta v. ramealis (Thelephora) 7:169

hirsutum (Stereum)....... 7:150

hiulca (Peniophora)....... 12: 272

Huberianum (Stereum)...... 7:111

humifaciens (Peniophora) ... 12: 225

Humphreyi (Craterellus) .... 1: 344

hydnans (Corticium)....... 13: 233

hydnans (Radulum)........ 13: 233

hydrophorum (Stereum)..... 7: 89

hypnophilum (Corticium).... 13: 223

illaqueatum (Corticium)..... 13: 236

imbricata (Hymenochaete) ... 5: 325

imbricatula (Hymenochaete). . 5: 325

imbricatula (Thelephora)..... 5: 325

incanum (Corticium) ...... 13: 205

incarnata (Peniophora)...... 12: 307

incarnata (Gloeopeniophora) . . 12: 308

incarnata (Kneiffia) . . . . . . 12: 308

incarnata (Tulasnella)...... 6: 256

incarnatum (Corticium)...... 12: 308

incarnatum $v$. pinicola (Corti-

cium)........... 6: 256

inconspicua (Peniophora).... 12: 221

inconspicuum (Corticium).... 12: 221

incrustans (Corticium)...... 2: 752

incrustans (Sebacina)...... 2: 752

incrustans (Thelephora) ..... 2: 752

Indigo (Thelephora)........ 13: 301

inflata (Coniophora)....... 4: 247

inflata (Peniophora)....... 12: 267

infundibuliformis (Cladoderris) 11: 3

ingainicola (Microstroma) ... 11: 27 
insigne (Stereum)

insinuans (Coniophora)..... 4:268

insinuans (Stereum) ....... 4:268

insinuans (Thelephora)...... 4: 267

insolitum (Stercum)....... 7: 237

insularis (Hymenochaete).... $5: 358$

intermedia (Peniophora) . .... 7: 192

intybacea (Thelephora) ...... 1:217

investiens (Asterostromella) ... 13: 283

investiens (Corticium)...... 13: 283

investiens (Peniophora) .... 12: 307

investiens (Radulum?)....... 13: 283

investiens (Vararia)........ 13: 283

involucrum (Corticium).... 13: 271

irregularis (Peniophora) . . . . 12: 228

isabellina (Peniophora)..... 12: 253

isabellinum (Corticium). . . . . 3: 222

isabellinus (Hypochnus)..... 3: 222

jamaicense (Corticium) . . . . 13: 273

jamaicaense (Septobasidium) 3: 333

javanicum (Corticium)....... 13: 227

Juglandis (Microstroma) . . . . . 11: 27

Juniperi (Xerocarpus)...... 12: 338

Kalchbrenneri (Hymenochrete)

Kalmiae (Coniophora)........

Kalmiae (Corticium)........

Karstenii (Exobasidium) . . . . 2: 649

Karstenii (Peniophora)....12: 254, 286

Karstenii (Stereum) . . . . . . 12: 286

Kaufimanii (Peniophora) . . . 12: 296

Kmetii (Eichleriella)....... 2: 747

Kmetii (Radulum)......... 2: 747

koleroga (Corticium)...... 13: 292

koleroga (Pellicularia) ....... 13: 292

Kunzei (Hymenochaete)..... . 5: 323

Kunzei (Thelephora) . . . . . . 5: 323

laciniata (Thelephora).....1: 219, 220

lactea (Thelephora)........ 13:212

lactescens (Corticium)...... 13: 253

lactescens (Glococystidium)... 13: 253

lactescens (Sebacina)...... 13: 336

lactescens (Thelephora)...... 13: 253

lacteum (Corticium)....... 13: 212

laeta (Cyphella).......... 1: 361

laeta (Hymenochaete)...... 5 : 323

laeticolor (Coniophora)..... 4: 261

laeticolor (Corticium)....... 4: 261 laeticolor (Xerocarpus)....... 4: 262

laetum (Corticium)........ 13: 223

laetum (Hyphoderma)...... 13: 223

laetum (Stereum)......... 5: 323

laeve (Corticium)......... 13: 280

laeve (Corticium)........ 12: 257

laevigata (Hymenochacte).... . 5: 348

laevigata (Peniophora)...... 12: $33 \mathrm{~s}$

laevigatum (Corticium) ...... 12:335

lacvis (Cantharellus)........ 1: 362

laevis (Peniophora) . . . . . 12: 257

laminata (Peniophora) . . . . 12: 246

Langloisii (Cyphella)....... 1: 368

Langloisii (Septobasidlium) .... 3: 335

lateritius (Craterellus)....... 1: 330

laxa (Hymenochaete)....... . 5: 340

laxa (Hymenochaetella) . . . . . 5: 340

laxa (Peniophora)......... 12: 224

leonina (Hymenochaete)..... 5: 353

lepida (Peniophora)....... 12: 295

Leprieurii (Septobasidium)... 3: 332

leprosa (Peniophora)....... 12: 254

leptaleum (Corticium)....... 13: 279

leucosporum (Microstroma)... 11: 27

leucothrix (Coniophora)...... 4: 257

leucothrix (Corticium)....... 4: 257

Leveilliana (Eichleriella)..... 2: 744

Leveillianum (Corticium).... 2 744

Leveillianum (Stereum)...... 2: 745

lilacina (Peniophora)....... 12: 348

lilacina (Thelephora)....... 12: 348

lilacino-fuscum (Corticium) . . 7: 229

lilacino-fuscum (Stereum).... 7:229

lilacinum (Septobasidium)... 3: 343

limonia (Peniophora)...... 12: 275

Litschaueri (Corticium) . . . . 13: 259

livida (Peniophora)........ 12: 239

livida (Phlebia).......... 13: 243

livida (Thelephora)........ 13: 243

livido-caeruleum (Corticium). . 13: 260

livido-caeruleum (Gloeocystid-

ium . . . . . . . . . . . 13: 261

lividum (Corticium)....... 13: 243

lobata (Telephora) . . . . . . . 7: 169

lobata (Thelephora)........ 7: 163

lobatum (Stereum) . . . . . . . 7:162

longispora (Kneiffi: . . . . . . 12: 229

longispora (Peniophora) ..... 12: 229

longisporus (Hypochnus)..... 12: 229

ludoviciana (Peniophora).... 12: 244 
luridum (Curticium).

Iuridum (Gloeorystidium).

luter-balia (IIynenochacte).

luteobatium (Stereum)

lukisens (Cantharellus)

lutescens (Cruterellus)

luteriens (Merulius)

lutes: (Thelephora)

$1: 216 ; 13: 325$

\section{Macounii (Cortivium)}

mincrorlens (Neurodiscus)

mactorshiza (Thelephora)

macrorrhizum (Stereum).

macrospuna (Nebacina)

macrosporte" (Corticium)

magnahypha (Peniophora)

magnispora (Thelephora)

magnisporum (Stereun)

Mancianum (Stcremn) . .

Mancianus (Aleurodiscus)

marnsmoides (Craterellus)

marasmoides (Cymatella)

marginata (Cyphella) .

martiana (Peniophora)

martianum (Corticium)

medioburiensis (Peniophora)

mellea (Cyphella)

merismatorides (Lachnorladium)

merismatoiles (Clavaria).....

merismatoides (Pterula).......

merismatoides (Tremelloden(Iron)

mexicana (Peniophora)

mexicana (Eichleriella)

mexicanum (Corticium).

II.exicanum (Septobasidium)

Micheneri (Lachnocladium)

Micheneri (Stereum).1:214; 7:

miniata (Peniophora)

miniata (Thelephora)

ninima (Cymatella)

minutissima (Cyphella).....

molle (Corticium)

molle (Stereum)

Molleriana (Peniophora)

Molleriunum (Corticium)

mollis (Thelephora)

Montagnei (Hypolyssus)

montana (Peniophora)

monticola (Sebacina)
13: 256

13: 272

13: 272

5: $32 ; 3$

5: 323

1: 336

1: 336

1: 336

13: 307

7: 93, 106

7: 92

2: 759

2: 759

12: 238

1: 211

7: 207

5: 190

5: 190

11: 7

11: 7

13: 316

12: 330

12: 330

1: 372

2: 740

2: 740

2: 740

2: 740

12: 243

13: 334

13: 251

13: 330

6: 270

128,237

12: 277

12: 277

11: 6

1: 367

13: 216

7: 155

12: 270

12: 270

7: 155

11: 5

12: 237

2: 761
12: 328 moricola (l'eniophora)

7: 203

moricola (Stereum)........ 7: 203

nultipartita (Thelephora) ... 1: 20:

multisetae (Hymenochaete). . 5: $3: 57$

multispinulosa (Hymenochaete) 7: 192

murina (Sebacina)........ 13: 337

M urraii (Thelephora) . . . . . . 7: 131

Murrayi (Stereum)........ 7: 131

Murrilli (Corticium) . . . . . 13: 289

musaecola (Cyphella) ....... 1: 380

nuseicola (Cyphella)....... 13: 316

muscicola (Hymenochaete).... 11: 31

muscicola (Phaeocyphella) .... 13: 317

muscicolum (Asterostroma) ... 11: 31

inuscigena (Cyphella)....... 1: 362

muscigena (Thelephora) ..... 1: 362

mutata (Peniophora)....... 12: 299

mutatum (Corticium) . . . . . 12: 299

mycetophila (Tremella) ...... 2: 656

mycetophilum (Foxobasidium) . 2: 656

Myrtilli (Exobasidium)...... 2: 649

mytilina (Thelephora)...... 7: 141

neglecta (Peniophora)...... 7: 204

neglectum (Stereum)....... 7:204

nicaraguae (Stereum)....... 7: 196

nicaraguense (Stereum) . . . . . 7: 196

nicotiana (Helvella)........ 5: 325

nigricans (Protocoronospora). 11: 27

nitidulum (Stereum)...... 7: 101

nivosus (Aleurodiscus) ....... 5: 193

nuda (Peniophora)........ 12: 345

nudum (Corticium)......... 12: 345

Nyssae (Corticium) . . . . . 7: 129

Oakesii (Aleurodiscus)...... $5: \mathbf{5} 183$

Oakesii (Corticium)........ 5 : 183

obscura (Peniophora) ...... 7:222

obscura (Thelephora)....... 7: 222

obscuratus (Hypochnus) ...... 3: 216

occidentale (Stereum) ........ 7: 136

occidentalis (Lloydella)...... 7:294

occidentalis (Peniophora)..... 7: 201

ocellata (Grandinia)........ 13: 243

ochracea (Yeniophora)....... 12: 345

ochracea (Solenia)......... 11: 19

ochracea (Thelephora)...... 7: 150

ochraceo-flava (Thelephora).... 7: 1S3

ochraceo-flavum (Stereum).... 7: 183

ochraceum (Corticium)...... 13: 241 
ochrofarctum (Corticium)... 13: 275 ochroleuca (Hypochnopsis) . . . 13: 294 ochroleucum (Corticium)....7: 208, 235 ochroleucum (Stereum).... 7: 148, 235 ochroleucus (Hypochnus)..... 13: 294 ochrosporus (Craterellus).... 1: 334 ochrostroma (Asterostroma)... 11: 34 ocreatus (Craterellus)....... 1: 334 odontioides (Peniophora)... 12: 223 odorata (Peniophora)...... 12: 289 odorata (Phanerochaete)..... 12: 289 odoratum (Lachnocladium).6: 270, 278 odoratus (Cantharellus)...... 1: 331 odoratus (Craterellus) ...... 1: 331 odoratus (Merulius)......... 1: 331 odorifera (Thelephora)....... 1: 214 olivacea (Coniophora)...... 4:257 olivacea v. botryoides ('Thelephora) .................. olivaccum (Corticium)....... olivascens (Coniophora). olivascens (Corticium)...... 4: 265 olivascens (Hypochnus) ..... 3: 220 olivascens (Zygodesmus) ..... 3: 3:220 opaca (Hymenochaete) ..... 5: 364 ornatipes (Clavaria)......... 9: 65 ornatipes (Lachnocladium) . . . 9: 9: 65 ostrea (Stereum).......... 7: 155 ostrea (Thelephora)........ 7:155 Overholtsii (Corticium)..... 13: 245 Oxycocci (Exobasidium)...... 2: 649

pallescens (Corticium)...... 4: 267 pallescens (Hypochnus)...... 4: 267 pallescens (Stereum)....... 4: 267 pallescens (Thelephora)...... 4: 267 pallida (Bresadolina)....... 7: 104 pallida (Clavaria).......... 6: 273 pallida (Hymenochaete) . 5: 367; 7: 196 pallida (Thelephora)....2: 734; 7: 104 pallidofulvus (Hypochnus) . . . 13: 321 pallidofulvus (Zygodesmus).... 13: 321 pallidum (Asterostroma)..... 11: 29 pallidum (Lachnocladium) .... 6: 673 pallidum (Stereum)........ 7: 104 pallidum (Tremellodendron) .. 2: 734 Palmarum (Cyphella)....... 1: 377 palmata (Thelephora)....... 1: 201 palmata v. americana (Thelephora). palmatus (Craterellus) ..... 1: 324 paniculatum (Corticium) ... 13: 303 pannosa (Thelephora)...... 7: 104 pannosus (Hypochnus) . . . . . 3: 223 pannosus (Zygodesnus) ..... 3: 223 papyrina (Peniophora) ...... 7: 196 papyrinum (Stereum) ...... 7:196 paraphysatum (Corticium) .. 13: 117 patelliformo (Stereum)..... 7: 182 patens (Cyphella)......... 13:317 Patouillardii (Septobasidium) 3: 332 paupercula (Hymenochaete)... 7:216 paupercula (Peniophora)..... 7: 216 Peckii (Clavaria).......... 9: 67 Peckii (Cyphella)......... 1:377 Peckii (Exobasidium)....... 2 2: 649 Peckii (Peniophora)....... 12: 291 pectinatum (Corticium) .... 13: 286 pedicellata (Thelephora) ..... 3: 224 pedicellatum (Septobasidium)

3: $323 ; 13: 330$

pellicula (Corticium).....13: 212, 263 pelliculare (Corticium) ...... 13: 196 penicillatus (Aleurodiscus)... $5: 201$ peniophoroides (Hypochnus) 3: 234 perdix (Thelephora)....... 7: 227 perexigua (Cyphella)....... 1: 378 pergamenum (Stereum) ..... 7: 101 perplexa (Thelephora)...... 1:223 pertenue (Corticium)........ 12: 315 pertenuis (Peniophora)...... 12: 315 petalodes (Stereum)........ 7: 114 Pctersii (Coniophora)........ 4: 248 Petersii (Corticium).......12: 274, 320 pezizoides (Tubercularia) .... 7: 121 pezizoides (Cyphella) ..... 1: 365, 378 pezizoidcum (Corticium)..... 7: 121 phosphorea (Auricularia)..... 13: 301 phosphorescens (Peniophora) 12: 273 phyllophila (Peniophora) .... 12: 241 piliseta (Peniophora)...... 12: 242 pilosa (Peniophora)....... 12: 291 pilosum (Corticium)...... 13: 262 pilosus (Hypochnus)...... 3: 221 pinnatifida (Hymenochaete) . 5: 355 Pini (Sterellum).......... 7: 123 Pini (Stereum) ......... 7: 123 pinicola (Septobasidium) .... 13: 330 1: 201 pistillaris (Craterellus) ...1: 341; 9: 69 
plumbea (Sebacina) .........

2: $765 ; 3: 241 ; 13: 337$ plunhescens (Sebacina) $.3: 241 ; 13: 337$ plunbeun (Corticium) ...... 13: 261 podlachin (Selacina)...... 2: 763

Pogonati (Craterellus) ...... 1: 362 polygonia (Thelephora)...... 13: 268 polygonium (Corticium) ...... 13: 268 polygonium (Gloeocystidium).. 13: 268 polygonium v. fulvescens (Gloeo-

cystidiunn).

13: 269

polygonoides (Corticium).

13: 224

polygonoides (Lyomyces)..... 13: 225

polyporoidea (Coniophora).... 4: 247

polyporoidea (Solenia) ..... 11: 16

polyporoideum (Corticium).... 4: 247

polyschista (Sebacina) ..... 13: 338

populnea (Peniophora)...... 13: 324

populneum (Stereum)...7: 237; 13: 324

poriaeformis (Solenia) ...11: 23; 13: 319

porrectum (Stereum) ........ 7: 234

porrigens (Cyphella)....... 1: 368

portentosum (Corticium) ..... 13: 187

portentosum v. crystallophorum

(Corticium).............

portentosum (Stereum)........

praetermissa (Peniophora) .... 12: 316

prasina (Coniophora)....... 4: 265

prasinum (Corticium)...... 4:265

prolifera (Thelephora)...... 7: 115

proliferum (Stereum)....... 7:115

protrusum (Corticium)..... 13: 260

pruinata (Peniophora)...... 12: 340

pruinata (Peziza)........ 11: 23

pruinatum (Stereum)........ 12: 340

pseudopedicellatum (Septo-

basidium)

Pseudotsugae (Corticium) ... 13: 246

pteruloides (Thelephora) ..... 2: 740

pubera (Peniophora)........ 12: 313

puberum (Corticium)........ 12: 313

pubescens (Stereum) . . .7: 178; 11: 10

pulcherrima (Hymenochaete).. $\quad$ 6: 318

pulchrum (Stereum)........ 6: 323

pulverulenta (Cymatella) ... 11: 7

pulverulentum (Stereum)..... 7:131

pulverulentus (Craterellus) ... 11: 7

punctulatum (Corticium) .... 13: 179

purpurascens (Stereum)...... 7: 204

purpurea (Hymenochaete) ... 7: 192 purpurea (Kneiffia)....... 7:192

purpureum (Stereum)...... 7:124

pusiola (Thelephora)........ 1: 208

pusiolum (Stereum)....... 7: 109

puteana (Coniophora)....... 4: 240

puteanum (Corticium)....... 1: 240

quisquiliare (Stereum)...... 7: 95

quisquiliaris (Thelephora).... 7: 95

racemosum (Corticium).... 13: 287 radians (Stereum).......7: 167, 169 radiatum (Stereum)........ 7: 181 radiatum v. reflexum (Stereum) 7:181 radicans (Podoscypha). .7: 108; 13: 326 radicans (Stereum).... .7: 108; 13: 326 radicans (Thelephora) .13: 326; 7: 108 radicatum (Corticium)...... 12: 320 radiosa (Thelephora) ........ 13: 263 radiosum (Corticium) ....... 13: 263 rameale (Stereum)........ 7: 169 Ravenelii (Cyphella)....... 1: 371 Ravenelii (Peniophora)...... 12: 269 Ravenelii (Stereum)....... 7: 90 Ravenelii (Thelephora)...... 1: 207 ravum (Corticium)........ 13: 251 reflexa (Auricularia)........ 7: 150 reflexa (Hymenochaete)..... 5: 336 regularis (Thelephora)...... 1: 207 reniforme (Stereum)....... $\mathbf{5 : 3 1 0}$ reniformis (Hymenochaete) ... $\quad \mathbf{6}: 310$ resupinatum (Hydnum) ..... 5: 311 retiforme (Septobasidium) .... 3: 338 retiformis (Thelephora)...... 3: 338 Rhacodium (Hypochnus).... 13: 322 rhodella (Peniophora)....... 12: 254 rhodellum (Corticium)....... 12: 254 rhodocroa (Peniophora)...... 12: 254 Rhododendri (Fxobasidium)... 2: 649 Richardsonii (Hypocrea)..... 7: 121 rigens $($ Stereum)......... 7: 145 rigescens (Corticium)....... 13: 199 rigidula (Hymenochaete) .... $6: 318$ rimosissima (Peniophora).... 12: 341 rimosissimum (Corticium) .... 12: 341 rivulorum (Stereum)....... 7: 94 Rosse (Corticium)......... 13: 239 rosea (Thelephora)......... 13: 224 rosella (Tulasnella) ........ 13: 328 roseo-carnea (Thelephora).... 7: 229 
roseo-carneum (Stereum) ... 7:229

roseolum (Corticium) ..... 6: 257

roseolum (Corticium)....... 13: 224

roseopallens (Corticium).... 13: 240

roseum (Corticium)....... 13: 224

roseus (Aleurodiscus) ...... 13:225

roseus (Cantharellus)....... 1: 333

roseus (Craterellus)......... 1: 332

roseus (Merulius)......... 1: 332

Roumeguerii (Corticium) . . . 12: 270

Roumeguerii (Kneiffia) ...... 12: 270

Roumeguerii (Peniophora)... 12: 270

rubellum (Corticium)...... 13: 232

rubicundum (Corticium).... 13: 235

rubiginosa (Hymenochaete)... $\quad$ 5: 332

rubiginosa (Tomentella) ..... 3: 209

rubiginosum (Stereum) ...... 5: 332

rubiginosus (Hypochnus) .... 3: 209

rubiginosus (Zygodesmus).... 3: 209

rubrocanum (Corticium)..... 13: 230

rubropallens (Corticium) . . . 13: 229

rubropallens (Stereum) ..... . 13: 229

rubropallens (Thelephora).... 13: 229

rudis (Hymenochaete)...... 5: 346

rudis (Hymenochaetella)..... 5: 346

rufa (Cryptochaete)....... 7: 121

rufum (Stereum)......... 7: 120

rugispora (Hymenochaete)... 7: 188

rugisporum (Stereum)...... 7: 188

rugosa (Thelephora)........ 7: 143

rugosiusculum (Stereum) .... 7: 127

rugosum (Stereum)....... 7: 142

rutilans (Cytidia) ......... 11: 10

Saccardoi (Cyphella)....... 1: 373

Sacchari (Peniophora)..... 12: 328

salicina (Cytidia).......... 11: 10

salicina (Lomatia) . . . . . . . 11: 10

salicinum (Corticium)....... 11: 10

Sallei (Hymenochaete)...... 5: 314

salmoneum (Corticium).... 13: 255

salmonicolor (Corticium) .... 13: 227

Sambuci (Corticium)...... 12: 233

Sambuci (Hypochnus)....... 12: 233

Sambuci (Peniophora)...... 12: 233

sanguinea (Kneiffia) . . . . . . 12: 274

sanguinea (Peniophora)...... 12: 274

sanguineum (Corticium)..... 12: 274

sanguinolentum (Stereum)... 7: 144

saxitas (Stercum)......... scabriseta (Hymenochaete)... . 7: 192

scabriseta (Lloydclla)....... 7: 192

scandens (Erysiphe)....... 13: 292

scariosa (Sebacina)........ 2: 762

scariosum (Corticium)...... 2: 762

Schomburgkii (Hymenochaete) $\mathbf{6}: 308$

Schrenkii (Eichlcriella)..... 2: 744

Schweinit:ii (Mcrisma) ...... 2: 740

Schweinit:ii (Peniophora) .... 7: 203

Schweinitzii (Septobasidium) 3: 324

Schweinitzii (Thelephora) ..... 2: 734

Schweinit:ii (Tremellodendron) 2: 734

scissilis (Thelephora)...... 1: 205

scoparia (Thelephora) ....... 1: 222

scriblitum (Stercum)........ 7: 237

scruposa (Hymenochaete)... 5: 318

scutellare (Corticium)...... 13: 192

sebacea (Thelephora)....... 2: 752

sebaceum (Corticium)....... 2: 752

secedens (Corticium)....... 2: 762

semivestitum (Lachnocladium) 6:271

sendaiense (Stereum)....... 7: 229

separans (Peniophora)..... 12: 232

sepium (Stereum) ........ 7: 215

septentrionale (Corticium) . . 13: 257

septocystidia (Peniophora) . 12: 260

seriale (Corticium)......... 12: 318

serialis (Peniophora)..12: 239, 281, 318

seriatum (Stereum) ........ $5: 192$

seriatus (Aleurodiscus) . . . . . $5: 192$

sericella (Thelephora)....... 7: 96

sericeum (Stereum)....... 7: 175

serum (Corticium) . . . . . . 12: 233

sessilis (Cyphella)......... 13: 317

setosa (Hydnochaete)....... 5: 312

setosa (Hymenochaete)..... 5: 368

setosa (Ptcrula).......... 6: 278

setosa (Thelephora)........ 5: 311

setosum (Lachnocladium) .... 6: 278

Seymouriana (Peniophora) . 12: 337

Sheari (Heterochaete) . 8: 377; 13: 338

Sheari (Peniophora) . . . . . 12: 268

Sheari (Sebacina).....2: 759; 13: 338

simile (Corticium) . . . . . . . 12: 336

similis (Peniophora) ....... 12: 336

simplex (Tremellodendron)

2: $742 ; 13: 339$

simulans (Corticium)....... 5: 340

simulans (Hymenochaete) ... 5 : 351

sinuosus (Cantharellus)...... 1: 337 


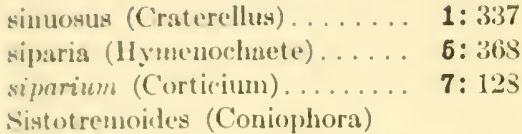

4: $249 ; 13: 312$

Sistotremoites (Tuetephora)

4: $249 ; 13: 312$

3: 213

siluensis (Iypochnus)

sociatum (Corticiun)

13: 192

Soluni (Corticium).

13: 295

Solani (H!ypochnus).

13: 295

13: 295

4: 263

4: 263

12: $2 \mathrm{SO}$

12: 290

sordilum (Corticium)

sordulenta (Coniophora)

4: 267,268

sordulentum (Corticium)

Sourerbeyi (Stereum).

Soucrbeyi (Theleplrora)

spadiceum (Stereum)

spaliceum v. plicalum (Stereum)

sparsus (Hypochnus)

spathularia (Skepperia)

spathularius (Craterellus) speciosa (Hymenochaete) .. 5: 307, 303 spectabilis (Thelephora) . . . . 7: 7: 96 spiculosa (Thelephora)...... 1:225 spilomea (Phlebia)........ 13: 275 spiniferum (Asterostroma)... 11: 33 spiniferum (Septobasidium). 13: 333 spiniferus (Hypochnus) .... 3: 218 spinulosa (Eichleriella) ..... 2: 747 spinulosum (Radulum) ..... 2: 747 Spongia (Septobasidium) . 3:339; 13:331 Spongia (Thelephora)....... 3: 339 spongiosa (Thelephora)...... 3: 216 spongiosun (Stereum)....... 1: 214 spongiosus (Hypochnus) ..... 3: 216 spreta (Hymenochacte)...... 5: 348 spretum (Corticium) Sprucei (Stereum). . spumeum (Corticium). spumoum (Stereun) Stevensii (Corticium) Stevensonii (Corticium) stipnta (Peziza) 13: 229

7: 163

7: 208

7: 208

13: 293

13: 211

11: 19

13: 258

13: $25 \mathrm{~S}$ stratosa (Peniophora)

12: 333 striata (Lloydella)......... 7: 186 striata (Thelephora) . ....7: 175, 186 striatuin (Stereum) ......7: 175, 186 strumosum (Stereum)....... 6: 190 strumosus (Alcurodiscus) .... 5: $5: 190$ styraciflua (Thelephora) ..... 7: 135 styracifluum (Stereumı)..... 7: 135 subalbum (Corticium) . . . . 13: 267 subulutacea (Kneiffia)....... 12: 288 subalutacea (Peniophora).... 12: $2 \$ 8$ subalulaceum (Corticium).... 12: 288 subapiculatum (Peniophora) .. 12: 280 subapiculatum (Corticium).... 12: 280 subaurantiacum (Corticium)... 21: 322 subceraceum (Corticium) ... 13: 239 subcinereum (Corticium).... 13: 277 subcontinuum (Corticium) ... 13: 288 subcorticale (Lachnocladium) . 9: 66 subcorticalis (Clavaria) ...... 9: 66 subcremea (Peniophora)..... 13: 303 subcruentatum (Stereum) 7:237; 13: 308 subcruentatus (Aleurodiseus)

$$
\text { 7: } 237 ; 13: 308
$$

subcyanea (Cyphella)....... 1:380 subforrugineus (Hypochnus)

3: $210 ; 13: 321$

subgelatinosa (Cyphella)..... 1:370 subgigantea (Peniophora) .... 13: 215 subgiganteum (Corticium) .... 13: 215 subiculosa (Peniophora).... 12: 259 subincarnatum (Corticium)... 12: 329 sublilacina (Thelephora)..... 3: 331 sublilacinum (Septobasidium) . 3: 331 subnullum (Corticium) .... 13: 209 subochracea (Corticium) ..... 4: 265 subochracea (Thelephora) . . . 13: 283 subochraceum (Corticium) . . . 13: 289 subpileatum (Stereum)..... 7: 213 subporiaeformis (Solenia) ... 11: 24 subrepandum (Corticium).... 7: 229 subroseum (Corticium)...... 6: 6: 257 subsimile (Lachnocladium)... 6 6: 272 subsulphurea (Peniophora)... 12:329 subsulphureum (Corticium)... 12: 329 subundulata (Thelephora).... 13: 312 subundulatus (Craterellus)... 13: 312 subvinosus (Hypochnus) ... 3: 231 subviolaceus (Hypochnus) . . . 13: 323 subzonata (Thelephora)..... 7: 150 
subzonatum (Corticium) .... 7: 150

suecineus (Aleurodiscus)..... 13: 309

suffocata (Coniophora). 4: 254; 13: 312

suffocatum (Corticium) . 4: 254; 13:312

sulcatum (Stereum) ...... 7:211

Sullivantii (Thelephora).... 7: 98

sulphuratum (Stereum) ..... 7: 148

sulphurca ('Thelephora) ...... 13: 177

sulphurea (Cyphella)........ 1: 360

sulphurea (Epithele)...... 6: 265

sulphurea (Peziza)......... 1: 360

sulphurea (Solenia)......... 11: 18

sulphureum (Corticium) 3 : 239; 13: 177 sulphurina (Peniophora)..... 12: 324

sulphurina (Tomentella)..... 12: 324

sulphurinus (Hypoehnus) . . . . 12: 324

surinamense (Stereum)..... 7: 71

Symploci (Exobasidium) . . 2: 641, 655

tabacina (Grandinia)....... 3: 218

tabacina (Hymenochaete).... $\mathbf{5}: 325$

tabacina (Peniophora)...... 12: 334

tabacina (Veluticeps)....... 6: 261

tabacinum (Corticium)...... 6: 261

tabacinum (Stereum)....... 5: 325

tabacinus (Aleurodiscus)..... 6: 261

Tasodii (Peniophora) ...... 12: 306

taxophilus (Craterellus) ..... 1: 339

tela (Cyphella)........... 13: 318

tela (Peziza) ............. 13: 318

tenax (Clavaria).......... 13: 339

tenax (Pterula) . . . . . . . . 13: 339

tenax (Tremellodendron) 7:67; 13: 339

tenella (Peniophora) . . . . . 12:298

tenerrimum (Stereum) ...... 7:100

tenue (Corticium)......... 12: 317

tenue (Gloeoeystidium) ...... 12: 317

tenue (Tremellodendron).... 2: 740

tenuis (Aleurodiscus) ...... Б: 200

tenuis (Hymenochaete)..... 5: 364

tenuis (Kneiffia) . . . . . . . 12: 317

tenuis (Odontia) . . . . . . . . 13: 321

tenuis (Peniophora)....... 12: 317

tenuissima (Hymenochaete)... 5: 315

tenuissinum (Stereum)..... 5: 314

tephra (Peniophora)....... 12: 339

tephrum (Corticium)....... 12: 339

terrestris (Thelephora)...... 1: 219

terricola (Peniophora)...... 12: 237

tessulatum (Corticium) ...... 13: 210 texana (Peniophora)...... 12: 251

texensis (Cyphella)........ 1: 371

Thaxteri (Cyphella)....... 13: 319

thelephoroides (Corticium).... 4:268

thclephoroides (Hypochnus) 3: 235; 4: 268

Thujae (Peniophora) ...... 12: 236

Tiliae (Cyphella).......... 1: 364

Tiliae (Peziza) .......... 1: 364

Tiliae (Trichopeziza)....... 1: 364

tomentosa (Hymenochacte)... 5: 368

trachychaete (Cyphella)..... 1: 379

tremellosa (Cytidia) ... . . . . 11: 12

trichopus (Clavaria)........ 9: 65

triste (Stereum)......... 7: 238

tristis (Hypochnus)....... 3:213

tristis (Tomentella)........ 3: 213

tropicale (Septobasidium) ... 3: 326

truncata (Clavaria) ......... 9: 69

Tsugae (Corticium) . . . . . 13: 276

tubereulatum (Cortieium) .... 13: 195

tuberculosum (Stereum)...... 7: 131

Tulasnei (Prototremella) .... 6: 6:56

Tulasnei (Tulasnella) . ..... 6: 6:256

turbinatus (Craterellus).... 13: 313

typhicola (Peniophora)..... 12: 319

umbrina (Coniophora) ....... 4:256

umbrina (Coniophorella)..... 4:256

umbrina (Hymenochaete) . . . 7: 192

umbrinum (Corticium) ... 3: 213; 4: 256

umbrinum (Stereum) ....... 7: 191

umbrinus (Hypochnus). 3: 213; 13: 323

Underwoodii (Stereum) ... . . 13: 327

undulatum (Stereum) . . . . . 7: 7: 100

ungulata (Hymenochaete) ... $\quad$ 5: 339

unicolor (Craterellus) ....... 1: 340

unicolor (Hymenochaete).... . 5: 342

unicolor (Peniophora)....... 12: 320

unicum (Stereum) . . . . . 7: 236

Vaccinii (Exobasidium) ....2: 639, 649

Vaccinii (Fusidium) ....... 2: 649

Vaccinii Myrtilli (Exobasidium).............. 2: 649

Vaccinii uliginosi (Fxobasidium) ..............2: 640, 654

vaga (Coniophora)......... 4:251

vaga (Phlebia).......... 3: 239

vagum (Corticium) ........ 13: 295

vagum v. Solani (Cortieium)... 13: 295 
varians (Matruchotia) ...... 11: 26

rariicolor (Stereum) ........ 7:150

vellereum (Corticium)...... 13: 179

reluticeps (Hymenochacte) ... 6: 6:260

velutina (Kneiffia)......... 12: 264

velutina (Peniophora)...... 12: 264

velutinum (Corticium)...... 12: 264

venosum (Corticium)....... 13:274

vernicosa (Peniophora)..... 12: 250

versata (I'eniophora)... . . . 12: 305

versicolor (Stereum) ........ 7: 166

versicolor (Thelephora) ...... 7: 167

versicolor v. fasciata (Theleph-

ora) ............ 7:155

versiforme (Stereum) ...... 7: 222

verticillata (l'eniophora).... 12: 285

vescum (Corticium)....... 13: 204

vesiculosum (Corticium) .... 13: 266

'cstipes (Clavaria) .....6:274; 9:67

vestipes (Lachnocladium) .6: 274; 9:67

vialis (Thelephora)........ 1:213

vibrans (Stereum) . . . . . . . 7: 179

villosa (Cyphella)......... 1: 365

villosa (Peziza) .......... 1: 365

villosa (Solenia).......... 11: 26

villosa v. polyporoidea (Solenia). 11: 16

vinaceum (Corticium) ..... . 13: 298

vinosa (Hymenochaete) ..... 7: 192 vinosa (Thelephora)........ 3: 215 vinososcabens (Corticium)... 13: 267 violaceo-livida (Peniophora)... 12: 347 violaceo-lividum (Corticium)... 12: 347 violea (Tulasnella)......... 6: 256 violeus (Hypochnus)........ 6: 256 viride (Iydnum) .......... 13: 324 viridis (Caldesiella)........ 13: 323 viridis (Odontia) .......... 13: 323 vitellinum (Stereum)........ 5: 190 viticola (Corticium) . . . . . . . 12: 322 viticola (Peniophora)....... 12: 322 viticola (Thelephora)........ 12: 322 vorticosum (Stereum)....... 7: 121

Weiri (Aleurodiscus) ....... 5: 204 Weiri (Peniophora)........ 12: 342 Willeyi (Thelephora)....... 7: 98

xanthellum (Stereum) ...... 7: 96 xanthopus (Merulius)....... 1: 336

Zelleri (Aleurodiseus) . . . . 13: 309 Zelleri (Craterellus)........ 13: 314 Zimmermanni (Corticium)... . 13: 227 zonata (Peniophora)....... 12: 245 zygodesmoides (Hypochnus) .. 3: 236 zygodesmoides (Thelephora) ... 3: 236 


$$
\begin{aligned}
& \text { a } 1= \\
& x_{n}=-4 x
\end{aligned}
$$

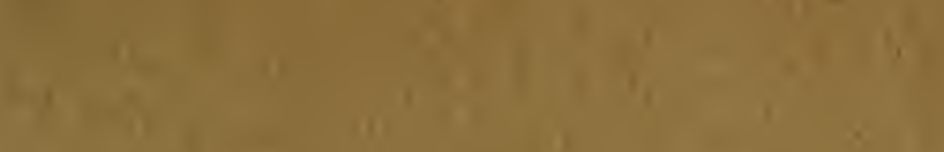

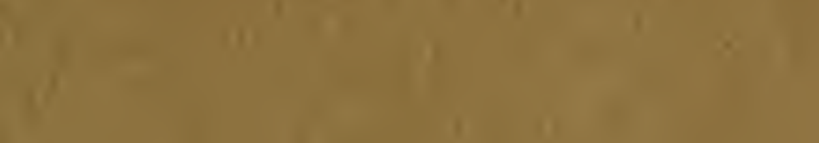

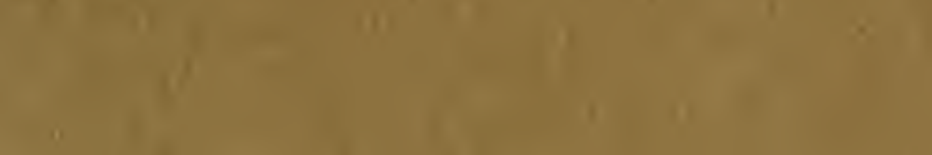

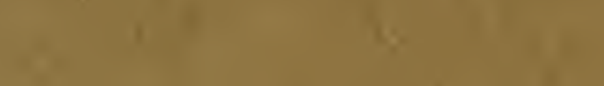

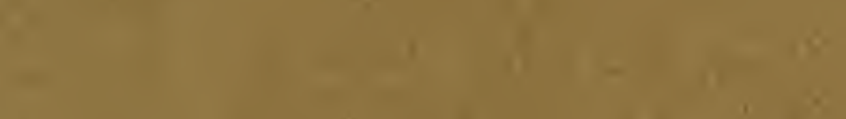

a

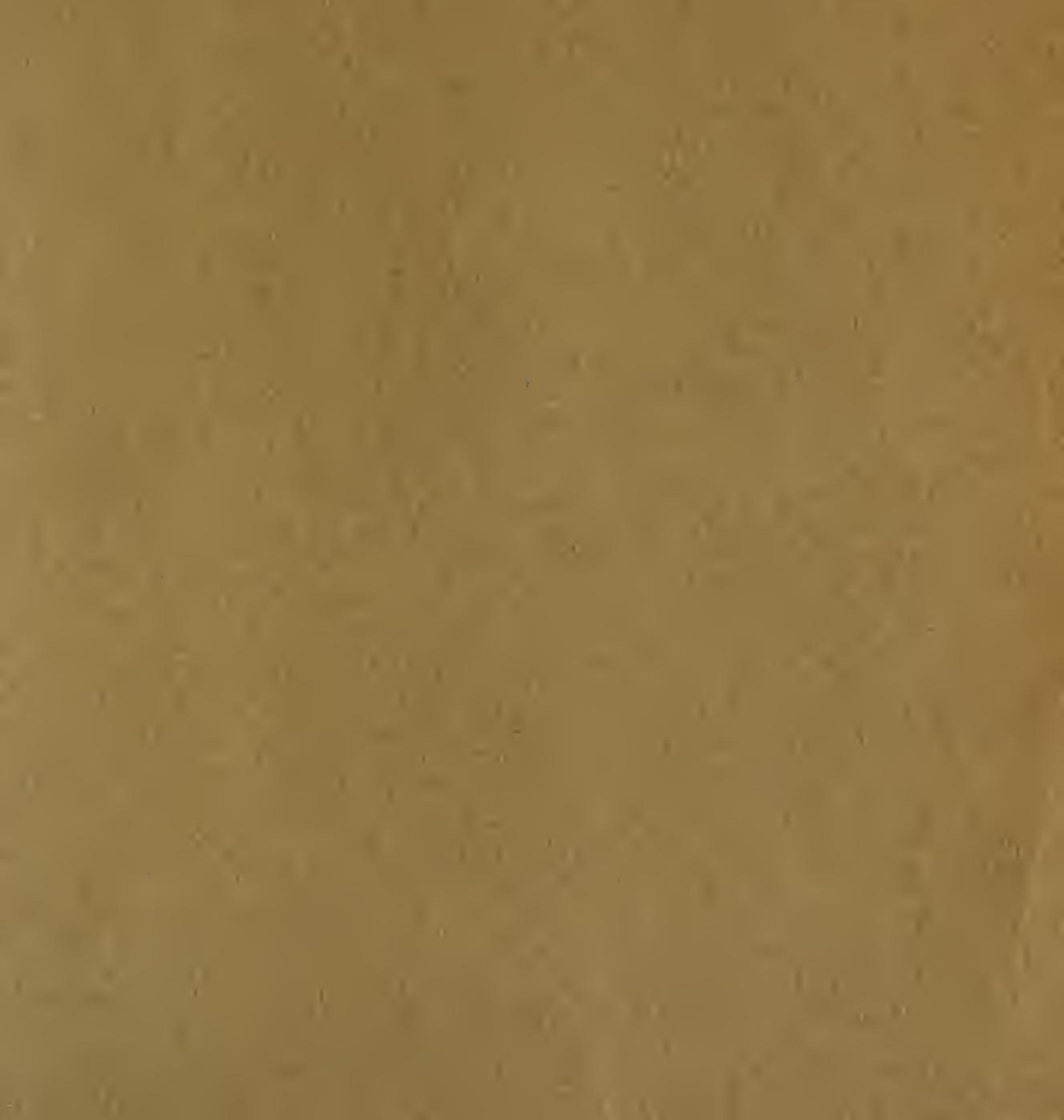







20

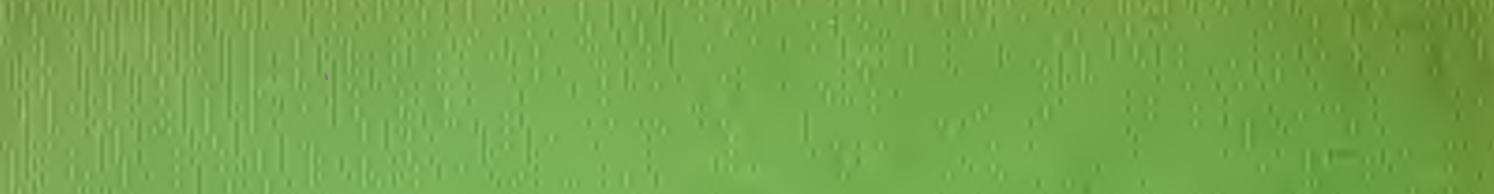
(1) we ing (1)

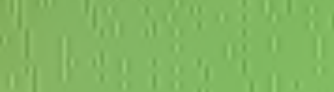

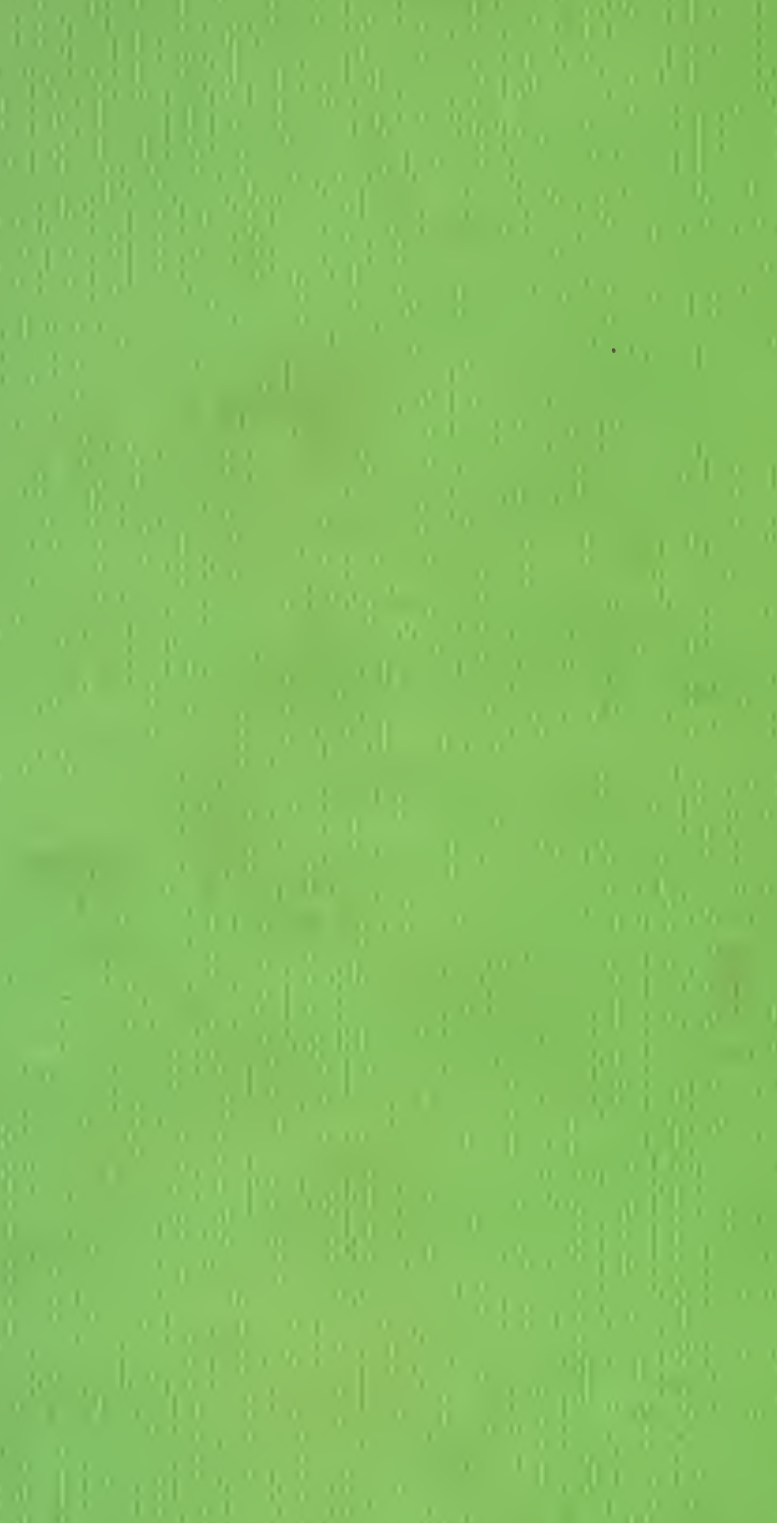

Ii,i, it:

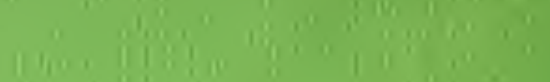

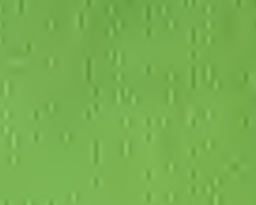
$11,2,2,3$

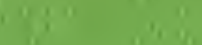
11" 